LIBRARYY

Tumenst , * Of

CALIFORIA

SAN DIEGO 
Digitized by the Internet Archive in 2007 with funding from Microsoft Corporation 


\section{GEOGRAPHICAL AND STATISTICAL NOTES ON MEXICO}

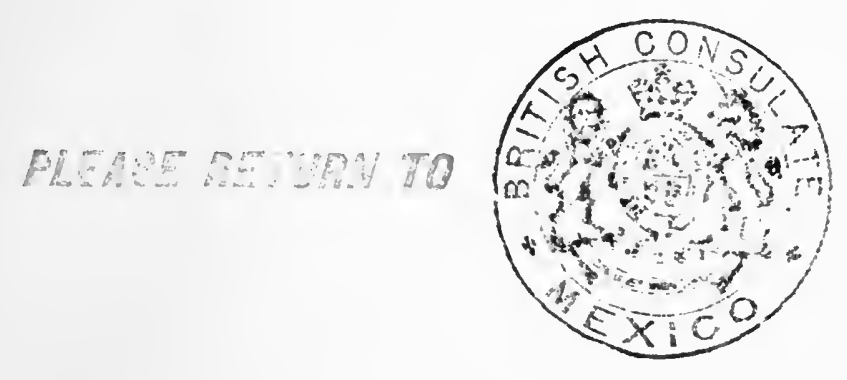

BY

MATIAS ROMERO

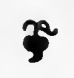

G. P. PUTNAM'S SONS NEW YORK AND LONDON Tbe Whickerbocker presg I 898 
COPYRIGHT, 1898

$\mathrm{BY}$

MATIAS ROMERO

Tbc Iknickerbocker Dress, Hew york 


\section{PREFACE.}

I am printing in book form the several articles that I have published from time to time during my many years' residence in the United States, with a view to dispel errors prevailing here about Mexico, and so promote the good will and increase the commercial, political and social relations between the two countries. Those papers are preceded by one containing geographical and recent statistical information on Mexico, that I have not seen collected in any single book in the English language. To answer a great many demands for information that I constantly receive from citizens of this country, I have concluded to give at once that paper to the public.

WASHING TON, Fanuary 3 r, 1898 . 



\section{CONTENTS.}

GEOGRAPHICAL AND STATISTICAL NOTES ON MEXICO . ‘ . I

Part I. Geography . . . . 3

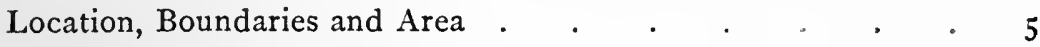

Location . . . . . . . . . 5

Boundary with the United States . . . . . . 5

Boundary with Guatemala . . . . . . . . . 6

Boundary with Belize . $\quad . \quad$. $\quad . \quad$. $\quad$. $\quad . \quad$. 6

Cession of Mexican Territory to the United States . . . 7

General Characteristics . . . . . . . . 8

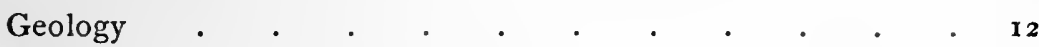

Mining . . . . . . . . . . . . . $\mathbf{r}_{3}$

Silver . . . . . . . . . . . . . . $\mathrm{I}_{3}$

Real del Monte Company . . . . . . . . ${ }^{15}$

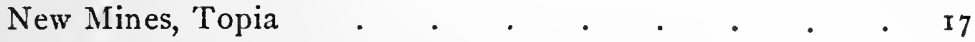

Li Hung Chang and the Mexican Silver Mines . . . 18

Gold . . . . . . . . . . . . 19

Coinage of the Precious Metals . . . . . . 2I

Coinage of Mexico from the Establishment of the Mints in 1537 to the End of the Fiscal Year 1896 . . . 21

Iron . . . . . . . . . . . $2 \mathrm{I}$

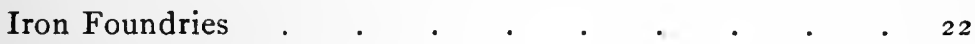

Copper . . . . . . . . . . . . . 22

Quicksilver • . . . . . . . . . . $\quad$. 23

Coal . . . . . . . . . . . . ${ }_{2} 23$

Mexican Miners . . . . . . . . $\quad{ }^{25}$

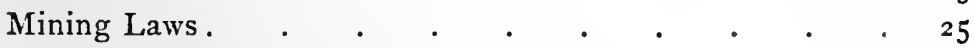

Mints and Duties on Silver . . . . . . . 27

Smelting Plants . . . . . . . . . ${ }_{2} 8$

Mexican Metallurgical Company . . • . . . ${ }_{28} 8$

National Mexican Smelter at Monterey . . . $\quad 28$ 
Central Mexican Smelter

Velardeña Mining Company.

The Chihuahua Mining Company

The Mazapil Copper Company, Limited . . • . 29

Sabinal Mining and Smelting Company, Chihuahua . . 29

La Preciosa . . . . . . . . . . . $\quad$. 29

The Boleo Smelter . $\quad . \quad$. $\quad . \quad$. $\quad . \quad$. 29

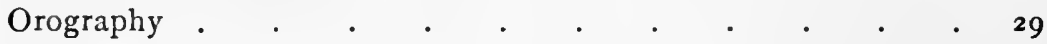

Hydrography . . . . . . . . . $\quad$. 32

Climate . . . . . . . . . . . 35

Summary of the Meteorological Observations Taken in Several Cities of Mexico during Several Years - 38

Summary of the Meteorological Observations Taken in

Several Localities of Mexico during the Year 1869 • 39

Mexico as a Sanitarium . . . . . . . . $4 \mathbf{I}$ Flora . . . . . . . . . . . . 42

Coffee . . . . . . . . . . . . . . 44

Sugar-cane . $\quad . \quad . \quad . \quad . \quad . \quad . \quad . \quad . \quad .45$

Tobacco $. \quad . \quad . \quad . \quad . \quad . \quad . \quad . \quad . \quad .45$

India-rubber . $\quad . \quad . \quad . \quad . \quad . \quad . \quad . \quad . \quad .46$

Cotton . . . . . . . . . . . . . 48

Agave . . . . . . . . . . . . 48

Henequen . . • . . . . . . . 49

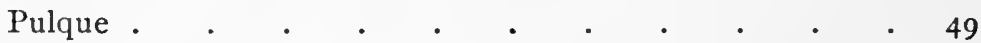

Cactus . . . . . . $\quad . \quad . \quad . \quad 51$

Cocoa . . . . . . . . . . . $5 \mathrm{I}$

Vanilla . . . . . . . . . . . $\quad .52$

Silk Culture . . . $\quad . \quad . \quad . \quad . \quad . \quad . \quad .53$

Cochineal . . . . . . . . . . 53

Rice . . . . . . . . . . . 53

Chicle, or Chewing-gum $\quad . \quad$. $\quad . \quad$. $\quad . \quad 53$

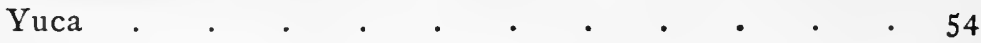

Ginger . . . . . . . . . . . $\quad . \quad 55$

Canaigre $. \quad . \quad . \quad . \quad . \quad . \quad . \quad . \quad . \quad .55$

Peppermint . . . . . . . . . . 55

Cabinet and Dye Woods $. \quad . \quad . \quad . \quad . \quad . \quad .55$

Grasses . . . . . . . . . . . 56

Alfalfa . . . . . . . . . $55^{6}$

Cattle-raising . . . . . . . . . . 56

Sheep . . . . . . . . . $5^{8}$

Products of Cold and Temperate Regions . . . . $\quad . \quad 5^{8}$

Fruits • . . . . . . . . . .58

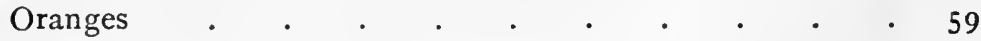

Lemons. . . . . . . . . . . 60 
Limes and Shaddocks .

Bananas

Pineapple

Cocoanut

Mangoes

Alligator Pear

Mamey.

6I

$6 \mathrm{I}$

62

62

Zapote

Papaya

Flowers

Irrigation

The Nazas Irrigation

Fauna

Ethnology

Mexican Indians.

Increase of Mexican Population

Decrease of the Indian Population

The Spaniards in Mexico

English and Germans in Mexico.

Americans in Mexico

Ruins

Uxmal

Palenque

Cholula

Teotihuacan

Mitla.

Languages

Synopsis of the Indian Languages of Mexico according to Don Francisco Pimentel . . . . . . $\quad$. 86

Population

Classification of Mexican States . . . . . . 90

Area and Population of the United Mexican States . . $9 \mathbf{I}$

Religion

Protestantism in Mexico

Political Organization

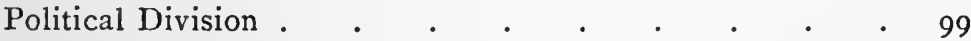

Army and Navy . . . . . . . . . . . $\quad . \quad 99$

Education . . . . . . . . . . . 100

Universities Established by the Spanish Government . . rox

School of Medicine . . . . . . . . 102

School of Engineering. . . . . . . . . 103

Mexican Technical Schools in the Present Time. . . 103

Reorganization of the Technical Colleges . . . . 104

Primary Education

104 
School Statistics $\cdot$ •

Libraries . . . . . . . . . . . 106

Newspapers . . . . . . . . . . 106

The Valley of Mexico . . . . . . . . . 106

The City of Mexico . . . . . . . . . . 107

Climate. . . . . . . . . . . IIo

Mortality in the City of Mexico . . . . . . III

Climatological Data of the City of Mexico . . . . II 2

Summary of the Meteorological Observations of the City of Mexico in 1896 . . . . . . . . II3

Railways . . . . . . . . . . . 115

President Diaz's Railway Policy . . . . . . 117

President Diaz's Statistics on Mexican Railways . . . I 8

Financial Condition of Mexican Railways . . . . II9

Annual Buildings and Earnings of Mexican Railways . I 20

Approximate Tonnage Moved by Central, National, Interoceanic, and Mexican Railways for Ten Years ended

December 3I, 1896 • . . . . . . I 21

Telegraphs . . . . . . . . . . • I 21

Postal Service . . . . . . . . . . . . . 123

Public Lands $\quad . \quad$. $\quad . \quad$. $\quad . \quad$. $\quad . \quad$. 124

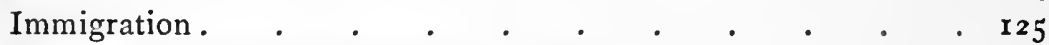

Inmigration from the United States . . . . . I26

Public Debt. . . . . . . . . . . 129

Banking . . . . . . . . . . . $13 \mathbf{I}$

Patents and Trademarks . . . . . . . . . ${ }^{3} 3^{2}$

Patents . . . . . . . . . . . 132

Trademarks . . . . . . . . . . $\mathbf{r}_{32}$

Shipping and Communications . . . . . . . 133

Money, Weights, and Measures . . . . . . . 133

Non-Official Publications (English) . . . . . . 134

Part II.-Statistics . . . . 135

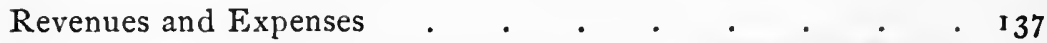

Revenue and Expenses of the Federal Government of Mexico

in 1808 and from 1822 to June 30,1867 . . . . I39

Revenue and Expenses of the Mexican Government from

July I, $\mathbf{1 8 6 7}$, to June 30 , 1888 . . . . . 140

Revenue and Expenses of the Mexican Government from

July I, $\mathrm{r} 888$, to June $30, \mathrm{I} 896$. . . . . I4I

Federal Appropriations during the Fiscal Years from 1868 to

I895 . . . . . . . . . . . 142

Sources of Revenue . . . . . . . . . . 143

Import Duties . . . . . . . . 143 
Additional Import Duties

Export Duties

Amount of Import Duties

Custom Receipts from 1823 to 1875

PAGE

Internal Revenue .

Receipts of the Custom Houses during the Twenty-seven Fiscal Years Ending June 30,1896 . . . .

Internal Revenue Receipts from January $x, 1875$, to June 30,1896

Direct Taxes

Receipts from Direct Taxes in the Federal District during the Twenty-seven Fiscal Years Ending June 30, 1896 .

Revenues of the Mexican States from I884 to I895 . . I50

Expenses of the Mexican States from 1884 to 1895 . . . $\mathrm{r}_{5} \mathrm{r}$

Revenues of the Municipalities of Mexico from $\mathbf{8} 88_{4}$ to $\mathbf{r} 895 \quad \mathbf{I} \mathbf{5}^{2}$

Expenses of the Municipalities of Mexico from 1884 to $1895 \quad 153$ State and Municipal Finances . . . . . . . $\mathrm{r}_{54}$ Foreign Trade . . . . . . . . . . . 155

Imports . . . . . . . . . . . . I55

Mexican Imports and Exports from 1826 to 1828 . $\quad$ I55

Imports in Mexico from July $\mathrm{r}, 1872$, to June $3 \circ, 1875$, and in the year $188_{4}-1885 \quad . \quad . \quad . \quad . \quad . \quad . \quad{ }_{156}$

Imports in Mexico from July 1,1885 , to June $3 \circ, 1886$, and from July 1,1888 , to June 30,1890 . . . . 157

Imports in Mexico from the Fiscal Year $1892-1893$, to the Fiscal Year $1895^{-1896}$. . . . . . 158

Exports

I 59

Imports in Mexico by Countries in the Fiscal Years $1888-1889$ and $1889-1890$, and Imports and Exports by Countries and Custom Houses in the Fiscal Years $1894-1895$ and r $895-1896$

Exports of Mexican Commodities from July I, I886, to June 30,1896

Statement of Exports of some Agricultural Products during the Fiscal Years from July I, I 877 , to June 30,1896 .

Value of Imports from Mexico from July I, 1882, to June

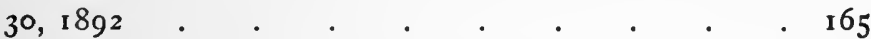

Resumé of Total Imports . . . . . . . . 167

Destination and Value of Exports from Mexico in the Fiscal Years from $\mathrm{I} 882$ to $\mathrm{I} 892$.

Total Exports

Trade between Mexico and the United States . . . . 170

Total Imports to Mexico and Imports from the United States for the Fiscal Years $1872-1873$ to $1895-1896$ 
Total Exports from Mexico and the Exports to the United States from $1877-1878$ to $1895-1896$.

Statement of the Commercial Transactions between Mexico and the United States from 1826 to $185^{\circ}$.

Commerce in Merchandise between the United States and Mexico by Years and Decades from I 85 I to 1897

Total Commerce between the United States and Mexico by Years and Decades from 1851 to 1897

Quantities and Values of the Principal and all other Articles of Imports into the United States from, and of Exports from the United States to, Mexico, $1858-1883$.

Quantities and Values of the Principal and all other Articles of Imports into the United States from, and of Exports from the United States to, Mexico, from r889-1897 . I81

Increase of 'Trade during the year $1896-1897 \quad . \quad . \quad$ I 84

Leading Merchandise Imports from Mexico . . . 184

Exports from the United States to Mexico . . . 184

Tropical Products Supplied by Mexico to the United States 185

Cattle Exported to the United States . . . . . 186 Coinage

Coinage by the Mexican Mints from their Establishment in 1535 to June 30,1895 .

Production of Gold and Silver in Mexico in 1879-1880, $1889-$ I890, and $\mathrm{r} 894^{-1895}$. . . . . . .

Export of Precious Metals and Minerals from Mexico in the years $1879-1880$, $1889-1890$, and $1894-1895 . \quad .188$

Exports of Silver from July I, 1872 , to June 30,1896 . . 190 Mexican Gold Exports

Mexican Gold Exported to the United States

Imports of Gold Bullion, Ore, and Coin from Mexico into the United States from I891 to I895 . . . .

Imports of Gold Bullion, Ore, and Coin from Mexico into the United States from 1892 to 1896 .

Gold Exported from Mexico to the United States from I89 I to 1896

Statement by the Department of Communications of Mexico

of the Railroad Mileage in Operation on October $3 \mathrm{r}$, 1896

Resumé of Railways in Mexico in 1895 . . . . $\quad$ r 95

Mexican Central . . . . . . . . . 196

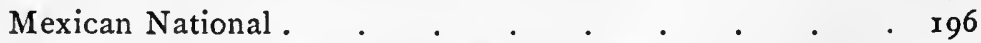

Earnings and Expenses of the Mexican National from 1889 to $x 896$ 


\section{Contents}

Mexican International .

Mexican Southern .

Other Railroads

Mexican Railroad

Interoceanic Railway

Sonora Railway .

Hidalgo and Northeastern Railway .

Mérida and Progreso Railway .

199

Tehuacan and Esperanza Railway

201

201

202

202

202

Mérida and Peto Railway .

203

203

Sinaloa and Durango (Altata to Culiacan) Railway . . 204

Mérida and Campeche Railway.

204

Mérida and Valladolid Railway

204

Tlalmanalco Railway .

San Juan Bautista and Carrizal Passenger Railway .

205

San Andrés and Chalchicomula Railway .

205

Orizaba and Ingenio Railway

Santa Ana and Tlaxcala Railway

205

206

Cárdenas and Rio Grijalva Rail

Toluca and San Juan de las Huertas Railway.

Vanegas, Cedral, Matehuala, and Rio Verde Railway . 207

Mérida and Izamal Railway . . . . . . 207

San Márcos and Nautla Railway . . . . 207

Monterey and Gulf Railway . . . . . . 208

Córdova and Tuxtepec Railway . . . . . 208

Maravatío and Cuernavaca Railway . . . . . 208

Salamanca and Santiago Valley Railway . . . . 208

Monte Alto Railway . . . . . . . . 209

Valley of Mexico Railway . . . . . . . 209

Puebla Industrial Railway . . . . . . 209

Mexican Northern Railway . . . . . . 209

Mexico, Cuernavaca, and Pacífic Railway . . . 209

Federal District Tramways . . . . . . 2 I0

Veracruz and Alvarado Railway . . . . . 2 Io

Total Traffic and Receipts of Mexican Railways . . . 210

Traffic and Receipts of the Mexican Railways . . . 2 II

Railway Subsidies Paid by the Mexican Government . . . 2 II

Subsidies Paid by the Mexican Government to Railway Companies up to June 30 , I 896

Detailed Statement of the Subsidies Paid by the Mexican

Government to the Railway Companies . . . 2 I3

r. Mexican Railway . . . . . . . . 2 I3

2. Hidalgo Railway . . . . . . . . $2 \mathrm{I}_{3}$

3. Veracruz \& Alvarado Railway . . . . . 2 I3 
5. Interoceanic Railway . . . . . . . . 214

6. Occidental Railway . . . . . . . 214

7. Mexican Central and sundry branches. . . . 214

8. Mexican National and branches . . . . . 215

9. Sonora Railway with a branch . . . . . 216

10. Mérida \& Valladolid Railway with a branch . . 216

II. Mérida \& Campeche Railway via Kalkini . . . 216

12. San Marcos \& Nautla Railway . . . . . 216

13. Toluca \& San Juan de las Huertas Railway. . . 217

14. Vanegas, Cedral, Matehuala, \& Rio Verde Railway . 217

15. Jimenez \& Sierra Madre Railway . . . . 217

16. Mexican Southern Railway . . . . . . 217

17. Tonala \& Frontera Railway . . . . . . . 217

18. Monterey \& Mexican Gulf Railway . . . . 218

19. Tecolula \& Espinal Railway . . . . . 218

20. Pachuca \& Tampico Railway . . . . . 218

21. Maravatio \& Iguala Railway . . . . . 218

22. Mexican Northeastern Railway . . . . . 218

23. Veracruz \& Boca del Rio Railway . . . . 219

24. Tula, Zacualtipan \& Tampico Railway . . . 219

25. Natamoros, Izucar, \& Acapulco Railway . . . 219

26. Lower California Railway . . . . . . 219

27. Monte Alto Railway . . . . . . . 219

28. Tehuantepec Railway . . . . . . . 219

I. Contractors, Edward Learned \& Co. . . . . 219

2. Contractor, Mr. Delfin Sanchez . . . . 220

3. Mac-Murdo Contract . . . . . . 220

4. Stanhope, Hampson, \& Corthel Contract. . . 220

Public Debt . . . . . . . . . . . $22 \mathrm{I}$

Statement of the National Debt of Mexico to June 30, 1896221

Statement of the Federal Public Debt on June 30, $1896^{\circ}$. 222

Post-Office and Telegraph Service . . . . . . . 223

Post-Offices in Mexico in 1895 by States . . . . : 223

Earnings and Expenditures of the Post-Office and Telegraph

Services from July I, I 869 to June 30 , 1896

Number of Pieces Transported by Mexican Mails from 1878

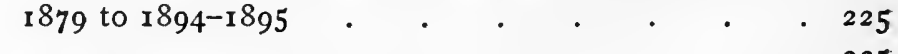

Banks

List of Mexican Banks . . . . . . . . . 225

Situation of the Mexican Banks on December 31, 1894 . 226

Public Lands . . . . . . . . . . 226

Free Titles of the Indian-town lands issued to the inhabitants

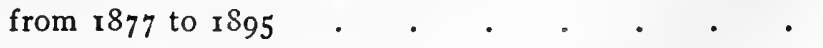


Titles issued for unwarranted possession of Public Lands by Private Parties in 1894 and 1895

Titles of public lands issued to Private Parties in 1894 and

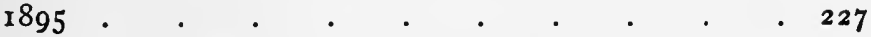

Titles issued in 1894 and 1895 to Surveying Companies . 228 Education . . . . . . . . . . . 228

Newspapers Published in Mexico in 1895 . . . . 228

Public Schools supported by the Federal, State, and Municipal Administrations in 1895 . . . . . . 229

Schools supported by Private Parties . . . . . 23I

Public Libraries in Mexico . $\quad . \quad$. $\quad . \quad . \quad$. $\quad . \quad$. $\quad . \quad 233$

Manufacturing Establishments in Mexico in 1893 . . . $\quad 233$

Summary of Factories existing in Mexico in 1893 . . 236 Navigation . . . . . . . . . . . . 237

Vessels arrived at-Mexican Ports in 1895 . . . . 238

Vessels departed from Mexican Ports in 1895 . . . 239

Resumé of arrivals and departures from I885 to I895 . . 239

Foreign Passengers arrived at Mexican Ports in 1895 . . 240

Foreign Passengers departed from Mexican Ports in 1895 . 241

General resumé of Passengers arrived and departed by Port and Rail in 1895 . . . . . . . . . 242

Vessels arrived at and departed from Mexican Ports during the Fiscal Years $1894-95$ to $1895-96$. . . . 243

Agricultural Products :

Resumé of Agricultural Products in Mexico . . . . 243 Conclusion.

Federal Revenue and Expenses of Mexico in the Fiscal Year 1896-97. · $\cdot$.

Imports and Exports of Mexico by Countries and CustomHouses in the Fiscal Year $1896-97$. . . . . 246

Trade between Mexico and the United States during the first nine months of the Calendar Year I897 . . . . 247

Mexican Exports to the United States . . . . . 247

Mexican Imports from the United States . . . . . 248

APPENDIX . . . . . 249

Mexico as a Central American State . . . . . . 249

Five States of Central America . . . . . . . $25^{\circ}$

Mexico . . . . . . . . . . . $\quad$. $25 \mathbf{I}$

Geographical Extension of Central America . . . . 25 I 
Mexican Profiles .

From Veracruz to Mexico by Orizaba, by the Mexican Railway

From Apizaco to Puebla, a branch of the same road .

From Veracruz to Mexico, by the Interoceanic Railway

From the City of Mexico to Morelos, a branch of the same road

From Puebla to Izucar de Matamoros, a branch of the same road

From Mexico to El Paso del Norte or Ciudad Juarez by the Central Mexican Railroad .

From Aguascalientes to Tampico, a branch of the same road.

From Irapuato to Guadalajara, a branch of the same road .

From Mexico to Laredo Tamaulipas by the Mexican National Railway

From Acámbaro to Pátzcuaro, a branch of the same road .

From Piedras Negras or Ciudad Porfirio Diaz to Durango, by the Mexican International Railway . . . 26I

From Sabinas to Hondo, a branch of the same road . . 262 From the City of Mexico to Cuernavaca and Acapulco . 262

From Puebla to Oaxaca, by the Mexican Southern Railway. ${ }_{26} 6$

From Coatzacoalcos to Salina Cruz, by the National Tehuantepec Railway . . . . . . . 263

From the City of Mexico to Pachuca, by the Hidalgo and Northeastern Mexican Railway . . . . . 264 Northeastern Railway from Mexico to Tizayuca . 264 Hidalgo Railway to Tuxpan . . . . . 264

From Tepa to Pachuca, a branch of the Hidalgo Railway

From San Augustin to Irolo, a branch of the Hidalgo Railway

Bridle-Path from Durango to Mazatlan 255 257 258 258 26 I 261
262
262
263 264
264 264 264 265

Wagon Road from Manzanillo to Guadalajara . . . 265 Wagon Road from Tehuacan to Oaxaca and Puerto Angel . 266

THE VALLEY OF MEXICO'S DRAINAGE • 266.

Topographical Conditions of the Valley of Mexico . . $\quad 267$

Work done by the Indians . . . . . . . 267

Work done by the Spaniards . . . : . . 269

Work done by the Mexican Government . . . . 274

The Tunnel . . . . . . . . . . 276

The Canal . . . . . . . . . . 277

The Sewage . . . . . . . . . . . 279

Completion of the work $\quad . \quad . \quad . \quad . \quad . \quad . \quad . \quad 279$ 
GEOGRAPHICAL AND STATISTICAL NOTES ON MEXICO 



\title{
GEOGRAPHICAL AND STATISTICAL NOTES ON MEXICO.'
}

\author{
(Corrected to Fune 30, 1897.$)$
}

$\mathrm{F}^{\text {on }}$

OR a long time past I have felt the need of a short treatise containing geographical and statistical information about Mexico, to answer the many queries received on that subject by the Mexican Legation in Washington. A statistical abstract about Mexico, such as most nations publish every year, is greatly needed, especially now when the attention of business men and young men is awakening to the possibilities of Mexico. It was partly with the purpose of supplying that need that I prepared this article, which will, I hope, at least serve

1 This article first appeared in the Bulletin of the American Geographical Society of New York of December 31, 1896. A club of the City of Washington requested me, in January, 1888, to deliver a lecture on Mexico, and, as I had not time to prepare one, I consented to give an informal talk on the subject, which I did on January I6th of that year. Most of my talk was taken down by a stenographer, and was the basis of the article which appeared in the Bulletin of the American Geographical Society of New York. That Society did me the honor of electing me one of its honorary members, at the request of Honorable Frederick A. Conkling, on January 25, 1870, and $I$ have ever since felt that $I$ owed it a debt which I could only pay by sending it a contribution about Mexico. The pressure of my official duties in Washington on the one hand, and my inability to treat properly the many subjects connected with a description of Mexico, added to the difficulty of compressing them into a few pages; on the other, delayed that work much longer than I desired or expected. I have added considerably to this article in the present edition, especially in that part which embraces statistical information about Mexico, and I am sure that in so far as concerns the fulness of that information and the most recent data, my article stands above any previous publication on the subject. 
to call attention to that country, and awaken a desire for reading other and better monographs and books on Mexico written by more competent men. I have borrowed from the descriptions of others, especially in what appears under the heading of Geology, Geography, and Fauna. 


\section{PART I.}

GEOGRAPHY 



\section{GEOGRAPHY.}

LOCATION, BOUNDARIES, AND AREA.

Location.-Mexico is situated between $14^{\circ} 30^{\prime} 42^{\prime \prime}$ and $32^{\circ} 42^{\prime}$ north latitude, and between $86^{\circ} 46^{\prime} 8^{\prime \prime}$ and $\operatorname{II}^{\circ} 7^{\prime} 31^{\prime \prime} 89$ longitude west of the meridian of Greenwich, embracing therefore $18^{\circ} 11^{\prime} 18^{\prime \prime}$ of latitude and $30^{\circ} 2 \mathrm{x}^{\prime} 23^{\prime \prime} 89$ of longitude. It has an area of 767,326 square miles. It is bounded on the north by the United States of America, on the southeast by Guatemala and Belize, on the south and west by the Pacific Ocean, and on the north and east by the Gulf of Mexico and the Carribean Sea.

Boundary with the United States.-The boundary with the United States is fixed by the treaties of February 2, 1848 , and December 30 , 1853 , and begins at the mouth of the Rio Grande River on the Gulf of Mexico, follows the river for I 136 miles, beyond El Paso, Texas, to the point where it strikes parallel $3 \mathrm{r}^{\circ} 47^{\prime}$ north latitude, and from there runs along said parallel for a distance of one hundred miles, and thence south to parallel $3 \mathrm{I}^{\circ} 2 \mathrm{O}^{\prime}$ north latitude; from there west along this parallel as far as the IIIth meridian of longitude west of Greenwich; thence in a straight line to a point on the Colorado River, twenty English miles below the junction of the Gila; thence up the middle of the said River Colorado to the intersection with the old line between Upper and Lower California, and thence to a point on the Pacific Ocean, distant one marine league due south of the southernmost point of the Bay of San Diego ; the total distance from El Paso to the Pacific being 674 miles. The whole extent of the boundary line between the two countries is 1833 miles.

The boundary line with the United States runs from southeast to northwest, the mouth of the Rio Grande being in $25^{\circ} 57^{\prime} 14^{\prime \prime} 74^{\prime \prime \prime}$ north latitude; while the line reaches on the Pacific latitude $32^{\circ} 32^{\prime} 1^{\prime \prime} 34^{\prime \prime \prime}$; the point where the boundary line strikes the Colorado River is farther north, reaching $32^{\circ} 4^{\prime}$ of north latitude. Mexico has, therefore, on the western, or Pacific side, $6^{\circ} 34^{\prime} 4^{\prime \prime} 20^{\prime \prime}$ of latitude more than on the eastern or the Gulf of Mexico side. 
Boundary with Guatemala.-The boundary with Guatemala is fixed by the treaties of September 27, I882, and April I, 1895, and runs from a point on the Pacific coast three leagues distant from the upper mouth of the River Zuchiate, and thence, following the deepest channel thereof, to the point at which it intersects the vertical plane which crosses the highest point of the volcano of Tacaná, and distant twentyfive miles from the southernmost pillar of the gate of Talquian, leaving that gate in the territory of Guatemala; the determinate line by the vertical plane defined above until it touches the River Zuchiate at the point of its intersection with the vertical plane which passes the summit of Buenavista and Ixbul ; the determinate line by the vertical plane which passes the summit of Buenavista, determined by the astronomical observations, and the summit of the Ixbul hill from where it intersects the former to a point four kilometres beyond said hill; thence to the parallel of latitude which crosses the last-named point, and thence eastward until it reaches the deepest channel of the Chixoy up to its junction with the Usumacinta River, following that river until it reaches the parallel situated twenty-five kilometres to the south of Tenosique in Tabasco, to be measured from the principal square of that town; the parallel of latitude referred to above, from its intersection with the deepest channel of the Usumacinta, until it intersects the meridian which passes at one third of the distance between the centres of the Plazas of Tenosique and Sacluc, this distance being calculated from Tenosique; from this meridian, from its intersection with the parallel above mentioned to the latitude of $17^{\circ} 49^{\prime}$; and from the intersection of this parallel with the latter meridian indefinitely toward the east.

The southern end of the Guatemalan line on the Pacific is in $14^{\circ} 24^{\prime}$ north latitude, while the northern end, on the Caribbean Sea, is in $17^{\circ}$ $49^{\prime}$ north latitude, being a difference of $3^{\circ} 25^{\prime}$ in favor of the latter. The calculated length of the southern boundary is 642 miles.

Boundary with Belize.-To the southeast of Yucatan extends the territory of Belize, occupied by a British settlement under a permit granted to them by the Spanish Government to cut wood within the limits mentioned in the treaty concluded between the Kings of Great Britain and Spain on November 3,1783 , and amended on July I4, I 786 .

British Honduras, according to Mr. George Gil, F.R.G.S., in his book, "British Colonies," published in London in 1896 , was declared a separate colony of Great Britain, under a Lieutenant-Governor subordinate to the Governor of Jamaica, in the year I862, previous to which time it had been a dependency of Jamaica. In 5884 a Governor and Commander-in-Chief was appointed, by Letters Patent, and thus the colony became independent of Jamaica. On April 30, 1859, Great 
Britain signed a treaty with Guatemala, within whose boundaries most of British Honduras was situated, defining the boundary of that colony.

The limits between Mexico and Belize are defined by a treaty signed at the City of Mexico on July 8, 1893, and ratified by the Mexican Senate on April 19, I897, and begin at the mouth of Bocalarchicaa strait which separates the State of Yucatan from Ambergris Key and adjacent islands, runs along the centre of the channel between said islands and the mainland, in a southeasterly direction, until it reaches the parallel $18^{\circ} 9^{\prime}$ north latitude; thence northwesterly at an equal distance between two keys marked on the map annexed to the treaty, to meet the parallel $I 8^{\circ} 10^{\prime}$ north latitude; thence, turning toward the west, along the neighboring bay, as far as $88^{\circ} 2^{\prime}$ west meridian, thence toward the north until it reaches the parallel $18^{\circ} 25^{\prime}$ north latitude, thence it runs toward the west as far as meridian $88^{\circ} 28^{\prime} 32^{\prime \prime}$ north, this point being the mouth of the Hondo River; thence following its deepest channel, passing to the west of Albion Island and running up the Arroyo Azul until the latter stream crosses the meridian of the Garbutt Falls at a point north of the boundary lines of Mexico, Guatemala, and British Honduras; and from that point following the meridian of Garbutt Falls, running in a southerly direction up to $17^{\circ} 49^{\prime}$, north latitude which is the boundary line between Mexico and Guatemala, leaving the so-called Snoska or Xnobba River in a northerly direction and in Mexican territory.

Cession of Mexican Territory to the United States.-Mexico has ceded to the United States, by the treaty of Guadalupe-Hidalgo of February 2, 1848 , and the Gadsden Treaty of December 30, $1853,93 \circ, 590$ square miles, comprising over one-half of her former territory. The same cession is considered in the United States under three heads-first under the boundary treaty signed in Washington on April 25, 1838 , between the United States of America and the Republic of Texas, under which Texas was annexed to the United States in 1845 ; second, under the cession of the Guadalupe-Hidalgo Treaty, and the third under the Gadsden Treaty.

As Mexico did not recognize the independence of Texas until the treaty of Guadalupe-Hidalgo was signed, we consider that she only gave her consent to that annexation by said treaty, and therefore that the cession of territory made then to the United States embraced also Texas.

Mr. S. W. Lamoreaux, former Commissioner of the General Land Office, published in 1896 a map of the United States, which contained in detail the different sections of territory annexed to the same in different periods from France, Spain, Mexico, and Russia, where the Mexican annexations are clearly defined. From official data of that office, I take the following figures representing the area of each of the Mexican cessions : 
First, annexation of Texas, which embraces in whole or in part the following States and Territories :

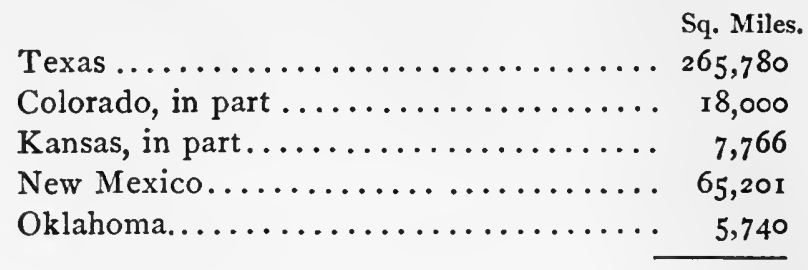

Total ................... $\quad 3^{62,487}$

Second, cession by the Guadalupe-Hidalgo Treaty, embracing in whole or in part the following States and Territories :

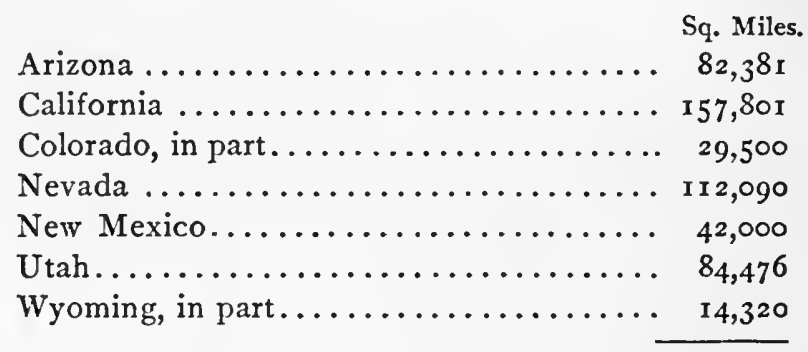

Total $\ldots \ldots \ldots \ldots \ldots \ldots \ldots \ldots \ldots \ldots \ldots$

Third, cession by the Gadsden Treaty, containing additions to the following Territories:

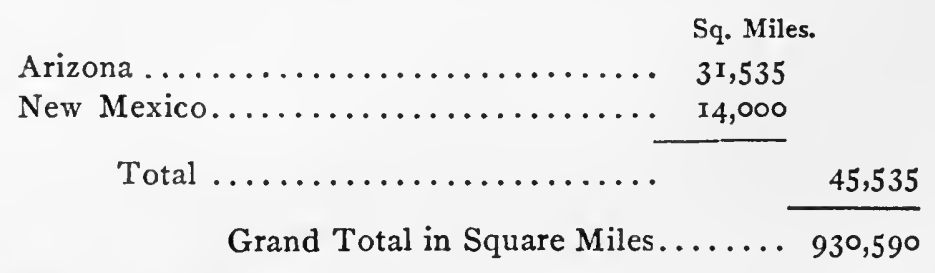

General Characteristics.-Mexico is bounded on the east by the long curve of the Gulf of Mexico and by the Caribbean Sea, and its eastern coast is 1727 miles long; on the west it is washed by the Pacific Ocean, its coast describing the arc of a still larger circle, for a length of 4574 miles; but after passing the latitude of the City of Mexico, about the meridian $19^{\circ}$ of north latitude, going south, the continent makes a decided turn towards the east, the Gulf of Mexico forming the northern border, and the Pacific Ocean the southern border.

Mexico has the shape of a cornucopia, with its narrowest end tapering toward the southwest, its convex and concave sides facing 
the Pacific and the Atlantic, respectively, and its widest end toward the north, or the United States. I look forward to the time, which I do not think far distant, considering our continuity of territory to the United States and our immense elements of wealth, when we shall be able to provide the United States with most of the tropical products, such as sugar, coffee, tobacco, india-rubber, etc., ${ }^{1}$ which they now import from several other countries.

The widest portion of Mexico is, therefore, its northern extremity, or its boundary with the United States. The narrowest point is the Isthmus of Tehuantepec, about one hundred miles from one ocean to the other ; and after passing it the country expands again to the southeast towards Yucatan and Chiapas until it reaches the boundary with Guatemala and Belize.

Yucatan resembles but little in its configuration Mexico proper, as it is a level country formed by coral reefs and beds, and whose ruins show it to have been the seat of a high civilization and an advanced people.

Although the greater part of Mexico is on the North American continent proper, as the Isthmus of Panama divides North from South America, a large portion of it lies in Central America. Geographically speaking, Central America is the portion of North America embraced between the Isthmus of Tehuantepec and Panama, and of this vast territory Mexico holds about one-third. In a paper published in the Bulletin of the American Geographical Society of New York, of March 3r, I894, I dealt especially with this subject. ${ }^{2}$

The broken surface of Mexico formerly made travelling there very difficult, for which reason the country was but little known, even by Mexicans themselves, as its configuration did not allow of the building of good roads, and to travel any considerable distance it was necessary to go by mule paths, without comfortable inns, and running great risks, owing to the disturbed condition of the country. It required, therefore, time, expense, endurance, and an object in view to travel widely there. I was always desirous of knowing as much as possible of the country, and I have made long trips, many of them on horseback, solely for the purpose of studying certain regions, and I think that before the railway era, I was perhaps one of the Mexicans who knew

${ }^{1}$ In his Notes on Mexico, Lempriere, a distinguished traveller and historian, says: "The merciful hand of Providence has bestowed on the Mexicans a magnificent land, abounding in resources of all kinds-a land where none ought to be poor, and where misery ought to be unknown-a land whose products and riches of every kind are abundant and as varied as they are rich. It is a country endowed to profusion with every gift that man can desire or envy; all the metals from gold to lead; every sort of climate, from perpetual snow to tropical heat, and of inconceivable fertility."

${ }^{2}$ A copy of that paper is appended to this article. 
most of the country and who could, therefore, most clearly realize the difficulty of knowing it thoroughly. From this it can be readily understood how difficult it would be for a foreigner, without any previous knowledge of the country and ignorant of its language, to know it by a few days' sojourn there. Yet many travellers who have been in Mexico only a few days write about it on their return home, just as if they knew it perfectly, making necessarily many serious and sometimes laughable mistakes.

The natural beauties of Switzerland are well known; but to me that country is hardly to be compared with Mexico, as everything in Mexico is on a much grander scale. In the latitude in which Switzertand is situated the snow line is quite low, and, therefore, most of the peaks of the Swiss mountains, while not so high as the Mexican mountains, are covered with perpetual snow, which embellishes the country, and which, melting in summer, supplies the beautiful lakes of that country with fresh water. Therefore, only in the beauty of many snow peaks, beautiful fresh-water lakes, good roads, and fine hotels has Switzerland the superiority over Mexico.

Historians, travellers, and writers of the present day compare Mexico with Egypt. There is no doubt that between the legends and romance with which the history of each of these countries abounds there is a striking resemblance. The pyramids and ancient relics in the form of buildings, images, and undeciphered hieroglyphics on stones, coins, etc., found in both countries, all contribute to the general belief that, centuries ago, the people of Mexico and Egypt were connected by some tie, were in some way of the same race and had the same ideas. To-day in Mexico, the manner of living, of cultivating the soil, and many other peculiarities in the manners and customs of the Mexican people forcibly remind the traveller of Upper and Lower Egypt. ${ }^{2}$

${ }^{1}$ In a very bright article about Mexico by Mr. Charles Dudley Warner, published in Harper's Illustrated Monthly Magazine for June, I897, I find the following sentence supporting my assertion :

"In the cities he is reminded of Spain, and of ten of Italy (since the Catholic Church prevails), but in the country and in small towns the appearance is Oriental, or rather Egyptian. This resemblance to Egypt is due to the color or colors of the inhabitants, to the universal use of the donkey as a beast of burden, to the brown adobe walls and mud huts covered with cane, to the dust on the foliage, the clouds of dust raised in all the highways, and to a certain similarity of dress, so far as color and rags can give it, and the ability of men and women to squat all day on the ground and be happy."

Mr. Theodore W. Noyes, of Washington, in a descriptive article on Mexico, published in December, I895, makes the following parallel between Mexico and Egypt:

". . . The Egyptian shaduf finds its counterpart in the well sweep of Irapuato where strawberries are grown and sold every day in the year, and where irrigation is resorted to, systematized, and on a grand scale. In the absence of trees and rocks 
I, myself, although I have only visited Lower Egypt, and that as a tourist in a very hasty manner and for a very few days, was greatly struck by the great similarity that I found between the two countries and between the habits of the native Egyptian and the Mexican Indians. The Egyptian plows are used by the Mexican Indians, and they are drawn in Mexico as in Egypt by oxen whose yokes are fastened to their horns, while in other countries they are fastened on their necks. Several of the agricultural products of Egypt and Mexico are exactly the same, and the way in which foods are prepared in both countries is, too, very similar; and I also found similar traits and race characteristics between the Egyptian Copts and some tribes of the Mexican Indians.

The great difference between Egypt and Mexico is that Mexico lacks "irrigation," which has made Egypt-that small corner of the earth-the most remarkable and productive country in the world. Owing to the great stretch of latitude from the Rio Grande to the Guatemala boundary, everything that grows in Egypt, and in fact in any other part of the world, can be produced in Mexico by the aid of irrigation.

the Egyptian shaduf is small, is composed of prepared timbers, and the counterpoise to the well bucket is an immense chunk of dried, hardened Nile mud. The Mexican shaduf utilizes a forked tree and swings across it a long tapering tree trunk or branch, and the counterpoise consists of a large sink stone or mass of stones fastened together. Although Mexico stretches farther south than Egypt, the two countries lie, generally speaking, between the same parallels of latitude, but the altitude of Irapuato is 5000 feet above the sea-level of the Nile, so that the same degree of undress is not expected or found in the Mexicans as in the Egyptian shaduf workers. I saw, however, in the neighborhood of Irapuato two Indians at well sweeps working side by side who were dressed only in white cotton loin cloths, who looked like the twin brothers of shaduf workers whom I have seen photographed on the Nile. . . . The watercarrier of Cairo is much like his brother of Guanajuato, where a long earthen jar is used. The groups about the fountains with jars of water bodily borne on the women's heads or on a protecting turban-like ring, or balanced on the men's shoulders, are also Oriental. Corn is ground between two stones in Asiatic fashion.

"Egyptian sand spouts are common. Also Egyptian types of domestic utensils of pottery. The Mexican woman with a baby at her back securely fastened in the reboso, which throws the infant's weight on the mother's shoulders, is to be compared with the Egyptian woman whose reboso covers her face while the child straddles her shoulders, holding to her head and leaving her hands unfettered as in the Mexican fashion. There are no Egyptian camels, but even more numerous donkeys, the patient burros. The Indian villages, either of adobe or bamboo, the thatched roofs and organ cactus fences, and alive with goats, donkeys, or snarling curs, are African in effect. There Aztecs picture writings resemble the Egyptian, the paper being made from the maguey instead of the papyrus. The Aztecs employed captives on great public works as in Egypt. Mexico thus has pyramids with much broader base than those of Egypt, though not nearly so high, and idols quite as ugly. Gold ornaments, beads, and other highly prized antiquities are found in the tombs as in Egypt." 


\section{GEOLOGY.}

The geology of Mexico has been but imperfectly studied. In the higher ranges the prevailing formations are granite, which seem also to form the foundations of the plateaus, above which rise the traps, basalts, mineral-bearing porphyries, and more recent lavas. Hence, Lyell's theory that Mexico consisted originally of granite ranges with intervening valleys subsequently filled up to the level of the plateaus by subterranean eruptions. Igneous rocks of every geologic epoch certainly form to a large extent the superstructure of the central plateau. But the Mexican table-land seems to consist mainly of metamorphic formations which have been partly upheaved, partly interpenetrated, and overlaid by igneous masses of all epochs, and which are chiefly represented by shales, greywacke, greenstones, silicious schists, and especially unfossiliferous limestones. All these formations are alike remarkable for the abundance and variety of their metalliferous ores, such as silver, silver glance, copper, and gold. Gneiss and micaceous schists prevail in Oaxaca and on all the southern slopes facing both oceans. But the highest ranges are formed mainly of plutonic and volcanic rocks, such as granites, syenites, diorites, mineral-bearing trachytes, basalts, porphyries, obsidian, pearlstone, sulphur, pumice, lavas, tufa, and other recent volcanic discharges. Obsidian (itzli) was the chief material formerly used by the natives in the manufacture of their cutting implements, as shown by the quarries of the Cerro de las Navajas (Knife Cliff), near Real del Monte and Pachuca in the State of Hidalgo. Vast deposits of pumice and the purest sulphur are found at Huichapam and in many of the craters. But immeasurably the most valuable rocks are the argentiferous porphyries and schists of the central plateau and of Sinaloa, unless they are destined to be rivalled by the auriferous deposits of Sonora. Horizontal and stratified rocks, of extremely limited extent in the south, are largely developed in the northern states, and chalk becomes very prevalent towards the Rio Grande and Rio Gila valleys. To this chalk and to the sandstones are probably due the sandy plains which cover vast tracts in North Mexico, stretching thence far into New Mexico and Texas. Here the Bolson de Mapimi, a vast rocky wilderness inhabited until recently by wild tribes, occupies a space of perhaps 50,000 square miles in Coahuila and parts of the surrounding States.

None of the horizontal layers seem to be very rich in ores, which are mainly found in the metamorphic, palæozoic, and hypogene rocks of Durango, Chihuahua, and the south. Apart from Sinaloa and Sonora, which are now known to contain vast stores of the precious metals, nearly all the historical mines lie on the south central plateau at elevations of from 5500 to 9500 feet. A line drawn from the capital to Guanajuato, and thence northwards to the mining town of Guadalupe 
y Calvo of Chihuahua, and southwards to Oaxaca, thus cutting the main axis of upheaval at an angle of $45^{\circ}$, will intersect probably the richest known argentiferous region in the whole world.

Of other minerais the most important are copper, found in a pure state near the city of Guanajuato, and associated with gold in Chihuahua, Sonora, Guerrero, Jalisco, Michoacan, and elsewhere; iron in immense masses in Michoacan and Jalisco, and in Durango, where the Cerro del Mercado is a solid mountain of magnetic iron ore; lead associated with silver, chiefly in Oaxaca ; tin in Michoacan and Jalisco ; sulphur in many craters; platinum, recently found in Hidalgo ; cinnabar, also recently found in Morelos and Guerrero; "steppe salt" in the sandy districts of the north; "bitter salt" at Tepeyac and many other places ; coal at various points ; bismuth in many parts ; marble, alabaster, gypsum, and rock-salt in great abundance throughout the plateaus and the sierras.

MINING.

Mexico is, perhaps, the richest mining country in the world, and the production of silver-notwithstanding the imperfect methods and other drawbacks with which it has contended-represents over one-third of the product of the world, according to official statistics. Almost all the mountains of Mexico are of the metalliferous character, but those which seem richest in mining deposits are the western cordillera, extending from the State of Oaxaca to Sonora, a distance of about 1600 miles from northwest to southeast.

Humboldt gave as his opinion that Mexico would be " the treasure house of the world." Subsequent history has, in a great measure, confirmed the opinion of the great savant of his time. Still a more conservative authority has quite lately asserted that only one-tenth of the mining resources of Mexico is known. This last estimate, I am sure, is inside rather than outside of the facts. Mexico has always been considered the great silver producer, and, considering her area, and taking the century as a measure, she is the greatest silver producer of the world.

Silver.-The central group of mines in the three mining districts of Guanajuato, Zacatecas, and Catorce, in the States of Guanajuato, Zacatecas and San Luis Potosi, which have yielded more than half of all the silver heretofore found in Mexico, lies between $2 \mathrm{I}^{\circ}$ and $24^{\circ} 30^{\prime} \mathrm{N}$., within an area of about 13,000 square miles. Here the Veta Madre lode of Guanajuato alone produced $\$ 25^{2,000,000}$ between $155^{6}$ and I 803 .

In the beginning of this century Humboldt found two Guanajuato mines-the famous "Conde de Valenciana" and the "Marques de Rayas"-producing annually 550,000 marks, 4,400,000 ounces, of silver, 
one-seventh or one-eighth of the entire American output. From January I, I 787 , to June II, I 79 I, the Valenciana yielded $\mathrm{I}_{3}, 896,4 \mathrm{I} 6$ ounces of silver, its ore averaging a little over roo ounces to the ton. Though flooded, this fine old mine is still far from exhausted.

Gold occurs chiefly, not on the plateau in association with silver, but on the slopes facing the Pacific, and apparently in greatest abundance in Sonora, near the auriferous region of Lower California. The production would have been larger if an improved process of reducing the metals had been used, but during the whole colonial period and up to the present time, we have used the patio system, which consists in grinding the ore, stirring it until it is reduced to a fine dust and mixing it then with salt and copper amalgam; after the paste dries somewhat, salt is added in proportion to the amount of silver supposed to be in the ore; the material is then mixed with shovels and trodden by mules, and, after a day or two, another mixture of copper, vitriol, and salt is added; after that it is mixed and trodden again; then quicksilver is finally added, and then more mixing and treading. This process is repeated from five to fifteen times until the silver and quicksilver unite to form an amalgam, which is gathered into bags, and that requires about forty days. Most of the quicksilver is squeezed out and the rest is evaporated and run off into tubs. This method saves 50 or 60 per cent. of rich ore and, besides being very long, is rather imperfect, as it leaves a great deal of silver in the ore, and only rich ores could be treated by it ; but it was on the whole the easiest and cheapest.

Some of the old mines were worked until finally they became so deep that, with the methods then used, as buckets were employed instead of pumps, and steam had not been employed as power, it was impossible to drain them. Naturally in a deep mine the water flows in from springs, and the deeper a mine becomes the more water it has. These mines were worked until it was seen that it was impossible to drain them, and then they were abandoned, even though they were rich in metals. During our war of independence almost all the mines were abandoned for the want of guarantee to life and property, and the mining industry, therefore, declined considerably ; but recently the old mines have been worked again and the production of silver has increased very considerably. ${ }^{2}$

${ }^{1}$ Mr. J. A. R. Waters of the firm of Waters Bros., Mining Engineers of the City of Mexico, said of his visit to the Jesus Maria District of the State of Chihuahu, where he went to examine the mine worked by the Pinos Altos Co., as follows:

" The district is very thoroughly mineralized and is pierced by veins more frequently than any district I ever saw. The general formation is very similar to that of Cripple Creek, with the exception that it is not traversed by the great porphyry dikes that occur there and in other parts of Colorado. The country formation is largely braccia. The ore is generally free milling, and is treated with stamps and pan amalgamation, the finer ores being treated with Huntington mills. There is little waste of values." 
Real del Monte Company.-It would be interesting to refer briefly to the ups and downs of one of the mining enterprises of Mexico-the Real del Monte-as a typical case which exemplifies what has happened with many other of our mines, namely, that sometimes they yield large profits, and soon afterwards they cause tremendous losses. The Real del Monte is located about three miles from Pachuca, a large mining centre and the capital of the State of Hidalgo, distant about sixty miles southeast of the City of Mexico.

In I 739, a Biscayan, by the name of Don Pedro Jose Romero de Terreros, came from Santander and settled in Queretaro. He acquired a fortune of $\$ 60,000$ in a small store in 1749 , closed up his affairs, and started to return to his native land. . On reaching Pachuca he met an old mining friend, Don Jose Alejandro Bustamante, who called his attention to the Real del Monte. In company with Bustamante he staked out the Biscaina, Santa Brigida, and Guadalupe mines and began to get the water out, but they soon exhausted their united funds. However, they succeeded in raising money in the City of Mexico on hard terms and drained their properties by a tunnel, which started at Moran, on the northern slope of the mountains, and, running 9000 feet through hard porphyry rock, struck the vein at a depth of 600 feet. This was accomplished a few years later in 1759 . Bustamante by this time had died, but Terreros continued the work. On striking the vein he drained it, and in 1760 began the erection of the Hacienda de Regla, to work the rich ore he was taking out. He took out $\$ 15,000,000$ at a small cost, repaid his advances, built and presented to the King of Spain a man-of-war and 4700 bars of silver, for which he was created Conde de Regla. He lived in grand style in the City of Mexico, and built a palatial residence on Cadena Street.

He died in 1781 , and was succeeded by his son, the second Conde, who from 1774 to 1783 struggled with the water, which, as depth was attained, was very severe ; according to Ward, twenty-eight horse-whims were employed in the drainage at great expense and unsuccessfully. However, they had gotten down to 324 feet below the Moran adit on the Biscaina vein in the Guadalupe and Santa Teresa shafts. The production was $\$ 400,000$ per year, drainage costing $\$ 250,000$ per year, and sinking was abandoned, and the work was confined to drifting above water level.

From I80I to I $809, \$ 300,000$ per year was taken out, but the cost of extraction was severe. Humboldt visited the property, and in 1810 the war of independence broke out, and all operations were suspended. Meanwhile the water rose and the Moran tunnel caved in, and so allowed the water to rise to an enormous height, and the district went to rack and ruin.

In 1822 the Conde's administrator, Don Ignacio Castelazo, made a 
report, and by his Italian mining friend, Rivafinoli, sent it to the Conde, who was living in England.

That country was only too anxious to reap for themselves some of the spoils that Spain had gleaned from Mexican mines. Here was their opportunity, many became interested, and the celebrated mining expert of that day, Mr. John Taylor, the founder of the present London firm now so heavily interested in South Africa, Taylor Bros., was sent to make an examination, and in 1824 the English Real del Monte Company was formed on the following terms:-The company leased the mines and haciendas for twenty-one years: Ist. The capital invested was to be returned from the products of the mines with interest ; $2 d$. The Conde was then to have one-half of the remaining proceeds yearly; 3 d. Meanwhile he was to receive $\$ 16,000$ per year as an advance against his portion or anticipated profits. In case of failure of this third clause the lease would be cancelled and everything revert to the Conde. As the outlay amounted to over $\$ 5,000,000$ and no profit ensued, it amounted to a rent of $\$ 16,000$ per year.

In I 824 Captain Vetch, of the Royal Engineers, was sent out as manager. He brought three ships filled with one thousand tons of machinery, pumps, etc., and after untold trials in transportation and erection, finally got them to their destination. All this was done by English engineers, machinists, miners, and workmen, nearly all Cornishmen, under the direction of Colonel Colquhoun, a Peninsular veteran, who finally died of yellow fever with over fifty of his men. After unheard-of troubles they got everything by 1826 safely landed in the Real del Monte. The magnitude of the task may be understood when the almost roadless condition of the country is considered, and the bringing up of the machinery from the coast was a splendid example of British tenacity and pluck.

Captain Vetch had now cleaned out the Moran adit and the Dolores shaft, and the machinery was at once erected. The stock now rose from $\$ 500$ to $\$ 8000$ per share. The Conde had, in the meanwhile, borrowed money from the company and made the twenty-one-year lease perpetual, the annual rent of $\$ 16,000$ remaining in force.

By 1829 Captain Vetch had grappled with the water question, and with an annual cost of $\$ 30,000$ had accomplished what the first Count had paid $\$ 250,000$ for, and extracted metal 324 feet below the Moran adit.

Captain Tindall, R.N., succeeded Captain Vetch, and a new shaft (1830) was commenced on the Santa Teresa and called the Terreros shaft. It was 1140 feet to the vein and was started at four points, and was connected in 1834 by drifts run from several levels, and then raised and sunk on. The work came out as true as if it had been done from the surface, thanks to the correctness of the plans of the English mine surveyors. 
A 54-inch engine was erected, and with it they sank to 720 feet below the Moran adit. At this point water overpowered them. This was in 1838 , and Captain John Rule, who had succeeded Captain Tindall, put in a 75-inch engine at Dolores, and removed the 54-inch one to Acosta. Captain Rule enjoyed a salary of $\mathcal{E}_{10,000}$ per year, and all other payments were in proportion. He struck two bunches of rich ore, one on the Santa Brigida, near Acosta, and the other on La Biscains, near Dolores. From these two and one at Torreros they had produced $\$ 10,481,475$ at a cost of $\$ 15,381,633$ or nearly $\$ 5,000,000$ loss in twenty-three years. By 1846 the stock had fallen to $\$ 12.50$ from $\$ 8000$ a share.

In 1848 , Mr. J. H. Buchan arrived, representing the English stockholders. He found water in the mines and increasing; a heavy debt of $\$ 5,000,000$, bearing a tremendous interest; no money on hand and no ore. So in October, $\mathbf{1} 848$, by order of the bondholders he turned over the business to a Mexican company-the present one-composed of Manuel Escandon, Antonio and Nicanor Beistegui, Mr. Mackintosh, and others for the paltry sum of $\$ 130,000$. The haciendas, stock, and ores on hand were worth millions, but the English company could not dispose of them.

This was the end of the famous English Real del Monte Company. Their Mexican successors reduced expenses, completed the adit from Omotitlan commenced by the first Conde, which, running 13,500 feet, cut the mines I I Io deeper and struck immediately the bonanza in the Rosario, which tradition says had previously been discovered and covered up by Captain Rule.

New Mines, Topia.-We have now a great many districts that were not known by the Spaniards and have recently been discovered. Notable among them is the Sierra Mojada district in the State of Coahuila. The State of Durango has, on the west slope of the Sierra Madre mountains, the mining camps of Topia, Sianori, Birimoa, Gusanillas, Canelas, Ventanos, El Pando, Rodeo, and San Fernando; and with the exception of San Fernando they are close together, a square, one of whose sides is forty miles, would almost cover them all. This section has all the elements to form the basis of a great mining and smelting centre, as is evident by the great deposits of galena in the Topia district; in fact, this is the only place on the coast where lead ore is found in abundance ; and smelting, if done at all, must rely on Topia for its supply of lead ores. In no other part of Mexico are lead ores so cheap, because of the fact that to realize on them at all they must be transported on mule-back to Culiacan in the State of Sinaloa, a distance of 106 miles, at a rate of $\$ 26.40$ silver per ton, and from there by rail to Altata, a distance of thirty-nine miles ; and from Altata by steamer to San Francisco, or to Guaymas, and thence by rail to the vol. I. $\rightarrow 2$ 
smelters in the United States, very much at the same cost. La Liona mine of this district is a very rich mine, its vein being almost vertical, and is tapped from both sides of the mountain, with tunnels at right angles to the vein. Where the tunnels intersect the vein, the vein is driven on in both directions from the tunnels; stopes are opened, and chutes for ore are put in every seventy-five feet. The vertical distance between the tunnels is 125 metres. This mine can easily produce one thousand tons per month of clean galena, and would produce that much metal if there was a market for it.

There are other mines as large and perhaps better than La Liona, as, for instance, La Madrugada mine, formerly owned by Santa Fé Railroad employees, but now controlled by Mr. Charles Miller, of Franklin, Pa., connected with the Standard Oil Company. Topia is a great dry-ore camp as well. One thousand tons of dry ores can easily be mined there per month, were there a market for them, such as a commercial smelter located centrally to treat the ores of this and adjoining districts. Such smelter would have the advantage of an inexhaustible supply of good water the year round, fine iron ore, and limestone for fluxes.

At Topia there are four mills for the treatment of zincy ores, and dry ores assaying below one hundred ounces silver per ton. The lixiviation process by hyposulphite of soda is employed in the four mills or haciendas, two of them employ occasionally the patio process as well. Two of the mills and two mines are lighted by electricity; the dynamo that furnishes light for one of the mills and both of the mines is driven by water power. Below the mills operated by water power, there is sufficient fall and sufficient water to furnish the power to operate compressed-air drills in all the large mines.

The other mining camps of this district, although not so well developed as Topia, are also in process of development and in a very good condition. Velardeña is also in the State of Durango, but on the other or eastern side of the mountains, and is located in a comparatively new district, where the previous owners had failed. Mr. James F. Mathews purchased the Velardeña property, erected a smelter after the International Railroad Company had extended their main line from Torreon to the city of Durango, passing near the mine, and from the beginning has run five of the six furnaces almost continuously. During 1896 the Velardeña smelter smelted on an average 175 tons of ore per day.

Li Hung Chang and the Mexican Silver Mines.-When Li Hung Chang, the Chinese Viceroy, was in Washington, in August, 1896, he inquired of me about the production of the Mexican mines, and I, trying to be conservative, informed him that they produced about $\$ 50,000$,000 a year. He then inquired how long they would continue yielding that amount. I answered that it was uncertain, but that, judging from present appearances, it could safely be said that it might be for one 
hundred years. This seemed incredible to him, and he said that I had been so long absent from Mexico-for he had previously asked me how long $I$ had been in this country-I could not know the real wealth and abundance of our mines, and he was very positive that I had made a mistake. He assured me that the silver mines in China yielded occasionally something, but soon were exhausted, and it was impossible to get any silver out of them, and judging the Mexican silver mines from those he had seen at home, he was, of course, incredulous as to their yield.

Some years ago, and when the Mexican mines only yielded about $\$ 20,000,000$ a year, I predicted that their annual yield would reach $\$ 100,000,000$, and that prediction is about being verified, as the present product exceeds $\$ 60,000,000$.

Gold.-Gold was used freely in Mexico before the Spanish conquest, and history teaches us how Cortez induced Montezuma to deliver to him his gold treasury.

As soon as Mexico was conquered, Bernal Diaz del Castillo, one of the cotemporary historians, tells us that Cortez inquired very carefully about the place where the Indians obtained their gold, whether there were placers, mines, or washings, and his agents were taken to some localities in the State of Oaxaca, where they were told was the gold supply, but, whether the Indians concealed the real location of the gold deposits, or for other reasons, the Spaniards did not obtain much gold. I have known recently of unavailing efforts having been made of persons from the United States who have tried to ascertain the localities where the Indians obtained their gold, that is-the places which were shown to Cortex in Oaxaca as gold deposits.

There is a river in the State of Guerrero which flows over a country with hills abundant in gold formation, which carries nuggets that the natives find without any difficulty, and it is called for that reason the Gold River. That river passes over some mountains where gold is found, and then comes to a place where a natural dam is formed, and the gold carried by the washings in the rainy season sinks when reaching that place, and every indication shows that there must be a very large deposit of gold there. A military engineer suggested, the last time I was Secretary of the Treasury in Mexico, that the bed of the river be changed by the Mexican Government, a work which did not present serious obstacles, and thus allow excavations to be made and the gold deposits found. It was thought advisable to make some preliminary examinations in the way of boring, and for that purpose the necessary orders were issued to send soldiers there, but I understand the project was given up and nothing was accomplished. I have no doubt that at some future time that matter will be taken up, and a great deal of gold will be found there. 
Our production of gold has so far been comparatively small, because the mining and reduction of gold are more difficult and expensive than the same operations in silver, and our gold production has really been the amount of gold which has been found in our silver. For many years, when the amount was small, it was not separated, and for that reason old Mexican dollars have in China greater value than newly coined ones; but recent improvements have made it easy and cheap to make the separation of the two metals. Now that gold has risen so much in value, its mining is beginning to be developed in Mexico on a comparatively large scale, and I have no doubt that before long Mexico will be one of the largest gold producers of the world.

Mexico is an undeveloped country, in fact there are parts of Mexico as unknown as was Central Africa a few years back. From the Sonora gold district, south, on the west side of the Sierra Madre, to the State of Oaxaca, there is a gold belt as rich as California, Alaska, and South Africa combined. It is known that in the State of Sinaloa there are gold placers and gold washings, and that they are also found in every State from there south on the line of this belt. ${ }^{2}$

The gold output of Sonora, now beginning to attract attention, is only the first contribution of Mexico to the world's stock of the yellow metal. The west side of the Sierra Madre has a belt rich in gold, and when the world discovers this fact capital will flock to Mexico to dig it out, and Mexico will become one of the first gold producers of the world, as she has been in silver.

Specimens of "float" rich in gold have been brought from the State of Guerrero. These indications of gold have not been followed up, because no one has been progressive enough to advance the means necessary to prospect this belt. To prospect in a country where often water fit to drink must be carried, where food for man and beast must be carried, and where in many places roads must be cut with machete and axe, cannot be done without the spending of money in outfit and expenses.

The principal gold-producing States will be Sonora, Sinaloa, Guerrero, and Oaxaca, but in all of them gold-mining is yet in its beginning.

${ }^{1}$ I take from a report of Mr. Cramer, a mining engineer sent to Mexico by the Geological Society of Washington, D. C., as Commissioner to explore the gold fields of that Republic, the following, which refers to only one of the many new gold fields that are being found there :

"There exists an extensive 'gold placer' situated about thirty miles from Durango in the mountain devoid of vegetation; the rock that is found in greater quantities is porphyry. I estimate that one ton of ore will yield at least $\$ 50$ of gold.

"Gold is found all over the mountain, though in such imperceptible filaments that it is hard to recognize it with the naked eye ; however, every piece of stone contains the same proportion of gold." 
Coinage of the Precious Metals.-Mexico has produced about onehalf of the silver supply of the world. In the statistical portion of this paper I shall give full details of the production of gold and silver in Mexico, coinage, etc., and here I will only append the total coinage of gold and silver according to official statistics of the Mexican Government, which is the following:

COINAGE OF MEXICO FROM THE ESTABLISHMENT OF THE MINTS IN I537 TO THE END OF THE FISCAL YEAR OF I896.

\begin{tabular}{|c|c|c|c|c|}
\hline COLONIAL, EPOCH. & GOLD. & SILVER. & COPPER. & TOTAL. \\
\hline 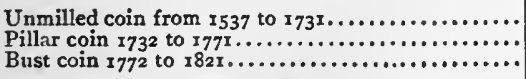 & $\begin{array}{r}8,497,950 \\
19,889,014 \\
40,391,447\end{array}$ & $\begin{array}{r}752,067,45^{6} \\
441,629,211 \\
888,563,989\end{array}$ & $\begin{array}{r}200,000 \\
342,893 \\
\end{array}$ & $\begin{array}{l}760,765,406 \\
46 \mathrm{I}, 518,225 \\
929,298,329 \\
\end{array}$ \\
\hline INDEPENDENCR, & $\$ 68,778,411$ & $\$ 2,082,260,656$ & $\$ 542,893$ & $\$ 2,151,5^{81}, 960$ \\
\hline $\begin{array}{l}\text { Iturbide's Imperial Bust, from } 1822 \text { to } 1823 \ldots \ldots \ldots \\
\text { Republic Eagle-1824 to } 30 \text { June, } 1873 \ldots \ldots \ldots \ldots\end{array}$ & $\begin{array}{r}557,392 \\
45,040,628 \\
\end{array}$ & $\begin{array}{r}18,575,569 \\
740,246,485 \\
\end{array}$ & $\$ 5,235,177$ & $\begin{array}{r}19,132,96 x \\
790,522,290 \\
\end{array}$ \\
\hline REPUBLIC. & $\$ 45,598,020$ & $\$ 758,822,054$ & $\$ 5,235,177$ & $\$ 809,655,251$ \\
\hline Eagle coin, from I July, 1873 , to $3 \circ$ June, $1896 \ldots$ & $\$ 11,561,080$ & $\$ 557,5^{81}, 690$ & $\$ 203,296$ & $569,346,066$ \\
\hline
\end{tabular}

SUMMARY.

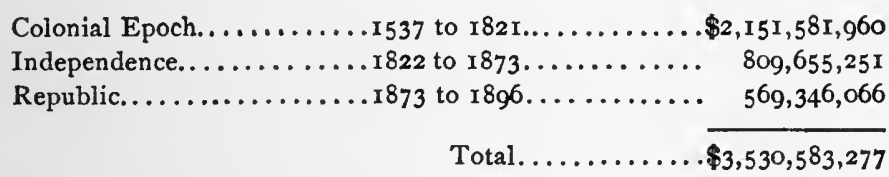

Iron.-Iron, the most useful of all the metals, is found in such vast abundance in Mexico that, could it be even partially utilized, that Republic would become one of the wealthiest of modern communities. One of the largest mines was discovered by Gines Vazquez del Mercado, in Durango, in $\mathbf{1 5 6 2}^{6}$, and its appellation of "Cerro del Mercado" still preserves his name. The hill, which is 4800 feet long by I Ioo feet in width and 640 feet in height, is almost a solid mass of mineral, averaging about seventy per cent. of metal and from which could be extracted more than $300,000,000$ tons of solid ore; this only to the level of the plain, beneath which it probably extends to an unknown depth.

The iron is also magnetic to a high degree and its power is greater when the grain is fine. This may delay fusion, but the result is an excellent wrought iron, with none of the inconveniences caused by earthy substances mixed with the iron. I have no doubt that when the coal mines are developed the iron industry will make great strides and that we will be able to manufacture most of at least the low grades of the iron goods required for our comsumption. In several other places besides our Iron Mountain we have iron with very little phosphorus, which makes first-class steel and is as good as the best produced in Cuba or Spain. 
The deposits of iron in Mexico are sufficient to supply the universe for centuries to come. There is but one thing lacking, and that thing is-cheap fuel. Nature never works by halves; those immense deposits of iron never were put where they are without the means near at hand for their utilization. Coal exists, but it has not been mined yet on a large scale, as it will be hereafter.

But even at the present time the principal supply of pig-iron comes from native ore, the output being consumed by the producers in the manufacture of iron goods. The main iron mines now being worked are located at Durango, Zimapán, Zacualtipán, Tulancingo, and Leon. For the most part these mines are found in the midst of great forests, in consequence of which cheap fuel is found in the form of charcoal, the iron made from which being of very superior quality, free from phosphorous, and, price and other things being equal, is always preferred to the imported pig. It is manufactured in charcoal furnaces exclusively.

There is, however, quite a considerable amount of pig imported, principally from Alabama, and Scotch pig from England. The great drawback to importations heretofore has been the immense quantity of scrap iron, which, during the lapse of centuries, had accumulated, unused, throughout the Republic. This, however, is becoming well-nigh exhausted ; and for that reason the demand for imported pig is increasing, the native output not keeping pace with the need for it. Much scrap iron also has come from railroads, another source of supply which is not increasing with the demand.

Imported pig ranges in price in the City of Mexico from $\$ 50$ to $\$ 60$ silver per ton, the native producers aiming to keep their price just about the same.

Iron Foundries.-There are in the City of Mexico, in addition to several small ones, seven large foundries, as follows: the Mexican Central Railroad foundry, the Mexican National Railroad foundry, the Artistic, the Delicias, Charreton Bros., V. Elcoro \& Co., and Hipolito David. There are also large foundries at Pachuca, Puebla, Chihuahua, Durango, and Monterey, as well as smaller ones at Irapuato, Guanajuato, Zacatecas, Veracruz, Guadalajara, Mazatlán, Oaxaca, and Morelia.

Copper.-Copper is now quite an important product of Mexico, and is used to a certain extent in the country, but as the supply far exceeds the home demand, it is exported to the United States and Europe. That which finds its way to this country enters chiefly in the form of matte, and is refined into casting or electrolytic copper. What goes to Europe is blister copper, or approximately so, from the Boleo mine in Lower California, where a French company is working a large group of copper mines. The point of most activity is Santa Rosalia, on the 
Gulf of California, where the company treats the ore in its own smelting plant adjoining. The matte, or black copper, is sent to Europe in the same vessels that bring out coke. The company gives employment to thousands of hands directly and indirectly, owns its own steamers, and solicits workmen all along the coast. But this enterprise, large as it is, shows the progress that has been made and the difficulties overcome by individuals. The country itself is arid and sterile, and there is little encouragement for others to prospect, or even develop, when found, apparently good prospects, owing to the natural difficulties to be overcome and the vast capital necessary to successfully carry on mining operations; as success is hardly to be obtained except by treating the ores on the ground, as the Boleo Company has done.

At the same time the enterprising firm of Guggenheim has established its works at Aguas Calientes, adding very considerably to the copper product, and the increase of matte shipments from San Luis Potosi and Monterey makes a large difference from former returns. To judge from the official figures, the amount of copper produced in I 896 was not less than 22,000 metric tons, the greater production being from the Boleo mines.

Quicksilver.-The production of quicksilver can only be approximated from imports, as the native production is far short of the requirements of the country. In I895 the amount imported was 8I 8,704 kilos, with a value of $\$ 54 \mathrm{r}, 664$, while during the past year the amount imported was 854,526 kilos, with a value of $\$ 574,153$. The only inference to be drawn from these figures is that the production in Mexico in the past year as compared with 1895 has not increased, and the figures of production given in the Engineering and Mining Fournal of I 895 may be accepted as correct for 1896 .

Coal.-Fuel is perhaps the greatest and most pressing need of Mexico. For centuries the population of the whole country has used wood for fuel, until the most thickly inhabited portions of the country are completely destitute of trees. This condition of things is a very serious objection to the increase of manufacturing, as it is impossible to manufacture cheaply when fuel commands a very high figure. Coal, which has to be transported sometimes for thousands of miles before it reaches the centre of the country, becomes very expensive. At present rates the cost of wood in the City of Mexico is equal to $\$ 14$ a cord, while coal ranges from $\$ 16$ to $\$ 22$ per ton according to grade, and one source of supply is the artificial fuel of compressed coal dust brought from England, and in use not alone on the Veracruz Railway, but in various local industries, while coal also comes from West Virginia, Alabama, etc. The distances of the sources of coal supply and its consequent cost led to the attempt of utilizing the peat deposits which 
are of great extent and practically inexhaustible within ten miles of the City of Mexico.

In the Tlahualilo district of the State of Coahuila, for instance, owing to the distance from the nearest coal mines, the question of fuel is very important, as there are at present more than three hundred horse-power in constant use, and the amount is steadily increasing. The main supply is from the mesquite brush, which is cleared from the new lands as the work of ditching and preparation advances. The hulls of the cotton seed also make a hot but quick fuel for some of the larger stationary engines. The wheat, straw and cotton bushes are utilized for brick-burning and for the domestic purposes of the laboring population.

Those acquainted with industrial conditions in Mexico and making investigations with a view to the establishment of new industries in that Republic, are consequently impressed with the fact that, in spite of the cheap labor, favorable climatic conditions, and good home markets, the lack of cheap fuel is exceedingly detrimental to a large proportion of the industries of this country ; but fortunately large deposits of coal are now being discovered in the Republic. At Salinas, in the State of Coahuila, a large bed of coal is being worked by the International Railroad Company, which furnishes fuel for that road and even for a portion of the Southern Pacific Railroad and for some of the manufactories in Monterey. In the district of Tlaxiaco, in the State of Oaxaca, a very rich coal-field has been discovered, but for the present it is inaccessible and before a railroad can be built to tap it it cannot be used, as the expense of transportation would be exceedingly high. Sonora contains a carboniferous area, several miles in extent, with innumerable veins from five to sixteen feet in thickness, of hard, clean, anthracite coal, carrying as high a percentage in fixed carbon as the best coal mined in Wales. The ledge is thirty miles in length and averages sixteen feet in width, showing a quantity sufficient. to supply the entire Pacific coast with anthracite coal of the first quality for years to come. The configuration of that State and the proximity of the sea make it comparatively easy to work it.

At Jiquilpan, State of Michoacan, almost immediately south from Negrete station on the Guadalajara branch of the Mexican Central Railroad, a large coal-field has been discovered. While it is not probable that either anthracite or first-class bituminous coal will be found in these fields, still the great value of even an ordinary class of coal will be appreciated by those acquainted with industrial conditions in Mexico. The coal measures of the Chapala district probably belong to the tertiary period, and lie in stratified rock overlaid by an outflow of basalt or lava, at an elevation of 250 or 300 feet above Lake Chapala. 'The general series of rocks has been examined and pronounced. 
as coal-bearing by an eminent geologist. The measures are quite extensive, being easily traced from Yurecuaro to near Ameca with occasional interruptions through volcanic intrusion. The developments already made, show that the coal or lignite veins extend over perhaps thirty square miles. How much beyond these limits, it would be impossible to state. It exists in considerable quantities. There are a number of veins overlying each other, and varying from two inches to fifty inches in width; but, as the explorations have not yet found the veins in place, it is impossible to say exactly what their condition will be. A feature which adds considerably to the value of these deposits is an extensive deposit of bog iron in the immediate vicinity. If further exploration discovers considerable quantities of commercially valuable coal, it is easy to estimate the results to the industries. Other beds of coal have been discovered but of less consequence, and in several of the northern states of Mexico there are known to exist large deposits.

Mexican industries will be completely revolutionized when they can use cheap coal instead of wood for all purposes, thus cheapening the cost of manufacturing by using cheaper fuel, which is so important an item of expense in manufacturing.

Mexican Miners. - While the laborers employed in Mexico will not compare in efficiency with the labor of the miner in the United States, it must be borne in mind that the American miner works eight hours and receives $\$ 3$ per day, or $\$ 6$ in Mexican money, and $\$ 6$ in Mexican money will employ from eight to twelve Mexicans, wages varying from 50c. to $75 \mathrm{c}$. per day. As for the climatic conditions, it is only necessary to say that in all the mining districts of Mexico a miner can work 365 days in the year. There is never any snow or cold weather in winter, and the heat in the summer is not so extreme as in St. Louis, Chicago, or New York, and never enervating. A pair of blankets at night are indispensable every night in the year.

Mining Lazes. - The mining laws of Mexico issued during the Spanish rule, which were kept in force until $\mathrm{r} 884$, were both liberal and wise, and were intended to encourage mining. The domain of the mines remained in the Government and it gave temporary titles to anybody who discovered one, and who was willing to work it, but only as long as work was done in the mine. When the discoverer or owner could not for any reason continue to work it, and allowed a certain time to elapse without doing any work, the mine reverted to the Government and anybody else willing to work it could obtain a temporary title over it. This system was changed, by our Mining Code of $\mathbf{1 8 8 4}$, to the effect of giving the mines in fee simple to the discoverers of the same, whether they were worked or not by those who denounced them, and the only cause for forfeiting the title is the failure to pay a 
tax of \$ro per pertenencia, a "pertenencia" being our unit of a mining property and consisting of a hectare or a square 100 metres on each side, equivalent to 2.47 acres. The rights of the owner of the land are not interfered with, and in case anybody discovers a mine upon another man's property, the landlord continues to own the surface, and all the discoverer is entitled to is the mineral underground and so much of the surface as is necessary to work it, for buildings and other mining requirements, and for that the owner of the ground is compensated by agreement, or, if no amicable agreement can be reached, by arbitration.

Mining litigation is quite rare in Mexico, and it does not take long to get a final decision, as mining cases are tried before a single judge, and appeals lie to the Supreme Courts of the different states, and to the Federal Supreme Court in Mexico. To the honor of the courts in Mexico be it said, as may also be said of the judiciary in the States and the United States Federal Courts, they are above reproach.

A concise statement of the provisions of the present mining laws of Mexico will not be out of place here.

The law grants to all inhabitants of the country the right to acquire and work mines. He has to denounce a new mine. A denouncement means making a location. When the location of a claim has been determined upon, all possible data are obtained concerning it before the denouncement is made. It may be a rich old mine, and yet if the law has not been complied with it is subject to relocation. The law grants to any inhabitant of the Republic the right to explore for mineral. All districts have their mining agents and all the prospector has to do is to have the regular form of petition used in making out a denouncement, as it is called, made out and submitted to the mining agent of the district. If there does not happen to be a mining agent in the district, the petition is presented to the local postmaster. The expense of registering the petition is $\$ \mathrm{I}$. After registering the petition, the mining agent has thirty days in which to appoint an expert to examine the property, who has eight days in which to reply to the summons, and if he accepts the service, the mining agent issues in duplicate a document stating that the claim has been denounced and directing objecting parties to make known their prior claims within a period of four months from the date of the denouncement, or forf eit any right to the property.

The charge of the expert for making a report upon the claim, together with the plans, is about \$15 per claim and travelling expenses. The expert has sixty days in which to send in his plans and report. The notification that the property has been denounced is published in the official journal of the district, the cost of which varies in the different states, from $\$ 2$ to $\$ 4$ being the usual fee. 


\section{IDining.}

The cost of making up a mining title is from $\$ 10$ to $\$ 12$. Titles, when once granted, unless fraud is shown, are irrevocable so long as the taxes are paid, which are ten dollars per year on each "pertenencia," and no work or manual labor is necessary to hold the same. The taxes may be paid quarterly or annually, at the discretion of the holder, to the mining agent of the district in which the property is denounced, or by special arrangement they may be paid at the office of the Federal Treasury in the City of Mexico. After the title is granted, it must be registered in the district where the denouncement is made, and also entered upon the books of the stamp office, for which no fees are charged.

\section{MINTS AND DUTIES ON SILVER.}

Under the Spanish laws all silver paid a duty; and as most of it was coined, that duty was levied on coinage, and the exportation of bullion was prohibited; but of course a great deal was smuggled, both during the Spanish rule and still more when Mexico was opened to foreign trade after our Independence. When I occupied for the first time the Treasury Department of Mexico in I868, it seemed to me an outrage against the mining industry of the country to require the miners-especially those who were far removed from the mints-to take their bullion from the mints, at a heavy expense and risk, coin it there and take it back to the mines, and from there to the ports to be exported to London, where it was often again turned into bullion; and as the contracts made with the lessees of the mints did not allow the free exportation of bullion, I proposed and succeeded in having enacted a law for the purpose of allowing bullion to be exported, provided that it paid the coinage duty at the respective custom-houses for the benefit of the mint's lessees; and this condition of things, extraordinary as it may seem, was a great relief to the silver producers, and continued until the Mexican Government could recover all the mints and be free to legislate on the subject, which it was able to do partially during my last incumbency of the Treasury Department; they all since having been recovered.

We had thirteen mints in the country to coin the silver extracted from our mines, which, in the precarious condition of the Mexican Treasury, were sometimes rented to private parties who advanced a sum that seemed large at that time, although it was a trifle in comparison to their profits, as they collected a duty of nearly $4 \frac{1}{2}$ per cent. upon the amount of bullion coined, and they credited to the Government only $I_{2} \frac{1}{2}$ per cent. of the same, the laws requiring that only coined silver could be exported. But now that silver can be transported easily from the mine to the mint, since a railway system has been built, the mints have been reduced to four, - one in the City of Mexico, which 
is the principal one ; one at each of the cities of Guanajuato, Zacatecas, and Culiacan, the last being the capital of Sinaloa.

Besides the mint or coinage duties, silver was taxed in Mexico with an export duty which sometimes was as high as twelve per cent. on the value of the silver, which, together with the mint duty, amounted to seventeen per cent., not taking into account other taxes and local duties. Only the rich character of the Mexican mines could stand that burden.

The duties on silver have been readjusted and reduced considerably, until now they only amount, as established by the law of March 27,1897 , to a coinage duty of two per cent. and a stamp duty of three per cent., which are paid at the Assay Office of the Mint when coined, or at the custom-house when exported in bullion, ores, or other compounds. When exported in ores in their crude condition, the duty has a rebate of ten per cent. A small duty representing the cost of the operation is also charged for assaying, refining, smelting, and separating the metals.

\section{SMELTING PLANTS.}

The Tariff Act of October 1, 1890 , having levied a duty upon lead ore, which prevented that Mexican product from coming into the United States in the shape it had come before, the American companies, who had been developing the lead ore in Mexico, established smelting plants in the country for the purpose of treating there the lead ore, and sending it as pig-lead to the United States.

The smelting plants that have been established in Mexico, and their capacity and output, taken from official data received from the Mexican Government, up to December 31, 1896, are the following:

Mexican Metallurgical Company. - This company, of which Mr. Robert S. Towne is president, obtained a charter from the Mexican Government on March 20, 1890 , to establish five smelting plants in Mexico, two with the minimum capacity of 200 tons a day, two of 150 tons, and one of roo tons. The first one is located at Morales, five kilometres west of the city of San Luis Potosi. During the fiscal year I 895 to 1896 , this plant received 62,370 and $020 / 1000$ metric tons of ore from the States of Chihuahua, Coahuila, Durango, Guanajuato, Jalisco, Mexico, Michoacan, Nuevo Leon, Queretaro, San Luis Potosi, and Zacatecas. This plant yielded during the same year 16,019 and $070 / 1000$ metric tons of base lead bullion, with 3,198,924.14 troy ounces of silver, valued at $\$ 4,882,177.5^{\circ}$; and 8268 and $37 / 100$ troy ounces of gold, valued at $\$ 161,338.63$.

National Mexican Smelter at Monterey.-This company, whose president is Mr. Daniel Guggenheim, obtained a charter from the Mexican Government on October 9, 1890 , to establish three smelting plants in Mexico, two with a minimum capacity of 300 tons per day, 
and one with roo tons. The first plant is located in the outskirts of the city of Monterey, has ten furnaces of the water-jacket system, and seven smelting furnaces for lead ore. From July, r892, to June, I8g6, this plant has smelted 521,809 and $769 / 1000$ metric tons of ore, yielding 78,067 and $14 \mathrm{I} / 1000$ tons of lead, with 515,382 kilograms of silver, with a value of $\$ 21,824,597.93$, having used foreign coke to the value of $\$ 1,474,385.81$, and Mexican coke to the value of $\$ 73,268.08$.

Central Mexican Smelter.-The second smelter of the Guggenheim Company is located at Aguascalientes. It has a department for concentrating copper ores, one for smelting the same ores, consisting of three furnaces, and another with four furnaces for smelting lead ores. This plant smelted from the 26 th of December, 1895,606 and $190 / 1000$ tons of lead, containing 6502 kilograms of silver and 28 and $71 / 100$ kilograms of gold, with a value of $\$ 341,09$ I.

Velardeña Mining Company.-This company, whose president is $\mathrm{Mr}$. Edward W. Nash, obtained a charter from the Mexican Government on May I 5, 1893, for the construction of two smelting plants in Mexico, with a capacity of 200 tons a day each. From November 30,1893 , to June 30,1896 , this plant smelted I 10,000 tons of ore, yielding 9069 and $680 / 1000$ tons of lead containing $1,850,685$ troy ounces of silver and 6192 ounces of gold.

The Chihuahua Mining Company.-This company, whose president is Mr. Jolnn B. Shaw, obtained a charter from the Mexican Government May 26, I893, and is located near the city of Chihuahua. Up to July 28 , 1896 , it had smelted 28,555 tons of lead ore, yielding 3761 tons of lead and 529,450 troy ounces of silver.

The Mazapil Copper Company, Limited.-This company established a plant at Concepcion del Oro, Zacatecas, and has smelted 5000 tons of lead ore containing silver.

Sabinal Mining and Smelting Company, Chihuahua.-This company owns the mines of Santa Juliana and Santa Inez, which yield 30 per cent. of lead, with a mixture of silver, and smelts their ore, notwithstanding that the cost of a ton of coke amounts to $\$ 37.50$.

La Preciosa. - A smelter under that name has been established at Tepeyahualco, State of Puebla, but I do not have any data about the company owning it, and the date of its contract with the Mexican Government, nor the amount of ore smelted there.

The Boleo Smelter.-I have already spoken of this plant, which smelts copper ores at Santa Rosalia, Lower California.

\section{OROGRAPHY.}

Mexico is traversed by two cordilleras or high ranges of mountains running almost parallel to the coast, one along the Gulf of Mexico and the other along the Pacific Ocean. The former runs from ten to 
one hundred miles from the coast, leaving an imperceptibly inclined plane from the sea to the foot of the mountains; while the cordillera on the Pacific side runs, on the whole, very near the coast, leaving a very narrow strip of land between the same and the sea, and from this run several branches in different directions. The most continuous range is the Sierra Madre of the Pacific, which may be traced, at a mean elevation of over 10,000 feet, from Oaxaca to Arizona. Parallel to this is the Lower Californian range (Sierra de la Giganta) 3000 feet, which, however, falls abruptly eastwards, like the Atlantic escarpments. The California peninsula seems to have been detached from the mainland when the general upheaval took place which produced the vast chasm now flooded by the Gulf of California. Corresponding with the Sierra Madre on the west are the more interrupted eastern scarps of the central plateau, which sweep around the Gulf of Mexico as the Sierra Madres of Nuevo Leon and Tamaulipas at an elevation of about 6000 feet. These are crossed by the routes from Tula to Tampico, the highest pass being 4820 feet; from Saltillo to Monterey 3400 , and at several other places.

Of the central cross ridges the most important orographically and historically is the Cordillera de Anahuac, which surrounds the Mexican (Tenochtitlan) and Puebla valleys, and which is supposed to culminate with Popocatepetl and Ixtacihuatl. But these giants belong to a different or rather more recent system of igneous upheaval, running from sea to sea between $18^{\circ} 59^{\prime}$ and $19^{\circ} 12^{\prime} \mathrm{N}$. in almost a straight line east and west, consequently nearly at right angles to the main axis of the central plateau. The line is clearly marked by several extinct cones and by five active or quiescent volcanoes, of which the highest is Popocatepetl, lying south of the capital, nearly midway between the Pacific and the Atlantic. East of the central point of the system. are Citlaltepetl, better known as the peak of Orizaba, on the coast south of Veracruz, to which correspond on the west the recently upheaved Jorullo in Michoacan, Colima $(12,800)$ near the coast in Jalisco, and the volcanic Revillagigedo group in the Pacific. South of this line and nearly parallel, are the sierras of Guerrero, and southeast of the Tehuantepec Isthmus those of Oaxaca and Chiapas towards the Guatemala frontier. In the same direction run the islands of Cuba and Hayti, which probably belong to the same Central American system.

In the course of centuries these high mountains have become disintegrated by the rains and other natural elements, and a great many spaces between them filled up, forming a series of valleys and other spots quite delightful in climate and very rich in agricultural resources. This series of valleys, which we call the central plateau, runs from about one hundred and fifty miles east of the City of Mexico, traversing all of Mexico in a northwesterly direction. So level is the plateau. 
that even when there were no wagon roads in Mexico one could travel in a carriage from the City of Mexico to Santa Fé. Baron Humboldt and other geologists considered the cordilleras of Mexico as a portion of the Andes of South America, which originate in Patagonia, extending over the whole of that continent; but researches were made specially by a corps of engineers, who surveyed Mexico during the French Intervention, arrived at a different conclusion, and consider that the Andes proper end in Panama, and that the Mexican cordilleras are entirely independent from that lofty chain of mountains.

In contrast with the plains and at times barren districts of the central plateau, it is occasionally broken by depressions of the soil, known as barrancas, descending sometimes one thousand feet and measuring several miles across, which are covered with a luxuriant vegetation of trees and shrubs, and watered by small streams running through the middle of the valley. Among the most remarkable ones are the barranca de Beltran descending the western slope from Guadalajara to Colima, and the barranca de Mochitilte from Guadalajara to Tepic.

One of the pre-eminently interesting features of Mexico is the mountain of Jerullo, in this section, which has been born within recent times. The natives described to Alexander von Humboldt the convulsions of the earth during its birth, and the frightful spectacle of the huge mass thrusting its giant shoulders among its neighbors, making room for itself in their ranks.

The best way to illustrate the broken surface of Mexico is to give the altitudes of some of the principal localities, both from the coast to the interior and from the interior back to the coast, taken from the measurements made by the railroad companies and by the engineers of the Mexican Government in the national wagon roads where railroads are not yet running. I append to this paper a list of such altitudes, with their distances, whenever I have been able to find them, which I consider the best illustration that could be presented on this subject.

\begin{tabular}{|c|c|c|}
\hline MoUNTAINS. & STATES. & $\begin{array}{l}\text { ELEVATION } \\
\text { IN FEET. }\end{array}$ \\
\hline Popocatepetl................. & Mexico................ & I 7,540 \\
\hline 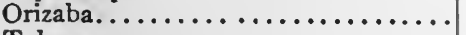 & Veracruz and Puebla.......... & 17,362 \\
\hline 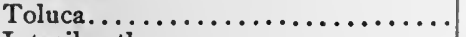 & Mexico................ & 15,019 \\
\hline 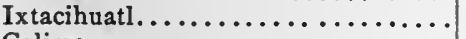 & Mexico and Puebla........... & 16,076 \\
\hline Colima................. & 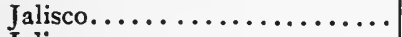 & 14,363 \\
\hline Zapotlan......... & Jalisco................ & 12,743 \\
\hline San Martin or Tuxtla. & 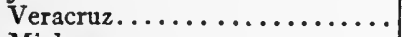 & 4,921 \\
\hline Tancitaro............ & Michoacan........... & 12,467 \\
\hline Jorullo............ & Michoacan.......... & 4,265 \\
\hline Tacana or Soconusco .... & 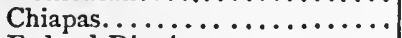 & 7,436 \\
\hline Guarda............... & Federal District............. & 9,731 \\
\hline Ajusco $\ldots$ & Federal District... & 13,628 \\
\hline Cofre de Perote.. & Veracruz............ & 13,415 \\
\hline Zempoaltepec......... & 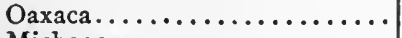 & I I, I 4I \\
\hline Pico de Quinceo............. & Michoacan.............. & 10,905 \\
\hline 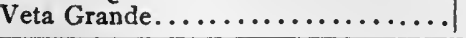 & Zacatecas................ & 9,140 \\
\hline
\end{tabular}


The above are the principal mountain peaks of Mexico, the first ten being volcanoes, with their heights according to the most recent measurements :

\section{HYDROGRAPHY.}

The eastern Mexican coast, washed by the Caribbean Sea and the Gulf of Mexico, is low, flat, and sandy, except near the mouth of the Tabasco River, where at some distance from the coast appear the heights of San Gabriel, extending northeast and southwest for several miles; but the majestic mountains of Veracruz, especially the volcano of Orizaba, visible for many leagues to seaward, form a picturesque background which relieves the monotony of the shore region of that State. On the Pacific side the coast, although generally low, is here and there roughened by spurs extending from the cordillera to the ocean.

The principal gulfs are those of Mexico, California, and Tehuantepec, the first of which ranks among the largest in the world.

We are not blessed with good harbors on the Gulf coast. Veracruz is an open roadstead, and we are now spending large sums of money in trying to make it a good port. Our best harbors are on the Pacific coast, as Acapulco, which is a large one; Manzanillo, a very fine although a very small one; and $\mathrm{La} \mathrm{Paz}$, on the Gulf of California. By artificial means we expect to improve our harbors considerably.

The development of the harbor of Tampico is remarkable. A short time ago the depth of the bar roadstead was only eight or nine feet. Now steamships drawing twenty-four feet of water enter the port. The deepening of the entrance to the harbor has been accomplished by means of jetties, just as the mouth of the Mississippi was deepened by the Eads jetties. A very large part of the imports of Mexico enter now by the port of Tampico.

The more noteworthy bays are those of Guaymas, Santa Barbara, Topolobampo and Navachiste, in the Gulf of California ; Concepción, La Paz, and Mulejé, on the west coast of the same gulf; San Quentin, Magdalena, and Amejas, on the Pacific coast of Lower California ; and San Blas and Valle de Banderas, on the coast of Tepic.

We have no lakes as large as those with which the United States is favored, and the Lake of Chapala, a beautiful spot where country houses are now being built, is the largest lacustrine basin in Mexican territory. The Valley of Mexico has six lakes, two of fresh and six of salt water. The other lakes in Mexico are Catemaco, in the State of Veracruz ; Cairel and Carpintero, in the State of Tamaulipas ; Encantada, in Tabasco ; Bacalar, in Yucatan ; Alcuzague, in Colima ; Cuitzeo, Tacascuaro, and Patzcuaro, in Michoacan; Yuriria, in Guanajuato ; and Meztitlan, in Hidalgo. 
Mexico has a great many islands, situated near the coast, although not any of very great area, the greater number being uninhabited, although some of them are very fertile, and could be the seat of a large population. Among the most important are: El Carmen, the largest in the Gulf of Mexico; San Juan de Ulua and Sacrificios, opposite the port of Veracruz ; Mujeres, in the Caribbean Sea ; Guadalupe, about seventy-five miles from the west coast of Lower California; the Tres Marias group, about thirty miles from the same coast; the Revillagigedo group, not far from the coast of Colima; and adjoining the coast of the State of Michoacan, the Alcatraz Island.

As I have already stated, Mexico has a very broken surface, with high mountains, causing streams to run down a very inclined plane, forming torrents with rapid cascades, which contribute to embellish the natural features of the country. These conditions, however, prevent us from having large navigable rivers, and furnishing a cheap way of transportation, which is one of the greatest advantages the United States enjoys, and which so largely contributed in its early days to the development of the country, making transportation to long distances both easy and cheap. While the torrents descending from the nountains afford an immense water-power-which, in the course of time, may be used as a motor for industrial purposes-they meet when they reach a valley and run smoothly there through a ravine until finally they reach the coast, and it is therefore only at a comparatively small distance from the sea that they can be made navigable.

Our principal rivers, measuring their positions from north to south, are the Rio Grande-which from El Paso, Texas, to the sea, is the boundary line between the two countries, and which used to be a large river; but as it rises in Colorado and passes through New Mexico, and the inhabitants of both have taken for irrigation purposes most of the water that it carries, it becomes entirely dry during the dry season after the freshets, very much to the distress of the inhabitants of its borders from El Paso to Ojinaga, especially on the Mexican side, which has been inhabited for three hundred years, the people using the water for irrigation-on the other side there being hardly any population,and now they find that their farms are entirely worthless for want of water. After passing Presidio del Norte, now called Ojinaga, the Conchos River and other tributaries of the Rio Grande River supply it with water, although not to the extent it had before the water was taken in Colorado and New Mexico. The Mescala, or Balsas River, rises in the central plateau near the Valley of Mexico, passes by the State of Puebla to the southwest, by Mixteca of Oaxaca, and finally empties into the Pacific at Zacatula. As indicated by its name, it is, to a limited extent, navigable along its lower reaches; above the bar it is accessible to small craft, which, higher up, are arrested by rapids, 
whirlpools, and a high cascade. The Pánuco River rises north of the Valley of Mexico. Under the names of Tula and Montezuma it describes a vast semicircular bend towards the west across the Hidalgo uplands and collects the waters of the Huasteca of Veracruz and Tamaulipas, beyond which it is joined by the various streams flowing from Queretaro, and finally empties into the Gulf of Mexico at the port of Tampico. The Tampico bar, improved by jetties, is now the best harbor on our Gulf coast. The Rio Lerma or Santiago, the Tololotlan of the Indians, is also a considerable stream. By the riverain populations it is, in fact, known as the Rio Grande, while the inhabitants of Michoacan call it also Cuitzeo, from the large lake situated in their State. It rises in the State of Mexico in the very centre of the Anahuac plateau, and its farthest sources, issuing from underground galleries, descend from the Nevado de Toluca down to the twin lake of Lerma, the remains of an inland sea which formerly filled the Upper Toluca valley north of the $\mathrm{Ne}$ vado volcano. At its issue from the lake, or rather marshy lagoon, the Lerma stands at the great altitude of 8600 feet, and during its winding northwesterly course across the plateau, the incline is very slight. In this upland region it is swollen by several affluents, some of which, like the main stream itself, flow from lakes dotted over the table-land. After completing half of its course at La Barca, the Ler$\mathrm{ma}$ is still 5600 feet above sea-level. Here, some 280 miles from its source, it enters the large Lake Chapala, near its eastern extremity; but about twelve miles below the entrance it again emerges through a fissure on the north side of the lake, and still continues to flow throughout its lower course in the same northwesterly direction.

The Grijalva and Usumacinta rivers, rising in the State of Chiapas, after being joined by many others, some of them coming from Guatemala, empty into the Gulf of Mexico by one of its mouths at the city of Frontera in the State of Tabasco. The Papaloapam River rises in the State of Oaxaca, passes through the State of Veracruz, and empties into the Gulf of Mexico at the town of Alvarado, a few miles south of Veracruz.

The rains increase considerably the amount of water in the rivers, but as their duration is not very long this soon subsides. When the streams rise near the sea, as is the case on the coast of Chiapas on the Pacific, they become so swollen immediately after the rains that it is impossible to ford them, and as there are no bridges, it is necessary to wait until early the next day when the freshet has subsided.

Springs are rare, and some of the rivers run in deep mountain beds, without receiving smaller tributaries, while the rapid evaporation on a light soil, covering porous rocks, leaves the surface dry and hot and unable to support much vegetation beyond the cactus and low grasses. 
We are blessed with quite a number of mineral springs, although very few of them are used, most of them being at places not easily accessible; but in this regard I do not think we have any cause to envy any other country.

\section{CLIMATE.}

By looking at the map it will be perceived that Mexico, being intersected by the Tropic of Cancer and stretching across eighteen parallels of latitude, must, from its position alone, necessarily enjoy a great diversity of climate. But from its peculiar configuration this feature is affected far more by the altitude of the land than by its distance from the pole or the equator. This is especially true of the more fertile and populous section lying within the torrid zone, where three distinct climatic regions are distinguished, not according to their horizontal, but according to their vertical position. The warm climate has the heat of the torrid zone and prevails on the sea-coast in the sandy and marshy tracts fringing the Gulf of Mexico and the Pacific Ocean, in other low places below 3000 feet above the level of the sea, and in some of the valleys higher than that, but protected entirely from the winds. But the night breezes refresh the temperature in the evening and make it bearable during the day, the heat never being so oppressive as it is in summer in the more northern latitudes. This region is also much refreshed in summer by the rains, which are abundant and fall regularly during that season. The heat of the sun increases considerably the evaporation from the sea, and when the evaporation reaches the cool atmosphere of the sky, it is naturally condensed into water and falls in this region. The rains begin generally in June, increase considerably in July, and end in November, although this varies in different regions, the rains lasting longer in those near the sea than in the inland districts. They are so abundant that they form the main reliance of the agricultural industry, and there are few regions which use water for irrigation, depending entirely upon the rainfall; therefore, when in a year by some atmospheric phenomena, the rains are late or very scarce, we had a famine in Mexico, which can now be averted by importing cereals through our railroads, as was the case in 1893 . The rains fall regularly and at fixed intervals, that is, about from one to three hours every day, and after the rain is over, the atmosphere is clear and pleasant, and in well drained places the ground becomes dry, so that it causes no inconvenience to the inhabitants.

The rains have such a decided effect on the atmosphere that in most of the country the seasons are divided into the rainy and dry season, and very few realize what spring and fall mean. As our climate is so even, the trees do not lose their leaves at any given time, but one 
by one as they grow old and die; and as the leaves die they are replaced gradually and imperceptibly by new ones, so that the phenomenon familiar to northern latitudes, of trees losing all their leaves in the autumn and regaining them in the spring, is quite new to anybody going to a temperature that has both extremes.

The differences of climate depending upon the different degrees of altitude are so great in Mexico that the vegetable products of this vast country include almost all that are to be found between the equator and the polar circle.

The mean temperature in the hot region varies from 77 to 82 degrees, Fahrenheit, seldom falling below 60 , but often rising to roo degrees, and in the sultry districts of Veracruz and Acapulco occasionally to ro4 degrees, although the heat is not oppressive as is the summer heat of the eastern portions of the United States. The vegetation is, of course, in consequence entirely tropical. In the southern region the climate on both seaboards may be described as humid, hot, and rather unhealthy, and in places where stagnant water and marshes exist-which are often found on the coast on account of the sea water flowing in and remaining there-intermittent and remittent fevers prevail, and in some localities during the summer yellow fever and black vomit are endemic. These conditions could easily be remedied by proper drainage of the swamps and marshy districts.

The heat of the Gulf of Mexico when the atmosphere begins to cool in the polar regions causes a depression in the barometer, and consequently very strong north winds, which sweep over the coast with terrible force, causing great havoc. They generally begin in September and last until the winter season sets in about December. As the country is narrow, the effect of the north wind is felt all over it and that is the prevailing wind. In the City of Mexico, for instance, notwithstanding its altitude and that it is protected by high mountains from the northern winds, the temperature falls when the northerns prevail on the Gulf coast, and it becomes cloudy and drizzly, and the same effect is felt, more or less, in other portions of the country. As the country narrows towards the southeast, especially at Tehuantepec, the northern wind blows with but small obstacles, and its force and effects are felt all over it. The districts in the mountains bordering the Pacific are affected in the same way as the City of Mexico.

From 3000 to 5000 feet above the level of the sea is located our temperate zone, which succeeds the hot zone in a verticle position, and embraces all the higher terraces, and portions of the central plateaus themselves. The mean temperature is from 62 to 70 degrees, Fahrenheit, varying not more than 4 to 5 degrees during the season, thus making one of the very finest climates on the face of the earth. In this privileged region both extremes of heat and cold are unknown, 


\section{Climate.}

and it has several cities-Jalapa and Huatusco in the State of Veracruz, Chilpancingo in Guerrero, Ameca in Jalisco, and many others too numerous to mention here. As these places are generally located on the slopes of mountains and not far removed from the ocean, the evaporations from the sea form clouds which are detained in their course by the high peaks and are precipitated into rain. In this region the semi-tropical productions are abundant, and with them are often combined the products of tropical and cold regions. I have seen in my own native place, the city of Oaxaca, located in the temperate region, a farm where wheat and sugar-cane were growing on the same piece of ground.

The cold region is located from 7000 feet above the sea-level upwards, and has a mean temperature of from 59 to 63 degrees, Fahrenheit. Most of the grand central plateau is located in this region, except in such places as are in a great depression of ground and in deep ravines, where a warm temperature and tropical products are found. The rainfall is about five times less than in the temperate zone. This region, of course, produces all the growths of the cold latitudes, as wheat, oats, apples, etc., etc.

The portion of the country that is most thickly inhabited lies in the central plateau, and is quite high above the level of the sea, and so sheltered from the winds and storms by the mountains as to make the climate even, temperate, and delightful. The impression prevails in the United States that Mexico, lying to the south and running towards the equator, must be much warmer than this country; but this is not so. Even in warm places, like the lowlands on the coast, we do not have the extreme hot weather that is experienced in summer in the United States. The sea breezes refresh the atmosphere at night and cool it considerably, making, therefore, a very great contrast with the summer heat in this country. The medium climate of the Valley of Mexico, for instance, which is the one that has been best observed and understood, varies comparatively little between summer and winter, its greatest variations being between day and night on the same day.

The climatic conditions of Mexico are undergoing great changes on account of the destruction of the forests. The country had formerly a great deal of rain and much humidity in the atmosphere, being covered with thick forests; but with the difficulty of transporting the coal already found, the population has had to depend entirely for their supply of fuel upon charcoal, and this has in the course of time denuded the mountains, changing very materially the climatic conditions of some regions in the country. But in the lowlands, being thinly inhabited, the case is different, and the country is still so thickly wooded that it is impossible to pass through it, unless an open path 
is made with a great deal of difficulty, by felling very high trees and low brush and weeds. In this region abound forests of mahogany, cedar, rosewood, etc. I will later state more in detail the conditions of the fuel question in Mexico.

As a whole, the Mexican climate, if not of the most invigorating nature, is certainly one of the most delightful in the world. The zone of temperate lands, oceanic slopes, enjoy an everlasting spring, being exposed neither to severe winter, nor to intolerable summer heats; in every glen flows a rippling stream; every human abode is embowered in leafy vegetation; and here the native plants are intermingled with those of Europe and Africa. Each traveller in his turn describes the valley in which he has tarried longest as the loveliest in the world; nowhere else do the snowy crests or smoking volcanic cones rise in more imposing grandeur above the surrounding sea of verdure, all carpeted with the brightest flowers. In these enchanting regions there is still room for millions and millions of human beings.

The following table prepared by the Meteorological Observatory of the City of Mexico shows the meteorological conditions of the principal Mexican cities during several years, their elevation upon the sea-level being marked in metres and the temperature under the Centigrade scale.

SUMMARY OF THE METEOROLOGICAL OBSERVATIONS TAKEN IN SEVERAL CITIES OF MEXICO DURING SEVERAL YEARS.

\begin{tabular}{|c|c|c|c|c|c|c|c|c|c|c|c|c|c|}
\hline \multirow[b]{2}{*}{ LOCALITIES. } & \multirow[b]{2}{*}{$\begin{array}{l}\text { 䓵 } \\
\dot{z}\end{array}$} & \multirow{2}{*}{ 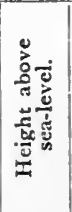 } & \multirow{2}{*}{ 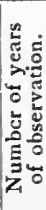 } & \multirow{2}{*}{ 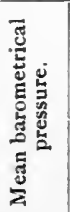 } & \multicolumn{3}{|c|}{$\begin{array}{l}\text { TEMPERATURES } \\
\text { IN THE SHADE. }\end{array}$} & \multirow{2}{*}{ 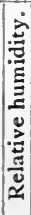 } & \multicolumn{2}{|c|}{ CLOUDS. } & \multicolumn{2}{|c|}{ WIND. } & \multirow{2}{*}{ 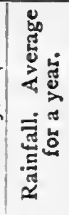 } \\
\hline & & & & & 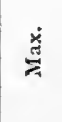 & 点 & 苟 & & 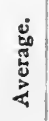 & 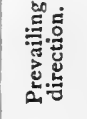 & 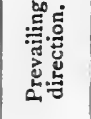 & | & \\
\hline Ontere & $\mid \begin{array}{rr}0 & 1 \\
25 & 40\end{array}$ & $\mathrm{~m} .6$ & 7 & & 0 & & ${ }^{\circ}$ & & & & 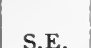 & & \\
\hline Itillo, Coa & $\begin{array}{ll}25 & 40 \\
25 & 25\end{array}$ & $\begin{array}{r}495.0 \\
1633.0\end{array}$ & 4 & $\begin{array}{l}709.1 \\
632.1\end{array}$ & $\begin{array}{l}33.2 \\
34.0\end{array}$ & $\begin{array}{r}11.7 \\
-2.8\end{array}$ & $\begin{array}{l}21.0 \\
16.8\end{array}$ & $6 I$ & 4.4 & N. & N. & I. 4 & $\begin{array}{r}3413 \\
527\end{array}$ \\
\hline uliacan Si & 2448 & 34.2 & I & 754.9 & 35.9 & 12.5 & 25.6 & 62 & . & & & $\cdots$ & 12 \\
\hline $\mathrm{Si}$ & 24 II & 4.0 & 4 & $759 \cdot 3$ & 34 & 10 & 25 & 77 & 3.4 & N. & N.W. & 1.7 & \\
\hline & 2246 & 2496.0 & 10 & 573.4 & 21 . & & 1 & $4^{8}$ & 3.2 & S.I & S.E. & 2.6 & 01 \\
\hline P. & 229 & 1890.0 & 9 & 613 & 33 & -1.8 & $\mathbf{I}$ & 60 & $4 \cdot 4$ & & E & 1.3 & 38 \\
\hline ... & 224 & 1924.0 & 10 & 607.8 & 24.0 & 12. & & 57 & 4.0 & S.S.E. & W.S.W & 1.2 & 53 \\
\hline$\ldots$ & 2153 & 1861.0 & I & 605.1 & 29 & 2 & 18.6 & & .... & $\cdots$ & $\mathbf{N}$ & $\cdots$ & \\
\hline $\mathbf{u}$ & $214 I$ & 376.0 & I & $765 . \mathrm{x}$ & & 10.0 & & $8 \mathrm{x}$ & .... & & & & 201 \\
\hline & 217 & 1798.0 & 14 & $617 \cdot 4$ & 35 & $-I \cdot I$ & 18.9 & 66 & 4.9 & & N.S & 0.6 & \\
\hline Guz & $2 \mathrm{I}$ & 2060.0 & 5 & 60 & 30. & $1 \cdot 3$ & 17.6 & $5^{8}$ & $5 \cdot 3$ & & & .. & \\
\hline $\mathrm{Tu}$ & 2059 & & 2 & 763.0 & & ..... & 24.5 & 82 & $4 \cdot 3$ & & W. & & \\
\hline Gua & $204 \mathrm{I}$ & 156 & 7 & $6_{3} 6.2$ & $35 \cdot 5$ & $-4 \cdot 5$ & 19.7 & 53 & $\cdots$ & & & & \\
\hline , Que & 2035 & 1850.0 & 3 & 613.8 & 33 & & 18.1 & 59 & $4 \cdot r$ & & E. & 0.6 & \\
\hline Hid. & 207 & 2460.0 & I & 574.8 & 27.2 & 0.6 & 13.7 & 59 & 4.2 & S. & N.E. & 2.4 & $43^{6}$ \\
\hline 1e.. & I9 49 & 1976.0 & $\begin{array}{lll}\mathbf{I} & & \\
\end{array}$ & ...... & $\cdots$ & $\cdots$ & 18.3 & 60 & 3.5 & & N.E & .... & \\
\hline Micl & 1931 & 2138.0 & I & & & & I6. I & & $4 \cdot 3$ & & W. & $\cdots$ & III \\
\hline . $F$ & 1926 & 2282.5 & 15 & 586.4 & 31.6 & -1.7 & 15.4 & 60 & 5.0 & S.W & & 0.8 & \\
\hline D. F & 1912 & 2322.6 & 9 & 583.6 & 28.6 & 0.8 & & 62 & $\cdots$ & & & .... & 668 \\
\hline Pueb & $\begin{array}{lll}19 & 03\end{array}$ & 2172.0 & 14 & 593.2 & 31.9 & -1.1 & 15.7 & 63 & $4 \cdot 7$ & E.N & N.E. & I.9 & 92 \\
\hline Tlac & $\begin{array}{ll}18 & 3^{6}\end{array}$ & $3 \cdot 5$ & I & 76 & $\ldots \ldots$ & $\ldots \ldots$ & & 80 & 4.8 & $\mathbf{N}$ & N.E. & . & \\
\hline Oаxaca, Oax.. & 1704 & $154^{1}$ & $\mathrm{I}$ & $63^{6} 6.6$ & 32 & 6. & 20 & 80 & & & & & \\
\hline
\end{tabular}




\section{Clímate.}

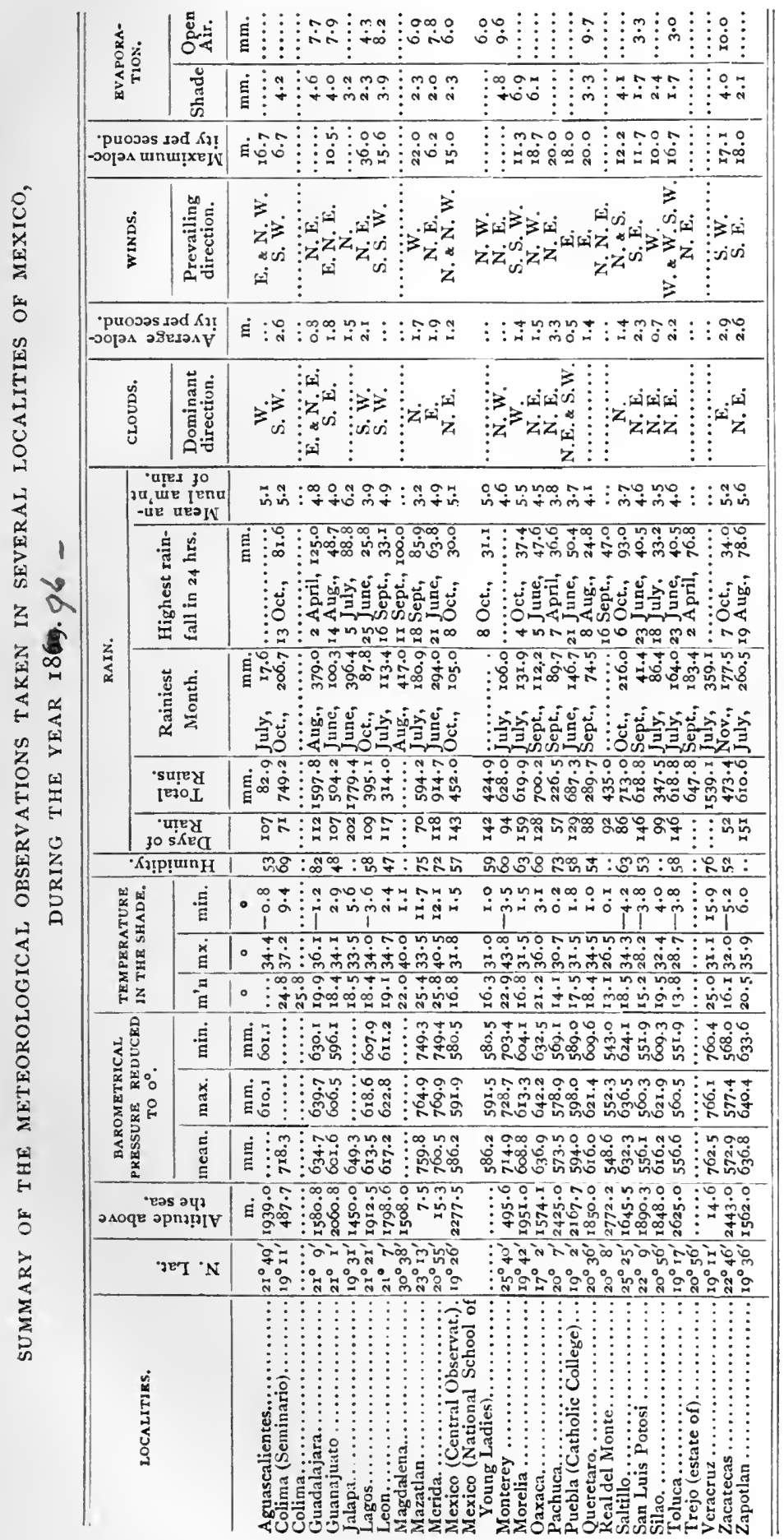


The table on page 39 shows the results of the meteorological observations taken in the principal cities of Mexico during the year 1896 .

Professor Mariano Barcena, director of our National Meteorological Observatory or Weather Bureau, furnished me the following data about the maximum and minimum of temperature and greatest oscillation both in summer and winter of several cities in Mexico, located both at the sea-level like Merida and Mazatlan, at different altitudes like Jalapa, San Luis Potosi, Oaxaca, and at the highest level like the cities of Mexico, Pachuca, and Zacatecas, showing the mildness of the Mexican climate.

\section{CITY OF MEXICO.}

Maximum temperature in the shade in summer......84.9, May 5 th.

Maximum temperature in winter........... 72.0, December.

Minimum temperature in winter.............. January and February.

Greatest oscillation in one day in winter....... 13.7

Greatest oscillation in one day in summer. . . . 32.9

\section{puebla (state of PUEbla).}

Maximum temperature in the shade in summer.....83.8, April.

Maximum temperature in winter............ 74.7 , February.

Minimum temperature in winter............ 32.9, January.

Greatest oscillation in one day in winter.......... 36.3

Greatest oscillation in one day in summer........... 34.4

\section{OAXACA (STATE OF OAXACA).}

Maximum temperature in the shade in summer...... 93.7, May.

Maximum temperature in winter............. 83.1, February.

Minimum temperature in winter............. 39.2, January and December.

Greatest oscillation in one day in winter........... 39.

Greatest oscillation in one day in summer........ 37.8

\section{JALAPA (STATE OF VERACRUZ).}

Maximum temperature in shade in summer....... 89.6, April.

Maximum temperature in winter............ 87.1, December.

Minimum temperature in winter ............. 33.8, February.

Greatest oscillation in one day in winter........... 35.3

Greatest oscillation in one day in summer........ 32.0

\section{QUERETARO (STATE OF QUERETARO).}

Maximum temperature in the shade in summer....... 90.I, April and June.

Maximum temperature in winter ............. 80.4, December.

Minimum temperature in winter.............. 32.9, January.

Greatest oscillation in one day in winter........... 39.4

Greatest oscillation in one day in summer........ 34.7 
guaNajuato (STATE OF GUANAJUato).

Maximum temperature in the shade in summer..... 9I.9, April.

Maximum temperature in winter............ 82.0, February.

Minimum temperature in winter .............. 36.0 , January.

Greatest oscillation in one day in winter.......... 36.7

Greatest oscillation in one day in summer........ 36.7

LEON (STATE OF GUaNajuato).

Maximum temperature in the shade in summer..... $9 \mathrm{I} .6$, May and June.

Maximum temperature in winter............. 77.0 , February.

pachuca (state of hidalgo).

Maximum temperature in the shade in summer...... 80.2, May.

Maximum temperature in winter............. 77.0, December.

Minimum temperature in winter.............. 32.4, December.

Greatest oscillation in one day in winter .......... 33.3

Greatest oscillation in one day in summer........ 28.6

\section{REAL DEL MONTE (STATE OF HIDALGO).}

Maximum temperature in the shade in summer.... 80.2, March. Maximum temperature in winter............. 74. I, January.

Minimum temperature in winter.............. 31.6, January.

\section{SALTILLO (STATE OF COAHUILA).}

Maximum temperature in the shade in summer...... 89.6, April.

Maximum temperature in winter........... 75.7, January.

Minimum temperature in winter............ 12.2, February.

Greatest oscillation in one day in winter.......... 32.8

Greatest oscillation in one day in summer......... 25.6

\section{MERIDA (STATE OF YUCATAN).}

Maximum temperature in the shade in summer........ 103.6, April and June.

Maximum temperature in winter............. 92.8, January.

Minimum temperature in winter............. 47.8, February.

Greatest oscillation in one day in winter.......... 37.1

Greatest oscillation in one day in summer........ 38.7

Mazatlan (STATE of Sinaloa).

Maximum temperature in the shade in summer...... 91.o, September.

Maximum temperature in winter............ 84.0, December.

Minimum temperature in winter ............ 15.8, February.

Greatest oscillation in one day in winter......... I6.9

Greatest oscillation in one day in summer........ 17.5

\section{MEXICO AS A SANITARIUM.}

Although the City of Mexico, on account of its present unsatisfactory sanitary conditions, of which I will treat in speaking of that city and which I am sure will be remedied before long, cannot be considered now as the best place for invalids, there are many other localities in the country presenting great advantages as sanitariums. 
The mild nature and evenness of most of our climate is very favorable to certain diseases-especially pulmonary ones-and when that advantage becomes well known the central plateau of Mexico will be the best sanitarium for lung diseases, and especially for tuberculosis. Other lung diseases requiring a warmer climate could find desirable places in certain valleys in the temperate zone like Cuantla, Cuernavaca, Tasco, Iguala, and others. These very conditions, namely, the even and mild climate both in summer and winter, will make it a country visited by thousands of pleasure or health seekers who wish to escape both extremes of the northern climate. Even now we would have a much larger travel from this country if we had convenient accommodations for travellers, but our hotels are not yet as comfortable as those in the United States.

FLORA.

The short and imperfect description of the climate of Mexico, made above, will show that we can raise all the products of the three different zones into which the earth is divided, and the most remarkable thing is that we can raise them almost on the same ground. By going only a few miles, for instance, travelling on horseback four or five hours from a low to a higher locality, we change from the torrid to the temperate zone, and therefore we can have the products of both with comparatively little trouble; and by going four or five hours higher still, we change from the temperate to the frigid zone, and these are advantages of our geographical position which can be appreciated only by those who have experienced them. ${ }^{1}$

${ }^{1}$ Mr. Charles Dudley Warner, editor of Harper's Monthly Magazine, in a brilliant article published in the July, I897, number of that periodical, gives the following description of the rapid descent from the cold to the temperate and hot regions of Mexico, which may be considered as a specimen of the scenery in many other localities of that country. In many other places, where there are no wagon-roads, but only a footpath, the descent is a great deal more rapid, often 5000 feet in four or five miles, and then the contrast is still greater. At Maltrata for instance, an Indian town about 5000 feet above the level of the sea, the natives offer their tropical fruits to the passengers of the Mexican Railway going from Veracruz to the City of Mexico, and they leave with what they have left after the train starts to climb the mountains to the Central Plateau to an altitude of about 9000 feet, and they reach Esperanza, the first station on the Central Plateau far ahead of the train, which has to describe a long, zigzag course before getting there. I have selected the following extract from Mr. Warner's article because it relates to one of the historical places of Mexico :

"Cuernavaca is distinguished as the actual meeting-place of the pine and the palm. It lies only a little more than fifty miles south of the City of Mexico; but in order to reach it there is a mountain to be crossed which is at an elevation of over ten thousand feet. A railway climbs up this mountain, over the summit, to a wind-swept plain, in the midst of pine forests, called Tres Marias-marked by the sightly peaks of the Three Marys. By long loops and zigzags it is crawling down the mountain on 
The Mexican Southern Railway, from Puebla to Oaxaca, descends in a few hours, by a series of fertile terraces, from an elevation of seven thousand feet to one of about seventeen hundred and fifty feet, when ths wonderful Cañon de los Cues is reached, a region of cocoa-nuts and bananas. But all the valleys and terraces in March are green or yellow with wheat and corn and sugar-cane. It confuses one's ideas to pass a field of wheat, the green blades just springing from the ground, and then a field ripe for harvest, and then a threshing-floor where the grain is being trodden out by mules. This means that you can plant and reap every day in the year, if you can obtain water in the dry season, and do not wait for the regular and copious summer rains.

The magnificent arboreal vegetation embraces one hundred and fourteen different species of building timber and cabinet woods, including oaks, pines, firs, cedars, mahogany, and rosewood; twelve species of dyewoods ; eight of gum trees: the cacao and india-rubber, copal, liquid-ambar, camphor, turpentine, pine, mezquite yielding a substance

the other side to Cuernavaca. Mexico City has an elevation of seven thousand five hundred feet, Tres Marias of about ten thousand, and Cuernavaca of five thousand. The descent by the wagon-road is in length only twelve miles, but the drop in that distance is five thousand feet, so that the traveller passes very quickly from temperate to tropical conditions. . . .

"From the heights Cuernavaca seems to lie in a plain, but it is really on a promontory between two barrancas, and the whole country beyond is broken, till the terraces fall off into more tropical places, where the view is bordered by purple mountains. Indeed, the little city in the midst of this tumultuous plain is surrounded by lofty mountains. The country around, and especially below to the south, is irrigated, and presents a dozen contrasts of color in the evergreen foliage, the ripening yellow crops of sugar-cane and grain, the clusters of big trees here and there about a village or a hacienda, and the frequent church-towers. All this is loveliness, a mixture of temperate and tropical grace, but there is grandeur besides. Looking to the east, say from the Palace of Cortez, over the fields of purple and green and yellow and brown, where the graceful palms place themselves just as an artist would have them in the foreground of his picture, the view is certainly one of the finest in the world. There is in the left the long mountain range with the peaks of Tres Marias, and along the foot of it haciendas and towers, cones of extinct volcanoes and noble rocky promontories. To form the middle-distance mountains come into the picture, sloping together to lead the eye along from one "value" to another, violet, purple, dark or shining as the sun strikes them, while on the left is a noble range of naked precipices of red rock, always startling in color. It is some two thousand feet up the side of one of these red cliffs that there is the remains of an ancient city of Cliff-dwellersalmost inaccessible now, but once the home of a race that understood architecture and knew how to carve. The lines of this natural picture, the fields, the intervening ledges, the lofty mountains, all converge to the spot the artist would choose for the eye to rest, and there, up in the heavens, are the snow-clad peaks of Popocatepetl and Iztaccihuatl, about seventeen thousand five hundred feet above the sea, volcanic creators of the region, and now undisputed lords of the landscape. In the evening these peaks are rosy in the sun; in the morning their white immobility is defined against the rosy sunshine." 
similar to gum-arabic, dragon trees, and the almacigo or Callitris quadvalvis, from which sandarac is extracted. Among the oil-bearing trees and plants, of which there are seventeen varieties, are the olive, cocoa palm, almond, sesame, flax, the tree yielding the balsam of Peru, and others. There are fifty-nine classified species of medicinal plants, and many more are mentioned by botanists as still unclassified by science.

Of the many delicious fruits which grow in the tropical regions, only a few-the pineapple, the banana, and the cocoa-nut-are known in this country, the orange being rather a semi-tropical fruit. The others require, as all fruits do, cultivated taste, and, therefore, if imported here would not find a market. Even those which do come here are of very inferior flavor, owing to the fact that they are cut green so as to prevent their decay during transportation, and they, of course, have a less agreeable taste than in the place where they grow. Of the banana, for instance, we have about twenty varieties, some of whichthe richest in my opinion-grow to a size from twelve to fifteen inches in length and from two to three inches in diameter.

We can raise in Mexico all the products of the world because we have all climates, from the perpetual snow to the burning sun of the equator; but it would take a great deal more space than I can dispose of in this paper, to mention all the agricultural products we can raise, and I will, therefore, confine myself to only such as I think are now of more importance.

Coffee.-Mexico has many localities well suited for the raising of coffee, and the production of that berry can in the future be very largely increased. In the proper locality, namely, zone, ground, and climate, coffee can be raised on a large scale at comparatively small cost, affording always a large profit, whatever may be in the future its price in foreign markets.

I have had personal experience in coffee-raising, having made a coffee plantation in the district of Soconusco, in the State of Chiapas ; and I took especial interest in visiting other plantations, both in Mexico and Guatemala, where coffee had attained a large development. My experience has shown me that the best zone for coffee is located between one and five thousand feet above the level of the sea, as coffee is not a product of the hot but of the temperate zone. On the highlands, as a rule, the quality of the coffee is better and the yield large, while the lowlands give an earlier but smaller yield. There are coffee plantations in Mexico, almost down to the level of the sea, which are yielding coffee, and from that to the elevation of six thousand feet, producing also a very good quality of coffee. For further information on this subject, I refer the reader to a treatise on coffee-raising on the southern coast of the State of Chiapas, which I published in the City of 
Mexico in 1874 , and which contains detailed information on the several. factors affecting that industry.

It is interesting to know the production of coffee in Mexico, taken from some statistics for 1896 :

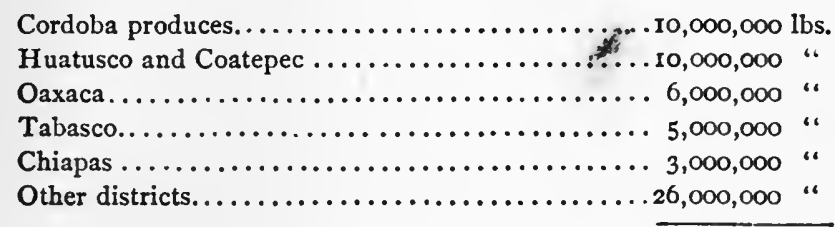

$60,000,000$ lbs.

Sugar-Cane.-Mexico has many localities where sugar-cane can be raised at a very small cost, and where that industry can be made very lucrative, although we hardly produce enough sugar for our home consumption. From the sea-level to the frost line, which ranges, in different localities, from three to five thousand feet above the sea-level, sugar-cane can be raised in Mexico to great advantage. I have seen the cane in some places, especially in Soconusco, attain a height of twelve feet and a diameter of about five inches; and in some localities it lasts from ten to eighteen years without need of replanting, and can be cut for grinding twice a year. When it is considered that in some places, like Louisiana, sugar has to be planted, as I believe, every two years, and that it is liable to be destroyed by frosts, the advantages of Mexico for that industry are apparent.

The favorable conditions of Mexico for raising sugar-cane are so great that $I$ have seen the natives in the Indian town of Loxicha, in the State of Oaxaca, plant a small plot of sugar-cane, grind it with primitive wooden mills moved by hand power, using very primitive earthen pans, to evaporate the juice and make brown sugar-losing of course a great part of the saccharine matter in the cane,-transport the sugar, sometimes a distance of thirty miles on mule-back, and sell it at one cent per pound, and still make a profit.

For sugar-cane the lowlands are the best, and the plant is essentially a tropical one. It will grow, however, at very considerable altitudes, but when planted in the mountains it takes a longer time to ripen, and soon ceases to give remunerative crops. There was in southern Veracruz a sugar-cane only six months old which had a circumference of $7 \frac{1}{2}$ inches. Where that cane grew the yield of cane per acre was about 80 tons when twelve months old. The elevation was something like rooo feet. It is true, however, that the bulk of the cane grown in Mexico is to be found above 2000 feet, but I am convinced that a lower altitude would produce even better results.

Tobacco.-Among the tropical products of superior quality that we 
raise in the hot zone, I should mention tobacco, the Mexican tobacco being, in General Grant's estimation, superior to the Havana article. The natural conditions of soil and temperature are the same in Cuba and Mexico, but we had not the superior experience of the Cubans in curing the leaf until the late insurrection broke out in Cuba, in 1868 , when a great many Cubans went to Mexico to plant tobacco. As the land has been planted in Cuba with tobacco for nearly four hundred years, and as tobacco is a very exhausting crop, it has become indispensable to manure the land with guano, while in Mexico we have virgin land, and tobacco being a comparatively new industry, no guano needs to be used. General Grant, whom I consider a competent judge, detected the taste of guano in the Havana cigars, of which ours is free, and he, therefore, preferred to smoke the Mexican cigars.

In Cuba the exhausted soil cannot produce'all the leaves that are required for the world's supply of Havana cigars, and the want can only be filled through the use of Mexico leaf tobacco, the weed produced in other countries having similar conditions. The Marquis de Cabañas sent to Sumatra a quantity of seed when it became obvious that the soil of the tobacco region of Cuba was fast being worn out. $\mathrm{He}$ sent seed also to Java and to the United States, but it was found that it was impossible to raise tobacco of the quality of that raised in Havana anywhere but in Mexico. That raised in Java from Havana seed was very coarse and rank, replete with nicotine and meconic acid, and devoid of those delicate essential oils that give the Havana and Mexican tobacco their fine aroma.

The tobacco plant is a native of the tropics, and thrives best in the hot lands. It is a hardy plant, however, and will grow well in northern latitudes in the summer time. It often happens that the land in the tropics is actually too rich for the successful cultivation of tobacco.

India-Rubber.-The lowlands of Mexico, especially those adjoining the Pacific Ocean and which have a very warm and moist climate, are very well adapted for the india-rubber tree, which attains a large size and yields a considerable amount of india-rubber. We used to have whole forests of them, which fact shows that they were in their proper conditions of soil and climate, as they could outgrow the rank vegetation of the tropics, and prevent the growth of most of the other large trees in the forests; but india-rubber gatherers have destroyed most of them, and I imagine that there is a comparatively small number left.

I have always thought that the production of india-rubber would before long cease to be sufficient to supply the demand, and that, therefore, the value of that article would increase with the lapse of time. Now it is to be expected that the enormous expansion during the last few years of the cycle-tire, electrical motor-car, cab, and kindred industries will lead to the bestowal of increased attention on 
the world's rubber supply, which is so intimately associated with the existence of these industries.

Thinking that a plantation of india-rubber trees would be very remunerative, I devoted considerable attention to that subject, and in 1872 started one of 100,000 trees in a place admirably located for the purpose, bordering on the Pacific Ocean and between two large rivers, in the same district of Soconusco. In an article published in 1872 , under the title "India-Rubber Culture in Mexico," I compiled all the information on the subject that I could obtain, supplementing it with the experience that I had acquired. Unfortunately, for reasons of a political nature, I had to abandon that plantation, and when the trees that I had planted grew large enough to yield rubber, they were tapped by the natives and entirely destroyed, but my work gave me an experience which I considered of great value. For further information on this subject I refer the reader to the above mentioned article.

The india-rubber trees that grow in Mexico are not the Haevea guianensis that grows in Brazil, but the Castilloa elastica, and if we have any of the Haevea guianensis I have not seen them.

Enough has been written lately on rubber cultivation to show that the profits, in Mexico at least, would be very great; indeed, 300 per cent. on the capital invested is a possible return, after five years, from cultivating Castilloa elastica in that Republic. This is a return which provides plenty of margin for contingencies. Rubber-growing is no longer in the experimental stage, as witness the plantation of La Esmeralda, in Oaxaca, to which further reference is made below. Cultivated india-rubber plantations are few, for the reason that, in some degree like the coffee plant, the india-rubber tree requires a long period of continuous cultivation before making any return to the cultivator. Mexico affords excellent opportunities for the development of this admittedly profitable industry. On this point the authority of Sir Henry Nevil Dering, the British Minister to Mexico, who, in a recent report to the Foreign Office on the cultivation of india-rubber, says : "The regions most favorable for the growth of this important, yet rarely cultivated, india-rubber tree are the plains of Pochutla, Oaxaca, and also along the banks of the Copalita River where the tree is found in astonishing numbers. Few are the plantations of india-rubber trees existing in the Republic of Mexico. The principal one is La Esmeralda, in Juquila, Oaxaca, which has over 200,000 trees, eight years old." According to the same report the total expense for five years' cultivation of a "rubber plantation of 100,000 trees will not exceed $\$ 25,000$ in silver and the yield of 100,000 trees at the first year's harvest will bring the planter $\$ 120,000$, besides the product obtained from the corn, vanilla beans, cacao, and bananas raised from side planting. The net profit on the investment, after de- 
ducting the entire cost of the land and all expenses up to the first year of harvesting, will be $\$ 95,000$, and each of the succeeding harvests, for twenty-five or thirty years, will bring a steady income of over $\$ 100,000$." This is 400 per cent. per annum net profit on the investment. These calculations are based upon the production of a fiveyear-old tree, but the report adds that "this product will be gradually increased every year for the next four or five years."

Cotton.-We have many regions in Mexico very favorably located for the cultivation of cotton. I am aware that the cotton-growers of the United States hold that what they call their cotton belt has peculiar conditions for the production of their staple, which, in their opinion, do not exist in any other portion of the globe, and they believe, therefore, that nobody can compete with them in this regard. Without any intention of depreciating the advantages of the cotton belt of this country, I am of the opinion that there are in Mexico lands as well adapted for the production of cotton as the best in this country, and in some regions perhaps better; yet, notwithstanding these advantages, and although our wages are low, cotton is produced cheaper in the United States, and is sold with profit by the planters for one-half the price that it commands in Mexico. So great is the difference in the price of this staple in the two countries that, notwithstanding an import duty on cotton of eight cents per kilogram, or almost five cents per pound, which is equivalent to fifty cents ad valorem, we import from this country a very large portion of the cotton we manufacture. I do not overlook the fact that cotton is raised here by negro labor, which is considerably cheaper than white labor, but, even assuming that wages in this case be the same in both countries, the difference in cost is so great that some other factor besides labor must enter into the expense of production.

As our cotton manufactories are increasing, more especially because of the protection afforded to home products by the depreciation of silver, we now produce only about one half of the cotton we manufacture, and have to import the other half from the United States; but I am sure that before long we shall not only produce enough for our own consumption but also for export.

Agave.-The whole central plateau abounds in many species of agave, which are used for several purposes. In the eastern portion of the plateau, that is, from the City of Mexico towards Veracruz, in the region called the Plains of Apam, the agave yields a large quantity of a white juice, similar in appearance to milk, which when fermented is used as a tonic, and is an intoxicating beverage. The amount of alcohol it contains is small-about 7 per cent., I believe-but imbibed in large quantities it is quite intoxicating. The use of this beverage, called pulque, has become very extensive in Mexico, and it must have 
very superior qualities both as a tonic and nutritive, when many live on nothing but corn and pulque. In the mining districts, where a great deal of nervous force is expended working in a high temperature and under very unhealthy atmospheric conditions, this drink is almost indispensable, and I imagine that when a way is discovered to keep it for some time, and its medicinal qualities become better known, it will be exported in considerable quantities and used by foreign countries. From the agave of other districts a drink is made called mescal, which has some remarkable therapeutic properties, the most celebrated being made in a district of the State of Jalisco called Tequila, from which it takes its name; and in the very dry and stony regions of Yucatan another species of agave grows, which seems to derive its food wholly from the atmosphere, yielding a very good fibre, much like manilla, which we now export in large quantities, particularly to New York. All the agave yields a first-class fibre as raw material, either for paper or cordage-some of it being rather coarse, like the Yucatan henequen, and some of it almost as fine and glossy as silk, like pita.

Henequen.-By far the most important of our fibre industries is the cultivation and preparation of the fibre known as "Sisal hemp," so called from the name of the port from which it used to be principally exported, and in the United States as "henequen hemp." The plant which produces it is a species of agave which flourishes to best advantage in stony and arid land at the level of the sea. The present prosperity of the state of Yucatan, a large proportion of which is too sterile to yield any other crop, is due almost entirely to the development of this industry. The plant requires very little cultivation, and the separation and cleaning of the fibre is effected very cheaply. The yield of fibre is estimated at the rate of 1000 to I 200 pounds per acre.

Pulque.-The pulque plant is indigenous to Mexico, often growing wild on the uplands, where for months and years at a time no rain falls ; and it is also largely cultivated on the Plains of Apam, a large tract of land lying in the States of Mexico, Puebla, and Hidalgo, about sixty miles east of the City of Mexico. 'The plants are transplanted when two or three years old with much care, then cultivated in fields especially prepared for the purpose, each acre containing from 360 to 680 plants.

Nature requires the plant to be milked, when the liquor is ready to flow, for the use of man, else the superfiuity of juices will cause the growth of a thick stem from the centre of the plant, which shoots up some ten or fifteen feet, putting out branches at the top, with clusters of yellowish flowers. These branches are symmetrical, and the effect is like a lofty, branched candlestick.

When the pulque is first extracted, before the process of fermentation sets in, it is sweet and scentless, and in this state is preferred by vol. $1-4$ 
those unaccustomed to the drink. The fermentation takes place in tubs constructed for the purpose, and to aid or expedite the process a little "madre pulque," or pulque mother, is added, which hastens the chemical change. At times fermentation is retarded by a cold spell at the vats. When the laborer draws the sweet sap with his rude siphon, made either of a gourd or a calabash and a hollow horn tip, he discharges the contents into a pig- or goat-skin swinging at his back. The "agua miel" in this stage is like a green water in appearance and taste. Soon carbonic acid is formed, and it becomes milky, and resembles in taste very good cider. The amount of carbonic acid contained is so great, and the decomposition so incredibly rapid, that in a few hours it would become vinegar if not closely watched. To prevent this the pulque dulce, or sweet pulque, is poured into a tinacal-an oxhide strapped to a square wooden frame, and capable of holding a considerable amount of the liquid. These tinacals are of various sizes, to meet the emergencies of the situation.

To the sweet pulque is added an equal proportion of milk, and then a slight dose of infusion of rennet. This is not enough to coagulate it, but sufficient to induce a slight amount of putrescence, as in cheese. The putrid odor and flavor of pulque as sold in the pulque shops is due to the rennet alone, for the belief that this is caused by the flavor of the pigskin, in which it is brought to market, is without foundation.

From the tinacal it is poured into a hogshead by means of pigskins, and it is transferred to the barrels of venders from the hogsheads of the "haciendado" by means of the same skins.

The plants are wholly independent of rain and storm, and are of a beautiful deep-green color. The pulque is carried every day to the City of Mexico, by special trains, in "barricas," or large tierces, and by "cueros de pulque," or pigskins filled with the liquid.

The plant does not arrive at maturity or yield its sap before its eighth year. During the growth of the plant a central bulb is formed for its coming juices. This is scooped out, leaving a cavity or hole large enough to hold a few quarts. This cavity is made in the bottom and middle of the plant. The juice exudes into this cavity and is taken out daily by being sucked into a long-necked gourd on the siphon principle, by the Indian laborers, and then poured into the tubs taken to the fields and then removed to the vats.

The outlay on each plant up to maturity is calculated generally at about $\$ 2$, and the return is from $\$ 7$ to $\$ 10$, according to the size of the plant. Its period of production is about five months, and each plant supposed to yield from 125 to 160 gallons of liquid during that time.

The principal regions for the cultivation of the maguey are the arid limestone chains of hills, and here, in many places, the hole for the 
reception of the young plant is made with a sort of crowbar with a sharp point, used principally in the quarrying of tepatate, the chief building material of the Mexican capital. It is usual to aid the young plant by putting some good soil into the hole. These young plants are suckers which the mature maguey throws out on all sides, and which have to be removed before the heart is tapped for the sweet sap, which is the "agua miel," or honey water, of the pulque.

The leaves of the pulque plant are long and pointed, with prickles along the edges. Sometimes these leaves are very large, and the bunches of them springing from the common stalk are enormous. The bruised leaves are made into a kind of paper-a rather tough, stiff, and hard paper-and they are also used in their natural state as a thatch for the roofs of the common huts or houses occupied by the peons. A kind of thread is also made from the fibrous texture of the leaves. A rough needle and pin are made from the thorn, and from the root a cheap and palatable food is made.

Cactus.-Mexico is often called "the land of the cactus," and the multitudinous development of cactus forms in that country cannot be appreciated by any one who has not seen them in their home in the hot land. There is a species known as the giant or candelabra cactus, which has a single stem, from which spring innumerable branches, the whole plant resembling an immense candelabrum. I have seen in Oaxaca, some candelabra cacti about twenty feet in height by thirty in diameter. Some cacti shoot in single, column-like stems, others run like leafless vines, and others resemble needle cushions stuck full of needles.

Cocoa-Cocoa is produced in several localities. That of Soconusco, in the State of Chiapas, is of so excellent a quality that when Mexico was a colony of Spain it was the only kind used by the Spanish royal family. On account of the expense and difficulty of transportation, and the cultivation of cheaper quality in other localities, the production has dwindled down to an insignificant amount, and now hardly enough is grown to supply the demand in that district; but it is universally acknowledged that the Soconusco cocoa is the best in the world.

The best elevation for cocoa is from 300 to rooo feet, and the tree seldom thrives well at an altitude exceeding 3000 feet. Warmth and moisture are necessary for the successful cultivation of this plant.

The State of Tabasco produces a very good quality of cocoa, although it cannot be compared with that of Soconusco. In other places it grows very well also, but for various reasons the production, instead of being developed, has dwindled down until it is not enough for home consumption, and we have to import some, especially from Venezuela and Ecuador. One disadvantage of the cocoa industry is 
that the tree requires several years to reach maturity and to bear fruit, and few investors can afford to wait the necessary time.

Vanilla.-The vanilla bean grows very luxuriantly on the Gulf coast of Mexico, and it has been for some time a very profitable production, especially in the counties of Papamtla and Misantla, in the State of Veracruz, on account of the excellent quality of the bean and the high price which it brings. It grows in a region which is subject to intermittent and remittent fevers, and sometimes yellow fever, and where labor is very scarce; for these reasons it has not attained a greater development. I hardly think there is any locality where the vanilla vine grows better than in Mexico.

Vanilla requires a hot, moist climate, and, therefore, the lowlands are best suited for its culture. Very little of the vanilla produced in Mexico is at present grown at an elevation exceeding 1000 feet. At the same time it is claimed that in some places it thrives up to 3000 feet.

The vines will usually produce considerable vanilla in the third year, and they will yield considerably more during the fourth, fifth, sixth, and seventh years, and the production then begins to decrease. But before this time new rootlets have been dropped from the old plants, which form new vines that take the place of the old ones; thus the plantation is kept in a state of continued production. The central portion of the Isthmus of Tehuantepec is one of the most suitable regions for its cultivation, as much wild vanilla is found growing in the forests there.

The Mexican vanilla dealers have established five grades, namely : First, vanilla "fina," or legal, the beans and pods of six and a half inches long, or upwards, short in the neck, sound and black, and the beans which become split or open, provided they have the foregoing qualities and the split does not extend more than a third of the pod. This class is again divided into "terciada," which is composed of the shortest pods ; "primera chica," "primera grande," "marca menor," and "marca mayor," the largest of all. Second, "vanilla chica," those pods which differ from the "terciada" only in being shorter, two of them counting as one of the first class. Third, vanilla "zacate," the pods of all sizes, which are off color through being gathered before becoming properly ripe, or being over-cured ; "pescozuda," "vana," "cueruda," and "aposcoyonada," names for pods in a more or less damaged condition. Fourth, vanilla "cimarrona," the wild vanilla in good or fair condition, three pods counting as one of the first class. Fifth, the "rezacate," composed of the very short pods; of those split all the way up to the stalk, of the badly damaged, of the very immature, and of the greatly over-cured; of this, six pods count as one of the first class. 
After the sizing and classification are finished, the pods are tied up in bunches of $100-150$, so as to weigh one pound, and wrapped in filtering paper and tin foil.

Silk Culture.-The mulberry-tree and silkworm industries have a very great future in Mexico, and are destined to produce a veritable revolution in the industries of the central plateau of that country. The mulberry tree can be grown in Mexico almost to an unlimited extent, especially in the central plateau, and, as wages are low, the raw silk can be manufactured at a great profit. Several experiments have been made on a small scale, more particularly in the Valley of Mexico, by Mr. Hipolito Chabon, a gentleman of French descent, and he has obtained most satisfactory results. I have no doubt that the time is not far distant when the silk industry will assume great proportions in Mexico, and we will be able to stand among the foremost silk-producing countries of the world.

Cochineal.-The cochineal is a bug which feeds on the cactus; and which, when fully developed, is brushed off the cactus leaves and roasted to prevent decomposition, being then ready for market. It is raised to great advantage in Mexico, and especially in the valleys of the State of Oaxaca. When it was the only article used to dye red it was very valuable, commanding sometimes between four and five dollars per pound, and it made the wealth of that State. But recent discoveries in chemistry have supplied other substances for dyeing which are very cheap, especially aniline, and the price of cochineal has fallen considerably, so that now it is hardly raised at all. When it had a high price, it was raised in Guatemala, and it was the beginning of the wealth of that State. It is now raised, I understand, in several other countries.

Rice.-Rice grows very well in Mexico, and I have not seen any district where it is necessary to inundate the fields to favor its production, although I understand it is also raised in that way in some localities. It is generally planted just as wheat and barley are in the United States, needing no irrigation and depending entirely on the rainfall. I imagine that raising rice by inundation would be more expensive, and also be dangerous, because it could not fail to affect the salubrity of the country.

Chicle, or Chewing-Gum.-This article, like many others, grows wild in Mexico, where the demand that has arisen for it in the United States has begun to develop its production. For some time past the shipments from Mexico have been on an increasing scale, owing, no doubt, to the comparatively high prices which ruled early in 1896 .

Every year a larger extent of forests is worked for chicle, resulting in a steady growth of the production since the gum first became an important commercial article, about ten years ago. Prior to that 
time 7 or 8 cents a pound was considered a good price, and in 1896 it was sold at $3^{6}$ cents. The importation into the United States constitutes almost the entire production, and the amounts and values are thus officially reported by the Statistical Bureau of the United States for the fiscal years ending June 30 :

1894 .

Chicle .............. r,903,655 lib.

Value................ \$490,438

- Average............... 25 $5 \frac{4}{5}$ cents per lib. 32 cents per lib.

The following statement has been compiled from official data collected by the Mexican Government, the value of the chewing-gum being in silver :

\begin{tabular}{|c|c|c|}
\hline $\begin{array}{c}\text { Year. } \\
\text { I } 885-86 . .\end{array}$ & Pounds. & $\begin{array}{ll} & \text { Value. } \\
\$ \quad 156,402\end{array}$ \\
\hline $\begin{array}{r}1885-80 \ldots \ldots \ldots \ldots \ldots \\
1886-87 \ldots \ldots \ldots \ldots \ldots\end{array}$ & $\begin{array}{r}929,959 \\
\mathbf{r}, 254,853\end{array}$ & $\begin{array}{r}150,402 \\
353,641\end{array}$ \\
\hline r887-88..................... & $\mathbf{I}, 542,794$ & 371,673 \\
\hline 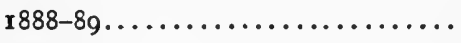 & $2,037,783$ & 592,810 \\
\hline $1889-90 . \ldots \ldots \ldots \ldots \ldots \ldots \ldots \ldots$ & $1,827,131$ & 714,242 \\
\hline 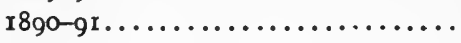 & $2,457,653$ & $\mathbf{r}, 284,682$ \\
\hline$r 8 g r-92 \ldots \ldots \ldots \ldots \ldots \ldots \ldots \ldots$ & $2,494,177$ & 703,572 \\
\hline $1892-93 \ldots \ldots \ldots \ldots \ldots \ldots \ldots \ldots \ldots \ldots$ & $\mathrm{I}, 757,8 \mathrm{I} 3$ & 705,167 \\
\hline $1893-94 \ldots \ldots \ldots \ldots \ldots \ldots \ldots \ldots \ldots$ & $2,645,722$ & 803, org \\
\hline $1894-95 \ldots \ldots \ldots \ldots \ldots \ldots \ldots \ldots \ldots \ldots$ & $\mathbf{1}, 668,636$ & 679,367 \\
\hline $1895-96 \ldots \ldots \ldots \ldots \ldots \ldots \ldots \ldots \ldots \ldots$ & $3,297,371$ & $I, 527,838$ \\
\hline$\cdots$ & & 413 \\
\hline
\end{tabular}

Yuca.-Yuca, or starch-plant, called manioc in South America, is a bush from four to six feet high, having tubers, like horse-radish, six to ten to every plant, and weighing from one to twelve pounds each. It is an important product of Chiapas and may be sown at any time, but it is better to do so from the stems when the rains begin, say in the month of May, by opening ditches five feet apart, and planting the cuttings, eight inches long, in them consecutively, leaving one foot between. Vegetable and sandy soil is best adapted for it, although it can be planted and will thrive in any kind of land. In arid and hard soil it needs plowing. If the land has been thoroughly cleared before planting it requires but little weeding during cultivation. A year after being sown, if the soil is rich, it will begin to yield tubers which must be dug up at the time the tree begins to flower. In replanting after digging the tubers, a slip is left standing and this will bear in twelve months. Besides extracting the starch from the tubers, the leaves are used as fodder for stock.

Sir Henry Dering, the British Minister to Mexico, sent recently to the Foreign Office some practical notes on the cultivation in Mexico of the "Yuca" or cassava plant, pineapple, ginger, "chicle" or chewing- 
gum, sarsaparilla, jalap, licorice, canaigre, and ramie, and I shall quote here from his notes on some of those products.

The yuca is to the peon, in the tropical section of the Republic, what potatoes are to the poor and working people of Ireland. Yuca is a native of the country, and its rise dates back before the conquest of Hernan Cortez, and it has always formed a portion of the food of the ancient and present Mexicans, especially those living in Veracruz, Oaxaca, Chiapas, Tabasco, and Yucatan. It has been estimated that the returns of yuca cultivation are immense; the yield of an acre contains more nutritive matter than six times the same area of wheat.

Ginger.-Ginger is found growing wild in various parts of Mexico. The returns from an acre of land vary considerably, but when cultivated under favorable conditions, the crops ought to be 4000 pounds and upward. A ten-acre patch would yield annually from $\$ 5000$ to $\$ 7000$.

Canaigre.-Though for years canaigre has been used in Mexico, both for medicinal and tanning purposes, it has but recently attracted the attention of the outside commercial world as a valuable source of tannic acid. The result of investigations has been to create a great demand for canaigre in the tanning business of European countries, and more recently in the leather-making centres of the United States. The only supply now to be obtained of this plant is from the wild growth along the rivers and valleys of Western Texas, New Mexico, and Mexico, and a fear has been felt for some time that with the constantly increasing demand the present sources of supply must become exhausted.

Peppermint.-Water mint (mentha vulgaris) thrives very well on the central plateau of Mexico and in some sections of the warm zone, especially along the rivulets and small lakes. There is no reason why the peppermint (mentha piperita), as well as spearmint and tansy, should not grow in abundance in Mexico, as they belong to the same family and require the same climatic conditions. As the oil of peppermint is very extensively employed in medicines and the arts, the cultivation of this plant will be profitable to Mexico.

Cabinet and Dye Woods.-In the low, hot countries we have all the cabinet woods growing wild and a great many dye woods, some of which are indigenous to Mexico, like the Campechy wood, not being found in other countries. It would take too long to enumerate the different kinds of cabinet woods we have, and I will only say that it happens with them as with our fruits, that only such of them as have been introduced here, like mahogany, cedar, rosewood, ebony, and a few others, are known in this country and in Europe, while hundreds of other kinds as hard as those and of as fine, if not a finer grain, are found in the wild woods of Mexico. 
Grasses. - In the lower regions of Mexico, especially at the sea-level, we have various grasses which can be grown at very little expense and which make very good food for cattle, fattening them very much, and in comparatively short time. While I lived in Soconusco, I used to buy lean cattle, three years old, at $\$ 10$ per head ; and letting them pasture on the grass, the expense being little more than that of a few men to take care of the cattle, without providing them with any shelter, pens, or anything of that kind, only giving them about once a month some salt, at the end of four or five months they became very fat and could be sold on the spot at $\$ 25$ a head. The fattening grasses can bevery easily cultivated, because they are of such rank growth that they do not allow any other vegetation to spring up on the same spot, and so save the expense of cleaning the ground of weeds; which, in the hot regions is very great, as vegetation is there very rank.

Alfalfa.-The alfalfa grows very luxuriantly in almost every placein Mexico, and it is so abundant there, that it has very little commercial value. It is nowhere dried and kept for fodder, but of course such use can be made of it. Land good for alfalfa has a very low price, and we are greatly surprised when we hear that in California the alfalfa land is worth $\$ 100$ an acre.

Cattle Raising.-Mexico has special advantages for the raising of cattle, not only because of its mild climate, which renders unnecessary the many expenses required in the northern section of this continent, but also on account of the grasses that grow in several localities and that constitute very good food for cattle, as I have just stated.

Mexico will be, before long, a very large producer of cattle and other animals, and they will form a large share of her exports. Mexico has. sent within two years about 400,000 small undeveloped cattle to the United States at about $\$ 15$, Mexican silver, per head, and has also sent nearly her entire output of cotton-seed meal to the United States and Europe at about $\$ 16$, silver, per ton. The meal sent to the United States. is fed to cattle. The Mexican cattle sent there take the place of the better stock which is sent to Europe, causing virtually a five-thousand. kilometre railway haul against the short haul in Mexico to reach the coast. In addition we have to pay import duties in the United States. This is a sufficient evidence that a large profit could be made by fattening cattle with the cotton-seed meal in Mexico, and shipping the fattened cattle direct to Europe, even using the best cattle of the country. But rapid improvement should be made in the class of cattle for beef purposes. Cotton-seed meal is the feed to be relied on chiefly. The quantity of it produced already is sufficient to fatten a large number of stock. The cattle should also be fed with a small amount of corn along with the meal during the last month of feeding to harden and whiten the meat, as feeding only with cotton-seed meal makes the 


\section{Jlora.}

meat dark, and militates against its selling value to some extent, and the corn can be easily and profitably supplied. The total cost of fattening a steer should not reach $\$ 15$ silver. There is an unlimited demand in Europe for choice meats at about r 2c., gold, per pound, and no import duties have to be paid. Poor classes of meat are a drug in all markets of the world. With these great advantages placed within easy reach, the producers in Mexico of grain and stock have a guarantee of ready sale at good prices for all they can produce.

Inquiry was made in Liverpool about the possibilities of the Mexican live-animal trade with England, and it was found that the initial difficulty is the small size of the Mexican cattle, as cattle weighing I 200 pounds are considered small by the trade there, and from 900 to rooo pounds is therefore extremely small. The smallest Texan cattle ever imported in Liverpool averaged 1226 pounds.

The best Mexican steers can be made to weigh 1200 pounds if well fattened. The difference in cost of transportation on account of lighter weight is but small in proportion to the cheapness of Mexican cattle. Cattle breeders in Mexico, on the whole, have not advanced much in developing good breeds of cattle. They do not appreciate their value, nor would they pay one-half their actual cost, though they can be had from the United States at half of what they would cost from Europe. Herefords are the best breed. I am sure that the railroads will do all they can to encourage that industry by charging as low rates as possible, as they would thus develop an industry which in the course of time would become very profitable to them.

A great need of Mexico is a reliable supply of good and healthy water through artificial means, well distributed over the stock ranges to prevent the great loss by death through lack of water, as well as the heavy shrinkage of meat and tallow, by so much unnecessary travelling of stock to water. They cannot grow fairly, much less fatten, and over one-half the annual increase die of exhaustion, while the value of the stock lost in one year would supply permanent water at convenient distances and prevent three-fourths of the loss and shrinkage now sustained. It has been amply proved that stock water can be secured under the most unfavorable conditions.

It would be to the advantage of the breeder to import some English short-horn bulls, with the object of breeding larger cattle, so as to make profitable the export of cattle to England, as animals should weigh from 1200 to 1300 pounds. This has been done in Texas and in the Argentine with beneficial results, and the improvement in the cattle from the latter place has been most marked during the last five years. With the proper attention, the same good results could be achieved in Mexico.

The English steamers that bring a large quantity of merchandise 
to Mexican ports have trouble in even securing ballast to get out of those ports, and have to traverse the Gulf and United States coasts to secure loads for the return trip. Their owners are willing and ready to supply facilities for the exportation of live stock and frozen meats if assured of a sufficient traffic to justify them in the expense, for they prefer reloading direct for Europe to going elsewhere for freight. The time required to return direct from Mexican ports is but little more than from New York and Baltimore, and is sufficiently short to warrant good service in transportation of live stock, and the cost would practically be the same as from United States ports. The United States is beginning to export beef and stock from Galveston to Europe, which is practically the same distance as from the Gulf ports of Mexico.

Mexico could export annually and easily after the next ten years 400,000 of fattened cattle, which would increase considerably the amount of our exports, and this trade would greatly assist the development of many other industries.

The desired result in question could be hastened by mixing good foreign labor with the native labor. The latter would be better fed, clothed, and educated, as well as encouraged, taught, and compelled to do better work, and thus the country's physical and mental welfare would be greatly promoted.

Sheep.-The same conditions apply to the sheep and wool industry. It is a great mistake for the Mexican sheep-owners to raise a class of sheep that yield each only from one to two and one-half pounds of very coarse and inferior wool, annually, while they themselves wear goods manufactured from foreign wools, and the domestic-cloth manufacturers are also under the necessity of importing largely of fine wools. Mexico possesses natural resources for producing all the wools of every grade that she needs, with a large quantity over for export, not to speak of choice grain-fed mutton for domestic and foreign consumption.

The custom of killing so much poor stock is a terrible waste of resources, as one well-fattened animal will render twice as much as a thin or poor one.

Products of Cold and Temperate Regions.-I will not speak of the products of the cold and temperate regions of Mexico, such as Indian corn, wheat, oats, barley, and others, because their cultivation is well understood in the United States, and I could say here nothing new to the American reader, but will only state that they all grow very well in the proper regions of Mexico.

FRU1TS.

We produce in Mexico a great many tropical fruits that are not sent to the United States because there is no market for them for the reason that they are not known here. Some of them are delicious, 
and with the facilities of communication, I have no doubt that they will become known and a taste will be developed for them in this country. I will speak here only of such of our tropical fruits as come to the United States.

The advantage of tropical fruits growing in their proper zone and climate is immense, as the expense of planting and cultivating them outside of their proper limits is very great and there is always danger of their destruction.

Oranges.-Orange trees, like any other fruit trees, depend in Mexico on the rain, and, except in a private garden or private grounds, are not irrigated. While the orange tree is a hardy plant, it thrives best and yields the most luscious fruit in the tropics. Elevation exceeding 2500 feet is not, as a rule, desirable for orange culture.

The advantages of irrigation in orange culture are great in the subtropical regions of Mexico. 'The fruit of the irrigated orange tree is of a very superior quality, while the tree itself has a longer lease of life and is less subject to attacks from insects and diseases of a fungoid nature. One of the conditions primarily requisite to the growing of a marketable orange is that the trees be watered at judiciously regulated intervals during and for a short time after the blossoming season. Attacks from insect and fungoidal pests, which are most disastrous, and to which the trees are peculiarly subject during the blossoming period, are rendered even more dangerous by the prevalence of a considerable amount of humidity in the atmosphere which is always conducive to the development of parasitic germs or fungoidal spores. An abundance of moisture in the ground but a comparatively small amount in the air is the condition most to be desired during and just after the blossoming season. This is to be had by irrigation, but, generally speaking, not without it. Under irrigation, the soil is also much less subject to deterioration, owing to the superior fertilizing properties of water taken from wells and streams. Rain water, aside from containing a small percentage of ammonia, which it receives from the air, only acts as a medium to transmit the nutriment from the soil to the tree, while water taken from wells or streams holds in solution the renewing materials which are directly communicated to the plant proper.

In the more elevated orange districts of Mexico, the trees should be watered about once every twenty days during the dry season.

In some places our oranges are as sweet as if they had been preserved in sugar, and this, notwithstanding the fact that no attention is paid to their cultivation, that they grow almost wild, and without irrigation.

I think that the distillation of orange blossoms would prove very profitable. The production of flowers per tree is given at from 22 to 55 pounds in the case of sweet oranges, and from 60 to roo pounds per tree from the bitter variety. 
In flavor and productiveness the Mexican orange is unsurpassed. In the majority of the districts but little care or attention is given to the cultivation of the trees. Scientific orange culture in Mexico is practically unknown. The introduction from other countries of different varieties of the plant for experimental purposes is just being commenced.

The price of oranges in Mexico at the present time, in districts reasonably near lines of transportation, is about $\$$ II per thousand, Mexican money, on the tree. It is the practice of the producer to sell the fruit on the trees, the buyer picking, packing, and shipping it at his own expense.

About one hundred trees are usually set out to the acre, the average yield being from 800 to 1000 oranges to the tree. I know of trees in Mexico which have a record of having produced ro,000 oranges. This, however, is very exceptional.

A properly cultivated and prudently man'ged grove at the end of five years' growth should prove as profitably as a coffee plantation of the same size, at the end of five years.

The production of the orange trees begins in the third or fourth year and increases up to the twelfth, and, in some cases, to the fifteenth or sixteenth year. It is considered best to cut the fruit up to the fifth year, not permitting it to mature.

A book prepared by Frederico Atristain, entitled Cultivo y explota-cion de Naranja, and published by the Department of Fomento of the Mexican Government, contains a great deal of reliable information on the subject of orange culture in Mexico.

After an orange tree has been yielding sweet oranges for many years, it very likely exhausts the substances of the earth which give the sweet taste to the fruit, and it begins to lose its sweetness, until finally, if the land is not manured, as is almost always the case in Mexico, the oranges become bitter.

A recent cyclone, which lowered considerably the temperature in Florida, destroyed in one day, I understand, about $12,000,000$ orange trees, thus causing ruin or serious loss to thousands of men engaged in that large industry, while the orange region in Mexico is entirely free from frosts and consequently from such dangers.

Lemons.-In the hot and temperate regions of Mexico lemons grow very well. 'There are some districts of the country, like Soconusco, where the natives plant the lemon trees very close together, for the purpose of making a hedge or fence, and, notwithstanding that the trees have not the necessary conditions of sunlight and air for their proper development, they grow very well. I do not know of any place in Mexico where lemons have been cultivated for commercial purposes; but I am sure they could be made a very lucrative industry. 
Limes and Shaddocks.-Lime trees prosper very well in Mexico, bearing large amounts of delicious fruit. I have not seen in the United States any of our limes, at least such as are imported here are not like ours, and $I$ have no doubt that if known our limes would find a good market in this country. The lime should not be planted at an altitude exceeding 1000 feet. We grow also a very large kind of shaddock, which we call "toronja," and which is not imported in this country, but which if known here would find a good demand. It grows very luxuriantly and attains at times a very large size, even eight inches in diameter, having a very thick peel.

Bananas.-The banana thrives anywhere from the sea-level to an elevation of 5000 feet, and is one of the many Mexican fruits which yield to the planter an immense profit. The whole Mexican coast produces the banana spontaneously and in very great abundance. On the lands near the sea, at an elevation of 600 to 700 feet, large planta. tions of bananas can be started at a cost of five cents per plant, including all expenses. At the end of the first year, the plants begin to bear, and 1000 plants, which have cost $\$ 50$, will produce $\$ 1000$ as a minimum. The following year the yield is double that amount, and almost without expense. At the end of one year, the plant produces one bunch which is worth in the United States from 75 cents to \$I gold, the cost to the farmer being not more than 25 cents per bunch in Mexican currency. After the first year, the sprouts from the old plant grow up and give double the first year's yield.

There is perhaps no tropical plant easier of cultivation than the banana. The suckers having been planted out at the commencement of the rainy season, they will grow vigorously, and produce fruit in about a year. The land must be kept free from weeds, and an occasional turning up of the soil will prove beneficial. Before the plant throws out its flowering stem, suckers will make their appearance above the ground, and these will require careful attention. While the plant is young, all the suckers except one should be cut away, the best plan being to sever them with a sharp spade. Thus all the vigor of the plant is thrown into the fruiting of the first stem, and the growth of the one to supplant it, and, in this way, fine large bunches can be reckoned on. The second stem usually produces a finer bunch of fruit than the first, but, as the land becomes exhausted, the bunches of course decrease in size, and this shows the necessity for manure in some form or other.

Bananas are used extensively as shade for young coffee and cocoa trees, and in places where an export banana trade has been established, the formation of a cocoa plantation is a very inexpensive matter, as the return in fruit from the bananas will pay for the cultivation of the cocoa until the trees are able to give a small crop. 
The important feature, and the one upon which the success and profit of the industry depend largely, is that of cheap and certain transportation facilities. That requisite is easily obtainable ; for instance, there are extensive and cheap lands for sale along the Tampico branch of the Mexican Central Railroad, from which the fruit can be shipped either all by rail, or by rail to Tampico, and thence by boat.

We have many kinds of bananas in Mexico, of different sizes, colors, and flavors, ranging in length from two to eighteen inches, and from one-half of an inch to three inches in diameter. The largest, which in some places are thought unfit for food, are in others, like Soconusco, considered the best; very likely on account of their different quality. When roasted the latter are very juicy, and taste exactly as if they had been preserved in sugar. Some people on the coast live almost entirely on bananas, this fruit forming their principal food. The banana is likewise a tropical plant, and thrives best on the lowlands.

Pineapple.-The Toltecs and Aztecs knew how to cultivate the pineapple, and when the Spaniards conquered Mexico, they found the fruit in the markets of the towns on their way from Veracruz to the great Tenochtitlan. "From time immemorial," Sir Henry Dering says, "the pineapple has been cultivated in Amatlan, a town five miles south of Cordoba, from where the ancient Mexicans used to get their main supply." Now it is grown in tropical Hidalgo, Puebla, Veracruz, Tabasco, Chiapas, Oaxaca, Morelos, Guerrero, Michoacan, Colima, Jalisco, and Tepic. "Besides the fruit being very delicious and wholesome," Sir Henry Dering says, "a fine wine and vinegar are made of the juice. The leaf furnishes a fibre of extraordinary strength and fineness, making it even more valuable than the fruit. The fibre is made into ropes, cables, binding twine, thread, mats, bagging, hammocks, and paper. A pineapple rope three and a half inches thick can support nearly three tons. A textile fabric as fine and beautiful as silk is made of this fibre too. It is believed that the fine cloth of various colors used by the upper classes among the Aztecs was made of the pineapple fibre. The modern Mexicans do not manufacture it much now, except in the Isthmus, where the Zapotec Indians still make a cloth from it and from wild silk. One cause for its disuse is the slow and wasteful manner in which it is separated." Pineapples will grow at elevations of from 2000 to 3000 feet above the level of the sea, but the best and most delicate fruit is produced on the lowlands.

Cocoa-Nut.-We have in our lowlands near the sea many kinds of palms called corozo, bearing different kinds of fruit, growing in large bunches and the fruit very abundant, being in the shape of a small egg, very rich in oils, and making also a very good food, although it is hardly used now for any purpose. The palm tree bearing the cocoa-nut grows, of course, very luxuriantly, and does not require any care after 
it is once planted. The cocoa-nut prefers the sea-coast and high temperature. The saline breezes from the sea are very beneficial to it. I have not seen in Mexico the species of palm bearing the date, perhaps because it has not been planted there; but I am sure that we could raise it, as we have several sections with a climate similar to that of Egypt and Asia Minor, where the date palm grows so well.

Mangos.-The mango is a very fine fruit, but requires a cultivated taste, and is generally disliked the first time it is eaten. It has a very large bone, although that is not the case in fine qualities, called Manilla mango, which has a very thin one and a great deal of pulp. The mango occasionally comes to the United States, but being a very frail fruit, has to be taken from the tree when very green. It does not ripen well, and, if taken when beginning to ripen, it reaches its destination in a decayed condition.

Alligator Pear.-The alligator pear is one of the most delicious fruits that we raise in Mexico, and is properly called vegetable butter, being a good substitute for butter. It is not eaten by itself ; the most usual way to eat it is in salad. We have several kinds and sizes of this fruit. The seed of the alligator pear is oval-shaped and quite large, about 4 inches in length by $\mathrm{I} \frac{1}{2}$ in diameter, and of some oily substance, which, I have no doubt, has some good medicinal properties.

Mamey.-The same is the case with the seed of the mamey, a fruit unknown in the United States, having a red pulp, and a very large seed covered with a thin shell. The Indian women extract an oil from that seed and use it for their hair, and I think it must have many more useful medicinal properties.

A great many other of our fruits have seeds containing substances which I have no doubt will be found, when analyzed, to be very valuable to therapeutics.

Zapote.-The zapote is one of our tropical fruits which does not come to this country. I have just heard that the seeds of the zapote have recently been found by a Mexican doctor to be a very good narcotic, which does not produce the ill effects of the drugs now in use.

Papaya.-This fruit, which grows in our hot lands resembles the melon in shape, pulp, and seeds, but its color is of a yellowish-red. It was considered a very common fruit, but recently it was found to be a powerful digestive, and it is already used in Europe as a medicine under the name of Papaine.

\section{Flowers.}

Mexico is a favored country for flowers. They grow wild in a great many places, and they can be raised at very little cost, as there is no need of hot-houses or any other expensive appliance to cultivate them. The Indians in the small towns around the City of Mexico 
make a business of raising flowers, and they sell handsome bouquets, as artistically made as any in this country, for a mere trifle. A bouquet which, for instance, in New York would cost \$5 in winter, could be had in the City of Mexico all the year round for 25 cents; and I look forward to the time when flowers will be exported in large quantities from Mexico to the United States if the protective policy of the country does not interfere.

\section{IRRIGATION.}

At the time of the Spanish invasion of Mexico, the Indians in those parts of the country where the population was greatest were dependent upon irrigation for a large part of their cereals, and for cotton, which played so important a part in their economy. As the same method had been employed from time immemorial in Spain, it followed that on the partition of the soil among the Spanish conquerors, irrigation became an important factor in their agriculture ; but with expansion of population large tracts of land have come to depend entirely upon the rain.

In recent years Mexican agriculture has depended almost altogether on the rainfall, except in a few places well supplied with water, and where irrigation is both cheap and easy; but the inhabited portions of the country have been depleted of their timber by the natives for the purpose of using the wood for fuel or lumber. In more recent years, the building of railroads has increased considerably the demand for wood both for sleepers and for fuel for locomotives, and the consequence is that a great change is taking place in the climatic conditions of the country and that fuel is exceedingly high. In no other country is there so much timber-a good deal of it not yet full grown-consumed annually as in Mexico. The consumption of timber for railroad purposes alone, not to mention that used in mines, smelters, and as fuel in cities and towns, is incalculable.

Competent authority in Mexico, among whom is the Inspector of Manufactories, created for the purpose of insuring the collection of the internal-revenue tax, considers that only in the Federal District of Mexico the consumption of wood exceeds 4000 English cords daily, used as fuel in the factories, railroads, and other plants of that city.

The consumption of charcoal by private families in the old-style open cooking grates is at least 500,000 pounds in the Federal District of Mexico, which is equivalent to 2,500,000 pounds of wood taken from the scanty forests of the central plateau, and that consumption would be very much reduced if, instead of those old-fashioned grates, iron cooking stoves should be used; and to encourage their use, when I was last in the Treasury Department of Mexico, I was instrumental in reducing considerably the duties on the same.

Another cause of the destruction of the forest in Mexico consists 
in the primitive way in which the Indians raise their crops. They own in common a large tract of land, and they begin to till near their towns, commencing by destroying the forests and planting every year in a different locality, because, more especially in the lowlands, the vegetation springs up so rank after the first year's crop that it is very difficult to keep the ground clear of weeds. In this way they clear new land every year, going farther and farther from their town, until sometimes their crops are raised at a distance of as much as thirty or forty miles from their homes. The natural result is the destruction of the forests around the towns and at some considerable distance from the same, and consequently the diminution of the rainfall. I was greatly struck, on my last visit to Mexico, in 1896 , by the scantiness of water at an Indian town called San Bernardino, in the sierra district, about five miles north of Teotitlan, the county seat of the district, which I had visited in November, $\mathbf{1} 855$, and found then exceedingly abundant in rainfall and consequently in water, as well as all the mountains north of that place, which extend for about eighty miles to the lowlands on the Gulf of Mexico. On my recent visit, however, I found a great scarcity of water : a small stream of probably not more than one-half an inch in diameter, carried in very primitive wooden troughs, was all the water the town had, and that only during the rainy season, the people being obliged to go a considerable distance for water in the dry season; this being only one illustration of what the destruction of the woods is doing in Mexico.

The city of Oaxaca, at the foot of the Sierra, used to be, in my young days, very well supplied with water, using for that purpose several streams coming from the mountains; but during the last dry season the scarcity of water has been such as to cause a real water famine.

The diminution of the rains, together with other atmospheric phenomena, which takes place from time to time, produces in some years drought that prevents the crops from being raised; as the country produces at present only the corn necessary for its consumption, which cannot be kept from year to year on account of its being eaten by insects. This diminution was very disastrous before the railroad era, causing serious famines. Since the railways were built, we import in such years corn from the United States, spending several millions of dollars in providing ourselves with that staple. All that will be changed, and we shall be able to produce cereals enough not only for home consumption, but even for export, when we begin to use irrigation. The configuration of the country allows dams that will retain sufficient water both for irrigation and manufacturing purposes, to be built at comparatively little expense.

Large tracts of land in Western Asia, Northern Africa, and Southern Europe-countries which, according to historians, were once densely 
populated and gardens of the world-are now uninhabited and barren wildernesses; and this has been brought about by the wholesale destruction of the forests and the absence of any law to protect them and provide for their replanting. In the United States it has been seen that not only does the decrease of the forest area lessen the rainfall, but also the fall of snow in the winter months, the consequence being a marked decrease in the supply of water for irrigation purposes from the streams and rivers dependent for their supply on the snowy mountain tops.

Along the Mississippi River it is a common observation of the river pilots and old steamship hands that the summers are becoming more and more dry and the streams smaller, and that the big river itself has shown a marked decrease of "navigability" every year during the past twenty years. All this is caused by the indiscriminate chopping down of the forests at the head of the principal tributaries of the big river. Statistics from Russia, Germany, Spain, Italy, Palestine, Australia, and India all prove beyond a doubt that the protection of the forests is a matter of vital importance.

Mexico is not only suffering from an annual decrease in rainfall, owing to the continual decrease in the timber-bearing area, the rainfall being more and more unequal every year during the past twenty years but the winters are becoming more and more severe, and the frosts are reaching farther and farther south each year. This is undoubtedly due to the wholesale destruction of timber now going on throughout that Republic.

The Government can cope with this matter only by legislation, and having before it the example of the rest of the world, the Mexican Government should act without delay and in a manner that would benefit, not only the present, but also future generations; and I understand it has been studying the advisability of prohibiting the use of wood for the locomotives and sleepers. Experience has shown that in tropical countries iron sleepers last much longer, and are, on the whole, cheaper than wooden ones, and our supply of coal will soon be ample enough to furnish all the fuel necessary for the railway and mining industries.

One of the most profitable investments for capital in the near future will undoubtedly be the construction of reservoirs in the mountains, dams in the rivers, artesian-well boring, the erection of pumping machinery on a large scale, together with the introduction of modern devices and appliances that will facilitate the successful cultivation of the soil and assure crops of all descriptions in all parts of the country where it has been proved that irrigation must be resorted to. Not only are these requirements essential for the conservation of water for irrigation purposes, but many large cities throughout the Republic are without any certain water supply; and many that have a sufficient supply 
show by their death-rates that that supply is bad, and during the greater part of the year is the cause of wide-spread disease.

Again, much is to be gained by the use of these waters for the generating of power for the use of factories, mines, electric lighting, railways, and street cars, even should one hundred miles or more intervene between the generating plant and the machinery it is proposed to apply to it.

It seems marvellous that the Mexico of to-day-presenting, as it does, more natural resources, a greater variety of climate, cheaper labor, and better facilities for the construction of dams, reservoirs, canals, etc., than almost any other country-should be so far behind the times in a matter that has become an absolute necessity before the greater portion of its area can be thoroughly populated. The great increase in value of a piece of land after it is irrigated ought to be inducement enough for capital to be invested in such works. Competent engineers contend that Mexico, owing to its topographical and geological features, will be found to present most favorable conditions for the construction of reservoirs, dams, gravitation canals, the erection of pumping plants driven by wind, steam, gasoline, electricity, or even water power, and also for the cutting off and bringing to the surface of the underflowing waters, which are known to exist in greater abundance there than elsewhere on the face of the globe, as nature has been very prodigal to it in these respects.

Irrigation in arid countries is the corner-stone of civilization, and, to make a country self-sustaining, agriculture should be the first aim of its inhabitants. Agriculture must come first ; manufacturing and mining cannot thrive until the food supply is forthcoming.

With the extension of railway lines and the notable impulse given to agricultural enterprise within the last twenty years, Mexican landowners have improved more and more upon the earlier methods, and have, to an increasing extent, applied the principles of engineering science to the methodical cultivation of the large tracts into which their holdings are usually divided.

The Nazas Irrigation.-Some notice of an irrigation enterprise in Mexico will show how much we are now doing in this line.

The great plan of northern Mexico embraces nearly the whole of the States of Chihuahua and Coahuila, being bounded east and west by the sierras of the Pacific and Gulf coasts respectively. It consists of two watersheds, - that of the Rio Grande to the north, and the the so-called desert of the Bolson of Mapimi in the south. It is about four hundred miles wide by six hundred long, and maintains a general level of about four thousand feet above the sea, although much broken by local mountain ranges. The Bolson of Mapimi has much the same formation as the basin of the Great Salt Lake. 
It receives the drainage of all the eastern slopes of the Durango sierras and the western slopes of the Coahuila ranges, but possesses no outlet. As a consequence, throughout its whole area, the rivers run into broad, shallow lakes, whence the waters are gradually lost by evaporation during the dry season. Of these rivers, the largest is the Nazas, which has a course of nearly three hundred miles from its source to where it is dispersed over the shallows, called on modern maps Lake Mayran. Sixty or seventy years ago the Nazas discharged its waters into a series of extensive lagoons, occupying what is now the fertile Laguna district of Durango and Coahuila.

At that time a phenomenal and long-continued rainfall so overcharged the, then, bed of the Nazas as to cause it to open a new course, and leave the Cayman lagoons thirty miles on one side. In the course of years these lagoons were converted into a mesquite wilderness, almost dead level, and composed of a deposit of the finest detritus, of unknown depth. The central depression of this lake-bed filled a broad valley running north and south, and surrounded by a parallelogram of mountains. The area thus comprised was about two hundred and ten square miles of pure vegetable loam, locally known as the Lake of Tlahualilo. This cuenca, or bowl, was the spot chosen about six years ago for the establishment of the great irrigation enterprise.

The problems involved called for courage and high administrative qualities, as well as technical engineering knowledge. It had early developed that the lands left dry by the changed course of the river were of extraordinary fertility, and half a century ago these tracts, immediately adjacent to the river, had been taken up and brought under irrigation after the rough methods then practised. The result was that, by 1890 , about 250,000 acres of this land were under ditch, and the region was producing the greatest part of the cotton grown in Mexico, as well as heavy crops of corn and wheat. The Tlahualilo basin was known to be the richest portion of this district, but the thirty miles of sun-baked desert separating it from the present course of the river presented an obstacle to utilization which proved too formidable for the cultivators of the Laguna country. In 1889 a project was formulated for carrying a ditch across the intervening desert to the head of the Tlahualilo cuenca, and converting the whole of the latter area into a huge hacienda.

Preliminary survey showed that the lowest level of the basin to be irrigated was about roo feet below the point on the river Nazas which it was proposed to dam; that the main canal, on account of topographical conditions, would require a development of 39 miles; and that the slope of the lands within the basin was such that about r 75 square miles out of the 2 ro composing the basin could be advantageously irrigated. A company was formed to undertake the work. 
A dam of piles and riprap was thrown across the river at a point where it is about 1500 feet wide at flood. From this dam the line of the main canal was traced to the entrance of the Tlahualilo,-a distance of 39 miles. The canal terminated in a distributing tank at the entrance to the irrigable area, whence it bifurcated, one arm being carried along the western side of the basin.

The rainfall in the Bolson of Mapimi is confined to a few days of heavy showers about the beginning of June and the beginning of December. But up in the mountains of Durango, where the Nazas takes its rise, the rainfall at the same season is very heavy and protracted, resulting in high water in the river, which lasts for several weeks at a time. It is during these freshets that the cultivated lands in the Nazas district are irrigated. For the rest of the year they receive no water, except from occasional brief showers. In the Tlahualilo basin, a week or ten days of irrigation is all that is needed in the course of a year, the water soaking easily and quickly through the almost impalpable silt, and the hot sun forming a protecting crust which checks evaporation, and retains the moisture in the subsoil for a surprisingly long time. In fact, owing to their long roots, the cotton plants strictly require irrigation only once every other year, but corn and wheat, of course, must receive it at each planting. The distribution of the waters is regulated by government schedule, each property on the river being allotted its proportion of water, according to priority of settlement. Each canal on the river is permitted to take as many irrigations as it desires during the season of high waters, but in strict rotation. That is, after a property has taken one quota, it cannot repeat the process until all the others have taken theirs, when its second quota is available. Where another property, as often happens, does not care to use all the water to which it is entitled, its further allotments may be used by its neighbor. The waters, on leaving the river, are heavily charged with sediment largely volcanic in its origin, and this is deposited on the lands at each flooding in the shape of extremely fine mud.

Six years of experience with this property demonstrates the fact that irrigation, when applied to fertile land under a carefully planned and thoroughly executed system, where the water supply is owned by the user, puts agriculture among the least dubious of industries. The system adopted by the Tlahualilo Company is especially worthy of attention, because of the notable unity of plan pursued from the inception of the enterprise to its fullest development, and of its resultant economies. It was on this property that a disastrous experiment of colonization from Alabama took place in the year 1896 , when hundreds of negroes were taken from Alabama and other points of the southern portion of the United States under the supposition that they could 
withstand the down-pour of the tropical sun of Mexico, and by their knowledge of the cultivation of cotton succeed in carrying out the purpose of the men who undertook the enterprise. Unused to food conditions in Mexico, especially for want of bacon and corn bread, they were infested with sickness, which caused great mortality among them, and frightened and demoralized they fled from Tlahualilo, this experiment showing very plainly that Mexican planters cannot rely for labor on the colored people of the United States.

The production of cotton and corn in the vicinity of Torreon can be increased eightfold by building reservoirs in the Nazas River and its tributary cañons, to hold the water back for the irrigation of the vast area of fine cotton and corn lands that are yet unproductive, simply through the non-retention of the great amount of water flowing to the sea, unused, annually, and the same result could be obtained by doing the same thing with many other rivers in Mexico. With onefourth of the water now needed to produce a good crop, the same amount of grain can be produced by good cultivation. The reason is that by the methods now in vogue in most parts of the country, so little soil is loosened.by the plow that nearly all the water runs off, where rain is relied on, and only with a great amount of rain can a crop be raised. When irrigation is used, the water required to keep the hard ground moist is entirely in excess of the reservoir, rain, and river supplies. This is the reason of the short grain supply and of the necessity for importing during years of drought large quantities of corn. If the ground were plowed deep and well, it would absorb most of the rainfall and create sufficient surface moisture to meet the moisture from below, which would counteract the dry action of the atmosphere on the soil and roots of the grain, which, by its luxuriant growth, would soon shade the ground, and thus contribute still further to the retention of moisture.

The fact is, taking Mexico as a whole, that there is not a year so dry but that with good cultivation, sufficient grain can be raised to supply domestic demands, while all the excess above that quantity in favorable seasons should be used as feed for stock, which would supply the large quantities of lard, tallow, hard-oil, etc., now being imported, and would leave a large amount for export, together with a considerable quantity of meat for the same purpose, thus helping to cover the balance of foreign trade and keeping our silver dollars in the hands of the farmers and stockmen, to improve and increase their lands, herds, and flocks.

FAUNA.

The present Mexican fauna belongs, like its flora, to the North American zone, so far as regards the plateau regions, and to the Antilles in respect to the coast lands round the Gulf, while that of the 
Pacific seaboard is intermediate between the Californian and South American. In the general aspect of its terrestrial animals, Mexico is connected more with the United States, whereas in its marine forms the reverse movement has taken place. Thus the prevailing species in the Gulf of Mexico as far as Tamaulipas and Texas, and the Pacific coast northwards to Sonora and Lower California, have migrated from South America. The species in the two oceanic basins differ almost completely; and, despite the proximity of the Pacific and Atlantic shores, their shells are quite distinct.

The fauna includes three species of large felidæ, the puma or American lion, jaguar, and ocelot; among the smaller is the wildcat. Wolves are common in the northern States, and also the coyote; besides which there are bears, wild boars, and bisons. A species of sloth is found in the southern forests, with five varieties of monkeys. Of the other wild animals the principal are hares, rabbits, squirrels, two or three kinds of deer, beavers, moles, martens, and otters.

All the domestic animals introduced by the early Spanish settlers have multiplied prodigiously. The horses, though small, retain the spirit and graceful form of the Andalusian or Arabian stock, from which they mainly sprang.

The waters of the estuaries and coast streams teem with fishes, all the numerous varieties of which differ on the two oceanic slopes, but still present a certain analogy in their general distribution. Turtles are taken in considerable numbers on the coast, and the carey, or turtle-shell, of Yucatan and Guerrero is the object of a trade valued at $\$ 20,000$ yearly.

The ophidians are represented by a few boas in the southern forests, and several species of snakes, some extremely venomous, as the rattle and coral snakes. The largest lizard is the iguana, whose flesh is by some of the natives used as food. Noxious insects infest the hot regions in myriads ; alacranes, or scorpions, in two different varieties, are everywhere feared, and many children were every year killed by their sting in the city of Durango before the proper antidote was found and used. Scolopendras, gigantic spiders, tarantulas, and mosquitoes abound.

Bees are numerous and their wax is an article of export, and the silkworm, though comparatively neglected, yields an annual profit of some importance. The birds of prey are eagles, hawks, and zopilotes, or turkey-buzzards, the scavengers of the coast towns, with three or four species of owls. Domestic fowl are extremely abundant. The parrots, humming-birds, trogons, and so forth, vie in richness of plumage with those of Brazil, and the Mexican songsters, the prince of which is the zenzontle, or mocking-bird, are unequalled by those of any other country. 
Of all the Mexican fauna, two only have been domesticated : the huahulotl (Meleagris Mexicana), which is a species of duck, and the turkey, introduced into Europe by the Spaniards from the West Indies, hence by the French called "coq d'Inde." The techichi, an edible dumb dog, was soon exterminated when taxed by the Spanish authorities. The other farmyard animals have all been introduced into Mexico by the conquerors.

In the Gulf of California, and especially near La Paz, and the neighboring archipelagoes, extensive beds of pearl oysters are fished. Some other islands in the same gulf are frequented by myriads of various species of aquatic birds, and have already yielded many hundred cargoes of guano.

It is noteworthy that the Pacific islands, lying at some distance from the coast, have all a fauna different from that of the mainland. Thus the little Tres Marias group, about sixty miles off the coast of Jalisco, has a special species of humming-bird. The Revillagigedo Archipelago also forms a separate zoölogical zone, and the island of Guadalupe, over one hundred and fifty miles distant from Lower California, has eleven species of land birds, every one of which differs from the corresponding species on the adjacent continent.

\section{ETHNOLOGY.}

Mexico is inhabited by native Indians found there during the Spanish conquest, by descendants of the conquerors of Mexico and other European races, and by a mixture of the two. There are so few inhabitants of African descent that it is hardly worth while speaking of them. The proportion of this population is about as follows: Of European descent, 19 per cent. ; native Indians, 43 per cent. ; mixed races, $3^{8}$ per cent.

Mexican Indians. - The native Indians found by the Spaniards belong to several nations and tribes, having different features and entirely distinct languages. The principal of these tribes are the following, some of which are now extinct:

$\begin{array}{lll}\text { Otomi, } & \text { Apache, } & \text { Tarahumara, } \\ \text { Chichimec, } & \text { Irritilas, } & \text { Tepehuan, } \\ \text { Huaxtec, } & \text { Tamaulioecs, } & \text { Sabaibos, } \\ \text { Totonac, } & \text { Zacotec, } & \text { Acaxee, } \\ \text { Mixtec, } & \text { Huastec, } & \text { Xixime, } \\ \text { Zapotec, } & \text { Zoqué, } & \text { Concho, } \\ \text { Mahuas, } & \text { Opata, } & \text { Manosprietas, } \\ \text { Toltec, } & \text { Guaicuri, } & \text { Comanche, } \\ \text { Olmecs, } & \text { Yaqui, } & \text { Cuachichils, } \\ \text { Xicalancs, } & \text { Mayo, } & \text { Tarascos, } \\ \text { Tula, } & \text { Seri, } & \text { Mixé. }\end{array}$


These tribes have been classified in the following families :

\author{
Mexican Family; \\ Sonorense Opata-Pima Family ; \\ Guaicura y Cochimi Laimon Fam- \\ ily ; \\ Seri Family ; \\ Tarasco Family ; \\ Zoque-Mixé Family ;
}

Totonaca Family ;

Mixteco-Zapoteca Family ;

Matlalzinga ó Pirinda Family ;

Maya-Quiche Family;

Chontal Family :

Huave Family ;

Apache Family ;

\section{Otomi Family.}

There is a great deal of similarity between the Mexican Indians and the Malay Asiatic races-especially the Japanese branch-which gives foundation to the idea that the aborigines of Mexico originally came from Asia, or vice versa. ${ }^{1}$ Their intensely black hair and eyes, their brown or yellow color, their small stature and the slight obliquity

I The following extracts from the San Francisco, Cal., Bulletin of June 7, 1897, confirm my views on the subject :

"Information is received from Australia concerning the reports of F. W. Christian of the Polynesian Society, who has returned to Sydney after an extended tour of the islands of the South Seas, the Caroline group especially, where he has been on a successful search for ethnological specimens. These reports are of great importance to the scientific world and are said to let much light on a vexed question which has puzzled the most learned savants for years. Mr. Christian has discovered extensive traces of the Chinese and Japanese in the islands of the Pacific, and claims to have discovered evidence pointing to the existence of a civilization of nearly two thousand years ago, which is linked with the ancient civilization in Central America, and will probably explain the origin of the Aztec races.

" Under the auspices of the Polynesian Society, according to advices from Sydney, via Honolulu, received per Coptic yesterday, Mr. Christian worked. The gentleman spent nearly two years looking for traces of the Chinese in the islands, and was Iucky enough to find ancient records, specimens of handiwork and weapons which proved that Asiatic races were extensive traders among the South Sea group thousands of years ago. Evidence of a very decisive nature was secured which shows that a large trade was carried on via the islands of the Caroline group, between China and Central America, and that the ancient Chinese were more inclined to emigrate than their latter-day brethren and colonized extensively.

"Extensive inquiries were made as to the traditions of the islanders, and many discoveries were made concerning the early history of the Malays with regard to navigation, all proving that the Torres strait's route to the Pacific was not taken, but that voyages were made to many of the Caroline islands.

"The coincidence is a strange one that a despatch from Hermosillo, Mexico, dated June 6th, reports that a rock recently discovered in the mountains of Magdalena district, State of Sonora, which is covered with Chinese inscriptions, has just been visited by Sen Yup, a well-educated Chinese of Guaymas. He says the inscriptions are Chinese, but are somewhat indistinct. He made a copy of them, and has translated enough of the lines to show that the writing was probably inscribed on the rock at least two thousand years ago." 
of their eyes, are features common to the Mexican Indians and the Japanese. When I first came to Washington, at the end of 1859 , not having been out of Mexico before, I retained very vivid recollections of the Mexican Indians, with whom I had been somewhat closely associated; and shortly afterwards the first Japanese Embassy came to this country and was received in a very solemn manner by Mr. Buchanan, then President of the United States. The Embassy consisted of about forty persons altogether, comprising ministers, secretaries, interpreters, servants, etc., and were dressed in their national gala costumes, not having yet adopted the European one. The Diplomatic Corps having been invited to the reception, I attended as a member of the same, and was greatly struck by the remarkable similarity which I found between the Japanese members of the Embassy and the Mexican Indians, whom I had just left. It seemed to me that had I collected at random forty Mexican Indians and dressed them in the same gorgeous costumes that the Japanese wore, nobody could have detected the difference.

Some of the Indian languages seem to me to resemble strongly the Oriental ones, though of course I cannot speak with authority, as I do not know any of those languages and have heard only the Chinese, Japanese, and Korean spoken; but I am sure that if any educated and intelligent Chinese should go to Mexico and spend some time among the Indians, he would find traces in the language which would contribute greatly to clear up this problem. Mr. Tateno, a former Japanese Minister, who visited Mexico, found, during his short stay in that country, several words that are used in Japan and that have the same meaning in both countries. I am aware that Señor Pimentel, a very learned philologist, who made a special study of the languages of the Mexican Indians, finds no similarity at all between them and the Chinese or other Oriental languages; and that even the Otomi language, which is monosyllabic, he finds to have no similarity to the Chinese. But, notwithstanding that great authority, I believe that the aborigines of both continents, that is, Asiatic and American, were originally of the same race, and that there must be some relationship between their respective languages.

The Indians of the different tribes do not generally mix with one another, but intermarry among themselves, and this fact contributes largely to their physical decay, and makes very difficult, at least for some time to come, the complete assimilation of all the Mexican population.

The Mexican Indians are on the whole a hard-working, sober, moral, and enduring race, and when educated they produce very distinguished men. Some of our most prominent public men in Mexico, like Juarez as a statesman, and Morelos as a soldier, were pure-blooded 
Indians, ${ }^{1}$ and fortunately there is no prejudice against their race in Mexico, and so when they are educated they are accepted in marriage among the highest families of pure Spanish blood.

I have been a great deal among them, and my knowledge of their characteristics only increases my sympathy and admiration for them. In the State of Oaxaca, for instance, where I spent the early years of my life, I have seen Indians from the mountain districts, who, when they had to go to the capital, especially to carry money, would form parties of eight or ten to make a ten days' round trip, carrying with them their food, which consists of roasted ground corn, which they take three times a day; stopping at a brook to mix it with water, and

${ }^{1}$ Sir William Hingston, President of the Surgery Section in the Second PanAmerican Medical Congress, held at the City of Mexico in October, 1896 , in an interview which was published by The Gazette of Montreal, Canada, of December 2, I896, said, concerning his visit to Mexico, among other things :

"The pure-blooded Indian was seen on all sides. . . .

“The Spaniards would seem to have pursued the same course as was followed by the original French settlers, they did not shove aside the native Indians as useless iumber, to be gotten out of the way, as a distinguished Harvard professor puts it, but they treated them as people in possession of the soil, with whom it was not only right but proper to ally in marriage. I have always regarded our North American Indian as the best type of the aborigines in stature. I still believe he is, but not so in intellect. The broad, massive forehead of the native of Mexico, and his soft but prominent and intelligent eye, are evidences of mental power.

'I take from a spicy article published by Mr. Charles Dudley Warner, in Harper's Magazine for June, 1896 , the following description of the dress of the poorer classes in Mexico :

"Herbert Spencer might extend here his comments on the relation of color to sex. It is the theory that all the males of birds have gay plumage in order to make them attractive to the other sex, while the females go in sober colors. This is also supposed to hold true of barbarous nations. The men who dress at all, or use paint as a substitute, wear bright colors and more ornaments than the women, while the gentle sex is content to be inconspicuous. Needless to say that in what we call civilization, this rule is reversed. The men affect plain raiment, while the women vie with the tropical birds of the male gender. Tried by this test Mexico has not reached the civilization of the United States. The women of the lower orders are uniformly sober in apparel, and commonly wear drawn over the head a reboso in plain colors. The scant dress is usually brown or pale blue. It is the men who are resplendent, even the poorest and the beggars. The tall conical hats give to all of them an "operatic" distinction; the lower integuments may be white (originally) as also the shirt and the jacket; or the man may have marvellous trousers, slit down the sides and flapping about so as to show his drawers, or sometimes, in the better class, fastened down with silver buttons; but every man of them slings over his left shoulder or wraps about him, drawing it about his mouth on the least chill in the air, a brilliantly colored sarape, or blanket, frequently of bright red. Even if he appears in white cotton, he is apt to wear a red scarf round his waist; and if he is of a higher grade, he has the taste of a New York alderman for a cravat. This variety and intensity of color in the dress of the men gives great animation and picturesqueness to any crowd in the streets, and lights up all the dusty highways." 
sleeping on the bare ground, preferring always the open air; getting up before daylight and starting on their journey at daybreak immediately after their early meal, speaking no Spanish and travelling about forty miles a day. When they reached the city of Oaxaca, they would remain there one or two days, and go back to their homes without taking part in any dissipation. They prefer to live in the high, cool localities, and they have their patch of ground to raise corn and a few vegetables in the hot lowlands, sometimes thirty miles away from their homes, and carry their crops on their backs for all that distance. They make very good soldiers, and military leaders have used them to great advantage during our revolutions.

Professor Starr's theory that we are all on this Continent assuming the type of the Indian, is, in a measure, true. It is nothing new, for it was already indicated by an English physician travelling in the British colonies before the United States were thought of.

The great task of the Mexican Government is to educate our Indians and make them active citizens, consumers, and producers, elevating their condition. Before we think of spending money to encourage European immigration to Mexico, we ought to promote the education of our Indians, which I consider the principal public need of the country.

Increase of Mexican Population.-In the beginning of the century Baron Humboldt, who visited Mexico and studied very carefully the conditions of the country, thought that the Indian race, which was then very numerous, would continue to increase and would be the preponderant race of Mexico, as far as numbers were concerned, as it showed a large proportion in a census made in 1810 by Don Fernando Navarro y Noriega, and which appears in Baron Humboldt's Political Essay of Nerv Spain. According to that census the population of Mexico was then divided as follows :

European and American Spaniards......... $1,097,928$

Indians.......................... 676,281

Mixed races or castes................., 338,706

Secular ecclesiastics................. $\quad 4,229$

Regular ecclesiastics................ $\quad 3,112$

Nuns...................... $\quad{ }_{2,098}$

Total.......... $\overline{6,122,354}$

Including among the Europeans the ecclesiastics and nuns, the population was, according to that census :-

Europeans..............1,107,367 or 18 per cent.

Indians................, 376,28 I

Mixed races. ........... 1,338,706

Total...... $\overline{6,122,354}$ " 100 " ، 
In the census of 1875 the following results appear :-

European race and descen-

dants of the Spaniards..... I,899,031 or 20 per cent.

Mixed race.............4,082,918

Native Indian race......... $3,513,208$

\begin{tabular}{lrcc} 
& 43 & 4 & " \\
37 & " \\
\hline 100 & &
\end{tabular}

The increase of population in the 65 years which elapsed between the two censuses mentioned, deducting from the census of 1810 the inhabitants of Texas, New Mexico, and Upper California, who had passed to the United States, numbering 58,338 , was

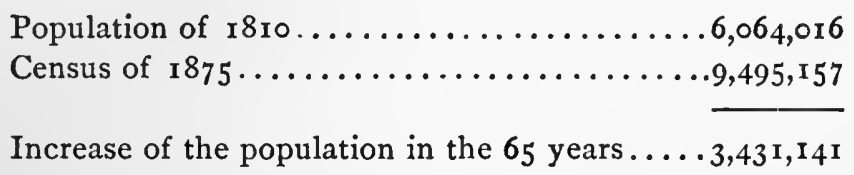

From the preceding data it appears that the European race nearly doubled its population in the space of 65 years, and at the rate of I.I. per cent. of increase per year ; that the mixed race trebled it at the rate of 3.25 ; and that the native race diminished it at the rate of 0.058 per cent. per annum.

Families in Mexico are generally very large, often having ten or fifteen children. I remember how much surprise it caused in Washington, my stating in the presence of Señor Don Jacobo Blanco, the Mexican Commissioner in the late International Boundary Commission, who was recently here for a year finishing his office work and maps and preparing his report, that he was the twenty-fourth child in his family, his father having been twice married.

Decrease of the Indian Population.-It further appears that the Indian population has been decreasing since the beginning of the present century, notwithstanding the fact that the Indian race on the whole is very prolific.

The causes of the decrease of the Indian population in Mexico are various ; bad nourishment, insufficient shelter from the inclemency of the weather, wretched attendance in sickness, and many others, some of which I shall mention here, having contributed toward the degeneration and decline of the race.

The small-pox, owing to the carelessness or indolence of the parents in regard to vaccination, or their repugnance to it, causes deplorable ravages in this race, more especially among the individuals that live at any considerable distance from the cities.

Indian women, even when far advanced in pregnancy, do not ab- 
stain from hard labor, and, without any care for their coming offspring, continue grinding their corn until the moment of parturition. Then, before the proper time for taking the child from the breast, it is fed with food unsuitable for its age and difficult of digestion, which occasions diarrhœa or other maladies that either cause its death or at least contribute to its imperfect development.

Another circumstance which causes the degeneration of the Indians is their premature marriages. In Mexico the marriageable age for women has been fixed by law at eighteen years, and in the tierra caliente, or hot country, at fourteen; but in some places Indian girls are married at twelve. Every Indian father considers it his duty to marry his children, whether boys or girls, as soon as they are of age, the parents of course making the match to suit themselves.

This used to be the case not only with the Indians, but even with persons of Spanish descent. I once heard General Degollado, a very good and prominent man in Mexico, say, that the day he married he took, immediately after the ceremony was over, his bean-shooter and went to shoot birds, because he had no conception of what he had done, his parents having arranged the match for him; but he added that he could not possibly have made a better choice of a wife.

The Indians are strong by nature ; and in this is to be found the fact that so many of them reach an advanced age, in spite of their scant and poor food, their unhealthy mode of living, and their damp and unwholesome habitations, consisting of miserable huts where whole families are huddled together.

The Spaniards in Mexico.-The Spaniards are a money-making, wonderfully frugal race, since they have been battling with hard conditions at home for centuries. The Spaniard in Mexico is-as Richard Ford who spent thirty years in the peninsula, and who was a close observer, depicts him-a hardy, temperate man, well fitted, under favorable conditions, to become a dominant influence.

In Mexico, the energy of the Spaniard is remarkable. He is forceful of word and phrase, energetic in his movements, immensely vital, tremendously persistent, and wonderfully enduring. After thirty years behind a counter selling groceries, he retires, a man of fortune; not always large, but sufficient, and is still a man of force and ready for undertakings demanding good brain power and courage. They come over mere lads, from ten to fifteen, toil and moil, feed frugally, and sleep hardly, and they become millionaires, bank directors, great mill owners, farmers on a grand scale, hot-country planters and monopolists, for the Spaniard is born with the "trust" idea; while his sons are too of ten dudes and spendthrifts.

The thrifty Spaniard toils and saves, and his ambition is to marry a rich girl, frequently the daughter of a Mexican landowner, and so he 
lays the foundation for permanent wealth; for everywhere, the world over, the man who gets the lands and holds on to them is the wealthy man. Speculators and financiers come and go like bubbles on a river, but the landed proprietor keeps a permanent clinch on humanity.

There is one check to the growth of Spanish influence in Mexico, and that is the climate. All Europeans, no matter what their nationality, become physically modified by residence in the new world; and nowhere is the effect of climate more noticeable than in the tropics. The children of the Spanish residents are less energetic than the parents, and the third generation are altogether Creoles. Just as the Mexican of Spanish descent is, as a rule, less energetic, not so vascular, and less vigorous than the Spaniard, so is the American less full-blooded and leaner than the Englishman. The change that takes place in the human organization, transplanted from the old world to the new, is a profound one.

English and Germans in Mexico.-The present century has seen many changes in the commercial world of Mexico; the great English houses have almost all disappeared; especially has this been marked in the dry-goods, or draper's business. The Germans, with superior economy, if with no more of enterprise, drove the English out of that profitable business, and in time themselves succumbed to the still closer methods of the Barcelonettes who gained a foothold in the business which they have successfully maintained. The dry-goods business in the Republic is largely in the hands of men who speak the French language. From the great houses of the capital go forth bright young men, trained to business habits who are established over branch concerns in the interior and coast towns. Their employers become their backers, and a close intimacy is maintained, to the mutual advantage of older and younger merchants.

Very few of the foreigners who settle in Mexico, and especially Spaniards, are educated, as most of them hardly know how to read and write. They very seldom become naturalized Mexicans, and almost always keep their allegiance to the country of their origin. That seemed natural when Mexico was in constant turmoil, and many of the foreigners going there expected to make large fortunes by means of diplomatic claims; but that reason can hardly hold good now, when the country is at peace, and perfect security is extended to every inhabitant. If the foreigners continue keeping their old nationality when they become permanent settlers of Mexico, some changes may be necessary in the legislation of the country affecting their condition.

Americans in Mexico.-It will be very difficult for the fun-loving, self-indulgent, Anglo-Saxon Englishman of America to compete with these self-denying Spaniards, capable of living with the nose to the grindstone twenty, twenty-five, or thirty years, eating always sparingly, 
drinking wine, but in moderation, spending no money, dressing poorly, and ever with a fortune accumulating. The American wants to cut a dash and so does the Englishman, else the English would have maintained their commercial supremacy in Mexico. They lost it to the more frugal and economical Germans.

The American is a speculator, a dreamer of golden dreams; he lives for the eyes of other people; he is not capable of the patience that keeps a man tied to a desk or shop for half a lifetime, making a savings bank of himself.

Some Mexicans are afraid that a free influx of citizens from this country may Americanize it. This is true as to the means of transportation, the introduction of electric lights, improved hotel accomodations, and where similar improvements are concerned. But there is no doubt of the persistence of traditions and habits, and the influence of climate. It is difficult to introduce the American push and restlessness in business, and to overcome the habits formed in many centuries of letting the morrow take care of itself. There must be the mid-day siesta, and the number of working days is reduced by several feast days, saints' days, and holidays, besides the Sundays. There is no doubt that the productiveness of nature is an inducement to very leisurely labor, and the lack of any sharp division of seasons is a sort of moral discipline, as well as a stimulus to extra exertion in summer to prepare for winter. What must be the effect upon character when this stimulus is wanting? It is possible, of course, that industry will be stimulated by the inflow of settlers from the north, and that Mexico will take on new enterprise and productive vigor; but $I$ think it is easier for Americans in Mexico to fall into Mexican ways and Mexican moral views than it is to convert the Mexicans to the American view of life. I do not doubt that Mexico has a great industrial, agricultural, and manufacturing future, but I fancy that its power of absorption, like that of Egypt, is greater than its facility of adaptation.

Ruins.-We have in Mexico some of the most ancient and remarkable ruins, and although there are different surmises about the time at which they were built and the people who built them, nothing is known positively about them.

The principal ones are in Uxmaland and Chichen Itza in Yucatan Comalcalco in Tabasco, Teotihuacan and Cholula in Puebla and Tlaxcala, and Mitla in Oaxaca.

Uxmal.-Uxmal is not far from the city of Merida, the capital of the State of Yucatan, supposed to have been built by the Mayas, and different books have been written about them, especially one by Dr. Augustus Le Plongeon, a French savant, who passed many years in Yucatan, studying its magnificent ruins, and published in New York, in 1896 , a book entitled Queen Moó and the Egyptian Sphinx, in which 
he contends that the empire of the Mayas, which had its seat at Yucatan, was the cradle of civilization, and that from there it went to India, Egypt, and finally to Greece and Western Europe.

Palenque.-Very likely the same Mayas built the large ruins which still exist in the district of Palenque in the State of Chiapas, and in some places in Guatemala.

Cholula.-The great pyramid of Cholula, made known to the scientific world by Humboldt, which is eight miles from Puebla, has been pictured and described. Its base is rooo feet on each side, and it is built in two great terraces, the first being 71 feet, and the second 66 feet, in height. The top is 203 by 144 feet. So far as investigations have revealed, the great pyramid is artificial and is constructed of sundried brick.

Teotihuacan.-Teotihuacan, an ancient city lying twenty-five miles northeast of the City of Mexico, and occupying an area of about one and a half or two miles, contains some of the most remarkable series of ruins. To the north of the ruins is a truncated pyramid, rectangular in form, squared to the points of the compass, and known as the Pyramid of the Moon. South of it, at a distance of about 1300 yards, is another pyramid of similar form, known as the Pyramid of the Sun. Its perpendicular height is 223 feet, and its base measures about 735 feet from east to west. Both pyramids are united by a straight street, which starts from a circular plaza at the south side of the Pyramid of the Moon, and loses itself in the barranca south of the Pyramid of the Sun.

These colossal pyramids are regarded as among the most ancient monuments of Mexico, far antedating the civilization found by the Spaniards. They are wonderful illustrations of what perseverance and time will accomplish. Now even the means which the builders used for handling the immense blocks of volcanic stone with which they constructed is unknown. Other ruins, in the character of little mounds, are found scattered over the extensive plain in which the two pyramids are situated. The street or avenue which united the latter is called the "Road of the Dead." Along its entire length, parallel to it on both sides, there is a terrace constructed of cement, clay, and broken lava, faced with a coating of mortar or plaster, highly polished, and painted red and white. Desire Charnay removed the rubbish from one of the mounds on the side facing this road, and discovered what he calls a "palace," with two large halls and various small rooms. In 1886, Señor Don Leopoldo Batres made an excavation in one of the mounds, and found two polychrome frescos painted on the wall of the building which was laid bare. The question is naturally asked, how these monuments came to be covered? Was it by an earthquake, or by the hands of the builders themselves? Señor Batres inclines to voL. $1-6$ 
the latter view, as he found the roofs of the houses perfectly preserved, while the interior of the rooms was in every case filled with stones neatly fitted into the spaces, and joined with a clayish cement to form a compact mass. His conclusion as to the pyramids is, that they are two great temples erected to two old Mexican divinities. Each pyramid consists of five terraces, which diminished in size until the height of 223 feet was reached. Each has on one of its sides a stairway six and one-half feet in width, which makes five zigzag turns, and leads to the sanctuary or shrine on the summit. The outer surface of the pyramids, and perhaps the interior as well, was plastered over with a mortar of lime, hard and smooth, and decorated with frescoes, representing quasi-historical events and scenes.

The small mounds scattered over the area occupied by the ruins were, according to Batres, dwellings and small shrines. Each contained from six to twelve rooms, quadrangular and rectangular in form. The cornices as well as the walls were beautifully ornamented in colors. On some as many as twenty tints had been used. The doors were rectangular, never trapezoidal in form, although the latter style has been erroneously attributed to ancient American architecture. They measure eight feet in height by about three feet in width. The houses had neither windows nor balconies. The city was crossed by subterranean aqueducts constructed of stone, the walls of which were plastered with firm and smooth mortar. Near the Pyramid of the Moon, among the rubbish, there was a monolithic statue of colossal dimensions. It represents a woman with a characteristic head-dress, and wearing a necklace of four strings of beads. Travellers in Teotihuacan can find countless miniature heads modelled in clay anywhere on the freshlyplowed stretches of level land that lies across the broad, straight Micoatl, or "Path of the Dead." They vary in length from one to two inches, and invariably have nothing more than a neck attached to them. They may be distinguished by this peculiarity from those that are applied as ornaments to terra cotta vases, and from fragments of "idols." The features and peculiar head-dresses that adorn these little heads of Teotihuacan vary greatly, and this diversity has given rise to, and been quoted in proof of, the migration of tribes, of the mixtures of widely differing races, or of their succession to each other in the occupation of the Valley of Mexico. Owing to the unfamiliar aspect of some of these head-dresses, it has been asserted that they could not be even "Toltec," but must be relics of still more remote and unknown races of men. Various uses have been assigned to them, the commonest supposition being that they were in some way associated with ceremonies relating to the dead. There is probably no subject connected with Mexican archæology, except the calendar, that has given rise to more discussion. Dr. E. B. Tylor regarded them as a puzzle, 
and Professor F. W. Putnam has spoken of them as the "riddle of the many heads." Desire Charnay saw in some of them Chinese and Japanese masks, and even types of the white race, proving in his opinion how many races must have been mingled or succeeded each other on this old continent.

Mitla.-About twenty miles east of the city of Oaxaca is an Indian town called Mitla, near which still remain the ruins of great edifices and palaces. The temples were built, it is supposed, by the ancient Zapotecas, and are the most interesting relics of the earlier civilizations of Mexico. The first description of these ruins was given by the Spanish priest, Burgoa, who accompanied the conquerors of Montezuma. The interior of the principal hall or room of the main palace is supposed to be the teocali of the high priest. The peculiar architecture and elaborate and grotesque decoration can easily be observed. It is astonishing to see the enormous size of the stones used in the walls of these temples. Professor Bickmore said that he had seen nothing to equal them except at Baalbec, in Syria. At Mitla are found some clay images, mostly miniature, doubtless of gods, but some of them no doubt portraits, and some of these bore a striking resemblance to the little heads found at the pyramids of the Sun and Moon in the Valley of Mexico; that is, some of them had the slant Oriental eyes, and others Ethiopian features, very different from any races we now know in these regions. The ruined temples of Mitla are covered with stucco, which was painted Pompeiian red. There is a pyramid also at Mitla, and there are some elaborately wrought sepulchral chambers.

\section{mies}

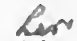

I borrow from Mr. Vivien Cory the following extracts of his description of the ruins of Mitla.

"There are four of these places; the first is almost entirely destroyed, only some huge monolithic slabs supported horizontally upon tottering piles of broken stones remaining; while everywhere amongst the ruins have sprung up the grass huts of the Mexican Indians, and of the fourth or one farthest from the hamlet nothing but indication of the site is left, upon which the Spaniards have reared a modern church. It is in the two palaces that lie between, each slightly raised above the surrounding country on a separate eminence, that the interest centres.

"One of these is in the form of a double Greek cross, its stem running north and south, and its arms extended east and west. In the centre is the large court, surrounded on all sides by rising ground and ruined mounds of stones : there are traces still remaining of the foundations, that speak of four apartments built upon these mounds to face the court, but of these those on the west and south sides have disappeared; on the east side, only two colossal pillars and a portion of the walls remain, while to the north side the whole apartment forming the head of the cross has been spared and stands almost unharmed in its original beauty and richness. The façade of this apartment extends the whole length of the court, one hundred and forty-one feet, and its height is a little over ffteen feet: the material is freestone, the color a faint, dull, amber tint, soft as the light seen in the sky at evening. In the centre are three square portals and above these 
forming the head-piece to them all extends one long and narrow panel of carving, a high relief of the natural stone on a crimson ground. The whole façade is composed of a series of these panels, from the straight line of the foundation-stone to the straight line of the summit, nine panels being on each side of the entrance, arranged in three tiers, divided by horizontal bands of the natural stone. In some of the panels, the ground retains still a faint tint of its former rich vermillion, in others, all color has subsided into the soft neutral shade of the freestone. The designs are wonderfully rich and varied, thirteen different patterns being represented on this façade alone; all these designs are remarkable for the straight lines in which they are executed and the absence of all curves. Throughout all the ruins, upon the walls of which appear twenty-three different models of carving, only two of these represent any curve in their design. In one of these two there is visible the form of the Arabic letter ' $L$ ' placed horizontally, and in the other a double curve ' $\mathrm{S}$,' possibly intended to represent or suggest the snake. With these exceptions the designs are of the Greek key pattern, variations on this, or parallelograms.

"Behind this façade is a narrow court, roofless as all the courts are, and empty, save for six colossal pillars standing at even distances down the centre, and giving to this chamber the name of Hall of the Monoliths. Each pillar is one solid stone, eleven feet high and eleven feet in circumference. A low stone passage leads from this chamber northward to the smallest and richest court of all, entering it at the southeast corner. There is comparatively little trace of the destructiveness of the elements or the iconoclasm of man here. The court and all the four chambers opening from it are perfect and singularly rich in carving. The court is perfectly square and the chambers are entered from it, each through one square doorway, the roof of which is formed by a huge monolith, thirteen feet long and with a richly carved face. Of these four lintels each has a separate design. Each of the four walls has six panels, the uppermost extending the whole length of the wall, two smaller panels being on either side of the entrance, and one long narrow one above it. Between the panels stand out in high relief the horizontal and vertical edges of the freestone, forming a symmetrical frame to each panel.

"Within the four chambers the walls are designed differently, the carving running simply and evenly round the entire room in three straight horizontal bands, each band possessing a separate pattern and being about three feet in width. Beneath these bands of carving was originally, evidently, a dado of vermillion stucco, of such fine and delicate quality that the smooth and polished surface resembles marble. Portions of this delicate stucco still adhere to the crumbling walls in places and are of various colors, scarlet, black and white. In some instances this stucco seems to have been plain, simply bearing a brilliant polish, in others, there remains distinctly traced in white upon a crimson ground, a wierd, fantastic, yet handsome design, the head; half horse, half dragon, repeated in four inch squares. This latter ornamented stucco, however, does not appear except in the fourth palace, containing the Spanish church, where it is visible on the walls of one of the courts, now used as a stable for the padre's horse. Leaving the richest of the centre palaces, passing through a gap in the ruined wall on the south side, descending the elevation on which it is placed and ascending the opposite eminence, the patio of the second palace is reached. This is almost wholly in ruins; three of the façades that face the court remain indeed, but the great smooth slabs with which the walls were faced have been torn away at the base, and most of the beautiful panels of carving stripped from the front. Yet it is in this ruined palace that one lingers longest and to which one's feet return, drawn by an irrisistible fascination ; for this palace contains the tomb and the pillar of death.

"This subterranean vault is called by general consent a sepulchre, but there is no line of history, no record, no tradition even, left to explain to us its origin and use. It 
may have been a torture-chamber, sacrificial hall, or tomb. The excavation is but a little below the surface of the court, now carried down so deeply that the light is wholly excluded. From the entrance there is enough to fill the interior with a sad, gray twilight. The vault is in the form of a simple cross lying north and south; its walls are massive and heavily decorated with panels of carving let into their sides, while it is roofed by enormous monolithic slabs that reach from wall to wall. In the centre of the cross, just where by descending a few steps one enters the tomb, stands the pillar of death, round which, the Indians say, should a man clasp his arms he must shortly afterwards die. Does not this very tradition, handed down perhaps through the long file of countless years, seem to indicate that this pillar was some ancient stone of sacrifice to which human victims were bound or chained, and from which death alone released them? As one gazes at the massive column, that one man's arms alone could not entirely encircle, the eye notices an indentation round the base where the column sinks into the floor. The stone is corroded and worn away as by the long friction of ropes or chains.

"Most of the panels do not consist of actual carving, though they produce that effect at a few yards' distance ; they are formed in reality by small slabs of the freestone cut perfectly square and inserted edgeways into the wall, the remaining edges standing out at various distances from it and thus forming the different designs. This, although a work of infinite patience, does not necessarily presuppose a high stage of civilization, no instrument sharper than hard stone being required to cut the slabs of soft freestone; and that only a stone instrument was employed by the workers seems indicated by the fact that, in the large panels where the stone is actually carved, the edges are not sharp, but rounded, as if made with a blunt tool. The effect of the panels of inserted squares of stone, however simply produced, is that of the most finished and clear-cut carving and the designs themselves are rich and elaborate. There is no crudity, no harshness in them, no suggestion of the primitive savage's scratching on his native rock; but rather that of Greek work on some Athenian temple. The patterns have a complicated elegance and distinction of line that can only be produced by a people of cultivated mind and eye.

" Evidence, too, of what high grade of civilization in some ways at least they must have arrived at, lies in the gigantic stones that they have placed as lintels over their doorways and which in their immense weight and bulk have defied the greed or rage of all the succeeding races to remove or destroy. The mystery here is the Egyptian mystery of the Pyramids; that these enormous blocks of stone are resting here in positions and elevations where it would require all the modern knowledge of mechanics, engineering skill, and mechanical appliances to place them ; and, as in Egypt, so here the mystery will never be solved, as the builders have passed hence and left no clue. The solid stone rests there upon its supporting pillars before the eye as it has rested for a thousand years, but how the perished hands lifted and placed it there remains its own inviolable secret.

"Leaving the palace court by the south side and following the road to the dry and stony bed of a wide river, if one turns aside here a little to the eastward he finds himself facing a Zapotecan mound, a solid base composed of earth and stones, in which are visible at intervals large slabs of cement, portions of terraces and tiers that originally formed its sides. Ascending this, from the summit one can overlook the whole valley."

\section{LANGUAGES.}

About one hundred and fifty different Indian languages are known to have been spoken by the Mexican Indians. The Spanish monks accompanying the conquerors and who went to the country soon after- 
wards compiled grammars and even dictionaries of some of these languages; but the Indians falling into a semi-barbarous state after the conquest, having lost their civilization and literature, their languages have either disappeared completely or become very primitive. and it is ascertained that some of them have become entirely extinct.

The Spanish is, of course, the language of the country and most of the Indians speak it, although very imperfectly and incorrectly; only a small portion of them speaking no language but their own.

The chief languages spoken in Mexico proper, excluding Chiapas and Yucatan, are as follows :

Nahuatl or Mexican (Aztec) with Acaxee, Sabaibo, Xixime, Cochimi, Concho and other members of the same family.

Seri, Upanguaima, and Guaima.

Papago, Opata, Yaqui, Mayo, Tarahumara, Tepehuan, Cora, etc.

Apache or Yavipai, Navajo, Mescalero, Llanero Lipan, etc.

Otomi or Hia-hiu, Pame, Mazahua, etc.

Huaxtec, Totonac.

Tarascan, Matlaltzincan.

Mixtec, Zopotec, Mixé, Zoqué, Chinantec.

Señor Don Manuel Orosco y Berra wrote a treatise on the language of the Indian tribes in Mexico entitled "Geography of Languages," which describes the languages of the races who inhabited Mexico, and Señor Don Francisco Pimentel enlarged upon that work, making philological comparisons, and from the data collected by both authors Señor Don Antonio Garcia Cubas a distinguished Mexican geographer made the following synopsis of the Indian languages spoken in Mexico.

SYNOPSIS OF THE INDIAN LANGUAGES OF MEXICO, FORMED ACCORD-

ING TO THE CLASSIFICATION OF DON FRANCISCO PIMENTEL.

Note.-The sign * indicates that the classification is doubtful.

\begin{tabular}{|c|c|c|c|}
\hline GROUPS. & FAMILIES. & LANGUAGES. & DIALECTS. \\
\hline \multirow{3}{*}{ 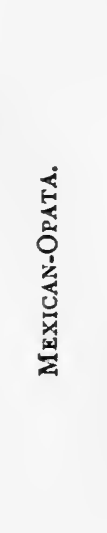 } & & $\begin{array}{l}\text { Ist Order.-Languages polysyllabic, } \\
\text { polysynthetic of sub-flexion. }\end{array}$ & \\
\hline & $\underset{\text { Mrxican. }}{1 .}$ & 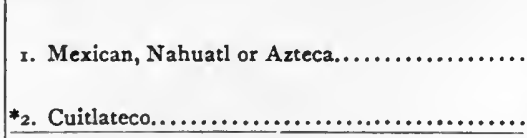 & $\left\{\begin{array}{l}\text { Conchos, } \mathrm{Si} \\
\text { naloense, }{ }^{*} \mathrm{Ma} \\
\text { zapil, Jaliscien- } \\
\text { se, Ahualulco, } \\
\text { Pipil, Niquiran. }\end{array}\right.$ \\
\hline & & 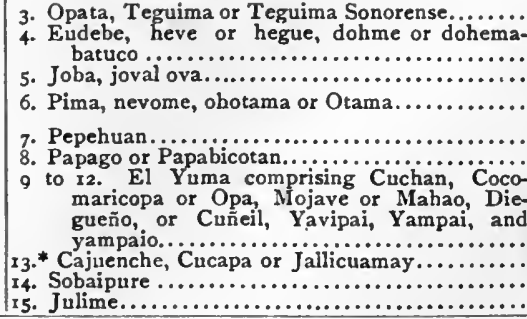 & $\begin{array}{l}\text { Tecoripa. } \\
\text { Sabaqui. } \\
\text { Various. }\end{array}$ \\
\hline
\end{tabular}




\begin{tabular}{|c|c|c|c|}
\hline GROUPS. & FAMILIES. & LANGUAGES. & DIALECTS. \\
\hline \multirow{11}{*}{ 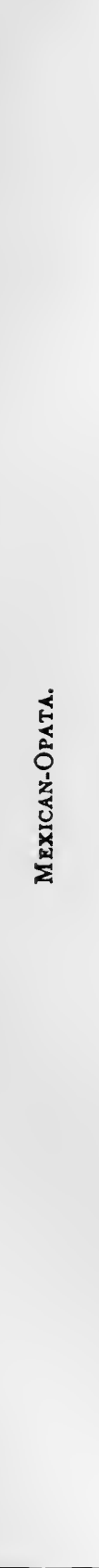 } & \multirow[b]{2}{*}{$\begin{array}{l}\text { II. } \\
\text { SONORENSE OR } \\
\text { OPATA-PIMA. }\end{array}$} & $\begin{array}{l}\text { Ist Order. - Languages polysyllabic, } \\
\text { polysynthetic of sub-flexion. }\end{array}$ & \\
\hline & & 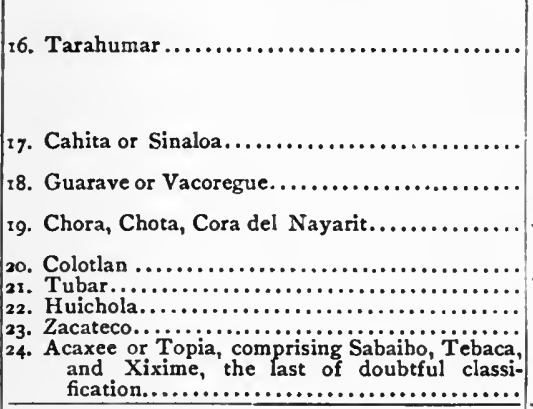 & $\begin{array}{l}\left\{\begin{array}{l}\text { Varogio or Chi- } \\
\text { nipa, Guaza- } \\
\text { pare, Pachera, } \\
\text { and others. }\end{array}\right. \\
\left\{\begin{array}{l}\text { Yaqui, Mayo, } \\
\text { Tehueco or Zua- } \\
\text { que. }\end{array}\right. \\
\left\{\begin{array}{l}\text { Muutzicat, } \\
\text { Teacucitzin, } \\
\text { Ateanaca. }\end{array}\right. \\
\text { Various. }\end{array}$ \\
\hline & $\begin{array}{l}\text { III. } \\
\text { COMANCHE SO- } \\
\text { shONB. }\end{array}$ & $\begin{array}{l}\text { 25. Comanche, Nauni, Paduca, Hietan or Getan. } \\
\text { 26. Caigua or Kioway. } \\
\text { 27. Shoshone or Chochone. } \\
\text { 28. Wihinasht. } \\
\text { 29. Utah, Yutah or Yuta. } \\
\text { 30. Pah-Utah or Payuta, } \\
\text { 31. Chemegue or Cheme-huevi. } \\
\text { 32. Cahuillo or Cawio. } \\
\text { 33. Kechi. } \\
\text { 34. Netela. } \\
\text { 35. Kizh or Kij. } \\
\text { 36. Fernandeño. } \\
\text { 37. Moqui and some others spoken in the United } \\
\text { States......................................... }\end{array}$ & Various. \\
\hline & $\begin{array}{l}\text { IV. } \\
\text { Texana OR CoA- } \\
\text { HUILTBCA. } \\
\end{array}$ & 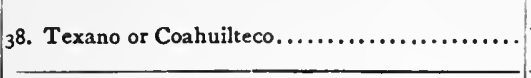 & Various. \\
\hline & *K. & 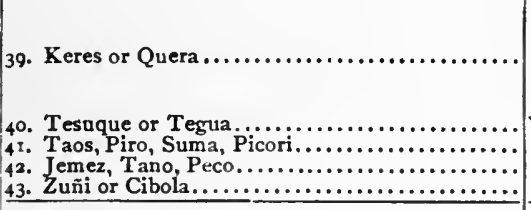 & $\begin{array}{l}\left\{\begin{array}{l}\text { Kiwomi or Ki- } \\
\text { vome, Cochi- } \\
\text { teumi or Qui- } \\
\text { me, Acoma and }\end{array}\right. \\
\text { Various. }\end{array}$ \\
\hline & $\begin{array}{l}\text { VI. } \\
\text { Mutsun. }\end{array}$ & 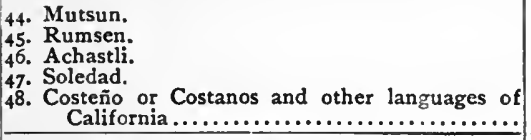 & \\
\hline & $\begin{array}{l}\text { VII. } \\
\text { Guaicura. }\end{array}$ & 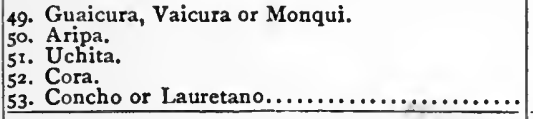 & \\
\hline & $\begin{array}{c}\text { VIII. } \\
\text { COCHIMI-LAIMON. }\end{array}$ & 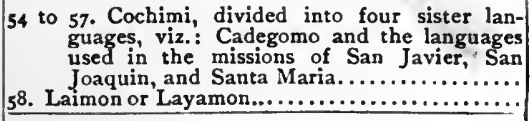 & \\
\hline & $\begin{array}{l}\text { IX. } \\
\text { SERI. }\end{array}$ & 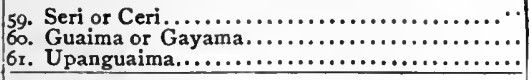 & \\
\hline & $\begin{array}{c}\mathbf{X} . \\
\text { TARASCA. }\end{array}$ & 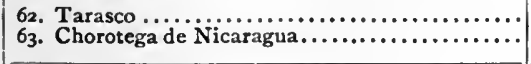 & \\
\hline & $\begin{array}{l}\text { XI. } \\
\text { ZOQUE-MIXE. }\end{array}$ & 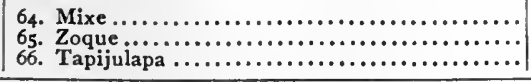 & Various. \\
\hline
\end{tabular}




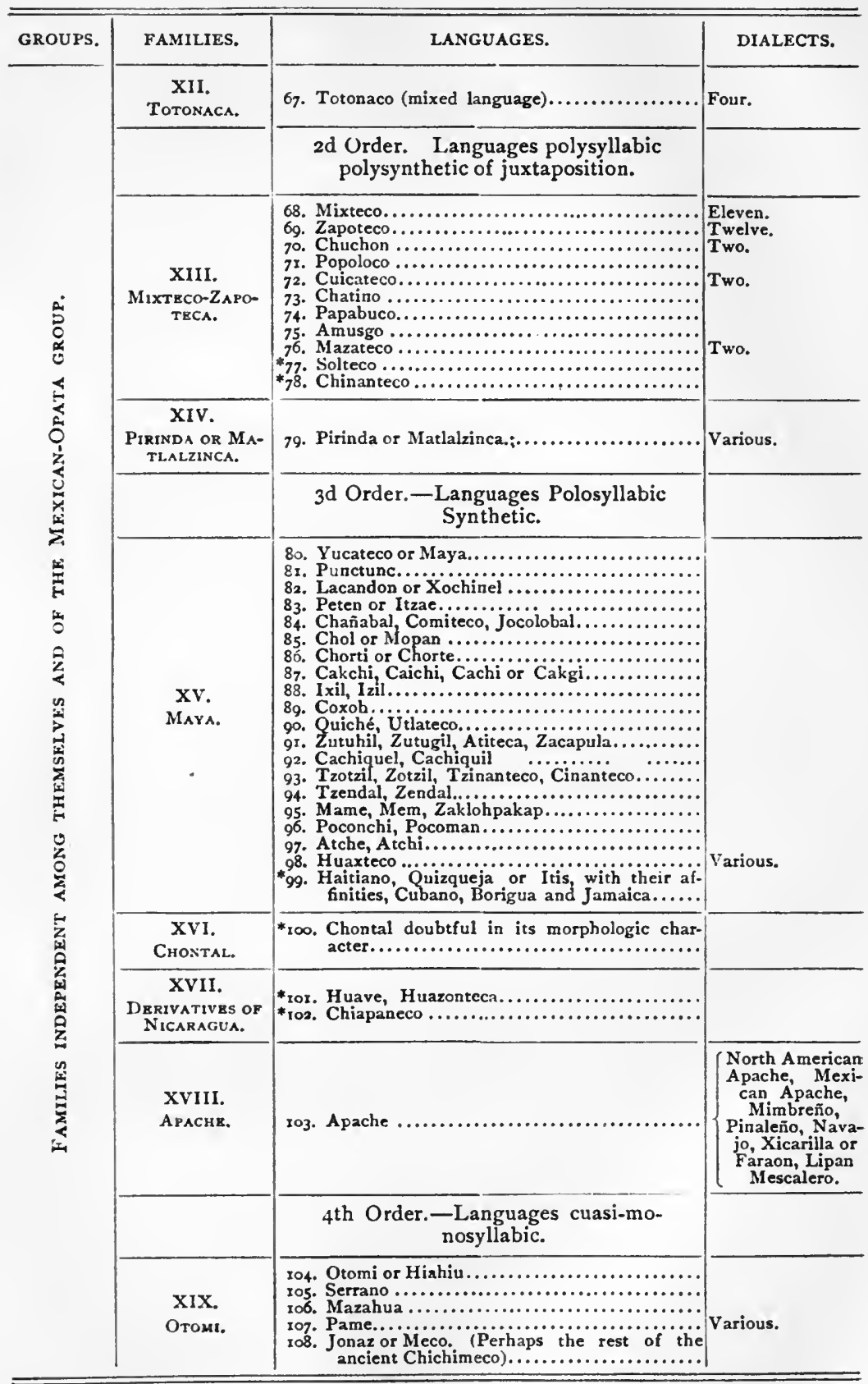




\section{Dopulation.}

\section{POPULATION.}

We have until recently taken a regularly correct census of our population. The first reliable census was made in 1795, under Revillagigedo's viceroyalty, the second in 1810 by Don Fernando Navarro y Noriega, the third one was estimated by Mr. Poinsett, United States Minister in Mexico, in 1824, and the others have been taken by the Mexican Government.

The following is a statement of the general results of our various censuses :

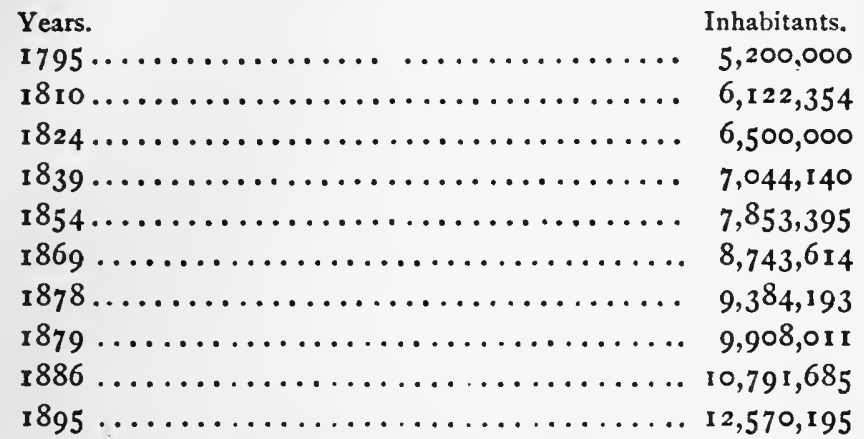

The population of Mexico appears to be, from our last census, taken in $1895,12,570,195$, which would give 16.38 for each square mile; but from my personal knowledge of the country, I am quite sure that it is not less than $15,000,000$. It is very difficult to take a correct census in Mexico, because there is not the proper machinery in operation for that purpose, and especially because a great many districts are inhabited by Indians, who are impressed with the fear that if they inscribe themselves in the census they will be taxed or drafted into the military service, and they try to avoid registration.

A great many of our people live in such remote districts that they are practically cut off from communication with other portions of the country, and in fact are almost isolated; and this constitutes still another difficulty in the way of taking a correct census. These people generally raise everything they need for their living, as well as for their clothing. They also raise their domestic animals, and wear either cotton or woollen clothes, manufactured by the women. The configuration of the country, which makes transportation very expensive, together with the very sparse population, has caused their isolation, and this explains why some agricultural products which are very cheap in other countries are very dear in certain districts of Mexico, as prices can be easily controlled, there being no possibility of competition. While sugar, for instance, costs $25^{\circ}$ cents per pound in some districts, it can be had in others for one cent. This fact shows also that a year of good crops was often a real misfortune to these districts. 
The upper lands being the healthiest, most of the population in Mexico is settled in the central plateau; a relatively small portion lives in the temperate zone, while the torrid zone is very thinly populated. I imagine, at a rough calculation, that about 75 per cent. of the population make their abode in the cold zone, from 15 to 18 per cent. in the temperate zone, and from 7 to ro per cent. in the torrid zone.

From the synopsis of our censuses, inserted above, it appears that the population in Mexico has duplicated during the last century, and although that increase does not keep pace with the increase in the United States, because this has been really wonderful, it compares favorably with the increase in other countries. Mexico also, as a new country and one full of possibilities, ought to have increased its population more rapidly, but its slow progress can be accounted for in several ways.

Under the head of Ethnology I enumerated the different races inhabiting Mexico and stated the number of inhabitants belonging to each, and I gave at length the reasons for the slow increase of the Indian population, which is the largest in Mexico. I will only add here that while the Indians lead a very abstemious and simple life, marry while very young and generally have a family of several children, they are at the same time subject to epidemics. Notwithstanding that the race on the whole is sturdy and little subject to disease, the mortality is very large among the children for want of proper nutrition and care. The losses caused by our civil wars could not at all explain the slow increase of our population, and the only way in which I can account for it is that they are not so well prepared as the people of the United States and other more advanced countries, to bear the discomforts of life and climate, and that, therefore, they cannot bring up all the children born in the family, among whom there is annually a great mortality.

Classification of Mexican States. Under the Spanish rule Mexico was divided into several provinces, the Spaniards trying to divide the provinces in accordance with the different nationalities of the aborigines found there, and each province possessing a very large extent of territory. After our independence and when we established a Federal government, each province was made a state, and since then some of the largest states have been divided into two or even three smaller ones. In the chapter on Political Organizations I shall give further information on this subject.

The Mexican states are classified in several ways, and generally as Northern, Southern, Central, Pacific, and Gulf States ; but it is difficult to make a proper division of them, because there are several included in two denominations. I will, therefore, divide them into Northern States, calling so those bordering on the United States; Southern States, 
those bordering on Gautemala and Belize; Gulf, Caribbean Sea, and Pacific States, those bordering on their respective waters; and Central States those which do not belong to any of the above denominations, although I do not consider this a proper classification, because the State of Tamaulias included among the Northern States, and the States of Tabasco, Campeche, and Yucatan among the Southern States, are all on the Gulf of Mexico, and are, therefore, Gulf States, the latter being also washed on their southern side by the Caribbean Sea, and the State of Sonora, classified as a Northern State, borders on the Pacific ; the State of Chiapas, included among the Southern States, also borders on the Pacific, and, therefore, is, like Sonora, also a Pacific State.

Our last official census, taken in 1895 , gives the following results by States, which I compared with the census of 1879 .

AREA AND POPULATION OF THE UNITED MEXiCAN STATES.

\begin{tabular}{|c|c|c|c|c|c|c|c|}
\hline & \multirow{2}{*}{ STATES. } & \multirow{2}{*}{$\begin{array}{l}\text { AREA IN } \\
\text { SQUARE } \\
\text { MILES. }\end{array}$} & \multicolumn{2}{|c|}{ POPULATION } & \multirow{2}{*}{$\begin{array}{l}\text { POPULA- } \\
\text { TION PER } \\
\text { SQUARK. } \\
\text { MILE. }\end{array}$} & \multirow{2}{*}{ CAPITAL. } & \multirow{2}{*}{$\begin{array}{l}\text { POPULA- } \\
\text { TION. }\end{array}$} \\
\hline & & & in 1879. & in 1895 . & & & \\
\hline 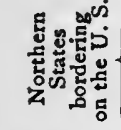 & $\begin{array}{l}\text { Tamaulipas ....... } \\
\text { Nuevo Leon...... } \\
\text { Coahuila ......... } \\
\text { Chihuahua ....... } \\
\text { Sonora........... }\end{array}$ & $\begin{array}{l}32,585 \\
24,324 \\
62,376 \\
87,820 \\
76,922\end{array}$ & $\begin{array}{l}140,137 \\
203,284 \\
130,026 \\
225,541 \\
115,424\end{array}$ & $\begin{array}{l}204,206 \\
309,607 \\
235,638 \\
266,831 \\
191,281\end{array}$ & $\begin{array}{r}6.3 \\
13.1 \\
3.7 \\
3.0 \\
2.4\end{array}$ & $\begin{array}{l}\text { Ciudad Victoria.. } \\
\text { Monterey........ } \\
\text { Saltillo ......... } \\
\text { Chihuahua ...... } \\
\text { Hermosillo...... }\end{array}$ & $\begin{array}{r}14,575 \\
56,855 \\
19,654 \\
18,521 \\
8,376\end{array}$ \\
\hline 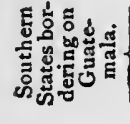 & $\begin{array}{l}\text { Yucatan........... } \\
\text { Campeche........ } \\
\text { Tabasco.......... } \\
\text { Chiapas........ }\end{array}$ & $\begin{array}{l}35,214 \\
18,091 \\
10,075 \\
27,230\end{array}$ & $\begin{array}{r}302,315 \\
90,413 \\
104,747 \\
205,362\end{array}$ & $\begin{array}{r}297,507 \\
99,458 \\
134,794 \\
313,678\end{array}$ & $\begin{array}{r}8.4 \\
5.0 \\
13 \cdot 3 \\
11.5\end{array}$ & $\begin{array}{l}\text { Mérida............ } \\
\text { Campeche....... } \\
\text { S. Juan Bautista.. } \\
\text { Tuxtla Gutierrez. }\end{array}$ & $\begin{array}{r}36,720 \\
16,631 \\
27,036 \\
7,882\end{array}$ \\
\hline & Veracruz. & 29,210 & 542,918 & 855,975 & $29 \cdot 3$ & Jalapa.... & 18,173 \\
\hline 总 & 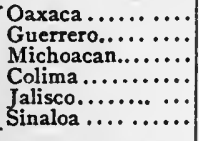 & $\begin{array}{r}35,392 \\
25,003 \\
22,881 \\
2,273 \\
31,855 \\
33,681\end{array}$ & $\begin{array}{r}744, \infty \infty \\
295,590 \\
66 \mathrm{r}, 534 \\
65,827 \\
983,484 \\
186,491\end{array}$ & $\begin{array}{r}882,529 \\
417,621 \\
889,795 \\
55,677 \\
1,107,863 \\
256,414\end{array}$ & $\begin{array}{r}24.9 \\
16.7 \\
38.8 \\
24.5 \\
34.8 \\
7.6\end{array}$ & $\begin{array}{l}\text { Oaxaca ........... } \\
\text { Chilpancingo..... } \\
\text { Morelia........... } \\
\text { Colima........... } \\
\text { Guadalajara...... } \\
\text { Culiacan ........ }\end{array}$ & $\begin{array}{r}32,641 \\
6,204 \\
32,287 \\
19,305 \\
83,870 \\
14,205\end{array}$ \\
\hline & $\begin{array}{l}\text { Aguascalientes... } \\
\text { Durango........... }\end{array}$ & $\begin{array}{r}2,051 \\
38,020\end{array}$ & $\begin{array}{l}140,430 \\
190,846\end{array}$ & $\begin{array}{l}103,645 \\
294,366\end{array}$ & $\begin{array}{r}35.1 \\
7.7\end{array}$ & $\begin{array}{l}\text { Aguas Calientes.. } \\
\text { Durango.......... }\end{array}$ & $\begin{array}{l}31,619 \\
42,165\end{array}$ \\
\hline & $\begin{array}{l}\text { Guanajuato } . . . \cdots \\
\text { Hidalgo........... }\end{array}$ & $\begin{array}{r}11,374 \\
8,920\end{array}$ & $\begin{array}{l}834,845 \\
427,350\end{array}$ & $\begin{array}{r}1,047,238 \\
548,039\end{array}$ & $\begin{array}{l}92.1 \\
6 \mathrm{r} .6\end{array}$ & $\begin{array}{l}\text { Guanajuato } . . . . \\
\text { Pachuca.......... }\end{array}$ & $\begin{array}{l}39,337 \\
52,189\end{array}$ \\
\hline तुँ & Morelos.......... & 2,774 & 159,160 & $\begin{array}{l}159,800 \\
838,737\end{array}$ & 57.6 & Cuernavaca ...... & 8,554 \\
\hline & $\begin{array}{l}\text { Mex } \\
\text { Puel }\end{array}$ & $\begin{array}{r}9,250 \\
\times 2,207\end{array}$ & $\begin{array}{l}710,579 \\
784,466\end{array}$ & $\begin{array}{l}838,737 \\
979,723\end{array}$ & $\begin{array}{l}90.7 \\
80.2\end{array}$ & $\begin{array}{l}\text { Toluca. } \\
\text { Puebla }\end{array}$ & $\begin{array}{l}23,648 \\
91,917\end{array}$ \\
\hline & $\begin{array}{l}\text { Querétaro......... } \\
\text { Tlaxcala ......... } \\
\text { San Luis Potosi... } \\
\text { Zacatecas......... }\end{array}$ & $\begin{array}{r}3,558 \\
1,595 \\
25,323 \\
24,764\end{array}$ & $\begin{array}{l}203,250 \\
138,988 \\
516,486 \\
422,506\end{array}$ & $\begin{array}{l}227,233 \\
166,803 \\
570,814 \\
452,720\end{array}$ & $\begin{array}{r}63.9 \\
104.6 \\
22.5 \\
18.2\end{array}$ & $\begin{array}{l}\text { Querétaro......... } \\
\text { Tlaxcala......... } \\
\text { San Luis Potosi . } \\
\text { Zacatecas........ }\end{array}$ & $\begin{array}{r}32,790 \\
2,874 \\
69,676 \\
40,026\end{array}$ \\
\hline 它它 & $\begin{array}{l}\text { Tepic. } \\
\text { Lower Califo......... }\end{array}$ & $\begin{array}{l}11,279 \\
58,345\end{array}$ & . $\ldots \ldots \ldots$ & $\begin{array}{r}144,308 \\
42,287\end{array}$ & $\begin{array}{r}12.8 \\
0.7\end{array}$ & $\begin{array}{l}\text { Tepic........................ } \\
\text { La Paz and .... } \\
\text { Ensenada de }\end{array}$ & $\begin{array}{r}16,266 \\
4,737\end{array}$ \\
\hline & $\begin{array}{l}\text { Federal District ... } \\
\text { Islands........... }\end{array}$ & $\begin{array}{r}463 \\
\times, 47 x\end{array}$ & $\begin{array}{r}351,804 \\
\ldots \ldots \cdots \cdots\end{array}$ & 484,608 & 1046.7 & City of Mexico... & 339,935 \\
\hline & Totals & 767,226 & $9,908,011$ & $12,570,195$ & & & \\
\hline
\end{tabular}




\section{RELIGION.}

All Mexicans are born in the Catholic Church, that being the prevailing religion of the country; but there is no connection between Church and State, and the Constitution guarantees the free exercise of all religions.

While Mexico was a colony of Spain and for many years afterwards, the catholic religion was the only one allowed in the country, and anybody professing any other would expose himself to great hardships if he avowed that he was a dissenter, especially while the Inquisition was in existence.

The clergy became one of the principal pillars of the Spanish domination in Mexico. In the early part of the present century the Church was flourishing, and it was the high-water mark of clerical prosperity. The humble Mexican priests did the hard laborious work, while the Spanish-born ecclesiastics filled the great bishoprics and other great posts and lived at their ease, and the great convents in their most lucrative positions of control were practically in Spanish hands.

Huge convents occupied a considerable part of the site of the City of Mexico, Puebla, Morelia, Guadalajara, Querétaro, and other cities. The incomes of the convents were derived from endowments, amounting to a large sum. To support the high ecclesiastics, great sums were derived from tithes. The archbishop of Mexico had an income of $\$ 130,000$ a year; the bishops of Puebla, $\$ 110,000$; of Michoacan, $\$ 100,000$; and of Guadalajara, $\$ 90,000$. Meantime, the parish priests, who bore the brunt of Christian work among the masses, were living on very moderate sums. The Church erected in Mexico buildings which are remarkable for their dimensions and taste. ${ }^{1}$

'Mr. Charles Dudley Warner in the Editor's Study of Harper's Illustrated Monthly Magazine for July, 1897, speaks in the following way of the church edifices in Mexico :

"Somebody of authority, by the way, ought to explain why Mexico has so many church edifices that go to the heart of the lover of beauty, and why the United States has so few that are interesting. Aside from the great Gothic monuments in Spain, Mexico surpasses Spain in interesting ecclesiastical architecture. It has more variety, more quaint beauty, more originality in towers and façades. The interiors are generally monotonous, and repetitions of each other. The Spaniards, in an age of faith, built churches, convents, monasteries, all over the county, in remote and unimportant Indian villages, and as far north as their patient ministers of religion wandered, even to the bay of San Francisco. In these edifices the Spanish ingenuity and enthusiasm prevailed, but they were largely executed by Indian builders and artists; and if there is Sarasenic feeling shown, there are also, especially in ornamentation, traces of that aboriginal artistic spirit which, long before the Spanish conquest, executed both in stone and in pottery singularly attractive work. Even within a hundred years of our own time Indian genius has been distinguished. Those who think that this genius is only exhib- 
Not all the great dignitaries of the Church exhibited an unchristian selfishness, for many often spent their income in pious and charitable works, and in prosecuting missionary undertakings among the Indians of the remote distances.

The wealth of the Church was loaned out at a moderate rate of interest to landed proprietors, who formed the moral support of the Church among the laity and whose influence was prodigiously strong. The wealth of the Church was mostly in mortgages, while it held a large amount of real estate. In the City of Mexico and other places, the clergy owned a large portion of the real estate and held a great many mortages, and, to its credit be it said, was not at all usurious, exacting only a fair rate of interest and being hardly ever oppressive in dealing with delinquent debtors.

After the Revolution which effected the independence of the country, the ecclesiastical life began to cease having many of the attractions it had before. While many men became friars from genuine inclination and vocation, not a few went into the religious life because it gave them support without hard labor, and because it was one of the best careers opened to young men at the time.

The nunneries sheltered a great many pious women, who effected some good as educators of the young, as almoners for the wealthy, and as nurses of the sick. There were abuses, of course, but on the whole the religious life afforded a refuge for many thousands of good women who felt drawn to works of charity and usefulness. Rich young girls were often over-persuaded to enter the convents, by avaricious and scheming priests, but such abuses are common to all religions. The Liberal party thought that the best way to destroy the Church influence in Mexico was to suppress convents, both of friars and nuns, because they

ited in bizarre forms, and in such small details of design and color as the potter can attain, should see at Querétaro the work of Tresguerras, architect, sculptor, and painter. Any modern architect, who is led away by straining after effect in a grotesque combination of distinct Greek styles with mediæval and early English, having no note of originality anywhere, conld study with profit the simple elegance-as simple as the Old Louvre- of the Bishop's Palace in Querétaro, or the wood-carving in the church of the sequestered Convent of Santa Rosa. In my remembrance there is not, on such a great scale, any wood-carving in the world equal to it in freshness and largeness of execution and in beauty of design. It could not have been all done by the hand of Tresguerras, but it was all from his designs and under his superintendence. Of course, as to civic and ecclesiastic architecture, climate and lack of popular taste for the beautiful put limits upon our architectural work, but it is worth the while of the American architect to consider whether he cannot learn more from our sister republic below the Tropic of Cancer than he is likely to get from the well-studied structures of Europe. In many petty and poverty-stricken Indian villages are charming towers and curious façades which would be a most valuable education in the principles of taste to any American community." 
were considered a nest of superstition, and they thought that the best interest of the country required to close them.

During our civil wars the clergy contributed large amounts to the support of the conservative governments, which it often established. It is thought that in 1853 , General Santa Anna abandoned the Conservative Government, which he then presided over, because the Archbishop of Mexico did not give him all the money he required to carry on the war waged against him by the Liberal party.

The wealth accumulated by the Church of Mexico was used for the purpose of supporting the conservative governments, whose policy was to keep the statu quo, and was therefore opposed to progress of any kind. The Church became a very prominent factor in politics, and could upset and establish governments at its pleasure, fomenting the many revolutions which were constantly breaking out. It was thought necessary, therefore, to destroy the political power of the Church before we could establish and maintain peace, and that work was done by what we call our Laws of Reform, issued in 1859 , which established a complete independence between the Church and the State, and were intended to completely end the domination of the Catholic Church in civil affairs in Mexico: the Church property was confiscated, so that even the houses of worship are now the property of the government; all convents of friars and nuns were closed, all religious ceremonies-such as processions and wearing a distinctive dress,-were ordered to be confined to the interior of the edifices; the cemeteries were secularized, and marriage made exclusively a civil contract. No religious instruction or ceremony is allowed in the public schools, and never is a prayer offered as a part of the program of a national celebration. In an article, which I published in the North American Review, of January, 1895, entitled "The Philosophy of the Mexican Revolutions," I dwelt especially on this subject, and to that article $I$ refer the reader who may desire more detailed information.

The Liberals were not the first to dispose of the Church property and revenues, as the Spanish Government, under the rule of Godoy, in 1805 and 1806 , to secure funds to form a redemption provision for the royal vales or credit notes, pounced on the property of the Church in Mexico, and that, later on, when the Mexicans rose in their war for independence, the royal authorities took another part of the Church's wealth to fight the patriots.

The bigoted Catholic element which used to be decidely opposed to any liberal government and was always conspiring to overthrow it, has since the downfall of Maximilian, become satisfied that the condition of things has changed having accordingly changed their course, and now there are thousands of progressive catholics in Mexico sincerely devoted to their Church, who see only danger and eventual 
disastrous defeat in the adoption of a program of reaction. They go with the times and support the administration of Gen. Diaz because, on the whole, it suits them, and manifests no hostility to their conscientiously held convictions. The pope's influence seems to be directed to assuaging ancient rancors, and to the calming of passionate resentments, which is a great deal better for the Church.

Protestantism in Mexico.-The Liberal party proclaimed as an inherent right of man, freedom of conscience and the free exercise of one's religion; but the question was really only a theoretical one, since excepting a few foreigners, no one in Mexico had any other religion than the Catholic. The clergy, the Church party, and all strict Mexican catholics were greatly opposed to the introduction of Protestantism, because protestants were looked upon as heretics whose purpose was to divide the Mexican people into different sects, disturbing their religious unity, which they considered a source of national strength, and ultimately aiding in what some Mexicans fear is the aim of this country, that is : the final absorption of Mexico. When the struggles between the Liberal and the Church party terminated in favor of the former in 1867 , with the withdrawl of the French army from Mexico and the downfall of Maximilian, the time came to put into practice the principles of the Liberal creed, and protestant organizations in the United States sent missionaries to Mexico for the purpose of establishing and propagating the protestant religion there. The Mexican Government could not refuse to allow the missionaries the free exercise of the Protestant or any other faith, because that right was guaranteed to all men in our constitution, and also because it has been a principle for which the Liberal party had been contending during many years.

But we went, then, further than allowing the Protestants the free exercise and preaching of their religion, and as I am in a measure responsible for that step, I think it proper to give my reasons for the same. My opinion has never been favorable to missionary work, because although I recognize that some religions have higher moral principles than others, I think that on the whole they are all intended to accomplish the same purpose, that all are good, when practised in good faith. It has always seemed to me that Christian missionaries sent to heathen countries would be looked upon in the same manner as would be heathen missionaries sent to Christian countries. But even supposing that it should be proper and desirable for the Christian religion, on account of its high morals and principles, to send missionaries to heathen countries for the purpose of converting them to Christianity, that principle would scaracely hold good in Christian countries of different denominations, and Catholicism is a Christian religion-whatever abuses it may have committed,-and I think the natural tendency 
of all religions when they are predominant is to absorb and misuse power ; but that Protestants should send missionaries to a Catholic country seems to me inconsistent. In principle, therefore, Mexico is hardly the proper field for Protestant missionaries, notwithstanding that there is a great deal of room for improvement there, in so far as religious matters are concerned.

After having witnessed the terrible consequences of religious intolerance and political domination of the Catholic Church in Mexico, I was of course greatly impressed with the condition of things existing in the United States, where all religions are tolerated and none attempts to control the political destinies of the country. I thought that one of the best ways to diminish the evils of the political domination and abuses of the clergy in Mexico was to favor the establishment of other sects, which would come in some measure into competition with the Catholic clergy and thus serve to cause it to refrain from excesses of which it had been guilty before. When, after having lived for ten years in the United States, from I 859 to I868, I returned to Mexico and took charge of the Treasury Department there, just at the time when the religious question was being solved, I, therefore, favored the establishment of a Protestant community as planned by Mr. Henry C. Riley, since made a Bishop, a gentleman of English parentage, born in Chili, who had been educated in London and New York and was graduated with high honors at Columbia College, New York, who spoke equally well English and Spanish, and eagerly desired to establish a Mexican National Church in competition with the Roman Catholic, in which undertaking, I understand, he used his own funds. He proposed to buy one of the finest churches, the main church of the Franciscan convent, which had been built by the Spaniards, located in the best section of the City of Mexico, and which could not now be duplicated but for a very large amount of money ; and with the hearty support of President Juarez, who shared my views and who was perhaps a great deal more radical than I was myself on such subjects, I sold the building which had become national property after the confiscation of the Church property, for a mere trifle, if I remember rightly about $\$ 4000$, most of that amount being paid in Government bonds which were then at a nominal price.

The magnificent building sold to Dr. Riley's community was bought recently by the Catholic Church to restore it as a Catholic temple, for the sum of $\$ 100,000$, as I understand. My assistance was rendered to the Protestant cause for the reasons that I have stated, and not because I had adopted the Protestant faith ; therefore the action of the Mexican Government in the matter at the time I speak of, was all the more praiseworthy. Dr. Butler bought about the same time another part of the same convent of San Francisco, where he established a Methodist Church in a very creditable building. 
It is true that a great many Mexicans, namely the Indians, do not know much about religion and keep to their old idolatry, having changed only their idols, that is, replaced their old deities with the images of the Saints of the Catholic Church, but it would be difficult for the Protestant missionaries to reach them. The Spaniards labored zealously to make the natives adopt the Catholic religion, and although they succeeded wonderfully, it was a task too difficult to fully accomplish in the three centuries of the Spanish domination in Mexico.

I do not think that the American Protestant missionaries in Mexico have made much progress, and I doubt very much whether Mexico is a good field for them; but they are satisfied with their work, and they think that under the circumstances, they have made very good progress.

The number of Catholic churches and chapels in the country was, in 1889 , I0, 1 12, while the number of Protestant places of worship was I19. On August I2, r890, there were in the municipality of Mexico 320, 143 Catholics and 2623 Protestants.

The American missionaries, and especially Dr. Riley, whom I consider a very benevolent and unselfish man, have established Protestant schools and asylums for children, spending considerable money in maintaining such institutions. Of course poor parents were glad to send their children to the Protestant schools and asylums when they could not afford to keep them at home or send them to more desirable places, and these Protestant institutions were of a very benevolent character and worthy, therefore, to be encouraged. Parents in such cases declared themselves to be partial to Protestantism, but only for the sake of having their children accepted in the Protestant schools and asylums, and this made the Protestants think they were making a great many converts.

Now and then a Catholic priest would renounce Catholicism and accept Protestantism, and such occurrences were always considered as great triumphs for the Protestant cause, but although in some instances such changes have been made in good faith, in others they were made for selfish purposes, and they never had any great weight with the community.

I have no prejudice against Protestantism; on the contrary, I admire greatly many of its principles, and in speaking on this subject I consider myself perfectly impartial and unbiassed.

In February, 1888, the Evangelical Assembly, representing the various Protestant denominations and Evangelical Societies conducting missionary operations in the Republic of Mexico, was held in the City of Mexico. They claimed that, notwithstanding the difficulties of language and climate and the other obstacles with which they had to contend, they found that they had over 600 congregations, 192 foreign and $5_{7}^{85}$ native workers, over 7000 in the day schools, and about 10,000 
in the Sunday-schools, 18,000 communicants and a Protestant community of over 60,000 souls. Ten small publishing-houses are turning out millions of pages each year, and their church property is valued at nearly a million and a quarter dollars in silver.

POLITICAL ORGANIZATION.

Mexico was the largest and richest American colony of Spain, and for this reason it was called New Spain. The City of Mexico grew during the Spanish rule to be larger than Madrid, the capital of the Spanish Kingdom, the population of the country being estimated in I 810 , just before the independence movement began, at $6,122,354$; while the public revenue of the whole colony amounted to the very large sum of $\$ 20,000,000$ yearly, the only exports of the country being silver and gold, and commodities of great value in small volume and weight, such as cochineal, vanilla, indigo, and a few others.

Mexico accomplished her independence in 1821 , and since then has had two Federal Constitutions, both modelled after the Constitution of the United States; two Central Constitutions, which organized the country into a centralized republic, and two ephemeral empires, one under Iturbide, lasting ten months, from 1822 to 1823 , and the other under Maximilian, established by French intervention, lasting from $\mathbf{I} 864$ to $\mathrm{I} 867$.

Mexico is now organized, under the Constitution of the $5^{\text {th }}$ of February, 1857, with its several amendments, into a Federal Republic, composed of twenty-seven states, two territories, and a federal district, and the political organization is almost identical with that of this country. The powers of the Federal Government are divided into three branches-Legislative, Executive, and Judicial. The Legislative is composed of a House of Representatives and a Senate; the members of the House are elected for two years and the senators for four, the Senate being renewed by half every two years. Representatives are elected by the suffrage of all male adults, at the rate of one member for every 40,000 inhabitants. The qualifications requisite are to be at least twenty-five years of age and a resident of the State; and for senators thirty years.

The Executive is exercised by a President elected by the electors popularly chosen, who holds his office for four years, without any provision forbidding his re-election. He has a cabinet of seven members, namely : Secretary of Foreign Affairs, of the Interior, of Justice and Public Instruction, of Fomento, which means promotion of Public Improvements, and includes public lands, patents, and colonization; of Communications and Public Works, of the Treasury, and of War and Navy. No Vice-President is elected, but by an amendment to our Constitution, promulgated April 24, 1896, in the per- 
manent or temporary disability of the President, not caused by resignation or by leave, the Secretary of State, and after him the Secretary of the Interior, shall exercise that office until Congress elects a President pro tempore. In case of resignation, Congress, accepting it, elects a President pro tempore, and in case of leave the President recommends to Congress the person to fill that office.

The Federal Judiciary is composed of a Supreme Court, consisting of eleven Judges, four substitutes, one Attorney-General, and one Fiscal, chosen for six years; three Circuit and thirty-two District Courts.

The States are independent in their domestic affairs, and their governments are similarly divided into three branches : the Governor, the Legislature, and the State Judiciary.

As we adopted the federal system rather to follow the example of the United States than to suit the conditions of Mexico, that system did not work with us so easily or so satisfactorily as it works here; and the tendency is rather to centralization and to the increasing of the powers given by the Constitution to the Federal Government. In the article above mentioned published in the North American Review, for January, $x 896$, entitled, "The Philosophy of the Mexican Revolutions," I I dwelt particularly on the results of our having copied almost literally the political institutions of the United States, and gave a general idea of our political condition.

Political Division.-When the federal system was established in Mexico, in 1824, each of the old provinces under the Spanish rule was organized as a State, and our Constitution of October 4, I824, enumerated nineteen States. After the war with the United States we lost Texas, New Mexico, and California; but since then as I stated in the chapter on population some of the larger States have been divided into two, or even three States, as was the case with the old State of Mexico, out of which were formed the three present States of Mexico, Hidalgo, and Morelos. Our present Constitution, of February 5, I857, enumerates twenty-four States; but we now have twenty-seven.

The tabular statement published above, under the head of "Population," shows the number of States which form the Mexican Confederation, their area, population, and capital cities.

Army and Navy.-During our civil wars, and for some time later, we had to keep a very large standing army, and our army acquired recently a very high degree of discipline and efficiency. The Liberal party always favored the reduction of the army, while the Church party favored a large army, as our old regular army, on the whole, took sides with the Church. Soon after the restoration of the Republic, in 1867 , the Mexican army consisted of : Infantry, 22,964; engineers, 766 ; ar-

1 This article will appear in this volume under the head of "Historical Notes on Mexico." 
tillery, 2304 ; cavalry, 8454 ; rural guards of police, 2365 ; gendarnierie, 250 ; total, 37,103; and was commanded by II Major-Generals, 73 Brigadier-Generals, 104I Colonels, Lieutenant-Colonels, and Majors, and 2335 Commissioned Officers. The total fighting strength, including reserves, is stated to be 132,000 infantry, 25,000 cavalry, and 8000 artillery. Every Mexican capable of carrying arms is liable for military service from his twentieth to his fiftieth year.

Notwithstanding that General Diaz is himself a soldier, he has followed the policy of the Liberal party of reducing the army as much as possible, and in his report of November 30,1896 , in which he informs his fellow citizens of his results of his sixteen years administration, he gives the following figures, showing the reduction he has been able to accomplish in the army since 1888 :

The army had, in I888, according to President Diaz's report, the following personnel :

Major-Generals................... 16

Brigadier-Generals ................... 84

Commissioned Officers................

Non-Commissioned Officers............. 2,566

Soldiers ....................... 29,367

Total........................ 33,238

In 1896 the personnel had been reduced in the following numbers :

Generals........................ 24

Commissioned Officers................. $\quad$ I66

Non-Commissioned Officers .............. 299

Soldiers $\ldots \ldots \ldots \ldots \ldots \ldots \ldots \ldots \ldots \ldots, 8,170$

Total..................... $\overline{8,659}$

The Mexican navy is now in its inception, as it consists of a fleet of two dispatch vessels, launched 1874 , each of 425 tons and 425 horsepower, and severally armed with a four-ton muzzle-loading gun, and four small breech-loaders. A steel training ship, the Zaragoza, of r 200 tons, was built at Havre, in $189 \mathrm{r}$; four gun-boats are building, and a battle-ship and cruiser are projected; five first-class torpedoboats have been ordered in England. The fleet is manned by ninety officers and five hundred men.

\section{EDUCATION.}

In 1521, the City of Mexico fell into the hands of the conquering Spaniards, and exactly eight years after that event there was established in the City of Mexico the College of San Juan de Letran, for giving secondary education to intelligent Indians as well as to the sons of the 
invading race. Thus, ninety years before the landing of the Pilgrims, the City of Mexico had its "Harvard."

Universities Established by the Spanish Government.-The first viceroy of New Spain, as Mexico was called then, fourteen years after the conquest, petitioned the King of Spain to permit him to found a university in Mexico, and, anticipating from his knowledge of the good-will of the Spanish-rulers that the desired permission would be given, the viceroy took the responsibility of establishing certain classes in the higher learning, a fact which does not support the commonly held theory that Spain has always been the enemy of education and of popular enlightenment. Owing to the slow means of communication in those days, and the legal steps necessary to be taken in the mother country, the university was not formally established until I553, or eighty-three years before Harvard College was opened. The great event of setting on foot the university came under the enlightened rule of the second viceroy, Don Luis de Velasco, who did so many great things for Spain's new dependency.

Later on, in 1573 , there were founded in Mexico the colleges of San Gregorio and San Ildefonso, the latter still open, but modernized into the national preparatory school, a really great institution in that city of many schools. A few years later, long before the 17 th century had dawned, came the founding of two more colleges and a divinity school, so that in the first sixty-five years of Spain's control in Mexico no less than seven seats of the higher learning had been established on secure foundations.

No wonder that Mexico's capital became known as the Athens of the new world, producing men of great learning, such as Don Juan Ruiz de Alarcon and such notably erudite women as Juana Inez de la Cruz. The extensive library of "Americana," belonging to Don Jose de Agreda, of that city, containing over 4000 books, many of them invaluable, attests the literary, antiquarian, scientific and artistic activity of the Spaniards who planted there in a short space of time so much of learning and such vast institutions dedicated to the instruction in all the higher branches of knowledge.

At the outset the University of Mexico gave instruction only in mathematics, Latin and the arts. Medicine and surgery were not esteemed highly during the middle ages, and it was not until long after the revival of learning in the Renaissance that the physician came to be considered as a true man of science. So it is not to be marvelled at that the University of Mexico waited until ${ }_{157} 8$ to establish a chair of medicine-the first in the new world discovered by Columbus. The first chair of medicine was a morning class, and a single professor carried his students through a four years' course unaided. In I 599, a second medical professorship was added ; in $166 \mathrm{r}$, anatomy and surgery 
were added, and, consequently dissection was authorized. At the outset the viceroys appointed the professors, but after a time the candidates for chairs had to win the coveted prizes through competitive examinations.

The early students were not railroaded through. They had to study four years to obtain the diploma of a bachelor of medicine; then went out into active life, and, on gaining practical knowledge, received, passing a fresh examination, the diploma of licentiate of medicine, and, later, that of doctor of medicine.

School of Medicine.-In 1768 a decree was issued for the establishment in the City of Mexico of a royal college for surgeons, similar to institutions in Cadiz and Barcelona. This college was a very complete one, instruction being given in anatomy and dissection, in physiology, operations, clinical surgery, and medical jurisprudence. There were graduated also from the college all the dentists, bonesetters, phlebotomists, and midwives. A knowledge of Latin was not essential to receive a medical degree until 1803 .

In 1821 , Mexico having achieved her independence, the same careful watch over education continued, and in 1833 a general revision of educational institutions was ordered under the administration of Don Valentin Gomez Farias a leader of the Liberal party and the university was closed, because it was considered to have conservative tendencies, and a general board of education organized, which, among other things established what was called the School of Medical Science, with ten professors, giving a remarkably complete and modern course. On account of a revolution which occurred in 1834 which overthrew the Gomez Farias Government, the new school of medicine was closed, and the old university reopened ; but, as the officials of the university, on making a careful study of the conditons of the new school of medicine rendered an impartial report, setting forth its manifold advantages it was decided to keep open the institution.

The incessant revolutions and consequent changes of government brought many evil things to pass, and the medical professors at times found themselves without salaries, and nobly devoted themselves to their classes without remuneration. They at one time were deprived of their building and literally thrown into the street. Better times came, however, the successive governments began to give substantial aid to the school, and in 1845 it took the name it still bears, the National School of Medicine. After more vicissitudes, many movings and trials which bore hard on the enthusiastic professors, the National School of Medicine finally was located where it now remains, in a part of the enormous edifice belonging formerly to the Inquisition.

In the chaos of succeeding revolutions the salaries of the professors were often unpaid, but the devoted men of science struggled on, 
assisted by wealthier students and contributing often out of their own slender means to keep the school alive; but, in 1857 , a better era commenced, and not since then, with rare exceptions, have there been any interruptions in financial aid from the various governments. All the other institutions of learning suffered the same fate and were exposed to similar ups and downs.

School of Engineering.-Our mining college is the best in Spanish America, and it was established when engineering was hardly taught, and endowed by a portion of the taxes levied by the Spanish Government on mines. Its edifice is one of the best built by the Spaniards in their colonies, and still stands as a great monument, embellishing the City of Mexico.

The above given facts will show how early did Mexico open great schools for the higher education, and how solicitous was the Spanish government to maintain them. But, three centuries of devotion to learning, antedating the war for independence, planted there firmly a love of knowledge which is now exhibited in the great government schools, in a city full of students, in innumerable private schools, in the well-filled public primary institutions, in night schools for adults, and in the thirty-five bookstores of that city.

Mexican Technical Schools in the Present Time.-The edifice of the first University in America, founded by the Spanish crown in r $55 \mathrm{I}$, is to-day occupied by the National Conservatory of Music. The National Academy of Art, ancient Academy of San Carlos, stands where Fray Pedro de Gante founded, in 1524 , the first school of the New World-a school for Indians. The Normal School for males, with its six hundred pupils and its first-class German equipment, occupies the old convent of Santa Teresa, $\left({ }_{1678}\right)$. The Normal School for females has fourteen hundred pupils, an expensive building of 1648 . The fine old Jesuit College of San Ildefonso, erected in 1749 at a cost of $\$ 400,000$ is now filled with a thousand pupils of the National Preparatory School. The National College of Medicine is housed in the old home of the Inquisition ( I $_{32}$ ), an edifice whose four hanging arches at each corner of the lower corridor are famous. The building was taken for its present purpose in this century, the Holy Office dying in America with the Independence, but the medical college was established by royal decree of $\mathbf{1 7 6 8}$. It has now several hundred pupils. San Lorenzo ( ${ }^{5} 598$ ) is now the manual trainingschool where poor boys are gratuitously taught lithography, engraving, printing, carpentry, and many other trades. The similar institution for girls is of course modern, dating only from 1874 . The National Library, with its 200,000 volumes, dwells in the splendid sequestered Church of San Agustin. The National Museum occupies part of the million-dollar building erected in $173 \mathrm{I}$ for the royal mint. And so on 
through a list that would rival that of any other country. The School of Mines and Engineering, however, stands as one of the first. Its magnificent building of Chiluca, the nearest to granite the valley affords, was built for it by Tolsa in 1793, and cost three millions. The institution named the Colegio de la $\mathrm{Paz}$, better known as the Vizcainas is one of the principal establishments for the education of young women, founded in r 734, at a cost for construction alone of about $\$ 2,000,000$, subscribed by three Spanish merchants, who also provided funds for its support. These funds, when insufficient to meet expenses, are supplemented by the Federal Government. We have also a very high grade Military School located at the historical grounds of Chapultepec, which educates fine soldiers.

As late as 1824 Humboldt declared, "No city of the New Continent, not excepting those of the United States, presents scientific establishments so great and solid as those of the capital of Mexico." Except as to the buildings, of course, so much could not be said today, as wealth and numbers have made other countries take more: rapid strides in higher education. Some of the universities of the United States pay even $\$ 10,000$ a year to professors and they therefore can secure the best talent.

From the time of the Spanish domination in Mexico to but a few years ago, the Mexican Government considered itself bound to give to the people free secondary education, and for this purpose colleges for all literary and scientific professions were established in the City of Mexico, and each State did the same in its respective capital, in so far as its means allowed it, so that anybody who intended to follow a scientific career could do so without any expense to himself.

The result of the free technical schools has been that most of the young men of well-to-do families in Mexico follow a literary career and that does not cost them anything, and we have more lawyers, doctors, engineers than we really need for the country.

Reorganization of the Technical Colleges. - We had before 1868 several higher colleges and in each of them the same careers were taught, as law, medicine, engineering, etc., but in the reorganization of our national colleges which took place in that year, it was thought proper to establish a special college for each career, and a preparatory college for such elementary studies as would be required for all careers, such as elementary mathematics, physics, chemistry, etc., etc., so that we now have in the City of Mexico, supported by the Federal Government a special school for engineering, one for law, one for medicine, another for agriculture, etc., etc., but each State generally supports one technical college where all literary careers are taught.

Primary Education.-Comparatively little attention was paid to the primary education, and the public schools were so deficient that. 
parents of some means did not send their children to them, but to private schools where they were better attended to. The fact that the elevation of the people depends on their primary education has caused common schools to be established in the country, and now the States vie with each other for the purpose of establishing the best system of common schools and increasing their number.

The Mexican Government has been too much disturbed since its independence to earnestly promote the education of the Indians. I consider that one of the first duties of Mexico is to educate the large number of Indians which we have, and when that is accomplished the whole condition of the country will change, as it will be able in a few years to increase by several millions its productive and consuming population.

In 1896 the Federal Congress of Mexico passed a law which was promulgated on June $3 \mathrm{~d}$ of that year, making primary education obligatory on all the inhabitants of the Federal District and Territories, and placing public education under the control of the Federal Government, having been before under the respective municipalities.

In almost all the States education is free and compulsory, but the law has not been strictly enforced. Primary instruction is mostly at the expense of the municipalities, but the Federal Government makes frequent grants, and many schools are under the care of the beneficent societies.

School Statistics.-Statistical reports on public instruction for 1876 showed an aggregate of 8165 primary schools, with an attendance of 368,754 children of both sexes throughout the Republic. Reports for I895 show a total number of public schools for both sexes throughout the Republic amounting to 10,915 , in which are instructed 722,435 scholars, at an aggregate cost of $\$ 5,455,549.60$. The proportion of children of both sexes attending the school is, with respect to the general population, nearly five per cent., and that of the children of school age, actually attending school about 27 per cent. with an average yearly outlay per capita of $\$ 7.55$. The entire number of private schools for both sexes, including those supported by religious and civil associations, is 2585 , with a total attendance of $81,22 \mathrm{I}$. Adding these to the preceding figures we have an aggregate of 13,500 schools with an attendance of 803,656 scholars. The number of schools in the country for professional technical education is 136 , attended by 16,809 pupils of both sexes.

In the Federal District there are 454 public primary schools with an attendance of 44,776 pupils, and 247 private schools with an attendance of 19,334 pupils. In the matter of education Mexico now stands upon a plane as high, if not higher, than any of the Spanish American Republics, out-ranking even Chili and the Argentine Republic, both of which greatly surpassed her in former years. 
The statistical part of this paper will contain detailed information about the number of schools established in each State, their cost, etc., during the year 1895 , which complements the information embraced in this chapter.

Libraries.-Many great and noteworthy public and private libraries attest the ineradicable love of learning characteristic of the Mexican people. In 1894 there were in the Republic the National Library, with 200,000 volumes, and 102 other public libraries. There were in that year 22 museums for scientific and educational purposes, and 3 meteorological observatories. Our National Library at the City of .Mexico collected all the books possessed by the libraries of the different convents when they were suppressed by the National Government, and has therefore a very large number of rare and valuable books.

Nezespapers. - The number of newspapers published was 363 , of which 94 are published in the capital : 4 in English, 2 in French, and I in German, showing that the Press has not attained there the great development that it has in this country.

THE VALLEY OF MEXICO.

The Valley of Mexico is one of the finest spots in the world. Surrounded by high mountains-almost at the foot of the two highest in the country, Popocatepetl and Ixtaccihuatl-with a very rare and clear atmosphere and a beautiful blue sky, especially after a rain ; it is really a centre of magnificent scenery. The rareness of the atmosphere makes distant objects appear to be very near, and when looking from the City of Mexico at the mountains which surround the Valley, one imagines that they are at the end of the City, while some of them are at a distance of forty miles. The view of the Valley from Chapultepec Hill, which is about one hundred and fifty feet high and distant about three miles from the City, towards its western extremity, where our military school now is and where the President has made his summer residence, is one of the most beautiful with which the earth is endowed. I have seen the Bosphorus, Constantinople, the Bay of Naples and other spots in the world which are considered to be most remarkable for their natural beauty, but I think the view of the Valley of Mexico from Chapultepec can be advantageously compared with any of them, if it does not excel them all.

Six lakes are within the limits of the Valley,-Chalco, Zochimilco, Texcoco, Xaltocan, San Cristobal, and Zupango, the two former being of fresh water and the others of salt water-and, as they have no natural outlet the City of Mexico has been deprived for some time of a proper drainage and its health has been affected very materially thereby. But the colossal undertaking of making an artificial outlet is 
now practically finished. In an article which I published in the Engineering Magazine in January, I895, I dwelt especially on the work done during four centuries to accomplish that great end. ${ }^{1}$

The prevailing wind in the Valley of Mexico is northwest and north-northwest, which blew $25^{\circ}$ times during the year 1883 ; while the southern winds, which are very dry, are rare, as they only blew 5 I times in that year; but at the same time they have greater velocity than the others, and the greatest relative velocity of the winds is 3.0. The west and northwest winds are very damp.

At the present stage of industrial development, speaking especially of the Valley of Mexico, the question of a cheaper combustible is the one of supreme importance. In the absence of water-power of importance and permanence of volume, the only solution of the problem so vital to the growth of manufactures there lies in procuring abundant and cheap fuel.

\section{THE CITY OF MEXICO.}

The City of Mexico, located in the western end of the valley, on the Anahuac plateau, at an altitude of $735^{\circ}$ feet above the sea level in $19^{\circ} 26^{\prime}$ north latitude and $99^{\circ} \circ 7^{\prime} 53^{\prime \prime} .4$ longitude west of Greenwich, covering about twenty square miles, is one of the most ancient cities of this continent, was the capital of the Aztec Empire, of the Spanish Colony of New Spain and now of the Mexican Republic, and of the Federal District of Mexico.

Mexico dates either from the year 1325 or 1327 , when the Aztecs, after long wanderings over the plateau were directed by the oracle to settle at this spot. For here had been witnessed the auspicious omen of an eagle perched on a nopal (cactus) and devouring a snake. Hence the original name of the city, Tenochtitlan (cactus on a stone), changed afterwards to Mexico in honor of the war god Mexitli. The eagle holding a snake in her beak and standing on a cactus upon a stone, is the coat-of-arms of the Mexican Republic. With the progress of the Aztec culture the place rapidly improved, and about 1450 the old mud and rush houses were replaced by solid stone structures, erected partly on piles amid the islets of Lake Texcoco, and grouped around the central enclosure of the great teocalli. The city had reached its highest splendor on the arrival of the Spaniards in 1519 , when it comprised from 50,000 to 60,000 houses, with perhaps 500,000 inhabitants, and seemed to Cortes, according to Prescott's, "like a thing of fairy creation rather than the work of mortal hands." It was at that time about $\mathrm{I} 2$ miles in circumference, everywhere intersected by canals, and connected with the mainland by six long and solidly constructed causeways, as is clearly shown by the plan given in the edition of

1 That article is appended to this paper. 
Cortes's letters published at Nuremberg in $1524 .^{1}$ After its almost destruction in November, 1521, Cortes employed some 400,000 natives in rebuilding it on the same site; but since then the lake seems to have considerably subsided, for although still 50 square miles in extent, it is very shallow and has retired two and a half miles from the city.

During the Spanish rule the chief event was the revolt in 1692 , when the municipal buildings were destroyed. Since then Mexico has been the scene of many revolutions, was captured by the United States Army after the battle of Chapultepec, on September 13, 1847, and by the French Army under Marshall Forey in 1863 . But since the overthrow of Maximilian, and the French Intervention in 1867 , peace has been established and it has become a great centre of civilizing influences for the surrounding peoples.

The City of Mexico is 263 miles by rail from Veracruz on the Atlantic, 290 from Acapulco on the Pacific, 285 from Oaxaca, 863. from Matamoros on the frontier with the United States, and 1224 miles. from El Paso. Mexico is the largest and finest city in Spanish America, and at one time larger than Madrid, the capital of Spain, forming a square of nearly 3 miles both ways, and laid out with perfect regularity, all its six hundred streets and lanes running at right angles north to south and east to west, and covering within the walls an area of about ten square miles, with a population now of 539,935 .

The present City of Mexico is almost twice as large as the old one, it having increased towards the northwest, and, strange to say, the new portion is not laid out as regularly as the old one. All the main thoroughfares converge on the central Plaza de Armas, or Main Square, which covers 14 acres, and is tastefully laid out with shady trees, garden plots, marble fountains, and seats. Here also are grouped most of the public buildings, towering above which is the Cathedral, the largest and most sumptuous church in America, which stands on the north side of the plaza on the site of the great pyramidal teocalli or temple of Huitzilopochtli, titular god of the Aztecs. This church, which was founded in 1573 and finished in 1657 , at a cost of $\$ 2,000$,$\infty 00$, for the walls alone, forms a Greek cross, 426 feet long and 203 feet wide, with two great naves and three aisles, twenty side chapels, and a magnificent high altar supported by marble columns, and surrounded by a tumbago balustrade with sixty-two statues of the same rich gold, silver, and copper alloy serving as candelabra. The elaborately carved choir was also enclosed by tumbago railings made in Macao, weighing twenty-six tons, and valued at about $\$ 1,500,000$. In the interior, the Doric style prevails, and Renaissance in the exterior, which is adorned by five domes and two open towers 218 feet high. At the foot of the

${ }^{1}$ Reproduced in vol. iv. of H. H. Bancroft's History of the Pacific States, San Francisco, 1833, p. 280. 
left tower was placed the famous calendar stone, the most interesting relic of Aztec culture, which is now at the National Museum.

The east side of the plaza is occupied by the old vice-regal residence, now the National Palace, with 675 feet frontage, containing most of the Government offices, ministerial, cabinet, treasury, military headquarters, archives, meteorological department with observatory, and the spacious halls of ambassadors, with some remarkable paintings by Miranda and native artists. North of the National Palace, and forming portions of it, are the post-office and the national museum of natural history and antiquities, with a priceless collection of Mexican relics.

Close to the cathedral stands the Monte de Piedad, or national pawnshop, a useful institution, endowed in r744 by Don Manuel Romero de Terreros with $\$ 375,000$, and now possessing nearly $\$ 10$,$\infty 0^{\circ}, \infty \circ$ of accumulated funds. Facing the cathedral is the Palacio Municipal, or City Hall, 252 feet by 122 , rebuilt in 1792 at a cost of $\$ 150,000$, and containing the city and district offices, and the merchant's exchange.

Around the Plaza San Domingo were grouped the convent of that name, which contained vast treasures buried within its walls, the old inquisition, now the school of medicine, and for some time the Custom House, which has now been removed to the city boundary. In the same neighborhood are the Church of the Jesuits and the School of Arts, which is, in the language of Brocklehurst, " an immense workshop, including iron and brass foundries, carriage and cart mending, building and masonry, various branches of joinery and upholstery work, and silk and cotton hand-weaving."

Other noteworthy buildings are the national picture gallery of San Carlos, the finest in America, in which the Florentine and Flemish schools are well represented, and which contains the famous Las Casas, by Felix Parra; the national library of St. Augustine, with over 200oo volumes, numerous MSS., and many rare old Spanish books; the mint, ${ }^{1}$ which since $r 690$ has issued coinage, chiefly silver, to the amount of nearly $\$ 3,000,000,000$; the Iturbide Hotel, formerly the residence of the Emperor Iturbide; the Mineria, or schools of mines, with lecturerooms, laboratories, rich mineralogical and geological specimens, and a fossil horse, three feet high, of the Pleistocene period.

${ }^{1}$ The Spanish Government intended during last century to build a spacious, costly, and magnificent mint in the City of Mexico, and its plans and specifications were approved by the king, but by a mistake of the clerks in Madrid, they were forwarded to Santiago, Chili, instead of being sent to the City of Mexico, and it was in consequence built there. The building was so fine that, not having any mint at Santiago, it was used as the Government House, and it is now the Executive Mansion and Departments, and it is called "La Moneda," an abbreviation of "La Casa de Moneda," which is the Spanish name for mint. 
Among the twenty scientific institutes, mention should be made of the Geographical and Statistical Society, whose meteorological department issues charts and maps of unsurpassed excellence.

Owing to the spongy nature of the soil, the Mineria and many other structures have settled out of the perpendicular, thus often presenting irregular lines and a rickety appearance.

Before 1860 half of the city consisted of churches, convents, and other ecclesiastical structures, most of which have been sequestrated and converted into libraries, stores, warehouses, hotels, and even stables, or pulled down for civic improvements. Nevertheless there still remain fourteen parish and thirty other churches, some of large size, with towers and domes. San Francisco Street is the leading thoroughfare, and is rivalled in splendor only by the new Cinco de Mayo Street, running from the National Theatre to the cathedral.

It would take a great deal more space than it is convenient to give in this paper, should I attempt to make a longer description of the City of Mexico which, being one of the oldest on this continent and the largest and principal one during the three centuries of the Spanish rule, it has quite a number of remarkable buildings and monuments and a very important history, a great deal of romance being connected with it.

The City of Mexico is not only the capital of the country, but the real head of the Republic; and the aim of all other Mexican cities is to follow in its footsteps and imitate as much as possible the City of Mexico, which to them is a beau ideal and a real paradise.

The City of Mexico is now literally encircled with a belt of factories-cotton, paper, linen, etc., packing houses, brick works, cork factories, soap works, etc., and cheaper fuel will add largely to their number. They have been able to show profits under the load of a dear combustible, and they will welcome the introduction of any fuel, which will enable them to work even more successfully.

Climate.-From the official reports of Professor Mariano Barcena, Director of the National Meteorological Observatory of the City of Mexico, of the weather conditions in 1895 , it appears that there were I 2 I cloudy days. But the rains were mostly at night or late in the afternoon, of short duration, and immediately succeeded by sunshine showers. Long periods of rainy weather are unknown there. The total rainfall for the year, less than twenty inches, will convey a fair idea of the dryness of the climate. The mean temperature in the shade for 1895 was 60 degrees, the highest being 65, reached in April, and the lowest 53, in January, a temperature rather which avoids both extremities. The mean temperature for the summer months were: June, 64 degrees ; July, 62 ; August, 62 ; September, 61.

The table on page I 2 , prepared by the Weather Bureau of the City 
of Mexico, contains the average annual climatological data of that city from the years 1877 to 1895 .

More detailed data about the climatological conditions of the City of Mexico during the year 1896 , prepared also by our Weather Bureau, is appended on page $\mathrm{II} 3$.

Mortality in the City of Mexico.-During the year 1896 the total mortality in the City of Mexico, under a recorded population of 330,698 , was $15,5^{6} 7$, not including I 275 still-births, equivalent to 4.70 per cent. The principal diseases which caused that mortality were those affecting

1 A BRIEF HISTORICAL SKETCH OF THE METEOROLOGY IN THE MEXICAN REPUBLIC.

Priest José Antonio Alzate stands in the first place among those who have cultivated the meteorological science in our country, being he who first devoted himself to its study, and made regular observations during more than eight years, as he himself says in his Descripcion topografica de México (1 738 to 1799). Of these observations, he, unfortunately, only published those belonging to the last nine months of the year 1769 , in his famous Gaceta de Literatura de México, I788 to I 795. He also published many articles describing some phenomena and instruments, climates of towns, value and usefulness of observations, as he had done in others of his publications : Diario Literario de Mexico, 1768 ; A suntos varios sobre Ciencias y Artes, 1772 to 1773 ; and $O \mathrm{Bb}_{\text {- }}$ servaciones sobre la Fisica Historia Natural y Artes uitiles, 1787 . He was the first in determining the height of the City of Mexico.

After these labors of Father Alzate, we find in the journal El Sol regular series of observations published, daily, from the I4th of June, I824, to the I 4 th of January, 1828. Dr. John Burkart in 1826; Sr. Francisco Gerolt from 1833 to 1834 , at the School of Mines; Sr. José Gómez de la Cortina, Conde de la Cortina, from 184 t to 1845 ; the members of the Geographical Section of the Army Staff from I842 to I 843 ; the Astronomer Sr. Francisco Jiménez in 1858; the School of Mines in the years 1850, 1856, 1857, and $185^{8}$; Sr. Ignacio Cornejo, M.E., at the same school from 1865 to 1866 ; and Sr. Juan de Mier y Terán at the "Escuela Preparatoria" from 1868 to 1875 , respectively, made some meteorological observations.

A series of observations from 1855 to 1875 were made at the Hacienda de San Nicolás Buenavista, and another one at the city of Córdoba from 1859 to $186_{3}$, by Dr. José Apolinario Nieto; Sr. Carlos Sartorius at the Hacienda del Mirador (State of Veracruz); Sr. Miguel Vclázquez de León, and his sons, Joaquín and Luis, engineers, from 1869 up to the present, at the Hacienda del Pabellón; Sr. Gregorio Barreto from 1869 to 1880 , at the city of Colima; General Mariano Reyes, Sr. José María Romero, engineer, and Sr. Pascual Alcocer, from 1870 to the present date, at the city of Querétaro; Sr. Lázaro Pérez from I874 to I885, at the city of Guadalajara; Sr. Isidoro Epstein at the City of Monterrey, I855; Sr. Vicente Reyes, a civil engineer and architect, at the city of Cuernavaca, 1873,1874 , and 1876 ; Sr. Joaquin de Mendizabal Tamborrel, an engineer, at the city of Puebla, I872 to 1873 ; Sr. Augustin Galindo at the same city, 1875; Professor Manuel M. Cházaro at San Juan Michapa (State of Veracruz), 1872 to 1873 ; Priest Pedro Spina, S. J., at the city of Puebla, 1876 , and perhaps many others from whom we have no notice, have devoted themselves to making meteorological observations.

The "Sociedad de Geografía y Estadistica " the most ancient scientific society in Mexico, distributed, in 1862 , some instruments and instructions to observers.

Finally, on the 6th of March, 1877, being President of the Republic, General 


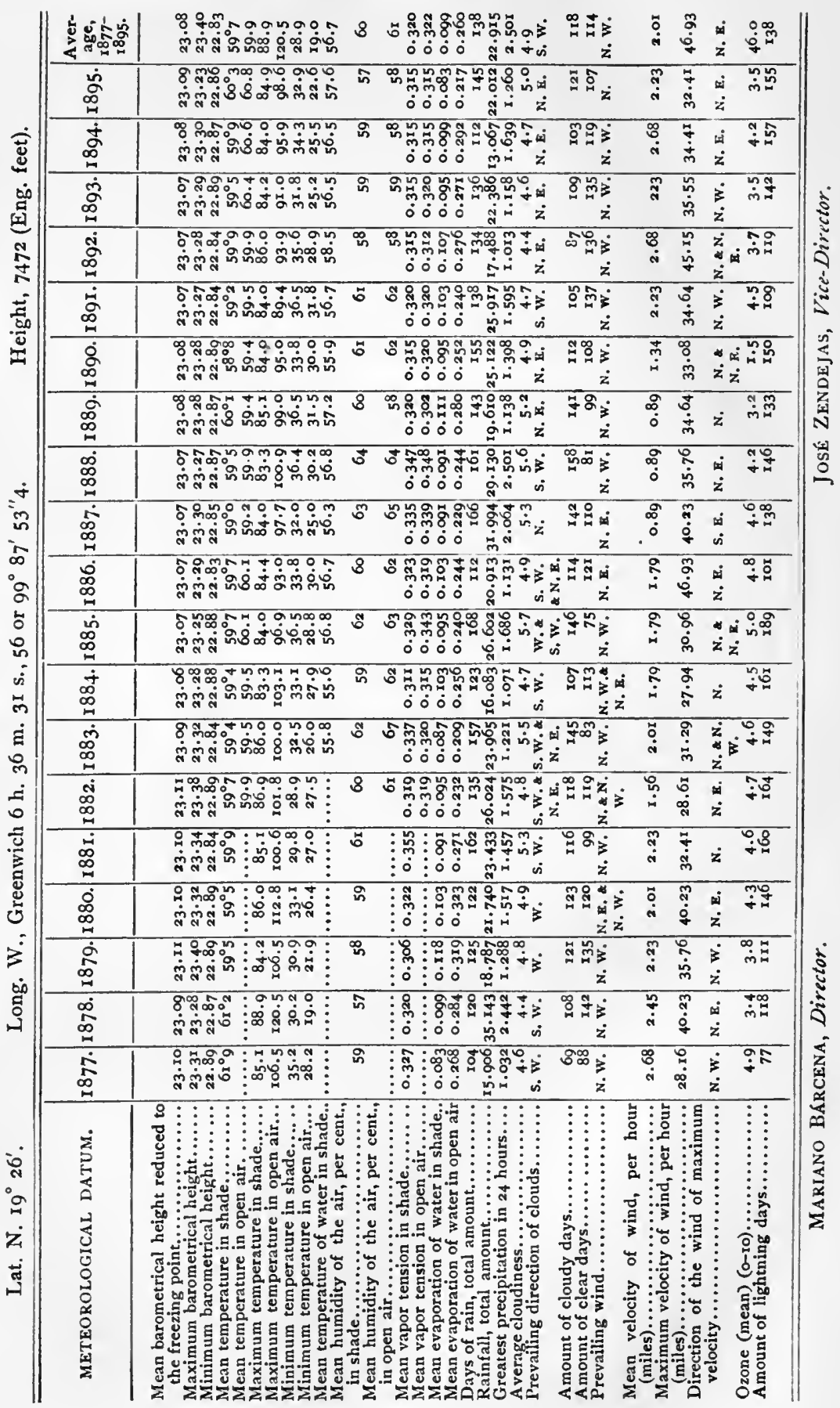




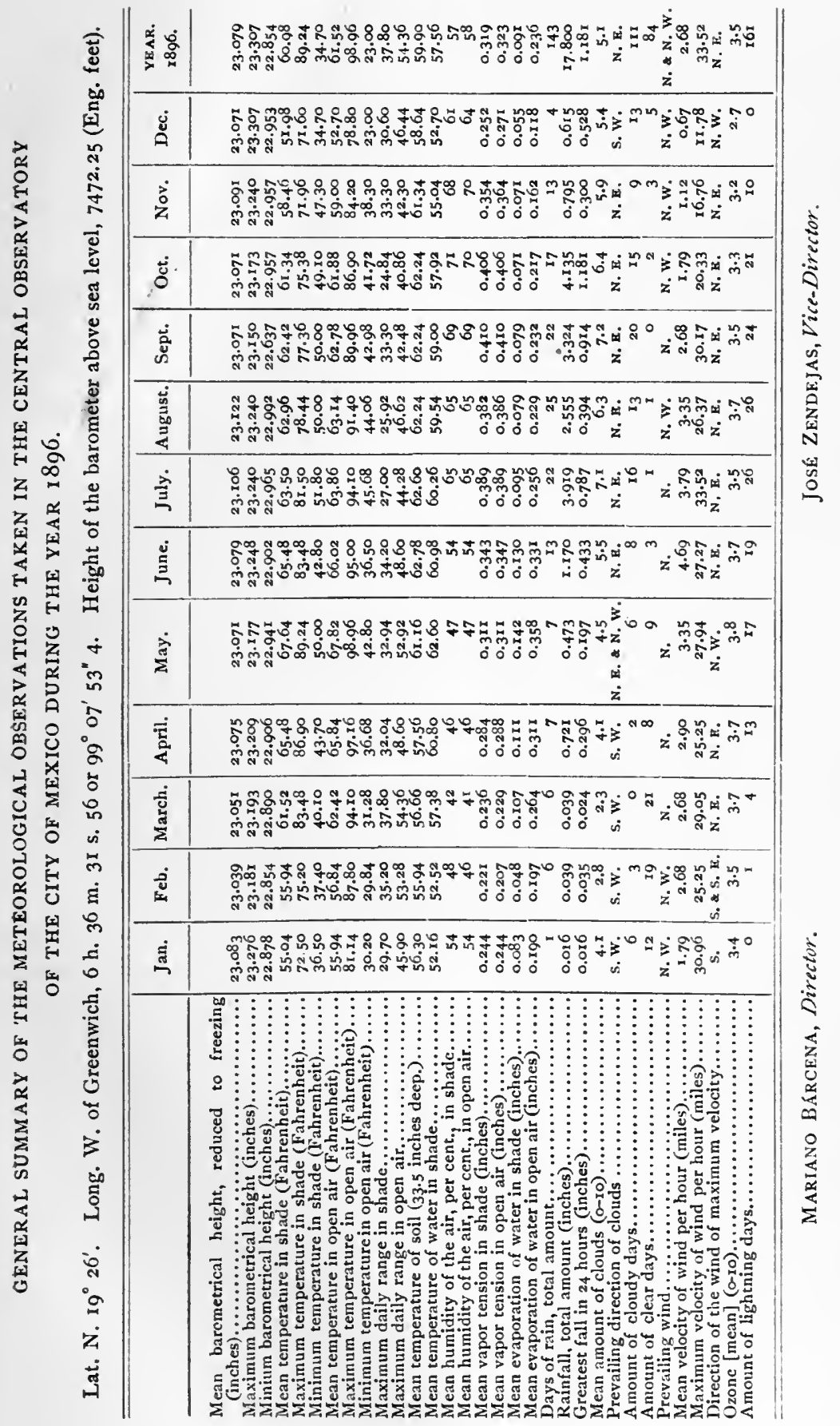


the digestive and respiratory organs, the former amounting to 4472 or I. 35 per cent. of the population and the latter to 3904 or I.I 8 per cent. of the population, and both causing 8376 deaths or $53.8 \mathrm{I}$ per cent. of the total number of deaths. Deaths by typhus and typhoid fevers and small-pox, which are supposed to make such great ravages in the City of Mexico, were in reality insignificant, the deaths by the former amounting in that year to 480 or 0.14 per cent. of the population, and the deaths by small-pox were, in the Federal District, embracing the City of Mexico and twenty-three suburban towns, 217 or 0.047 per cent. of the population of the District which is 473,820 . Small-pox only attacks the very poor people, and, strange to say, also foreigners, even in case they have been vaccinated in their country, and to be free from small-pox they must be vaccinated in Mexico.

The months of the greatest mortality during the same year were from February to May, and of the smallest the month of August, showing that the unhealthy months are the dry months, that is before the rains set in.

The mortality in the City of Mexico is indeed very large, and it is due principally to two causes, first, the want of proper drainage and sewerage for the refuse of the city, a trouble which is now almost com-

Porfirio Diaz, and by the suggestion of General Vicente Riva Palacio, then Secretary of Public Works, the Central Meteorological Observatory was established. From that date up to the present, an uninterrupted hourly observation is regularly taken during the day and the night in the Central Meteorological Observatory. Some magnetical observations have also been made, and the Observatory is now thought of being removed to a more suitable spot.

After the establishment of the Central Meteorological Observatory, some official or private meteorological stations have also been established as follows: Aguascalientes (Instituto del Estado); Guadalajara (Escuela de Ingenieros), observer, Augustín V. Pascal ; Guanajuato (Colegio del Estado), observer, Genaro Montes de Oca ; León (Escuela Secundaria), observer, Mariano Leal ; Mazatlán (Observatorio Astronómico y Meteorológico), observer, N. González; Oaxaca (Colegio del Estado), observer, Dr. A. Domínguez; Pachuca (Instituto del Estado), observer, Dr. N. Andrade; Puebla (Colegio Católico and Colegiu del Estado), observers, Priest P. Spina and B. G. González respectively; Querétaro (Colegio Civil), observer, J. B. Alcocer; San Luis Potosí (Instituto del Estado), observer, Dr. G. Barroeta; Toluca (Instituto del Estado), observer, S. Enríquez; Veracruz, observer, G. Baturoni ; Zacatecas (Instituto), J. A. Bonilla. Dr. Manuel Andrade, of Huejutla; Dr. Matienzo, of Tampico: Father Pérez, of Morelia ; Fatber Arreola, of Colima; Father Castellanos, of Zapotlán ; Sr. Pascual Borbón, of Tacámbaro, are enlightened observers to whom the Central Meteorological Observatory is indebted for their valuable co-operation, and also to the telegraph operators of the "Telegraph system," who send, daily, some weather observations to this office.

The staff of the Central Meteorological Observatory is now as follows: Director, Mariano Bárcena; Vice-Director, José Zendejas, C.E. ; Second Observer, Francisco Toro; Assistants, Rafael Aguilar, Francisco Quiroga, Angel Robelo, José Torres, and J. 1. Vázquez. 
pletely remedied, and the second, the unhygienic way of living of the poor classes, among whom takes place the largest mortality.

The very large number of still-births which occurred in the City of Mexico in 1896 , almost exclusively among the poor classes, shows the little care that the poor women take of themselves, and is enough to explain the present large mortality.

\section{RAILWAYS.}

For many years the government earnestly endeavored to further the construction of railroads in Mexico, but the broken surface of the country made the building of these roads very expensive. Until 1873 the means of internal locomotion were mainly limited to a few wagon roads, over which travelled twenty-four regular lines of diligences, under one management; and bridle-paths from the central plateau over the sierras and terrace lands down to a few points on both coasts.

In 1854 the first railroad was finished, connecting the City of Mexico with Guadalupe, about three miles in length, and another from Veracruz to Tejeria towards the City of Mexico about twelve miles in length; these being the only railroads that were built, up to $186 \mathbf{1}$. During the French Intervention the French army extended the Tejeria road to Paso del Macho, about thirty-five miles further, to the foot of the mountain, so as to be able to transport their army, with the shortest delay possible, out of the yellow-fever zone, toward the central plateau ; and an English Company, which had a grant for a road from the City of Mexico to Veracruz, which was supposed at the time to be the only one that could be built in Mexico, extended the Guadalupe road to Apizaco in the direction of Veracruz and not far from Puebla.

No construction of consequence was done immediately after the French Intervention, because the country was generally in a disturbed condition, although several efforts were made in that direction by President Juarez, under whose administration a new and very liberal grant was given to the Veracruz railway company. The Veracruz road was finished in $\mathbf{1} 873$, during Señor Lerdo de Tejada's Presidency, and when General Diaz became President in 1876 he earnestly promoted railroad building; and we now have two trunk lines connecting the City of Mexico with the United States-the Mexican Central to El Paso, Texas, with a branch from San Luis Potosi to the port of Tampico, and another from Irapuato to Guadalajara, which has recently been extended to Ameca, towards the Pacific; and the Mexican National to Laredo, Texas, with several branches. Another trunk line from Eagle Pass to Torreon and Durango, which it is intended shall finally reach the Pacific, has also been built by Mr. C. P. Huntington and his associates. There is besides a line from Nogales to Guaymas, built and owned by the Atchison, Topeka, and Santa Fé 
Company; and these four lines connect us with the main systems of the United States, our lines being in fact extensions of the United States railway system.

We have now two lines from the City of Mexico to Veracruz, the old Veracruz road passing by Orizaba, and the Interoceanic, which runs from Veracruz by Jalapa and the City of Mexico and is intended to reach the Pacific. All of our roads, excepting the one built by Mr. Huntington, have had large subsidies paid by the Mexican Government, and in one case, that of the Veracruz railroad, the subsidy paid was $\$ 560,000$ per year, for twenty-eight years, or about $\$ 57,47$ I per English mile, although the average subsidy per mile, according to President Diaz's report, dated November 30,1896 , is $\$ 14,380$.

The Tehuantepec railway, running from Coatzacoalcos on the Gulf of Mexico to Salina Cruz on the Pacific, about one hundred and thirty miles in length, has been built at great expense and at a great sacrifice by the Mexican Government. I published in the Engineering Magazine for March, $1894,{ }^{1}$ an article stating the different efforts made by the Mexican Government to have that road built, and the advantages that we expected from it as a highway of trade between the Atlantic and the Pacific. The Mexican Government has recently made a contract with Messrs. E. Weetman, Pearson \& Son, of London, for the building of good harbors at both ends of the road, and when that is accomplished we expect that a great deal of eastern trade will pass through Tehuantepec.

With the exception of the Tehuantepec road, we have not yet any road running from the Atlantic to the Pacific, although several are in process of construction. The descent of the mountains is on the $\mathrm{Pa}$ cific slope a great deal more difficult than on the Gulf coast, where the large centres of population are located near the Gulf, and this explains why none of the roads have so far been able to reach the Pacific Ocean.

Our railway system extends now, in the direction of Guatemala, as far as the city of Oaxaca, where we are only about five hundred miles away from our frontier with Guatemala. In other directions, our system reaches the principal cities and commercial and mining centres of the country.

The total mileage of railway in 1895 was $6989 \frac{1}{2}$ English miles. President Diaz, in his above mentioned report gives, the total mileage of railways in Mexico as 11,469 kilometres or 7126 miles; and in his message to Congress on April I, r897, he stated that the railway mileage had been increased by $23^{8}$ kilometres $55^{\circ}$ metres, finished and received by the Government, and 248 kilometres built, but not yet received officially, making a total mileage of II,955 kilometres $55^{\circ}$ metres, or 7.429 miles.

${ }^{1}$ This paper will appear in this volume. 
President Diaz's Railzway Policy.-President Diaz deserves a great deal of credit for his efforts to promote in Mexico, material improvements, and especially in railroad building. When he came into power, in 1877 , public opinion was very much divided as to the policy of allowing citizens of the United States to develop the resources of the country by building railroads, working mines, etc. Our experience of what took place in consequence of the liberal grants given by Mexico to Texan colonists made many fear that a repetition of that liberal policy might endanger the future of the country by giving a foothold in it to citizens of the United States who might afterward, if circumstances favored them, attempt to repeat the case of Texas. President Lerdo de Tejada seemed to share such fears judging by his policy in this regard. But President Diaz, as a broad-minded and patriotic statesman, believed that the best interest of the country required its material development, and that it would not be advisible to discriminate against citizens of the United States, as that country was more interested than any other, on account of its contiguity to Mexico, in developing the resources of our country by building an extensive system of railways, and would, therefore, be more ready than any other to assist in building them. He trusted, at the same time, that when the resources of the country should be more fully developed, it would become so strong as to be beyond reach of the temptation by foreign states or individuals. The results of the work done in Mexico so far show that General Diaz acted wisely, and proved himself equal to the task before him.

Many in Mexico, and myself among the number, thought that, as the railroads were such lucrative enterprises, especially in a country endowed with so many natural elements of wealth as Mexico, it would not be judicious to give their promoters any pecuniary assistance, in the shape of subsidies or otherwise, the more so as the finances of the country were then in a critical condition, and it would not be wise to increase its burdens by large pecuniary subsidies in aid of private enterprises. My opinion in this case was based mainly on what I had seen in the United States, namely : that long lines of railways are built in this country without any pecuniary assistance from the Government, and that when the Government subsidized any one line it became a source of great dissatisfaction and very unpleasant questions, which are yet unsettled. We feared also that such large subsidies as were asked by the railway promoters would amount in the end to so large a sum as to make it impossible for Mexico to pay it, discrediting the country. But in this case General Diaz's view seems to have been the right one, in so far as that it afforded a great inducement for the immediate building of large trunk lines of railways, which, without subsidy, might have been delayed for several years. He thought it 
worth while to spend large sums of money for the purpose of having railways built without delay, rather than trust to the fluctuations of confidence and credit in the foreign exchanges, that would enable the prospective companies to obtain the funds necessary to build their roads, trusting, at the same time, that the material development of the country promoted by the railroads would yield revenue enough to pay all the subsidies granted. Fortunately all railroad subsidies contracted by Mexico have been punctually paid, and their amount forms now a large item of our national debt. To pay some of them the mistake was made of negotiating a sterling loan on Europe, to pay a silver debt; but even in that way the transaction is not altogether a bad one.

General Diaz's policy was to give a railway subsidy to anybody asking for it without investigating the responsibility of the concern, with the idea that if the road was built the country would get the benefit of the same, and if it was not built nothing would be lost, as there was in all grants, a clause to the effect that if no building was done within a given time, the grant should by that mere fact be forfeited, the forfeiture to be declared by the Administration.

The system of subsidizing railways has a great many drawbacks, but at the same time commands some decided advantages, like giving the government the strict supervision over the roads who have to submit to it for its approval, tariffs for freights and passengers, the free carrying of the mails, the duty of the company to present to the government a yearly statement of its traffic, receipts, etc., and other similar advantages. In all grants to subsidized railroads there is a stipulation that at the end of ninety-nine years the road-bed would revert to the Mexican government.

President Diaz's Statistics on Mexican Railzways.-Before I close this chapter I think it will not be out of place to quote some remarks of President Diaz concerning our Mexican railroads, which occur in his above-mentioned report.

"In 1875 we had 578 kilometres 285 metres of railway, in 1885 we had 5915 kilometres, in 1886, 6018 kilometres, in November, 1888, 7940 kilometres, in June, 1892, 10,233, and including the tramways and other local and private lines, the amount was 11,067 kilometres; in September, 1894 , we had 11,100 kilometres; in April, I896, II,165 kilometres, and now we have II,469 kilometres.

"We stand first in railroad building of all the Latin-American countries. During the years 1877 to 1892 Mexico built more railroads than any other Latin-American State, being II,I65 kilometres; the Argentine Republic takes the second place, with 8108 kilometres, and Brazil the third, with 6I93 kilometres, built during the years mentioned. The average number of kilometres built per annum in Mexico during this period was 689 , the maximum having been reached in 
I $88 \mathrm{I}-82$

$1882-83 \ldots \ldots \ldots \ldots \ldots \ldots \ldots \ldots \ldots \ldots \ldots \ldots$

$1887-88 . \ldots \ldots \ldots \ldots \ldots \ldots \ldots \ldots \ldots \ldots \ldots$

1889
I938 kilometres

1727

1217

1263

The number of passengers carried in

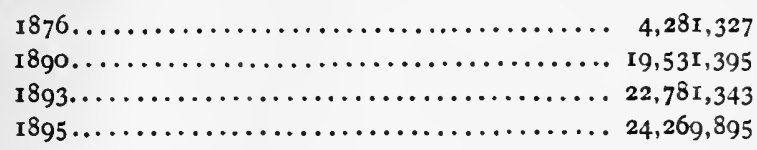

The freight handled in

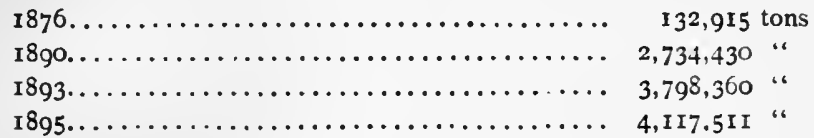

The gross receipts in

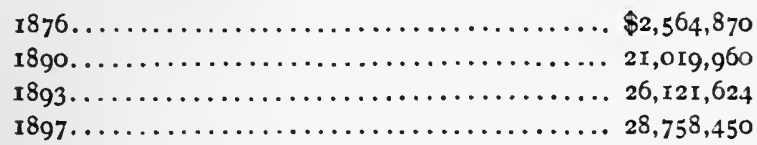

“The subsidies paid for railroads up to December, 1892 , averaged $\$ 8935$ per kilometre of road built and in operation at that date. This average is much less than that of the subsidies paid by other Latin-American countries, the Republic of Chili having averaged $\$ 17,635$ per kilometre, and the Argentine Republic $\$ 31,396$.

"The railroad system of the Republic has given the capital direct and rapid connection with our principal states. Throughout the length of the central plateau to the frontier, Mexico City is connected with the capitals of the states of Querétaro, Guanajuato, Jalisco, Aguascalientes, Zacatecas, Chihuahua, and San Luis Potosi by the Mexican Central Railway, and with Durango by the Mexican International; with the states of Mexico, Guanajuato, Michoacan, San Luis Potosi, Coahuila and Nuevo Leon by the Mexican National ; with the cities of Puebla, Orizaba, Cordoba, Veracruz, and Jalapa by the Mexican Railway and by the Interoceanic, and with Tehuacan and Oaxaca by the Mexican Southern from Puebla. Three lines connect the capital with the northern frontier; the Central, which terminates in Ciudad Juarez; the National, which runs to Nuevo Laredo; and the International, which, from its junction with the Central at Torreon, runs to Piedras Negras. And as to our various ports Guaymas is connected with Nogale on the northern frontier; Manzanillo with Colima ; Matamoros with Reynosa and San Miguel ; Tampico with San Luis Potosi and Monterrey; Veracruz with Jalapa and Mexico ; and the first really Interoceanic railway of the Republic across the Isthmus of the Tehuantepec, united the Atlantic and Pacific oceans by connecting the port of Coatzacoalcos, on the gulf, with the port of Salina Cruz on the Pacific coast. Southward from the capital of the Republic the Interoceanic traverses the State of Morelos, and the Mexico, Cuernavaca and Pacific Railway has its line located to the City of Cuernavaca and is pushing on through the state of Guerrero to the port of Acapulco. In the peninsula of Yucatan, the lines connecting Campeche and Merida are nearly finished; while the port of Progreso has rail communication with Merida."

Financial Condition of Mexican Railways.-Our railroads are doing remarkably well, and their traffic, especially domestic, is daily increas- 
ing and grows in much larger proportion than the foreign, or international traffic; and they are paying the interest on their debt, which is due and paid in gold, notwithstanding that they collect their freights in silver, which has been for several years at a great discount, losing at the present rate of exchange about one hundred per cent. in the operation; but their business is such that they can afford to suffer that loss.

In the statistical section of this paper will be found a list of our railroads, their mileage, earnings, and several other data, showing that they are in a prosperous condition, all of which will be of interest to those who desire to have a more intimate acquaintance with the railway system of Mexico. I will only insert here the following statement of the annual building and earnings of the Mexican railways, supplementing it with a comparative statement showing the tonnage moved by the principal railway lines, for the ten years ending December $3 x, x 896$, which shows a great increase in their business, and consequently in their earnings.

ANNUAL BUILDINGS AND EARNINGS OF MEXICAN RAILWAYS.

\begin{tabular}{|c|c|c|c|}
\hline \multirow{2}{*}{ YEAR. } & \multicolumn{2}{|c|}{ MILES OF ROADS BUILT. } & \multirow{2}{*}{ ANNUAL EARNINGS. } \\
\hline & Each year. & Total. & \\
\hline 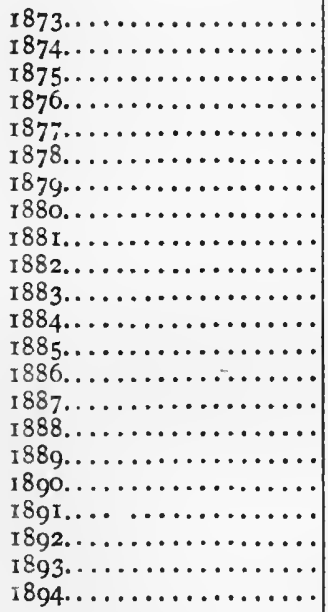 & $\begin{array}{r}-1-393 \\
47,087 \\
2,265 \\
3,739 \\
40,748 \\
91,950 \\
120,328 \\
429,858 \\
1,204,118 \\
1,073,404 \\
282,523 \\
73,614 \\
49,099 \\
323,084 \\
756,522 \\
390,650 \\
784,744 \\
495,015 \\
352,171 \\
14,829 \\
118,810\end{array}$ & $\begin{array}{r}359,306 \\
364,699 \\
418,001 \\
414,052 \\
417,791 \\
458,539 \\
550,488 \\
670,817 \\
1,100,675 \\
2,304,792 \\
3,378,196 \\
3,660,719 \\
3,734,332 \\
3,783,432 \\
4,106,516 \\
4,863,060 \\
5,253,096 \\
6,037,752 \\
6,532,711 \\
6,884,842 \\
6,870,015 \\
6,888,811\end{array}$ & $\begin{array}{r}\$ 2,097,104.55 \\
2,665,496.18 \\
2,799,696.13 \\
2,563,241.00 \\
3,213,434.17 \\
3,400,799.89 \\
3,828,718.65 \\
4,504,135.39 \\
5,679,193 \cdot 37 \\
9,883,719.51 \\
12,102,583.34 \\
11,089,136.39 \\
10,656,551.42 \\
11,373,667.63 \\
13,310,218.79 \\
16,121,267.79 \\
18,788,142.29 \\
20,919,287.14 \\
23,762,172.87 \\
25,363,922.29 \\
25,359,244.06 \\
-1\end{array}$ \\
\hline
\end{tabular}


COMPARATIVE STATEMENT, SHOW1NG APPROXIMATE TONNAGE MOVED BY THE UNDERMENTIONED RAILWAYS FOR THE TEN YEARS ENDED DECEMBER $3 \mathrm{I}$, I 896 .

(Compiled from published reports and information furnished by the respective railway companies.)

\begin{tabular}{|c|c|c|c|c|c|}
\hline \multirow{2}{*}{ YEAR. } & $\begin{array}{l}\text { CENTRAL } \\
\text { RAILWAY. }\end{array}$ & $\begin{array}{l}\text { NATIONAL } \\
\text { RAILWAY. }\end{array}$ & $\begin{array}{l}\text { INTFROCEANIC } \\
\text { RAILWAY. }\end{array}$ & $\begin{array}{l}\text { MEXICAN } \\
\text { RAJLWAY. }\end{array}$ & TOTAL. \\
\hline & Tons. & Tons. & Tons. & Tons. & Tons. \\
\hline $\begin{array}{l}1887 \ldots \ldots \ldots \\
1888 \ldots \ldots \ldots\end{array}$ & $\begin{array}{l}346,898 \\
477,530 \\
\text { Inc. } 34.4\end{array}$ & $\begin{array}{c}77,935 \\
372,800 \\
\text { Inc. } 37^{8.3}\end{array}$ & $\begin{array}{l}\text { I41, 090 } \\
\text { 197, } 231 \\
\text { Inc. } 39.7\end{array}$ & $\begin{array}{l}273,194 \\
318,893 \\
\text { Inc. I } 6.7\end{array}$ & $\begin{array}{r}839, \text { I I } 7 \\
\text { I, 366, } 454 \\
\text { Inc. } 62.7\end{array}$ \\
\hline $\mathbf{1} 889 \ldots \ldots$ & $\begin{array}{l}540,479 \\
\text { Inc. I3.I }\end{array}$ & $\begin{array}{c}428,314 \\
\text { Inc. } 14.8\end{array}$ & $\begin{array}{l}186,222 \\
\text { Dec. } 5 \cdot 5\end{array}$ & $\begin{array}{l}354,32 \text { I } \\
\text { Inc. II.I }\end{array}$ & $\begin{array}{r}\text { I, } 509,336 \\
\text { Inc. } 10.4\end{array}$ \\
\hline I8go... & $\begin{array}{l}609,382 \\
\text { Inc. x2.7 }\end{array}$ & $\begin{array}{l}472,0+5 \\
\text { Inc. Io, } 2\end{array}$ & $\begin{array}{l}281,769 \\
\text { Inc. } 51 \cdot 3\end{array}$ & $\begin{array}{l}384,584 \\
\text { Inc. } 8.2\end{array}$ & $\begin{array}{r}\text { I, 747,780 } \\
\text { Inc. } 15.7\end{array}$ \\
\hline $1891 . .$. & $\begin{array}{l}867,657 \\
\text { Inc. } 42.3\end{array}$ & $\begin{array}{l}502,856 \\
\text { Inc. } 7 \cdot 3\end{array}$ & $\begin{array}{l}277,866 \\
\text { Dec. I.3 }\end{array}$ & $\begin{array}{c}409, I_{5} \\
\text { Inc. } .6\end{array}$ & $\begin{array}{r}2,057,564 \\
\text { Inc. } 17.7\end{array}$ \\
\hline $18 g^{2} \ldots \ldots \ldots$ & $\begin{array}{l}1,091,785 \\
\text { Inc. } 25.8\end{array}$ & $\begin{array}{c}588,505 \\
\text { Inc. I } 7 .\end{array}$ & $\begin{array}{l}365, \text { I91 } \\
\text { Inc. } 3^{1 \cdot 4}\end{array}$ & $\begin{array}{c}367,980 \\
\text { Dec. Iо. }\end{array}$ & $\begin{array}{l}2,4 \text { I } 3,461 \\
\text { Inc. I } 7 \cdot 3\end{array}$ \\
\hline I $893 \ldots \ldots \ldots$ & $\begin{array}{l}860,187 \\
\text { Dec. } 21.2\end{array}$ & $\begin{array}{l}552,123 \\
\text { Dec. } 6.5\end{array}$ & $\begin{array}{l}380,805 \\
\text { Inc. } 4 \cdot 3\end{array}$ & $\begin{array}{l}385,923 \\
\text { Inc. } 4.8\end{array}$ & $\begin{array}{r}2,179,038 \\
\text { Dec. } 9.7\end{array}$ \\
\hline $1894 \ldots$ & $\begin{array}{r}898,484 \\
\text { Inc. } 4 \cdot 4\end{array}$ & $\begin{array}{l}558,382 \\
\text { Inc. I.I }\end{array}$ & $\begin{array}{l}444, \text { I } 9 \text { I } \\
\text { Inc. } 16.6\end{array}$ & $\begin{array}{l}433,637 \\
\text { Inc. } 12 \cdot 3\end{array}$ & $\begin{array}{r}2,334,694 \\
\text { Inc. } 7 . x\end{array}$ \\
\hline $1895 \ldots \ldots \ldots$ & $\begin{array}{l}1,047,038 \\
\text { Inc. } 16.5\end{array}$ & $\begin{array}{l}636,193 \\
\text { Inc. } 13.9\end{array}$ & $\begin{array}{l}464,976 \\
\text { Inc. } 4 \cdot 4\end{array}$ & $\begin{array}{l}453,289 \\
\text { Inc. } 4.5\end{array}$ & $\begin{array}{l}2,601,496 \\
\text { Inc. II.4 }\end{array}$ \\
\hline \multirow[t]{2}{*}{$1896 \ldots \ldots \ldots$} & $\begin{array}{l}\text { I, } 231,025 \\
\text { Inc. } 17.5\end{array}$ & $\begin{array}{c}782,106 \\
\text { Inc. } 22.9\end{array}$ & $\begin{array}{l}479,744 \\
\text { Inc. 3.I }\end{array}$ & $\begin{array}{l}756,330 \\
\text { Inc. } 66.8\end{array}$ & $\begin{array}{r}3,249,205 \\
\text { Inc. } 24.8\end{array}$ \\
\hline & $7,970,465$ & $4,971,259$ & $3,219,085$ & $4,137,336$ & $20,298, I_{45}$ \\
\hline
\end{tabular}

City of MeXico, May 19, 1897.

A. Blake.

\section{TELEGRAPHS.}

We have quite a number of miles of telegraph lines in Mexico, and our service is now as good as that of any other country. The first telegraph line built and owned in Mexico by a private company, liberally assisted by the government, extended from Veracruz to the City of Mexico. On November $5, x 85 x$, the first section was inaugurated from the City of Mexico to Nopalucan, and on May I9, I852, to Veracruz.

In 1853 another company established a line from the City of Mexico towards the north to Leon in the State of Guanajuato, and in 1865 a line was finished to San Luis Potosi.

In 1868 and 1869 a private company, called the "Jalisco Company" established the line between the City of Mexico and Guadalajara, which was soon afterwards extended to Manzanillo and San Blas. After the restoration of the Republic in 1867 , the Mexican government began to 
build lines to the principal centres of population of the country, and in 1890 it bought the Jalisco line, and in 1894 the Veracruz.

From 1869 to 1876 the States of Michoacan, Oaxaca, and Zacatecas established several lines in their respective jurisdictions. When General Diaz became President in 1876 , the National Telegraphic Lines only had 7927 kilometres.

In 1885 the Federal Goverment transferred to the States, without any cost, all the telegraphic lines which were considered of local interest, keeping only such as could be called trunk lines.

In 1893 we had 37,880 English miles of telegraph lines, of which 24, 840 belonged to the Federal Government, the remainder belonging in about equal parts to the States, private companies and railways.

The following statement, which I take from the Anuario Estadistico de la Republica Mexicano, 1895, shows the telegraphic lines belonging to the Federal Government, to the States, to private companies and to railroads :

Federal Lines......................43,416 k $780 \mathrm{~m}$

State Lines................... 5,544 068 "

Private Company Lines............. 4,730 980 "

Railroad Lines................. 9,76r 6I “ "

General Total................6 63,453 k 439 "

On November 30,1896 , the total mileage of our telegraph lines was, according to the President's report of that date, 45,000 kilometres, 27,962 English miles, and that amount was increased, according to the President's message of April I, I 897, to 45,259 kilometres, 28, I 23 miles.

In I89 I the operations of the various lines throughout the Republic involved the transmission of $1,050,000$ messages, of which about 800 ,0oo were private, and the remainder official. The receipts from this branch of the public service amounted to $\$ 469,305$ collected at 767 offices; the expenditure included for repairs an average of $\$ 3$ per kilometre, and for salaries a total of $\$ 67 \mathrm{r}, 43 \mathrm{I}$.

The proceeds of the Federal telegraphic lines were, according to President Diaz's report of November 30,1896 , as follows :

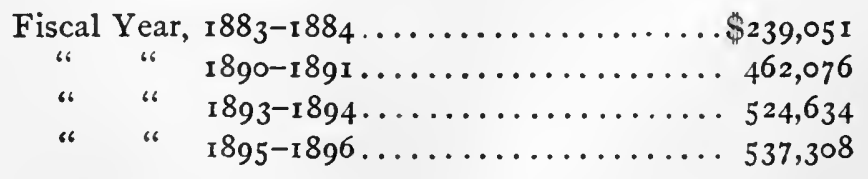

In the statistical portion of this paper will be found a detail statement of the earnings and expenses of the national telegraphic lines of 
Mexico for the 27 fiscal years which elapsed from July I, I869, to June 30,1896 , and such data as it is possible to obtain for the ten years which elapsed from July r, r869, to June 30,1879 .

Cables.-Up to $\mathrm{I} 887$ there was no communication between Mexico and foreign countries. In 1880 the Mexican Cable Co. built their cables from Galveston to Tampico, Veracruz and Coatzacoalcos, on the Gulf of Mexico, and a telegraphic line from Coatzacoalcos to Salina Cruz, on the Pacific, which was extended to Central and South America. Cables had been laid between Jicalango and El Carmen and between the rivers Grijalva and Coatracoalcos, and now through those cables we are in direct communication with the United States and Europe.

POSTAL SERVICE.

Our postal service has improved considerably of late. It was until recently quite imperfect on account of the difficult and expensive ways of communication. It used to be slow and so expensive that it was almost prohibitory, and up to 1870 the single postage of a letter, weighing one quarter an ounce was 25 cents, and double for any distance exceeding sixty miles. After Mexico entered into the Universal Postal Union, in 1870 , the postage of letters for foreign countries was reduced to 5 cents, and that reduction made it necessary to reduce the home postage from 25 to ro cents. Recently it has been reduced again from ro to 5 cents.

There were in the whole country, in $188_{3}$, one head post-office at the national capital, 53 first-class post-offices, 265 second class, for the most part inefficient, and ${ }_{5} \mathrm{I} 8$ postal agencies, little better than useless. The entire service as it was being rendered at 837 stations. The evils resulting from the very high postage were further aggravated by the insecurity of the mails. The revenue of the postal department in that year amounted to $\$ 817,244$.

The total number of post-offices and postal agencies in 1893 was

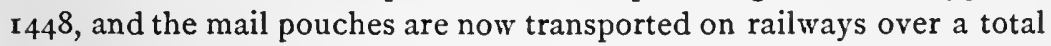
distance of 10,000 kilometres, or more than 6000 miles. Over the remaining distances in the interior the mails are conveyed either by stages or by foot or mounted carriers.

President Diaz gives in his report of November 30,1896 , the following statistics about our postal services :

Post Offices. Postal Agencies.

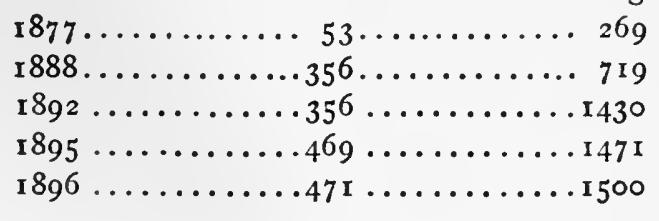


President Diaz states in his same report that the total number of pieces distributed by our mails in the year 1878 was $5,169,892$, while in the year 1896 the number increased to $24,000,000$.

For the purpose of communicating with foreign countries, especially before railroads were finished, the Mexican government granted large subsidies to steamship companies, running especially between Mexican and United States ports, and their amount increased considerably the expenses of our post-office department.

In the statistical part of this paper I shall insert the statement of the earnings and expenses of the postal service in Mexico, in the twentyseven years elapsed from July I, I 869, to June 30 , I 896 .

\section{PUBLIC LANDS.}

The Spanish government considered itself the owner of lands in Mexico, and it granted them to private parties under certain very liberal regulations. The Indians having been the original owners, and needing the lands to raise their food, and textiles for their clothing, could not be entirely deprived of them, and a large portion of the land was left to each municipality to be held generally in common by the inhabitants of the same. Large tracts of land remain, however, which . had not been granted either to the Indians nor to the Spanish settlers, and these we called vacant lands-Terrenos Baldios. The Mexican government succeeded Spain in the ownership of public lands, and with a view to make them available for colonization an easy system to dispose of them at a comparatively low price was established.

The greatest difficulty was to find the public lands, as they had never before been surveyed, and a great many were occupied without title by private parties. As such survey would be very expensive, the Mexican government devised a plan of contracting that work with private companies, paying them with one-third of the land measured, and in that way large portions of the public lands have been surveyed.

It appears from President Diaz's report to his fellow-citizens, dated November $30, \mathbf{1} 896$, that up to 1888 private companies had surveyed $33,8 \mathrm{II}, 524$, hectares of public lands, for which they received in payment for their work one-third or $11,036,407$ hectares. In the four years from 1889 to $1892,16,820,141$ hectares of public lands were surveyed by private companies, of which $I I, 213,427$ hectares belonged to the government, and in that way in less than ten years it was possible to survey $50,631,665$ hectares. Out of this amount the government sold to private parties and to colonization companies $1,607,493$ hectares, and to private companies who were in possession of public lands held by them without any title, which we call demacias, 4,222,99 I hectares. At the same time the government has been trying to divide the lands held in common by the Indian towns between the inhabitants of the 
same, and up to 1888 it had distributed in that manner 67,368 hectares among 2936 titles, and from 1889 to 1892 I80, 169 hectares among 4560 titles. In accordance with the provisions of our public land laws we sold to private parties, who pre-empted the lands for purchase, which we call "denuncio," $3,635,388$ hectares among 1504 titles, and from 1889 to 1892 1,353, 137 hectares among 1218 titles. From July I, I $89 \mathrm{r}$, to August I $8, \mathrm{r} 896,9,677,689$ hectares of land were surveyed, of which $6,504,9$ r 2 hectares belong to the government, and the balance, $3,172,777$ hectares, belong to private companies.

Every year the Department of Fomento publishes under authority of law a price-list of public lands, which have different prices in each state and are sometimes divided into three classes; the first, second, and third having each a different price. The following is the official price of public lands fixed by the Department of Fomento for the fiscal year $1895-1896$ :

\begin{tabular}{|c|c|c|c|}
\hline STATES & $\begin{array}{c}\text { PRICE } \\
\text { PER HECTARE }\end{array}$ & STATES & $\begin{array}{c}\text { PRICE } \\
\text { PER HECTARE }\end{array}$ \\
\hline Aguascalientes & $\$ 2.25$ & Oaxaca.. & \$1. Io \\
\hline Campeche... & I.80 & Puebla.... & 3.35 \\
\hline Coahuila .... & 1.00 & Queretaro..... & 3.35 \\
\hline Colima.. & 2.25 & San Luis Potosi. . & 2.25 \\
\hline Chiapas..... & 2.00 & Sinaloa ........... & I.10 \\
\hline Chihuahua..... & 1.00 & Sonora......... & 1.00 \\
\hline Durango ......... & 1.00 & Tabasco........ & 2.50 \\
\hline Guanajuato....... & 3.35 & Tamaulipas.... & 1.00 \\
\hline Guerrero......... & 1.10 & Tlaxcala..... & 2.25 \\
\hline Hidalgo....... & 2.25 & Veracruz..... & 2.75 \\
\hline Jalisco......... & 2.25 & Yucatan......... & 1.80 \\
\hline 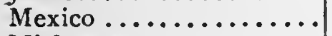 & 3.35 & Zacatecas.... & 2.25 \\
\hline Michoacan..$\ldots \ldots \ldots \ldots$ & 2.25 & District federal.. & 5.60 \\
\hline Morelos.... & 4.50 & Territore de Tepic. & 2.00 \\
\hline New Leon.......... & 1.00 & Territory of Lower Cal... & 0.65 \\
\hline
\end{tabular}

In the statistical part of this paper I shall insert some data about the sales of public lands by the Mexican government from r 867 to 1895 , and a statement of the titles issued from the years 1877 to 1895 .

\section{IMMIGRATION.}

It has always been the aim of the Mexican government from the time of the independence of the country, to encourage the immigration of foreigners, because Mexico being so large and the population so scanty, it was considered a necessity to promote the development of the country, to increase the population by inducing the settlement of foreigners, and different laws have been issued for that purpose.

Since the restoration of the Republic new laws have been sanctioned to encourage colonization, which allow colonists and the companies bringing them free importation of their personal goods and such articles 
as they may need for their subsistence and welfare for a reasonable term of years, exempting them at the same time from all kinds of taxesfederal, state, and municipal,- excepting only the stamp tax, and also exempting them from military and other personal service, and sometimes even going so far as to give a bounty for each colonist brought to the country. Under such laws several contracts were made with different companies, and 32 colonies have been planted in different sections of Mexico, of which 13 have been established by the government and 19 by private parties. In 1892 there were only 1266 families with a total number of 10,985 colonists. On the whole, the efforts made and the expenses incurred by the Mexican government in the establishment of those settlements of colonists, have had but unsatisfactory results, but they have paved the way for future experiments on a larger scale, especially if undertaken by private parties, and with only such assistance from the government as can be rendered by liberal legislation.

The principle obstacle which has prevented us from having a large immigration is our low wages. Those who immigrate are generally poor wage earners, who want to better their condition, and they could not go to a country where wages are a great deal lower than in the United States, or even in Europe, as they could never compete with the native labor of our Indians. We have now a surplus of labor and a deficit of capital, and cannot have a large immigration until such conditions are changed.

What Mexico needs is capital to develop her resources and give employment to labor, and then immigration will flow in as naturally as water seeks its level. Mexican credit will be established, so far as immigration is concerned, when her natural resources are developed, this being the only safe and reliable basis of such credit, and this will never be developed until those who have capital to invest are acquainted with the unparalleled opportunities for safe and profitable investment in Mexico. This will only be accomplished by plain, blunt, matter-offact and well-informed press agents, who lay before people who have money to invest the plain facts of the case.

Immigration from the United States. - I have often been asked for my opinion of the chances of Americans going to settle in Mexico, and have always answered that while Mexico is desirous of attracting good settlers, and while that country undoubtedly offers great inducements to foreign settlers, especially to those having some means, there are serious drawbacks which ought to be pointed out to the prospective immigrant from the United States, as a warning against a possible failure and disappointment.

The comforts of life in the rural districts of Mexico, where a settler from this country has the best chances, are scanty compared with simi- 
lar districts in the United States. The difference of race, language, religion, and education between a young man brought up in this country and the small Mexican farmers, are enough to create difficulties at first sight insuperable to any young man from the United States who settles there. If he establishes himself in a district inhabited only by Indians these difficulties are considerably increased. If the settler prefers the hot lands, which are the most fertile and productive, the severity of the climate is such as to challenge the courage of the bravest. The mosquitoes of several varieties, the flies, and many other insects are very annoying, besides the sickness inherent to such climate.

The question of labor is another great difficulty in the way, because, while it is cheap and abundant in the cold regions, it is generally scarce and unreliable in the hot lands.

The conditions of the two countries are so very different that the change experienced by one brought up in this country who goes into Mexico, is very apt to discourage the strongest and most sanguine, at least in the beginning, as the lapse of time makes anybody adapt himself to existing conditions and to appreciate the advantages of his new home.

The land question is also a serious objection. A large portion of the public lands have already been disposed of, and comparatively little of the public and private lands have been surveyed, and cannot easily be had in small lots. The large land-holders are unwilling to divide their estates, and the Indians holding large tracts of land are very reluctant to part with them at any price.

Coffee raising is undoubtedly one of the most profitable undertakings in Mexico, but at the same time it has serious drawbacks. It takes from three to four years before the trees begin to yield, and the planter must be provided with sufficient means to defray not only his personal expenses, but also those of the plantation, like houses, machinery, cultivation, etc., without receiving any proceeds until the third or fourth year. Besides, if he makes any mistake in the selection of his land, his profits will be considerably reduced. The general impression prevailing in Mexico is that coffee is the product of the hot lands, where the coffee trees need shade; but a plantation in such lands would cost a great deal more money to make and to keep, and would yield smaller profits than one located in the temperate zone, that is, just below the frost line.

1 The same views were expressed in Mexico to the State Department by the United States Consuls, and even published in the Consular Reports for August, I894, vol. xlv., No. 167, pp. 628,629 .

"Consular advices received at the Department of State warn Americans about emigrating to Mexico, with a view to permanent settlement, with insufficient means or without informing themselves in a reliable way as to the prospects for earning liveli- 
For the American common laborer who looks to his day's pay for his living, Mexico is unquestionably not the proper place to go. $\mathrm{He}$ cannot compete with the Mexican laborer, whose usual pay is from $3^{8}$ to 50 cents a day in silver, and he boards himself. For the man who has no means, unless he is especially qualified in some particular branch, and knows something of the language, and will work harder and longer hours, it is no place. There is room for the steady, sober, industrious mechanic or miner or tradesman who will adapt himself to new conditions and surroundings, leave all social, political, and other ambitions behind him, and who will attend strictly to his own business.

Those who are safest in going to Mexico are those who have a little capital, say from $\$ 2000$ in gold and upward, which will give them about twice that amount there; who can look around and decide what they propose to do, and where they want to settle. There is an excellent field for the small general farmer of the New England or Middle States type, who will raise a little of everything. Butter, potatoes, hogs, poultry, corn, vegetables, and small grain find a ready sale at good prices. I have seen the common article of corn, which is nearly always a sure crop, sell at from $\$$ I to $\$$ I.25 per bushel, Mexican money.

It is always best for the mechanic or miner to first secure a job before going to Mexico, and work for wages several months, and in the meantime study the situation, get acquainted with the language, the customs, and the people before going it alone.

The manner of living there and the customs of the people are totally different from those of the United States. Those going there will have to work harder and longer hours than in the United States, but they can save money. Ten years ago Americans went to Mexico to make money and return to the United States; to-day they go to find homes. I know several Americans who would not live in the United States again.

The climate of Mexico permits a man to work every day in the year. The cost of living and clothing is cheap, and a dollar in Mexican money can be made to go as far there as a dollar in American money in the United States, and a dollar there is easier to get.

In mining, Mexico offers inducements superior to any other coun-

hoods. While there are undoubtedly good opportunities in Mexico for enterprise, frugality, and thrift, it is like other countries, a land of varying conditions, and it often happens that disappointment is the result of emigration undertaken upon insufficient or misleading information, or without resources, which are always necessary for success in a new country. Many Americans have been induced by alluring statements as to the cheapness of coffee raising, etc., to emigrate to Mexico within the past year, and some have lost their all by so doing. For these reasons Consuls desire to caution Americans against the representations of speculators, who are always on the watch for the unwary." 
try; and whether a man has a thousand dollars or a million he can go there and make money if he exercises ordinary precaution and judgment, and if he makes up his mind to stand the discomforts of the country. It is a good country for the prospector, too, because there are no seasons against him, and there are many new fields entirely untouched; but he needs money enough to get there with and enable him to obtain the proper kind of outfit, and time to familiarize himself with the requirements of the law and select some district in which he wants to operate.

For the small capitalist, or for a small syndicate, there is no finer field for the organizing of small legitimate companies for the purposes of opening and working old abandoned mines, which are filled with débris or water, and which it will pay to clean out and work, and of which there are still many to be had. In times gone by they were abandoned because of the refractory condition of the ores, or lack of machinery, or want of transportation, all of which conditions have been removed. There is also a fine opening for capital for the exploration of the new gold-fields in the vicinity of Guadalupe y Calvo, in the range between Sonora and Chihuahua, in the State of Guerrero, and in many other localities.

There are in various parts of Mexico educated, experienced, and thoroughly reliable Americans to be found, who have lived a long while in the country, and know the language, the laws, and the people, and would be willing to give reliable information to young Americans wishing to go there.

\section{PUBLIC DEBT.}

The public debt of Mexico is represented by bonds drawing different rates of interest, some payable in gold and others in silver. In $\mathbf{1 8 2 5}$, very soon after our independence, we contracted two loans in London, both for $10,000,000$ pounds sterling, which we mainly used for buying war-ships and war material. On account of the disturbed condition of the country, the interest on that debt could not be paid punctually, and the bonds naturally fell to a very low nominal price. In I 85 I, after the war with the United States, we refunded that debt in new bonds, the interest of which was reduced from 5 to 3 per cent., which we expected to pay punctually, but the disturbed condition of the country made it impossible for us to do it. Finally, in 1888 , the debt was readjusted and gold bonds bearing 6 per cent. interest issued, and as we have paid since punctually the interest, they have reached par.

We had issued bonds from 1849 to $185^{6}$ to pay claims of English, French, and Spanish subjects under certain conventions signed with those countries, and such bonds were exchanged at different rates for the 6 per cent. gold bonds of our foreign debt. 
To build the Tehuantepec Railway we negotiated in London, in I888, another gold loan for $3,000,000$ pounds sterling at 5 per cent. interest.

The subsidies granted to railway companies were payable in silver, with a percentage of our import duties, but as they amounted to a considerable sum their payment reduced the revenue considerably, and the Mexican Government contracted in London in 1890 a gold loan at 6 per cent. interest, with which it paid the subsidies due up to that date to most of the railway companies.

We had to issue besides in $185^{\circ}$ what we call domestic or interior bonds, at 3 and 5 per cent. interest in silver, and we had other indebtedness of several kinds, caused by loans and other sources when the revenue of the Government was not enough to pay its expenses. All such debts have been consolidated into new bonds of 3 and 5 per cent. interest, payable in silver. Such railway subsidies as were not paid out of the proceeds of the loan of 1890 have been paid with bonds drawing 5 per cent. interest, paying both capital and interest in silver.

It is very onerous for Mexico when it is on a silver basis to pay in gold the interest of its foreign debt, because we have to buy gold at current prices, and it costs us now more than double its current price. When silver was about 50 cents on the dollar, as compared with gold, 6 per cent. interest of our foreign debt, cost us 12 per cent., and of course the further silver is depreciated the greater will be the cost of paying the interest of our gold debts.

President Diaz gives in his report of November 30,1896 , the following data about the cost to the Mexican Treasury of buying exchange to place in London the funds to pay us the gold interest on our foreign debt :

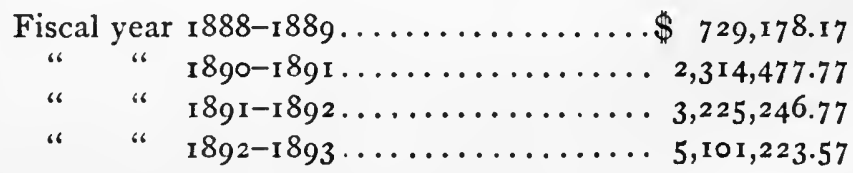

In the second part of this paper I will give a detailed statement showing the different kinds of bonds and obligations which constitute the Mexican debt, and here will only give the figures of the total amount, which are the following:

Sterling Mexican debt............\$1 4,675,895.49

Debt payable in silver........... 88,549,1 11.80

Total.................\$203,225,007.29

It is not possible to fix the exact amount of the debt of Mexico, either in silver or gold, because of the daily changes in the price of 
silver ; but as silver is the currency of the country, when the Mexican dollar is worth 24 pence in London, the amount of our debt in silver would be equal to our sterling debt, that is : $\$$ II $_{4}, 675,895.40$ added to our debt will make a grand total in Mexican silver of $\$ 317,900,902.78$.

BANKING.

Banking in Mexico is in its incipient state. The National Bank of Mexico, established in the City of Mexico in 1882 , with its branches in the principal cities of the country, has a monopoly for the issuing of notes in the capital which is only shared by such banks as were in existence before the National Bank of Mexico was chartered, like the Bank of London, Mexico, and South America, established during the French intervention in Mexico and recently remodelled under the name of the Bank of London and Mexico. The Mortgage Bank of Mexico enjoys that privilege also.

On June 3,1896 , a general banking law was issued by the Mexican Congress, which establishes the conditions under which banking institutions can be organized; but, of course, that does not affect the rights of the National Bank and other banks in the City of Mexico which had been chartered before the date of that law.

Formerly, owing to the expense and dangers of transportation, it was difficult to transport money from one place to another, and therefore exchange between cities in Mexico was very high, sometimes even ten per cent. from one city to another in the country. The rate has been reduced considerably since the railroads were built, but it is still quite high. To draw money from the City of Mexico to the City of Oaxaca, for instance, and vice versa, costs now one per cent. each way ; when money is required to be sent to smaller places the expenses are much higher, as it is necessary to send a man to the nearest town where the money can be placed by the banks, and pay to him a large commission-the expenses sometimes reaching ten per cent. To keep up this rate of exchange the National Bank makes its bills payable at a certain place so that they cannot be paid at any other.

Banking is very profitable in Mexico. The following is a statement of the earnings and dividends of the National Bank of Mexico, which began with a capital of $\$ 3,000,000$, increased since to $\$ 6,000,000$, having now a reserve fund of $\$ 5,500,000$, and is owned almost exclusively by Mexicans, being the fiscal agent of the Government :

\begin{tabular}{|c|c|c|}
\hline & NET PROFITS. & DIVIDENDS. \\
\hline 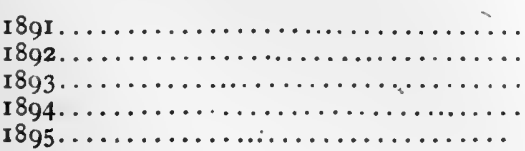 & $\begin{array}{r}\$ 1, \$ 13,623 \\
1,839,418 \\
2,355,464 \\
1,961,801 \\
2,200,626\end{array}$ & 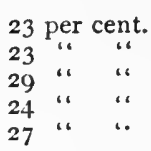 \\
\hline
\end{tabular}


The following is a statement, from official sources, of the earnings and dividends of the Bank of London and Mexico. Up to r89r it had a capital of $\$ 1,500,000$, which was then increased to $\$ 3,000,000$ :

\begin{tabular}{|c|c|c|c|}
\hline & NET PROFITS. & $\begin{array}{l}\text { DIVIDENDS EARNED, } \\
\text { PER CENT. }\end{array}$ & $\begin{array}{l}\text { DIVIDENDS DECLARED, } \\
\text { PER CENT. }\end{array}$ \\
\hline 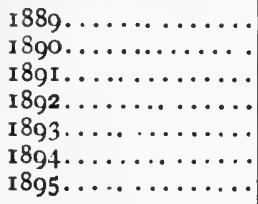 & $\begin{array}{r}\$ 243,246 \\
569,351 \\
703,522 \\
789,967 \\
618,653 \\
603,178 \\
557,710\end{array}$ & $\begin{array}{l}16 \\
36 \\
46 \\
26 \\
20 \frac{1}{2} \\
20 \\
18 \frac{1}{2}\end{array}$ & $\begin{array}{l}10 \\
20 \\
20 \\
16 \\
16 \\
14 \\
14\end{array}$ \\
\hline
\end{tabular}

Recently the capital stock of this bank was further increased to $\$ 10,000,000$, without any expense to the stockholders, as the reserve fund, which amounted to about $\$ 2,000,000$, was used to complete the new capital, and was issued to the regular stockholders as a stock dividend. The balance to complete the $\$ 5,000,000$ of new stock was offered to the public, the subscriptions amounting to $\$ 22,000,000$, or $\$ 17,000,000$ more than was wanted.

From this statement it will be seen that the existing banks are prosperous and in a flourishing condition, but the demand for increased banking facilities is such that new banks are being formed, and the operations of the old banks increased and extended in various directions.

\section{PATENTS AND TRADE-MARKS.}

Patents.-On June 7,1890 , the present patent law of Mexico was issued, and its provisions are very similar to the respective laws existing in this country.

Since the date of that law the following patents have been issued by our Department of Fomento :

\begin{tabular}{|c|c|c|c|}
\hline YEARS. & PATENTS. & 1NCREASE. & DIMINUTION. \\
\hline 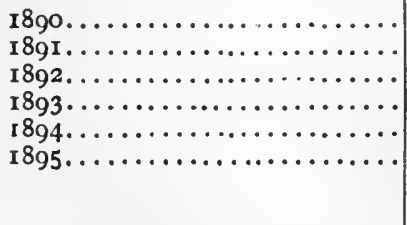 & $\begin{array}{r}63 \\
153 \\
168 \\
122 \\
125 \\
154 \\
785\end{array}$ & $\begin{array}{r}\cdots \\
90 \\
15 \\
\cdots \\
3 \\
29\end{array}$ & $\begin{array}{r}\cdots \cdots \\
\cdots \\
\cdots 6 \\
\cdots\end{array}$ \\
\hline
\end{tabular}

Trade-Marks.-On November $28, \mathrm{I} 889$, our present law regulating trade-marks was promulgated, and since then the following trademarks have been issued by the Department of Fomento : 


\begin{tabular}{|c|c|c|c|}
\hline YEARS. & TRADE-MARKS. & INCREASE. & DIMINUTION. \\
\hline 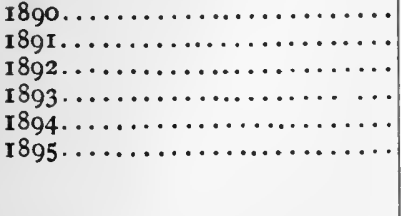 & $\begin{array}{r}97 \\
\text { I } 2 \\
\text { I6I } \\
108 \\
79 \\
91 \\
648\end{array}$ & $\begin{array}{r}\cdots \\
\text { I5 } \\
49 \\
\ldots \ldots \\
\cdots \\
\text { I2 }\end{array}$ & $\begin{array}{r}\cdots \\
\cdots \\
\cdots \\
\\
53 \\
29 \\
\cdots\end{array}$ \\
\hline
\end{tabular}

SHIPPING.

The mercantile marine of Mexico in 1895 comprised 52 steamers and 222 sailing vessels. The shipping included also many small vessels engaged in the coasting trade.

In $1893-94$, in the foreign trade, 1237 vessels of $1,314,625$ tons entered, and $121 \mathrm{I}$ vessels of $\mathrm{r}, 296,834$ tons cleared the ports of Mexico. In the coasting trade $772 \mathrm{r}$ of $\mathrm{r}, 623,37 \mathrm{r}$ tons entered and 7708 of $\mathbf{1}, 59^{2,754}$ tons cleared. In $\mathbf{x} 894-95$, in the foreign and coasting trade, there entered 9575 vessels of $3,428,973$ tons, and cleared 9557 of $3,359,684$ tons.

In the statistical portion of this chapter I will give official information about the number of vessels and their tonnage, which have entered and cleared from Mexican ports in recent years, the nations from which they came, and other valuable data.

MONEY, WEIGHTS, AND MEASURES.

The standard of value is silver. There is no paper currency except ordinary bank notes.

The silver peso or dollar of roo centavos is the unit of coin in Mexico.

The silver peso weighs 27.073 grammes, .902 fine, and thus contains 24.419 grammes of fine silver.

The ro-pesos gold-piece weighs 27.0643 grammes, .875 fine, and thus contains $23.68 \times 3$ grammes of fine gold.

The weights and measures of the metric system were introduced in I $85^{6}$; but the Indians and other ignorant people use the old Spanish measures. The principal ones are these :

Weight. - I libra $=0.46$ kilogramme, 1.014 lbs. avoirdupois.

I arroba $=25$ libras, 25.357 lbs. avoirdupois.

For Gold and Silver.-I marco $=\frac{1}{2}$ libra, 4,608 granos.

I ochava $=\epsilon_{2}$ tomines.

I tomin=12 granos.

20 granos $=1$ French gramme.

Length. - I vara-0.837 metre $=2 \mathrm{ft}$. $8 \frac{9}{10}$ English inches.

I legua comun ( $\mathrm{I}$ common league) $=5,000$ yards.

I legua marina (I marine league) $=6,666 \frac{2}{3}$ yards. 


\section{NON-OFFICIAL PUBLICATIONS.}

The following is a partial and rather incomplete list of (principally English) books about Mexico :

Аввотt, Gorham D., Mexico and the United States. New York, 1869.

Bancroft, H. H., A Popular History of the Mexican People. 8. London. Resources and Development of Mexico. San Francisco, 1894.

Brocklehurst, T. U., Mexico To-day. London, 1883.

BURKe, U. R., Life of Benito fuarez. 8. London, 1894.

Castro, Lorenzo, The Republic of Mexico in 1882. New York, 1882.

Charnay, D., Ancient Cities of the Nezw World. Tr. 8. London.

Chevalier, Michel, Le Mexique ancien et moderne. 18. Paris, 1886.

Conkling, Howard, Mexico and the Mexicans. New York, 1883.

Conkling, A. R. Appleton's Guide to Mexico. New York, 1890.

Crawford, Cora Hayward, The Land of the Montezumas. New York, I889.

Cubas, Antonio Garcia, Mexico, its Trade, Industries, and Resources. Mexico, I893.

Flint, H. M., Mexico under Maximilian. I2. Philadelphia, I867.

Gloner, Prosper, Les Finances des Etats Unis Mexicains. Bruxelles, 1895.

Gooch, F. C., Face to Face with the Mexicans. London, 1890.

Griffin, S. B., Mexico of To-day. New York, 1886.

Hamiton, Leonidas, Border States of Mexico. Chicago, 1882.

Hamilton, L. L. C., Hamilton's Mexican Handbook. London, 1884.

Janvier, Thomas A., The Mexican Guide. New York, 1886.

Kozhevar, E., Report on the Republic of Mexico. London, 1886.

la Bedolliere, Emile G. DE, Histoire de la guerre du Mexique. 4. Paris, 1866.

LeSTER, C. EDWARd, The Mexican Republic. New York, I878.

Noll, Arthur Howard, A Short History of Mexico. Chicago, I8go.

OBER, F. A., Travels in Mexico. Boston, U. S., 1884.

Prescott, W. H., History of the Conquest of Mexico. 8. London.

Ratzel, Fried., Aus Mexico, Reiseskizzen aus den Fahren 1874-75. Breslau, 1878 .

Rice, John N., Mexico, Our Neighbor. New York. (No date.)

Routrer, G., Le Mexique de nos fours. Paris, I895.

SCHROEDER, SEATON, The Fall of Maximilian's Empire as seen from a United States Gunboat. New York, 1887.

Scoвel, A., "Die Verkehrswege Mexicos und ihre wirtschaftliche Bedeutung."

In Deutsche Geographische Blätter. Band X, Heft I. Bremen, I887.

Through the Land of the Aztecs; or, Life and Travel in Mexico. By a "Gringo." London, 1892.

Wells, David A., A Study of Mexico. New York, 1887. 
PART II.

STATISTICS 



\section{STATISTICS.}

I do not know of any publication in which the latest statistical information about Mexico is compiled in a concise and complete form. One which perhaps is the fullest, published in Berlin by Messrs. Puttkammer \& Muhlbrecht, entitled Les Finances des Etats-Unis Mexicains, written by Mr. Prosper Gloner, contains a great deal more statistical information than others, and is of later date.

It has required a great deal of work, energy, and time on my part to collect the data contained in this paper, most of which is of an official character, and I am sure it is the most complete ever published, I having tried to make it very concise, so as to take the smallest space possible.

\section{REVENUES AND EXPENSES.}

The financial question was for many years the leading and the most difficult one in Mexico, because the urgent needs of the Treasury, especially on account of the disturbed condition of the country, made public expenses considerably exceed the revenue, and this condition did not allow of a thorough overhauling and settlement of the finances, nor did it contribute to establish the credit of the Government; but peace having prevailed since 1877 , a great improvement has taken place in the financial condition of Mexico; the revenue has increased considerably, and it has finally reached an amount amply sufficient to pay all our expenses. In fact, at the end of the fiscal year, ended June 30,1896 , we had for the first time in the history of Mexico since its independence, a surplus which amounted to $\$ 6,000,000$. The obnoxious tax which we inherited from the Spanish, called alcabalas, or interstate duties on domestic and foreign commerce, was a great drawback to internal trade, was finally abolished on July I, 1896 ; and the country being now in a condition when radical reforms can be introduced without serious disturbances.

Our expenses as an independent nation are necessarily large, and as a comparatively small portion of our population are really producers 
of wealth, upon them lies the whole burden of such expenses; that is, we are a nation of from twelve to fifteen millions of inhabitants, with a very large territory and a large coast on both oceans, requiring army, revenue, light-house, and police service, and other expensive institutions proportionate to such extent and population, when the portion which contribute to such expenses is only about one-fourth or one-third of the same.

It is a very difficult task to give a complete and correct statement of the revenues and expenses of the Mexican Government prior to the year 1867. The disturbed condition of the country made it often quite impossible to keep any account at all : such was the case especially from $185^{8}$ to 1860 , as during that period the City of Mexico and a large part of the country was occupied by the Church party under Miramon, and from 1863 to 1867 by the French Intervention. Besides that cause it was a very difficult matter for us to keep a correct account of public receipts and expenses, in some way for lack of a good system of book-keeping. To make a statement of the revenues and expenses of the Mexican Government since the independence of the country from Spain, I had to rely upon the reports made by Secretaries of the Treasury, which are, however, lacking for many years, and which contain rather an estimate than an account of the revenues and expenses, and I have made in that way the statement which I append under No. I, which embraces the revenues and expenses from the year 1808, the last of the Spanish rule in Mexico, to the year 1867 .

The forming of accounts was under the charge of the Federal Treasury of Mexico, and the Treasury kept its accounts with a very defective system of book-keeping, which prevented them from being correct. To remedy that difficulty, after the restoration of the Republic in 1867 , a bureau of accounts was established in the Treasury Department, but its accounts were seldom correct, because it did not have the necessary detailed data to make a complete account, and, as could be expected, the results in the accounts of both bureaus differ widely.

In 1880 the Federal Treasury was reorganized with a large number of clerks with a view to keep a full and correct account of public moneys, and from that year until $\mathbf{r} 888$ their accounts began to be better than before. In $\mathrm{r} 888$ the system was still remodelled and improved, and since then that office has been able to keep correct and complete accounts of our public revenues and expenses.

I also append a statement No. 2 of the revenues and expenses of the Mexican Treasury from July I, 1867 , to June 30,1888 . The first thirteen years in that statement are taken from the data furnished by the Bureau of Accounts of our Treasury Department. The account of the year $1879^{-1880}$ was taken from the account of the Federal 
Treasury, and the data for the year $1880-188 \mathrm{I}$ from the accounts published by the Liquidating Bureau established by the Mexican Government to close the old accounts and open the new ones under the new system. The accounts of the year $1888-1889$, which appear in statement No. 3, are all taken from the Federal Treasury of Mexico, and are complete and correct.

I also append a statement of the appropriations approved by the Federal Congress during the fiscal years from I 868 to 1895 . The actual expenses never exceeded the appropriations and the revenue was generally below them.

NO. I.-REVENUE AND EXPENSES OF THE FEDERAL GOVERNMENT OF MEXICO IN 1808 AND FROM I822 TO JUNE 30, 1867.

\begin{tabular}{|c|c|c|}
\hline & REVENUE. & EXPENSES. \\
\hline 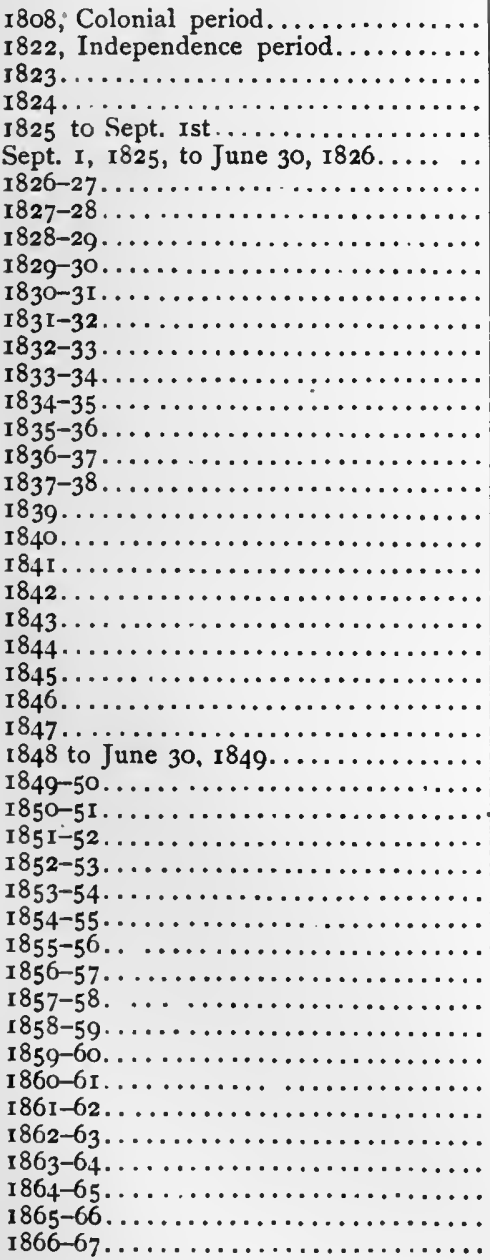 & $\begin{array}{rr}\$ 20,075,362 & 25 \\
9,328,740 & 00 \\
5,249,858 & 96 \\
15,254,601 & 03 \\
7,903,163 & 42 \\
14,770,733 & 30 \\
17,017,016 & 59 \\
13,644,974 & 69 \\
14,593,307 & 69 \\
14,103,773 & 28 \\
18,392,134 & 96 \\
17,582,929 & 15 \\
20,563,360 & 77 \\
21,124,216 & 81 \\
18,353,283 & 00 \\
26,382,303 & 90 \\
17,327,706 & 15 \\
25,018,121 & 77 \\
29,136,536 & 64 \\
21,227,263 & 43 \\
23,995,766 & 52 \\
30,682,369 & 40 \\
14,138,581 & 72 \\
15,86\end{array}$ & 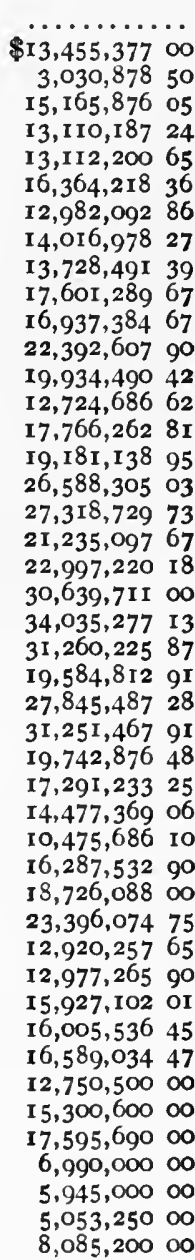 \\
\hline
\end{tabular}




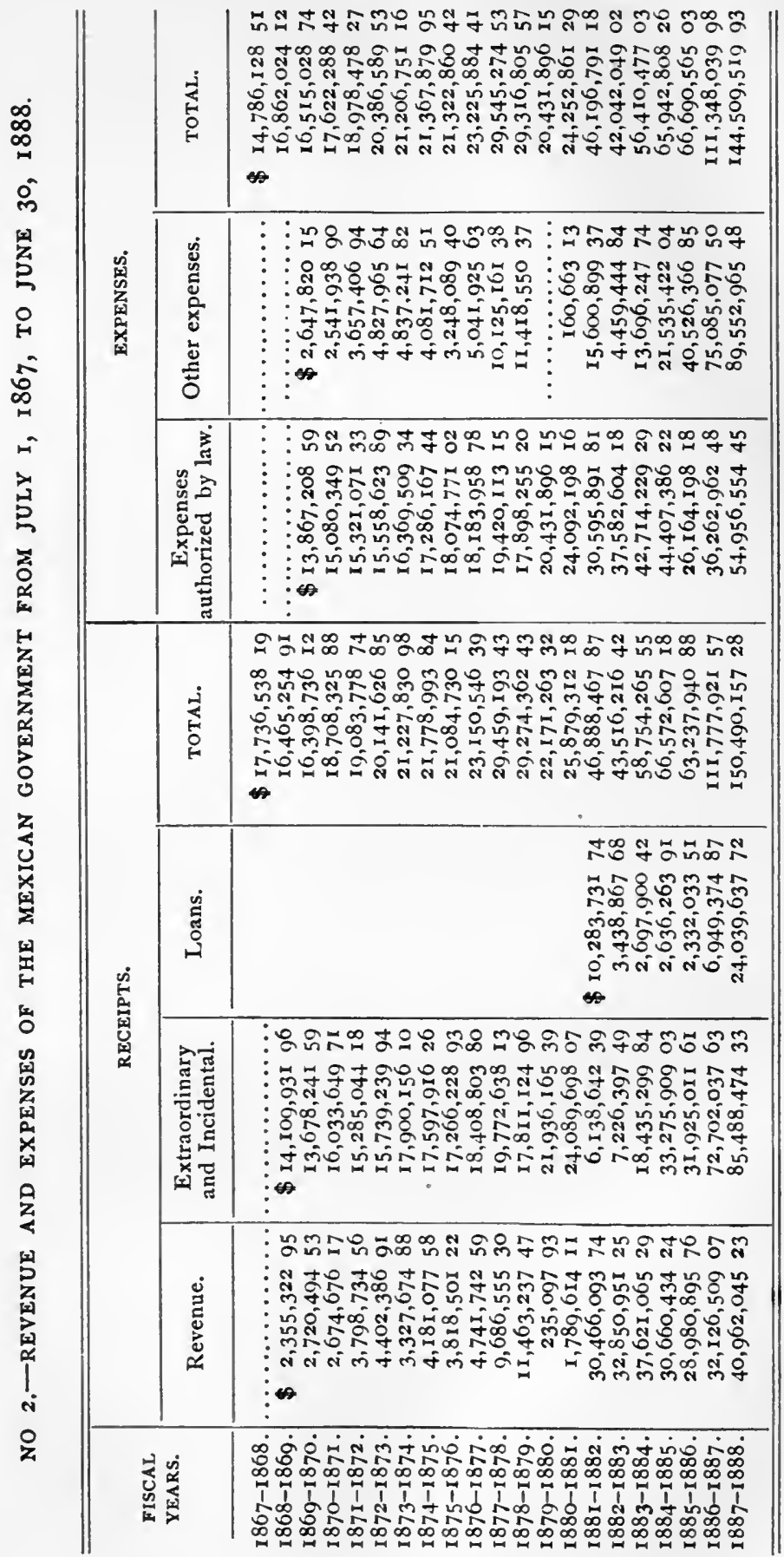




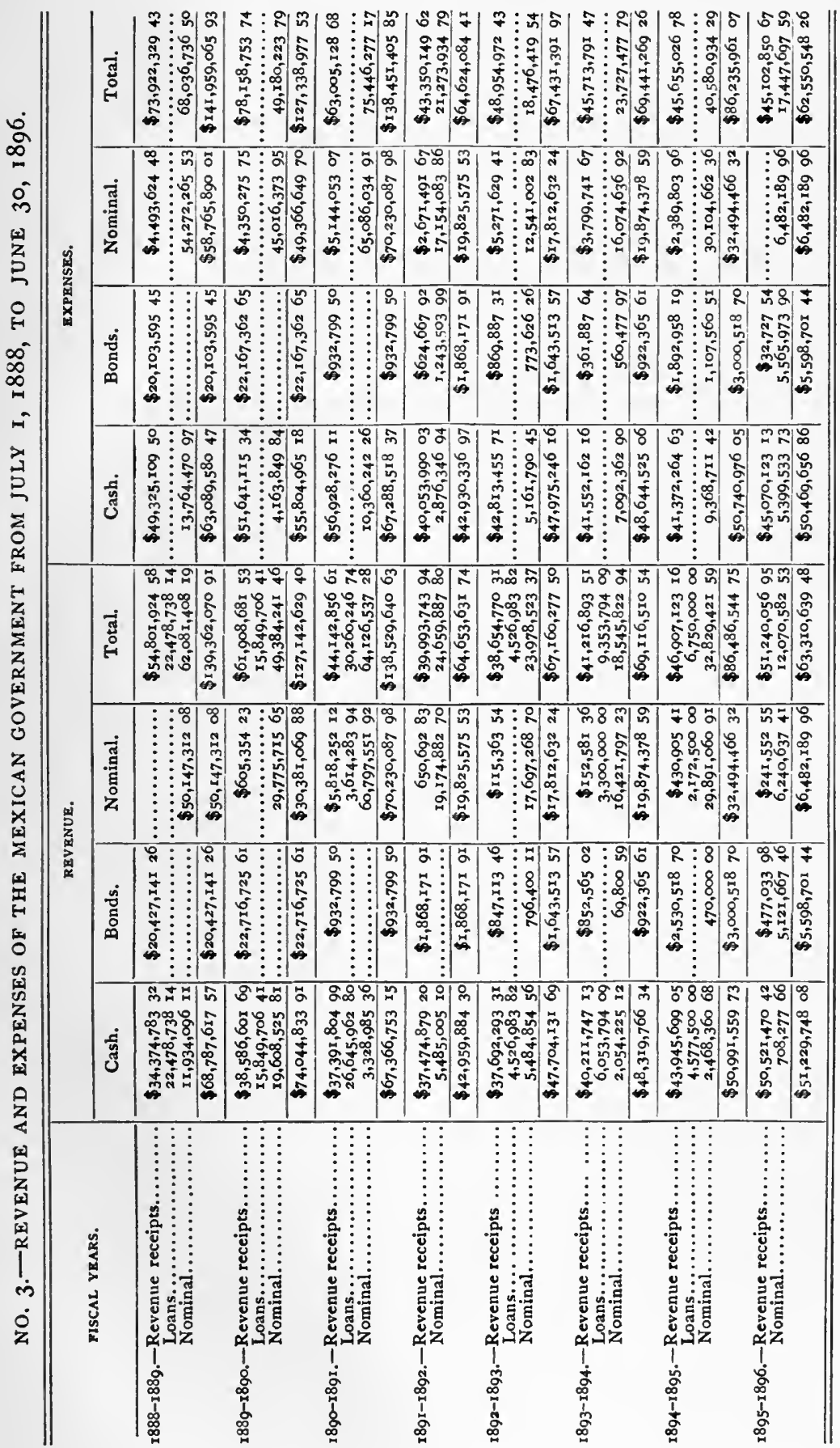




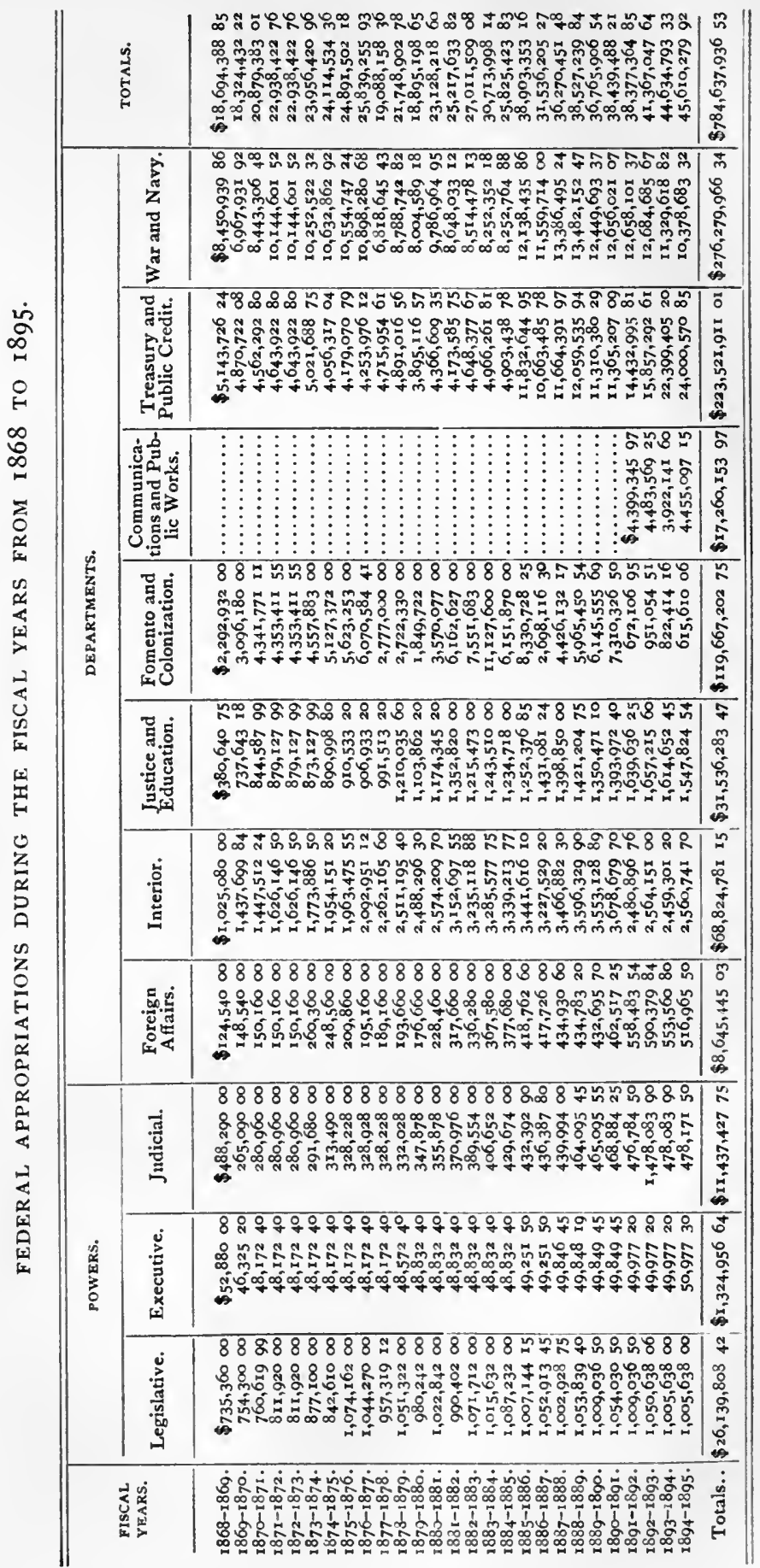


Sources of Revenue.-The Federal revenue of Mexico consists mainly of three sources : import duties, internal revenue, and direct taxes in the Federal District. Under the head of import duties we collect duties on imports, extra import duties which we call additional duties, and duties on exports.

The sources of revenue of the Mexican Federal Treasury during

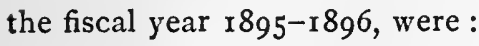

Imposts on foreign trade.......... $\$ 23,658,692$ 6x

Internal revenue............... 20,447,096 42

Direct taxes in the Federal District and

Territories............... 3,357,611 81

Public services.................. $1,81 \mathrm{I}, 045 \quad 30$

Nominal ................... I,955,30 I 94

Total................. $\overline{\$ 51,229,748 \circ 8}$

Import Duties.-Our tariff is a highly protective one, as we have always maintained a very high rate of import duties, almost prohibitory for a large portion of our population, which under such a system are practically excluded from the use of foreign commodities, to the material detriment of the fiscal revenue, the public wealth at large, and the advancement of the masses of our people. The causes which have induced such a high tariff are twofold : first, that, in a great measure, protective ideas have prevailed; secondly, and especially, the need of revenue, and the idea that the higher the rate of duties the larger would be the revenue collected. A new source of protection has been created by the depreciation of our currency, which acts as a powerful protection to our home commodities, in favor of our manufacturers to the disadvantage of the great body of consumers.

The protective policy in Mexico has been so deeply rooted that notwithstanding that I lean to freer trade, and that I have been three times at the head of the Treasury Department, and once for five years, I never was able to modify substantially that policy, because the condition of the Treasury was so precarious, that it would have been very rash to attempt any radical change on the face of a great reduction of an insufficient revenue which would have brought about disastrous results. For the same reason I was unable to do away with the obnoxious alcabala tax.

Our present tariff is divided into the following sections : ist, animal industry ; 2d, agricultural products ; $3 \mathrm{~d}$, metals and its manufactures ;

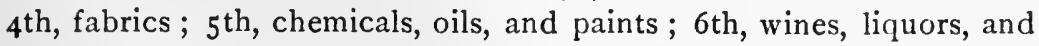
fermented drinks ; 7 th, paper ; 8th, machinery ; 9 th, carriages ; roth, arms and explosives, and $\mathrm{r}$ th, sundries. 
Additional Import Duties. - The additional duties collected by the Custom-houses are $\mathrm{I} \frac{1}{2}$ per cent. of the amount of the import duties, which is levied for the respective municipality; 2 per cent. of the same duties, for harbor improvements; and 2 per cent. in revenue stamps, making in all $5 \frac{1}{2}$ per cent. of the import duties. The custom-houses collect besides the import duties, tonnage and light-house duties, and pilot fees.

Export Duty.-Our export duties are levied upon cabinet and dyewoods, india rubber, cochineal, coffee, henequen, ixtle, indigo, fequila, jalap, tamarind, tobacco, mother-of-pearl, orchilla, vanilla, zacaton, and onyx.

The following statement shows the amount of export duties collected in Mexico from the fiscal year $188 \mathrm{I}-1882$ to $\mathrm{r} 894-\mathrm{r} 895$, expressing the commodities in which they were collected:

STATEMENT OF THE RECEIPTS FROM EXPORT DUTIES IN MEXICO FROM JULY I, I88I, TO JUNE 30, I 895 .

\begin{tabular}{|c|c|c|}
\hline FISCAL YEAR. & RECEIPTS. & COMMODITIES TAXED. \\
\hline 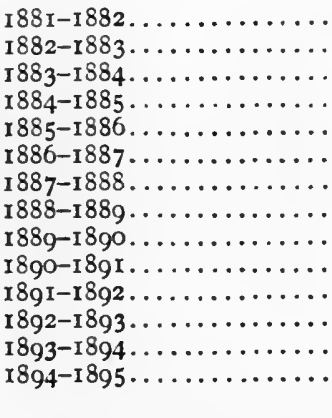 & 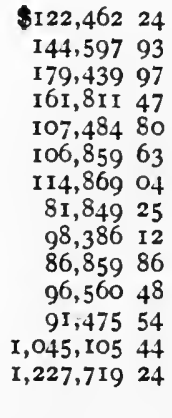 & 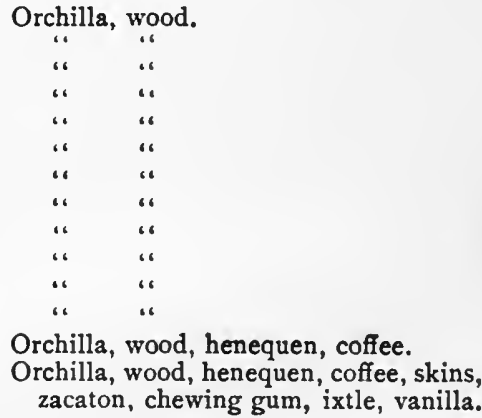 \\
\hline
\end{tabular}

Amount of Import Duties.-It is very difficult to give a correct statement of the receipts of the Mexican custom-houses before the year 1875. I append, however, one made from the reports of the Secretaries of the Treasury of Mexico, especially those of July 25, 1839, and September 16,1870 , and completed from the years $1839-1851$, with data obtained from the Comercio exterior de Mexico,by D. Miguel Lerdo de Tejada. From the fiscal year $1875-1876$, the Statistical Bureau of our Treasury Department began to publish detailed and correct statements of the custom receipts, and I append one embracing the fiscal years from 1875 to 1896 which shows how largely our import duties have increased. In the ten years elapsed from 1878 to I 888 the increase was over 67 per cent. as compared with the corre- 
sponding period from $1869-1879$, and the increase in the last seven years, $1889-1896$, was 16 per cent. as compared with the previous ten years, both periods making an increase of nearly roo per cent. over the first ten years of said statement :

\section{CUSTOMS RECEIPTS FROM I 823 TO THE FISCAL YEAR ENDING} JUNE 20, 1875 .

1823. From April ist to September 30 the receipts were $\$ 97$ I,345 77, which for a year of 12 months would be.

$\$ 1,942,691 \quad 54$

1825. From the Ist of January to the Ist of August, 1825 , the receipts were $\$ 4,472,06937$, which for a year of 12 months would be............. 1825-1826 From the Ist of September, I825, to June, $1826, \$ 6,414,38326$, which for a year of 12

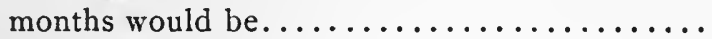

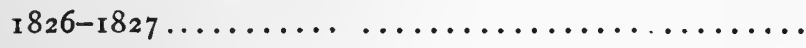
$1827-1828$ $1828-1829$ $1829-1830$ $1830-183 \mathrm{I}$ $1831-1832$ $1832-1833$ $1833^{-1} 834$ $1834-1835$ $1835-1836$ I $836-1837$ $7,666,40463$

From July I, I 837 , to December 3 I, I $838, \$ 4,258,4$ I I ro. Corresponding to one year of 12 months....... 1839 1840 $184 \mathrm{I}$ 1842 1843 I 844 1845 1846 1847 .

From January 1,1848 , to June $30,1849,18$ months...

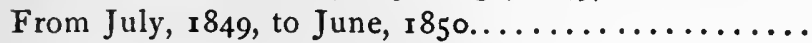
$1850-1851$

From July 1, 1851, to June $30,1852 \ldots \ldots \ldots \ldots$. I852-1853, according to the calculations of M. Haro $y$

Tamariz average from the preceding five years.

$9,621,57489$ $7,828,20844$ $5,692,02670$ $6,497,28893$ 4,8 I 5,4 I $8 \quad 25$ $8,287,08292$ $7,335,637 \quad 76$ $7,538,525 \quad 47$ $8,786,39694$ $8,920,408 \quad 28$ $5,835,068 \quad 5 \mathrm{I}$ $4,377,579 \quad 5^{2}$

$2,83^{8}, 940 \quad 73$ $5,577,890 \quad 67$ $8,309,91865$ $6,597,91232$ $6,034,34^{2} 29$ $8,507,47879$ $8,254,14196$ $5,814,048 \quad 69$ $6,747,93235$ $1,394,60952$ $6,660,0379^{6}$ $6,33^{8}, 437 \quad 50$ 5,337,068 62 $6,108,835 \quad 26$

$4,906,533 \quad 17$ 
$1853-1854$, according to the report of $M$. Olazagarre

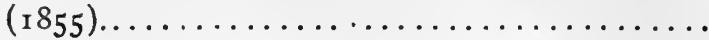

$1854-1855$, according to the report of $M$. Lerdo de Tejada $(1857) \ldots \ldots \ldots \ldots \ldots \ldots \ldots \ldots$ $1855^{-1856}$, according to the report makes the receipts for the first six months amount to $\$ 3,379,76$ I 35 , which for the year is.................. $6,759,52270$ $1856-1857$, average for the six years previous...... 6,854,06 I 78 $1857-1858$ $185^{8-1} 859$ $1859-1860$ $1860-1861$ $186 \mathrm{I}-\mathrm{I} 86 \mathrm{2}$ 1 $862-1863$ $1863-1864$ I $864-1865$ 1 $865-1866$ I $866-1867$ r $867-1868$, according to the amount of the receipts.... 1 $868-1869$ $\begin{array}{ll}66 & 66 \\ 66 & 66 \\ 66 & 66 \\ 66 & 66 \\ 66 & 66 \\ 66 & 66 \\ 66 & 66 \\ 66 & 66 \\ 66 & 66 \\ 66 & 66\end{array}$ $6,854,06178$ $6,854,06178$ $6,854,06$ I 78 $6,854,06178$ $6,854,06$ I 78 $6,854,06178$ $6,854,06 \mathbf{I} 78$ $6,854,06$ I 78 $6,851,06178$ $6,851,06178$ .

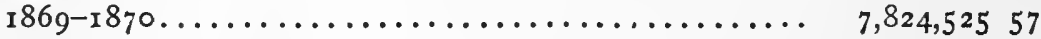

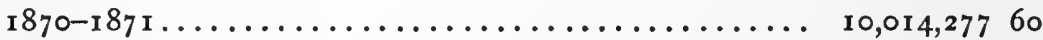

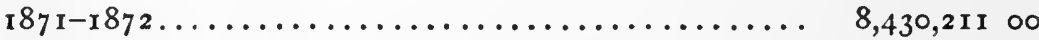
$1872-1873 \ldots \ldots \ldots \ldots \ldots \ldots \ldots \ldots \ldots \ldots \ldots \ldots \ldots \ldots \ldots \ldots \ldots \ldots \ldots \ldots, 1,833,117 \quad 5^{2}$

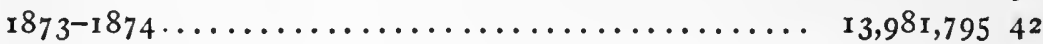

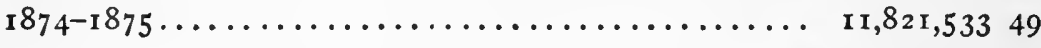

Total....................... \$367,725,836 or Average in one year...............\$7,071,650 69

Internal Revenue.-The Federal Treasury of Mexico depended up to I 867 mainly upon import duties, and as it was not safe to have only that source of revenue, when I occupied for the first time the Treasury Department, I introduced a system of internal revenue through the use of stamps, which met with a great deal of opposition at the time, but which has finally been developed very largely, yielding now almost as much as the import duties. The receipts during the six months from January Ist to June $30 t h$, 1875 , amounted to $\$ 1,097,-$ 66828 , which in a whole year would make, duplicating it, $\$ 2,195$, $33^{6} 56$, while in the fiscal year ended June 30 , 1896 , the receipts amounted to $\$ 18,078,95^{2} 54$, or nearly eight times as much.

We have had since r86 a comparative large source of revenue called Federal Tax, which up to 1892 was 25 per cent. of all the revenues collected by the States and Municipalities in Mexico. That rate 


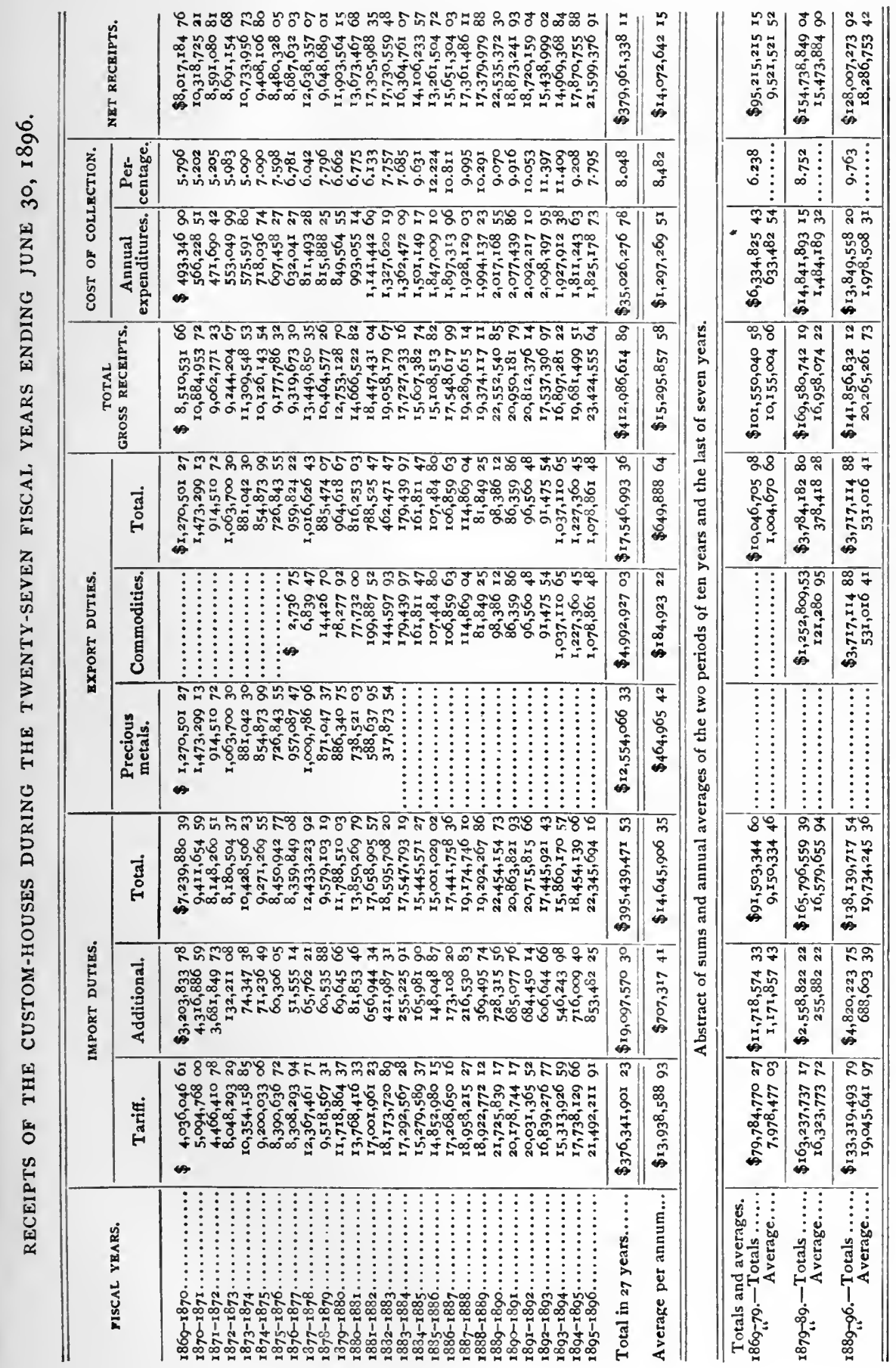


was increased in 1893 from 25 to $33 \frac{1}{3}$ per cent. on account of the deficit caused to the Federal Treasury by the depreciation of silver, and that tax which is paid in Federal stamps, constitutes a very large portion of our internal revenue receipts.

I append a statement of our internal revenue taxes with full details. INTERNAL REVENUE RECEIPTS FROM JANUARY I, I875, TO JUNE 30 , $\mathbf{x} 896$.

\begin{tabular}{|c|c|c|c|c|c|c|}
\hline FISCAL YEARS. & $\begin{array}{c}\text { GROSS } \\
\text { RECEIPTS. }\end{array}$ & $\begin{array}{l}\text { GROSS RE- } \\
\text { CEIPTS OF THE } \\
\text { FEDERAL TAX. }\end{array}$ & $\begin{array}{l}\text { TOTAL } \\
\text { RECEIPTS. }\end{array}$ & \multicolumn{2}{|c|}{$\begin{array}{l}\text { COLLECTION } \\
\text { EXPENSES. }\end{array}$} & \multirow[t]{2}{*}{$\begin{array}{c}\text { NET } \\
\text { RECEIPTS. }\end{array}$} \\
\hline $\begin{array}{l}\text { From Janu } \\
\text { June } 3 \circ,\end{array}$ & $\$ 328,63126$ & $\$ 769,03702$ & $\$ 1,097,668 \quad 28$ & & $\begin{array}{c}\text { Per- } \\
\text { centage. }\end{array}$ & \\
\hline 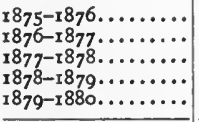 & 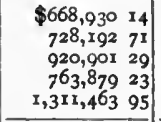 & 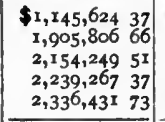 & 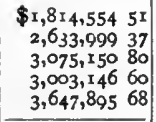 & 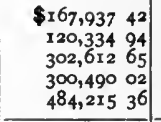 & $\begin{array}{r}9.255 \\
4.567 \\
9.840 \\
10.006 \\
13.274 \\
\end{array}$ & $\begin{array}{r}\$ 2,247,61709 \\
2,513,66443 \\
2,772,538 \\
2,702,656 \\
3,15 \\
3,164,88032 \\
\end{array}$ \\
\hline $\begin{array}{l}\text { verage per an- } \\
\text { um in five years }\end{array}$ & $\$ 878,673,46$ & $\$ 1,956,27593$ & $\$ 2,834,94939$ & $\$ 275$, I I 8 ०8 & 9.705 & $\$ 2,680,1^{1} 3^{1}$ \\
\hline $\begin{array}{l}1880-1881 \ldots \ldots \ldots \\
1881-1882 \ldots \ldots \ldots \cdots \\
1882-1883 \ldots \ldots \cdots \\
1883-1884 \ldots \ldots \ldots \\
1884-1885 \ldots \ldots \cdots\end{array}$ & 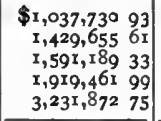 & 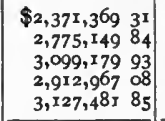 & 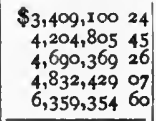 & \begin{tabular}{r|r}
$\$ 351,980$ & 01 \\
376,095 & 30 \\
420,132 & 04 \\
441,080 & 10 \\
489,043 & 89
\end{tabular} & & $\begin{array}{rl}\$ 3,057,120 & 23 \\
3,829,710 & 15 \\
4,270,237 & 22 \\
4,391,348 & 87 \\
5,870,310 & 71\end{array}$ \\
\hline & $\$ 1,84 I, 982 \quad 12$ & $\$ 2,857,22960$ & $\$ 4,699,21172$ & $\$ 415,666 \quad 27$ & 8.845 & $\$ 4,283,545 \quad 44$ \\
\hline $\begin{array}{l}1885-1886 \ldots \ldots \ldots \\
1886-1887 \ldots \ldots \ldots \ldots \\
1887-1888 \ldots \ldots \ldots \ldots \\
1888-1889 \ldots \ldots \ldots \ldots \\
1889-1890 \ldots \ldots \ldots \\
\end{array}$ & $\begin{array}{rr}\$ 2,761,886 & 56 \\
3,930,429 & 16 \\
4,654,190 & 93 \\
5,108,911 & 59 \\
5,575,067 & 62 \\
\end{array}$ & 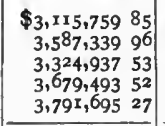 & \begin{tabular}{r|r|}
$\$ 5,877,646$ & $4 \mathrm{x}$ \\
$7,517,769$ & 12 \\
$7,979,128$ & 46 \\
$8,788,405$ & $1 \mathrm{r}$ \\
$9,366,762$ & 89 \\
\end{tabular} & 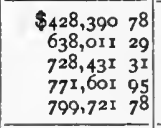 & $\begin{array}{l}7.288 \\
8.486 \\
9.000 \\
8.777 \\
8.538 \\
\end{array}$ & 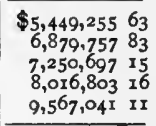 \\
\hline an- & $\$ 4,406,097 \quad 17$ & $\$ 3,499,845 \quad 23$ & $\$ 7,905,94240$ & $\$ 673,23742$ & $8.5^{16}$ & $\$ 7,43^{2}, 7$ 10 98 \\
\hline $\begin{array}{l}1890-1891 . . \\
1891-1892 . . \\
1892-1893 . . \\
1893-1894 \ldots \\
1894-1895 . . \\
1895-1896 . . \\
\end{array}$ & $\begin{array}{rr}\$ 5,624,340 & 94 \\
5,402,495 & 76 \\
6,625,265 & 53 \\
9,164,063 & 10 \\
10,098,795 & 63 \\
12,5 \times 9,676 & 93 \\
\end{array}$ & 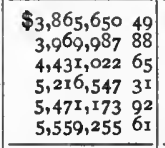 & $\begin{array}{rr}\$ 9,489,991 & 43 \\
9,372,483 & 64 \\
11,056,288 & 18 \\
14,380,610 & 41 \\
15,569,969 & 55 \\
18,078,932 & 54 \\
\end{array}$ & 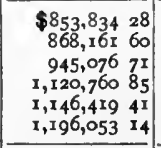 & $\begin{array}{l}8.955 \\
9.263 \\
8.548 \\
7.190 \\
7.363 \\
6.616 \\
\end{array}$ & 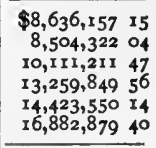 \\
\hline $\begin{array}{c}\text { Average in } s i x \\
\text { years ........... }\end{array}$ & $\$ 8,239,106 \quad 3 \mathrm{I}$ & $\$ 4,752,272,98$ & $\$ 12,991,37929$ & $\$ x, 02 x, 717 \quad 67$ & 7.865 & $\$ 11,969,66163$ \\
\hline otal in $2 x \frac{1}{3}$ years. & $\$ 85,397,03294$ & $\$ 70,849,42866$ & $\$ 156,246,4$ & $|\$ 12,950,38483|$ & 8.288 & $\$ 143,799,90839$ \\
\hline
\end{tabular}

Direct Taxes.-The third source of revenue of the Mexican Government are direct taxes collected in the Federal District, which includes the City of Mexico. They are levied on real-estate, scientific professions, commercial and industrial establishments, and work-shops. The real-estate for the purpose of this tax is divided into rural and urban, the former paying a tax of 2 per cent. on its rent when occupied, and 3 per cent. when not occupied, and the latter paying 8 per thousand of its registered value.

Taxes on professions vary from 50 cents to $\$ 20.00$ a month. The tax on commercial and industrial establishments is regulated by law. The commercial establishments, which pay license taxes are commis- 
sion agencies of all kinds : banking firms ; dry goods, groceries, wines, furniture, and jewelry stores ; insurance companies ; restaurants, hotels, and boarding-houses. Among the industrial establishments are embraced especially railway, telegraph and telephone companies ; cotton, woollen, and silk mills ; factories of all kinds ; iron smelters ; printing, engraving, and photographic establishments; coffee, corn, and flour mills, etc., etc.

When the alcabalas were abolished a direct tax was established upon some of the articles which paid the largest sums, namely: pulque, wheat flour, and domestic brandy distilled from molasses.

I annex a statement showing the proceeds of Direct Taxes in the Federal District during the last twenty-seven fiscal years.

RECEIPTS FROM DIRECT TAXES IN THE FEDERAL DISTRICT DURING THE TWENTY-SEVEN FISCAL YEARS ENDING JUNE $30,1896$.

\begin{tabular}{|c|c|c|c|c|}
\hline FISCAL YEARS. & GROSS RECEIPTS. & $\begin{array}{l}\text { COLLFCTION } \\
\text { EXPENSES. }\end{array}$ & $\begin{array}{l}\text { PER- } \\
\text { CENTAGE } \\
\text { FXPENSES. }\end{array}$ & NET RECEIPTS. \\
\hline 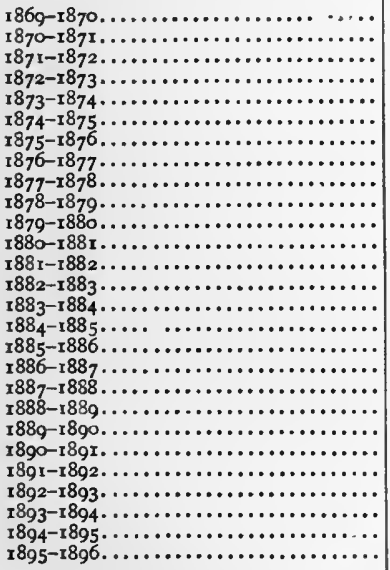 & $\begin{array}{rr}\$ 485,451 & 73 \\
502,146 & 64 \\
471,228 & 78 \\
477,654 & 75 \\
524,494 & 76 \\
531,149 & 09 \\
1,350,705 & 56 \\
516,510 & 80 \\
538,300 & 09 \\
559,217 & 21 \\
592,688 & 44 \\
634,498 & 92 \\
674,973 & 66 \\
753,579 & 80 \\
830,010 & 26 \\
1,092,656 & 37 \\
1,023,349 & 52 \\
1,040,143 & 16 \\
1,074,489 & 54 \\
1,125,202 & 97 \\
1,213,458 & 49 \\
1,306,746 & 37 \\
1,369,225 & 30 \\
1,436,875 & 70 \\
1,445,270 & 81 \\
1,497,251 & 90 \\
1,620,480 & 35\end{array}$ & $\begin{array}{rl}\$ 55,481 & 65 \\
53,924 & 28 \\
50,034 & 37 \\
51,939 & 05 \\
57,205 & 69 \\
56,663 & 64 \\
69,957 & 24 \\
47,685 & 23 \\
37,970 & 00 \\
51,160 & 08 \\
52,126 & 21 \\
52,260 & 50 \\
53,161 & 23 \\
98,264 & 24 \\
100,937 & 90 \\
89,892 & 38 \\
91,464 & 07 \\
84,861 & 27 \\
121,011 & 50 \\
97,635 & 14 \\
100,134 & 87 \\
103,740 & 02 \\
104,320 & 34 \\
115,817 & 86 \\
110,290 & 73 \\
108,255 & 57 \\
110,347 & 13\end{array}$ & $\begin{array}{r}11.42 \\
10.74 \\
10.62 \\
9.90 \\
10.90 \\
10.67 \\
5.18 \\
9.23 \\
7.05 \\
9.15 \\
8.79 \\
8.23 \\
7.87 \\
13.08 \\
12.16 \\
8.23 \\
8.97 \\
8.16 \\
11.26 \\
8.68 \\
8.25 \\
7.35 \\
7.62 \\
8.06 \\
7.63 \\
7.36 \\
6.81\end{array}$ & 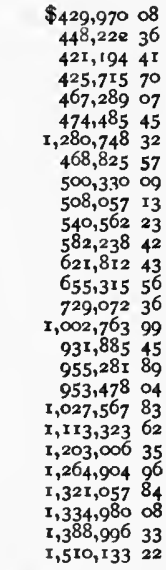 \\
\hline $\begin{array}{l}\text { Totals in the } 27 \text { years............... } \\
\text { Average per annum.............. }\end{array}$ & $\begin{array}{r}\$ 24,687,760 \\
912,028 \text { r } 8\end{array}$ & $\begin{array}{r}\$ 2,126,542 \text { 19 } \\
78,76082\end{array}$ & $\mathrm{~B}_{\mathrm{6}} \mathrm{6}_{5}$ & $\begin{array}{r}\$ 22,561,218 \\
835,60069\end{array}$ \\
\hline 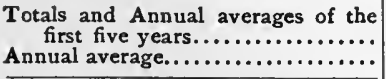 & $\begin{array}{r}\$ 2,460,97666 \\
49^{2}, 19533\end{array}$ & $\begin{array}{r}\$ 268,5^{8} 5 \text { O4 } \\
53,7^{1} 7 \text { or }\end{array}$ & 11.14 & $\begin{array}{rl}\$ 2,192,391 & 62 \\
438,478 & 32\end{array}$ \\
\hline $\begin{array}{l}\text { Total of the second five years....... } \\
\text { Annual average.................. }\end{array}$ & $\begin{array}{r}\$ 3,495,882 \\
699,176 \\
55\end{array}$ & $\begin{array}{r}\$ 263,436 \text { I9 } \\
52,687\end{array}$ & $7 \cdot 54$ & $\begin{array}{r}\$ 3,232,44656 \\
646,4^{89} 3^{1}\end{array}$ \\
\hline $\begin{array}{l}\text { Total of the third five years } \ldots \ldots \ldots \\
\text { Annual average } \ldots \ldots \ldots \ldots \ldots \ldots \ldots\end{array}$ & $\begin{array}{r}\$ 3,485,751 \\
684,550 \\
38\end{array}$ & $\begin{array}{r}\$ 356,750 \text { o8 } \\
71,350 \text { o2 }\end{array}$ & ro.42 & $\begin{array}{r}\$ 3,129,00100 \\
625,80020\end{array}$ \\
\hline $\begin{array}{l}\text { Total of the fourth five years....... } \\
\text { Annual average................. }\end{array}$ & $\begin{array}{r}5,355,841 \\
1,071,168 \\
31\end{array}$ & $\begin{array}{r}\$ 484,86436 \\
96,97287\end{array}$ & $\begin{array}{c}\cdots \cdots \cdots \\
9.05\end{array}$ & $\begin{array}{r}\$ 4,870,97720 \\
974, \text { r95 } 44\end{array}$ \\
\hline $\begin{array}{l}\text { Total of the fifth period of five years } \\
\text { Annual average.................. }\end{array}$ & $\begin{array}{r}\$ 6,771,57667 \\
1,354,3 \mathbf{1} 533\end{array}$ & $\begin{array}{r}\$ 534,30382 \\
106,86076\end{array}$ & $\begin{array}{c}\cdots \cdots \cdots \cdots \\
7.89\end{array}$ & $\begin{array}{r}\$ 6,237,272 \quad 85 \\
1,247,454 \quad 57\end{array}$ \\
\hline $\begin{array}{l}\text { Total of the sixth period of two years } \\
\text { Annual average................... }\end{array}$ & $\begin{array}{r}\$ 3, x \times 7,732 \\
1,558,866 \\
13\end{array}$ & $\begin{array}{r}\$ 218,60270 \\
109,30135\end{array}$ & $\cdots \cdots \cdots \cdots$ & $\begin{array}{r}\$ 2,899,129 \\
1,459,564 \\
18\end{array}$ \\
\hline
\end{tabular}




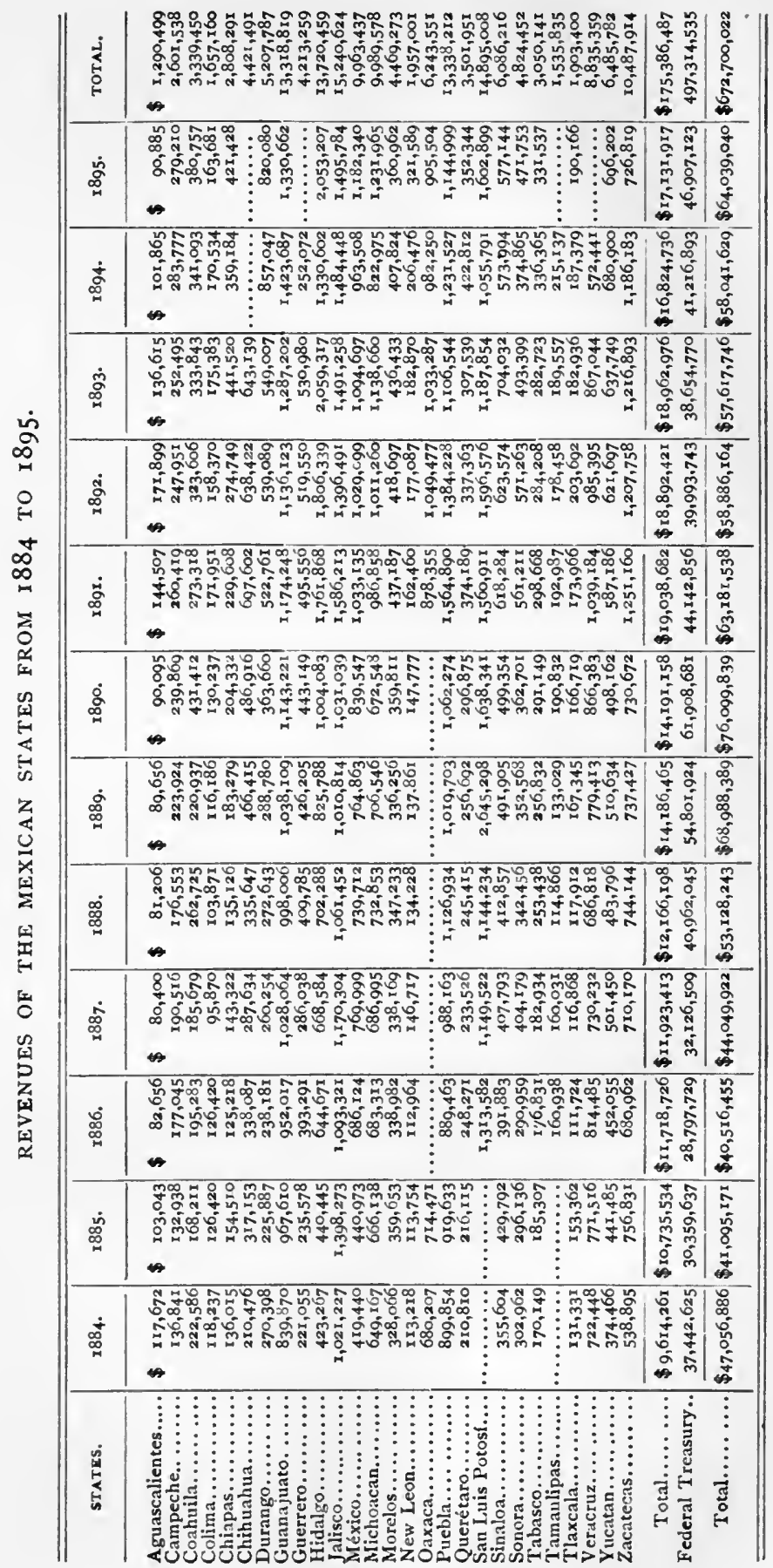




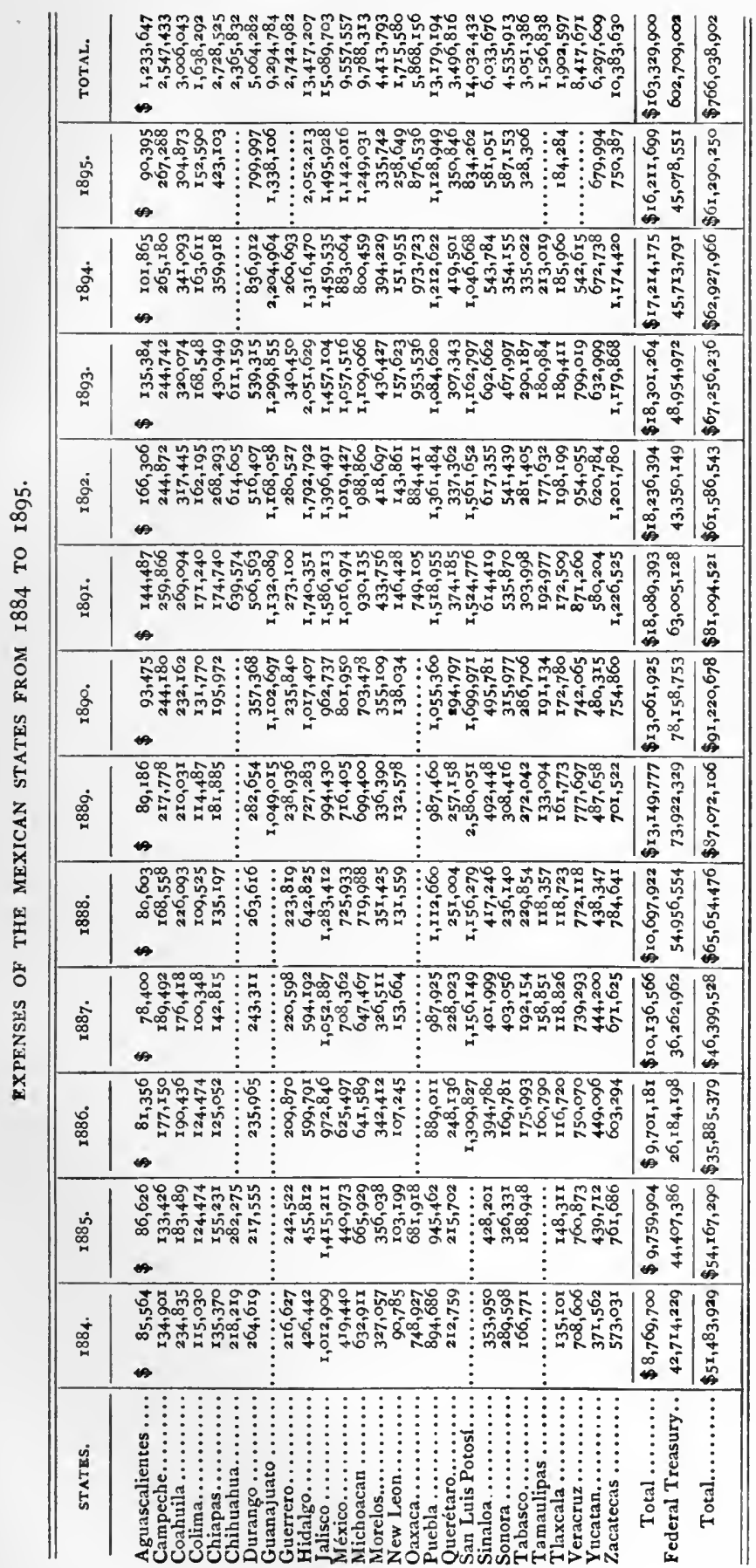




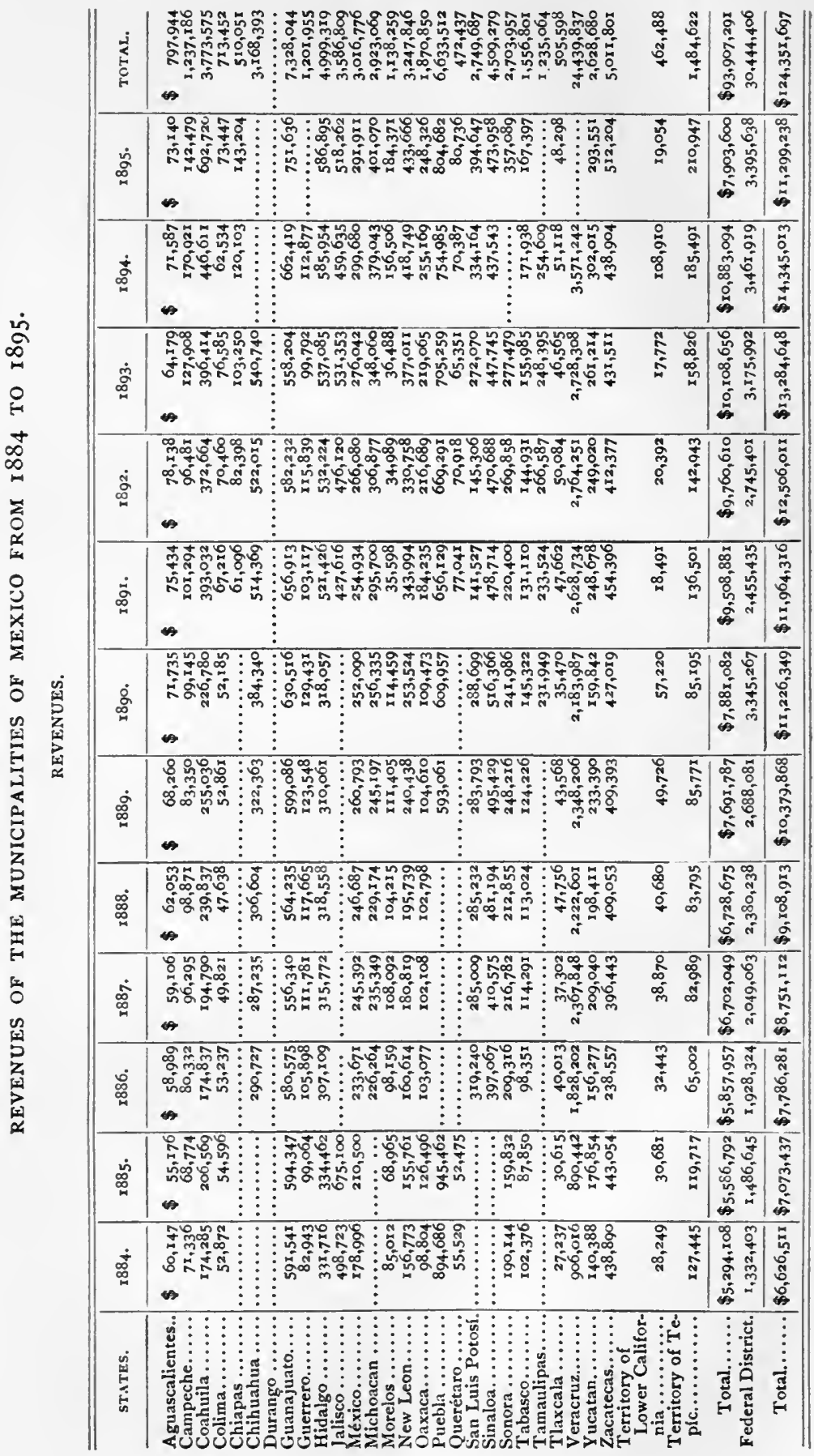




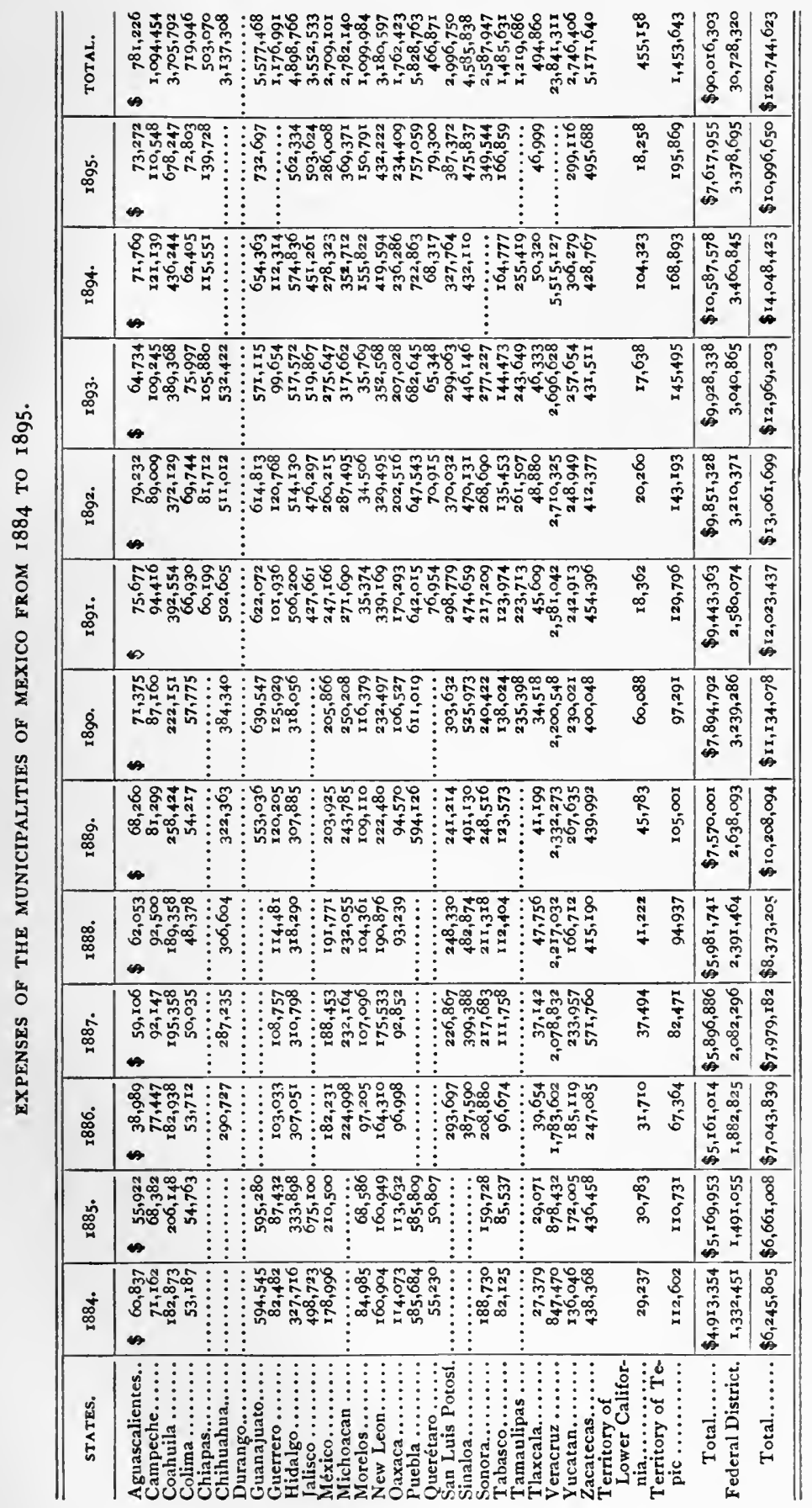




\section{STATE AND MUNICIPAL FINANCES.}

The best way in which I can give the state and municipal revenues and expenses in Mexico, is by inserting the detail amounts of the last twelve years of the revenues and expenses of each of the Mexican States, and a similar statement of the revenues and expenses of the municipalities of each State. That statement gives also the revenues and expenses of the City of Mexico, which have increased very considerably of late. In the year 1867 , after the restoration of the Republic, they only amounted to about $\$ 800,000$, while in the year I 895 , they had increased to $\$ 3,395,638$. (These statements are on pp. $150-153$.)

\section{FOREIGN TRADE.}

The foreign trade of Mexico was necessarily very small before the railway era, because transportation was exceedingly high on account of the broken condition of the country, and only articles of great value and comparatively small weight could be profitably exported, while the price of foreign commodities became very high, both on account of transportation charges and high import duties. Therefore, only rich people could afford to consume foreign commodities, and the exports of Mexico were practically reduced to silver and gold, and to a few commodities having small bulk and great value.

The normal cost of transportation on merchandise from the City of Mexico to Veracruz, a distance of one hundred Mexican leagues or $263^{\frac{3}{4}}$ English miles, used to be, before the railroad connecting both places was built, $\$ 68.75$ per ton of 2200 pounds, or more than 26 cents per mile and ton; and in extraordinary circumstances, as during the French Intervention in Mexico from $186 \mathrm{x}$ to 1867 , the freight was as high as $\$ 330$ per ton, or over $\$ 1.25$ per mile and ton. Therefore, no article could be transported unless it was very much needed and it commanded a very high price. The result was that not only the foreign but also the domestic trade was reduced to its smallest proportions, and that the people raised just enough to provide for the wants of themselves and their immediate neighbors. A fact that may seem incredible is, that for the same reasons, among the farmers, a good crop was considered a great misfortune.

Since the railways have revolutionized transportation, our products, especially agricultural commodities, have begun to be sent to foreign markets, and their exportation is increasing considerably. As yet the precious metals, especially silver, are the main exports from Mexico, representing during the fiscal year ended June 30 , 1896, 61 per cent. of our total annual exports ; but other commodities are now exported, and they are in a fair way to exceed, before long, the value of our silver exports. I have no doubt that with the opening of our railroads, if our exports cuntinue to increase in the same proportion as they have 
recently done, Mexico will be able to supply the United States with most of the tropical products now consumed and not yet produced here, and even with others, that would find a market if they could be cheaply transported.

The same difficulties which prevented us from having correct accounts of our public revenues and expenses, and which I have stated in speaking on that subject, made it very difficult for many years to have correct statistics of our imports and exports.

Imports.-I could not give even a tentative statement, which I could vouchsafe, of our total imports and exports from 1821 to 1867 , but the statement of the receipts of our custom-houses from I823 to I875, which appears on page 145 gives an approximate idea of our imports, considering that the receipts amount to about from 50 to 60 per cent. of the value of the imports.

I append a detailed statement of the imports and exports in Mexico during the years 1826,1827 , and 1828 , and the total imports and exports during the year 1825 .

From the fiscal year $1872-1873$ our Statistical Bureau began to make its reports, and I have concised them in the three annexed statements comprising most of those years, up to the fiscal year ended June 30, 1896. The commodities are divided in their respective classes in accordance with the different schedules of the tariffs then in force.

MEXICAN IMPORTS AND EXPORTS FROM I 826 TO I828.

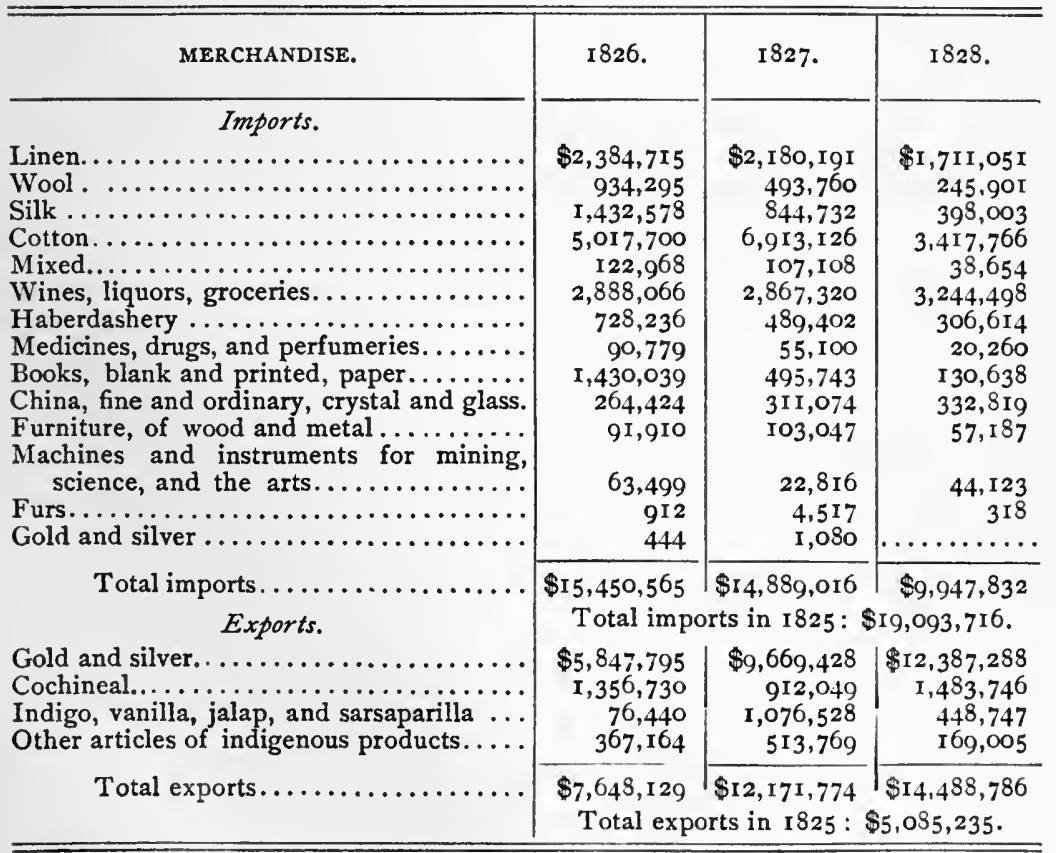




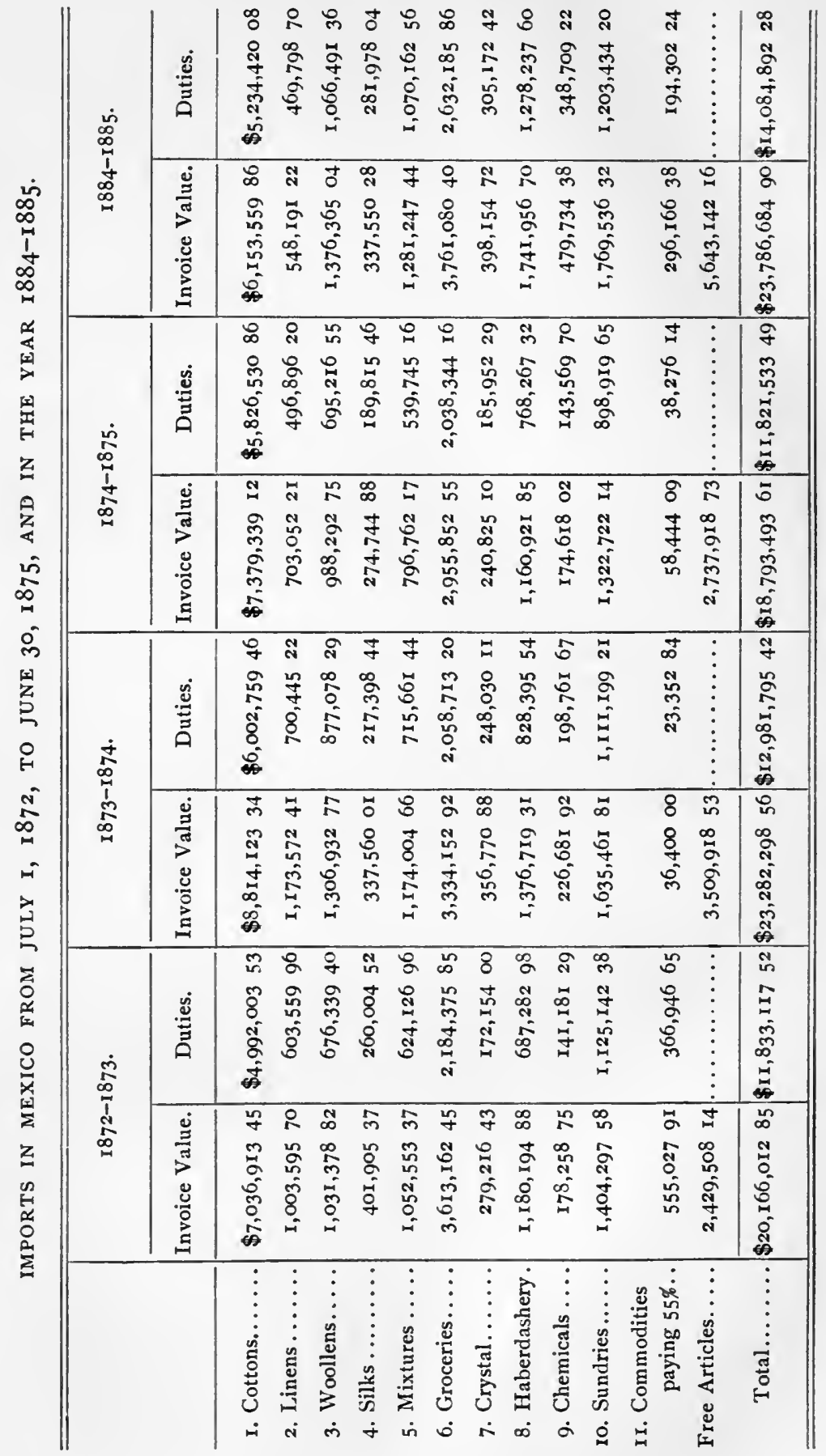




\begin{tabular}{|c|c|c|c|c|c|c|c|}
\hline \multirow{2}{*}{ 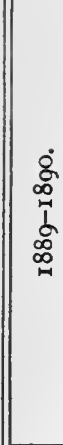 } & \multirow{4}{*}{ 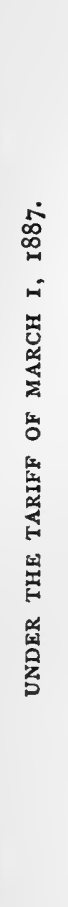 } & $\stackrel{\dot{\Phi}}{\mathscr{E}}$ & 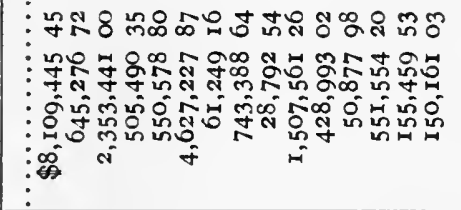 & 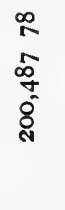 & 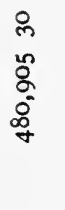 & 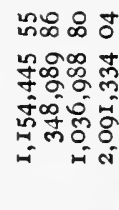 & 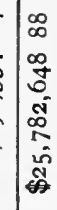 \\
\hline & & 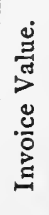 & 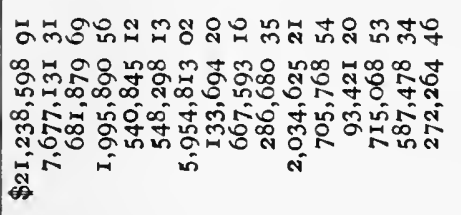 & 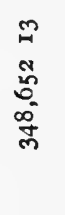 & 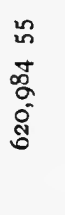 & 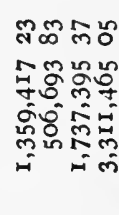 & 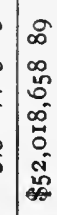 \\
\hline 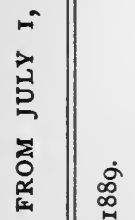 & & 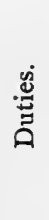 & 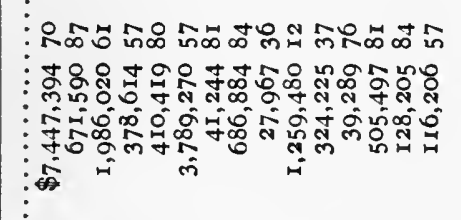 & $\begin{array}{l}\infty \\
\mathbb{R} \\
0 \\
\infty \\
\infty \\
\mathbb{N} \\
\mathbb{N}\end{array}$ & 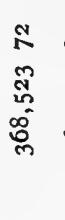 & 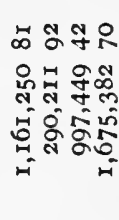 & : \\
\hline $\begin{array}{l}\infty \\
\infty \\
\infty \\
\infty\end{array}$ & & 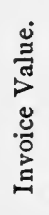 & 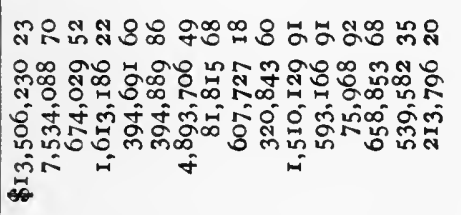 & 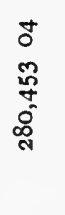 & 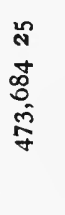 & 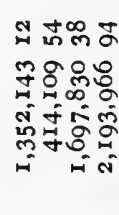 & 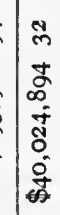 \\
\hline \begin{tabular}{l}
$\infty$ \\
$\infty$ \\
$\infty$ \\
\hdashline
\end{tabular} & \multirow{2}{*}{ 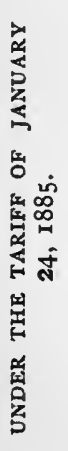 } & 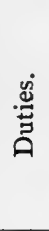 & 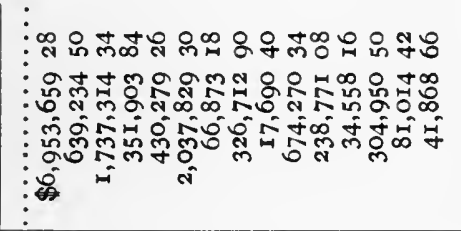 & 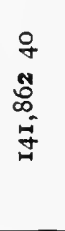 & 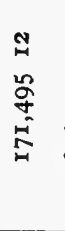 & 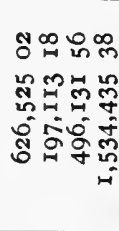 & 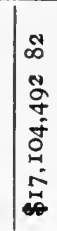 \\
\hline 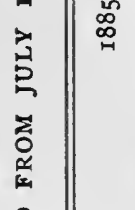 & & 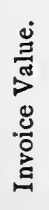 & 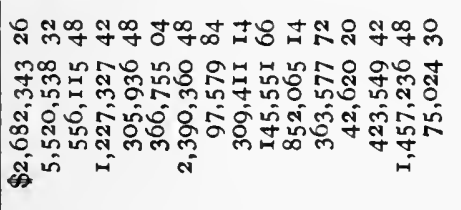 & 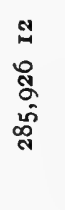 & 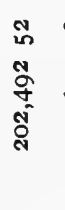 & 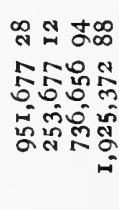 & 亪 \\
\hline & & & 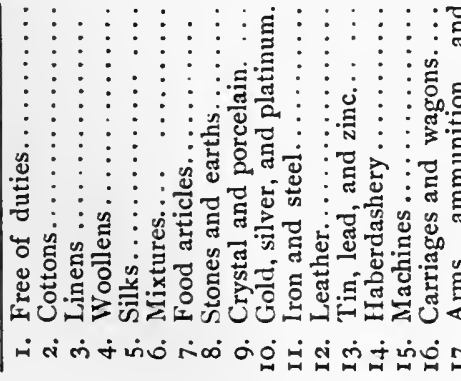 & 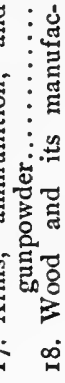 & 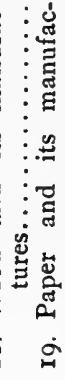 & 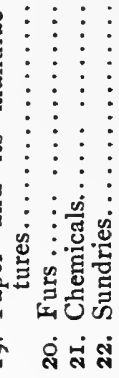 & 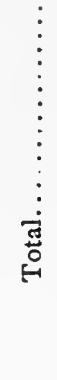 \\
\hline
\end{tabular}




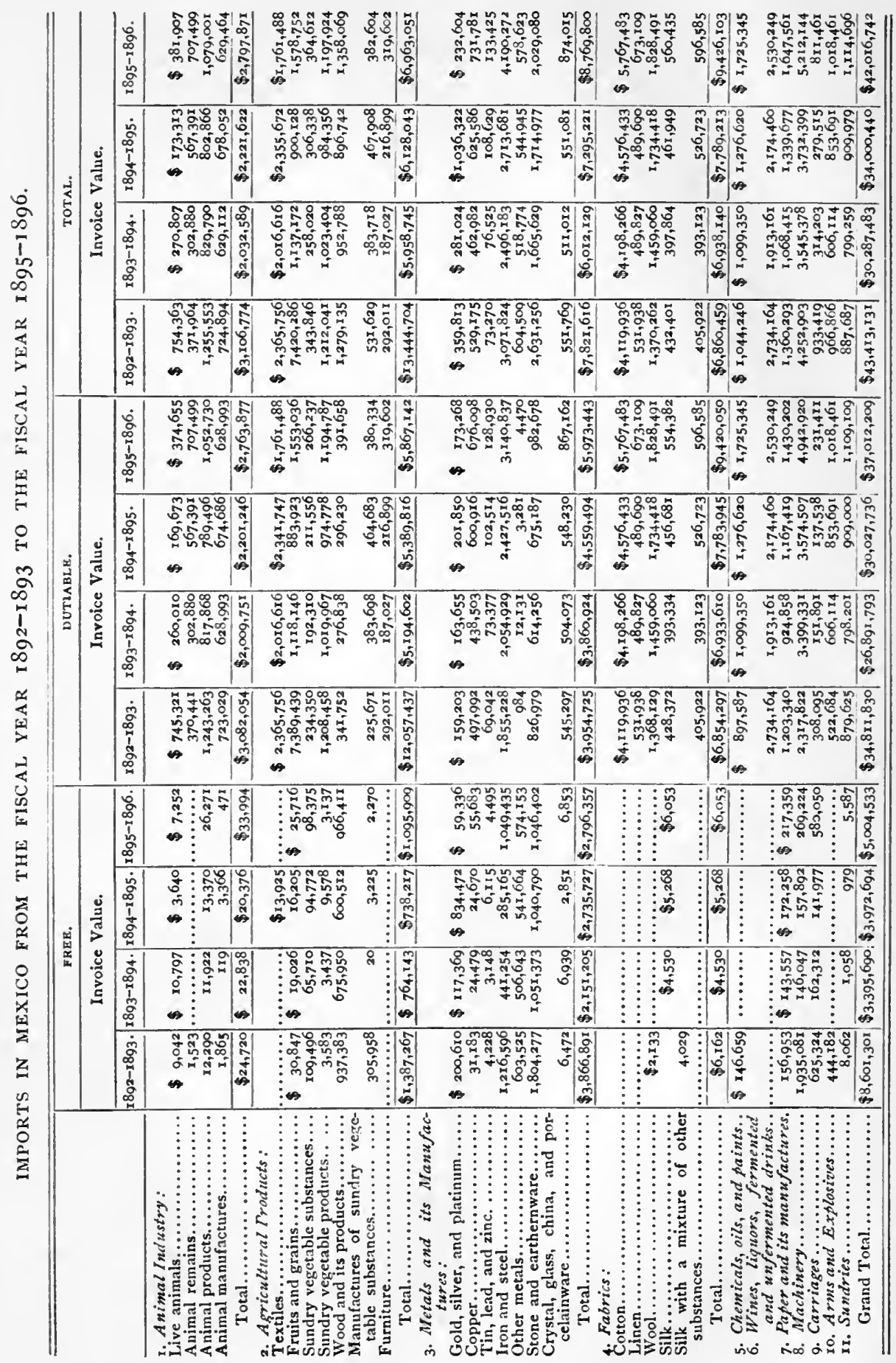


I append a statement which shows the imports and exports of Mexico during the two fiscal years $1894-1895$ and $1895-1896$, both by countries and by custom-houses, and the imports and duties by countries in the fiscal years $1888-1889$ and $1889-1890$.

Exports.-It would be difficult to make a correct statement of our exports previous to the fiscal year $1867-1868$. Their amount was very small for reasons already given, and as they principally consisted in silver, and almost all the silver coined was exported the coinage of which we have exact records, can be taken as the amount of exports, with the addition of from 30 to 40 per cent., representing the silver both in coin and bullion smuggled. I give a correct statement of our exports of agricultural commodities from the fiscal year $1877-1878$ to $1895-1896$, and also a statement of our exports of other commodities from the fiscal year. $1886-1887$ to $1895-1896$, which shows the rapid pace at which they are increasing.

The exports from Mexico are embraced in the following articles :

MINERALS.

Chapopote.

Coal.

Copper in bars.

Gold and silver coin.

Gold and silver bullion.

Lead in pigs.

Onyx.

Opals.

Ores of silver, copper, and lead.

AGRICULTURAL PRODUCTS.

Beans.

Bitter almonds and various fruits, kernels.

Chick-peas.

Cocoa.

Coffee.

Honey.

India-rubber.

Molasses.

Piloncillo (brown sugar).

Sugar, all grades.

FIBRES.

Henequen.

Ixtle.

Mallows fibre.

Pita.

Ramie.

Sotol.

Wool.
ANIMAL PRODUCTS.

Bones.

Cattle.

Chihuahua terriers.

Donkeys.

Goats.

Hair, horse.

Hair, rabbit.

Heron feathers.

Hides, raw and tanned.

Hoofs.

Horns.

Horses.

Mules.

Ox grease.

Sheep.

Skins of sheep and goat, dressed and undressed. MANUFACTURES.

Cotton, linen, worsted and silk domestic shawls (rebozos).

Guadalajara earthenware.

Maguey, brandy (Tequila and mescal.

Preserved sweet meats.

Rag puppets and dolls.

Rags (all sorts).

Wax, artificial flowers and Tortoise shell from the GuIf figures.

Woollen and worsted Mexi- Vanilla. can plaids or blankets Zacaton brush and broom (Zarapes).
Bananas.

Cocoanuts.

Lemons.

Limes.

Oranges.

Pine apples.

Walnuts, Nuevo Leon.

Tamarind pulp.

\section{FORESTRY。}

Cabinet woods, mahogany, moral, lind-aloe, tepeguaje, cedar, sandal, ebony, and rosewood.

Dye woods, brasil, camphor, moral, and other varieties of logwood.

Orchilla.

\section{SUNDRIES.}

Copal, chick, and sundry resinous substances.

Jalap, and other medicinal herbs.

Mother of pearl shells.

Pearls. of Cortez.

grasses. 


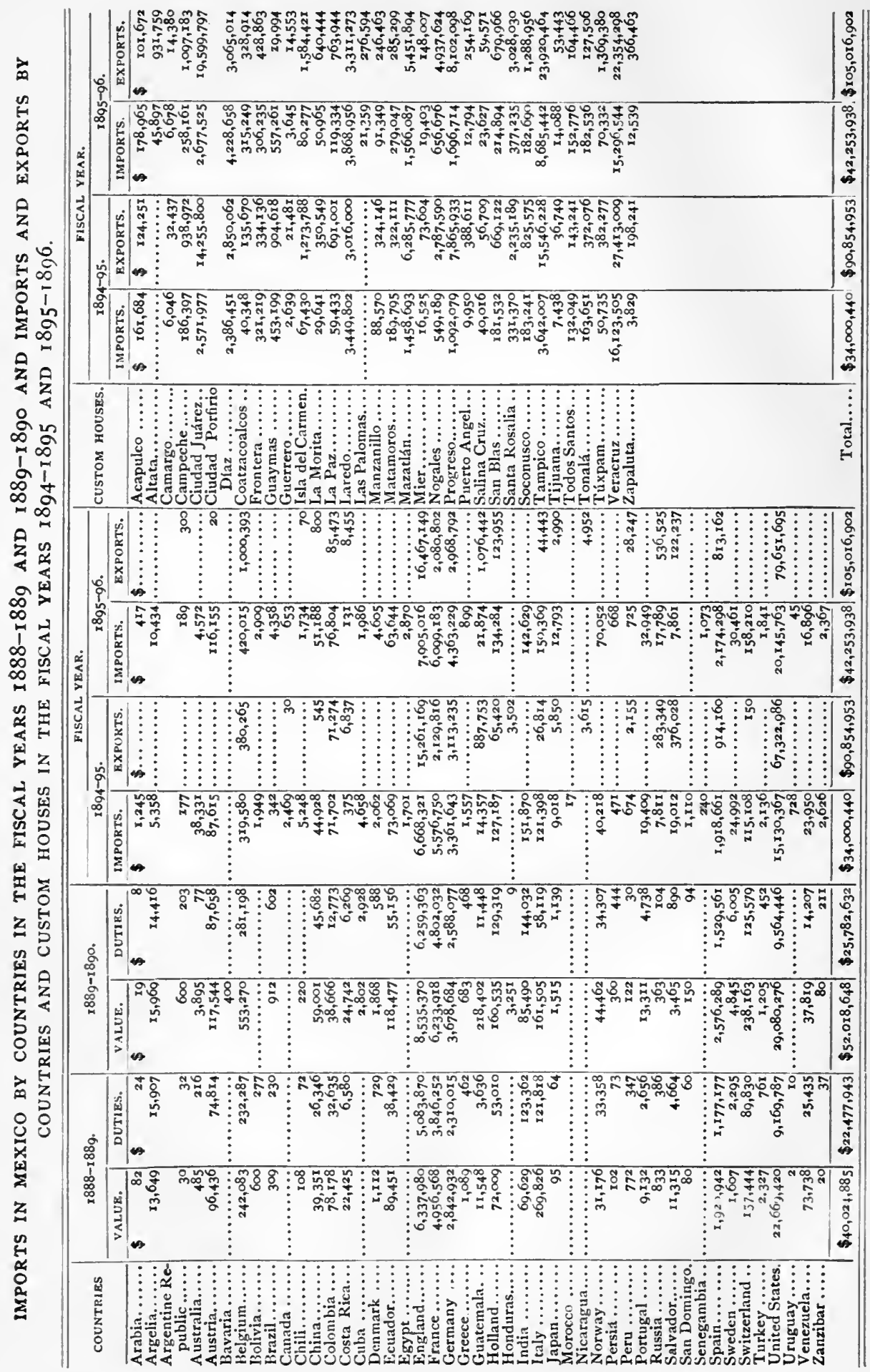


The following is a list of the value of metals and commodities exported from Mexico during the fiscal year $1895-1896$, which shows that they are all either mineral or agricultural products, these being only raw materials : The commodities are placed in the order of their relative importance in value.

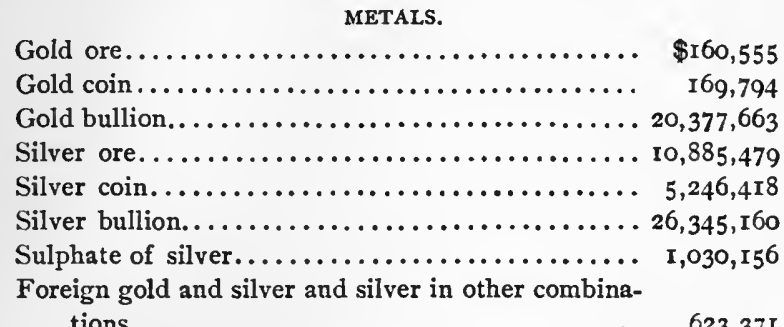

Total.

623,371

\section{$\$ 64,838,596$}

$\$ 8,103,302$

$6,763,821$

$4,206,880$

$3,909,485$

$2,531,624$

$3,546,770$

2,331,999

I, 527,838

I ,46I,ogo

I, 428,675

690,862

$6 \mathrm{I} 6,492$

352,737

270,176

258,668

246, I 50

I69,662

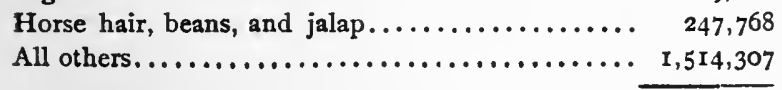

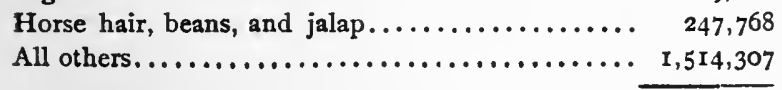

Total. 


\begin{tabular}{|c|c|c|c|c|c|c|c|c|c|}
\hline \multicolumn{2}{|c|}{ 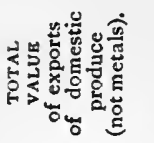 } & 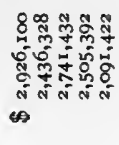 & 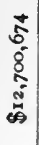 & $\begin{array}{c}\infty \\
0 \\
0 \\
0 \\
0 \\
\dot{0} \\
\dot{\infty}\end{array}$ & 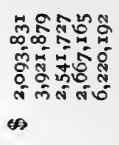 & 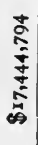 & 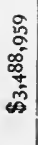 & 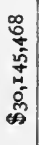 & 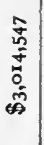 \\
\hline \multirow{2}{*}{ 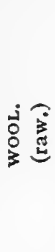 } & 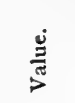 & 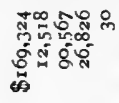 & 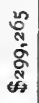 & 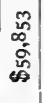 & 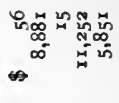 & 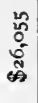 & 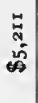 & 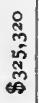 & 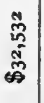 \\
\hline & 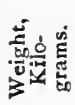 & 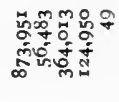 & 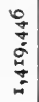 & $\begin{array}{l}\infty \\
\infty \\
\infty \\
\infty \\
\infty \\
\infty\end{array}$ & 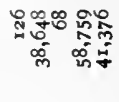 & 点 & 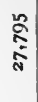 & 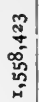 & 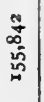 \\
\hline \multirow{2}{*}{ 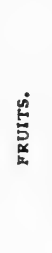 } & 胥 & 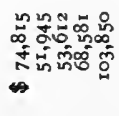 & 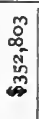 & $\begin{array}{c}0 \\
0 \\
\vdots \\
\vdots \\
6\end{array}$ & 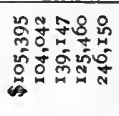 & 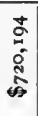 & 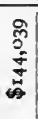 & 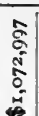 & $\begin{array}{l}8 \\
8 \\
0 \\
0 \\
0 \\
0\end{array}$ \\
\hline & 营施 & 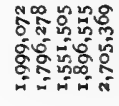 & 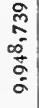 & 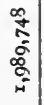 & 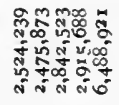 & 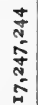 & 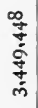 & $\begin{array}{c}m \\
0 \\
\vdots \\
\vdots \\
\vdots \\
\vdots \\
\vdots\end{array}$ & 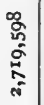 \\
\hline \multirow{2}{*}{ 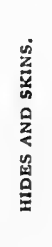 } & 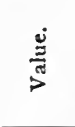 & 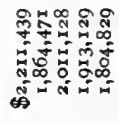 & 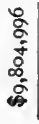 & 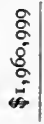 & 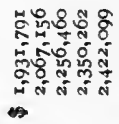 & 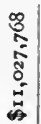 & 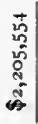 & 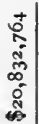 & 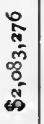 \\
\hline & 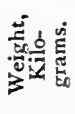 & 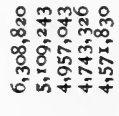 & 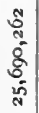 & 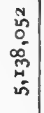 & 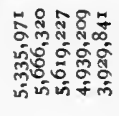 & 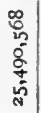 & $\begin{array}{c}m \\
\vdots \\
0 \\
8 \\
\text { n }\end{array}$ & $\begin{array}{l}0 \\
0 \\
\infty \\
0 \\
0 \\
0 \\
5 \\
5\end{array}$ & 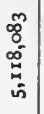 \\
\hline \multirow{2}{*}{ 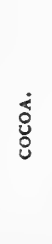 } & $\frac{\dot{y}}{\frac{\partial}{\text { लॉ }}}$ & 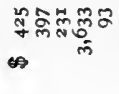 & 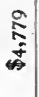 & 吕 & 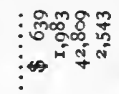 & 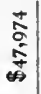 & 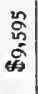 & 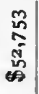 & 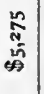 \\
\hline & 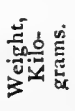 & 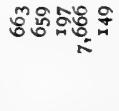 & 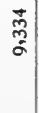 & 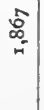 & & 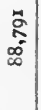 & \begin{tabular}{c}
$\infty$ \\
$\substack{n \\
\multirow{n}{*}{}}$
\end{tabular} & 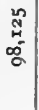 & $\begin{array}{c}\text { ב. } \\
0 \\
\sigma \\
\sigma\end{array}$ \\
\hline \multirow{2}{*}{ 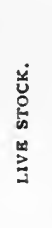 } & 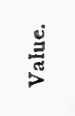 & 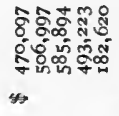 & 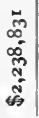 & 总 & 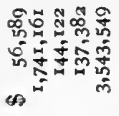 & 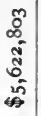 & 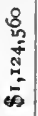 & 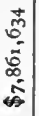 & 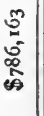 \\
\hline & 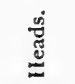 & 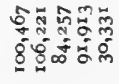 & 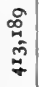 & $\begin{array}{l}\infty \\
0 \\
0 \\
\infty \\
\infty\end{array}$ & 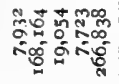 & $\underset{7}{5}$ & $\begin{array}{l}\text { a } \\
\text { ले } \\
\text { लू }\end{array}$ & \begin{tabular}{l}
8 \\
$:$ \\
\multirow{2}{*}{} \\
$\infty$ \\
$\infty$
\end{tabular} & 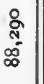 \\
\hline \multicolumn{2}{|c|}{ (1) } & 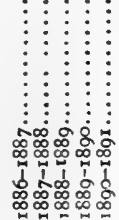 & 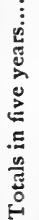 & 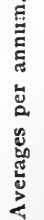 & 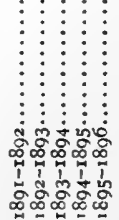 & 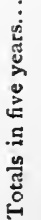 & 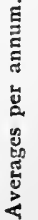 & 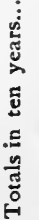 & 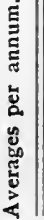 \\
\hline
\end{tabular}




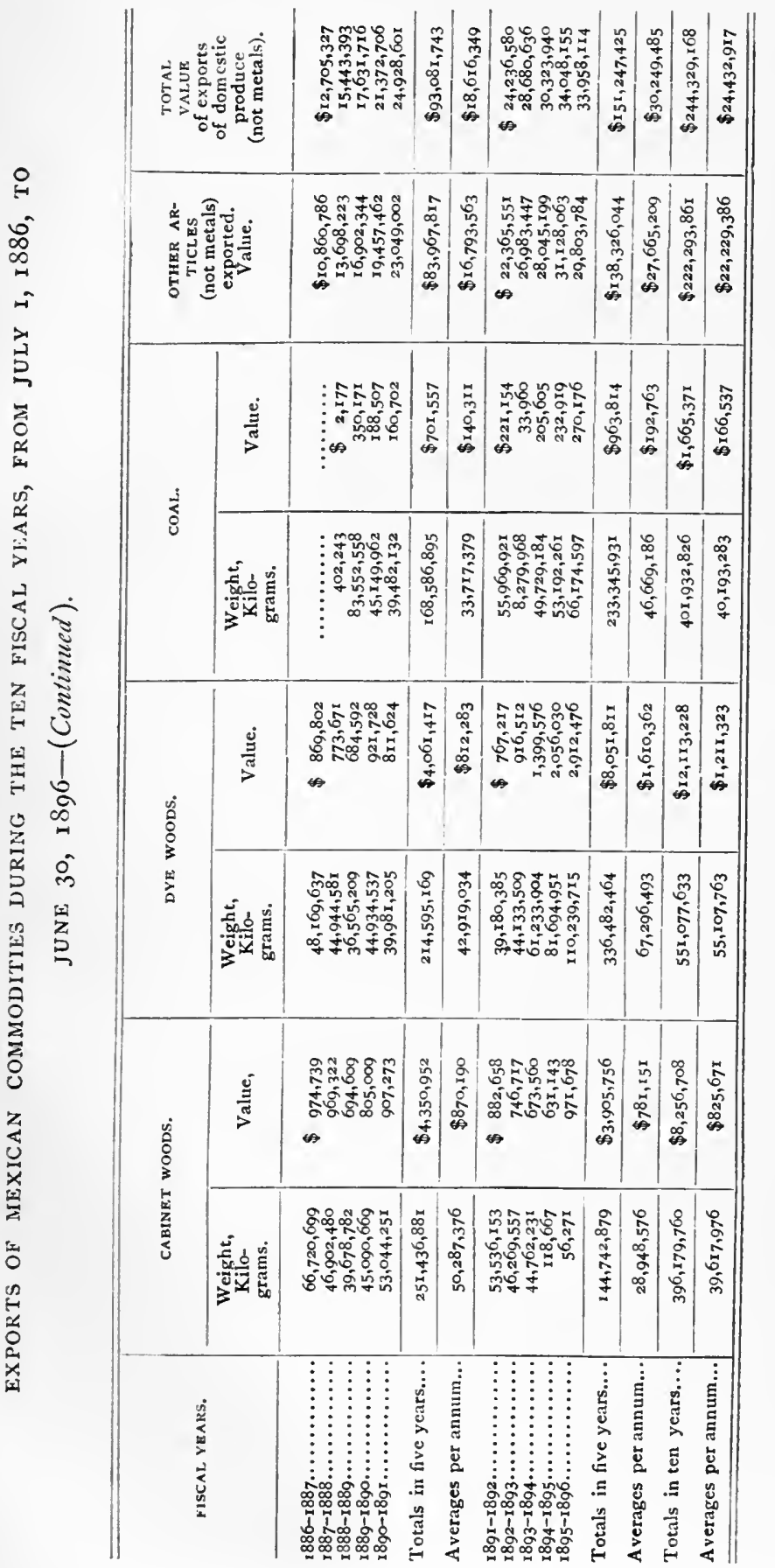




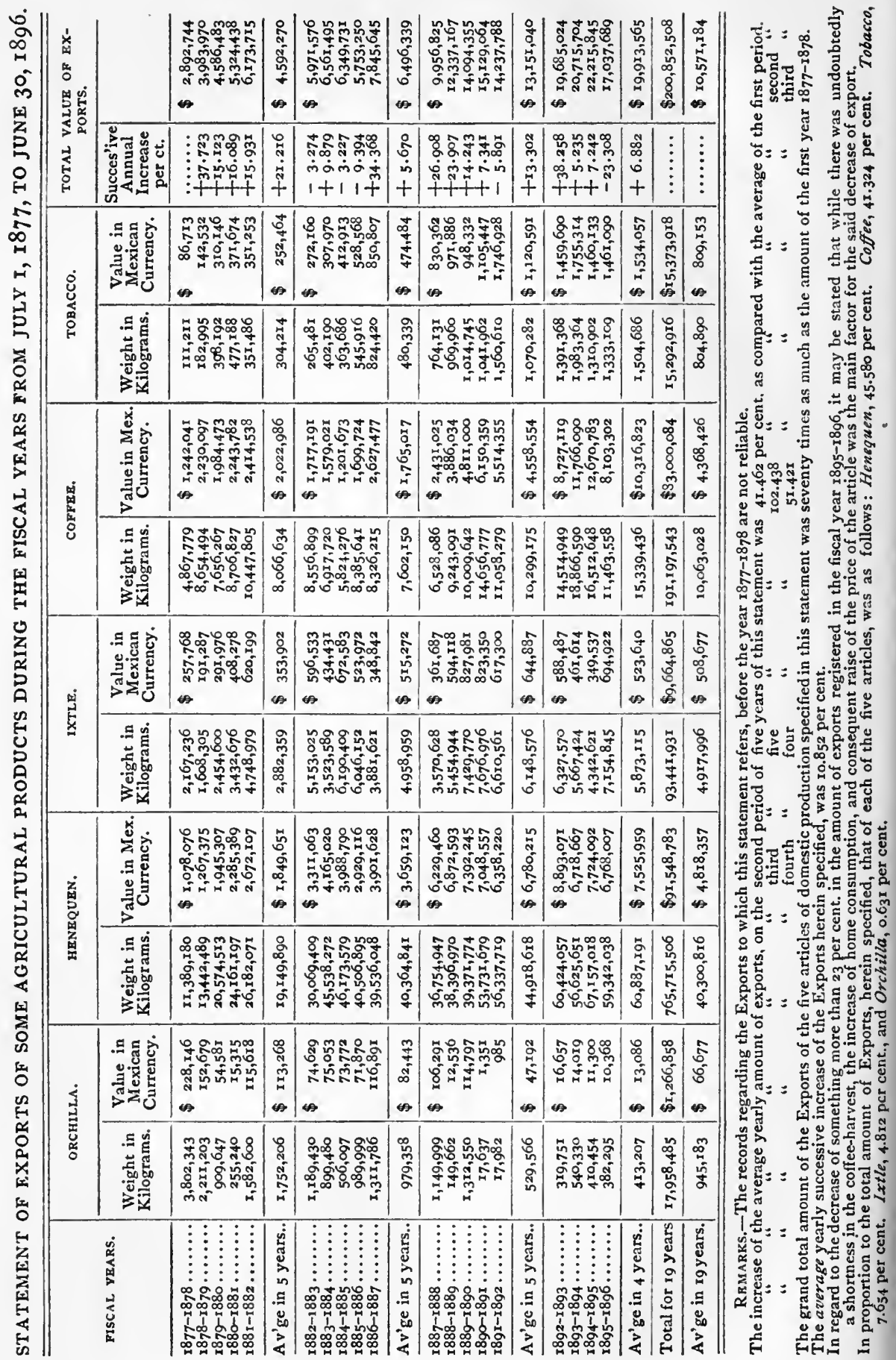




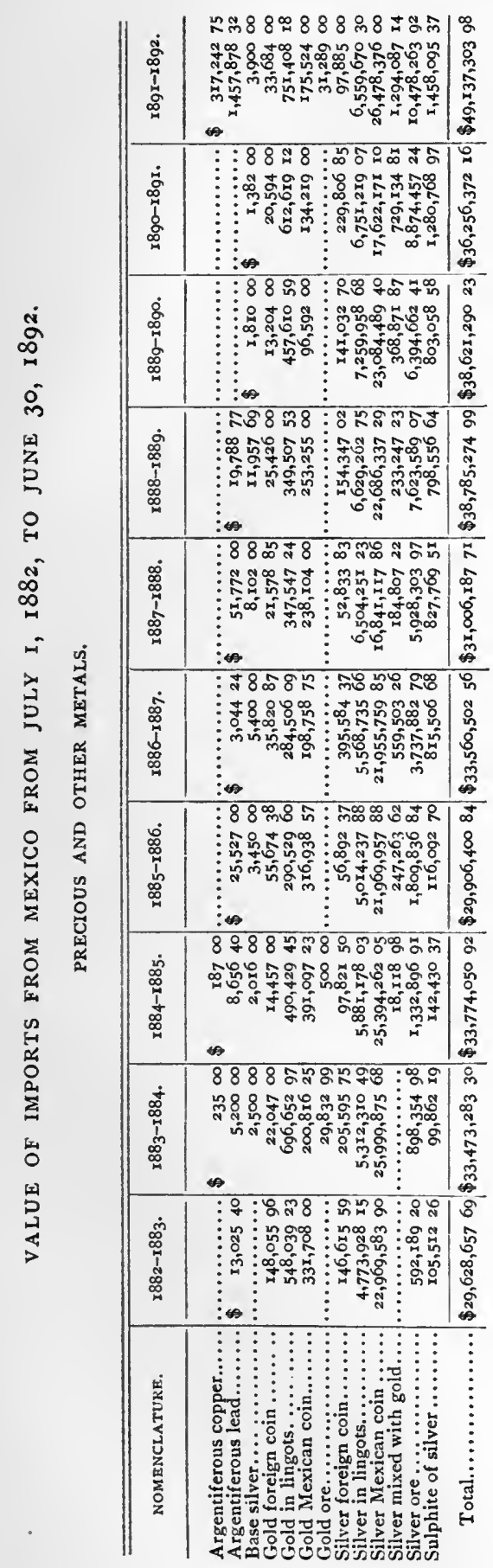

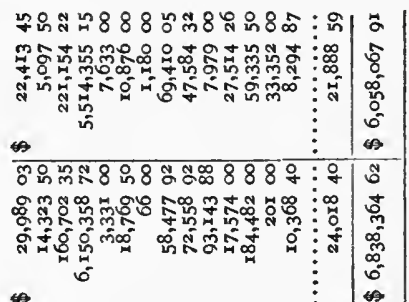

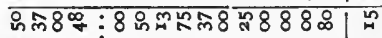

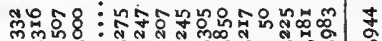

क्ष

\& $\quad$ i

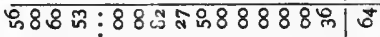

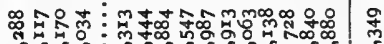

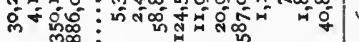

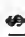

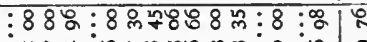

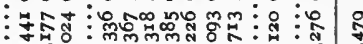

ส $\vdots$

¿

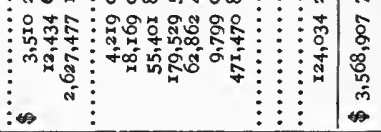

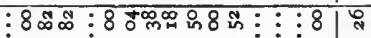

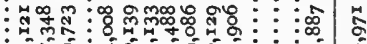

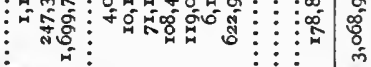

is $\vdots \quad \vdots \vdots \vdots 1 \%$

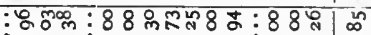

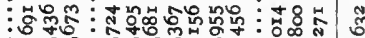

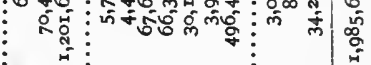

i $\vdots \quad \vdots 10$

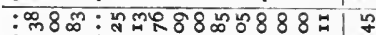

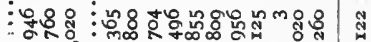

$\vdots$
$\vdots$
$\vdots$
0

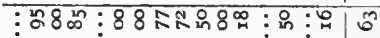

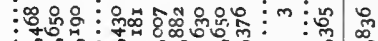

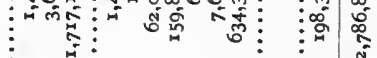

$\begin{array}{llll}\vdots & \vdots & \vdots & \vdots\end{array}$

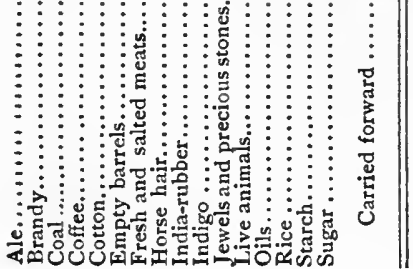




\begin{tabular}{|c|c|c|}
\hline & 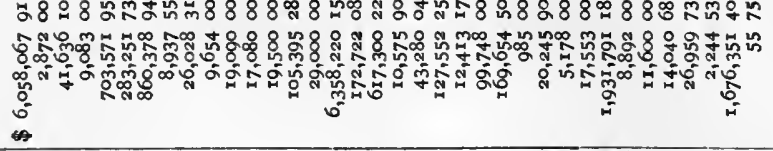 & 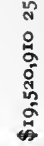 \\
\hline & 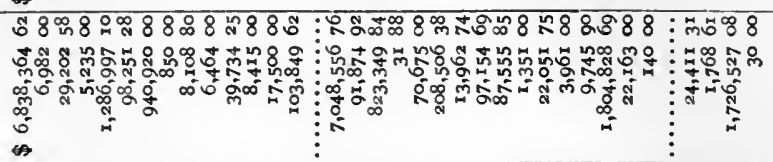 & 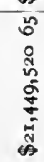 \\
\hline & 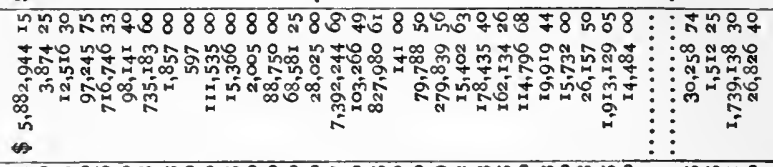 & 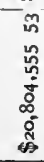 \\
\hline & 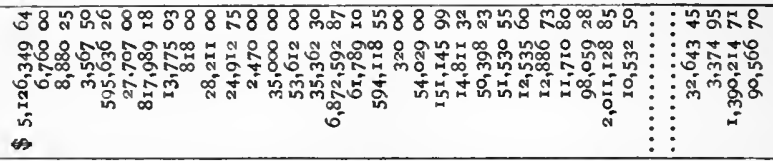 & 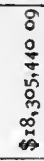 \\
\hline & 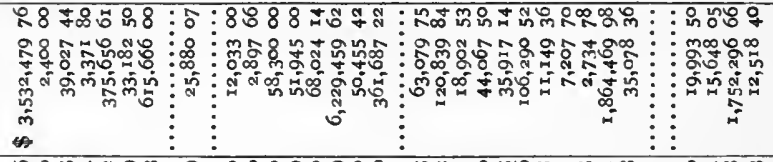 & 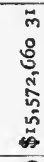 \\
\hline & 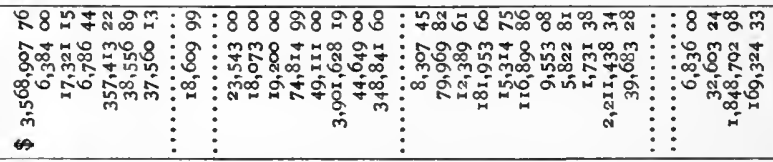 & 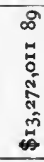 \\
\hline 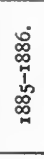 & 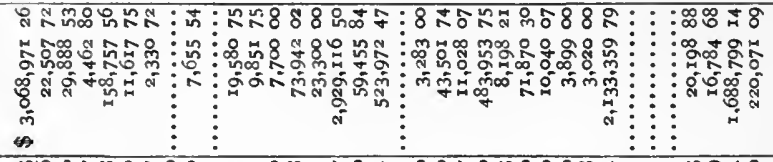 & 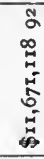 \\
\hline 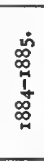 & 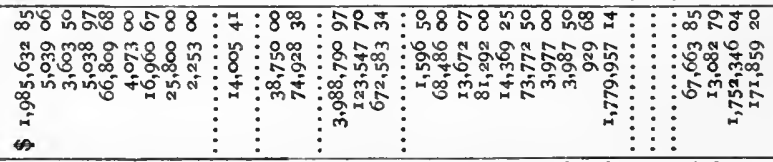 & 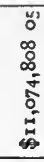 \\
\hline 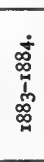 & 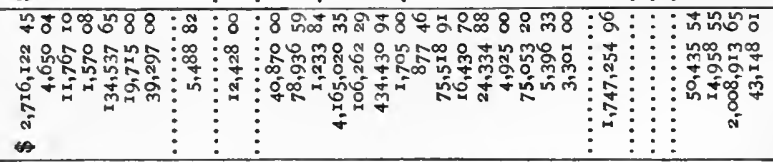 & 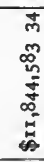 \\
\hline 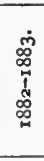 & 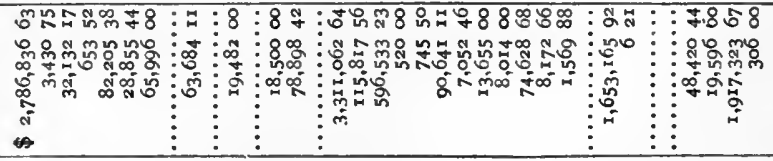 & 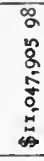 \\
\hline 递 & 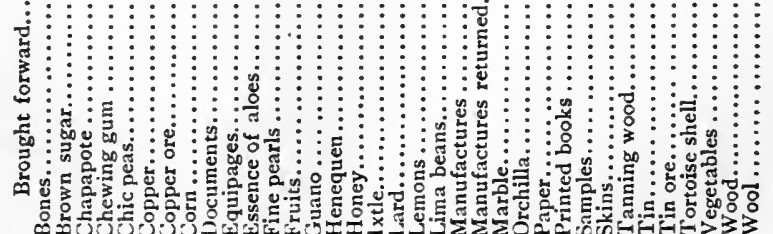 & 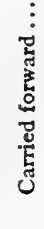 \\
\hline
\end{tabular}




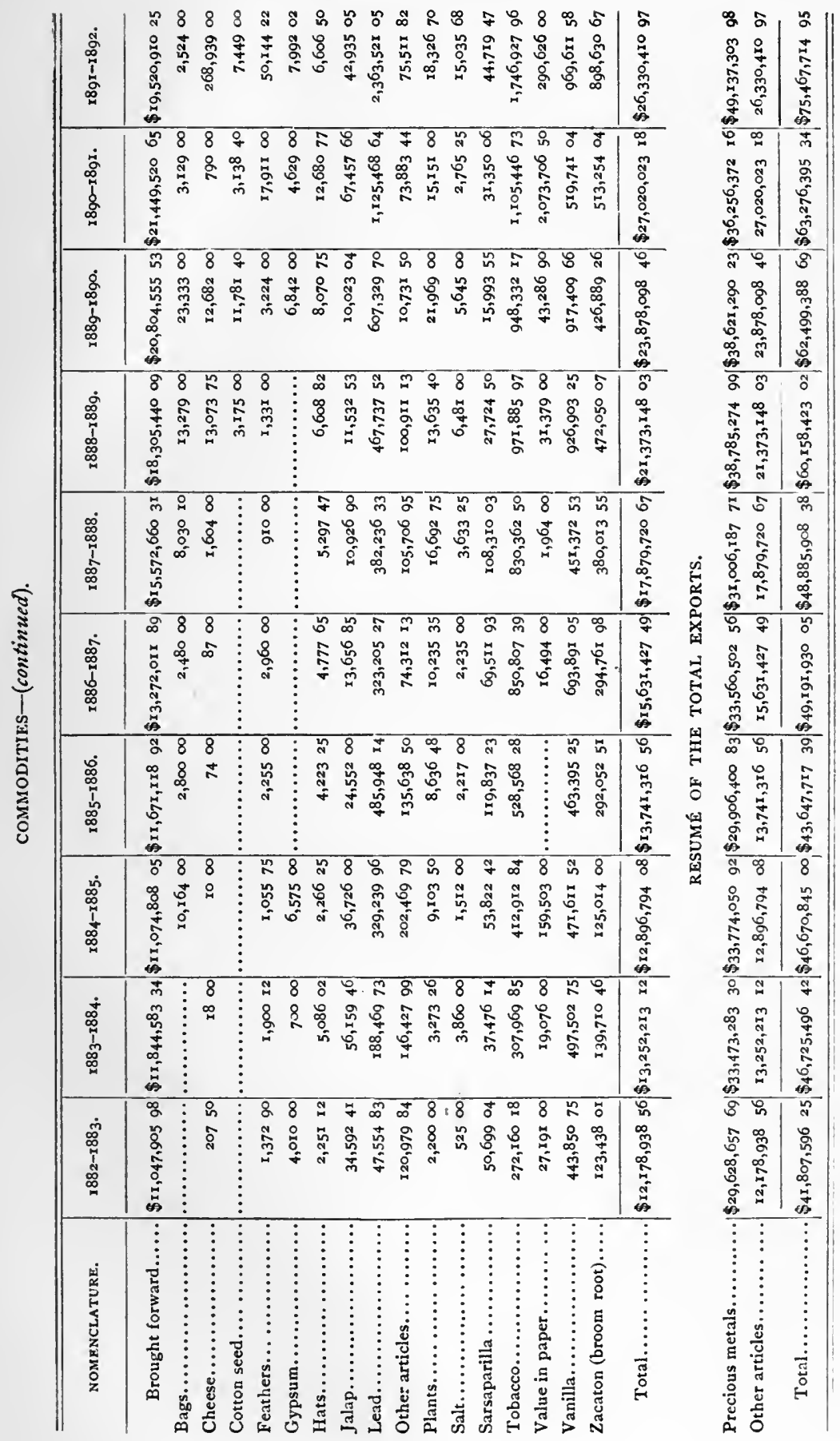




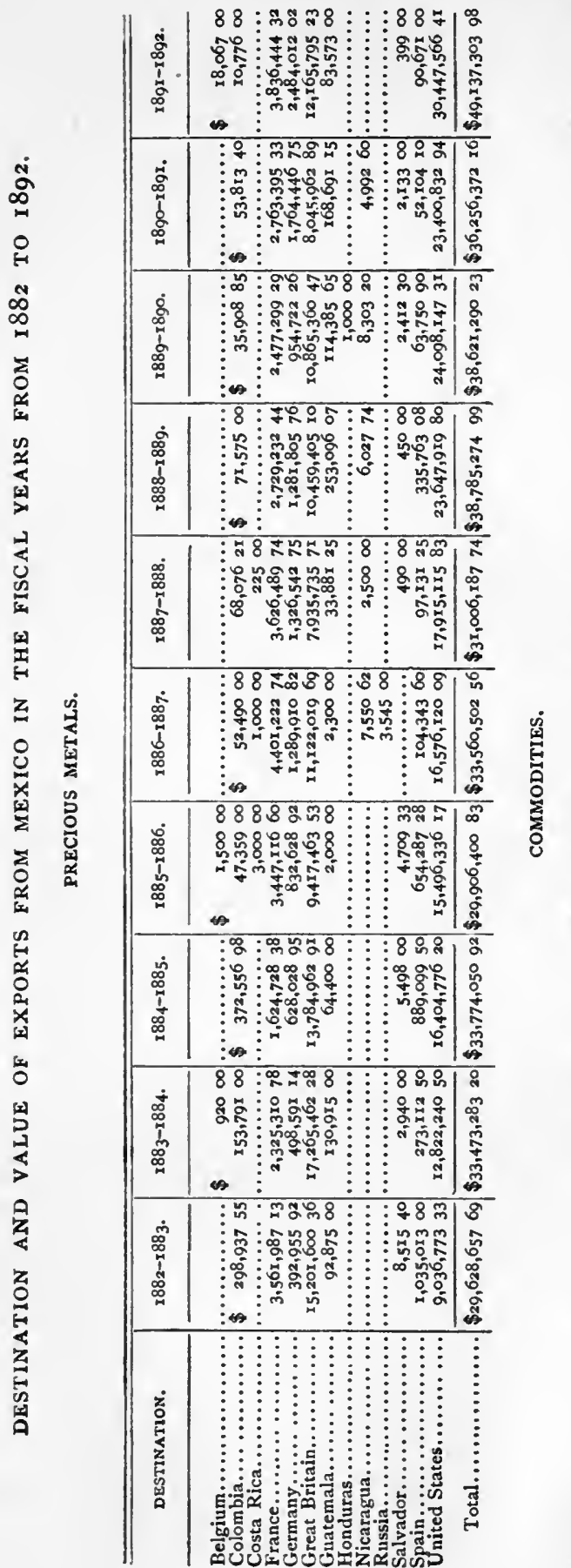

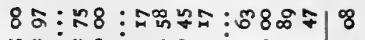

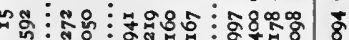

สำ

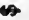

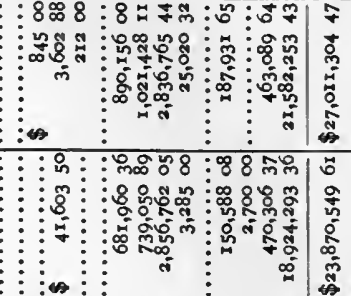

8 :

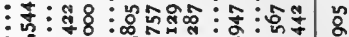

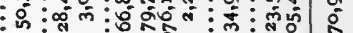

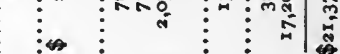

:뉴: :

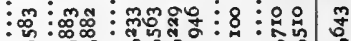

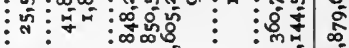

: $\quad m^{m}$

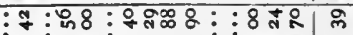

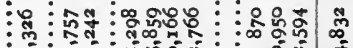

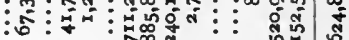

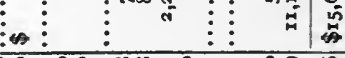

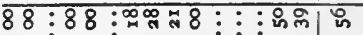

ผ๐

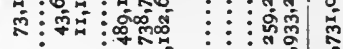

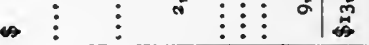

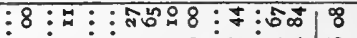

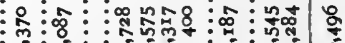

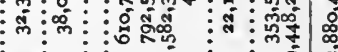

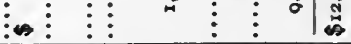

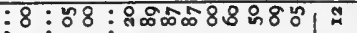

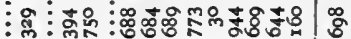

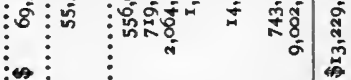

:8:0:8

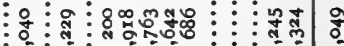

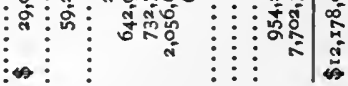

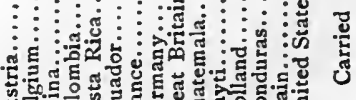

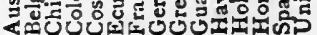



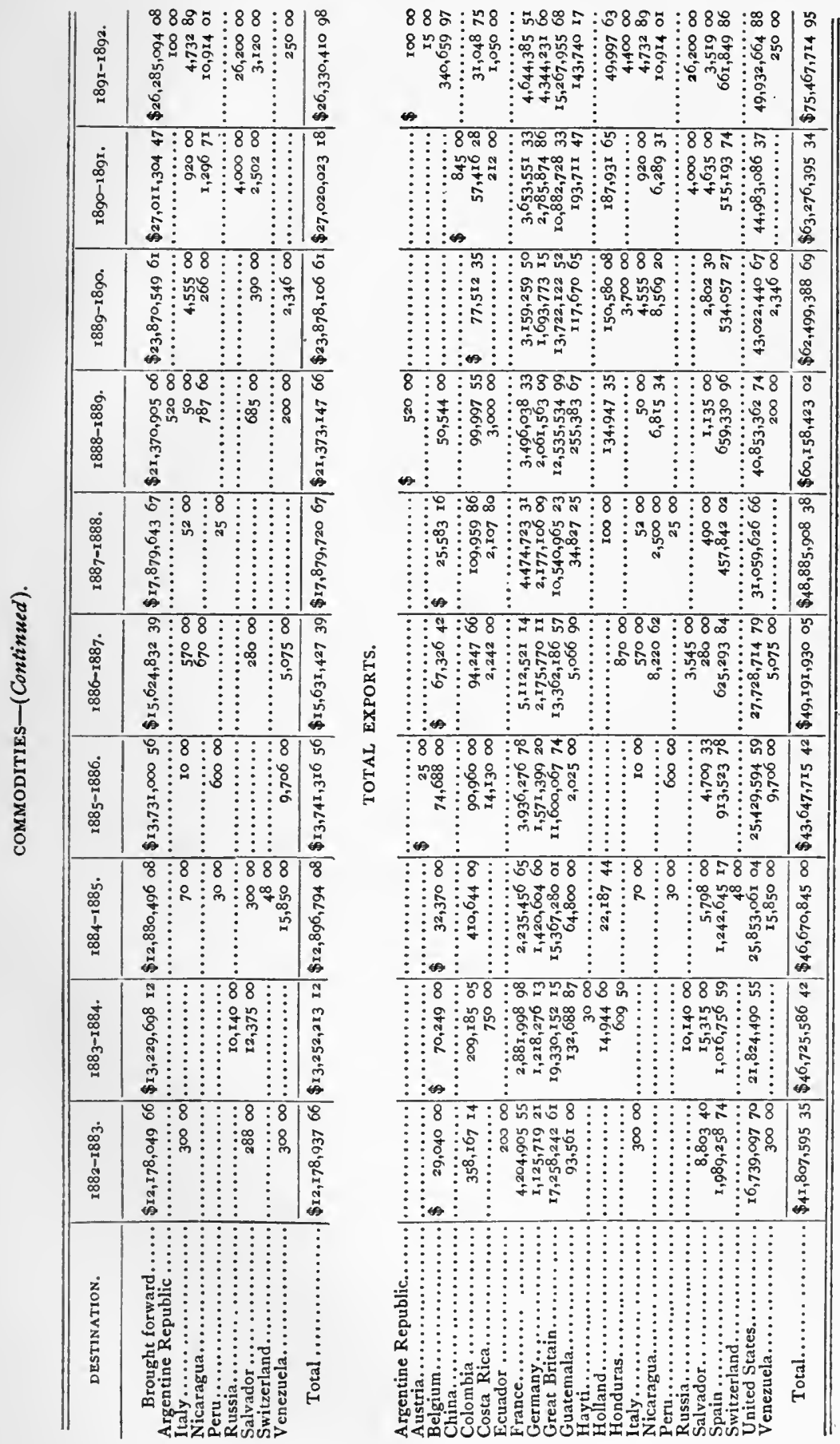


\section{TRADE BETWEEN MEXICO AND THE UNITED STATES.}

It is quite difficult to make a correct statement of the trade between Mexico and the United States, because the official data of both governments never used to agree, especially on account of the different currencies prevailing in the two countries. As we have the silver standard, all our public accounts are kept in silver, and that makes our exports appear twice as large in value as they really are, when stated in the money of the United States, while we give our imports in the value of the country from whence they come, that is their gold value. That fact, which has often been overlooked, has caused the prevailing idea that there is a very large balance of trade in favor of Mexico, because the exports of United States commodities in Mexico amount to a given figure a year, the imports to this country of Mexican commodities amount to over double that figure ; but it must be borne in mind that the former is in silver while the latter is in gold. For instance, according to the Mexican Bureau of Statistics the imports into Mexico of merchandise from the United States in the fiscal year ended June 30 , 1896 , amounted to $\$ 20, \mathbf{r} 45,763$, while the exports of metals and commodities from Mexico to the United States during the same year amounted to $\$ 79,65 \mathrm{I}, 695$, the proportion being almost four to one; but if the imports are doubled as they ought to be, because the Mexican currency is silver, they amount to $\$ 40,291,526$, and if the exports of Mexico into the United States, calculated also in silver, are reduced to gold, they will amount to one half or $\$ 39,825,847.50$.

In corroboration of this statement I will mention the fact that according to the data of the Statistical Bureau of the United States Treasury Department, the exports to Mexico of commodities and precious metals from the United States during the last fiscal year, ending June $3 \circ, 1897$, amounted to $\$ 23,535,213$ while the imports into the United States of commodities and precious metals amounted to $\$ 30$,714,366. Since March 1893, however, the Statistical Bureau of the United States Treasury Department, has reduced to gold the silver value of the Mexican metals and commodities imported in this country, and its data come now nearer to the mark, as in the year 1896 it gives the total exports of merchandise from this country into Mexico as $\$ 19,45^{\circ}, 25^{6}$, while the total imports of merchandise from Mexico into this country are $\$ 17,456,177$.

The figures of our exports appear very large in the Mexican returns, because our merchandise is sold in gold markets, and their gold price is reduced to silver, and increased in the same proportion in which silver depreciates. It is not therefore the amount of merchandise which has increased so much, as that the price has been swollen in reducing it from gold to silver. In that regard the returns from the United States Statistical Bureau are more in conformity with the facts. 
Another cause of the discrepancy between the statistics of both countries is that the Statistical Bureau of the United States Treasury Department had not, prior to March 3, 1893, any data of commodities exported to Mexico by way of the frontier, as there was no law which provided for the collection of such data, and a very large portion of the trade between the two countries is carried on by the frontier, especially since the railroads connecting both countries were finished. ${ }^{2}$ That deficiency was only in relation to the exports, as the imports were duly declared for the payment of duties, and therefore the statistics of the United States necessarily were deficient and incomplete about the exports to Mexico of United States commodities, and that accounts in a great measure for the discrepancy between the official data published by both governments, and for the great discrepancy between exports and imports which appear in the statistics of the United States for those years.

From the preceding remarks it will be understood why there is such a great discrepancy between the data of the respective Bureaus.

It is very difficult to make a correct statement of the trade between the two countries previous to the organization of the Bureau of Statistics of the United States; but I found in a book published in Washington in 1860 by Mr. Carlos Butterfield, entitled "The United States and Mexican Mail Steamship Line and Statistics of Mexico," a statement of the imports and exports between Mexico and the United States from I 826 to 1858 , taken as he states from official data of the United States Treasury Reports, which I will use.

That statement is complemented by two tables furnished to me by Hon. Worthington C. Ford, Chief of the Bureau of Statistics of the Treasury Department. The first contains a statement of the trade between the United States and Mexico, during the forty-six years from $185 \mathrm{I}$ to $\mathrm{r} 897$, and the second is a full statement of that trade, including gold and silver during the same period. (Pages 174 and 175 .)

I have prepared besides from the official publications of the Bureau of Statistics of the United States Treasury Department, a detailed statement of the commodities imported into the United States from Mexico, and exported from the United States to Mexico during the

${ }^{1}$ For these reasons the statements of the Statistical Bureau of the United States, previous to the fiscal year ended June 30,1892 , contained the following foot-note :

"In the absence of law providing for the collection of statistics of exports to adjacent foreign territory over railways, the values of exports to Mexico, from 1883 to 1893 inclusive, have been considerably under-stated. Since March, I893, there has been a law in force for the collection of exports by railways. According to official information from Mexican sources, the value of imports into that country from the United States during the year ending June 30,1888 , was $\$ 19,264,673$, including precious metals valued at $\$ 38,362$. Prior to 1866 the figures include gold and silver imported and exported. For 1866 and subsequent years, merchandise only." 
years $185^{8}$ to 1897 , which is complete so far as the records of this government go, and contains very valuable information.

I will give first a partial statement prepared by the Bureau of Statistics of the Mexican Government of the total imports to Mexico and the imports from the United States of America from the fiscal year $1872-1873$ to $1895-1896$, and then another detailed statement prepared by the same Bureau of the total exports from Mexico and the exports to the United States of America from the fiscal year $1877-1878$ to $1895-1896$.

From said data it will be seen that the trade of Mexico with the United States is increasing very rapidly, notwithstanding the difficulty thrown in the way by high protective tariffs. Only a few years ago, as will be seen by the appended statement, our largest trade was with Great Britain, the United States occupying the second place, while now the United States occupies the first place, both in amount of our exports and imports. ${ }^{1}$

Value of exports during the fiscal year $1872-1873$ with their destination.

Great Britain..........\$12,479,547.75

United States........... II $366,530.76$

France $\ldots \ldots \ldots \ldots \ldots \ldots, 4,604,417.38$

Panama (New Grenada)... I, $579,015.12$

Germany.............. $802,643.83$

Spain and the Island of Cuba $\quad 752,89 \mathrm{I} .9 \mathrm{I}$

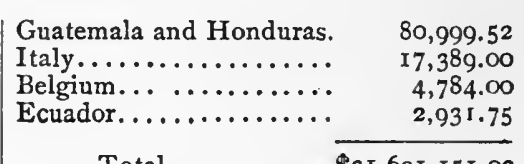

Total ........ $\overline{\$ 3 I, 69 I, I_{5} I .02}$

TOTAL IMPORTS TO MEXICO AND IMPORTS FROM THE UNITED STATES FOR THE FISCAL YEARS, I 872-I873 TO I895-I896.

\begin{tabular}{|c|c|c|}
\hline \multirow{2}{*}{ " } & $\begin{array}{l}\text { IMPORTS FROM THE } \\
\text { UNITED STATES. }\end{array}$ & TOTAL IMPORTS. \\
\hline & Value. & Value. \\
\hline 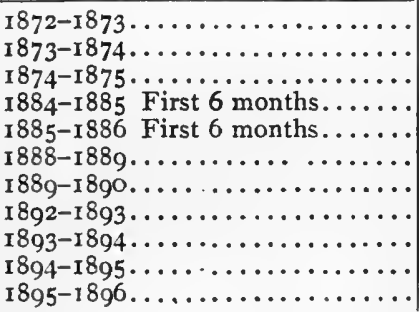 & $\begin{array}{r}\$ 5,231,255 \\
5,946,614 \\
5,028,636 \\
5,045,531 \\
5,145,736 \\
22,669,421 \\
29,080,276 \\
26,235,963 \\
14,351,785 \\
15,130,367 \\
20,145,763\end{array}$ & $\begin{array}{r}\$ 20,166,013 \\
23,282,299 \\
18,793,494 \\
11,893,342 \\
10,585,898 \\
40,024,894 \\
52,018,659 \\
43,413,131 \\
30,287,489 \\
34,000,440 \\
42,253,938\end{array}$ \\
\hline
\end{tabular}

Mexico, November, I896.

${ }^{1}$ This statement is corroborated by the following extract from an official report addressed to Lord Salisbury by Mr. Lionel Carden, British Consul-General at the City of Mexico, on the trade of Mexico during the year 1896 :

"The great increase in the imports of American goods this year must be regarded by British merchants and manufacturers as another warning that unless they soon make a serious effort, they will have to give up all hope of profiting by the increase in the Mexican import trade, and may even lose part of the very limited share of it they at present enjoy." 
TABLE SHOWING THE TOTAL EXPORTS FROM MEXICO AND THE EXPORTS TO THE UNITED STATES OF AMERICA FROM THE FISCAL YEAR I 877I 878 TO THE YEAR I $895-1896$.

\begin{tabular}{|c|c|c|c|c|c|c|c|}
\hline & \multicolumn{3}{|c|}{ EXPORTS TO THE UNITED STATES. } & \multicolumn{4}{|c|}{ TOTAL EXPORTS FROM MEXICO. } \\
\hline & $\begin{array}{l}\text { Precious } \\
\text { Metals. }\end{array}$ & Commodities. & Total. & $\begin{array}{l}\text { Precious } \\
\text { Metals. }\end{array}$ & Commodities. & & Total. \\
\hline $\begin{array}{l}1877-1878 \ldots \\
1878-1879 \ldots \\
1879-1880 \ldots \\
1880-1881 \ldots \\
1881-1882 \ldots \\
1882-188 \ldots \ldots \\
1883-1884 \ldots \\
1884-1885 \ldots \\
1885-1886 \ldots \\
1886-1887 \ldots \\
1887-1888 \ldots \\
1888-1889 \ldots \\
1889-1890 \ldots \\
1890-1891 \ldots \\
1891-1892 \ldots \\
1892-1893 \ldots \\
1893-1894 \ldots \\
1894-1895 \ldots \\
1895-1896 \ldots \\
\end{array}$ & $\begin{array}{r}8,664,052 \\
7,439,815 \\
6,848,231 \\
7,601,767 \\
5,451,731 \\
9,036,773 \\
12,822,241 \\
16,404,776 \\
15,496,336 \\
16,576,120 \\
17,915,116 \\
23,647,920 \\
24,098,147 \\
23,400,833 \\
30,447,566 \\
40,113,882 \\
36,681,273 \\
38,852,843 \\
51,071,661 \\
\end{array}$ & $\begin{array}{r}3,676,937 \\
4,741,724 \\
6,568,375 \\
6,556,424 \\
8,309,131 \\
7,702,325 \\
9,002,160 \\
9,448,285 \\
9,933,259 \\
11,152,595 \\
13,144,511 \\
17,205,443 \\
18,924,294 \\
21,582,253 \\
19,485,099 \\
23,723,761 \\
23,978,970 \\
28,470,143 \\
28,580,034 \\
\end{array}$ & $\begin{array}{r}12,340,989 \\
12,181,539 \\
13,416,606 \\
14,158,191 \\
13,760,862 \\
16,739,098 \\
21,824,401 \\
25,853,061 \\
25,429,595 \\
27,728,715 \\
31,059,627 \\
40,853,363 \\
43,022,441 \\
44,983,086 \\
49,932,665 \\
63,837,643 \\
60,660,243 \\
67,322,986 \\
79,651,695 \\
\end{array}$ & $\begin{array}{r}22,663,438 \\
21,528,938 \\
22,086,418 \\
19,354,704 \\
17,063,767 \\
29,628,658 \\
33,473,283 \\
33,774,051 \\
29,906,401 \\
33,560,503 \\
31,006,188 \\
38,785,275 \\
38,621,290 \\
36,256,372 \\
49,137,304 \\
56,504,305 \\
46,484,360 \\
52,535,854 \\
64,838,596 \\
\end{array}$ & $\begin{array}{r}6,622,223 \\
8,362,540 \\
10,577,136 \\
10,573,994 \\
12,019,526 \\
12,178,937 \\
13,252,213 \\
12,896,794 \\
13,741,316 \\
15,631,427 \\
17,879,720 \\
21,373,148 \\
23,878,099 \\
27,020,023 \\
26,330,411 \\
31,004,916 \\
32,858,927 \\
38,319,099 \\
40,178,306 \\
\end{array}$ & $\$$ & $\begin{array}{r}29,285,66 \mathrm{r} \\
29,891,478 \\
32,663,554 \\
29,923,698 \\
29,083,293 \\
41,807,595 \\
46,725,496 \\
46,670,845 \\
43,647,717 \\
49,191,930 \\
48,885,908 \\
60,158,423 \\
62,499,389 \\
63,276,395 \\
75,467,715 \\
87,509,221 \\
79,343,287 \\
90,854,953 \\
105,016,902 \\
\end{array}$ \\
\hline Total.... & $\$ 392,571,083$ & $\$ 272,185,723$ & $\$ 664,756,806$ & $\$ 677,209,705$ & $\$ 374,698,755$ & & $051,908,460$ \\
\hline
\end{tabular}

STATEMENT TAKEN FROM THE UNITED STATES TREASURY REPORTS OF THE COMMERCIAL TRANSACTIONS BETWEEN MEXICO AND THE UNITED STATES FROM 1826 TO 1850 .

\begin{tabular}{|c|c|c|c|}
\hline YEARS. & $\begin{array}{c}\text { EXPORTS FROM } \\
\text { MEXICO INTO } \\
\text { THE } \\
\text { UNITED STATES. }\end{array}$ & $\begin{array}{l}\text { EXPORTS FROM } \\
\text { THE UNITED } \\
\text { STATES INTO } \\
\text { MEXICO. }\end{array}$ & $\begin{array}{c}\text { TOTAL TRADE } \\
\text { BETWEEN } \\
\text { THE } \\
\text { TWO COUNTRIES. }\end{array}$ \\
\hline 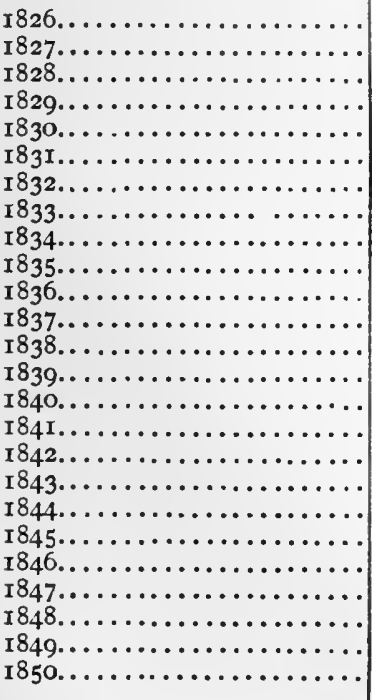 & $\begin{array}{r}3,916,000 \\
5,232,000 \\
4,814,000 \\
5,026,761 \\
5,235,241 \\
5,167,000 \\
4,293,954 \\
5,459,818 \\
8,666,668 \\
9,490,446 \\
5,615,819 \\
5,654,002 \\
3,127,153 \\
5,500,707 \\
4,175,000 \\
3,484,957 \\
1,996,694 \\
2,782,406 \\
2,387,000 \\
1,702,936 \\
1,836,621 \\
746,818 \\
1,581,247 \\
2,216,719 \\
2,135,336 \\
\end{array}$ & $\begin{array}{r}\$, 231,000 \\
4,163,000 \\
2,886,000 \\
2,331,151 \\
4,837,458 \\
6,178,000 \\
3,467,541 \\
5,408,091 \\
5,265,053 \\
9,029,221 \\
6,040,635 \\
3,880,323 \\
2,787,362 \\
2,164,097 \\
2,515,341 \\
2,036,620 \\
1,534,493 \\
1,471,937 \\
1,794,833 \\
1,152,331 \\
1,531,180 \\
692,428 \\
4,058,446 \\
2,090,869 \\
2,012,827 \\
\end{array}$ & $\begin{array}{r}\text { I0, I97,000 } \\
9,395,000 \\
7,700,000 \\
7,357,912 \\
10,072,699 \\
11,345,000 \\
7,761,495 \\
10,867,909 \\
13,931,721 \\
18,519,667 \\
11,656,454 \\
9,534,325 \\
5,914,515 \\
7,664,804 \\
6,690,341 \\
5,521,577 \\
3,531,187 \\
4,254,343 \\
4,181,833 \\
2,855,267 \\
3,367,801 \\
1,439,246 \\
5,639,693 \\
4,307,588 \\
4,148,163 \\
\end{array}$ \\
\hline $\begin{array}{c}\text { Total } \ldots \ldots \ldots \ldots \ldots \ldots \ldots \ldots \\
\text { Average } \ldots \ldots \ldots \ldots \ldots \ldots \ldots\end{array}$ & $\begin{array}{r}\$ 102,245,303 \\
\$ 4,089,812\end{array}$ & $\begin{array}{r}\$ 85,610,237 \\
\$ 3,424,409\end{array}$ & $\begin{array}{r}\$ 187,855,540 \\
\$ 7,514,222\end{array}$ \\
\hline
\end{tabular}


STATEMENT SHOWING THE COMMERCE IN MERCHANDISE BETWEEN THE UNITED STATES AND MEXICO, BY YEARS AND DECADES, FROM $\mathrm{I} 85 \mathrm{I}$ TO 1897 .

\begin{tabular}{|c|c|c|c|c|c|c|c|}
\hline \multirow{2}{*}{$\begin{array}{l}\text { YEAR } \\
\text { ENDING } \\
\text { JUNE } 3 \text {. }\end{array}$} & \multicolumn{3}{|c|}{ EXPORTS FROM THE UNITED STATES. } & \multicolumn{3}{|c|}{ IMPORTS INTO THE UNITED STATES. } & \multirow{2}{*}{$\begin{array}{c}\text { EXCESS OF } \\
\text { EXPORTS (-) } \\
\text { OR } \\
\text { IMPORTS (十). }\end{array}$} \\
\hline & Domestic. & Foreign. & Total. & Free. & Dutiable. & Total. & \\
\hline $\begin{array}{l}1851 \ldots \ldots \ldots \\
1852 \ldots \ldots \ldots \\
1853 \ldots \ldots \ldots \\
1854 \ldots \ldots \ldots \\
1855 \ldots \ldots \ldots \\
1856 \ldots \ldots \ldots \\
1857 \ldots \ldots \ldots \\
1858 \ldots \ldots \ldots \\
1959 \ldots \ldots \ldots \\
1860 \ldots \ldots \ldots \\
\text { Total }\end{array}$ & $\mid$\begin{tabular}{|l}
$\$ 1,014,690$ \\
$1,406,372$ \\
$2,529,770$ \\
$2,091,870$ \\
$2,253,368$ \\
$2,464,692$ \\
$3,017,640$ \\
$2,782,852$ \\
$2,252,162$ \\
$3,309,379$
\end{tabular} & $\begin{array}{r}567,093 \\
878,557 \\
1,029,054 \\
1,043,616 \\
668,236 \\
1,237,097 \\
597,566 \\
529,973 \\
667,580 \\
2,015,334 \\
\end{array}$ & $\begin{array}{r}1,581,783 \\
2,284,929 \\
3,558,824 \\
3,135,486 \\
2,921,604 \\
3,701,789 \\
3,615,206 \\
3,312,825 \\
2,919,742 \\
5,324,713 \\
\end{array}$ & $\begin{array}{r}27,666 \\
20,564 \\
4,148 \\
111,405 \\
17,508 \\
79,966 \\
62,307 \\
246,894 \\
234,112 \\
586,016\end{array}$ & $\begin{array}{r}693,120 \\
534,700 \\
751,952 \\
826,451 \\
887,242 \\
773,792 \\
964,566 \\
861,607 \\
1,009,972 \\
1,317,415\end{array}$ & \begin{tabular}{|r}
720,786 \\
555,264 \\
756,100 \\
937,856 \\
904,750 \\
853,758 \\
$1,026,873$ \\
$1,108,501$ \\
$1,244,084$ \\
$1,903,431$
\end{tabular} & $\begin{array}{r}-860,997 \\
-1,729,665 \\
-2,802,724 \\
-2,197,630 \\
-2,016,854 \\
-2,848,031 \\
-2,588,333 \\
-2,204,324 \\
-1,675,658 \\
-3,421,282 \\
\end{array}$ \\
\hline ro years.. & $\$ 23,122,79$ & $\$ 9,234,106$ & $\$ 3^{2,35}$ & $1,390,5^{86}$ & $\$ 8,620,817$ & $\$$ ro,o & $\$-22,345,49^{8}$ \\
\hline 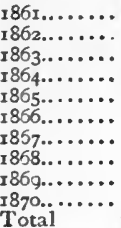 & \begin{tabular}{|r|}
$\$ 1,559,062$ \\
$1,840,720$ \\
$7,441,579$ \\
$7,765,133$ \\
$13,819,972$ \\
$3,701,599$ \\
$4,823,614$ \\
$5,048,420$ \\
$3,835,699$ \\
$4,544,745$ \\
\end{tabular} & $\begin{array}{r}651,364 \\
340,454 \\
1,579,045 \\
1,505,464 \\
2,530,867 \\
871,619 \\
572,182 \\
1,392,919 \\
1,047,408 \\
1,314,955 \\
\end{array}$ & $\begin{array}{r}\$ 2,210,426 \\
2,181,174 \\
9,020,624 \\
9,270,597 \\
16,350,839 \\
4,573,218 \\
5,395,796 \\
6,441,339 \\
4,883,107 \\
5,859,700 \\
\end{array}$ & $\begin{array}{l}253,703 \\
289,011 \\
446,070 \\
385,037 \\
369,915 \\
402,568 \\
402,779 \\
482,228 \\
511,319 \\
522,907 \\
\end{array}$ & $\begin{array}{r}632,409 \\
441,977 \\
2,597,812 \\
5,743,408 \\
5,850,959 \\
1,323,524 \\
669,157 \\
1,108,439 \\
1,824,845 \\
2,192,758 \\
\end{array}$ & $\begin{array}{r}886,112 \\
730,988 \\
3,043,882 \\
6,128,445 \\
6,220,874 \\
1,726,092 \\
1,071,936 \\
1,590,667 \\
2,336,164 \\
2,715,665 \\
\end{array}$ & $\begin{array}{r}\$-I, 324,314 \\
-1,450,186 \\
-5,976,742 \\
-3,142,152 \\
-10,129,965 \\
-2,847,126 \\
-4,323,860 \\
-4,850,672 \\
-2,546,943 \\
-3,144,035\end{array}$ \\
\hline ro years.. & $\$ 54,3^{80}, 543$ & $\$ 11,806,277$ & $\$ 66,186,820$ & $\$ 4,065,537$ & $\$ 22,385,288$ & $\$ 26,450,825$ & $\$-39,735,995$ \\
\hline $\begin{array}{l}871 \ldots \ldots \ldots \\
872 \ldots \ldots \ldots \\
873 \ldots \ldots \\
87 \ldots \ldots \ldots \\
874 \ldots \ldots \\
875 \ldots \ldots \\
876 \ldots \ldots \\
877 \ldots \ldots \ldots \\
878 \ldots \ldots \ldots \\
879 \ldots \ldots \ldots \\
880 \ldots \ldots\end{array}$ & $\mid \begin{array}{l}5,044,033 \\
3,420,658 \\
3,941,019 \\
4,016,148 \\
3,872,004 \\
4,700,978 \\
4,503,802 \\
5,811,429 \\
5,400,380 \\
6,065,974\end{array}$ & $\begin{array}{r}2,568,080 \\
2,122,931 \\
2,323,882 \\
1,930,691 \\
1,865,278 \\
1,499,594 \\
1,389,692 \\
1,649,275 \\
1,351,864 \\
1,800,519 \\
\end{array}$ & $\begin{array}{r}7,612,113 \\
5,543,589 \\
6,264,901 \\
5,946,839 \\
5,737,282 \\
6,200,572 \\
5,893,494 \\
7,460,704 \\
6,752,244 \\
7,866,493 \\
\end{array}$ & $\begin{array}{r}976,117 \\
1,156,257 \\
3,065,140 \\
3,026,661 \\
3,863,302 \\
3,920,633 \\
3,756,191 \\
3,723,281 \\
3,981,402 \\
4,852,659 \\
\end{array}$ & $\begin{array}{l}2,233,571 \\
2,846,663 \\
1,211,025 \\
1,319,703 \\
1,311,292 \\
1,229,939 \\
1,448,073 \\
1,528,221 \\
1,511,819 \\
2,356,934 \\
\end{array}$ & $\begin{array}{l}3,209,688 \\
4,002,920 \\
4,276,165 \\
4,346,364 \\
5,174,594 \\
5,150,572 \\
5,204,264 \\
5,251,502 \\
5,493,221 \\
7,209,593 \\
\end{array}$ & $\begin{array}{r}-4,402,425 \\
-1,540,669 \\
-1,988,736 \\
-1,600,475 \\
-562,688 \\
-1,050,000 \\
-689,230 \\
-2,209,202 \\
-1,259,023 \\
-656,900 \\
\end{array}$ \\
\hline roy & $\$ 46,776,42$ & 6 & $\$ 6$ & $\$ 3$ & $\$$ & $\$ 4$ & $\$-15,9$ \\
\hline 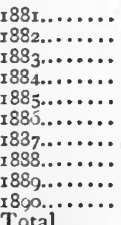 & $\begin{array}{r}9,198,077 \\
13,3^{24,505} \\
14,370,992 \\
11,089,603 \\
7,370,599 \\
6,856,077 \\
7,267,129 \\
9,242,188 \\
10,886,288 \\
12,666,108 \\
\end{array}$ & $\begin{array}{r}1,973,161 \\
2,158,077 \\
2,216,628 \\
1,614,689 \\
970,185 \\
881,546 \\
692,428 \\
655,584 \\
600,608 \\
619,179 \\
\end{array}$ & $\begin{array}{r}11,171,238 \\
15,482,582 \\
16,587,620 \\
12,704,292 \\
8,340,784 \\
7,737,623 \\
7,959,557 \\
9,897,772 \\
11,486,896 \\
13,285,287 \\
\end{array}$ & $\begin{array}{r}5,643,176 \\
5,310,796 \\
4,211,328 \\
5,334,689 \\
5,173,441 \\
6,808,757 \\
9,928,122 \\
11,042,772 \\
13,825,242 \\
15,536,100\end{array}$ & $\begin{array}{l}2,674,626 \\
3,151,103 \\
3,965,795 \\
3,681,797 \\
4,093,580 \\
3,879,215 \\
4,791,718 \\
6,287,117 \\
7,428,359 \\
7,154,815\end{array}$ & $\begin{array}{r}8,317,802 \\
8,461,899 \\
8,177,123 \\
9,016,486 \\
9,267,021 \\
10,687,972 \\
14,719,840 \\
17,329,889 \\
21,253,601 \\
22,690,915\end{array}$ & $\begin{array}{l}\$-2,8 \\
-7,0 \\
-8, \\
-3,6 \\
+0 \\
+2,5 \\
+6,7 \\
+7, \\
+9,7 \\
+9,4\end{array}$ \\
\hline ro years.. & $\$ 102,271$ & $\$ 12,382,085$ & $\$ 114,653,651$ & $\$ 82,814,423$ & $\$ 47,108,125$ & S129,922,548 & $\$+r 5,268,897$ \\
\hline $\begin{array}{l}1891 \ldots \ldots \ldots \\
1892 \ldots \ldots \ldots \\
1893 \ldots \ldots \ldots \\
1894 \ldots \ldots \ldots \\
1895 \ldots \ldots \ldots \\
1896 \ldots \ldots \ldots \\
1897 \ldots \ldots \ldots\end{array}$ & $\begin{array}{l}14,199,080 \\
13,696,531 \\
18,891,714 \\
12,441,805 \\
14,582,484 \\
18,686,797 \\
22,726,596 \\
\end{array}$ & & $\begin{array}{r}14,969,620 \\
14,293,999 \\
19,568,634 \\
12,842,149 \\
15,005,906 \\
19,450,256 \\
23,421,064\end{array}$ & $\begin{array}{r}23,364,519 \\
23,702,496 \\
27,145,469 \\
21,560,011 \\
12,903,789 \\
13,819,698 \\
13,990,017\end{array}$ & $\begin{array}{r}3,931,473 \\
4,405,029 \\
6,409,630 \\
7,166,995 \\
2,731,999 \\
3,636,479 \\
4,521,555\end{array}$ & $\begin{array}{l}27,295,992 \\
28,107,525 \\
33,555,099 \\
28,727,006 \\
15,635,788 \\
17,456,177 \\
18,511,57^{2}\end{array}$ & $\begin{array}{r}\$+12,326,372 \\
+13,813,526 \\
+13,986,465 \\
+15,884,857 \\
+629,882 \\
-1,994,079 \\
-4,909,492\end{array}$ \\
\hline 7 years.. & $5,225,00$ & $5,62 x$ & $\$ 119,551,628$ & $\$ 136,485,999$ & $\$ 32,803,160$ & $\$ 169,289,159$ & $\$+49,737,531$ \\
\hline
\end{tabular}

Treasury Department, Bureau of Statistics, Seftember 4, 1897.
Worthington C. Ford,

Chief of Bureau. 
STATEMENT SHOWING THE TOTAL COMMERCE BETWEEN THE UNITED STATES AND MEXICO, BY YEARS AND DECADES FROM I85I TO 1897 .

\begin{tabular}{|c|c|c|c|c|c|c|c|}
\hline \multirow{2}{*}{$\begin{array}{l}\text { YEAR } \\
\text { ENDING } \\
\text { JUNE } 30 .\end{array}$} & \multicolumn{3}{|c|}{ EXPORTS FROM THE UNITED STATES. } & \multicolumn{3}{|c|}{ IMPORTS INTO THE UNITED STATES. } & \multirow{2}{*}{$\begin{array}{r}\text { EXCESS OF } \\
\text { EXPORTS }(-) \\
\text { OR } \\
\text { IMPORTS }(+)\end{array}$} \\
\hline & $\begin{array}{c}\text { Mer- } \\
\text { chandise. }\end{array}$ & $\begin{array}{r}\text { Gold } \\
\text { Sil }\end{array}$ & Total. & cha & nd & Total. & \\
\hline \multirow[t]{2}{*}{$\begin{array}{c}1851 \ldots \ldots \ldots \\
1852 \ldots \ldots \ldots \\
1853 \ldots \ldots \\
1854 \ldots \ldots \ldots \\
1855 \ldots \ldots \ldots \\
1856 \ldots \ldots \ldots \\
1857 \ldots \ldots \ldots \\
1858 \ldots \ldots \ldots \\
1859 \ldots \ldots \ldots \\
1860 \ldots \ldots \\
\text { Total } \\
\text { 10 years... }\end{array}$} & $\begin{array}{r}\$ 1,581,783 \\
2,284,929 \\
3,558,824 \\
3,135,486 \\
2,921,604 \\
3,701,789 \\
3,615,206 \\
3,312,825 \\
2,919,742 \\
5,324,713 \\
\end{array}$ & $\begin{array}{r}\$ 2,652 \\
3,255 \\
1,734 \\
528 \\
1,200 \\
450 \\
\ldots \ldots \ldots \\
3,000 \\
72,804 \\
29,360 \\
\end{array}$ & \begin{tabular}{|}
$\$ 1,584,435$ \\
$2,288,184$ \\
$3,560,558$ \\
$3,136,014$ \\
$2,922,804$ \\
$3,702,239$ \\
$3,615,206$ \\
$3,315,825$ \\
$2,992,546$ \\
$5,354,073$ \\
\end{tabular} & $\begin{array}{r}720,786 \\
555,264 \\
756,100 \\
937,856 \\
904,750 \\
853,758 \\
1,026,873 \\
1,108,501 \\
1,244,084 \\
1,903,43 \mathrm{r} \\
\end{array}$ & $\begin{array}{r}\$ 1,083,993 \\
1,093,942 \\
1,411,885 \\
2,525,334 \\
1,978,080 \\
2,714,923 \\
4,958,984 \\
4,368,964 \\
4,095,890 \\
5,032,441\end{array}$ & $\begin{array}{l}\$ 1,804,779 \\
1,649,206 \\
2,167,985 \\
3,463,190 \\
2,882,830 \\
3,568,681 \\
5,985,857 \\
5,477,465 \\
5,339,974 \\
6,935,872 \\
\end{array}$ & $\begin{array}{r}+220,344 \\
-638,978 \\
-1,392,573 \\
+327,176 \\
-39,974 \\
-133,55^{2} \\
+2,370,651 \\
+2,161,640 \\
+2,347,428 \\
+1,581,799 \\
\end{array}$ \\
\hline & $\$ 32,356,901$ & $\$ 11_{4}, 983$ & $\$ 32,471,884$ & $\$ 10,01 r, 403$ & $\$ 29,264,436$ & $\$ 39,275,839$ & 803,95 \\
\hline $\begin{array}{l}\ldots \ldots \\
\ldots \ldots \\
\ldots \ldots \\
\ldots \ldots \\
\ldots \ldots \\
\ldots \ldots \\
\ldots \ldots \\
\ldots \ldots\end{array}$ & $\begin{array}{r}2,210,426 \\
2,181,174 \\
0,020,624 \\
9,270,597 \\
16,350,839 \\
4,573,218 \\
5,395,796 \\
6,441,339 \\
4,883,107 \\
5,859,700\end{array}$ & $\begin{array}{r}5,464 \\
\ldots . . . \\
51,588 \\
3,410,957 \\
664,241 \\
15,000 \\
56,452 \\
12,924 \\
2,000 \\
15,696\end{array}$ & $\begin{array}{r}\$ 2,215,890 \\
2,181,174 \\
9,072,212 \\
12,681,554 \\
17,015,080 \\
4,588,218 \\
5,452,248 \\
6,454,263 \\
4,885,107 \\
5,875,396\end{array}$ & $\begin{array}{r}886,112 \\
730,988 \\
3,040,882 \\
6,128,445 \\
6,220,874 \\
1,726,092 \\
1,071,936 \\
1,590,667 \\
2,336,164 \\
2,715,665\end{array}$ & $\begin{array}{r}\$ 2,803,101 \\
1,953,864 \\
1,485,702 \\
1,755,946 \\
1,133,299 \\
2,429,511 \\
2,849,038 \\
4,525,255 \\
4,895,842 \\
10,383,366\end{array}$ & $\begin{array}{r}3,689,213 \\
2,684,852 \\
4,526,5^{8} 4 \\
7,884,391 \\
7,354,173 \\
4,155,603 \\
3,920,974 \\
6,115,922 \\
7,232,006 \\
13,099,031\end{array}$ & $\begin{array}{l}3,323 \\
3,678 \\
5,628 \\
7,163 \\
50,907 \\
32,615 \\
31,274 \\
38,341 \\
6,899 \\
3,635\end{array}$ \\
\hline s.. & $\$ 66,186,820$ & $\$ 4,234,322$ & $\$ 70,421,142$ & $\$ 26,447,825$ & $\$ 34,214,924$ & $\$ 60,662,749$ & $-9,758,39$ \\
\hline $\begin{array}{l}1871 \ldots \ldots \ldots \\
1872 \ldots \ldots \ldots \\
1873 \ldots \ldots \ldots \\
1874 \ldots \ldots \ldots \\
1875 \ldots \ldots \ldots \\
1876 \ldots \ldots \ldots \\
1877 \ldots \ldots \ldots \\
1878 \ldots \ldots \ldots \\
1879 \ldots \ldots \ldots \\
1880 \ldots \ldots \ldots\end{array}$ & $\begin{array}{r}7,612,113 \\
5,543,5^{89} \\
6,264,901 \\
5,946,839 \\
5,737,282 \\
6,200,572 \\
5,893,494 \\
7,460,704 \\
6,752,244 \\
7,866,493 \\
\end{array}$ & $\begin{array}{r}\$ 38,500 \\
35,000 \\
165,262 \\
57,531 \\
33,501 \\
7,600 \\
5,239 \\
32,180 \\
9,040 \\
3,371 \\
\end{array}$ & $\begin{array}{r}7,650,613 \\
5,578,589 \\
6,430,163 \\
6,004,370 \\
5,770,783 \\
6,208,172 \\
5,898,733 \\
7,492,884 \\
6,76 \mathrm{r}, 284 \\
7,869,864 \\
\end{array}$ & $\begin{array}{r}\$ 3,209,688 \\
4,002,920 \\
4,276,165 \\
4,346,364 \\
5,174,594 \\
5,150,572 \\
5,204,264 \\
5,251,502 \\
5,493,221 \\
7,209,593 \\
\end{array}$ & $\begin{array}{r}\$ 14,301,475 \\
4,504,204 \\
12,154,060 \\
8,893,541 \\
6,460,389 \\
7,355,181 \\
10,240,319 \\
8,394,146 \\
8,554,598 \\
9,115,824 \\
\end{array}$ & \begin{tabular}{|r|}
$\mathbf{1 7}, 511,163$ \\
$8,507,124$ \\
$16,430,225$ \\
$13,239,905$ \\
$11,634,983$ \\
$12,505,753$ \\
$15,444,583$ \\
$13,645,648$ \\
$14,047,819$ \\
$16,325,4^{17}$ \\
\end{tabular} & $\begin{array}{l}9,860,550 \\
2,928,535 \\
0,000,062 \\
7,235,535\end{array}$ \\
\hline irs. & $\$ 55,278,231$ & $\$ 387,224$ & $\$ 5_{5}, 665,455$ & $\$ 49,318,883$ & $\$ 99,973,737$ & $\$ 139,292,620$ & $73,627,165$ \\
\hline $\begin{array}{l}1881 . \ldots \ldots \ldots \\
1882 \ldots \ldots \ldots \\
1883 \ldots \ldots \ldots \\
1884 \ldots \ldots \ldots \\
1885 \ldots \ldots \ldots \\
1886 \ldots \ldots \ldots \\
1887 \ldots \ldots \ldots \\
1888 \ldots \ldots \ldots \\
1889 \ldots \ldots \ldots \\
1890 \ldots \ldots \ldots\end{array}$ & $\begin{array}{r}\$ 11,171,238 \\
15,482,582 \\
16,587,620 \\
12,704,292 \\
8,340,784 \\
7,737,623 \\
7,959,557 \\
9,897,772 \\
11,486,896 \\
13,285,287 \\
\end{array}$ & \begin{tabular}{|r}
$\mathbf{1}, 500$ \\
18,446 \\
96,964 \\
335,635 \\
79,406 \\
110,035 \\
279,812 \\
319,408 \\
176,616 \\
240,912
\end{tabular} & $\begin{array}{r}\mathbf{x} \mathbf{1}, 1 \\
15,5 \\
16,6 \\
13,0 \\
8,4 \\
7,8 \\
8,2 \\
10,2 \\
11,6 \\
13,5 \\
\end{array}$ & \begin{tabular}{|r|}
$8,317,802$ \\
$8,461,899$ \\
$8,177,123$ \\
$9,016,486$ \\
$9,267,021$ \\
$10,687,972$ \\
$14,719,840$ \\
$17,329,889$ \\
$21,253,601$ \\
$22,690,915$
\end{tabular} & $\begin{array}{r}9,136,324 \\
6,631,938 \\
9,782,986 \\
13,015,901 \\
14,919,611 \\
16,935,396 \\
14,855,765 \\
14,032,637 \\
17,557,248 \\
18,155,809 \\
\end{array}$ & \begin{tabular}{|r|}
$17,454,126$ \\
$15,093,837$ \\
$17,960,109$ \\
$22,032,387$ \\
$24,186,632$ \\
$27,623,368$ \\
$29,575,605$ \\
$31,362,526$ \\
$38,810,849$ \\
$40,846,724$
\end{tabular} & $\begin{array}{l}388 \\
191 \\
525 \\
460 \\
442 \\
710 \\
236 \\
346 \\
337 \\
525 \\
\end{array}$ \\
\hline rs.. & $\$ I 14,653,651$ & $\$ r, 658,734$ & \$I16,312,385 & \$r $29,922,548$ & $\$_{135}, 023,615$ & $\$ 264,946,163$ & $\$+148,633,77^{8}$ \\
\hline $\begin{array}{l}\ldots \ldots \\
\ldots \\
\cdots \\
\cdots \\
\cdots \\
\cdots\end{array}$ & \begin{tabular}{|r} 
14,969,620 \\
$14,293,999$ \\
$19,568,634$ \\
$12,842,149$ \\
$15,005,906$ \\
$19,450,256$ \\
$23,421,064$
\end{tabular} & \begin{tabular}{|l}
$\$ 227,734$ \\
168,584 \\
473,942 \\
708,932 \\
551,064 \\
926,560 \\
114,149
\end{tabular} & \begin{tabular}{|r|}
$\$ 15,197,354$ \\
$14,462,583$ \\
$20,042,576$ \\
$13,551,081$ \\
$15,556,970$ \\
$20,376,816$ \\
$23,535,213$ \\
\end{tabular} & $\begin{array}{r}27,295,992 \\
28,107,525 \\
33,555,099 \\
28,727,006 \\
15,635,788 \\
17,456,177 \\
18,511,572\end{array}$ & $\begin{array}{r}\$ 14,297,431 \\
19,174,034 \\
22,951,604 \\
12,790,199 \\
9,644,160 \\
29,166,241 \\
12,202,794 \\
\end{array}$ & $\begin{array}{r}\$ 41,593,423 \\
47,281,559 \\
56,506,703 \\
41,517,205 \\
25,279,948 \\
46,622,418 \\
30,714,366 \\
\end{array}$ & $\begin{array}{r}+26,396,069 \\
+32,818,976 \\
+36,464,127 \\
+27,966,124 \\
+9,722,978 \\
+26,245,602 \\
+7,179,153 \\
\end{array}$ \\
\hline $7 y$ & $\$ 119,551,628$ & $\$ 3,170,9 \epsilon_{5}$ & $\$ 122,722,593$ & $\$ 169,289,159$ & $\$ 120,226,463$ & $\$ 289,5^{1} 5$ & $\$+166,793,029$ \\
\hline
\end{tabular}




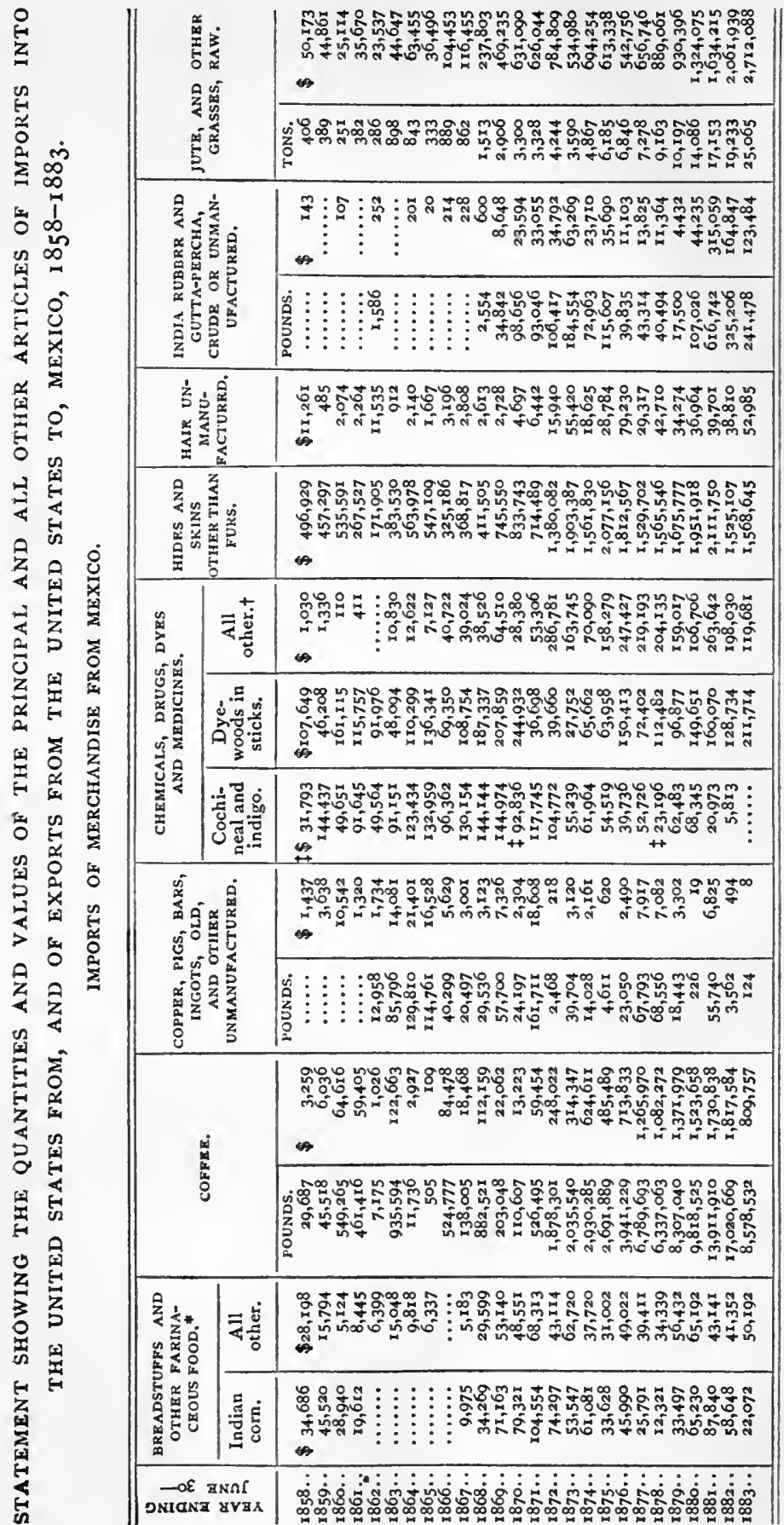


Trade witb the United states.

I 77

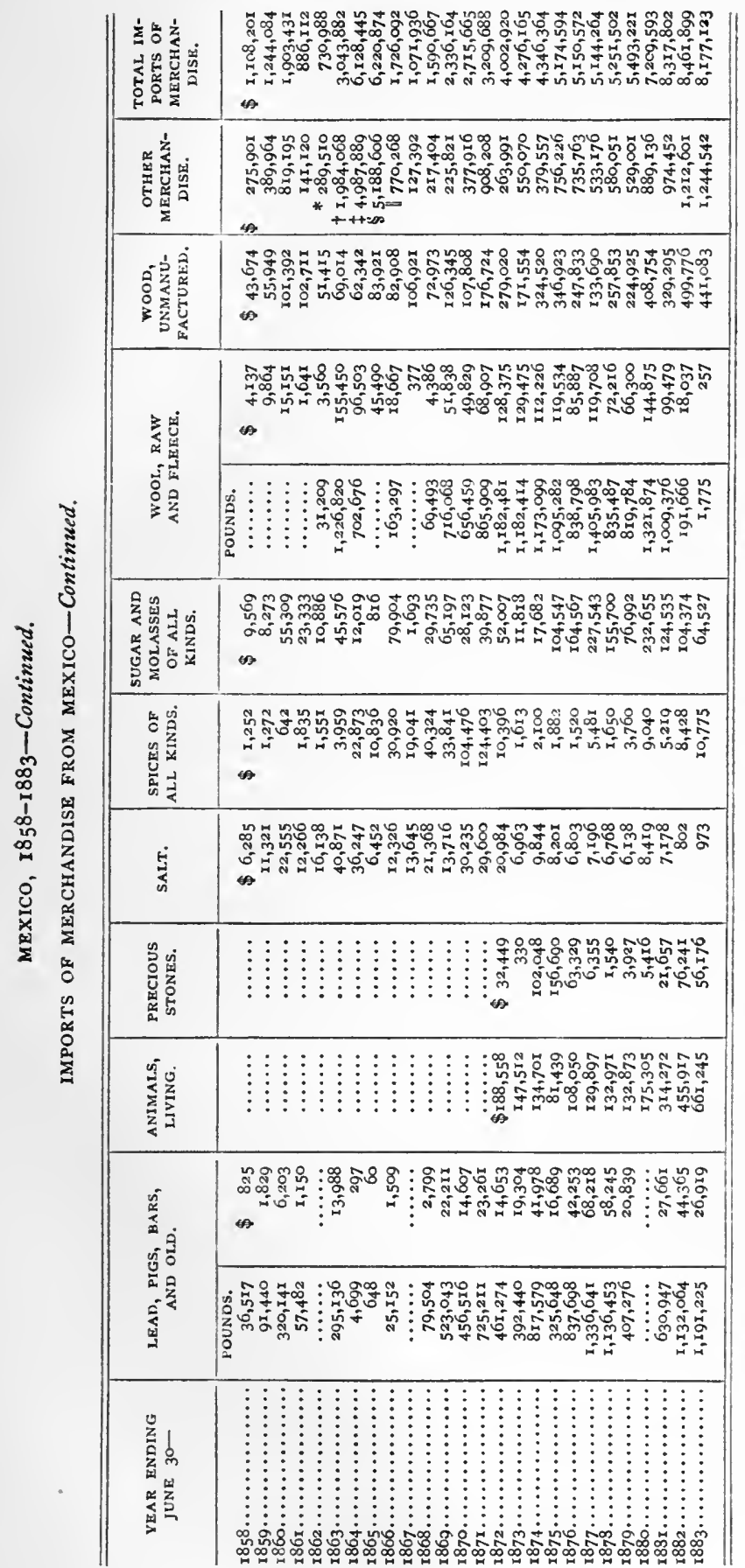




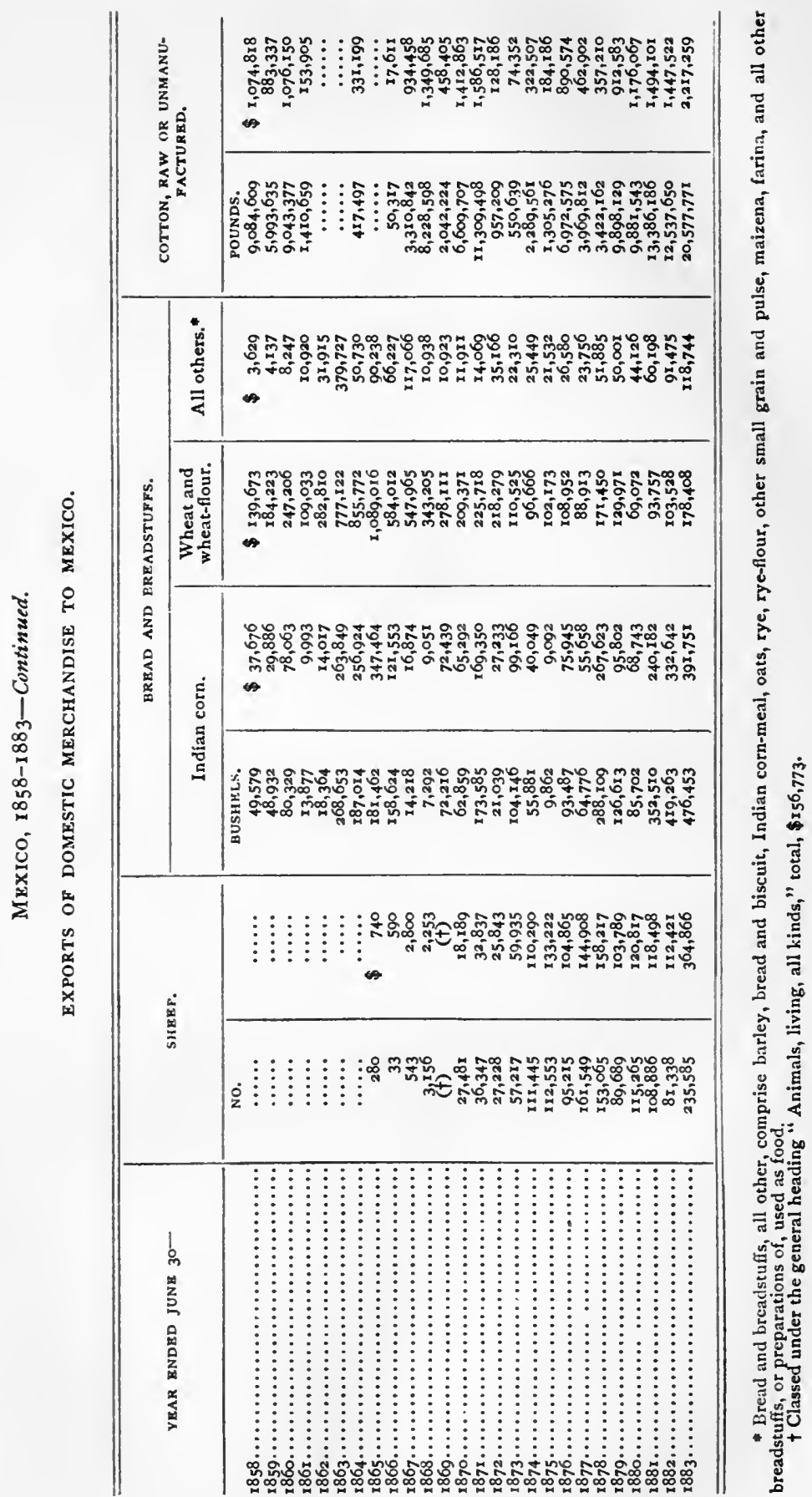




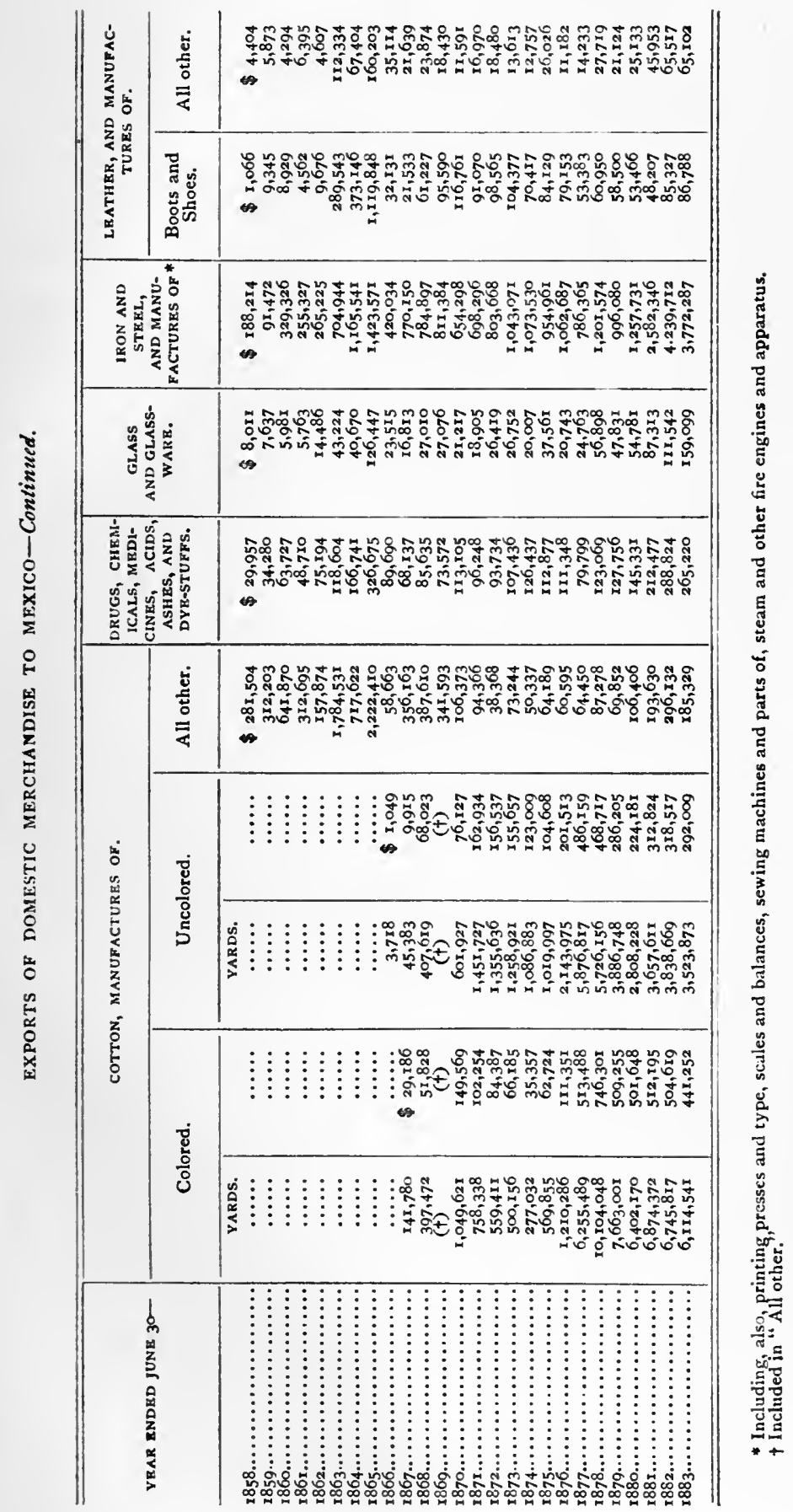




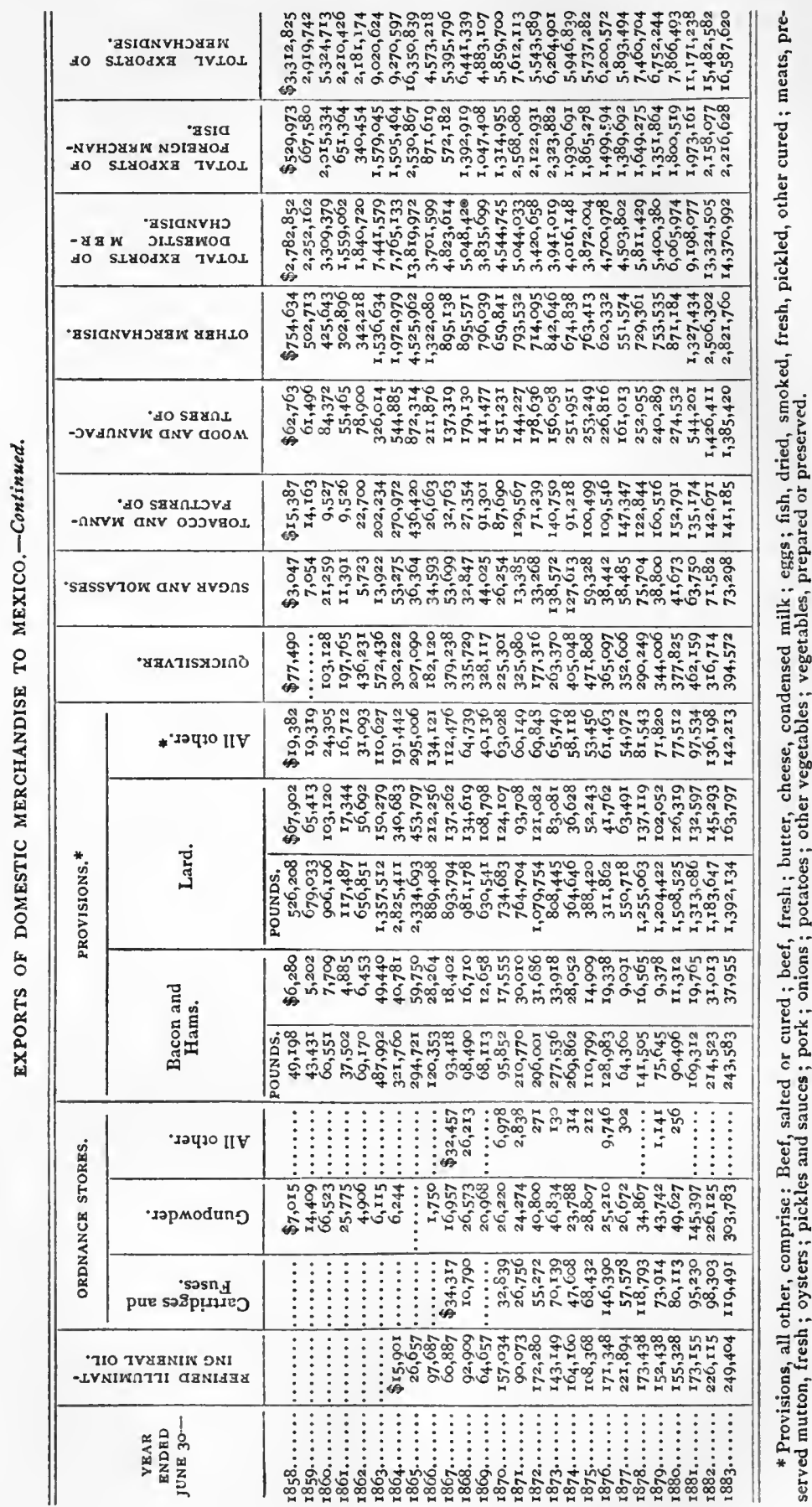


Trade witb the United Itates.

I 8 I

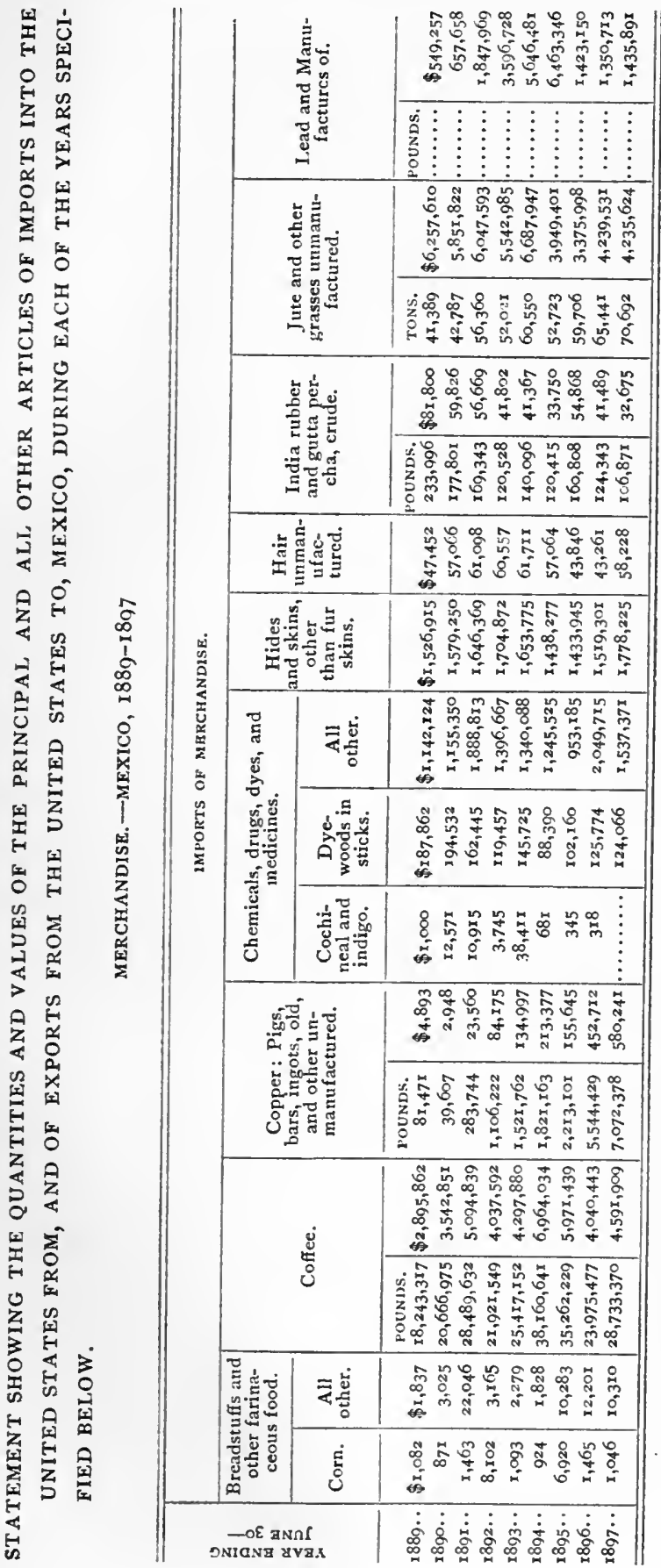



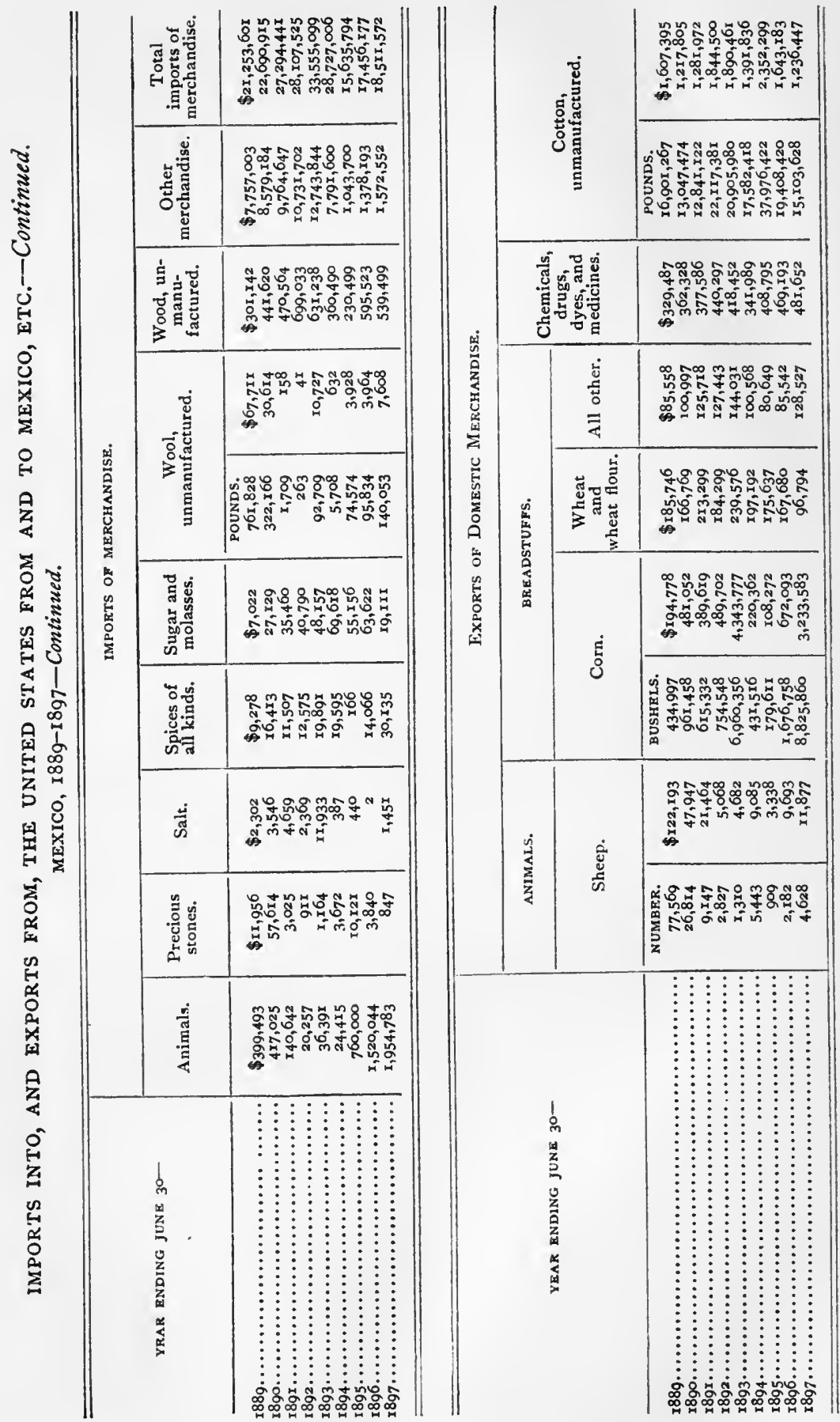


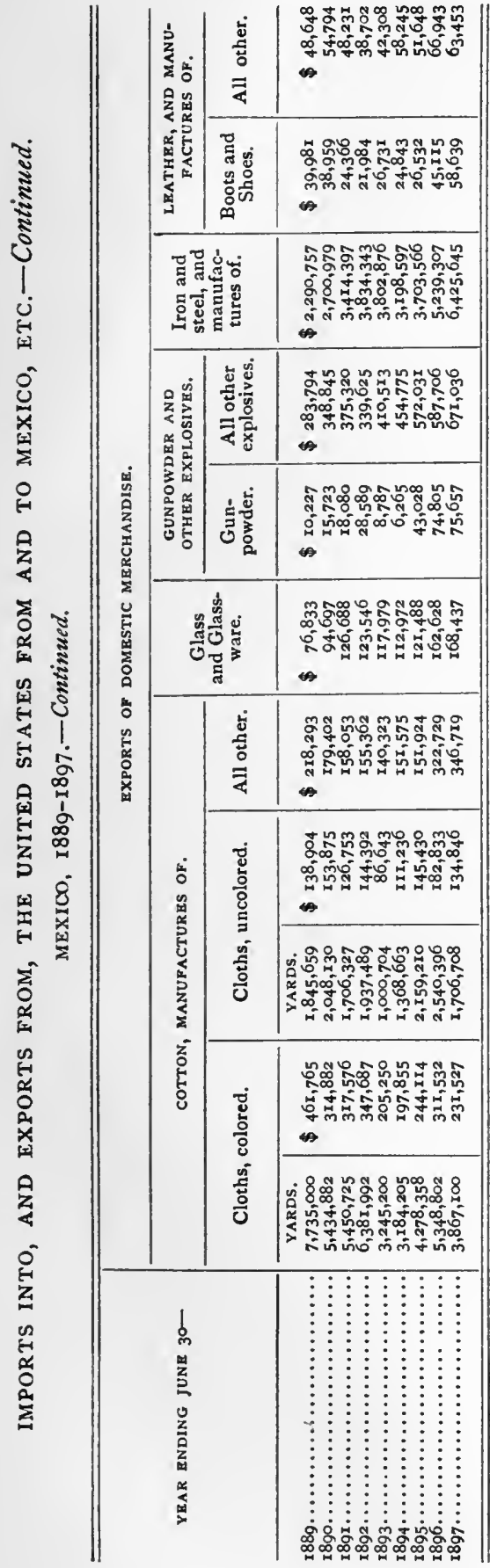

\begin{tabular}{|c|c|c|c|}
\hline \multicolumn{3}{|c|}{ 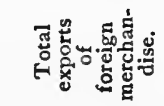 } & 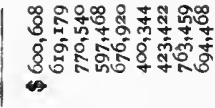 \\
\hline & \multicolumn{2}{|c|}{ 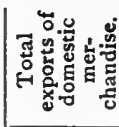 } & 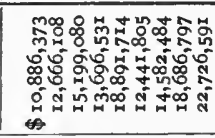 \\
\hline & \multicolumn{2}{|c|}{ 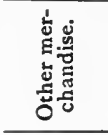 } & 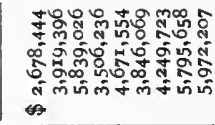 \\
\hline & \multicolumn{2}{|c|}{ 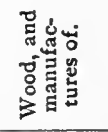 } & 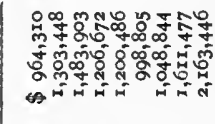 \\
\hline & \multicolumn{2}{|c|}{ 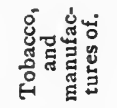 } & 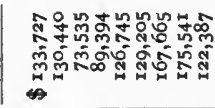 \\
\hline 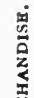 & \multicolumn{2}{|c|}{ 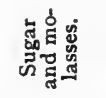 } & 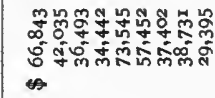 \\
\hline t: & \multicolumn{2}{|c|}{ 密它 } & 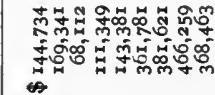 \\
\hline 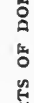 & \multirow{5}{*}{ 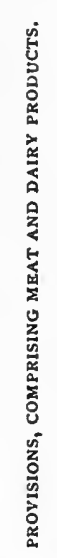 } & 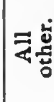 & 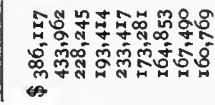 \\
\hline 递 & & \multirow{2}{*}{ 苟 } & 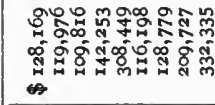 \\
\hline & & & 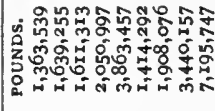 \\
\hline & & \multirow{2}{*}{ 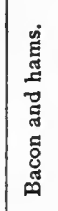 } & 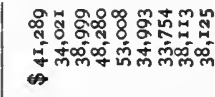 \\
\hline & & & 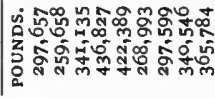 \\
\hline & \multicolumn{2}{|c|}{ 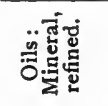 } & 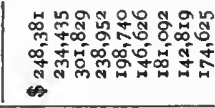 \\
\hline & \multicolumn{2}{|c|}{ 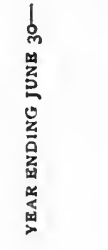 } & ơ \\
\hline
\end{tabular}


Increase of trade during the year 1896-97.-The data given in the chapter on Foreign Trade contain detailed statements of the amount of commodities and precious metals exported from Mexico into the United States during the last ten years, and I refer, therefore, to the same, those desiring more detailed information on that subject.

I give, however, a statement of the leading merchandise imported from Mexico into the United States, during the last fiscal year, compared with the fiscal year ended June 30,1896 , embracing only such imports as are not specifically stated in the data taken from the official reports of the United States Statistical Bureau, and which appear on pages 176 and 177 . The following data, also taken from the last official report of the same Bureau, shows a comparative increase of trade.

LEADING MERCHANDISE IMPORTS FROM MEXICO.

\begin{tabular}{|c|c|c|}
\hline & $\begin{array}{c}\text { FISCAL YEAR } \\
1896-1897 .\end{array}$ & $\begin{array}{c}\text { FISCAL YEAR } \\
\text { I } 895-I 896 .\end{array}$ \\
\hline 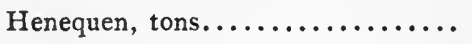 & 62,839 & 51,167 \\
\hline 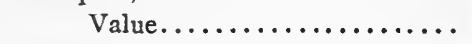 & $\$ 3,809,415$ & $\$ 3,339,180$ \\
\hline Ixtle fibre, tons. $\ldots \ldots \ldots \ldots \ldots \ldots \ldots$ & 6,313 & 12,207 \\
\hline Value................. & $\$ 335,84 \mathrm{I}$ & $\$ 717,585$ \\
\hline 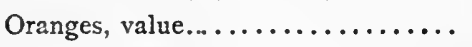 & $\$ 258,340$ & $\$ 2 \mathrm{I} 2,9 \mathrm{I} 3$ \\
\hline Tobacco, lbs.................... & 749,560 & 93,197 \\
\hline Value................... & $\$ 297,262$ & $\$ 28,025$ \\
\hline Mahogany, feet................ & 8,791 & 10,654 \\
\hline Value................ & $\$ 321,800$ & $\$ 4 I 4,8 I 7$ \\
\hline 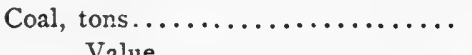 & 99,760 & 72,056 \\
\hline Value....... & $\$ 218,456$ & $\$ 146,813$ \\
\hline
\end{tabular}

I also append a similar statement of some of the articles exported from the United States into Mexico during the last fiscal year, compared with the previous one, ended June 30,1896 , embracing only such exports as are not specifically stated in the data taken from the official reports of the United States Statistical Bureau, appearing on pages 178 to $I 83$, and which I also take from the last official report of the same Bureau. When it is taken into consideration that the Mexican imports from the United States during the last fiscal year were made on a falling silver market, the annexed statement shows a considerable financial strength.

EXPORTS FROM THE UNITED STATES TO MEXICO.

(Fiscal year 1896-97 and preceding year.)

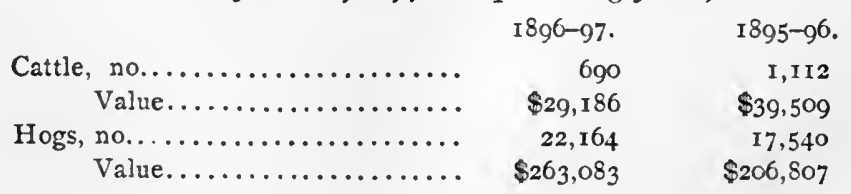




\begin{tabular}{|c|c|c|}
\hline & I $896-97$. & $1895-96$. \\
\hline Agricultural implements.......... & $\$ 130,825$ & $\$$ II 9,838 \\
\hline 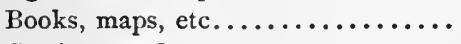 & $\$ 161,143$ & $\$ 107,384$ \\
\hline 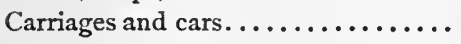 & $\$ 6$ I 5,468 & $\$ 687,425$ \\
\hline Coal and coke, tons................ & 2 I9, III & I 21,269 \\
\hline Value.................. & $\$ 643,715$ & $\$ 377,469$ \\
\hline 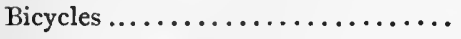 & $\$ 73$, II 7 & $\$ 24,278$ \\
\hline 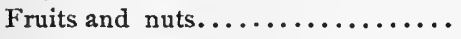 & $\$ 72,654$ & $\$ 78,497$ \\
\hline 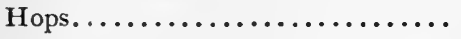 & $\$ 55,610$ & $\$ S, 289$ \\
\hline 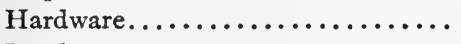 & $\$ 2,874,283$ & $\$ 2,455,400$ \\
\hline 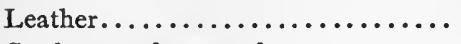 & $\$ 16,456$ & $\$ 24,014$ \\
\hline Crude petroleum, gals........... & $7,090,853$ & $6,779,059$ \\
\hline Value.................... & $\$ 349,021$ & $\$ 392,5$ IO \\
\hline Refined petroleum, gals.......... & 836,628 & 631,147 \\
\hline $\begin{array}{l}\text { Value } \ldots \ldots \ldots \ldots \ldots \ldots \ldots \\
\quad \text { (Includes lubricating oil.) }\end{array}$ & $\$ 174,107$ & $\$ 142,761$ \\
\hline Cotton-seed oil, gals............. & $\mathrm{I}, 6 \mathrm{I} 6,407$ & $I, 588,504$ \\
\hline 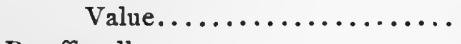 & $\$ 320,496$ & $\$ 337,892$ \\
\hline 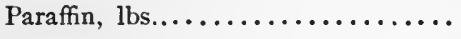 & $2,888,475$ & $2,975,476$ \\
\hline Value.................. & $\$ 144,805$ & $\$ 163,644$ \\
\hline 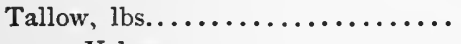 & 997,216 & $1,783,788$ \\
\hline 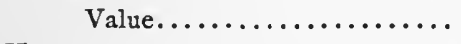 & $\$ 36,561$ & $\$ 77,050$ \\
\hline 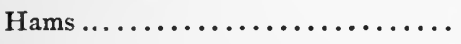 & $\$ 28,976$ & $\$ 29,487$ \\
\hline 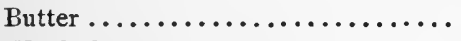 & $\$ 40,089$ & $\$ 33,169$ \\
\hline 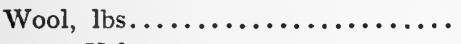 & $I, 698,952$ & $2,605,150$ \\
\hline Value.................. & $\$ 140,609$ & $\$ 238,316$ \\
\hline
\end{tabular}

Tropical Products Supplied by Mexico to the United States. - It will be interesting to state in what proportion Mexican imports of tropical products figure in the total imports of said commodities into this country.

From 1892 to 1896 the annual average of importation of vanilla beans into the United States was 205, I97 pounds, of which Mexico furnished 142,727 pounds, or $69 \frac{1}{2}$ per cent. Mexico receives for her vanilla crop, annually, $\$ 640,000$ gold.

Mexico's average annual exportation of coffee to the United States for the past five years was $28,927,410$ pounds, or 4.8 per cent., of the total American purchase of coffee, Brazil furnishing 70 per cent., Central America 7.6 per cent., Venezuela 6.4 per cent., and the British West Indies r.I per cent. There is plenty of room for the Mexican coffee-growing industry to expand. Mexico's fine flavored, mild coffees are steadily gaining in favor in the United States.

In henequen, or sisal grass, Mexico takes the leading place in the import trade of the United States, selling, of the total received there, 98.I per cent. The average annual importation for the past five years was 50, I 29 tons, of which Mexico furnished 49, I95, Cuba 277, British Australia 386 , and all other countries $27 \mathrm{r}$. Mexico received a yearly average, during the five years, for her henequen, of $\$ 4,218,267$, gold. All of which went to the State of Yucatan. 
In sugar, Mexico holds but an insignificant place in the American importation, which showed an annual average, during the past five years, of 3,827,799,48I pounds, Cuba furnishing 46.5 per cent. and Hawaii 7.9 per cent.

We could expand very largely our sugar production and supply this country with almost all of that product, but as sugar is produced in Louisiana and as Hawaii is likely to belong to the United States the protective policy of this country will not allow us to supply the United States with that commodity on a large scale.

Mexico is sending on an average every year, $1,400,000$ pounds of wool to the United States. In 1892 she exported but 190 pounds.

The United States takes, annually, an average of $50,493,000$ pounds of goat skins, of which Mexico furnishes 3,007,000, or 5.9 per cent. Of other hides and skins the United States imports $167,993,000$ pounds, Mexico's share being 4.3 per cent.

The cattle trade of Mexico with the United States increased considerably under the liberal provisions of the Wilson Bill, which taxed cattle with 20 per cent. ad valorem. The following statement shows how large the increase of that trade was under that bill :

CATTLE EXPORTED TO THE UNITED STATES.

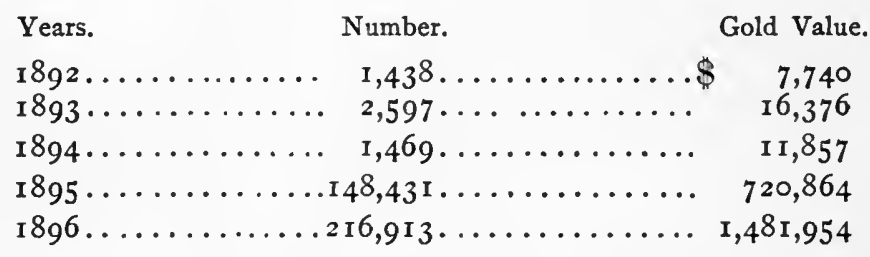

(Fiscal years ended June 3 oth.)

Mexico has been for at least two years the most important source of supply to the United States for cattle purchased abroad, Canada furnishing, in 1896 , cattle to the value of but $\$ 18,902$, and the United Kingdom $\$ 6,684$. The cattle trade is one in which American, as well as Mexican capital is embarked, but it will be considerably diminished if not completely destroyed under the highly protective tariff.

\section{COINAGE.}

In the chapter on Mining I gave a concise statement of the silver and gold coined in Mexico from the time of its discovery by the Spaniards to the fiscal year ended June $3 \circ, 1896$, and it appears from the same that the total coinage of silver amounted to $\$ 3,398,664,400$.

According to the report of the Director of the Mint (page 347) on the "Production of Precious Metals in the United States during 
the Calendar Year I 895," the last one out as this paper goes to press, the total production of silver of the world from 1493 to 1895 is \$10,$345,688,700$, the Mexican coinage being over one-third of the whole.

It must be borne in mind that that statement embraces, so far as Mexico is concerned, only the silver coined, and it does not take into consideration the silver used in the arts, which used to be a considerable amount, as almost every well-to-do Mexican had forks, spoons, plates and other table ware and household articles of solid silver. It does not embrace either such silver as was smuggled in bullion, which, considering the large extent of the Mexican sea coast, its scanty population and the general demoralization during our civil wars represents a very large amount. It can, therefore, be safely stated that the production of silver in Mexico, not coined, represents at least from one-fourth to one-third of the amount coined. Therefore, the production of silver by Mexico may be safely estimated at from $\$ 5,000,000,000$, to $\$ 6,000,000,000$, which is about one-half of the total product of the world.

The following statement shows the amount of silver coined by the several mints of Mexico from their establishment to June 30, I895, stating the years in which the coinage was made:

COINAGE BY THE MEXICAN MINTS FROM THEIR ESTABLISHMENT IN I535 TO JUNE 3O, 1895 .

\begin{tabular}{|c|c|c|}
\hline PERIOD OF COINAGE. & MINTs. & COINAGE. \\
\hline $1868-1895 \ldots$ & Alamos. & $\$ 22,828,869$ \\
\hline$I 863-1866 \ldots$ & Catorce....... & $1,321,545$ \\
\hline $1811-1895 \ldots \ldots$ & Chihuahua............ & $62,465,756$ \\
\hline $1846-1895 \ldots \ldots \ldots \ldots \ldots$ & 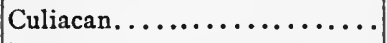 & $46,438,169$ \\
\hline $1811-1895 \ldots \ldots \ldots \ldots$ & 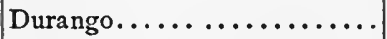 & $67,128,366$ \\
\hline $1812-1895 \ldots \ldots$ & 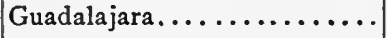 & $64,127,846$ \\
\hline $1844-1849 \ldots \ldots$ & Guadalupe y Calvo.. & $4,375,062$ \\
\hline I812-1895 ..... & Guanajuato............ & $307,364,150$ \\
\hline $1852-1895 \ldots \ldots \ldots \ldots$ & 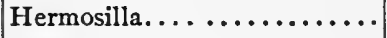 & $19,659,506$ \\
\hline $1535-1895 \ldots \ldots$. & 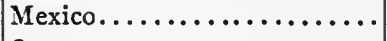 & 2,453, I IO, I Io \\
\hline $1857-1893 \ldots$ & Oaxaca................. & $5,761,045$ \\
\hline $1827-1893 \ldots$ & San Luis Potosi... & $\mathrm{I} 13, \mathrm{r} 43,358$ \\
\hline $1810-1812 \ldots$ & Sombrerete...... & $1,551,248$ \\
\hline $1827-1830 \ldots$ & Tlalpam........ & $1,162,660$ \\
\hline $1810-1895 \ldots$. & Zacatecas........... & $350,34 I, 499$ \\
\hline From 1535 to $1895 .$. & Total. & $\$ 3,520,779,189$ \\
\hline
\end{tabular}

I give a statement of the production of gold and silver in Mexico in the fiscal years $1879-1880,1889-1890$ and $1894-1895$, which shows 
a considerable increase in each of those years, and this statement only represents such amounts of the precious metals as were either exported in bullion or taken to the mints, and not the production that is otherwise disposed of.

\section{PRODUCTION OF GOLD AND SILVER IN MEXICO IN THE FISCAL YEARS I 879-I 880 , I 889-I 890 AND I $894-1895$.}

\begin{tabular}{|c|c|c|c|c|c|c|c|c|c|}
\hline & \multicolumn{3}{|c|}{$1879-1880$} & \multicolumn{3}{|c|}{$188 q-1890}$. & \multicolumn{3}{|c|}{$1894-1895}$. \\
\hline & $\begin{array}{l}\text { Kilo- } \\
\text { grams. }\end{array}$ & 㝕 & Value. & $\begin{array}{c}\text { Kilo- } \\
\text { grams. }\end{array}$ & है & Value. & $\begin{array}{l}\text { Kilo- } \\
\text { grams. }\end{array}$ & हैं & Value. \\
\hline $\begin{array}{l}\text { Gold coined........ } \\
\text { Gold exported..... }\end{array}$ & $\begin{array}{l}772 \\
622 \\
\end{array}$ & $\begin{array}{l}598 \\
032 \\
\end{array}$ & $\begin{array}{r}521,826 \\
420,131 \\
\end{array}$ & $\begin{array}{l}360 \\
677 \\
\end{array}$ & $\begin{array}{l}2 \times 9 \\
524\end{array}$ & $\begin{array}{r}243,298 \\
457,6 \mathrm{II} \\
\end{array}$ & $\begin{array}{r}807 \\
6,217 \\
\end{array}$ & $\begin{array}{l}260 \\
351\end{array}$ & $\begin{array}{r}545,237 \\
4,199,305\end{array}$ \\
\hline Total........... & $\mathbf{I}, 394$ & 630 & 941,957 & 1,037 & 743 & 700,909 & 7,024 & $6 \mathrm{Ix}$ & $4,744,542$ \\
\hline $\begin{array}{l}\text { Silver coined,...... } \\
\text { Silver exported .... }\end{array}$ & $\begin{array}{r}587,034 \\
74,302 \\
\end{array}$ & $\begin{array}{l}804 \\
310 \\
\end{array}$ & $\begin{array}{r}24,018,529 \\
3,040,079 \\
\end{array}$ & $\begin{array}{l}594,606 \\
362,418 \\
\end{array}$ & $\begin{array}{l}526 \\
697 \\
\end{array}$ & $\begin{array}{l}24,328,326 \\
14,828,36 \mathrm{I}\end{array}$ & $\begin{array}{l}675,277 \\
747,283 \\
\end{array}$ & $\begin{array}{l}55 x \\
490\end{array}$ & $\begin{array}{l}27,628,98 x \\
30,575,104\end{array}$ \\
\hline Total........... & $66 \mathrm{x}, 337$ & 114 & $27,058,608$ & 957,025 & 223 & $39,156,687$ & $\mathrm{I}, 422,56 \mathrm{x}$ & $04 \mathrm{r}$ & $58,204,085$ \\
\hline $\begin{array}{l}\text { Total of gold and } \\
\text { silver.......... }\end{array}$ & & & $\$ 28, \infty 00,565$ & & & $\$ 39,857,596$ & & & $\$ 62,948,627$ \\
\hline
\end{tabular}

The following statement gives the exports of the precious metals from Mexico during the same years embraced in the preceding table.

EXPORT OF PRECIOUS METALS AND MINERALS FROM MEXICO IN THE. FISCAL YEARS I 879-1880, I889-I890 AND I894-I895.

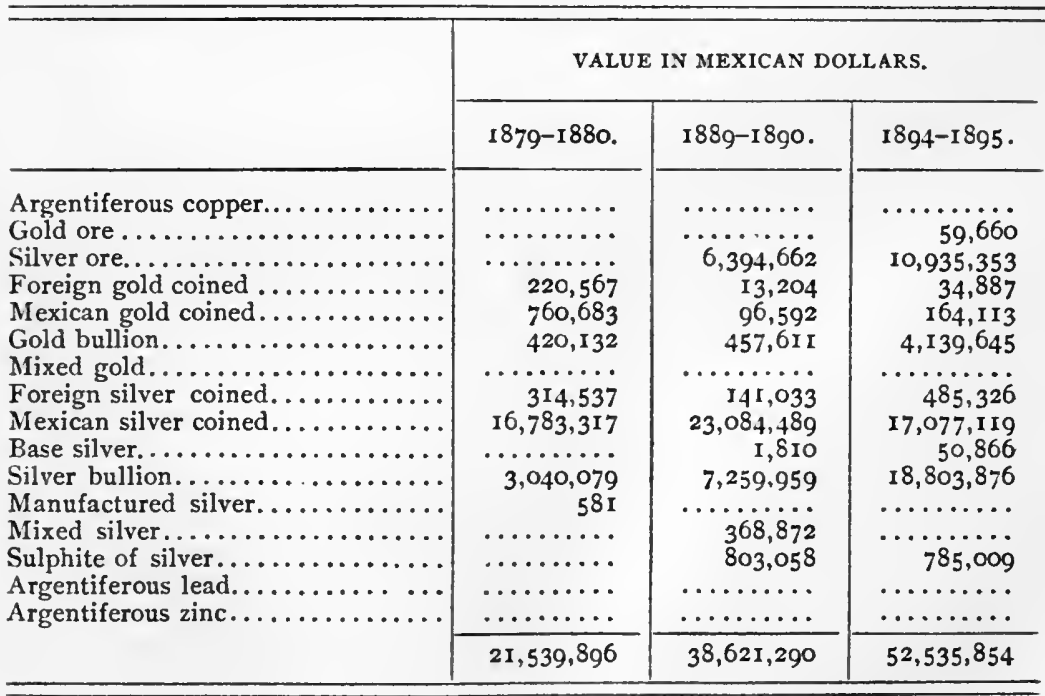


It may be interesting to state the amount of silver exported and coined in Mexican mints from 1874 to 1896 , which is the following:

\begin{tabular}{|c|c|c|}
\hline & EXPORTED. & COINED. \\
\hline 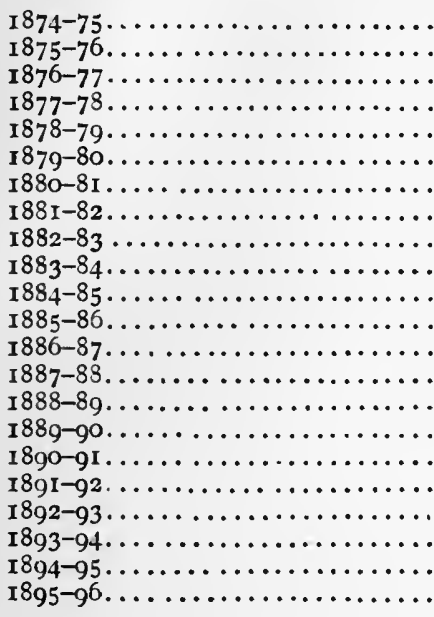 & $\begin{array}{r}16,038,215 \\
\ldots \ldots \ldots \\
\ldots \ldots \ldots \\
20,853,074 \\
19,339,151 \\
20,307,563 \\
17,774,910 \\
15,700,704 \\
28,441,212 \\
32,242,770 \\
32,770,900 \\
29,160,835 \\
32,642,785 \\
30,286,247 \\
37,982,948 \\
37,912,848 \\
35,259,131 \\
46,272,391 \\
44,303,593 \\
36,012,950 \\
36,716,870 \\
46,722,823\end{array}$ & $\begin{array}{l}\mathbf{1} 9,386,958 \\
19,454,054 \\
21,415,128 \\
22,084,203 \\
22,162,988 \\
24,018,529 \\
24,617,395 \\
25,146,260 \\
24,083,922 \\
25,377,379 \\
25,840,728 \\
26,991,805 \\
26,844,031 \\
25,862,977 \\
26,031,223 \\
24,328,326 \\
24,237,449 \\
25,527,018 \\
27,169,876 \\
30,185,612 \\
27,628,981 \\
22,634,788\end{array}$ \\
\hline $1895-96 \ldots \ldots \ldots \ldots \ldots \ldots \ldots$ & $\$ 616,741,920$ & $\$ 541,029,630$ \\
\hline
\end{tabular}

The preceding statement gives correct data of the exports of silver from the fiscal year $1874-1875$ to the fiscal year $1895-1896$, excepting the years $1875-1876$ and $1876-1877$, which are not included for want of data. The difference between the two amounts for these years is $\$ 75,712,290$, showing the large proportion of silver which was not coined, and was exported in bullion.

The following statement shows that the export of Mexican silver reached almost its minimum in the year $1887-1888$, and its maximum in the year $189^{2-1} 893$, with the exception of the last one. The minimum coincided with the first sterling loan negotiated by Mexico; the second sterling loan negotiated in 1890 caused a decrease in the export of Mexican silver coin of 26 per cent., as compared with the previous fiscal year of $1889-1890$.

The export of silver bullion has steadily increased since $187^{2-1873}$, until it was in $1895-1896$ seventeen times as large as in the first named year. During the first fiscal year of those embraced in the above table, the export of silver bullion was $\mathbf{I} .4$ to $\mathbf{2 2 . 6}$ as compared with silver coin, and in the year $1895-1896$ the proportion was 15.3 to 20.5 . In the year $1872-1873$ the export of silver bullion represented 6 per cent. of 
the total export of silver, while in the fiscal year $1895-1896$ it represented 20 per cent.

The export of silver ore only began in the fiscal year I886-1887.

EXPORTS OF SILVER FROM JULY IST, I872, TO JUNE 3OTH, I 896 .

\begin{tabular}{|c|c|c|c|c|c|}
\hline FISCAL YBARS. & corns. & BULLION. & ORES. & FOR & $\begin{array}{l}\text { TOTAL } \\
\text { VAIUE. }\end{array}$ \\
\hline 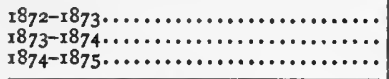 & $\begin{array}{r}22,626,065 \\
17,021,405 \\
15,372,254\end{array}$ & $\begin{array}{r}1,459,426 \\
1,217,853 \\
1,843,523\end{array}$ & $\begin{array}{r}199,596 \\
240,769 \\
79,443\end{array}$ & $\begin{array}{l}8,716 \\
1,359 \\
3,920\end{array}$ & $\begin{array}{r}\$ 24,293,803 \\
18,481,386 \\
17,299,140\end{array}$ \\
\hline$\cdots$ & $\$ 18,339,908$ & $\$ \quad 1,506,934$ & $\$ \quad 173,269$ & $4,66_{5}$ & $\$ 20,024,776$ \\
\hline $\begin{array}{l}\cdots \cdots \\
\cdots \cdots \\
\cdots \\
\cdots\end{array}$ & $\mid \begin{array}{r}18,120,297 \\
16,366,877 \\
16,783,3 x \\
13,183,955 \\
11,607,888\end{array}$ & $\begin{array}{l}2,560,859 \\
2,650,400 \\
3,040,079 \\
3,976,879 \\
3,540,994\end{array}$ & 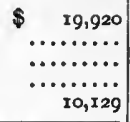 & $\begin{array}{r}87 \\
2,812 \\
58 x \\
376 \\
5,079\end{array}$ & $\begin{array}{r}\$ 20,701,163 \\
19,020,089 \\
19,823,977 \\
17,161,210 \\
15,163,990\end{array}$ \\
\hline$\ldots$ & $\$ 15,212,467$ & $\$ 3,153,842$ & 6,010 & $x, 787$ & $\$ 18,374,086$ \\
\hline 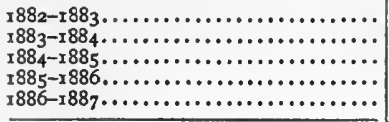 & $\mid \begin{array}{r}22,969,584 \\
25,999,876 \\
25,394,262 \\
21,969,958 \\
21,953,759\end{array}$ & $\begin{array}{r}4,773,928 \\
5,311,310 \\
5,899,297 \\
5,261,502 \\
6,128,239\end{array}$ & $\begin{array}{r}30,105 \\
67,815 \\
\ldots \ldots, \% \\
1,809,873 \\
3,737,883 \\
\end{array}$ & \begin{tabular}{|l|}
113,537 \\
111,112 \\
153,489 \\
145,070 \\
823,951
\end{tabular} & $\begin{array}{r}27,892,154 \\
31,490, I_{3} \\
3 \mathrm{I}, 446,848 \\
29,186,403 \\
32,643,832 \\
\end{array}$ \\
\hline ve & $\$ 23,657,4^{88}$ & $\$ \quad 5,474,855$ & $\$ 1,129,135$ & $\$ \quad 269,43^{2}$ & $\$ 30,53^{1}, 870$ \\
\hline 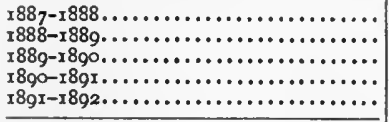 & $\begin{array}{r}7,794,245 \\
22,686,337 \\
23,084,489 \\
17,622,171 \\
26,478,376 \\
\end{array}$ & $\mid \begin{array}{ll}4,77 x, 328 \\
6,862,510 \\
7,628,83 \mathrm{I} \\
7,480,354 \\
7,853,757 \\
\end{array}$ & $\begin{array}{r}\$ 4,547,250 \\
7,623,589 \\
6,394,662 \\
8,874,457 \\
10,478,264 \\
\end{array}$ & $\begin{array}{r}475,942 \\
830,304 \\
804,869 \\
\mathrm{I}, 282,15 \mathrm{I} \\
3,237,116 \\
\end{array}$ & $\begin{array}{l}4 \\
-3,765 \\
2,740 \\
2,851 \\
2,133 \\
9,513 \\
\end{array}$ \\
\hline ver & $\$ \mathbf{x} 9,5$ & $\$ 6,9 \mathrm{x} 9,35^{6}$ & $\$ 7,5^{8}, 644$ & $\$ x, 326,076$ & 2,200 \\
\hline $\begin{array}{l}\cdots \\
\cdots \\
\cdots \\
\cdots\end{array}$ & $\begin{array}{r}\mathbf{2 7}, 1 \\
17,3 \\
17,0 \\
20,3 \\
\end{array}$ & $\begin{array}{r}\$ 8,126,593 \\
7,881,897 \\
18,803,876 \\
26,345,160 \\
\end{array}$ & $\begin{array}{r}\$ 10,940 \\
9,023 \\
10,935 \\
10,885 \\
\end{array}$ & $\begin{array}{r}\$ 9,008,215 \\
11,119,345 \\
835,875 \\
1,138,245 \\
\end{array}$ & $\begin{array}{l}55,246,423 \\
45,411,176 \\
47,652,223 \\
58,746,547 \\
\end{array}$ \\
\hline Aver & $\$ 20,50$ & $\$ 15,289,381$ & $\$ 10,446,294$ & $\$ 5,525,420$ & $\$ 5 I$ \\
\hline e twenty-tv & $\$ 429,047,100$ & $\$ 143,418,595$ & $\$ 85,898,933$ & $\$ 30,102,151$ & $\$ 688,47 x, 479$ \\
\hline verage for & $\$ 19,502, x_{4}$ & $\mid \$ 6,5 \times 9,027$ & $\$ 3,904,496$ & $\$ 1,368,279$ & $\$ 3 x$, \\
\hline
\end{tabular}

\section{MEXICAN GOLD EXPORTS.}

Our production of gold used to be very small for reasons already given, but the present high price of that metal is increasing considerably our output of the same.

The exports of gold from Mexico in the fiscal year ended June 30 , I 896 , amounted to $\$ 5,800,000$, as declared by the Mexican Bureau of Statistics, but even this statement is not correct, as it needs the following additions, shown by experience and reliable authorities: about I 5 per cent. for gold exports made without any return, 2 per cent. for undervaluation, 0.5 per cent. used in the arts in Mexico, I per cent., possibly more now, with the increasing prosperity of the country, retained in the banks, 2 per cent. in circulation, making a total of 20.5 per cent. to be added to the official return, which brings up the produc- 
tion of gold in Mexico to $\$ 6,989,000$ for the year 1896 and even this figure is considered very low.

Mexican Gold Exported to the United States.-The United States is our principal market for the gold we produce.

The following statement furnished to me on February 6,1897 , by the Director of the Mint of the Treasury Department of the United States, contains the imports of gold bullion, ore and coin into the United States, as reported by the Collector of Customs, from $189 \mathrm{I}$ to 1895 , and from the fiscal years ending June 30,1892 , to June 30,1896 .

"IMPORTS OF GOLD BULLION, ORE AND COIN FROM MEXICO INTO THE. UNITED STATES AS REPORTED BY COLLECTORS OF CUSTOMS.

\begin{tabular}{|c|c|c|c|c|}
\hline YEARS. & ORE. & BULLION. & COIN. & TOTAL. \\
\hline 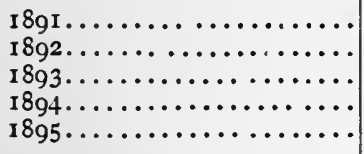 & $\begin{array}{l}\$ 222,085 \\
711,672 \\
507,647 \\
673,583 \\
997,221\end{array}$ & $\begin{array}{r}\$ 1,192,183 \\
1,714,440 \\
1,566,728 \\
1,064,721 \\
2,435,296\end{array}$ & $\begin{array}{r}367,015 \\
380,711 \\
265,315 \\
38,376 \\
34,217\end{array}$ & $\begin{array}{l}1,781,286 \\
2,806,823 \\
2,339,690 \\
1,776,680 \\
3,466,734\end{array}$ \\
\hline 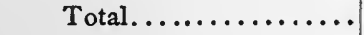 & $\$ 3,112,2$ I I & $\$ 7,973,368$ & $\$ 1,085,634$ & $\$ 12, I_{71}, 213$ \\
\hline
\end{tabular}

" For additional information see Report on Production of Precious Metals, 1894, page 248 , and the same report for 1895 , page 289 .

"Yours, R. D. Preston,

“Mint Bureau, February 6, I897."

"IMPORTS OF GOLD ORE, BULLION AND COIN FROM MEXICO INTO THE UNITED STATES AS REPORTED BY COLLECTORS OF CUSTOMS.

\begin{tabular}{|c|c|c|c|c|}
\hline $\begin{array}{c}\text { FISCAL YEARS ENDING } \\
\text { JUNE } 30 .\end{array}$ & ORE. & BULLION. & cols. & TOTAL. \\
\hline 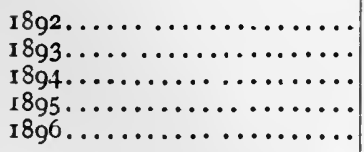 & $\begin{array}{r}246,849 \\
886,284 \\
502,023 \\
810,066 \\
1,108,839\end{array}$ & $\begin{array}{r}\$ 1,336,593 \\
1,923,565 \\
1,210,757 \\
1,635,852 \\
2,826,327\end{array}$ & $\begin{array}{r}542,499 \\
300,012 \\
116,823 \\
36,835 \\
72,482\end{array}$ & $\begin{array}{r}\$ 2,125,941 \\
3,109,861 \\
1,829,603 \\
2,482,753 \\
4,007,648\end{array}$ \\
\hline 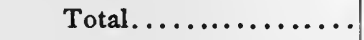 & $\$ 3,554,06 \mathrm{I}$ & $\$ 8,933,094$ & $\$ 1,068,65 I$ & $\$ 13,555,806$ \\
\hline
\end{tabular}

“Treasury Department, Mint Bureau, February 6, I 897."

Mr. Preston completed the above information with other data obtained from private parties in the following manner : communicated to me in a letter dated, February 6, 1897, enclosing the two preceding statements.

"I would add, for your information, that from returns received by this Bureau, from private refineries, and the deposits of foreign bullion at the Mints and Assay 
Offices of the United States during the calendar years 1894 and 1895 the amount of gold credited to Mexico was reported to be as follows :

1894.

Reported by private refineries as extracted from Mexican ores and

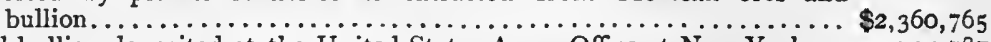
Gold bullion deposited at the United States Assay Office at New York... 735,787 Deposited at the Mint at San Francisco.................... 290,713

Total.............................. $\$ 3,387,26_{5}$

I895.

Gold extracted from Mexican ores and bullion by private refineries..... $\$ 3,843,783$ Gold deposited at the United States Assay Office at New York....... 560,775 Mexican gold bullion deposited at the United States Mint at San Francisco 504,745

Total................................ $\$ 4,909,303$

The preceding official data from the United States Treasury Department was not complete, as will appear from the following table prepared by the Bureau of Statistics of the Mexican Republic :

GOLD EXPORTED FROM MEXICO TO THE UNITED STATES.

CALENDAR YEARS.

\begin{tabular}{|c|c|c|c|c|c|c|}
\hline & 1891. & 1892. & 1893. & 1894. & 1895. & 1896. \\
\hline 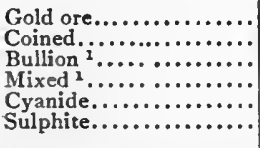 & 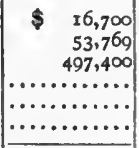 & 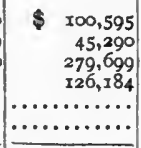 & 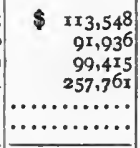 & $\begin{array}{r}5,767 \\
177,089 \\
1,606,152 \\
144,515 \\
\ldots \ldots \ldots . \ldots . \\
\cdots \ldots \ldots \ldots \\
\end{array}$ & $\begin{array}{r}87,695 \\
109,421 \\
4,368,898 \\
\ldots \ldots . . . . . \\
31,231 \\
3,026 \\
\end{array}$ & $\begin{array}{r}324,305 \\
477,505 \\
6,851,564 \\
528,460 \\
31,231 \\
3,026 \\
\end{array}$ \\
\hline $\begin{array}{l}\text { According to information } \\
\text { from Mexico.......... } \\
\text { According to information } \\
\text { from the United States }\end{array}$ & $\begin{array}{l}\$ 567,869 \\
\$ 1,781,286\end{array}$ & $\begin{array}{r}\$ 51,768 \\
2,806,823 \\
\end{array}$ & $\begin{array}{r}\$ 562,660 \\
2,339,690 \\
\end{array}$ & $\begin{array}{r}\$ 1,933,523 \\
1,776,680 \\
\end{array}$ & $\begin{array}{r}\$ 4,600,271 \\
3,466,734 \\
\end{array}$ & $\begin{array}{l}\$ 8,216,091 \\
12,171,213 \\
\end{array}$ \\
\hline \multirow[t]{3}{*}{ Differences.............. } & $+\$ 1,213,417$ & $\mid+\$ 2,255,055$ & $|+\$ 1,777,030|$ & $-\$ 156,843$ & $|-\$ 1,133,537|$ & $+\$ 3,955,122$ \\
\hline & \multicolumn{6}{|c|}{ FISCAL YEARS. } \\
\hline & $x 891-1892$ & $1892-1893$ & $1893-r 894$ & $\mathbf{1 8 9 4 - \mathrm { I } 8 9 5}$ & $1895-1896$. & TOTAL. \\
\hline 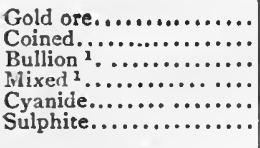 & 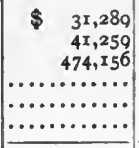 & $\begin{array}{r}145,785 \\
74,798 \\
115,642 \\
271,913 \\
\cdots \cdots \cdots \cdots \cdots \\
\cdots \cdots \cdots\end{array}$ & $\begin{array}{r}55,799 \\
121,915 \\
116,994 \\
256,547 \\
\cdots \cdots \cdots \cdots \\
\cdots \cdots \\
\end{array}$ & 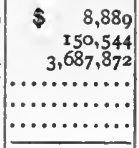 & $\begin{array}{r}160,555 \\
147,98 \mathrm{r} \\
4,608,959 \\
\cdots . . \ldots . . . \\
80,947 \\
3 \mathrm{I}, 332 \\
\end{array}$ & $\begin{array}{r}402,317 \\
536,497 \\
9,003,623 \\
528,460 \\
80,947 \\
31,332 \\
\end{array}$ \\
\hline $\begin{array}{l}\text { According to information } \\
\text { from Mexico............ } \\
\text { According to information } \\
\text { from the United States }\end{array}$ & $\begin{array}{r}546,704 \\
2,125,94 \mathrm{I} \\
\end{array}$ & $\begin{array}{r}\$ 608,13^{8} \\
3,109,86 x \\
\end{array}$ & $\begin{array}{r}\$ 551,255 \\
x, 829,603 \\
\end{array}$ & $\begin{array}{r}\$ 3,847,305 \\
2,482,753 \\
\end{array}$ & $\begin{array}{r}\$ 5,029,774 \\
4,007,648 \\
\end{array}$ & $\begin{array}{r}\$ 10,583,176 \\
13,555,806 \\
\end{array}$ \\
\hline Differences. & $+\$ 1,579,237$ & $+\$ 2,501,723$ & $+\$ I, 278,348$ & $|-\$ 1,364,552|$ & $\mid-\$ 1,022,126$ & $+\$ 2,972,630$ \\
\hline
\end{tabular}

From the Ist of July, I894, the "Bullion" includes the value of the gold contained in the mixed ore.

This instance shows how difficult it is for the commercial statistics of both countries to agree, even when the merchandise is entered with the same value in both as in the present case. 
RAIL WAYS.

The following table contains a list of all the railways, exclusive of the tramways, built in Mexico up to October $3 \mathrm{I}, \mathrm{I} 896$, prepared by the Department of Communications of the United Mexican States :

OFFICIAL STATEMENT MADE BY THE DEPARTMENT OF COMMUNICATIONS OF THE MEXICAN GOVERNMENT OF THE RAILROAD MILEAGE IN OPERATION ON OCTOBER 3I, I 896.

(x) The initials at the beginning of each line of this table stand for the guage of the railroads; $S$. for standard, N. for narrow, and B. for both.

\begin{tabular}{|c|c|c|c|}
\hline NAME. & $\begin{array}{c}\text { DATE OF } \\
\text { CONCESSION. }\end{array}$ & LENGTH. & FROM AND TO. \\
\hline (I) S. Mexican. & Nov. 27,1867 & 292.50 & $\begin{array}{l}\text { Mexico to Veracruz and Apizaco } \\
\text { to Puebla. }\end{array}$ \\
\hline $\begin{array}{l}\text { S. Mérida to Progreso. } \\
\text { N. Hidalgo. }\end{array}$ & $\begin{array}{l}\text { Jan. } \\
\text { Feb. } \\
\text { Fe, } 1874 \\
\end{array}$ & $\begin{array}{l}22.65 \\
92.43\end{array}$ & $\begin{array}{l}\text { Mérida to Progreso. } \\
\text { Tepa to Sototlan, Tepa to Pa- } \\
\text { chuca and San Augustin to }\end{array}$ \\
\hline B. Veracruz to Alvarado. & Mar. 26,1878 & 43.75 & $\begin{array}{l}\text { Veracruz to Medellin and Me- } \\
\text { dellin to Alvarado. }\end{array}$ \\
\hline $\begin{array}{l}\text { N. Mérida to Peto. } \\
\text { N. Interoceanic from } \\
\text { Acapulco to Vera- } \\
\text { cruz. }\end{array}$ & $\begin{array}{ll}\text { Mar. } & 27,1878 \\
\text { Apr. } & 16,1878\end{array}$ & $\begin{array}{r}68.97 \\
489.74\end{array}$ & $\begin{array}{l}\text { Merida to Ingenio de Sta. Maria. } \\
\text { Mexico to Veracruz, Mexico to } \\
\text { Puente Ixtla by Morelos and } \\
\text { branches of Virreyes to Libres } \\
\text { and San Nicolas. }\end{array}$ \\
\hline $\begin{array}{l}\text { N. Puebla to Izucar de } \\
\text { Matamoros. }\end{array}$ & May 6,1878 & 52.39 & $\begin{array}{l}\text { Los Arcos to Cholula, Cholula } \\
\text { to Atlixco and Atlixco to } \\
\text { Matamoros. }\end{array}$ \\
\hline $\begin{array}{l}\text { S. Mexican Western. } \\
\text { S. Mexican Central. }\end{array}$ & $\begin{array}{l}\text { Aug. } \quad \text { I6, I88o } \\
\text { Sept. } 8,1880\end{array}$ & $\begin{array}{r}38 \cdot 4^{8} \\
1,877 \cdot 15\end{array}$ & $\begin{array}{l}\text { Culiacan to Altata. } \\
\text { Mexico to Paso del Norte, Silao } \\
\text { to Guanajuato, Irapuato to } \\
\text { Guadalajara, Aguascalientes } \\
\text { to Tampico, San Blas to Hua- } \\
\text { ristemba and Guadalajara to } \\
\text { Ameca. }\end{array}$ \\
\hline N. Mexican National. & Sept. 13,1880 & $1,056.16$ & $\begin{array}{l}\text { Mexico to Laredo, Acambaro } \\
\text { to Psatzcuaro, Matamoros to } \\
\text { S. Miguel, Mexico to Salto, } \\
\text { belt tramways from suburbs } \\
\text { of Mexico called La Colonia } \\
\text { extension to Salto. }\end{array}$ \\
\hline $\begin{array}{l}\text { N. Mexican National } \\
\text { Construction Com- } \\
\text { pany. }\end{array}$ & Sept. I3, I880 & 88.30 & $\begin{array}{l}\text { Manzanillo to Colima and } \mathrm{Za}- \\
\text { catecas to Ojo Caliente. }\end{array}$ \\
\hline $\begin{array}{l}\text { S. Sonora. } \\
\text { N. Mérida to Valladolid. }\end{array}$ & $\begin{array}{ll}\text { Sept. } & 14,1880 \\
\text { Dec. } & 15,1880\end{array}$ & $\begin{array}{r}262.40 \\
67.53\end{array}$ & $\begin{array}{l}\text { Guaymas to Nogales. } \\
\text { Merida to Valladolid and Pro- }\end{array}$ \\
\hline N. Tlalmanalco. & Feb. $\quad 3,188$ & 16.56 & Tlalmanalco to Chalco and \\
\hline N. Mérida to Campeche. & Feb. 23, I88I & 97.80 & $\begin{array}{l}\text { Mérida to Campeche, Campeche } \\
\text { to Calkini and connecting line } \\
\text { with the railroad from Mérida } \\
\text { to Progreso. }\end{array}$ \\
\hline
\end{tabular}




Nane.
N. Campeche to Lerma.
S. Mexican Interna-
tional.

N. Nautla to San Marcos.

N. San Juan Bautista to Paso del Carrizal.

S. Chalchicomula.

S. Orizaba to Ingenio.

S. Santa Ana to Tlaxcala.

N. Cardenas to the River Grijalva.

N. Toluca to San Juan de las Huertas.

N. Vanegas, Cedral, Matehuala and Rio Verde.

S. Tehuacan to Esperanza.

S. Mérida to Izamal.

S. Chihuahua and $\mathrm{Hi}$ dalgo to the Sierra Madre.

N. Southern Mexican.

S. Tonala to Textla and Frontera.

S. Lower California.

S. Monterey to the Gulf.

N. Tecolutla to Espinal.

S. Córdova to Tuxtepec.

S. Pachuca to Tampico.

N. Maravatío to Cuernavaca.

N. Mexican Northeastern.

N. Salamanca to Jaral.

N. Monte Alto.

N. Veracruz to Boca del Rio.

S. National Tehuantepec.

S. Ometuscoto Pachuca.

S. Puebla Industrial.

S. Tula to Pachuca.

S. Minero.

S. Mexico to Cuernavaca and the Pacific.

N. Mixcalco to Santa June 13, 189o Cruz.
June 25, I $88 \mathrm{I}$

Sept. I7, I88I

Sept. 20, I88 I

Sept. 22, 1881

May 12,1883

May $\quad 25,1883$

Nov. 28,1883

May $\mathrm{I}_{5}, \mathrm{I} 884$

Nov. 13,1884

Apr. 21, 1886

Dec. I6, 1886

May 25,1887

Nov. IO, 1887

Dec. Io, 1887

May I9, 1888

June 5,1888

Aug. I6, I 888

Aug. 30, 1888

Aug. 30, 1888

Aug. 31, I 888

Government Road.

May 25,1889

July 21, 1889

Dec. 20, 1889

Mar. 20, 1890

May 30,1890
Dec. II, I 882

June II, I 883

Aug. 28, 1888
LENGTH.

3.73

Campeche to Lerma.

Porfirio Diaz City to Torreon and Durango, Sabinas to Hondo, Matamoros to Zaragoza, Hornos to San Pedro, branch from Velardeña and Monclova to Cuatro Cienegas.

47.22 San Marcos toward Nautla and branch to Libres.

3.57

S. Juan Bautista to Tamulte.

6.43 San Andres Chalchicomula.

4.69 Orizaba to Ingenio.

5.28 Santa Ana to Tlaxcala.

4.66 Cardenas to the River Grijalva.

$9 \cdot 77$

Toluca to San Juan de las Huertas.

40.39

Vanegas to Cedral and branch to Potrero.

31.07 Esperanza to Tehuacan.

40.9I Mérida to Izamal.

6.83 Chihuahua to the Sierra Madre and Jimenez to Balleza.

228.00 Puebla to Oaxaca.

3I.07 Tonala to Kilomete.

I6.78 San Quintin to the Colorado River.

388.12

Monterey to Treviño and Monterey to Tampico.

I3.04 Tecolutla to Espinal.

31.69 Córdova to Motzorongo.

6.21 Isolated Branch.

40.84 Maravatío towards Cuernavaca and branches to Agangueo to Trojes.

31.I2 Mexico to Tizayuca.

21.75 Salamanca to Jaral.

6.21 Tlalnepantla to Pedregal.

13.67 Veracruz to Boca del Rio.

192.38 Coatzacoalcas to Salina Cruz.

28.40 Ometusco to Pachuca.

22.2I Puebla to Constancia, Cholula and Huejotzingo.

43.49 Tula to Pachuca.

80.94 Escalon to Sierra Mojada and branches.

58.65 Mexico to Tres Marias and Puente de Ixtla to Mexcala.

2.77 Mixcalco to Santa Cruz. 


\begin{tabular}{|c|c|c|c|}
\hline NAME. & $\begin{array}{l}\text { DATE OF } \\
\text { CONCESSION. }\end{array}$ & LENGTH. & FROM AND TO. \\
\hline $\begin{array}{l}\text { N. Izucar of Matamoros } \\
\text { to Acapulco. }\end{array}$ & Nov. 21,1890 & 24.85 & Matamoros towards Acapulco. \\
\hline $\begin{array}{l}\text { N. Toluca to Tenango. } \\
\text { N. Hacienda of Xava- } \\
\text { leta to the San } \\
\text { Rafael Paper Fac- } \\
\text { tory. }\end{array}$ & $\begin{array}{l}\text { Nov. } 24,1891 \\
\text { Mar. } 24,1892\end{array}$ & $\begin{array}{l}4.35 \\
2.49\end{array}$ & $\begin{array}{l}\text { Toluca to Tenango. } \\
\text { Hacienda of Xavaleta to San } \\
\text { Rafael Paper Mill. }\end{array}$ \\
\hline $\begin{array}{l}\text { S. Esperanza to Xuchil. } \\
\text { N. Guanajuato to Do- } \\
\text { lores, Hidalgo and } \\
\text { San Luis de la Paz. }\end{array}$ & $\begin{array}{l}\text { Nov. } 29,1892 \\
\text { May } 24,1893\end{array}$ & $\begin{array}{r}15.84 \\
6.21\end{array}$ & $\begin{array}{l}\text { Esperanza to Xuchil Station. } \\
\text { Rincon on the National Rail- } \\
\text { road to San Luis de la Paz. }\end{array}$ \\
\hline $\begin{array}{l}\text { S. Villa Lerdo to San } \\
\text { Pedro de la Colo- } \\
\text { nia. }\end{array}$ & 3, 1893 & 15.84 & Villa Lerdo to Sacramento. \\
\hline $\begin{array}{l}\text { N. Celaya to the farms } \\
\text { of Roque and Plan- } \\
\text { carte. }\end{array}$ & 2,1893 & 9.07 & $\begin{array}{l}\text { Celaya to the farms of Roque } \\
\text { and Plancarte. }\end{array}$ \\
\hline $\begin{array}{l}\text { N. From La Compañia } \\
\text { to the Zoquiapan } \\
\text { farm. }\end{array}$ & June $\quad 13,1893$ & 5.17 & $\begin{array}{l}\text { La Compañia to the Zoquiapan } \\
\text { farm. }\end{array}$ \\
\hline S. Cazadero to Solis. & May 24,1893 & I8.64 & $\begin{array}{l}\text { Cazadero to point between } \\
\text { the stations of Solis and } \\
\text { Tepetongo. }\end{array}$ \\
\hline S. Industrial Railroads. & $\begin{array}{r}\text { Dec. } 18, \text { I } 895 \\
\text { Total....... }\end{array}$ & $\frac{1.86}{6,791 \cdot 30}$ & Mexico to Xochimilco. \\
\hline
\end{tabular}

(x) This amount does not include the tramways.

RESUME OF RAILWAYS IN MEXICO IN I 895 .

\begin{tabular}{|c|c|c|}
\hline & ILOMETERS. & MILES. \\
\hline Railroads under Federal Grants. . & $0,723, k I I 3$ & $6,663,022$ \\
\hline Tramways $\ldots \ldots \ldots \ldots \ldots \ldots \ldots \ldots \ldots \ldots \ldots$ & 427,583 & 265,687 \\
\hline Surburban Railways connecting towns....... & 410,164 & 254,863 \\
\hline Railroads belonging to private parties ...... & 87,000 & 54,059 \\
\hline Portable Railroad, Decauville System...... & 242,252 & I50,527 \\
\hline
\end{tabular}

As I have already stated most of the roads built in Mexico have obtained large subsidies from the government, and that fact has contributed very materially to their present prosperous financial condition, as they have used the proceeds of the subsidy, not only to build the roads, but in some cases to pay the interest on their bonds. On the whole Mexican roads are very prosperous, and the following statements taken from the official reports of the principal roads shows their trade and earnings are increasing considerably.

The Mexican roads like the Mexican Government have been very much crippled by their obligation to pay in gold the interest on their bonds and dividends on their shares, and as they collect their freights 
in silver, they have to buy gold at current prices to pay their gold obligations, and the depreciation of silver causes them a very great loss, but notwithstanding that serious drawback, the increase in their business and earnings has been such as to place them in a position to meet their gold obligations.

I give below a statement of the traffic and receipts of the three principal railways in Mexico, namely : the Mexican Central, Mexican National, and Mexican International, which I have obtained directly from the respective companies. I also give similar statements from the other roads, which I have taken from statements published by the Anuario Estadistico de la Republica Mexicana of 1895.

Mexican Central.-The Mexican Central is the largest road so far built in Mexico. The whole of the main line was opened for traffic in 1884 , and all figures for traffic previous to July I, I884, were thrown into Construction Accounts. The annexed statement of freights and earnings of this road begins therefore in $\mathrm{x} 885$, and shows a decided increase every year. I also append a statement of the traffic and earnings of this road and its branch from Tula to Pachuca, from I 88I to I 895 , taken from the Anuario Estadistico de la Republica Mexicana of 1895, which has been compiled from data furnished by the company to the Mexican Government. (See first table on page 197.)

EARNINGS OF THE MEXICAN CENTRAL RAILWAY FROM I885 TO I896.

MEXICAN CURRENCY.

\begin{tabular}{|c|c|c|c|c|c|c|c|}
\hline $\begin{array}{c}\text { CALEN- } \\
\text { DAR } \\
\text { YBAR. }\end{array}$ & $\begin{array}{c}\text { MILEAGE } \\
\text { OPBR- } \\
\text { ATED. }\end{array}$ & $\begin{array}{c}\text { METRIC } \\
\text { TONS } \\
\text { FREIGHT. }\end{array}$ & $\begin{array}{c}\text { FREIGHT } \\
\text { EARNINGS. }\end{array}$ & $\begin{array}{c}\text { NUMBER } \\
\text { OF PAS- } \\
\text { SENGERS. }\end{array}$ & $\begin{array}{l}\text { PASSENGER } \\
\text { EARNINGS. }\end{array}$ & $\begin{array}{l}\text { ALL OTHER } \\
\text { BARNINGS. }\end{array}$ & $\begin{array}{l}\text { TOTAL GROSS } \\
\text { EARNINGS. }\end{array}$ \\
\hline $\begin{array}{l}1885 \ldots \ldots \\
1886 \ldots \ldots \\
1887 \ldots \ldots \\
1888 \ldots \ldots \\
1889 \ldots \ldots \\
1890 \ldots \\
1891 \ldots \ldots \\
1892 \ldots \ldots \\
1893 \ldots \ldots \\
1894 \ldots \ldots \\
1895 \ldots \ldots \\
1896 \ldots\end{array}$ & $\begin{array}{l}1,235.90 \\
1,235.90 \\
1,235.90 \\
1,316.40 \\
1,461.85 \\
1,527.20 \\
1,665.11 \\
1,824.83 \\
1,846.64 \\
1,859.83 \\
1,859.83 \\
1,869.60\end{array}$ & $\begin{array}{r}226,13^{8} \\
245,398 \\
346,898 \\
507,631 \\
540,546 \\
609,382 \\
867,657 \\
1,091,785 \\
860,187 \\
898,484 \\
1,047,038 \\
1,231,025\end{array}$ & 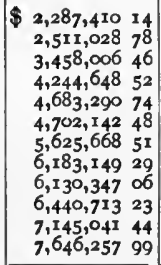 & $\begin{array}{r}512,272 \\
573,896 \\
601,393 \\
581,967 \\
675,144 \\
723,928 \\
742,993 \\
731,425 \\
792,025 \\
945,434 \\
1,030,911 \\
x, 259,623\end{array}$ & $\begin{array}{rrr}\$ 1,100,268 & 62 \\
1,168,750 & 24 \\
1,235,284 & 05 \\
1,321,511 & 96 \\
1,420,375 & 76 \\
1,436,317 & 68 \\
1,470,940 & 51 \\
1,439,571 & 60 \\
1,443,793 & 73 \\
1,576,801 & 33 \\
1,828,072 & 61 \\
1,934,612 & 78\end{array}$ & 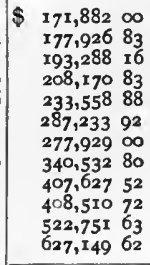 & $\begin{array}{rr}\$ 3,559,560 & 76 \\
3,857,705 & 85 \\
4,886,578 & 67 \\
5,774,331 & 31 \\
6,337,225 & 38 \\
6,425,694 & 08 \\
7,374,538 & 02 \\
7,963,253 & 69 \\
7,981,768 & 31 \\
8,426,025 & 28 \\
9,495,865 & 68 \\
10,208,020 & 39 \\
\end{array}$ \\
\hline Tot: & $18,938.99$ & $8,472,169$ & $\$ 61,057,70464$ & 9,171, OII & $\$ 17,376,30087$ & $\$ 3,856,5619 x$ & $\$ 82,290,5^{6} 742$ \\
\hline
\end{tabular}

Mexican National.-The Mexican National obtained its first concession from the Mexican Government in 1877 , but it was amended from time to time thereafter, until all the amended grants were grouped in the concession approved July 5,1886 , under which the road is now operated. The old companies did not print any reports, and there is no data running back further than the time when the bondholders took possession of the property at the foreclosure sale, which occurred in the City of Mexico on May 23, 1887. I give a statement of the traffic 
and earnings of the road from 1873 to 1895 , taken from the Anuario Estadistico de la Republica Mexicana in 1895 , which was compiled with data furnished to the Mexican Government by the company.

CENTRAL RAILWAY AND BRANCH FROM TULA TO PACHUCA.

\begin{tabular}{|c|c|c|c|c|c|c|}
\hline \multirow{2}{*}{$\underset{x}{\stackrel{0}{\alpha}}$} & \multirow{2}{*}{$\begin{array}{l}\text { PASSEN- } \\
\text { GERS. }\end{array}$} & \multirow{2}{*}{$\begin{array}{c}\text { PASSENGER } \\
\text { RECEIPTS. }\end{array}$} & \multicolumn{2}{|c|}{ FREIGHT. } & \multirow{2}{*}{$\begin{array}{l}\text { MISCELLANEOUS } \\
\text { RECEIPTS. }\end{array}$} & \multirow{2}{*}{$\begin{array}{c}\text { TOTAL } \\
\text { RECEIPTS. }\end{array}$} \\
\hline & & & Tons. & Kilos. & & \\
\hline I $88 \mathrm{I}$. & 303,543 & 62,27020 & 7,012 & 436 & 33,4 I 344 & 95,68364 \\
\hline 1882 . & 491,985 & $442,726 \quad 54$ & 202,304 & 993 & $x, 289,38724$ & $\mathbf{I}, 732, \mathbf{I} 1378$ \\
\hline 1883. & 653,669 & 726,830 o9 & 167,356 & 565 & $2,876,906 \quad 29$ & $3,603,73638$ \\
\hline I 8 & 761,687 & $x, x \mp 1,90696$ & IgO, 423 & 972 & $2,662,68486$ & $3,774,59182$ \\
\hline 1885. & 694,894 & $\mathrm{I}, \mathrm{I} I \mathrm{I}, 06254$ & 331,700 & 260 & $2,484,32568$ & $3,595,388 \quad 22$ \\
\hline 1886. & 769,655 & $1,185,66253$ & 255,027 & I I I & $2,754,6$ I 3 O2 & $3,940,27555$ \\
\hline 1887. & 797,693 & $1,251,74398$ & 356,448 & 976 & $3,721,358$ I3 & $4,973,102$ II \\
\hline I & 756,560 & $1,337,734$ Io & $5 \mathrm{I} 9,26 \mathrm{I}$ & 394 & $4,554,830 \quad 53$ & $5,892,56463$ \\
\hline I8 & 683,147 & $1,436,301$ o6 & 576,324 & 408 & $5,081,62868$ & $6,517,92974$ \\
\hline I 8go. & 736,730 & $x, 487,08660$ & 694,966 & 914 & $5,212,26 \mathrm{I} 40$ & $6,699,348$ oo \\
\hline 1891. & 753,276 & $1,512,41542$ & $1,005,447$ & 237 & $6,167,09256$ & $7,679,50798$ \\
\hline 1892. & 735,363 & $1,442,31099$ & $I, 100,364$ & 029 & $6,534,50742$ & $7,976,818$ \\
\hline & 792,025 & $1,443,79373$ & 860,186 & 545 & $6,537,974 \quad 58$ & $7,98 \mathrm{I}, 7683 \mathrm{I}$ \\
\hline & 945,434 & $\mathrm{I}, 576,8$ or 35 & 898,484 & O7I & $6,849,22395$ & $8,426,02530$ \\
\hline & $I, 030,9$ I I & $1,828,0726 \mathrm{I}$ & $1,047,037$ & 836 & $7,767,793$ o3 & $9,595,86564$ \\
\hline Total & $10,906,572$ & $\$ 17,956,718 \quad 70$ & $8,212,346$ & 747 & $\$ 64,528,0008 \mathrm{I}$ & $\$ 82,484,71951$ \\
\hline
\end{tabular}

MEXICAN NATIONAL RAILROAD.

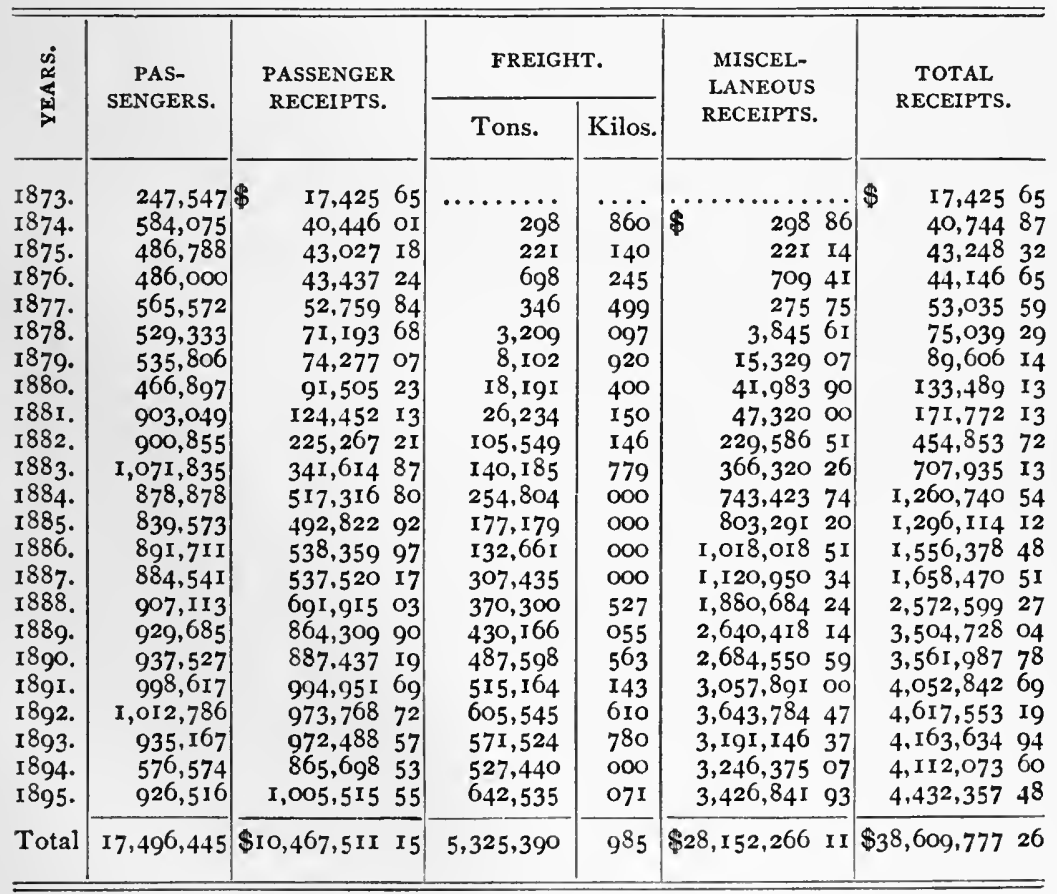




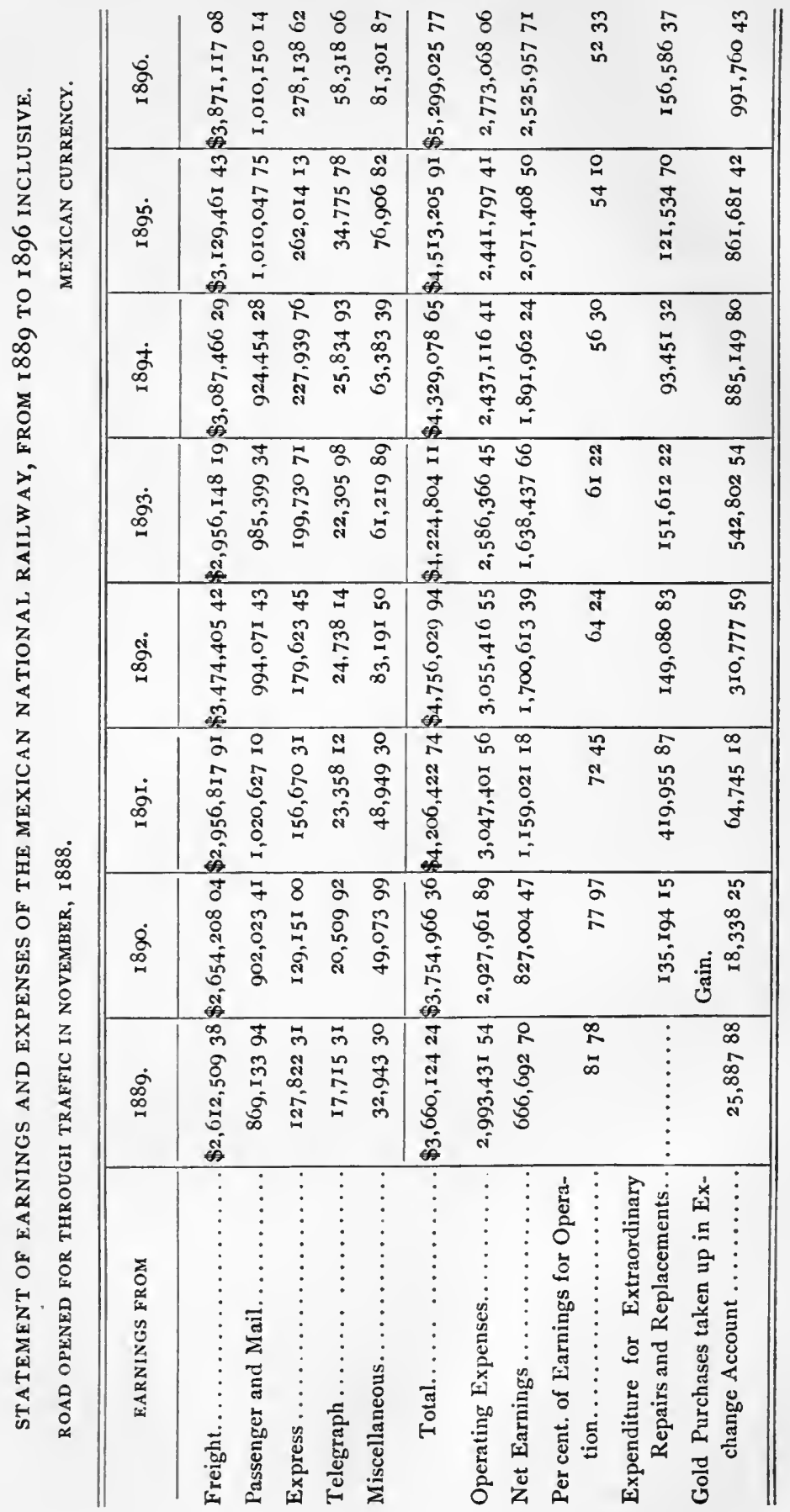


I also append a statement of the freights, passengers, express, telegraphs, and miscellaneous receipts, as well as the expenses and earnings of the road from the year 1889 to 1896 , taken from the last official report of the companies. It will be noticed that the traffic and receipts of this road, like the Central, have been steadily increasing from the time at which it began to be operated. (See table on page 198.)

MEXICAN INTERNATIONAL RAILROAD COMPANY.

GROSS EARNINGS IN MEXICAN MONEY.

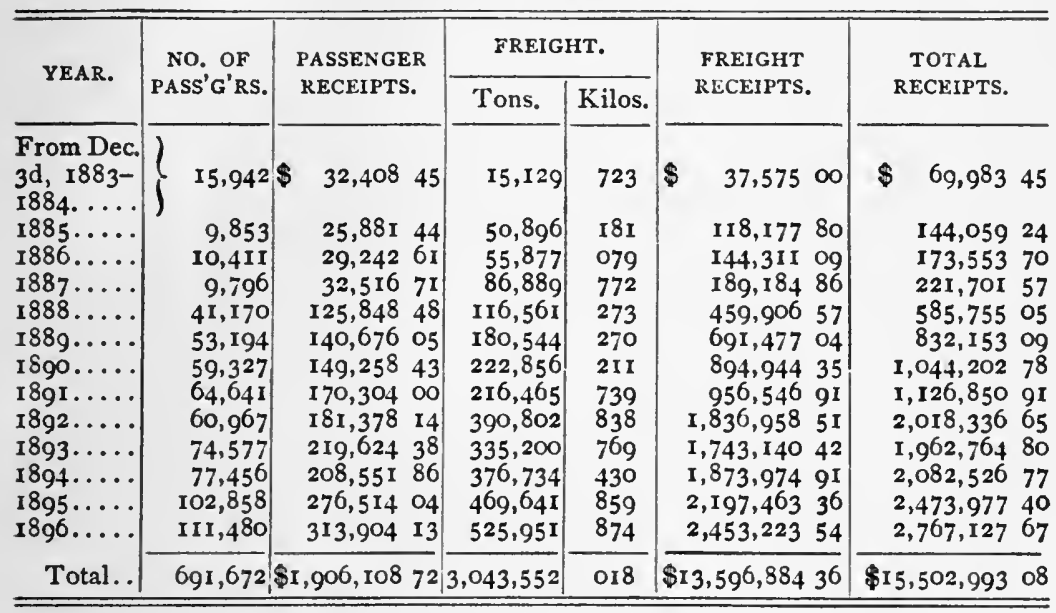

MEXICAN INTERNATIONAL RAILWAY.

(STATEMENT FURNISHED BY THE COMPANY.)

\begin{tabular}{|c|c|c|c|c|}
\hline YEAR. & $\begin{array}{c}\text { AVERAGE } \\
\text { KILOMETRES } \\
\text { OPERATED. }\end{array}$ & GROSS EARNINGS. & $\begin{array}{c}\text { AVERAGE } \\
\text { EARNINGS } \\
\text { PER } \\
\text { KILOMETRE. }\end{array}$ & $\begin{array}{l}\text { AVERAGE } \\
\text { EARNINGS } \\
\text { PER MILE. }\end{array}$ \\
\hline 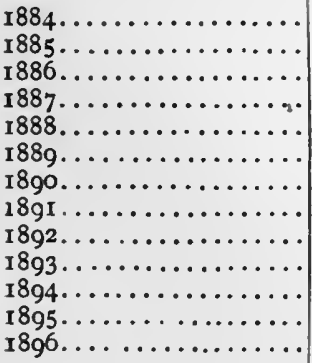 & $\begin{array}{r}245 \cdot 20 \\
273 \cdot 58 \\
273 \cdot 58 \\
273 \cdot 58 \\
573 \cdot 97 \\
636 \cdot 34 \\
637 \cdot 38 \\
658 \cdot 30 \\
746.37 \\
922.19 \\
922.19 \\
947.23 \\
1,011.02\end{array}$ & $\begin{array}{rr}103,307 & 98 \\
153,916 & 18 \\
185,150 & 25 \\
237,394 & 13 \\
656,781 & 41 \\
911,698 & 51 \\
1,126,366 & 41 \\
1,197,856 & 55 \\
2,095,726 & 14 \\
2,050,934 & 01 \\
2,169,121 & 47 \\
2,664,126 & 08 \\
2,900,925 & 33\end{array}$ & $\begin{array}{rr}421 & 49 \\
562 & 59 \\
676 & 76 \\
867 & 73 \\
1,144 & 28 \\
1,432 & 73 \\
1,745 & 64 \\
1,819 & 69 \\
2,807 & 89 \\
2,226 & 15 \\
2,352 & 14 \\
2,812 & 54 \\
2,869 & 30\end{array}$ & $\begin{array}{rr}612 & 37 \\
905 & 39 \\
1,098 & 11 \\
1,396 & 43 \\
1,841 & 47 \\
2,305 & 64 \\
2,839 & 77 \\
2,924 & 02 \\
4,518 & 67 \\
3,579 & 04 \\
3,785 & 29 \\
4,526 & 28 \\
4,617 & 69\end{array}$ \\
\hline & $8,120.93$ & $\$ 16,453,30445$ & $\$ 21,73893$ & $\$ 34,950 \quad 17$ \\
\hline
\end{tabular}

Mexican International. The Mexican International, which has been built without any subsidy from the Mexican Government, was opened for traffic in $188_{3}$, and its traffic and receipts, like the other two roads, have steadily increased. I append two statements of this road; the 
first, furnished me by the company, embraces its traffic and earnings from 1883 to 1896 ; and the second is another statement furnished me also by the company, showing the average kilometres operated, gross earnings, average earnings per kilometre, and average earnings per mile from the years 1884 to 1896 . (See the two tables on page 199.)

Mexican Southern Railway.-I give below a statement of the number of passengers, amount of freight and earnings of the Mexican Southern Railway, furnished to me by the Company, embracing nine months of the year 1893 and the whole of 1894 , as before the ist of April, I893, the road was run by the Contractors, and the Company has no data in their possession. I also append a statement taken from the Anuario Estadistico de la Republica Mexicana of 1895 , embracing the traffic and

MEXICAN SOUTHERN RAILWAY.

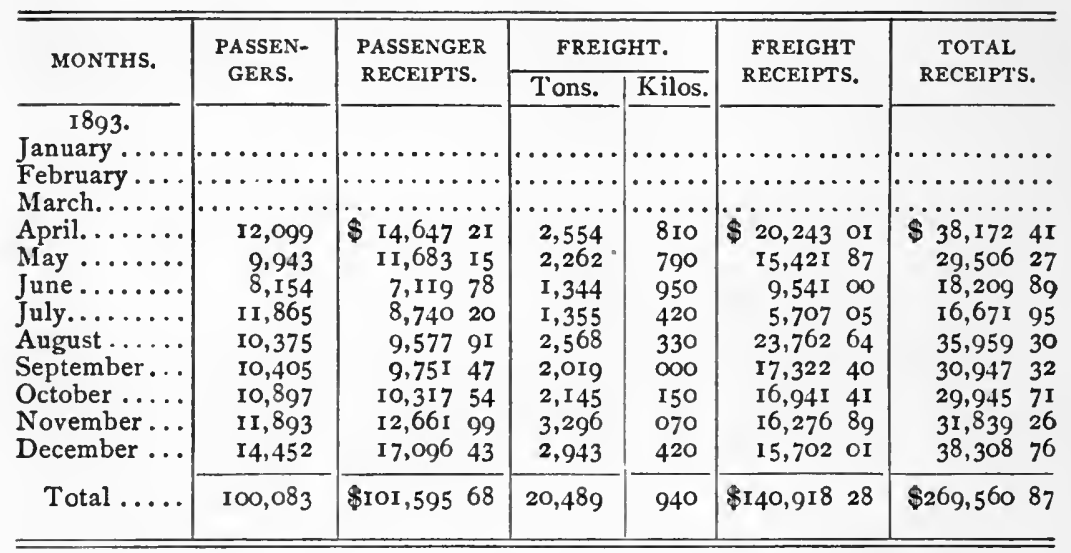

Number of Passengers according to official Tables....... I42,9I9. "Tons " " " .......27,917,510 k.

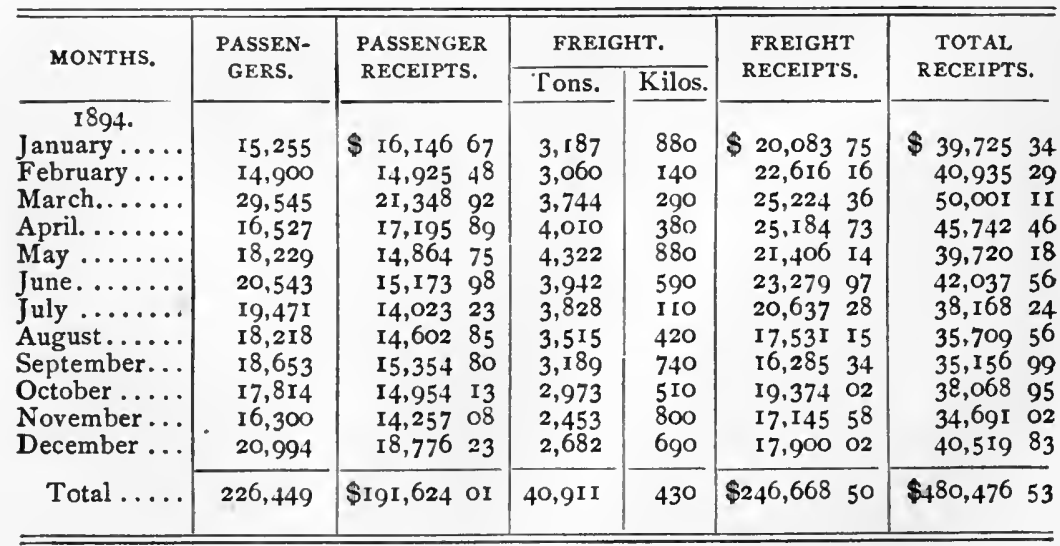


earnings of the Company during the years from 1890 to 1895 , taken from data furnished by the Company to the Department of Communications of Mexico.

MEXICAN SOUTHERN.

\begin{tabular}{|c|c|c|c|c|c|c|}
\hline \multirow{2}{*}{ YEARS. } & \multirow{2}{*}{$\begin{array}{l}\text { PASSEN- } \\
\text { GERS. }\end{array}$} & \multirow{2}{*}{$\begin{array}{l}\text { PASSENGER } \\
\text { RECEIPTS. }\end{array}$} & \multicolumn{2}{|c|}{ MERCHANDISE. } & \multirow{2}{*}{$\begin{array}{c}\text { OTHER } \\
\text { RECEIPTS. }\end{array}$} & \multirow{2}{*}{$\begin{array}{c}\text { TOTAL } \\
\text { RECEIPTS. }\end{array}$} \\
\hline & & & Tons. & Kilos. & & \\
\hline $\begin{array}{l}1890 \ldots \ldots \ldots \ldots \\
1891 \ldots \ldots \ldots \ldots \\
1892 \ldots \ldots \ldots \ldots \\
1893 \ldots \ldots \ldots \ldots \\
1894 \ldots \ldots \ldots \ldots \\
1895 \ldots \ldots \ldots \ldots\end{array}$ & $\begin{array}{r}76,788 \\
104,296 \\
143,037 \\
225,447 \\
218,213\end{array}$ & 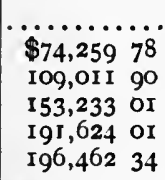 & $\begin{array}{l}\cdots \ldots \\
11,506 \\
26,977 \\
27,921 \\
40,911 \\
36,5 \text { I I }\end{array}$ & $\begin{array}{l}320 \\
490 \\
510 \\
430 \\
210\end{array}$ & 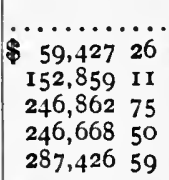 & $\begin{array}{rrr}\cdots & \ldots 3,687 & 04 \\
261,871 & \text { or } \\
400,095 & 76 \\
438,292 & 51 \\
483,888 & 93\end{array}$ \\
\hline Total...... & 767,781 & $\begin{array}{llll}\$ 724,591 & 04\end{array}$ & I 43,828 & 460 & $\$ 993,2442$ I & $\$ 1,7$ I 7,83525 \\
\hline
\end{tabular}

Other Railroads. The following statement shows the traffic and earnings of the Mexican, Interoceanic, Sonora, and minor railroads in Mexico, taken from the Anuario Estadistico de la Republica Mexicana of 1895 , compiled from data furnished by the respective companies to the Department of Communications of the Mexican Government.

MEXICAN RAILROAD.

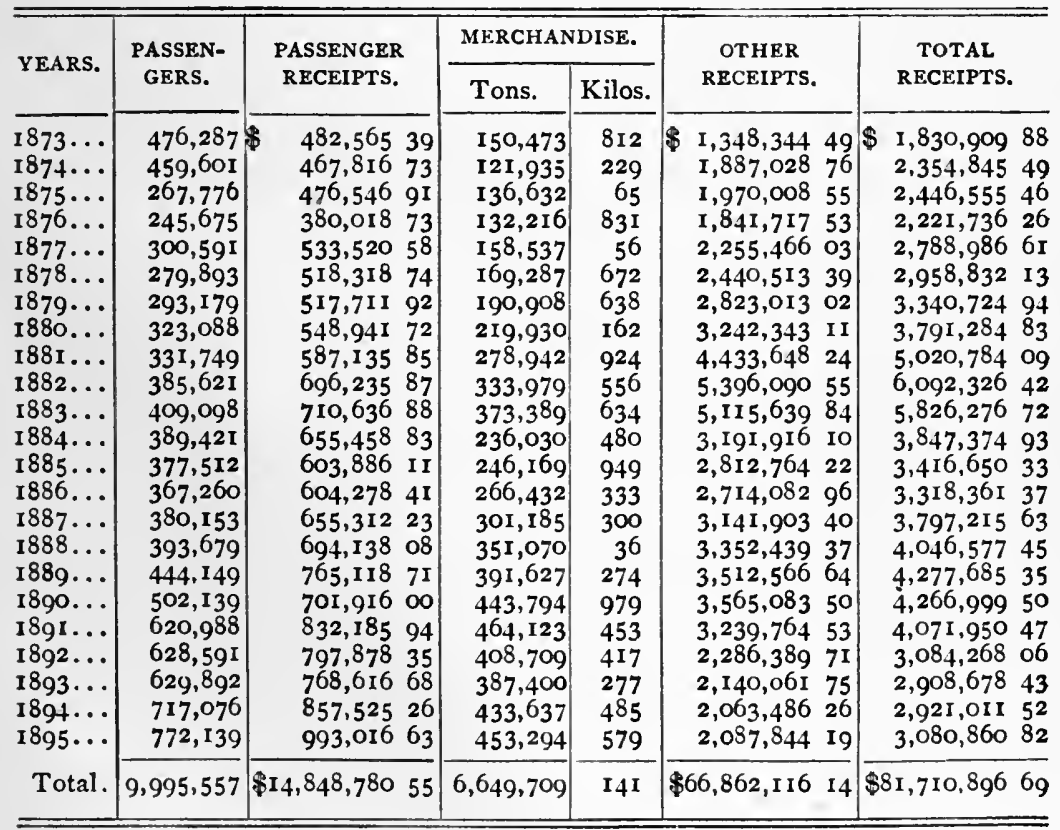


INTEROCEANIC RAILWAY.

\begin{tabular}{|c|c|c|c|c|c|c|}
\hline \multirow{2}{*}{ YEARS. } & \multirow{2}{*}{$\begin{array}{c}\text { PASSEN- } \\
\text { GERS. }\end{array}$} & \multirow{2}{*}{$\begin{array}{c}\text { PASSENGER } \\
\text { RECEIPTS. }\end{array}$} & \multicolumn{2}{|c|}{ MERCHANDISE. } & \multirow{2}{*}{$\begin{array}{c}\text { OTHER } \\
\text { RECEIPTS. }\end{array}$} & \multirow{2}{*}{$\begin{array}{c}\text { TOTAL } \\
\text { RECEIPTS. }\end{array}$} \\
\hline & & & Tons. & Kilos. & & \\
\hline 188 & 228,053 & $\$ 65,2779 \mathrm{I}$ & II, 43 I & 145 & $36,515 \quad 46$ & IOI,793 37 \\
\hline & 367,116 & 105,08331 & 49,942 & 548 & I 59,53564 & 264,61895 \\
\hline & 411,090 & I I I, 029 25 & 53 & 385 & 258,221 o5 & 369,25030 \\
\hline & 16 & 223,04958 & 56,822 & 222 & 356,90646 & $579,956 \quad 04$ \\
\hline & 63 & 247,52850 & 131,385 & $3 I 9$ & 407,59364 & $22 \quad 14$ \\
\hline & 606 & 240,23370 & 167,970 & 265 & 436,345 IO & 676,57880 \\
\hline & 569 & 224,8 I 5 I9 & $\mathrm{I} 48,00 \mathrm{I}$ & 913 & 482,003 I 8 & $706,818 \quad 37$ \\
\hline & $62 \mathrm{I}$ & 239,81248 & I 74, I94 & I 56 & 570,03320 & 809,84568 \\
\hline & 67 & ,809 77 & 200,386 & 400 & 658,06322 & 912,87299 \\
\hline & 59 & 269 & $\mathrm{O} 2$ & 920 & $710,84^{8} \quad 78$ & 982,4 I I 47 \\
\hline & 65 & 710 & 288,836 & $35^{8}$ & I,I 53,999 I3 & 10623 \\
\hline & 625 & 456,03580 & 282,3 II & 49 & $I, I 76,562 \quad 22$ & 24802 \\
\hline & & 466,7 & 367,762 & 66 & $1,376,488 \quad 38$ & $1,843,28769$ \\
\hline & & 486,0 & 383,503 & $\infty 00$ & $1,705,85974$ & 2, IgI, 93528 \\
\hline & & 420 & $440,64^{8}$ & $\infty$ & $1,912,19258$ & $2,404,10678$ \\
\hline & & & 464,975 & $\infty$ & $1,771,268 \quad 92$ & $2,262,65759$ \\
\hline Tot & $10,033,88 \mathrm{I}$ & $4,759,17300$ & $3,412,455$ & 782 & $13,172,436 \quad 70$ & $17,931,60970$ \\
\hline
\end{tabular}

SONORA RAILWAY.

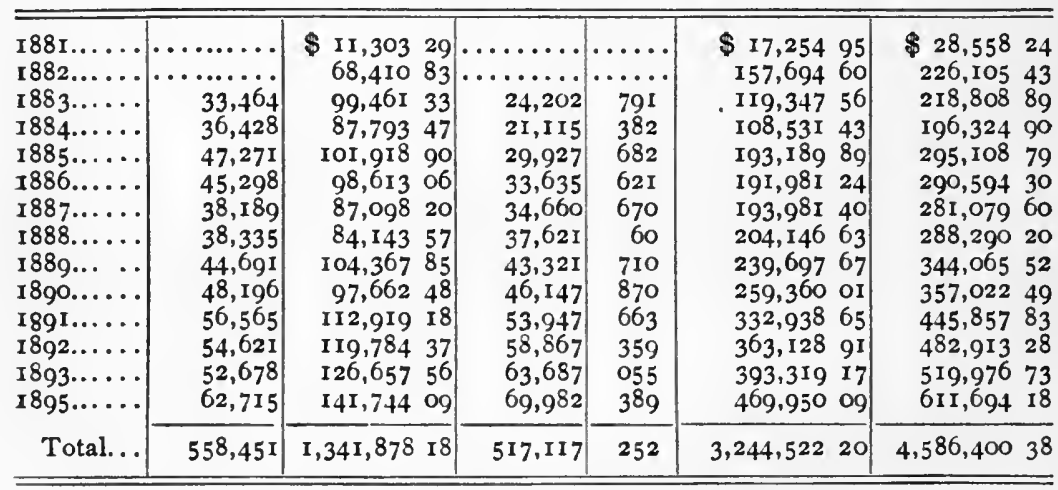

HIDALGO AND NORTHEASTERN RAILWAY.

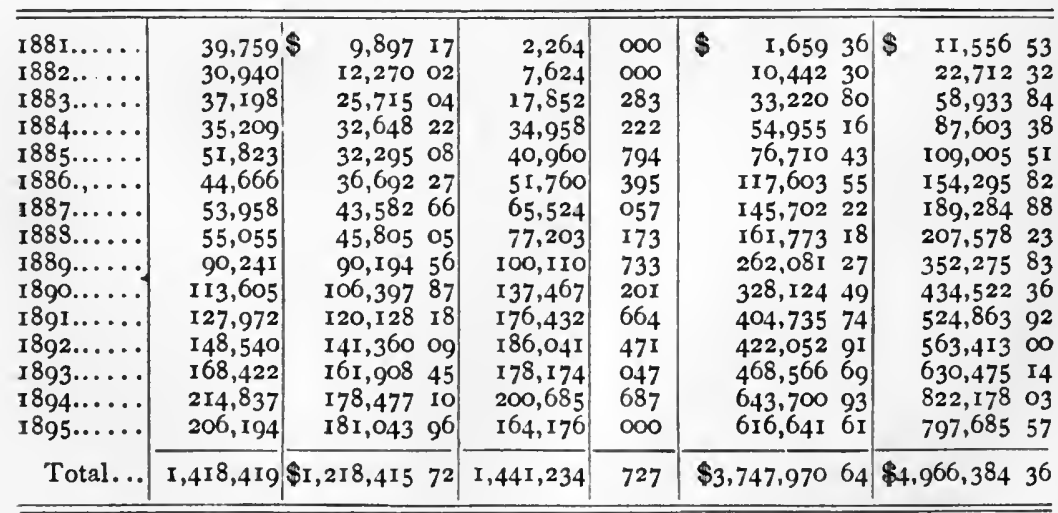


MÉRIDA AND PROGRESO RAILWAY.

\begin{tabular}{|c|c|c|c|c|c|c|}
\hline \multirow{2}{*}{ YEARS. } & \multirow{2}{*}{$\begin{array}{l}\text { PASSEN- } \\
\text { GERS. }\end{array}$} & \multirow{2}{*}{$\begin{array}{l}\text { PASSENGER } \\
\text { RECEIPTS. }\end{array}$} & \multicolumn{2}{|c|}{ MERCHANDISE. } & \multirow{2}{*}{$\begin{array}{c}\text { OTHER } \\
\text { RECEIPTS. }\end{array}$} & \multirow{2}{*}{$\begin{array}{c}\text { TOTAL } \\
\text { RECEIPTS. }\end{array}$} \\
\hline & & & Tons. & Kilos. & & \\
\hline r88r.. & 56,085 & $\$ 28,63950$ & $\ldots \ldots \ldots$ & $\ldots \ldots$ & 53,23600 & $8 \mathrm{r}, 87550$ \\
\hline I882... & 84,016 & 37,64238 & 41,934 & 297 & 75,24288 & II2,885 26 \\
\hline $188_{3} \ldots \ldots$ & 83,231 & 36,23983 & 59,859 & 715 & 108,24880 & $r_{44,488} \quad 63$ \\
\hline I 8 & 87,159 & $37,940 \quad 54$ & 95,962 & 902 & I39,299 59 & $\mathrm{I}_{77,240} \mathrm{I}_{3}$ \\
\hline I8 & $64, I 73$ & $29,0784 I$ & $79,6 \mathrm{II}$ & 737 & $120,389 \times 3$ & I 49,46754 \\
\hline I 886. & 77,139 & $33,353 \quad I 6$ & 58,239 & 254 & 78, I68 66 & III, 52 I 82 \\
\hline 1887 & 85,044 & $22,844 \quad 42$ & 46,055 & 714 & 52,99568 & 75,840 10 \\
\hline r 888 & rog,997 & 29,81276 & 30,872 & 512 & 64,29188 & 94,10464 \\
\hline & I 58,534 & $56,7638 \mathrm{I}$ & 44,6 I9 & 200 & 97,01737 & $\mathbf{I} 53,78 \mathrm{I}$ I 8 \\
\hline 18 & 162,701 & 55,56697 & 53,949 & 818 & $89,1398 \mathrm{I}$ & 144,70678 \\
\hline $18 c$ & I 29,989 & 46 , I55 85 & 34,486 & $\infty$ & 67,460 I8 & $x \mathrm{I}_{3}, 6 \mathrm{I} 6$ o3 \\
\hline 18 & 108, I 19 & $36,528 \quad 45$ & 28,656 & 499 & $83,593 \quad 75$ & 120,13220 \\
\hline 1893. & $9 \mathrm{I}, 29 \mathrm{I}$ & 39,276 08 & 34,406 & 476 & 96,23047 & 135,50655 \\
\hline $18 c$ & 79,653 & 33,387 I8 & 38,659 & $40 I$ & 68,5 I 3 O5 & IOI, $900 \quad 23$ \\
\hline 18 & & $38,228 \quad 8 I$ & $\ldots \ldots$ & . & $97,850 \quad 38$ & 136,079 I9 \\
\hline Total... & $1,377,131$ & $\$ 56 I, 45^{8}$ I 5 & 647,313 & 525 & $\$ 1,291,67763$ & $\$ 1,853,13578$ \\
\hline
\end{tabular}

TEHUACAN AND ESPERANZA RAILWAY.

\begin{tabular}{|c|c|c|c|c|c|c|}
\hline I 884 & , 343 & II, $427 \quad 64$ & 6,043 & 8 & I 87 & 1951 \\
\hline & 049 & 10,07720 & & 257 & $3 I, 90566$ & 41,98286 \\
\hline & 12,942 & $\dot{9}$, III 04 & 6,603 & 705 & 38,27180 & 47,38284 \\
\hline .. & $\mathbf{r}, 848$ & I0,080 I5 & 7,669 & 730 & $47,437 \quad 77$ & 57,51792 \\
\hline .. & 17,116 & $15.376 \quad 57$ & 8, & 045 & 0093 & 69,87750 \\
\hline & $\mathbf{r} 9,3^{85}$ & 20,67300 & 9,8 & 360 & 61,564 o9 & 82,237 og \\
\hline & 20,462 & I8,459 96 & 16, & 870 & $75,744 \quad 37$ & 94,20433 \\
\hline & I 7,426 & I 1,087 o6 & $14,38 I$ & 340 & 84 o8 & 79,77 I 14 \\
\hline & 15,102 & $8,792 \quad 35$ & & 5 Io & 44,602 o9 & 53,39444 \\
\hline & 16,096 & 9,4 II $5 x$ & 5 , & 530 & 37,99745 & 47,40896 \\
\hline $4 \ldots .$. & . . & 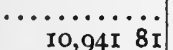 & $\cdots$ & $\cdots \ldots$ & 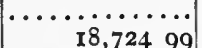 & $\cdots{ }_{20} 666{ }_{80}$ \\
\hline ot & 186,674 & $\$ I$ & & 160 & IO & $\$ 6$ \\
\hline & & & & & & \\
\hline
\end{tabular}

MÉRIDA AND PETO RAILWAY.

\begin{tabular}{|c|c|c|c|c|c|c|c|}
\hline I88I. & 22,852 & 3,91369 & $\cdots \ldots$ & $\cdots \cdots$ & 43060 & 4,344 & \\
\hline $1882 \ldots \ldots$ & $8 \mathrm{I}, \mathrm{IO} 2$ & 12,29358 & •...... & $\ldots \ldots$ & $2,6374 \mathrm{I}$ & $\begin{array}{r}4,344 \\
14,930\end{array}$ & 99 \\
\hline $1883 \ldots \ldots$ & 88,920 & $14,4223 I$ & 5,654 & II 5 & 4,83323 & 19,255 & 54 \\
\hline $1884 \ldots \ldots$ & $8 I, 566$ & I 7,8 I 829 & I, 063 & 915 & I I, 58849 & 29,406 & 78 \\
\hline 188 & 64, I 18 & I6,795 70 & I6,9I9 & 464 & 20,222 I0 & 37,017 & 80 \\
\hline I 8 & 62,983 & $16,728 \quad 82$ & 17,368 & o79 & $2 \mathrm{I}, 7$ IO $9 \mathrm{I}$ & 38,439 & 73 \\
\hline$\cdots$ & 62,763 & $15,943 \quad 55$ & 15,827 & 969 & 26,6 I9 7 I & 42,563 & 26 \\
\hline & 92,773 & $22,1466 \mathrm{I}$ & $20,23 I$ & 714 & 37,01376 & 59,160 & 37 \\
\hline & $99,76 \mathrm{I}$ & $25,35 \times 7$ 이 & 25,397 & 822 & 52,55395 & 77,905 & 65 \\
\hline & I 26,978 & 24,5 I4 70 & 30,024 & 477 & $69,390 \quad 02$ & 93,904 & 72 \\
\hline 18 & I 34,438 & 55,00797 & 27,106 & 666 & $85,602 \quad 24$ & 140,610 & $2 I$ \\
\hline I 8 & I 29,163 & $59,742 \quad 62$ & 28,266 & 475 & $1 \times 8,21420$ & 177,956 & 82 \\
\hline & 163,852 & 71,97064 & 36,202 & 439 & 128, I $156 \mathrm{I}$ & 200,086 & 25 \\
\hline & I 57,3 II & 70,898 o3 & 32,260 & 765 & I 21, $547 \quad 79$ & I 92,445 & 82 \\
\hline & 140,193 & 67, I34 69 & 37,853 & 723 & I 8, I 79 I I & 185,313 & \\
\hline Total & $\mathbf{I}, 508,773$ & $\$ 494,682$ 9o & 304,177 & 623 & $\$ 318,659$ I3 & $\$ 1,313,342$ & 03 \\
\hline
\end{tabular}


SiNALOA AND DURANGo (altata to CUliaCAN) RaILWAY.

\begin{tabular}{|c|c|c|c|c|c|c|}
\hline \multirow{2}{*}{ YEARS. } & \multirow{2}{*}{$\begin{array}{l}\text { PASSEN- } \\
\text { GERS. }\end{array}$} & \multirow{2}{*}{$\begin{array}{l}\text { PASSENGER } \\
\text { RECEIPTS. }\end{array}$} & \multicolumn{2}{|c|}{ FREIGHT. } & \multirow{2}{*}{$\begin{array}{l}\text { MISCELLA- } \\
\text { NEOUS } \\
\text { RECEIPTS. }\end{array}$} & \multirow{2}{*}{$\begin{array}{c}\text { TOTAL } \\
\text { RECEIPTS. }\end{array}$} \\
\hline & & & Tons. & Kilos. & & \\
\hline $\begin{array}{l}1882 \ldots \ldots \\
1883 \ldots \ldots \\
1884 \ldots \ldots \\
1885 \ldots \\
1886 \ldots \\
1887 \ldots \ldots \\
1888 \ldots \ldots \\
1889 \ldots \ldots \\
1890 \ldots \\
1891 \ldots \ldots \\
1892 \ldots \ldots \\
1893 \ldots \ldots \\
1894 \ldots \ldots \\
1895 \ldots \ldots\end{array}$ & $\begin{array}{r}2,727 \\
12,251 \\
21,776 \\
15,816 \\
23,171 \\
25,487 \\
27,904 \\
21,850 \\
42,987 \\
54,678 \\
39,494 \\
56,503 \\
38,451 \\
37,627\end{array}$ & $\begin{array}{rr}3,712 & 04 \\
7,816 & 94 \\
8,584 & 57 \\
8,786 & 88 \\
10,681 & 46 \\
10,705 & 56 \\
11,459 & 15 \\
9,318 & 46 \\
14,871 & 77 \\
19,170 & 23 \\
14,837 & 39 \\
14,152 & 07 \\
14,040 & 41 \\
15,768 & 25\end{array}$ & $\begin{array}{r}1,864 \\
3,913 \\
5,962 \\
4,953 \\
4,316 \\
5,962 \\
6,736 \\
6,535 \\
4,722 \\
7,442 \\
10,371 \\
12,893 \\
12,093 \\
8,538\end{array}$ & $\begin{array}{l}589 \\
457 \\
325 \\
364 \\
116 \\
325 \\
532 \\
236 \\
749 \\
886 \\
701 \\
822 \\
568 \\
024\end{array}$ & $\begin{array}{rr}5,155 & 65 \\
18,717 & 39 \\
25,019 & 62 \\
19,719 & 92 \\
20,880 & 39 \\
16,661 & 71 \\
23,650 & 34 \\
25,537 & 79 \\
18,911 & 41 \\
25,381 & 35 \\
28,131 & 17 \\
35,205 & 12 \\
38,393 & 29 \\
29,390 & 59\end{array}$ & $\begin{array}{rr}8,867 & 69 \\
26,534 & 33 \\
33,604 & 19 \\
28,506 & 80 \\
31,561 & 85 \\
27,367 & 27 \\
35,109 & 49 \\
34,856 & 25 \\
33,783 & 18 \\
44,551 & 58 \\
42,968 & 56 \\
49,357 & 19 \\
52,433 & 70 \\
45,158 & 84\end{array}$ \\
\hline Total. & 420,722 & $\$ 163,90518$ & 96,306 & 694 & $\$ 330,75574$ & $\$ 494,66092$ \\
\hline
\end{tabular}

MÉRIDA AND CAMPECHE RAILWAY.

\begin{tabular}{|c|c|c|c|c|c|c|c|c|}
\hline 1883. & 22,944 & $\$ 3,586$ Io & 462 & I69 & $\$$ & I, $120 \quad 32$ & $\$$ & 4,70642 \\
\hline 1884 & 97,295 & 13,16159 & 3,952 & 565 & & 5,20367 & & 18,36526 \\
\hline 1885 & 76,135 & 12,53594 & 7,794 & 570 & & $9,3063 \mathrm{I}$ & & $21,842 \quad 25$ \\
\hline & 65,274 & 10,77944 & 6,265 & 722 & & 9,57990 & & $20,359 \quad 34$ \\
\hline I 88 & 68,883 & 11,79363 & 8,106 & $8 I_{3}$ & & 13,26322 & & $25,056 \quad 85$ \\
\hline & 86,329 & 22,172 II & II, 514 & 018 & & 21,10670 & & $43,278 \quad 81$ \\
\hline 18 & 58,383 & 17,01746 & 12,534 & 035 & & $28,300 \quad 44$ & & 45,31790 \\
\hline 1890 & 75,496 & 28,93904 & 6,779 & $45^{8}$ & & I9,057 69 & & $47,996 \quad 73$ \\
\hline I89] & 96,994 & $35,303 \quad 04$ & 17,328 & $47^{8}$ & & 36,03570 & & $71,338 \quad 74$ \\
\hline $1892 \ldots \ldots$ & 87,954 & $33,59^{8}$ I I & 17,363 & 510 & & $39,330 \quad 26$ & & $\begin{array}{l}72,928 \\
37\end{array}$ \\
\hline I893.. & 124,983 & $56,034 \quad 3$ & 21,775 & IOI & & 53,39097 & & 109,42500 \\
\hline & $\cdots$ & $\because \cdots \cdots$ & & $\cdots$ & & & & \\
\hline 18 & I 39,349 & $66,174 \quad 14$ & 24,699 & 277 & & $72,923 \quad 31$ & & I 39,09745 \\
\hline Total... & I,,$\infty 0$,oI9 & $\$ 311,09463$ & I 38,575 & 716 & & $08,618 \quad 49$ & & $619,713 \mathrm{I2}$ \\
\hline
\end{tabular}

MÉRIDA AND VALLADOLID RAILWAY.

\begin{tabular}{|c|c|c|c|c|c|c|}
\hline 1883 & 18,123 & $2,570 \quad 17$ & & & 609 I 8 & 3,17935 \\
\hline I 884 & $75,54 \mathrm{I}$ & 12,59563 & 4,248 & 788 & 5,28796 & $\mathbf{1 7 , 8 8 3} 59$ \\
\hline 1885 & 100,015 & $18,5486 \mathrm{I}$ & 6,040 & 957 & 8,48763 & 27,03624 \\
\hline 1886. & 132,210 & $25,798 \quad 73$ & 25,181 & 498 & $33,276 \quad 45$ & 59,075 I8 \\
\hline 1887. & 176,501 & $32,298 \quad 87$ & 41,496 & 479 & $58,0964 \mathrm{I}$ & 90,39528 \\
\hline 188 & 183,973 & $37,957 \quad 45$ & 35,975 & 207 & 65,86426 & 103,82171 \\
\hline 1889 & 280,348 & 58,69 I 70 & $\mathbf{5 4 , 2 0 6}$ & 189 & II 5,03274 & I $73,724 \quad 44$ \\
\hline 1890 & 295,034 & 63,485 I8 & 50,781 & 662 & 96,61123 & 160,09641 \\
\hline 1891 & $264,78 \mathrm{I}$ & $60,366 \quad 76$ & 47,064 & 535 & $98,2123 \mathrm{I}$ & 158,57907 \\
\hline 1892 & 254,344 & 61,57370 & 46,124 & 159 & 134,20985 & $195,783 \quad 55$ \\
\hline 803 & 244,040 & 79,22348 & 50,633 & 534 & I 39,38468 & $218,608 \quad 16$ \\
\hline 1895 & I99,670 & $72,828 \quad 22$ & 62,342 & 134 & 165,98326 & $238, \ddot{8 I I}_{4}$ \\
\hline Total. & $2,224,580$ & $\$ 525,938 \quad 50$ & 424,095 & 142 & $\$ 921,05596$ & $\$ 1,446,99446$ \\
\hline
\end{tabular}


TLALMANALCO RAILWAY.

\begin{tabular}{|c|c|c|c|c|c|c|}
\hline \multirow{2}{*}{ YEARS. } & \multirow{2}{*}{$\begin{array}{l}\text { PASSEN- } \\
\text { GERS. }\end{array}$} & \multirow{2}{*}{$\begin{array}{l}\text { PASSENGER } \\
\text { RECEIPTS. }\end{array}$} & \multicolumn{2}{|c|}{ FREIGHT. } & \multirow{2}{*}{$\begin{array}{l}\text { MISCELLA- } \\
\text { NEOUS } \\
\text { RECEIPTS. }\end{array}$} & \multirow{2}{*}{$\begin{array}{c}\text { TOTAL } \\
\text { RECEIPTS. }\end{array}$} \\
\hline & & & Tons. & Kilos. & & \\
\hline I 883. & 39,688 & $\$ 4,02244$ & I0,8 13 & 000 & $\$ 5,564$ 9I & $\$ 9,5^{87} 35$ \\
\hline 1884 . & 40,2 I I & 4,59680 & $9,64 I$ & 000 & 7,27695 & I 1,87375 \\
\hline I $385 \ldots$. & 41,226 & 4,57743 & 7,466 & 713 & 6,830 o6 & II,407 49 \\
\hline 18 & 41,905 & 4,62128 & $6,8+5$ & 349 & 6,36051 & I0,98I 79 \\
\hline & 47,808 & $5,098 \circ 9$ & 8,083 & 538 & $6,788 \quad 75$ & I I, 88684 \\
\hline 188 & 46,150 & 5,07607 & 10,722 & 122 & 9,16456 & $14,24 I \quad 53$ \\
\hline r889. & 49,866 & $5,536 \quad 16$ & 13,7 Io & 170 & 11,56653 & 17,10269 \\
\hline 189 & 55,345 & 6,65420 & 24,988 & 131 & 12,01962 & 18,67382 \\
\hline I 891 & 61,236 & 6,76586 & 15,469 & 050 & 12,68468 & $19,450 \quad 54$ \\
\hline $18 c$ & 62,618 & 7,22565 & 12,303 & 020 & 9,85383 & $17,0794^{8}$ \\
\hline & 60,835 & 6,49230 & I 8,572 & 715 & I 5,430 59 & 21,92289 \\
\hline 1894. & .......... & $\cdots \cdots \cdots$ & $\cdots \ddot{B i s}_{3}$ & $\cdots \cdots$ & $\cdots \ddot{12}_{28} \ddot{6}_{6}$ & 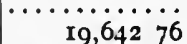 \\
\hline 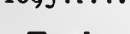 & & & & & & \\
\hline Total... & 618,665 & $\$ 68,02528$ & I 52,439 & 058 & \$II5,825 65 & $\$ 183,85093$ \\
\hline
\end{tabular}

SAN JUAN BAUTISTA AND CARRIZAL PASSENGER RAILWAY.

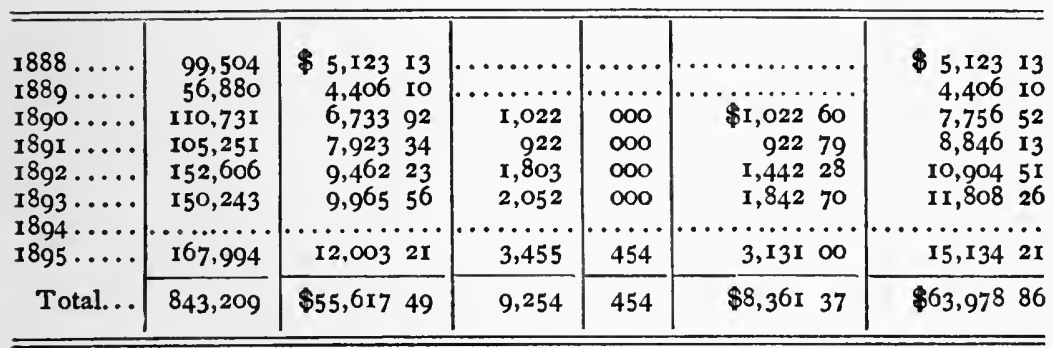

SAN ANDRES AND CHALCHICOMULA RAILWAY.

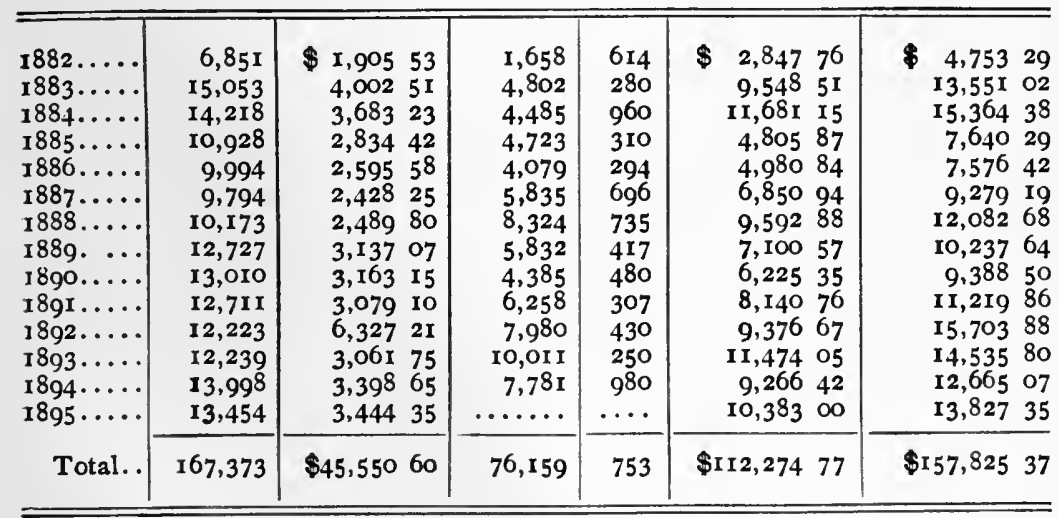


ORIZABA AND INGENIO RAILWAY.

\begin{tabular}{|c|c|c|c|c|c|c|}
\hline \multirow{2}{*}{ YEARS. } & \multirow{2}{*}{$\begin{array}{l}\text { PASSEN- } \\
\text { GERS. }\end{array}$} & \multirow{2}{*}{$\begin{array}{l}\text { PASSENGER } \\
\text { RECEIPTS. }\end{array}$} & \multicolumn{2}{|c|}{ FREIGHT. } & \multirow{2}{*}{$\begin{array}{l}\text { MISCELLA- } \\
\text { NEOUS } \\
\text { RECEIPTS. }\end{array}$} & \multirow{2}{*}{$\begin{array}{c}\text { TOTAL } \\
\text { RECEIPTS. }\end{array}$} \\
\hline & & & Tons, & Kilos. & & \\
\hline 1882 . & 38,636 & $\$ 4,47330$ & ... & & $\$$ & 4,47330 \\
\hline $1883 \ldots \ldots$ & 91,949 & Io,64594 & 237 & I68 & I97 64 & Io, $843 \quad 58$ \\
\hline $1884 \ldots \ldots$ & 94,323 & 10,92074 & 360 & 972 & 30082 & II, 22I 56 \\
\hline 1885. & 34,921 & 4,365 I 2 & 435 & 720 & 363 I0 & $4,728 \quad 22$ \\
\hline 1886 & 86,047 & $9,962 \quad 57$ & 384 & 813 & $350 \quad 18$ & I0,312 75 \\
\hline 1887. & 40,364 & $4,673 \quad 38$ & 121 & 344 & IOI 12 & 4,77450 \\
\hline 188 & $4 \mathrm{I}, 945$ & 4,800 oo & 182 & 400 & 15200 & 4,952 oo \\
\hline 188 & 46,640 & 5,40000 & I68 & 000 & 14000 & 5,54000 \\
\hline 189 & 106,773 & 12,362 20 & 504 & 000 & 42000 & 12,78220 \\
\hline 189 & $\mathrm{IO} 3, \mathrm{OII}$ & 12,532 10 & 612 & 000 & 51000 & 13,042 Io \\
\hline & 99,553 & 13,30320 & 750 & 000 & $728 \quad 36$ & 14,03156 \\
\hline 189 & 104.030 & 13,90050 & $\ldots$ & $\cdots$ & 40000 & 14,30050 \\
\hline $18 c$ & 104,019 & I3,990 77 & 704 & 000 & 52800 & $14,518 \quad 77$ \\
\hline & 132,650 & $17,43^{8} \quad 04$ & 748 & 000 & 56100 & I 7,99904 \\
\hline Total. . & $\mathrm{I}, \mathrm{I} 24,86 \mathrm{I}$ & $\$ 138,76786$ & 5,208 & 417 & $\$ 4,752 \quad 22$ & $\$ 143,520$ o8 \\
\hline
\end{tabular}

SANTA ANA AND TLAXCALA RAILWAY.

\begin{tabular}{|c|c|c|c|c|c|c|}
\hline I 883 & 58,068 & 82,86020 & & & 49438 & $\$ 3,3545^{8}$ \\
\hline I884. & II 7,560 & 8,58060 & $\ldots \ldots$ & $\ldots$ & I,494 I4 & I0,074 74 \\
\hline $1885 \ldots \ldots$ & 174,204 & 12,71498 & ....... & $\ldots$ & 1,48300 & I 4, I 9798 \\
\hline 1886. & I 56,676 & 6,73314 & $\because$ & $\ldots$ & $1,482 \quad 37$ & 8,21551 \\
\hline 1887. & II 7,518 & 8,46385 & $\ldots \ldots$ & $\ldots$ & $1,373 \quad 25$ & 9,837 I0 \\
\hline 1888 & 120,910 & 9,17928 & .. & $\ldots$ & 1,651 o2 & 10,83030 \\
\hline 1889 & I 10,574 & 8,29498 & $\ldots \ldots$ & $\ldots$ & 1,47520 & $9,770 \quad 18$ \\
\hline 1890 & 145,263 & 8,398 oo & ....... & $\ldots$ & 1,46982 & 9,86782 \\
\hline 189 & $66,7 \times 6$ & 9,09830 & $\ldots$ & $\ldots$ & 1,76928 & 10,86758 \\
\hline 1892. & 55,768 & 7,01174 & 750 & 000 & $1,280 \quad 03$ & $8,29 \div 77$ \\
\hline 1893. & 59,127 & 7,32640 & 3,829 & 003 & 2,434 I3 & $9.760 \quad 53$ \\
\hline I 894. & $\cdots \cdots$ & & & $\cdots$ & & m.n.m. \\
\hline I 895 . & 71,843 & 8,67035 & 2,038 & 440 & $2,3443^{8}$ & II,OI4 73 \\
\hline Total.. & $\mathrm{x}, 254,227$ & 897,33182 & 6,617 & 443 & $\$ 18,75100$ & \$116,082 82 \\
\hline
\end{tabular}

CÁRDENAS AND RIO GRIJALVA RAILWAY.

\begin{tabular}{|c|c|c|c|c|c|c|}
\hline I 886. & $\cdots$ & 263 OI & & & 52600 & $\$ 780$ oI \\
\hline 1887. & $\ldots \ldots$ & 40143 & .......... & $\cdots$ & 72257 & 1,12400 \\
\hline 1888. & $\ldots \ldots$ & 30907 & ........ & $\ldots$ & $78 \mathrm{II}$ & 1,09020 \\
\hline 1889. & $\ldots \ldots$ & 21672 & ........ & $\ldots$ & 83969 & $\mathrm{I}, 0564 \mathrm{I}$ \\
\hline $1890 \ldots$. & $\ldots \ldots$ & 38000 & ....... & $\ldots$ & 83969 & 1,21969 \\
\hline $189 \mathrm{I}$. & $\ldots \ldots$ & 48000 & ........ & $\ldots$ & 93969 & $I, 41969$ \\
\hline $1892 \ldots \ldots$ & ....... & $\ldots \ldots \ldots \ldots$ & ....... & $\ldots$ & ....... & .......... \\
\hline 1893. & ....... & .......... & ....... & $\cdots$ & ........ & ......... \\
\hline $1884 \ldots \ldots$ & ....... & .......... & ....... & $\cdots$ & ............ & ........... \\
\hline $1895 \ldots \ldots$ & $\cdots$ & $\cdots$ & ....... & $\cdots$ & ..... & $\cdots$ \\
\hline Total. . & $\cdot$ & $2,050 \quad 23$ & 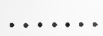 & $\ldots$ & $\$ 4,648 \quad 77$ & $\$ 6,699$ oo \\
\hline
\end{tabular}


TOLUCA AND SAN JUAN DE LAS HUERTAS RAILWAY

\begin{tabular}{|c|c|c|c|c|c|c|}
\hline \multirow{2}{*}{ YEARS. } & \multirow{2}{*}{$\begin{array}{l}\text { PASSEN- } \\
\text { GERS. }\end{array}$} & \multirow{2}{*}{$\begin{array}{l}\text { PASSENGER } \\
\text { RECEIPTS. }\end{array}$} & \multicolumn{2}{|c|}{ FREIGHT. } & \multirow{2}{*}{$\begin{array}{l}\text { MISCELLA- } \\
\text { NEOUS } \\
\text { RECEIPTS. }\end{array}$} & \multirow{2}{*}{$\begin{array}{c}\text { TOTAL } \\
\text { RECEIPTS. }\end{array}$} \\
\hline & & & Tons. & Kilos. & & \\
\hline $\mathrm{I} 885$. & 75,052 & 7,01639 & $\ldots$ & $\cdots$ & $\$ \mathbf{I}, \mathbf{I} 38$ I9 & $\$ 8,15458$ \\
\hline I 886. & 97,535 & 9,07895 & 6, I 33 & 000 & 5,20159 & $14,280 \quad 54$ \\
\hline $1887 \ldots \ldots$ & 94,874 & 8,78861 & $9,36 \mathrm{I}$ & 000 & $6,755 \quad 49$ & I 5,544 Io \\
\hline I $888 \ldots .$. & 93,512 & 8,47583 & $7,25 I$ & 750 & 4.72999 & 13,20582 \\
\hline 1889 & I 34, I 93 & I2,67797 & 13,483 & 088 & 8,087 o3 & 20,76500 \\
\hline I 890 & 178,072 & 16,26475 & I 8,595 & $86 \mathrm{r}$ & 12, I56 67 & $28,421 \quad 42$ \\
\hline $180 \mathrm{I}$. & I 56,917 & I5,29369 & I3,998 & 185 & I 1,08276 & 26,37645 \\
\hline 1892 . & 107,122 & 13,77747 & 13,924 & 530 & $11,702 \quad 56$ & 25,480 o3 \\
\hline I893.. & 176,241 & I6,340 90 & 14, I 28 & 510 & 11,69024 & 28,031 I4 \\
\hline & I21,949 & 15,32876 & 13,778 & 920 & I 1,536 IO & 26,86486 \\
\hline & 204,591 & I 8,2 IO I3 & 13,860 & 796 & 10,13678 & 28,346 9I \\
\hline Total. . & $I, 440,058$ & $\$ 141,25345$ & I 24,5 I 5 & 640 & $\$ 94,21740$ & $\$ 235,47085$ \\
\hline
\end{tabular}

VANEGAS, CEDRAL, MATEHUALA, AND RIO VERDE RAILWAY.

\begin{tabular}{|c|c|c|c|c|c|c|}
\hline I88g. & $\ldots \ldots \ldots$ & 44969 & 28 & 540 & $335 \quad 24$ & 78493 \\
\hline I $890 \ldots$. & Io, 848 & 5,763 I6 & 1,840 & $66 I$ & 15,49227 & 21,25543 \\
\hline I891 ..... & 36,742 & I2,783 O5 & 5,939 & 568 & $6 I, 51343$ & 74,29648 \\
\hline $18 g^{2} \ldots .$. & 44,502 & $\mathbf{I} 6,083$ II & $94, \mathrm{X} \mathbf{2}$ & 500 & 124,56569 & 140,64880 \\
\hline I893.... & 46,083 & I 6,030 O2 & 83,1 I 5 & OOO & I 4,50549 & 130,5355 I \\
\hline I $894 \ldots$. & 35,213 & $13,798 \quad 53$ & I I 3,384 & O०O & I $85,6495 \mathrm{I}$ & I 99,44804 \\
\hline 1895. & $\cdots \cdots$ & $\ldots \ldots \ldots$ & $\cdots$ & $\cdots$ & $\ldots \ldots \ldots \ldots$ & $\ldots \ldots \ldots \ldots$ \\
\hline Total. & 173,388 & $\$ 64,90756$ & 298,420 & 269 & $\$ 502,06163$ & $\$ 566,969$ I9 \\
\hline
\end{tabular}

MÉRIDA AND IZAMAL RAILWAY.

\begin{tabular}{|c|c|c|c|c|c|c|}
\hline$I 887 \ldots \ldots$ & 42,812 & $\$ 7,280 \quad 38$ & 2,729 & 000 & $3,954 \quad 64$ & $\$ I I, 23502$ \\
\hline $1888 \ldots \ldots$ & 78, IO2 & 18,98170 & 7,871 & $54 \mathrm{I}$ & $17,6568 \mathrm{I}$ & $36,638 \quad 51$ \\
\hline $1889 \ldots$. & 106089 & $38,330 \quad 34$ & I 1,633 & 376 & 28,06991 & $66,400 \quad 25$ \\
\hline I $890 \ldots . .$. & 106,883 & 54.462 IO & I0, I 46 & 374 & $29,995 \quad 33$ & $84,457 \quad 43$ \\
\hline т 89 г . . . . & 80,042 & $4 \mathrm{I}, 89 \mathrm{I} \quad 5 \mathrm{I}$ & 13,775 & 771 & $44,798 \quad 43$ & 86,68994 \\
\hline $1892 \ldots$. & 94,634 & 49,72903 & I8,094 & 768 & 65,56547 & I I 5,29450 \\
\hline $1893 \ldots$. & $96,45^{8}$ & 45,684 I 2 & 21,476 & 676 & $65,714 \quad 14$ & I I I , 398 26 \\
\hline 1894 & $\ldots \ldots$ & $52,56+78$ & $\ldots \ldots$ & $\ldots$ & $6 \mathrm{I}, 33545$ & II 3,90023 \\
\hline $1895 \ldots$. & ...... & 49,735 I 2 & $\ldots \ldots$ & $\ldots$ & 63,29549 & II $3,0306 \mathrm{I}$ \\
\hline Total.. & 605,020 & $\$ 358,659$ o8 & 85,727 & 506 & $\$ 380,38567$ & $\$ 739,04475$ \\
\hline
\end{tabular}

SAN MÁRCOS AND NAUTLA RAILWAY.

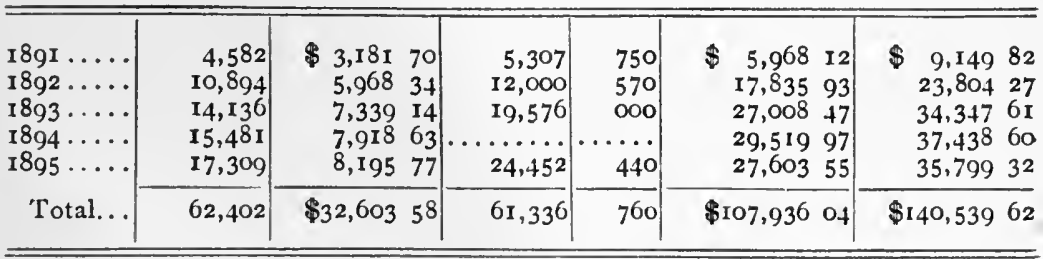


MONTEREY AND GULF RAILWAY.

\begin{tabular}{|c|c|c|c|c|c|c|}
\hline \multirow{2}{*}{ YEARS. } & \multirow{2}{*}{$\begin{array}{l}\text { PASSEN- } \\
\text { GERS. }\end{array}$} & \multirow{2}{*}{$\begin{array}{l}\text { PASSENGER } \\
\text { RECEIPTS. }\end{array}$} & \multicolumn{2}{|c|}{ FREIGHT. } & \multirow{2}{*}{$\begin{array}{l}\text { MISCELLA- } \\
\text { NEOUS } \\
\text { RECEIPTS. }\end{array}$} & \multirow{2}{*}{$\begin{array}{c}\text { TOTAL } \\
\text { RECEIPTS. }\end{array}$} \\
\hline & & & Tons. & Kilos. & & \\
\hline I889 & 16,714 & $\$ 17,14465$ & 4,197 & 432 & $\$ \quad 13,44052$ & $30,5^{85} \quad 17$ \\
\hline & 57,096 & 70,18508 & 168,204 & 600 & $791,398 \quad 47$ & $86 \mathrm{I}, 583 \quad 55$ \\
\hline 189 & 94,052 & II 2,910 64 & I 74,829 & 706 & $876,563 \quad 75$ & 989.47439 \\
\hline 189 & 99,802 & I I 9,39074 & 193,437 & 800 & 664,07242 & $783.463 \quad 16$ \\
\hline & 107,378 & 141,09386 & $238,44^{2}$ & $\infty 00$ & 820,43306 & 961,52692 \\
\hline 189 & ‥ & $\cdots$ & $\ldots$ & $\ddot{m}$ & $\cdots \cdot$ & .......... \\
\hline I\& & 127,900 & 150,00575 & 329,059 & 008 & $I, 162,00939$ & $1,312,015 \quad 14$ \\
\hline Total. . & 502,942 & $\$ 610,73072$ & $1,108,170$ & 546 & $\$ 4,327,91761$ & $\$ 4,938,648 \quad 33$ \\
\hline
\end{tabular}

CÓRDOVA AND TUXTEPEC RAILWAY.

\begin{tabular}{|c|c|c|c|c|c|c|}
\hline I889 & 26,537 & $\$ 4,8 I_{5} 27$ & & & $\$ x, 285 x_{3}$ & $\$ 6,10040$ \\
\hline I 890. & 49,142 & 8,917 o6 & $\cdots$ & $\ldots$ & 2,37997 & II, 297 O3 \\
\hline $1891 .$. & 23,542 & 14,00984 & $\cdots$ & $\ldots$ & 5,09798 & 19,10782 \\
\hline I892.. & 39,885 & 12,76751 & 2,235 & $57 \mathrm{I}$ & $5, \operatorname{III}$ I9 & I $7,878 \quad 70$ \\
\hline I893...... & 46,086 & 17,43362 & 3,730 & 424 & $9,828 \quad 94$ & $27,262 \quad 56$ \\
\hline $1894 \ldots \ldots$ & ........ & .......... & ......... & $\cdots$ & $\ldots \ldots \ldots$ & ......... \\
\hline I895.. & ....... & $\cdots$ & $\cdots$ & $\cdots$ & & $\cdots$ \\
\hline Total. & 185,192 & $\$ 57,94330$ & 5,965 & 995 & $\$ 23,70321$ & $\$ 8 \mathrm{I}, 6465 \mathrm{I}$ \\
\hline
\end{tabular}

MARAVATÍO AND CUERNAVACA RAILWAY.

\begin{tabular}{|c|c|c|c|c|c|c|}
\hline I89o. & 3,466 & $\$ 3,39966$ & $\cdots$ & $\cdots \cdot$ & $\$ 3,372$ I0 & $\$ 6,76$ I 76 \\
\hline 189 & 6,10 & 6,28394 & $\cdots$ & $\ldots$ & $16,74 \mathrm{I} \quad 4^{2}$ & 23,02536 \\
\hline $892 .$. & $9,08 \mathrm{I}$ & 8,04776 & $\cdots$ & $\ldots$ & $30,160 \quad 42$ & $3^{8,208} \quad$ I8 \\
\hline & 12,867 & $9,418 \quad 26$ & & . & 28,20199 & $37,620 \quad 25$ \\
\hline & 15 & 58 & $\cdots$ & $\cdots$ & $32,23^{8} \quad 33$ & $739 \mathrm{I}$ \\
\hline 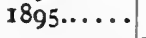 & 13,964 & 472 & $\cdots$ & $\ldots$ & 39,71480 & 51,07952 \\
\hline Total. & 60,706 & $\$ 49,73992$ & & 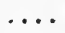 & $\$ 150,42906$ & $\$ 200,16898$ \\
\hline
\end{tabular}

SALAMANCA AND SANTIAGO VALLEY RAILWAY.

\begin{tabular}{|c|c|c|c|c|c|c|}
\hline 1889. & 4,709 & $\$ I, 4865 \mathrm{I}$ & 132 & 270 & $\$ \quad 30426$ & $\$ 1,79077$ \\
\hline $1890 . . . \ldots$ & 18,836 & $5,946 \quad 04$ & 529 & 080 & I,217 04 & 7,16308 \\
\hline $1891 . . . .$. & 25,432 & 8,554 II & 3,324 & 430 & 7,23767 & $15,79 \mathrm{I} \quad 78$ \\
\hline $1892 \ldots \ldots$ & 21,923 & 8,02059 & 2,815 & 940 & $5,325 \quad 03$ & $13,345 \quad 62$ \\
\hline $1893 \ldots \ldots$ & 22,674 & 7,71944 & 3,380 & 060 & 8,91074 & $\mathbf{1 6}, 630 \mathbf{1 8}$ \\
\hline $1894 \ldots \ldots$ & 27,496 & 8,74090 & 4,142 & 690 & $9,584 \quad 17$ & $18,325 \quad 07$ \\
\hline $1895 \ldots \ldots$ & 30,094 & 10,37666 & 7,799 & 050 & 13,96973 & $24,346 \quad 39$ \\
\hline Total. & $I_{5} I, I 64$ & $\$ 50,84425$ & 22,123 & 520 & $\$ 46,54864$ & $\$ 97,39289$ \\
\hline
\end{tabular}


MONTE ALTO RAILWAY.

\begin{tabular}{|c|c|c|c|c|c|c|}
\hline \multirow{2}{*}{ YEARS. } & \multirow{2}{*}{$\begin{array}{l}\text { PASSEN- } \\
\text { GERS. }\end{array}$} & \multirow{2}{*}{$\begin{array}{l}\text { PASSENGER } \\
\text { RECEIPTS. }\end{array}$} & \multicolumn{2}{|c|}{ FREIGHT } & \multirow{2}{*}{$\begin{array}{l}\text { MISCEILA- } \\
\text { NEOUS } \\
\text { RECEIPTS. }\end{array}$} & \multirow{2}{*}{$\begin{array}{c}\text { TOTAL } \\
\text { RECEIPTS. }\end{array}$} \\
\hline & & & Tons. & Kilos. & & \\
\hline $\begin{array}{l}1892 \ldots \ldots \ldots \\
1893 \ldots \ldots \\
1894 \ldots \ldots \\
1895 \ldots \ldots\end{array}$ & $\begin{array}{l}31,080 \\
30,888 \\
31,913 \\
39,041\end{array}$ & $\begin{array}{rr}\$ 2,652 & 89 \\
3,260 & 28 \\
3,318 & 14 \\
4,005 & 14\end{array}$ & $\begin{array}{l}4,006 \\
6,135 \\
6,221 \\
5,430\end{array}$ & $\begin{array}{l}000 \\
000 \\
000 \\
000\end{array}$ & $\begin{array}{rr}\$ 1,330 & 13 \\
1,965 & 72 \\
2,002 & 79 \\
1,410 & 85\end{array}$ & $\begin{array}{r}3,983 \text { O2 } \\
5,226 \text { o0 } \\
5,320 \\
5,41509 \\
\end{array}$ \\
\hline Total.. & 132,922 & $\$ I_{3,236} 45$ & 21,792 & 000 & $\$ 6,70949$ & \$I9,945 94 \\
\hline
\end{tabular}

VALLEY OF MEXICO RAILWAY.

\begin{tabular}{|c|c|c|c|c|c|c|}
\hline $18 g 1 . . .$. & $1,423,652$ & $\$ 99,6$ I $5_{5}$ og & 9,108 & $\infty 00$ & $\$ 5,91238$ & $\$ 105,527+\mathrm{I}$ \\
\hline $1892 \ldots .$. & $x, 639,873$ & I 9,37976 & $2 \mathrm{I}, \mathrm{I} 54$ & 000 & 12,3 IO 35 & I3I,6go 17 \\
\hline $1893 \ldots \ldots$ & $\mathbf{I}, 637, \mathrm{I} 35$ & I 10,16060 & $24,36 \mathrm{r}$ & Doo & 21,49748 & I $3 \mathrm{r}, 658$ o8 \\
\hline $1894 \ldots \ldots$ & .......... & $\ldots \ldots \ldots$ & $\ldots \ldots$ & $\ldots$ & $\ldots \ldots \ldots$ & $\ldots \ldots \ldots$ \\
\hline $1895 \ldots \ldots$ & $\ldots \ldots \ldots$ & $\cdots$ & $\ldots \ldots$ & $\cdots \cdots$ & $\ldots \ldots \ldots$ & $\ldots \ldots \ldots$ \\
\hline Total... & $4,700,660$ & $\$ 329$, I 5545 & 54,623 & $\infty$ & $\$ 39,7202 \mathrm{r}$ & $\$ 368,87566$ \\
\hline
\end{tabular}

PUEBLA INDUSTRIAL RAILWAY.

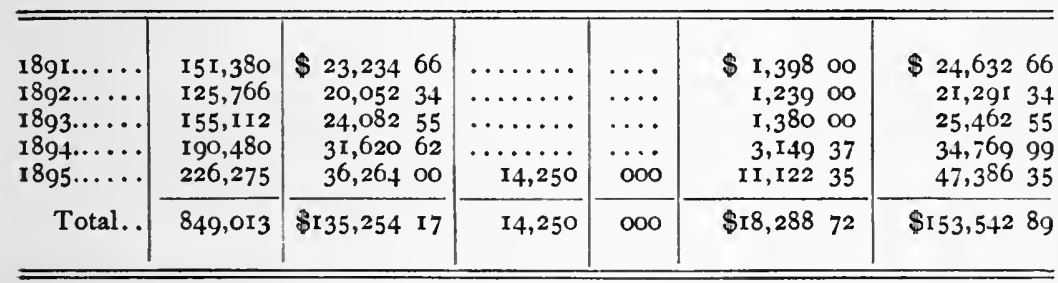

MEXICAN NORTHERN RAILWAY.

\begin{tabular}{|c|c|c|c|c|c|c|}
\hline & 4870 & ST, 80? 6 T & & & 8 & \\
\hline $1892 \ldots \ldots$ & $\begin{array}{l}4,0 / 0 \\
4,369\end{array}$ & $\begin{array}{r}14,80261 \\
14,8026 \mathrm{I}\end{array}$ & $\begin{array}{r}94,720 \\
\mathrm{I} 77,78 \mathrm{I}\end{array}$ & $\begin{array}{l}000 \\
825\end{array}$ & $\begin{array}{r}740,122 \\
\mathrm{I}, 337,85347\end{array}$ & $\begin{array}{r}15+1,625 \\
1,352,656 \text { o8 }\end{array}$ \\
\hline $1893 \ldots \ldots$ & 4,088 & 13,08790 & I 76,801 & 913 & $\mathrm{r}, 334,52447$ & $1,347,61237$ \\
\hline $1894 \ldots \ldots$ & $\ddot{3} \ddot{\text { is }}$ & ……. & & $\ldots$ & $\ldots \ldots \ldots$ & mo....... \\
\hline $5 \ldots . . \cdots$ & 4,274 & 13,420 I 8 & I 5 J, 744 & 929 & $\mathrm{r}, \mathrm{I} 49,069 \quad 15$ & $I, 162,48933$ \\
\hline Total. . & I $7,60 \mathrm{I}$ & $\$ 56$, I $_{3} 30$ & 601,054 & 667 & $\$ 4,561,570$ o7 & $\$ 4,617,68337$ \\
\hline
\end{tabular}

MEXICO CUERNAVACA AND PACífICO RAILWAY.

\begin{tabular}{l|l|l|l|l|l|l|l}
\hline $1895 \ldots . .$. & 17,209 & $\$ 19,21484$ & 84,434 & 000 & $\$ 130,66286$ & $\$ 149,87770$ \\
\hline
\end{tabular}


FEDERAL DISTRICT TRAMWAYS.

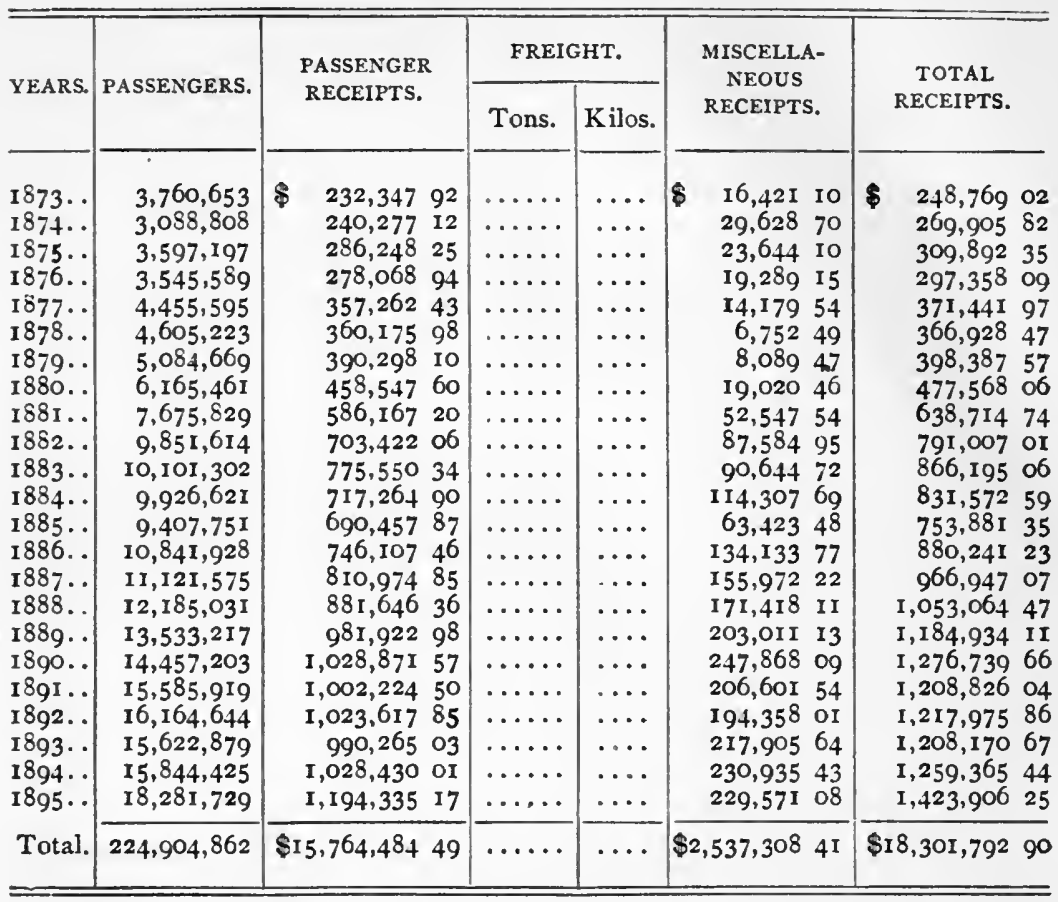

VERACRUZ AND ALVARADO RAILWAY.

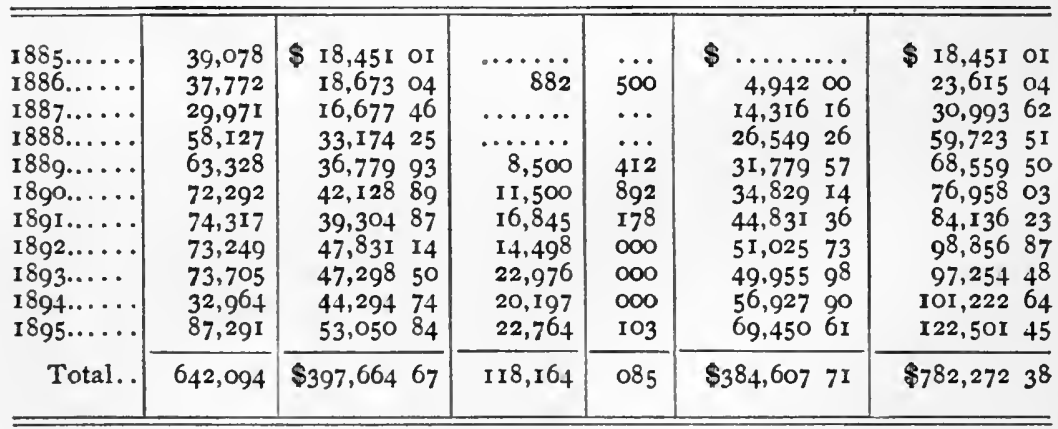

Total Traffic and Receipts of Mexican Railways.-Before concluding this chapter, I append a statement of the total traffic and receipts of the Mexican Railways from 1873 to I 895, taken from the Anuario Estadistico de la Republica Mexicana of 1895 , compiled in the Department of Communication of the Mexican Government from data furnished the same by the respective companies, in compliance with the provisions of their grants. 
RAILWAY SUBSIDIES PAID BY THE MEXICAN GOVERNMENT.

I append a statement of the railway subsidies paid by the Mexican Government from the beginning of railway construction to June $3^{\circ}$, 1896 , which is entirely correct, as it has been obtained from the accounts of the Federal Treasury of Mexico. I insert after that statement a detailed account of each of the railways to whom subsidies have

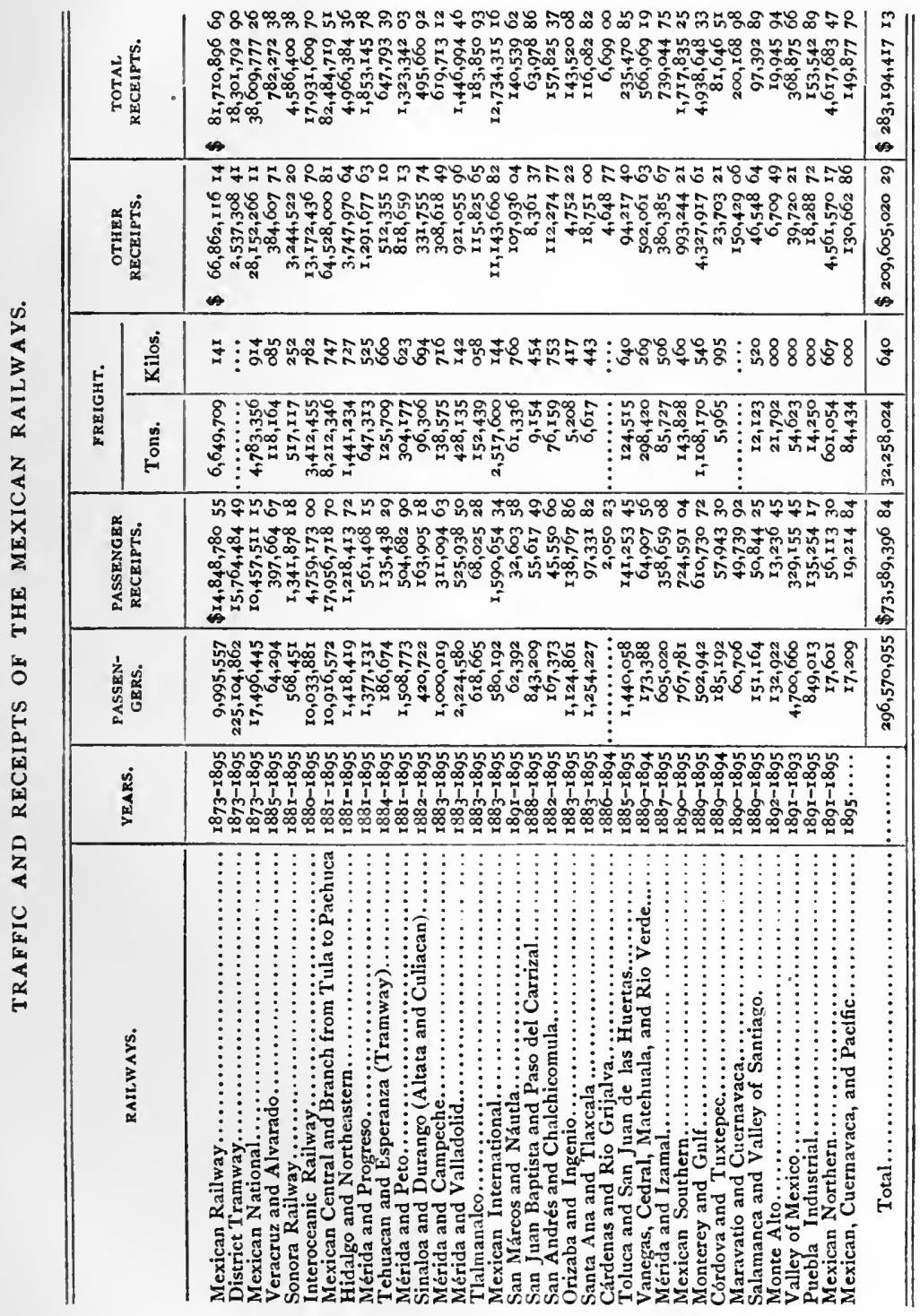




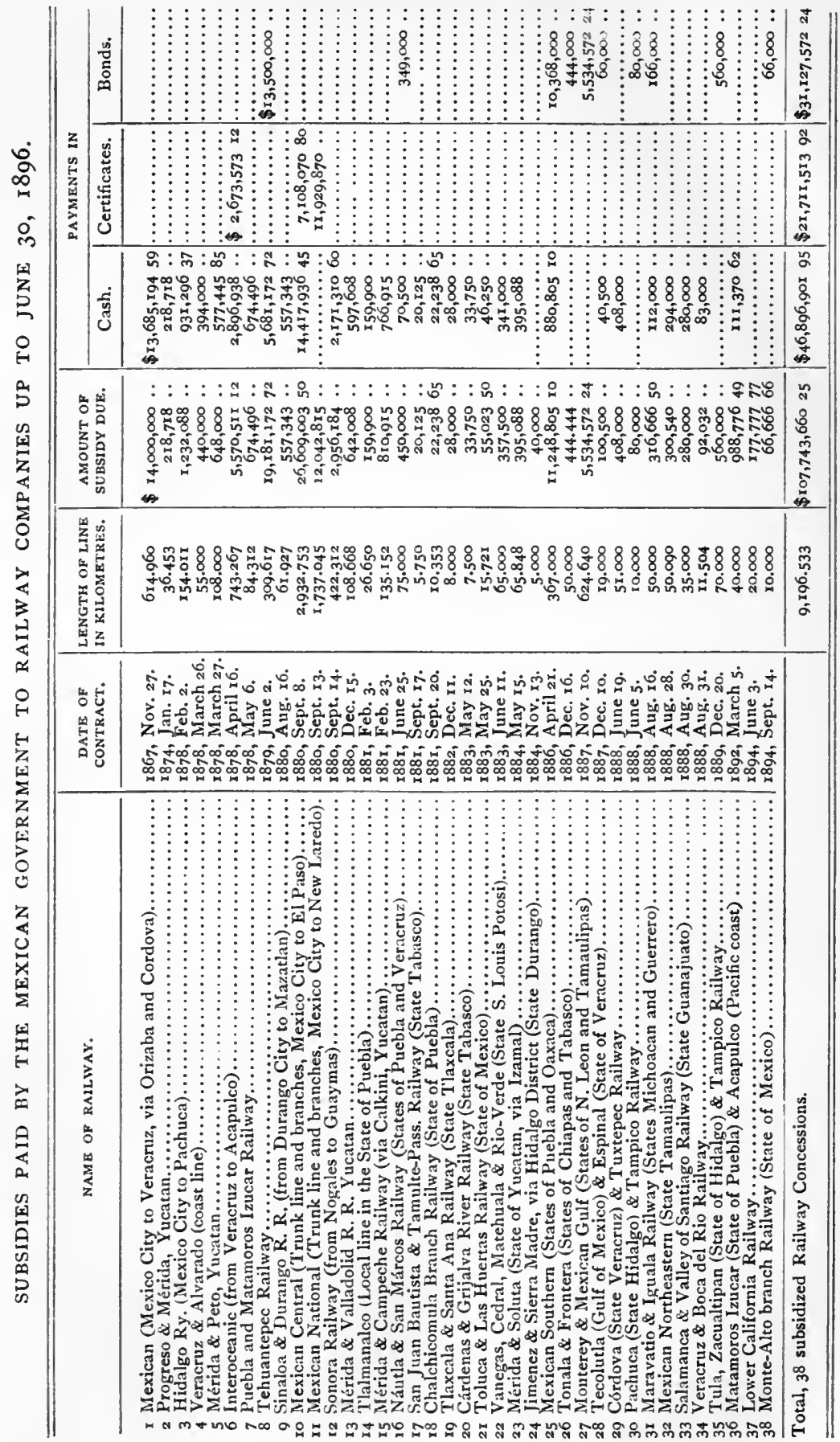


been paid, stating the number of kilometres built, the amount of subsidy due for the same, and the manner in which the subsidy was paid, that statement being the most complete that has so far been published :

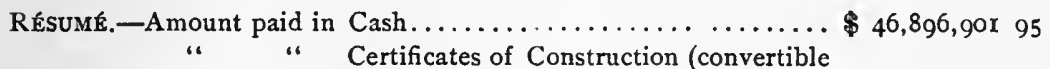
in five per cent. bonds)......... 21,7 $11,5 \mathrm{I} 392$ “ “ Bonds....................... $31,127,000$ 0 “ of Balance due (payable either in cash or Bonds), 8,008,244 38

Total amount of Subsidies, as per corresponding concessions, $\$ 107,743,66025$

The Tehuantepec Railway cost of construction is herein included, in order to give a complete statement of the Government's pecuniary outlay for the construction of railways in the country. As the $\$ 13,500,000$ amount of the five per cent. Bonds paid on account of the construction of this line to the contractors, McMurdo \& Co., represent a gold indebtedness, if reduced at the rate of 24 pence per dollar, the above total cost of railway construction should be increased by an equal amount, say $\$ 13,500,000$ Mexican currency-or a grand total of $\$ 121,243,660.25$.

DETAILED STATEMENT OF THE SUBSIDIES PAID BY THE MEXICAN GOVERNMENT TO THE RAILWAY COMPANIES.

I. Mexican Railway.-(From Mexico City to Veracruz.)

Subsidy as per original concession, $\$ 560,000$ per annum, during

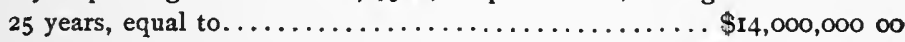

Paid previous to October $21,1890 \ldots \ldots \ldots \ldots$ 10, 187,31579

Balance in favor of the company, on October $2 \mathrm{I}, 1890$, as per special agreement of the same date.................. \$3,497,878 80

9\% deduction, for cash payment, according to the second clause of said agreement....... Total payment..................... I4,000,000 00

2. Hidalgo Railway.-(From Mexico City to Pachuca, Hid.)

Subsidy, $\$ 8000$, per kilometre, as per concession ......... \$r,232,088 oo Paid on account thereof in cash.......... \$93 1,29637

In $3 \%$ and $5 \%$ Bonds..................... 300,79163

Total payment....................... r, 232,088 00

3. Veracruz \& Alvarado Railway.-(Coast Line between the said ports.)

Subsidy due the Company, $\$ 6000$ per kilometre, as per con-

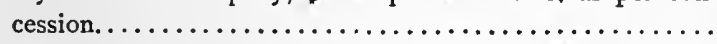

Paid on account thereof, in cash ......... \$394,000 00

In $3 \%$ Bonds..................... 46,000 $\infty \quad 440,00000$

4. Merida \& Peto Railway.-(Between the two named towns, State of Yucatan.)

Subsidy, due the Company, $\$ 6000$ per kilometre, as per con-

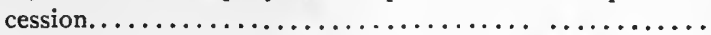

Paid in cash...................... \$577,445 85

In $3 \%$ Bonds....................... $70,554 \quad 15$

Total payment.......................... 648,000 oo 
5. Interoceanic RaIlway.-(Narrow gauge, from Veracruz to Acapulco, Pacific Coast.)

Subsidy due the Company.

$\$ 5,570,51112$

$483 . \frac{80}{864}$ Kilometres at $\$ 8000 \ldots \ldots \ldots \ldots \$ \$ 3,866,469$ I2

$\begin{array}{rlll}81.000 & \text { “ } & \text { “ } 6500 \ldots \ldots \ldots \ldots \ldots & 526,50000 \\ 140.000 & \text { “ } & \text { “ } 6000 \ldots \ldots \ldots \ldots & 840,00000 \\ 38.959 & \text { “ } & \text { unsubsidized.......... }\end{array}$

Construction bounty earned, as per concession on the Mexico \& Cuautla division........

Construction bounty earned, as per concession on the Jalapa \& Veracruz division........

$200,00000 \quad 5,570,51112$

Paid in cash............. \$2,896,938 oo

In certificates already paid for, out of the $3 \%$ of the Customs Receipts........ 2,673,573 I2

Total payment.................... 5,570,5 II 12

6. Occidental Railway.-(Between points in the States of Sinaloa and Durango.)

Length of the road, according to the concession 1373 kilometres, subsidy at the rate of $\$ 8000$, per kilometre, as follows :

From Altata, (Port on the Pacific Coast, Gulf of California), to Culiacan, capital of the State of Sinaloa.....6r. 997 kilometres constructed

From Culiacan to Durango and

Fresnillo cities .......6 600

A Branch to Guaymas ....... 536

“ “ "Mazatlan ......2 237

$$
1,373
$$

Subsidy due for the first 61.927 kilometres

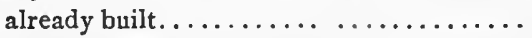

Construction bounty according to concession $\$ 1000$ per kilometre............... 6r,927 oo

Total amount due and paid for to the Company.......... \$557,343 00

7. Mexican Central, and sundry branches.-(Trunk-line, from Mexico City to El Paso del Norte, on the Rio Grande River.)

Subsidy due in accordance with the corresponding charter was $\$ 26,609,00350$ As follows : for 1970.000 kilometres of the trunk-line, of which 107 kilometres were subsidized at $\$$ r 500 per kilometre................ \$ 160,50000

And $1,863 . \frac{600}{6 i l o m e t r e s}$ at

$\$ 9500$ per kilometre........ 17,704,200 00 \$17,864,700 00

For 258.080 kilometres of the 


\section{Railways.}

Gaudalajara branch, which reduced as per special contract of Feb. 25, 1887, to $218 . \underline{580}$ kilometres at $\$ 9500$ per kilometre.............. \$2,076,510 o0

For $653 . \underline{500}$ kilometres of the Aguascalientes \& T a m pico Branch, at $\$ 9500$ per kilometre..................

For 25 kilometres of the San Blas \& Guaristemba at $\$ 9500$ per kilometre............ For 23. $\frac{378}{3}$ kilometres of Silao \& Guanajuato Branch at $\$ 9500$ per kilometre............

$6,208,25000$

$237,500 \infty 8,522,260 \infty$

This total amount, was settled and paid for in accordance with special agreement entered into by and between the Department of Public Works and the Company, on August 23, I890, as follows :

Lands, art-works, drafts and plans, etc., due by the Company as per settlement effected December 22, I881...............

Rebate off the subsidy corresponding to 6600 34,20439 kilometres of parallel lines, between Zacatecas \& Guadalajara, as per agreement therefor...$\ldots \ldots \ldots \ldots \ldots \ldots \ldots$.

Rebate off the subsidy on 50 kilometres of the line, between Tantoyuquita \& Tampico, as per agreement...................

Cash received by the Government of the State of San Luis Potosi, on account of the old branch line to Tampico..............

Certificates of construction paid at various Custom Houses out of the $8 \%$ of the receipts of the same, during the fiscal years $188 \mathrm{I}-1890$

Paid with bills of exchange on London out of the proceeds of the loan negotiated in

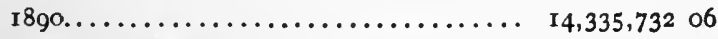

25\% discount on $\$ 19,820,793$ or, amount of the balance acknowledged in favor of the Company, according to the above mentioned agreement, (August 23, 1890)........ 4,955, I96 25 Total payment.......................... \$26,609,003 50

8. Mexican National, and branches.-('Trunk-line from Mexico City to Laredo, Tamaulipas.)

The Company constructed 1737.045 kilometres for which the Government owed the following subsidies :- 
On 1444.045 kilometres of the trunk line, at the rate of $\$ 7000$ per kilometre.......... . \$10,108,315 00

On 273.000 kilometres of the trunk line, at the rate of $\$ 6500$ per kilometre........... $\quad 1,774,50000$

On 20 kilometres of the Salto Branch at the rate of $\$ 5000$ per kilometre.............. $\quad 160,00000$

Total amount of subsidy due...................... $\$ 12,042,815$ on

The above amount was paid in certificates of construction for.. $\$ 11,929,870$ oo of which the sum of $\$ 8,746,72260$ was paid at several Custom-Houses during the fiscal years $1882-1895$, and the balance of $\$ 3,183,14740$, was converted, by special agreement between the Treasury Department and Messrs. Lionel Carden and H. P. Webb, as representatives of the Company in 5\% Bonds. The balance of $\$ 112,945$ which in the preceding statement, appears as pending of payment, was accepted by the Company, as the value of the Government's shares in the Salto Branch.

9. "Sonora Railway."-(From Guaymas, on the Gulf of California, to Nogales, on the boundary line.)

Subsidy on 422312 kilometres at the rate of $\$ 7000$ per kilometre, $\$ 2,956,134 \infty$ Paid to the Company, cash............ \$2,071,310 60

Fine against the forfeiture of the concession... 100,00000

3\% Bonds in accordance with the provisions of

the law of September 6 th, $1894 \ldots \ldots \ldots . \quad 784,87340$

Total payment..................... $2,956,184 \infty$.

10. "Merida \& Valladolid Railway," with a branch.-(Between these two towns in the State of Yucatan.)

Subsidy due on 108.688 kilometres at $\$ 6000$ per kilometre..... $\$ 642,008$ oo Paid for as follows, cash.............. \$ 597,608 o0

In 3\% Bonds (law of September 6th, 1894)... 44,400 00

Total payment.......................... \$642,008 00

11. "Merida \& Campeche Rallway," via. Kalkini.-(Between the capitals of the States of Yucatan and Campeche.)

Subsidy due on $135 . \frac{1525}{5}$ kilometres at $\$ 6000$ per kilometre, $\$ 810,91500$ Paid to the Company in cash............ \$ \$66,915 00

In $3 \%$ Bonds..................... $44,000,00$

Total payment.......................... \$810,915 00

12. "San Marcos \& Nautla Railway."-Between San Marcos station on the Mexican Ry. and Nautla bar on the Gulf of Mexico.)

Subsidy due on 75 kilometres at $\$ 6000$ per kilometre.........

Paid to the Company as follows: Cash...... $\$ 70,500$ oo

$\$ 450,00000$

In special $5 \%$ subsidy Bonds...............

In $3 \%$ Bonds according to the provisions of the

law of September 6 th, $1894 \ldots \ldots \ldots \ldots$.

349,00000

50000

Rebatement of subsidy on 5 kilometres running

parallel with the "Interoceanic Ry...... 30,000 00

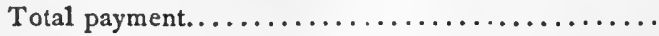


13. "Toluca \& San Juan de las Huertas Railway."-(Between the capital of the State of Mexico and the San Juan estate.)

Subsidy due on $15 . \frac{721}{}$ kilometres at $\$ 3500$ per kilometre.......

Paid to the Company, cash............ $\$ 46,25000$

In $3 \%$ Bonds (law of September 6th, I894).... 8,77350

Total payment.............................. $\$ 55,02350$

14. "Vanegas, Cedral, Matehuala \& Rio Verde Railway."(All townships within the State of San Luis Potosi.)

Subsidy due on 65.000 kilometres at $\$ 5500$ per kilometre.....

Paid to the Company, cash............. \$34r,000 on

In $5 \%$ Bonds (September 6th, I 894)........ If.500 oo

Total payment........................... $\$ 357,50000$

I5. "Jimenez and Sierra Madre Railway."-(Through the Hidalgo District, State of Chihuahua.)

Subsidy due on $5 . \frac{000}{6}$ kilometres at $\$ 8000$ per kilometre.......

The whole paid to the Company in 3\% Bonds (Law of Septem-

$\$ 10,00000$

ber 6 th, I894.

16. "Mexican Southern Railway." - $(367$ kilometres from the City of Puebla to Oaxaca.)

Subsidy due under agreement of May $4^{\text {th, }}$ I $892 \ldots \ldots \ldots \ldots$ II $, 248,805$ ro

First annuity of interest paid to the Company in conformity with the original concession of April 2rst, I886.................

Conversion of the remaining if annuities, as per the above named agreement, in special Bonds denominated of the " Oaxaca Trunk Line"..................... 8,558,888 55

Bounty paid to the Company, as per original concession, in Bonds (special).......... I,809, II 55

Total payment............. - $\$ 11,248,805$ I0.

Of the total amount of special Bonds issued, $\$ 10,368,000$ oo

Cashed ............................ I, 108,000 $\infty$

Outstanding................... 9,260,000 00

17. "Tonala" (State of Chiapas, Pacific Coast) and "FronTERA RaIlway."-(State of Tabasco, on the Gulf of Mexico.)

Subsidy on 50 kilometres at $\$ 8000$ per kilometre......... $\$ 400,000$

Paid to the Company with $6 \%$ Bonds, valued at

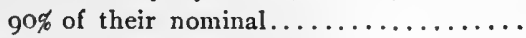

The balance shown in the preceding statement

$\$ 444,44400$

in favor of the Company for $\$ 44,444.00$ proceeds from the want of a Bond of less value than $\$ 1000$ of the corresponding issue. 
18. "Monterey" (Capital of the State of Nuevo Leon) and "Mexican Gulf Railway."-(Port of Tampico.)

Subsidy on $624 . \frac{640}{}$ kilometres at $\$ 8000$ per kilometre...... $\$ 5,534,57224^{\mathrm{I}}$

Wholly paid for in $5 \%$ Bonds, issued under the law of September 6th, 1894, with the exception of a balance of $\$ 572.24$, which, on account of the want of bonds of less value than $\$ 1000$, is still pending of settlement. Of the original issue of special Bonds given to the Company in payment of the subsidy, $\$ 235,000$ is still pending of conversion.

19. "Tecolutla" (a bar on the Mexican Gulf) and "Espinal RAILWAY." - (Both in the State of Veracruz.)

According to the original concession, the subsidy granted to this Company was on 19 kilometres at the rate of $\$+500$ in cash per kilometre; but under a new agreement, dated January, 2oth, 1892, it was settled as follows:

9 kilometres at the rate of $\$ 4500$ each in cash, $\$ 40,50000$ Io kilometres in Bonds at $\$ 6000$ each........ $60,000, \infty$

Total payment......................... \$100,500 00

20. "Pachuca" (Capital of the State of Hidalgo) and "TAMPICo Railway."-(On the Mexican Gulf.)

Subsidy on 10.000 kilometres at $\$ 8000 . \ldots \ldots \ldots \ldots \ldots \ldots$

Totally paid in Bonds, in accordance with the law of Septem-

$\$ \$ 0,00000$ ber 6 th, 1894 .

21. "Maravatio" \& "Iguala Railway."-(Towns in the States of Michoacan and Guerrero, respectively.)

Subsidy on 50 kilometres at $\$ 3000$ in cash and $\$ 3000$ in special Bonds, under ro\% discount off their nominal value, and paid for, cash,

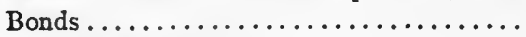

$\$ 112,00000$ 166,00000

Total payment..................... \$316,666 $50^{1}$

22. "Mexican Northeastern Railway."-(An extension of the "Hidalgo" Ry. to Tizayuca, in the State of that name.)

Subsidy on 50.090 kilometres at $\$ 6000 \ldots \ldots \ldots \ldots \ldots \ldots$ Paid for, in cash.................. \$294,000 00

In $3 \%$ Bonds....................... 6,540 o0

Total payment.......................... \$300,540 $\infty$

'Some of the total payments in this table do not correspond to the amount of subsidy due, because in some of those cases other payments have been made, like bounty, of which no account appears in the respective statement. In some cases a bounty was offered provided the road was finished before the time fixed in the respective grant. 
23. "Veracruz \& Boca del Rio Railway."

Subsidy acknowledged on II $\underline{\mathbf{6 0 4}}$ kilometres at $\$ 8000$ per kilo-

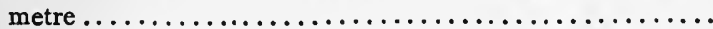

Paid for, cash.................. $\$ 83,000, \infty$

In $3 \%$ Bonds...................... $9,032 \infty$

Total payment........................... \$92,03200

24. "Tula, Zacualtipan" (State of Hidalgo), and Tampico RaILWAY.

Subsidy on 70.000 kilometres at $\$ 8,000$ per kilometre....... $\$ 560,00000$

The whole amount paid for in $5 \%$ Bonds, of which $\$ 285,000$

were outstanding on the 30 th of June, 1896 .

25. "Matamoros Izucar" (State of Puebla) and "Acapulco RaIlway."-(On the Pacific coast.)

Subsidy under contract of March 22d, 1895, on 40 kilometres. .

Paid as follows : cash, for the amount of $2 \%$ in-

$\$ 988,77649$

terest annuities paid to the Company in

conformity with the original concession...

$\$ 111,37062$

In $5 \%$ Bonds, according to the above con-

tract............................

877,40587

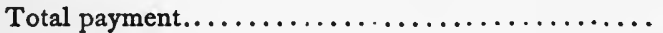

$\$ 988,77649$

26. "Lower California Railway."-(From the town of San Quintin to a point on the "Mexican Central," Chihuahua.)

Subsidy on 20 kilometres, payable in $6 \%$ Bonds at the rate of

$\$ 8000$ per kilometre, the said Bonds, afterwards converted in conformity with the corresponding law of conversion, were taken by the Company under Io\% discount off their

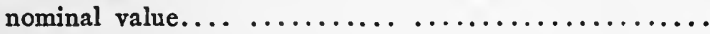

27. "Monte Alto Railway."-(Starts from the town of Tlalnepantla, on the Salto branch of the "Mexican National," towards Alizapan and Villa del Carbon.)

Subsidy on to kilometres at $\$ 6000$ per kilometre, payable in 6\% Bonds taken by the Company at the rate of $90 \%$ of their face value........................... \$66,666 66

28. Tehuantepec R. R.-(Between Coatzacoalcos on the Gulf of Mexico, and Salina Cruz, on the Pacific coast.)

COSTS OF CONSTRUCTION TO THE MEXICAN GOVERNMENT.

I. Contractors, Edward Learned \& Co.-(Contract of June 2d, 1879.)

35 kilometres, of which only 25 were paid for, at $\$ 7500 . . . \ldots \ldots \ldots \ldots \ldots$.

The Learned contract was'rescinded by the Mexican Government on August I6th, 1882; but hy agreement adjusted with J. Tyng, as representative of the contractors, who received the following payments :

\section{$\$ 187,50000$}




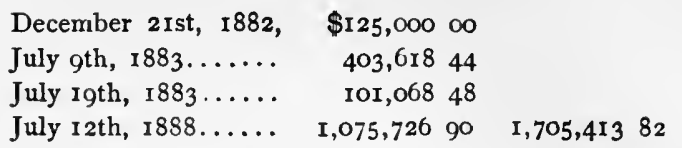

Total amount paid to Learned \& Co................

Of which amount the sum of $\$ 230,413.82$ represents interest accrued at the rate or $6 \%$ per annum ; so that the 35 kiloneters built by these contractors actually cost $\$ 14,083.25$ per kilometre.

2. Contractor, Mr. Delpin Sanchez.-(Agreement of October 5 th, 1882.)

This contractor received from the Government the sum of $\ldots \ldots \ldots \ldots \ldots \ldots \ldots \$ 1,079,13540$

For the purchase of material, which he only accounted for the amount of $\$ 908$,910.50 the balance of ............

Having been donated to the contractor according to special agreement of April 25 th, I 888 .

The same contractor received in 150 weekly installments of $\$ 1900$ each during the fiscal years $1885,1888 \ldots$.

Mr. Sanchez delivered as constructed 74 kilo$\$ 285,000$ 00 meters which were paid to him at the rate of $\$ 25,000$ each............. $\$ 1,850,000$ oo

3. Mac-Murdo Contract.-(Agreement approved by Decree of October I5th, I888.)

For the completion of the construction and the furnishing of all the rolling material, etc., and for which the Contractors received in payment in $5 \%$ Bonds, special issue, principal and interests payable in sterling currency,

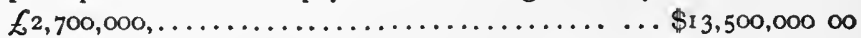

This contract was rescinded on the 13 th of January, 1892, when the contractors, in settlement of accounts, surrendered to the Government the sum of about $\$ 2,000$,000 as surplus proceeding from the sale of the said bonds, and delivered, more or less, 250 kilometres of the lines as built or repaired within the stipulations of the said contract.

4. Stanhope, hampson \& Corthel Contract.-(Made under Decree of December 6th, I893.)

For the construction of 59 kilometres and the completion of all the necessary works for the preservation and working of the whole line, for the fixed sum of, ..... \$r,483,035 00

Total cost of the line $\$ 19,181,17372$ 


\section{PUBLIC DEBT.}

In the first part of this paper I gave a brief statement of the different loans and liabilities which constitute the Mexican debt, and that statement will make it easy to understand the different issues and denominations of our bonds. Here I append a detailed statement of the National Debt of Mexico, up to June $3 \circ$, 1896 , submitted to Congress by the Secretary of the Treasury on the I 4 th of December, I896, and a further statement containing the same data in a more concise form.

\section{STATEMENT OF THE NATIONAL DEBT OF MEXico to JUNE $30,1896$.}

Bonded Debt, Principal and Interest payable in Sterling currency.

Six per cent. interest bearing Bonds for the Loan of 1888 , with ... \% sinking fund, Capital and Interest........ \$51,908,786 50

Six per cent. interest bearing Bonds for the Loan of 1890 , with .. \% sinking fund, Capital and Interest........

Six per cent. interest bearing Bonds for the Loan of 1893 , with .. \% sinking fund, Capital and Interest........ Five per cent. interest bearing Bonds for the Construc per cent. (non converted balance) Bonds of the Loan, contracted in London, 185I, Capital................

Total amount of outstanding Bonds, payable in Sterling currency.......................

Bonded Debt, Principal and Interest payable in Mexican Silver currency.

Three per cent. interest bearing Bonds of the Interior Consolidated Debt, Capital and Interest............

Five per cent. interest bearing Bonds of the Interior Redeemable Debt, first series, Capital and Interest.... Five per cent. interest bearing Bonds of the Interior $\mathrm{Re}$ deemable Debt, second series, Capital and Interest.

Subsidy Bonds, non converted balances, for sundry works and railways, Capital......................

Total $83,240,60998$

Railway Construction Certificates, pending of conver-

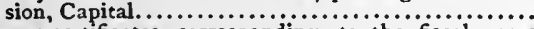
Balance-certificates corresponding to the fiscal years comprehended between 1882 and 1894 , Capital pending of conversion...............................

Total amount of bonded debt, payable in Mexican Silver currency.

Grand Total of Bonded Liabilities............. $30,068,71025$ $15,325,56150$ $13,500,000 \infty$ $134,153 \quad 12$

Liabilities from various sources, and in forms, other than Bonds, payable in Mexican Silver currency.

To Railway, Harbor Works and Drainage of the Valley

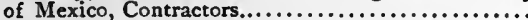

To Unpaid for Appropriations in the Budgets for the fiscal years between 1891 and $1896 \ldots \ldots \ldots \ldots \ldots$

To other credits pending of settlement : on account of

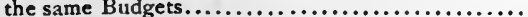

To Balances in Accourit-current due various Contractors with some of the Executive Departments...........

To sundry, cash or otherwise executed, Deposits, as guarantee for pending contracts .................

To provisional certificates issued on account of the 1888 ,

To cash or other values pending of classification in the corresponding accounts........................

To cash Receipts on account of credits, other than fiscal
and pending of payment to the corresponding offices.

To Balance due to Mint-Lessees........................

To outstanding Bills Payable......................

$83,570,051$ o6

Total Amount of Liabilities from various sources and in forms other than Bonds.... 


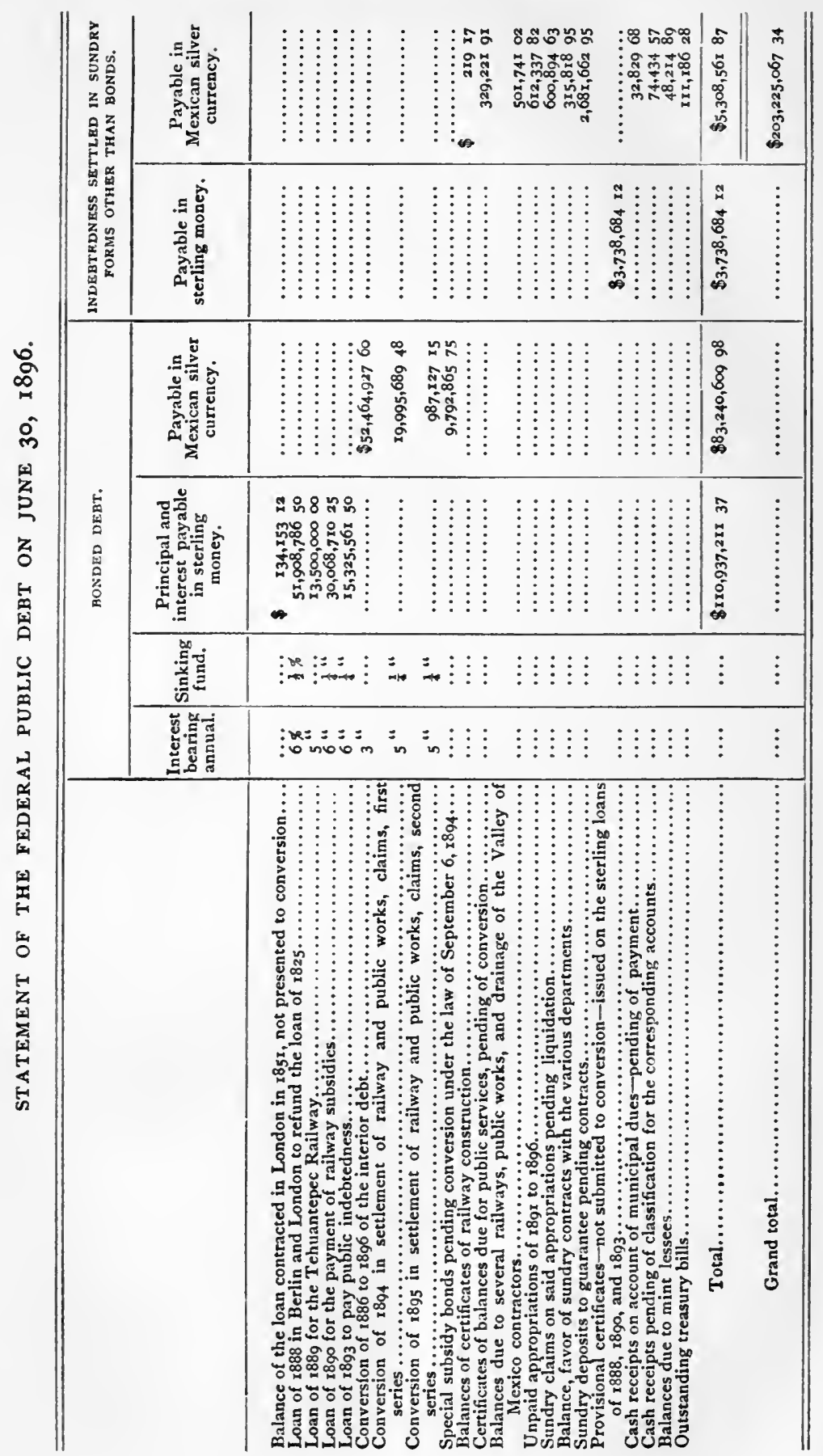




\section{POST-OFFICE AND TELEGRAPH SERVICE.}

I append a statement containing the number of post-offices, and postal agencies in each of the Mexican states in 1895 , and the number of postal pieces transported by Mexican mails from the years I $878-1879$ to $1894-1895$. (See page 225.)

I have prepared a statement of the earnings and expenditures of the post-office and telegraph services in Mexico during the twentyseven fiscal years elapsed from July I, r869, to June 30,1896 . It was not possible to obtain full data of the earnings of the telegraph lines during the first ten years of that period, on account of the defective way in which the books were kept by the Federal Treasury of Mexico. With that exception the data embraced in the following statement is correct, as it has been taken from the official accounts. (See p. 224.)

POST-OFFICES IN MEXICO IN I 895 BY STATES.

STATES.

Aguascalientes........

Campeche. ...........

Chiapas.............

Chihuahua...........

Coahuila ...........

Colima. .............

Durango ..............

Federal District........

Guanajuato..........

Guerrero...........

Hidalgo. ...........

Jalisco . . . . . . . . . . .

Lower California.......

Mexico .............

Michoacan ...........

Morelos.............

New Leon.............

Oaxaca..............

Puebla..............

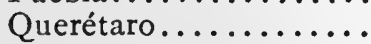

San Luis Potosí........

Sinaloa.............

Sonora.............

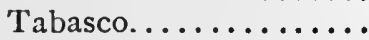

Tamaulipas...........

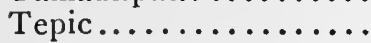

Tlaxcala...........

Veracruz...........

Yucatan............

Zacatecas ...........

Total
POST-

OFFICE.

\begin{tabular}{rr}
5 & 5 \\
8 & 3 \\
7 & 24 \\
24 & 58 \\
25 & 26 \\
2 & 9 \\
19 & 42 \\
1 & 8 \\
27 & 38 \\
13 & 31 \\
19 & 43 \\
35 & 83 \\
7 & 17 \\
14 & 21 \\
22 & 59 \\
9 & 9 \\
18 & 33 \\
22 & 39 \\
27 & 77 \\
7 & 10 \\
18 & 34 \\
16 & 28 \\
14 & 75 \\
5 & 16 \\
17 & 36 \\
7 & 13 \\
9 & 7 \\
36 & 82 \\
16 & 40 \\
20 & 23 \\
\hline 469 & 989 \\
\cline { 2 - 2 } 2 & \\
\hline & \\
13
\end{tabular}

Postai, Agencies.

TOTAL.

5

4

8 
EARNINGS AND EXPENDITURES OF THE POST-OFFICE AND TELEGRAPH SERVICES DURING THE LAST TWENTY-SEVEN FISCAL YEARS, FROM JULY I, I869, TO JUNE 30, I896.

\begin{tabular}{|c|c|c|c|c|c|c|}
\hline \multirow{2}{*}{$\begin{array}{l}\text { FISCAL } \\
\text { YEARS. }\end{array}$} & \multicolumn{2}{|c|}{ POST-OFFICE. } & \multicolumn{2}{|c|}{ TELEGRAPH. } & \multicolumn{2}{|c|}{ BOTH SERVICES.-TOTAL. } \\
\hline & $\begin{array}{c}\text { Dr. } \\
\text { Expenditure. }\end{array}$ & Ear & $\begin{array}{c}\text { Dr. } \\
\text { Expenditure. }\end{array}$ & Ear & ture. & $\frac{\mathrm{Cr} .}{\text { Earnings. }{ }^{1}}$ \\
\hline \multirow{3}{*}{$\begin{array}{l}1869-1870 . . \\
1870-1871 \ldots \\
1871-1872 \ldots \\
1872-1873 \ldots \\
1873-1874 \ldots \\
\text { Total in } \\
\text { five years.. } \\
\text { Average } \\
\text { per annum. }\end{array}$} & 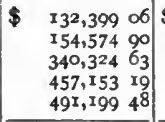 & $\begin{array}{l}\$ \quad 12 \\
16 \\
26 \\
47 \\
52\end{array}$ & 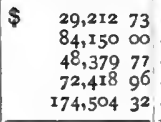 & 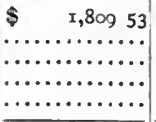 & $\begin{array}{ll}\text { II } & 79 \\
24 & 90 \\
04 & 40 \\
72 & 15 \\
03 & 80\end{array}$ & \\
\hline & $\$ 1,575,65126$ & $\$ I, 55^{I}, 3^{I I} 5^{I}$ & $\$ 408,6657^{8}$ & & $\$ 1,984,31704$ & . \\
\hline & $\$ \quad 315,13025$ & $\$ \quad 310,26230$ & $81,733 \times 6$ & & $\$ 396,8634 \mathrm{I}$ & \\
\hline \multirow{3}{*}{$\begin{array}{l}1874-1875 \ldots \\
1875-1876 \ldots \\
1876-1877 \ldots \\
1877-1878 \ldots \\
1878-1879 \ldots \\
\text { Total in } \\
\text { five years. } \\
\text { Average } \\
\text { per annum. }\end{array}$} & $\begin{array}{r}64 \mathrm{r}, 8 \\
480,2 \\
530,0 \\
682,0 \\
867,7 \\
\end{array}$ & \begin{tabular}{|l}
549 \\
455 \\
441 \\
590 \\
670 \\
\end{tabular} & $\begin{array}{l}606 \\
566 \\
60 \\
02 \\
00 \\
586\end{array}$ & $\begin{array}{l}\cdots \\
\cdots \\
\cdots \\
{ }^{\prime}\end{array}$ & $\begin{array}{r}832 \\
642 \\
664 \\
923 \\
\mathbf{1}, 126 \\
\end{array}$ & \\
\hline & $\$ 3,202,03463$ & $\$ 2,716$ & $\$ 987,28760$ & $\cdots$ & $\$ 4,189,322 \quad 23$ & . \\
\hline & $\$ 640,40693$ & $\$ \quad 543,27976$ & $\$ \quad 197,457 \quad 5^{2}$ & $\ldots$ & $\$ 837,86445$ & $\cdots$ \\
\hline \multirow{3}{*}{$\begin{array}{c}1879-1880 . . . \\
1880-1881 \ldots \\
1881-1882 \ldots \\
1882-1883 \ldots \\
1883-1884 \ldots \\
\text { Total in } \\
\text { five years.. } \\
\text { Average } \\
\text { per annum. }\end{array}$} & $\begin{array}{r}892 \\
983, \\
873, \\
840, \\
878, \\
\end{array}$ & $\begin{array}{r}702 \\
833 \\
704 \\
795 \\
698 \\
69 \\
\end{array}$ & \begin{tabular}{|rr}
$\$ 348,290$ & 24 \\
196,542 & 94 \\
570,155 & 25 \\
916,657 & 53 \\
677,729 & 50 \\
\end{tabular} & $\begin{array}{l}\text { 101,064 } 69 \\
135,144 \\
174,302 \\
1724 \\
219,384 \\
239,051 \\
235 \\
\end{array}$ & $\begin{array}{rrr}\$ 1,241,146 & 97 \\
1,180,149 & 11 \\
1,443,357 & 03 \\
1,757,012 & 23 \\
1,556,249 & 25 \\
\end{array}$ & $\begin{array}{r}\$ \quad 803 \\
968 \\
879 \\
\mathbf{1}, 014 \\
937 \\
\end{array}$ \\
\hline & $\$ 4,468,539 \mathrm{I}_{3}$ & $83.733,81995$ & $\$ 2,70$ & $\$ 868,94^{6} 31$ & $\$ 7,177,91459$ & $\$ 4,602$ \\
\hline & $\$ 893,70783$ & $\$ \quad 746,76399$ & $\$ 54$ & $\$ \quad 173$ & $\$ 1,43$ & $\$ 92$ \\
\hline \multirow{3}{*}{$\begin{array}{c}1884-1885 \ldots \\
1885-1886 \ldots \\
1886-1887 \ldots \\
1887-1889 . . \\
1888-1889 . . \\
\text { Total in } \\
\text { five years. } \\
\text { Average } \\
\text { per annum. }\end{array}$} & $\begin{array}{r}\$ 1,411 \\
751 \\
943 \\
956 \\
1,049 \\
\end{array}$ & $\begin{array}{ll}0 & 19 \\
9 & 80 \\
2 & 65 \\
3 & 74 \\
0 & 03\end{array}$ & $\begin{array}{ll}9 & 54 \\
3 & 67 \\
1 & 70 \\
4 & 24 \\
2 & 05\end{array}$ & $\begin{array}{l}77 \\
82 \\
87 \\
95 \\
13 \\
\end{array}$ & $\begin{array}{r}2,0 \\
1,3 \\
1,6 \\
1,7 \\
1,8 \\
\end{array}$ & $\begin{array}{r}82 \\
82 \\
93 \\
1,06 \\
1,21 \\
\end{array}$ \\
\hline & $\$ 5,112,324,7 x$ & $\$ 3,72$ & $\$ 3$, & $\$ I_{1}, 1_{3}$ & $9 \mathrm{r}$ & $\$ 4,868,2$ \\
\hline & $\$ 1,022,46494$ & $\$ 745,8254^{6}$ & $\$ 715,93124$ & $\$ \quad 227,81851$ & $\$ 1,73^{8}, 39618$ & $\$ 973,64397$ \\
\hline \multirow{3}{*}{$\begin{array}{l}1889-1890 . . . \\
1890-1891 . . \\
1891-1892 \ldots \\
1892-1893 . . \\
1893-1894 . . \\
\text { Total in } \\
\text { five years.. } \\
\text { Average } \\
\text { per annum. }\end{array}$} & $\begin{array}{r}\$ 1,126 \\
1,196 \\
1,342 \\
1,278 \\
1,25\end{array}$ & $\begin{array}{r}99 \\
1,08 \\
1,12 \\
1,15 \\
1,21\end{array}$ & $\begin{array}{r}87 \\
97 \\
1,04 \\
1,07 \\
95\end{array}$ & $\begin{array}{l}97 \\
59 \\
33 \\
96 \\
33\end{array}$ & $\begin{array}{l}58 \\
59 \\
55 \\
01 \\
30\end{array}$ & $\begin{array}{r}1,38 \\
1,54 \\
1,62 \\
1,68 \\
1,73 \\
\end{array}$ \\
\hline & 4,64645 & $\mathrm{II}$ & $\$ 4,91$ & $\$ 2,40$ & 13 & $\$ 7,97^{8}$ \\
\hline & $\$ x, 238,92929$ & $\$ \mathrm{x}, \mathrm{II}_{4}$ & $\$ 983,63554$ & 426 & 56483 & 228 \\
\hline \multirow{5}{*}{$\begin{array}{c}1894-1895 . . . \\
1895-1896 . . \\
\text { Total in } \\
\text { two years.. } \\
\text { Average } \\
\text { per annum. } \\
\text { Total in the } \\
\text { 27 years... } \\
\text { Average } \\
\text { per annum. }\end{array}$} & $\$ \begin{array}{r}633 \\
1,228\end{array}$ & $\begin{array}{r}\$ 1,33 \\
1,06 \\
\end{array}$ & $\begin{array}{r}531,94 \\
1,025,34 \\
\end{array}$ & $\$ 54$ & $\begin{array}{r}\$ 1,165,150 \\
2,254,131 \\
2,29 \\
\end{array}$ & $\begin{array}{l}1,885,0 \\
1,684,7\end{array}$ \\
\hline & $\$ 1,8$ & $\$ 2$ & $\$ 1,5$ & $\$ 1,16$ & $\$ 3,41$ & $\$ 3,569,7$ \\
\hline & $\$ 930,99283$ & $\$ 1,200,05370$ & $\$ \quad 778,648 \quad 3^{8}$ & $\$ \quad 584,82468$ & $\$ I, 709,641$ 2I & $\$ 1,784,87^{8} 3^{8}$ \\
\hline & $\$ 22,415,181 \quad 84$ & $\$ 19,703,305$ o5 & $\$ 14,160,45949$ & $\$ 5,584,00949$ & $\$ 3^{6}, 575,641 \quad 33$ & $\$ 21,019,60425$ \\
\hline & $\$ 830,19192$ & $\$ 729,752$ 04 & $\$ 524,46 \mathrm{I} 46$ & $\$ 328,471 \quad 14$ & $\$ 1$, & $\$ I$, \\
\hline
\end{tabular}

"The totals and averages per annum in the colums marked "Earnings" and "Total Earnings" only embrace seventeen years, as the returns for the first ten years being very incomplete are not computed. 
NUMBER OF PIECES TRANSPORTED BY MEXICAN MAILS FROM I878-1879 TO I $894-1895$.

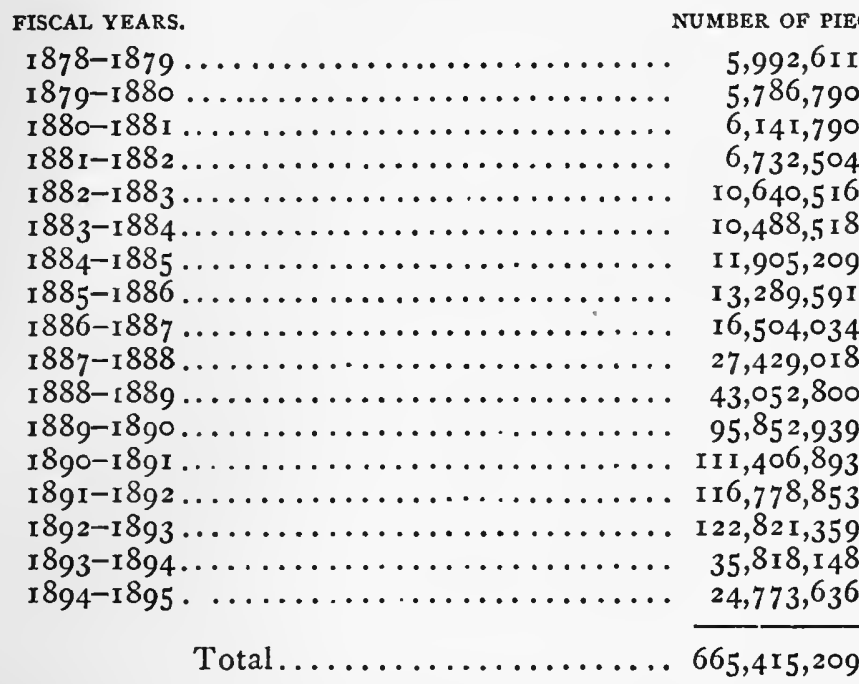

Printed matter, samples, and parcel post articles in the year 1894r895, weighed in grammes, $r, 107,755,679$.

The notable reduction which appears in the last two years is due to the fact that in the preceding years all correspondence was counted, namely: such pieces as were received and sent, and such as came in transit, while in the last two years only are accounted such as were sent.

\section{BANKS.}

The following statement contains a list of all the banks existing in Mexico up to December $3 x, 1895$, and their respective condition :

LIST OF MEXICAN BANKS.

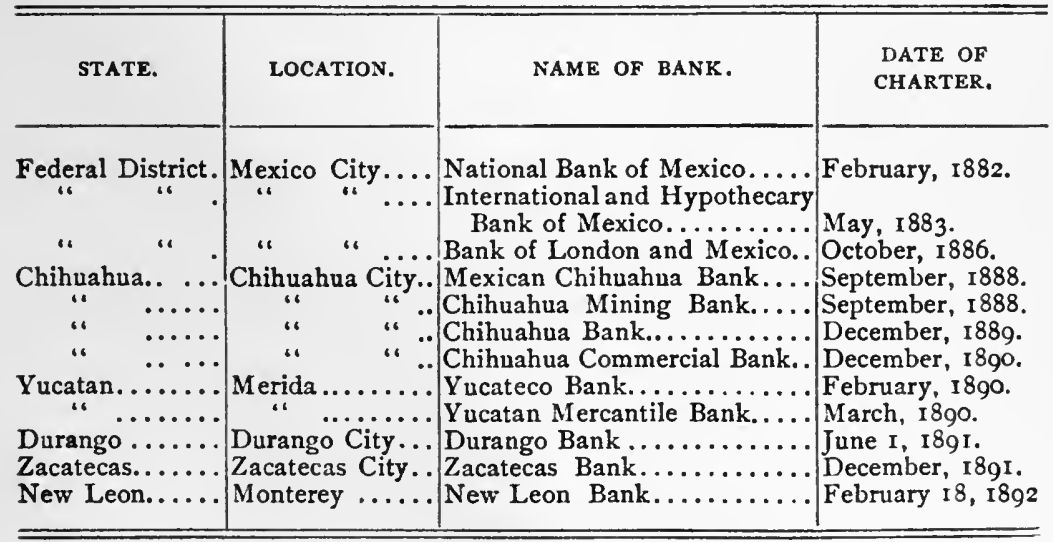


SITUATION OF THE MEXICAN BANKS ON DECEMBER 3I, I894.

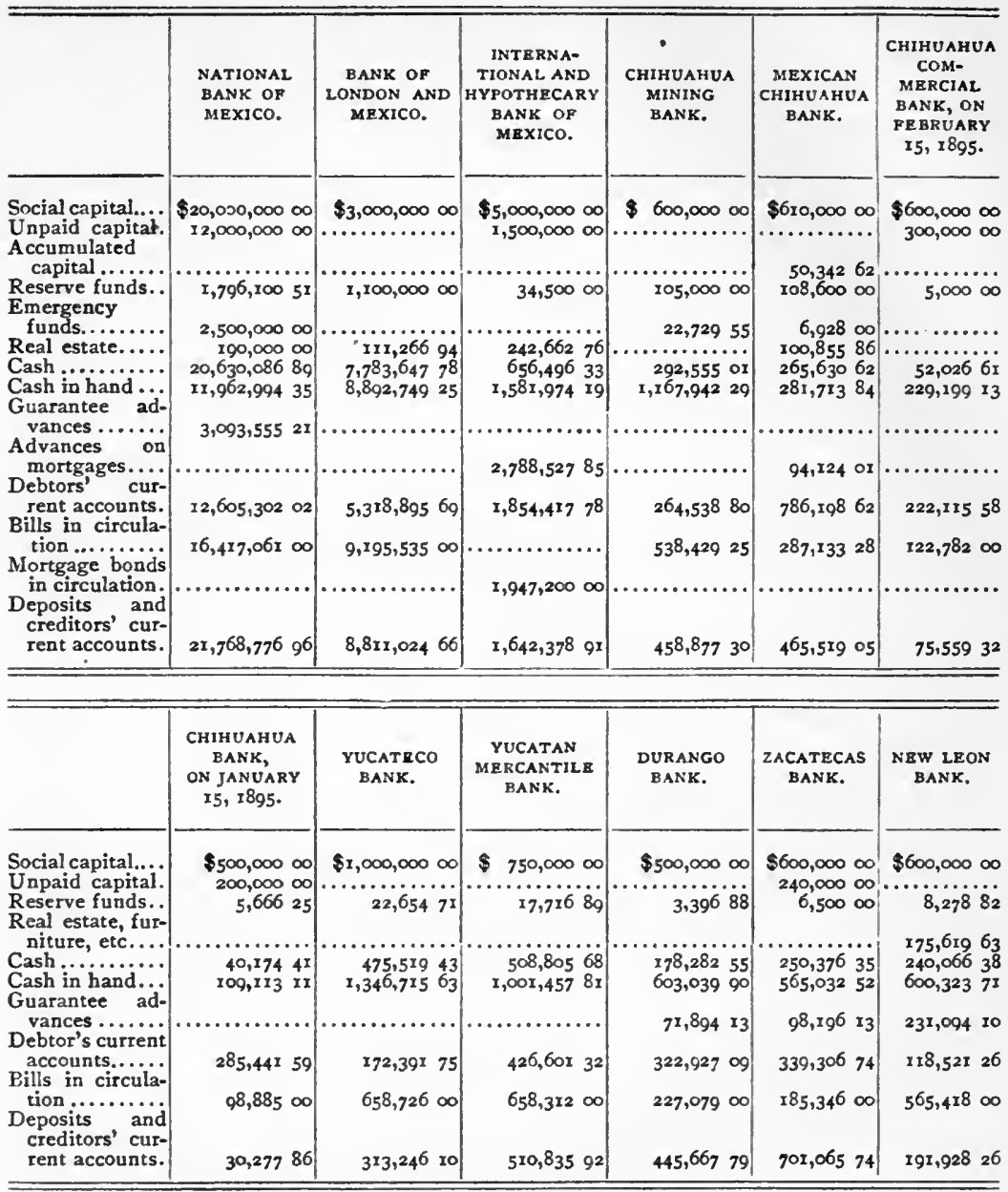

\section{PUBLIC LANDS.}

I append four statements of the titles of public lands issued by the Mexican Government. The first one embraces a résumé of the titles issued without cost, and under the act of December 14, I874, of the Indian town lands held in common, called in Spanish "Ejidos" to the respective inhabitants of the said towns, from 1877 to 1895 : the second embraces a résumé of the titles issued in 1894 and 1895 for public lands held by private parties as portions of public land bought from the government but which were in excess of the respective titles, which we call in Spanish "Demacias": the third one embraces a résumé of the titles of public lands issued to private parties in the years 1894 
and 1895 : and the fourth contains a résumé of the titles issued by the Mexican Government to surveying companies for one-third of the land respectively surveyed by them in 1894 and 1895 , according to law and the respective contracts.

$$
\begin{aligned}
& \text { FREE TITLES ISSUED UNDER THE ACT OF DECEMBER I4, I874, OF } \\
& \text { THE INDIAN TOWN LANDS TO THE RESPECTIVE } \\
& \text { INHABITANTS FROM } 1877 \text { TO I895. }
\end{aligned}
$$

\begin{tabular}{|c|c|c|c|c|}
\hline \multirow{2}{*}{ YEARS. } & \multirow{2}{*}{ TITLES. } & \multicolumn{3}{|c|}{ AREA. } \\
\hline & & Hectares. & Ares. & Cts. \\
\hline 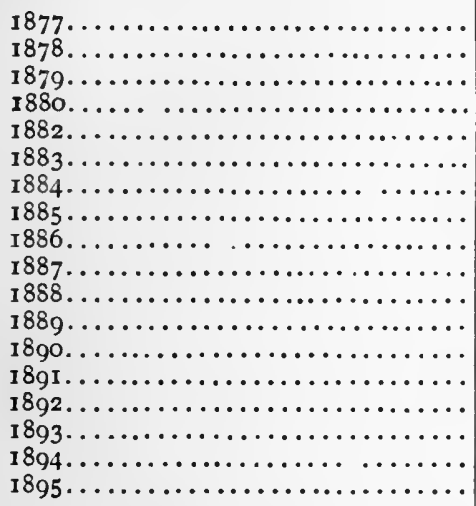 & $\begin{array}{r}1 \\
195 \\
72 \\
2 \\
195 \\
259 \\
1,932 \\
383 \\
774 \\
254 \\
1,524 \\
2,237 \\
1,130 \\
499 \\
1,449 \\
452 \\
791 \\
273\end{array}$ & $\begin{array}{r}85 \\
3,572 \\
128,144 \\
5,000 \\
5,629 \\
14,616 \\
61,497 \\
13,068 \\
20,662 \\
2,999 \\
20,547 \\
100,627 \\
68,086 \\
6,516 \\
15,807 \\
17,709 \\
6,262 \\
6,160\end{array}$ & $\begin{array}{l}06 \\
71 \\
94 \\
00 \\
29 \\
14 \\
56 \\
18 \\
93 \\
85 \\
73 \\
65 \\
31 \\
74 \\
30 \\
59 \\
71 \\
03\end{array}$ & $\begin{array}{l}00 \\
41 \\
56 \\
00 \\
69 \\
13 \\
94 \\
08 \\
12 \\
98 \\
16 \\
32 \\
86 \\
22 \\
95 \\
08 \\
49 \\
65\end{array}$ \\
\hline 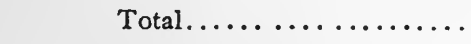 & 12,422 & 496,994 & 79 & 64 \\
\hline
\end{tabular}

\begin{tabular}{|c|c|c|c|c|c|}
\hline \multirow{2}{*}{ YEARS. } & \multirow{2}{*}{$\begin{array}{l}\text { Number } \\
\text { of Titles. }\end{array}$} & \multicolumn{3}{|c|}{ AREA. } & \multirow{2}{*}{ VALUE. } \\
\hline & & Hectares. & Ares. & Cts. & \\
\hline \multirow{3}{*}{$\begin{array}{l}\mathbf{1} 894 \ldots \ldots \ldots \ldots \ldots \ldots \ldots \ldots \\
{ }_{1} 895 \ldots \ldots \ldots \ldots \ldots \ldots\end{array}$} & 17 & $34,78 \mathrm{I}$ & 98 & 04 & $\$ 2 \mathrm{I}, 5549 \mathrm{I}$ \\
\hline & & & & & \\
\hline & 27 & 104,339 & 31 & 25 & $\$ 41,80903$ \\
\hline
\end{tabular}

TITLES ISSUED FOR UNWARRANTED POSSESSION BY PRIVATE PARTIES OF PUBLIC LANDS IN 1894 AND 1895.

\begin{tabular}{|c|c|c|c|c|c|}
\hline \multirow{2}{*}{ YEARS. } & \multirow{2}{*}{$\begin{array}{l}\text { Number } \\
\text { of Titles. }\end{array}$} & \multicolumn{3}{|c|}{ AREA. } & \multirow{2}{*}{ VALUE. } \\
\hline & & Hectares. & Ares. & Cts. & \\
\hline \multirow[t]{2}{*}{$\begin{array}{l}\text { I } 894 \ldots \ldots \ldots \ldots \ldots \ldots \ldots \ldots \\
\text { I } 895 \ldots \ldots \ldots \ldots \ldots \ldots\end{array}$} & $\begin{array}{l}2 I \\
\text { I } 9\end{array}$ & $\begin{array}{l}86,385 \\
59,265\end{array}$ & $\begin{array}{l}63 \\
24\end{array}$ & $\begin{array}{l}26 \\
84\end{array}$ & $\begin{array}{r}\$ 140,06772 \\
81,88395\end{array}$ \\
\hline & 40 & 145,650 & 88 & Io & $\$ 221,95167$ \\
\hline
\end{tabular}

TITLES OF PUBLIC LANDS ISSUED TO PRIVATE PARTIES IN I 894 AND I 895. 
TITLES ISSUED IN I 894 AND I 895 TO SURVEYING COMPANIES FOR ONE-THIRD OF THE LAND SURVEYED BY THEM.

\begin{tabular}{|c|c|c|c|c|}
\hline \multirow{2}{*}{ YEARS. } & \multirow{2}{*}{$\begin{array}{l}\text { Number } \\
\text { of Titles. }\end{array}$} & \multicolumn{3}{|c|}{ AREA. } \\
\hline & & Hectares. & Ares. & Cts. \\
\hline \multirow[t]{2}{*}{ 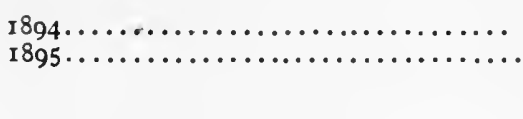 } & $\begin{array}{l}32 \\
29\end{array}$ & $\begin{array}{l}484,257 \\
243,576\end{array}$ & $\begin{array}{l}30 \\
\text { II }\end{array}$ & $\begin{array}{l}70 \\
81\end{array}$ \\
\hline & $6 r$ & 727,833 & 42 & $5 I$ \\
\hline
\end{tabular}

\section{EDUCATION.}

The following official data received by the Census Bureau of the Mexican Government contains the number of schools in the different States of Mexico, supported by the Federal, State, and municipal administrations, and the number of students attending the same. That statement does not include the States of Mexico and Veracruz, which are among those having the largest number of schools and attendance.

I also append a statement of the number of schools supported by private parties, with the number of pupils attending the same and their cost ; and finally a detailed statement of the public libraries existing in Mexico, and newspapers published in the country, taken from the publication of the Census Bureau in 1895 .

NEWSPAPERS PUBLISHED IN MEXICO IN I 895 .

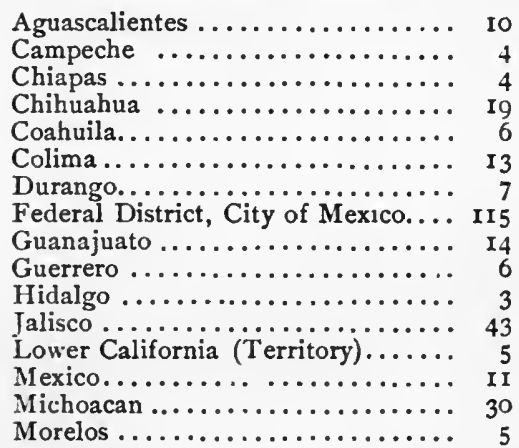

These are published in several languages, namely :

English.................... I2

French $. . . \ldots \ldots \ldots \ldots \ldots, \ldots, \ldots, r_{2}$

Dailies

Semi-weekly $\ldots \ldots \ldots \ldots \ldots \ldots \ldots \ldots \ldots \ldots+44$

Tri-weekly.................. 5

Weekly..................... 185

Semi-monthly.............. 79

Monthly .................. 87
New Leon............... 8

Oaxaca.................. 5

Puebla................... I7

Queretaro.................. I

San Luis Potosí............... 6

Sinaloa................... I4

Sonora ................... I2

Tabasco................... I4

Tamaulipas................. 20

Territory of Tepic............. 6

Tlaxcala ................... 2

Veracruz.................. 24

Yucatan.................. I8

Zacatecas................. I2

Total................

German .................. I

Spanish..................... 439

Total.............. 454

Bi-monthly ................ 3

Quarterly.................. 5

Yearly ...................... 3

Unknown.................. ro

Total.............. 454 
Eoucation.

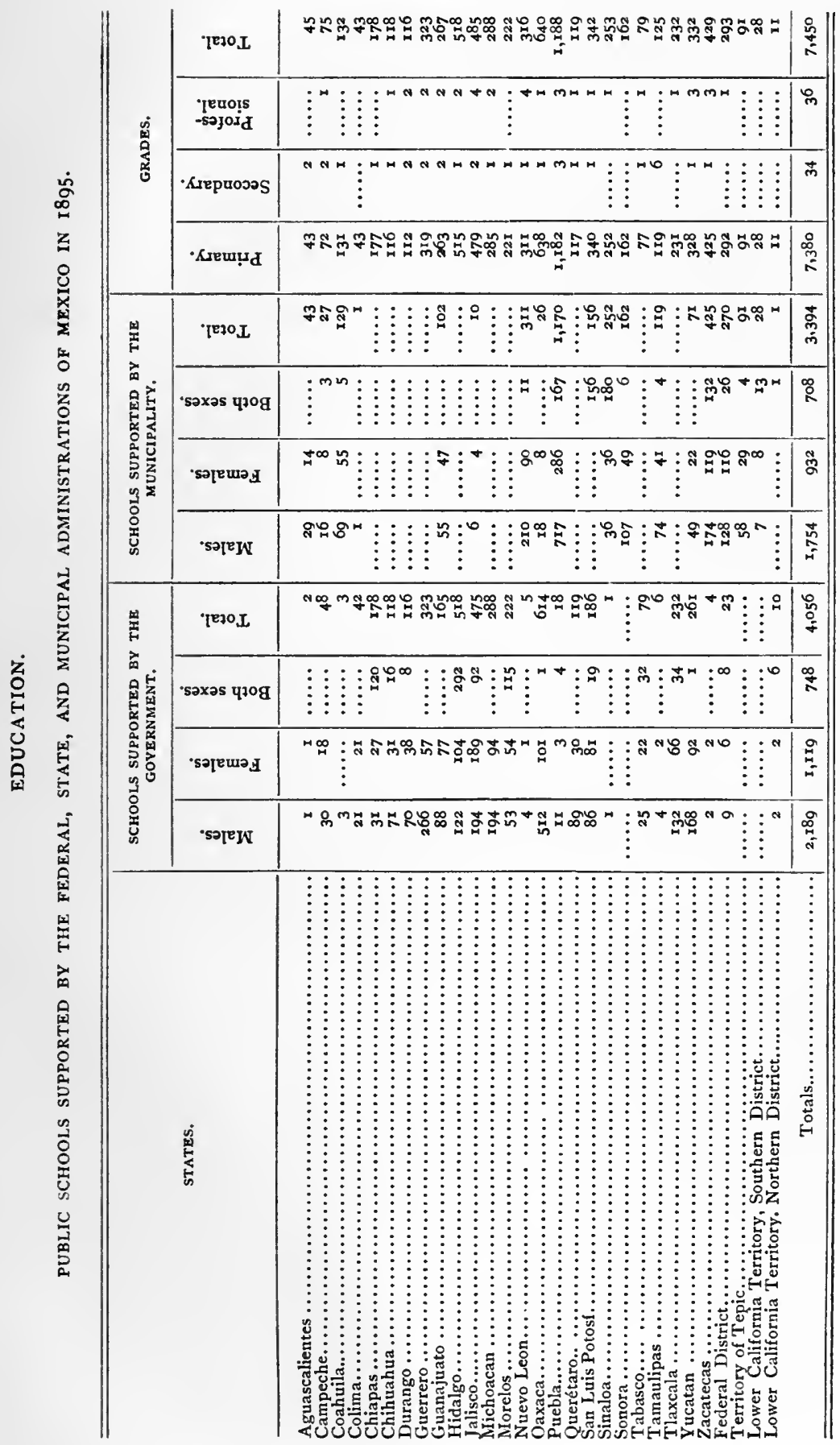




\begin{tabular}{|c|c|c|c|c|}
\hline & & פן & 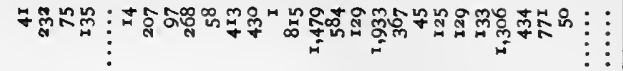 & 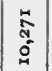 \\
\hline בัँ & 竞 & 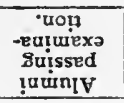 & 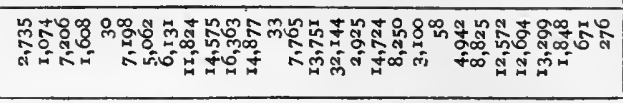 & \begin{tabular}{|l|}
8 \\
0 \\
0 \\
0 \\
ส \\
\end{tabular} \\
\hline 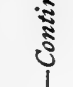 & \& & $\begin{array}{l}\text { pautuexa } \\
\text { !uunn!y }\end{array}$ & 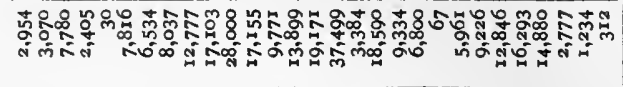 & 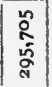 \\
\hline 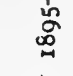 & & $\begin{array}{l}\text { SsueaK } \\
\text { SI } \sin O\end{array}$ & 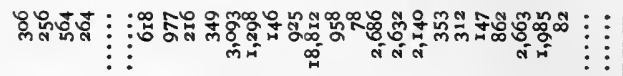 & 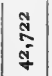 \\
\hline 8 & 峩 & $\begin{array}{c}\text { 'steak ST } \\
\text { of ox wor ty }\end{array}$ & 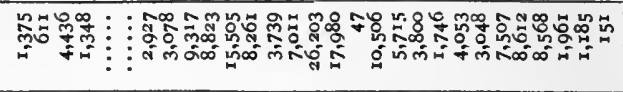 & 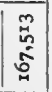 \\
\hline 结 & (2) & $\begin{array}{l}\text { sseas or } \\
\text { of } S \text { word }\end{array}$ & 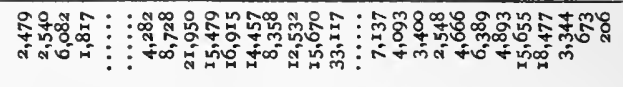 & 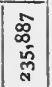 \\
\hline 要 & & $\begin{array}{l}\text { SseaK } \\
\text { S SIPAO }\end{array}$ & 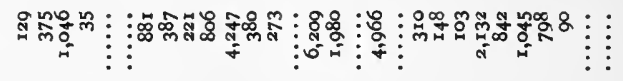 & ôn. \\
\hline$\underset{n}{3}$ & 总 & [" & 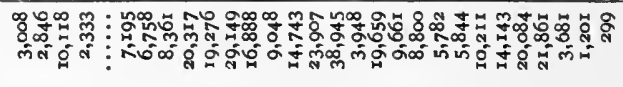 & $\left|\begin{array}{c}8 \\
0 \\
0 \\
\infty \\
0 \\
0\end{array}\right|$ \\
\hline Q & 畜蜜 & 'sә[еนrał & 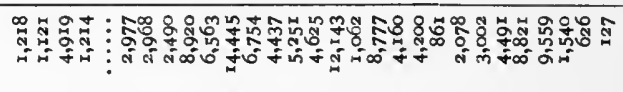 & 岺 \\
\hline 总 & 㩊员 & . & 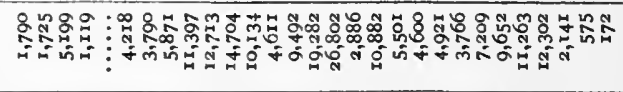 & 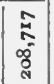 \\
\hline 量 & $\begin{array}{l}z \\
\text { 是. }\end{array}$ & [Езо $\mathrm{X}$ & 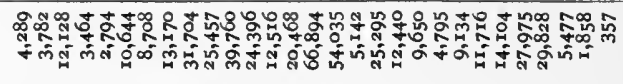 & 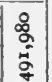 \\
\hline 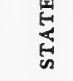 & 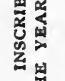 & •sə[ణயwว & 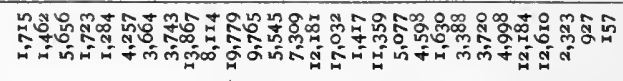 & 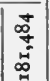 \\
\hline 妾 & 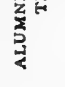 & 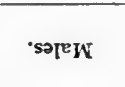 & 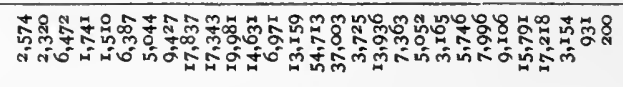 & $\left|\begin{array}{c}0 \\
\vdots \\
\vdots \\
\vdots \\
c \\
c\end{array}\right|$ \\
\hline 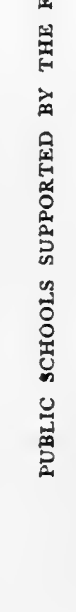 & & 惹 & 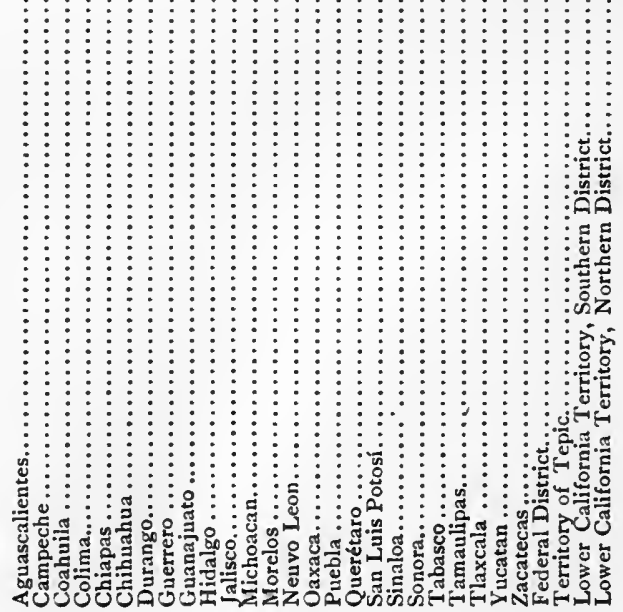 & 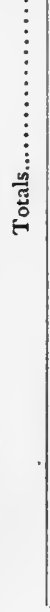 \\
\hline
\end{tabular}




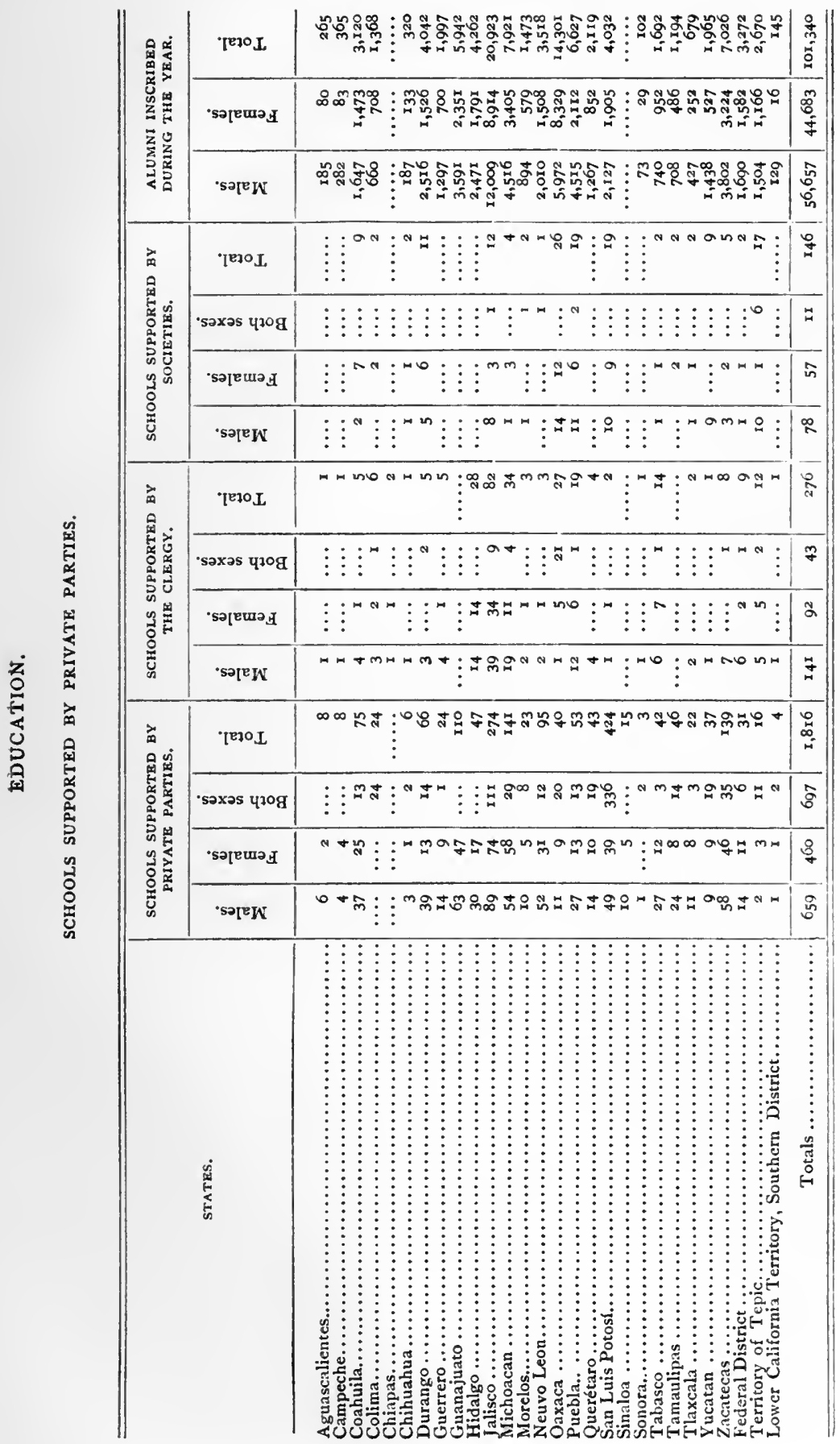




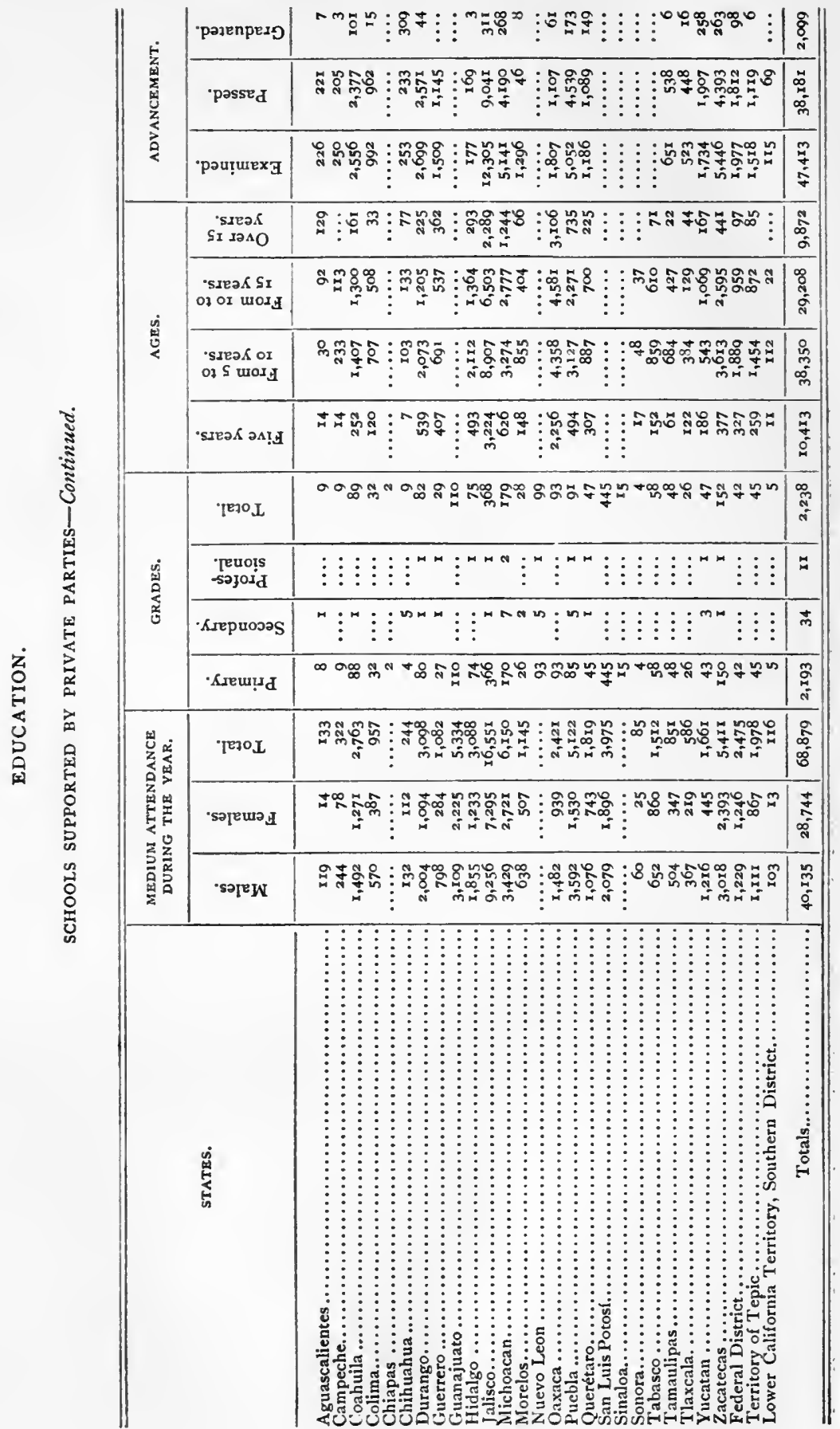




\begin{tabular}{|c|c|}
\hline 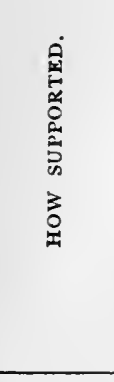 & 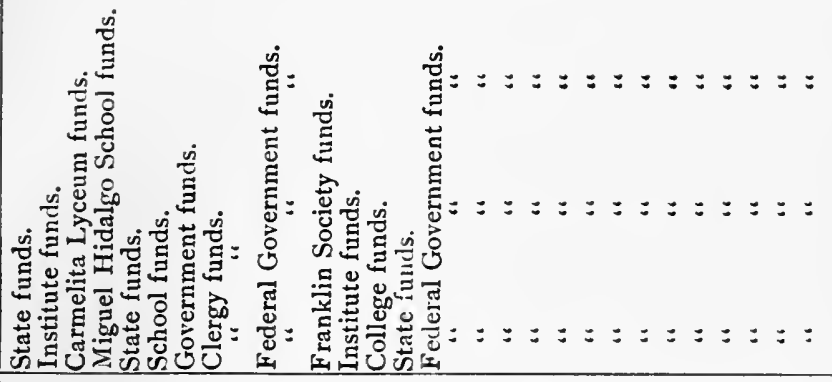 \\
\hline 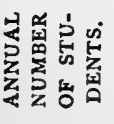 & 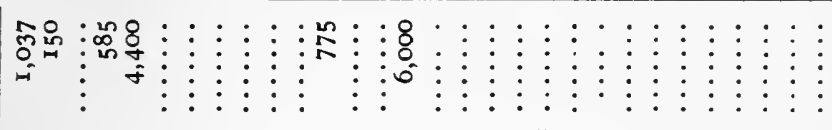 \\
\hline 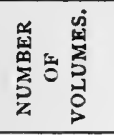 & 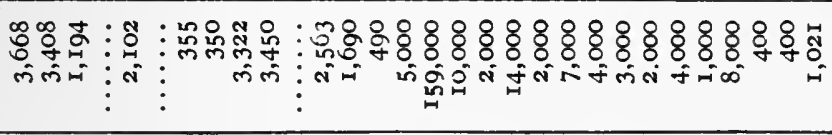 \\
\hline 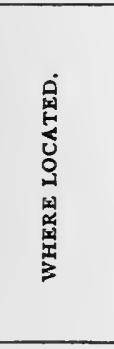 & 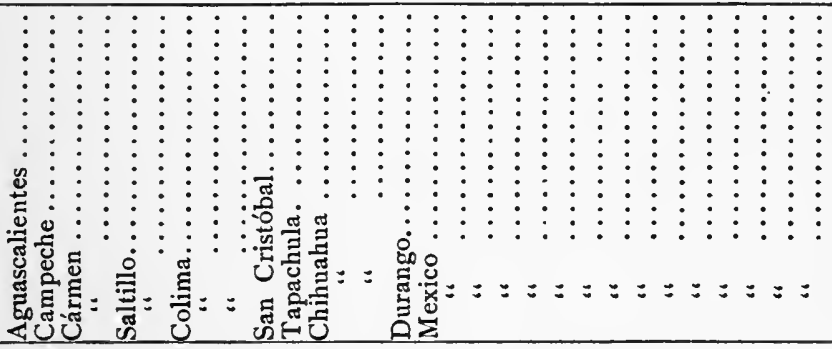 \\
\hline 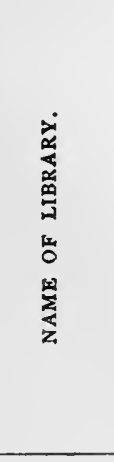 & 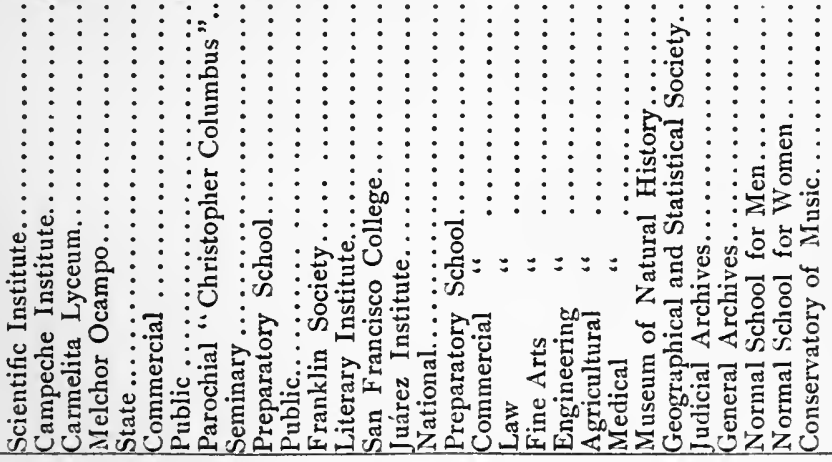 \\
\hline 点 & 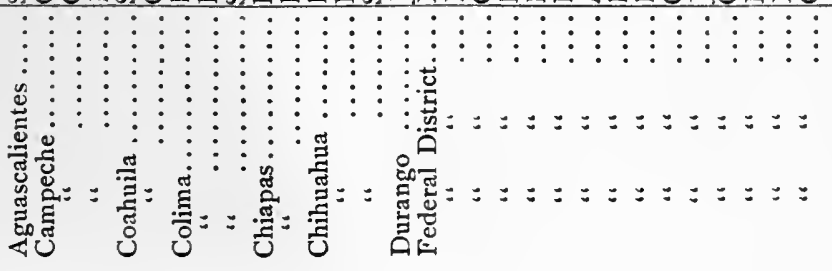 \\
\hline
\end{tabular}




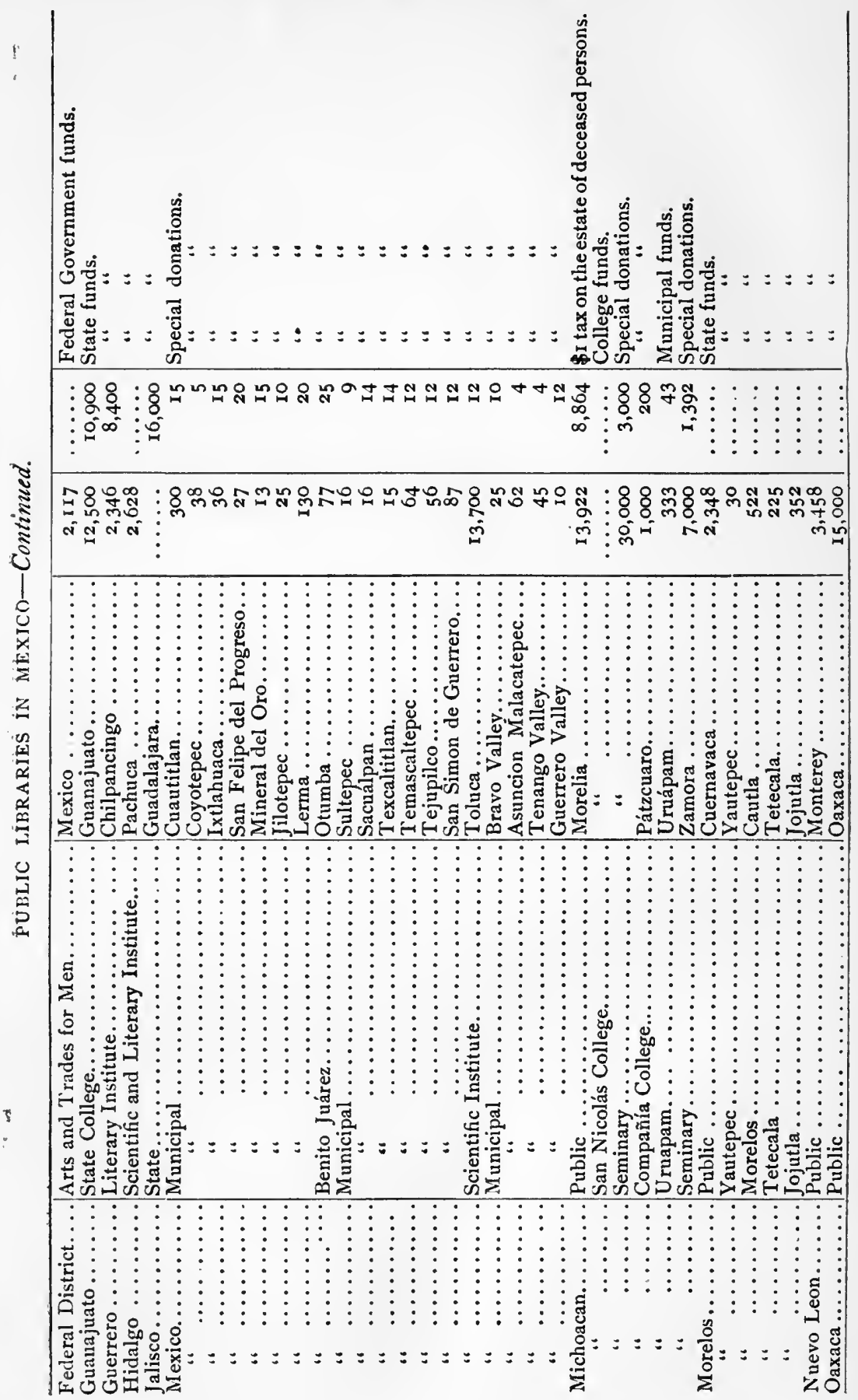




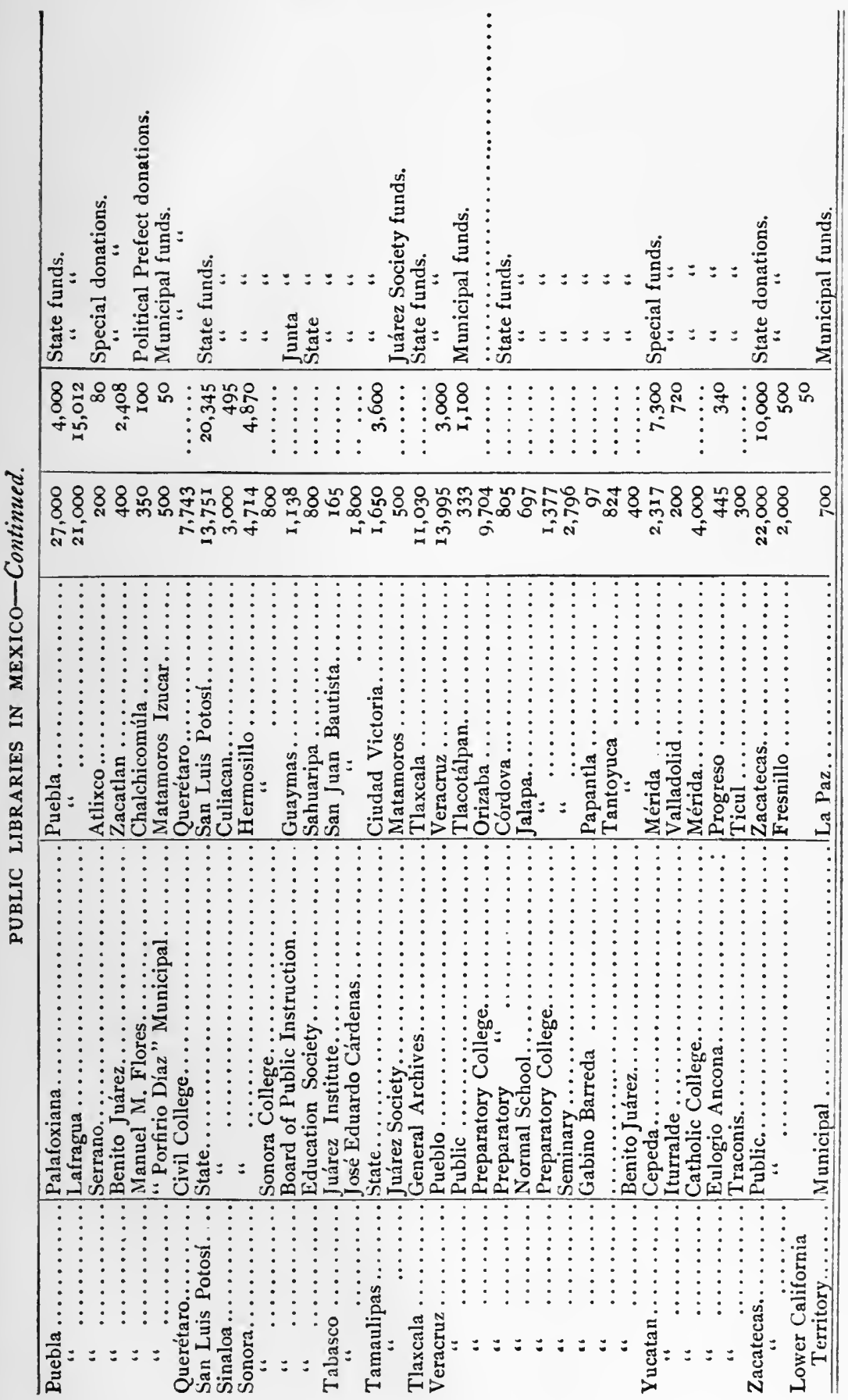




\begin{tabular}{|c|c|c|}
\hline [Ej०I & 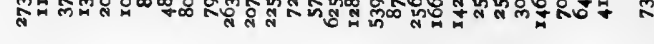 & 焉 \\
\hline 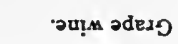 & N M & a \\
\hline . & - & $a$ \\
\hline 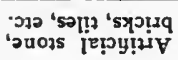 & 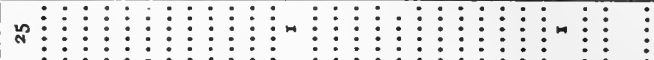 & a \\
\hline 'sэpसrJ & 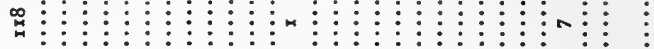 & $\stackrel{n}{\circ}$ \\
\hline su!̣ & & 용 \\
\hline - पગ્seas & $n$ & $a$ \\
\hline - sseis & 0 & n \\
\hline •ะा!ด & “ & m \\
\hline - Ssozzod & $\vdots$ & a \\
\hline 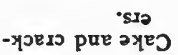 & $\approx \vdots$ & 邑 \\
\hline -sормод & & $n$ \\
\hline 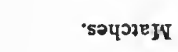 & 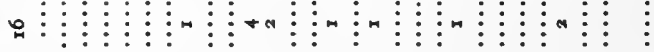 & $\infty$ \\
\hline${ }^{\circ} 005 \mathrm{eq}{ }^{\circ} \mathrm{L}$ & ส $\vdots$ & 7 \\
\hline -dros & $m \infty \vdots$ & $\frac{7}{2}$ \\
\hline -2oded & n & 용 \\
\hline 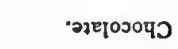 & $\infty \vdots$ & $\%$ \\
\hline 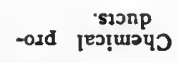 & $=\vdots$ & $\approx$ \\
\hline ·rogg & : & 离 \\
\hline "ן & లై & 冬 \\
\hline - Kpuesg & 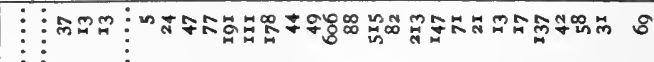 & 空 \\
\hline 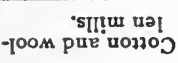 & 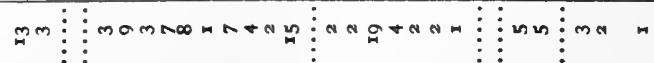 & $\approx$ \\
\hline 总 & 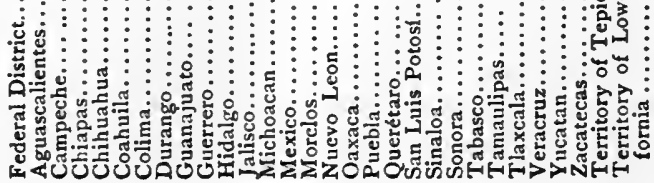 & $\begin{array}{c}\vdots \\
\vdots \\
\text { ฐूँ } \\
\text { H. }\end{array}$ \\
\hline
\end{tabular}


MANUFACTURING ESTABLISHMENTS IN MEXICO IN I893.

I take from Les Finances des Etats-Unis Mexicains of Mr. Prosper Gloner the following table, which purports to give the number of some of the manufacturing establishments in Mexico during the year I893. Mr. Gloner acknowledges that his table is very deficient, as he says in a note that appears at the foot of it that he failed to receive the data from 117 districts in different states of Mexico, and that besides the manufacturing establishments mentioned in his table there are in the City of Mexico the following: (See page 236.)

Carriages and wagons.................. II

Wax works.......................... 28

Agricultural implements................. 9

Wall paper....................... I

Coloring substances................... 2

Mineral and soda-waters................. 4

Carriage varnishes.................... 2

Jewelry boxes, etc..................... 9

Mucilage and paste.................... II

Card-board......................... 6

Scientific instruments.................. I

Playing cards...................... I

Pianos, organs, and harmonicas............ 4

Passementeries......................... 6

Type foundries.................... I

Gold and silver ribbons................

Perfumeries.......................... 6

Hats............................. 49

Musical instruments................... 6

Total..................... 159

NAVIGATION.

The total number of vessels, both steamers and sailing vessels, which arrived at and departed from Mexican ports during the year 1895, appears in the following statement.

I also append a statement showing the number of passengers who arrived in and departed from Mexico by sea and rail during the year I 895, mentioning both their nationality and the port of their arrival. The number appears exceedingly small when compared with the very large number coming from Europe to the United States; but I feel sure that before long we will have a large immigration. 


\begin{tabular}{|c|c|c|c|}
\hline \multirow{3}{*}{ 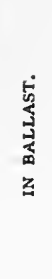 } & 恴 & 䑰 & 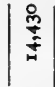 \\
\hline & 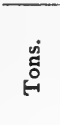 & 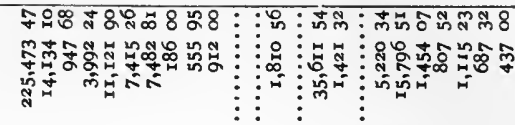 & 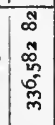 \\
\hline & $\rho_{j}^{b}$ & 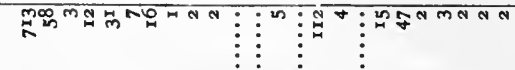 & 商 \\
\hline \multirow{3}{*}{ 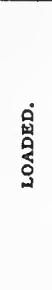 } & 意 & 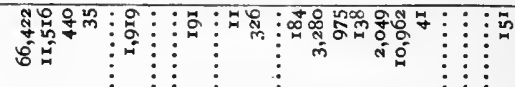 & 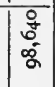 \\
\hline & 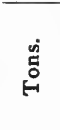 & 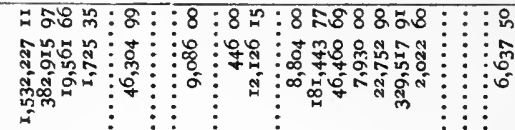 & 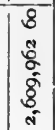 \\
\hline & 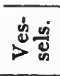 & 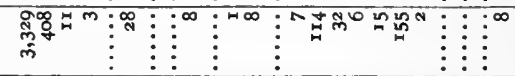 & $\stackrel{m}{\stackrel{m}{\sigma}}$ \\
\hline \multirow{3}{*}{ 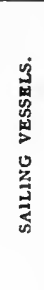 } & 密 & 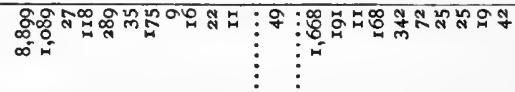 & 总 \\
\hline & 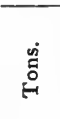 & 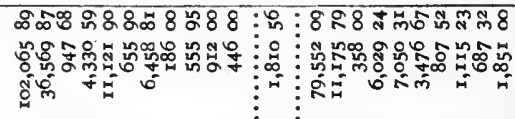 & 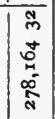 \\
\hline & 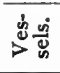 & 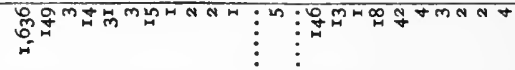 & ¿ิ \\
\hline \multirow{3}{*}{ 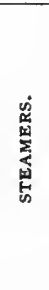 } & Uूँ & 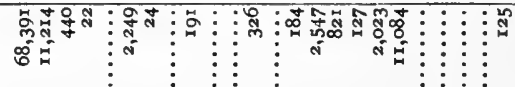 & 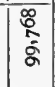 \\
\hline & $\stackrel{\dot{g}}{\stackrel{\leftrightarrow}{\leftrightarrow}}$ & 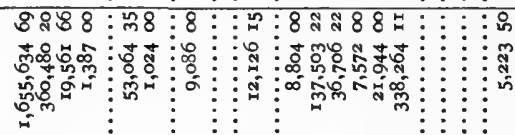 & 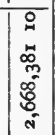 \\
\hline & $\frac{b}{8}$ & 舫 & ह્ \\
\hline \multirow{3}{*}{ 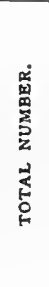 } & 旁 & 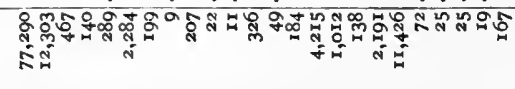 & 疍 \\
\hline & 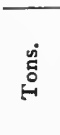 & 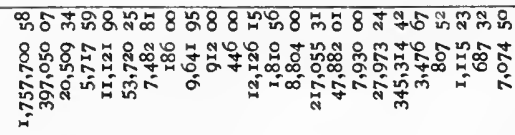 & 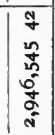 \\
\hline & 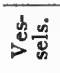 & 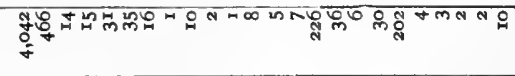 & 索 \\
\hline & & 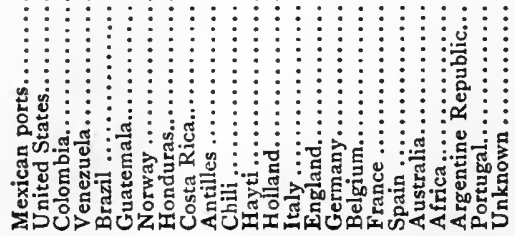 & 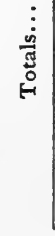 \\
\hline
\end{tabular}




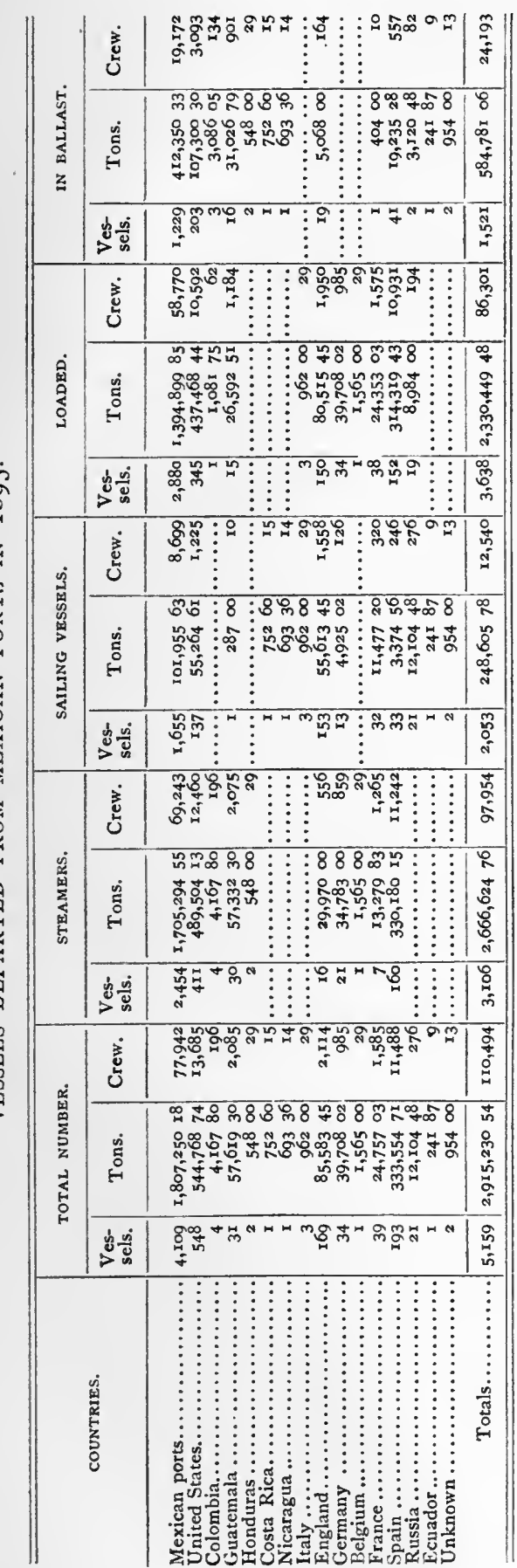

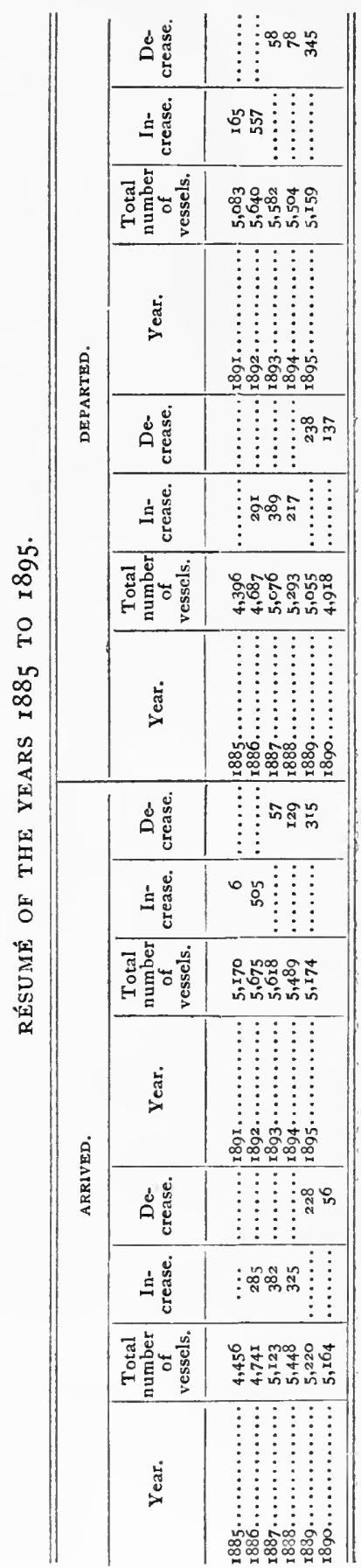




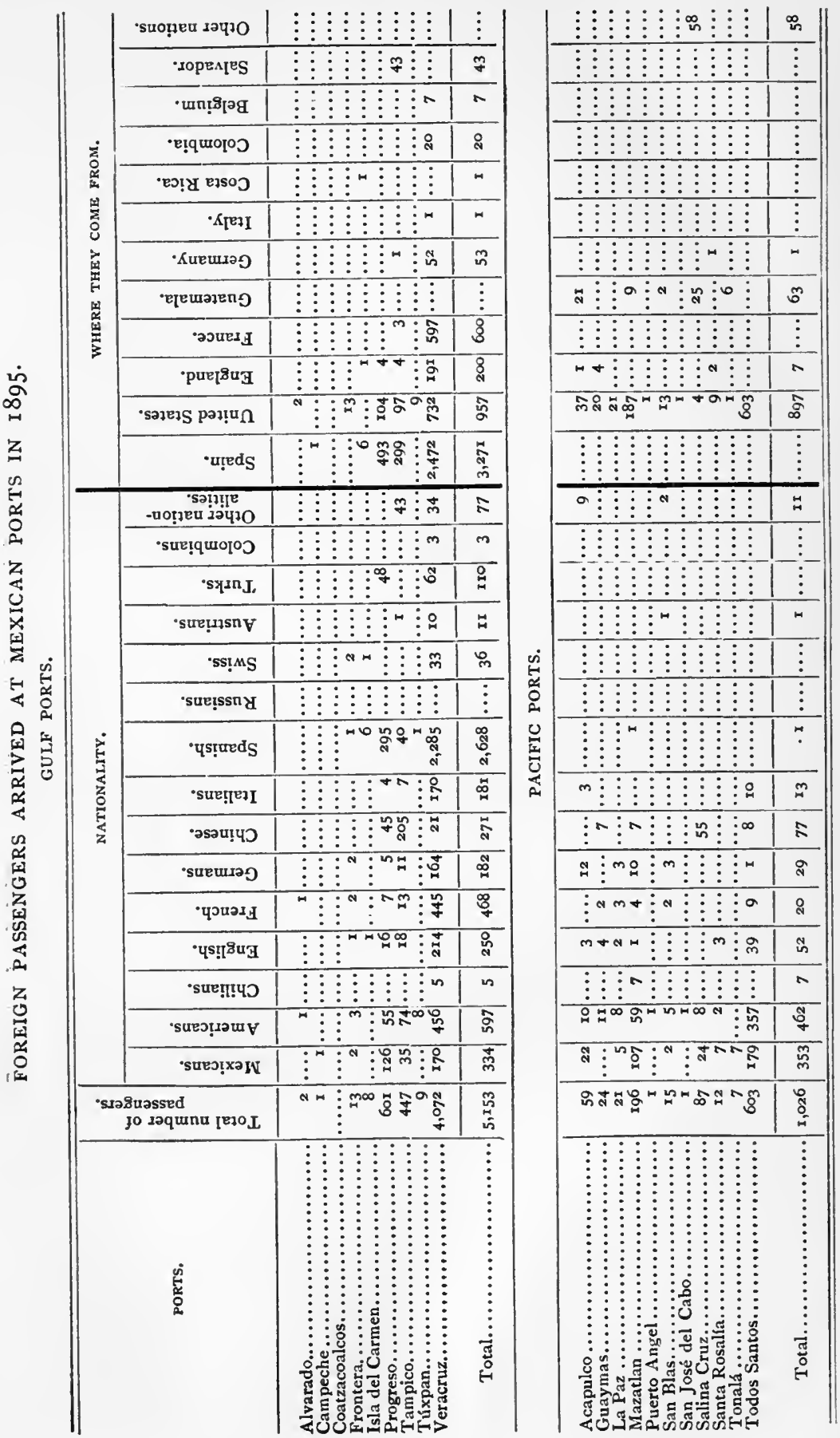


Mavigation.

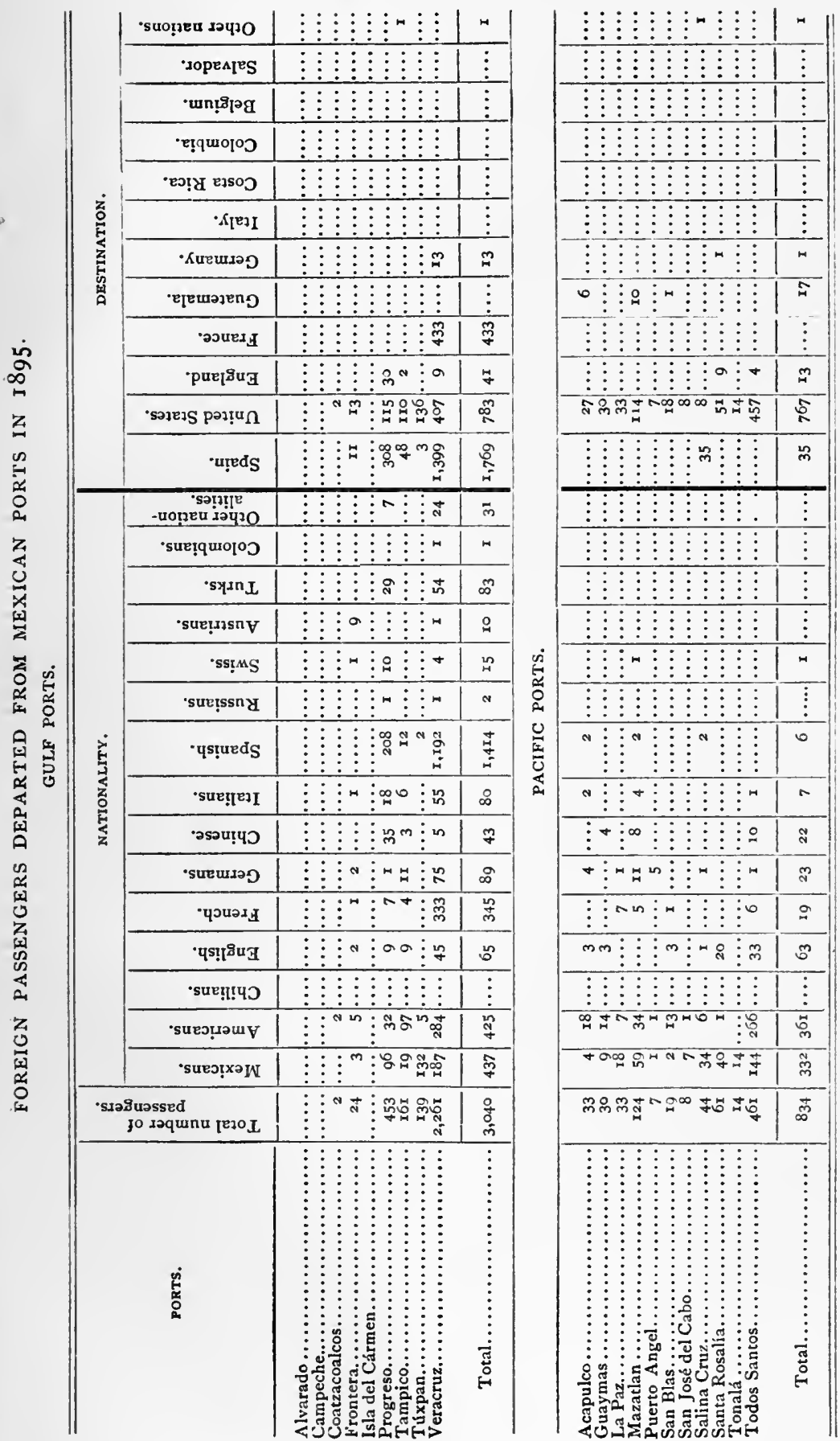


Itatistical Motes on ADexico.

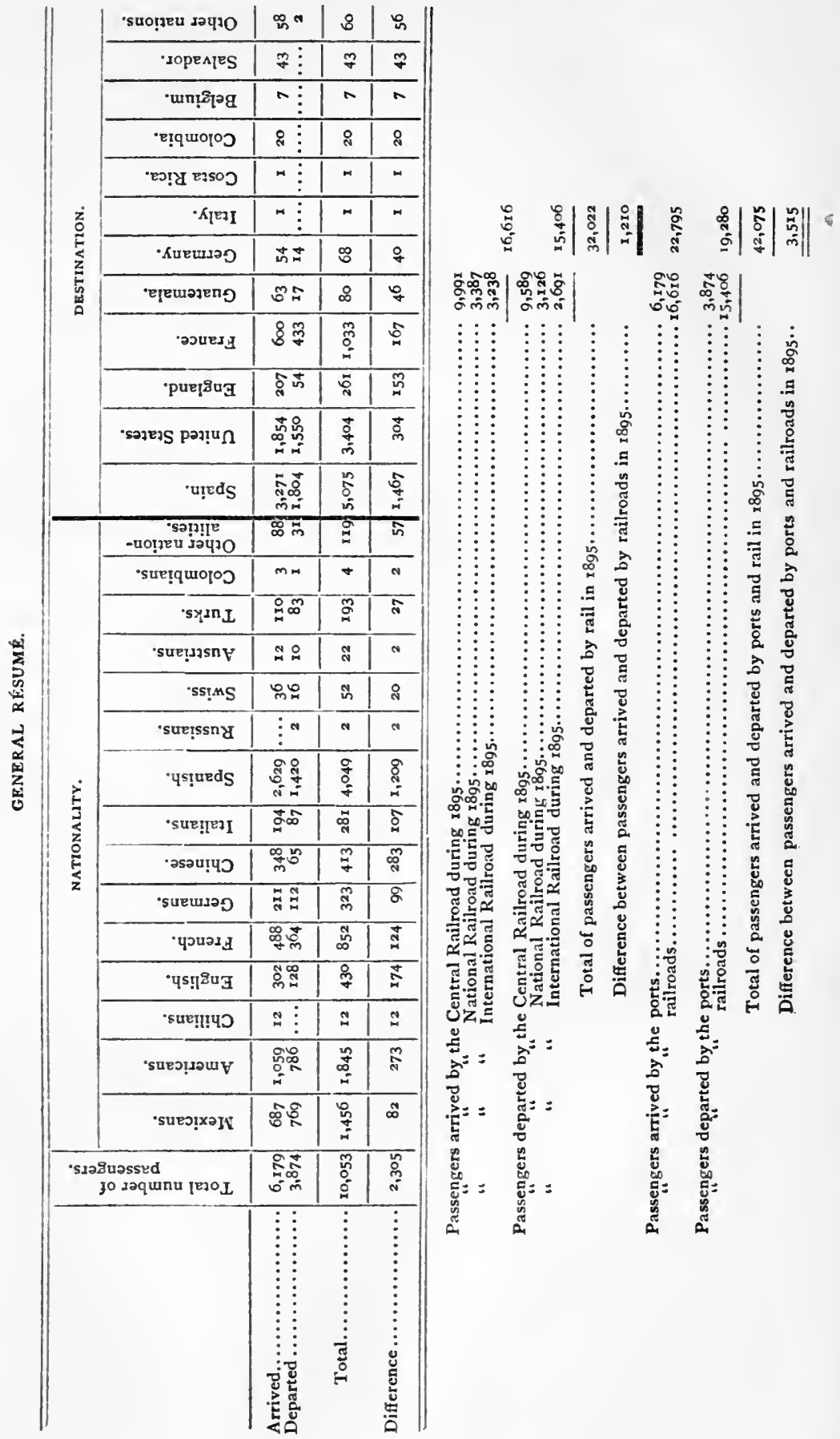


VESSELS ARRIVED AT AND DEPARTED FROM MEXICAN PORTS DURING THE FISCAL YEARS I 894-95 TO $1895-96$.

\begin{tabular}{|c|c|c|c|c|c|c|c|c|}
\hline & \multicolumn{4}{|c|}{ ARRIVED. } & \multicolumn{4}{|c|}{ DEPARTED. } \\
\hline & \multicolumn{2}{|c|}{ Steamers. } & \multicolumn{2}{|c|}{ Sailing vessels. } & \multicolumn{2}{|c|}{ Steamers. } & \multicolumn{2}{|c|}{ Sailing vessels } \\
\hline & $\begin{array}{l}\text { Ves- } \\
\text { sels. }\end{array}$ & $\begin{array}{l}\text { Ton- } \\
\text { nage. }\end{array}$ & $\begin{array}{l}\text { Ves- } \\
\text { sels. }\end{array}$ & $\begin{array}{l}\text { Ton- } \\
\text { nage. }\end{array}$ & $\begin{array}{l}\text { Ves- } \\
\text { sels. }\end{array}$ & $\begin{array}{c}\text { Ton- } \\
\text { nage. }\end{array}$ & $\begin{array}{l}\text { Ves- } \\
\text { sels. }\end{array}$ & $\begin{array}{l}\text { Ton- } \\
\text { nage. }\end{array}$ \\
\hline $\begin{array}{l}\text { Total navigation in the fiscal } \\
\text { year r894-1895............ } \\
\text { Total navigation in the fiscal } \\
\text { year } 1895-1896 \ldots \ldots \ldots \ldots \ldots\end{array}$ & $\begin{array}{l}4,078 \\
4,47 x\end{array}$ & $\begin{array}{l}3,083,050 \\
3,300,444\end{array}$ & $\begin{array}{l}5,497 \\
5,723\end{array}$ & $\begin{array}{l}345,923 \\
395,04 x\end{array}$ & $\begin{array}{l}3,399 \\
4,378\end{array}$ & $\begin{array}{l}3,026,964 \\
3,242,7 \times 1\end{array}$ & $\begin{array}{l}5,566 \\
5,856\end{array}$ & $\begin{array}{l}332,720 \\
390,765\end{array}$ \\
\hline Difference............... & 393 & 217,394 & 226 & 49,118 & 979 & 215,747 & 290 & 58,045 \\
\hline
\end{tabular}

AGRICULTURAL PRODUC'TS.

I take from the Anuario Estadistico de la Republica Mexicana of 1895 the following table, which gives the total production of some of our agricultural staples, although I feel perfectly satisfied that they are very much under-rated in said table, because of the difficulty in obtaining complete data about our agricultural productions, both for want of a proper machinery to collect it, and because manufacturers conceal the extent of these products for the purpose of avoiding taxation. I think if the figures in said table are duplicated they will be nearer the true production.

RÉSUMÉ OF AGRICULTURAL PRODUCTS IN MEXICO.

\begin{tabular}{|c|c|c|c|}
\hline ARTICLES. & BUSHELS. & $\begin{array}{c}\text { POUNDS AND } \\
\text { OTHER MEASURES. }\end{array}$ & VALUE. \\
\hline \multicolumn{4}{|l|}{ Cereals : } \\
\hline Rice............... & $\ldots \ldots \ldots \ldots \ldots$ & $27,174,32059$ & $\$ 1,400,29940$ \\
\hline Barley................ & $4,752,239$ & $\ldots \ldots \ldots \ldots \ldots$ & $3,587,68265$ \\
\hline Indian corn...$\ldots \ldots \ldots$. & $71,900,598$ & $\ldots \ldots \ldots \ldots \ldots$ & $75,695,3832 I$ \\
\hline 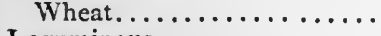 & $10,034,328$ & $\ldots \ldots \ldots \ldots \ldots$ & I $3,273,79050$ \\
\hline \multicolumn{4}{|l|}{ Leguminous : } \\
\hline Chhickling vetch (Arvejon)... & $25 \mathrm{I}, 230$ & $\ldots \ldots \ldots$ & 336.77140 \\
\hline 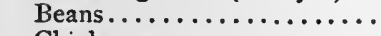 & $4,319,834$ & $\ldots \ldots \ldots$ & $7,269,12325$ \\
\hline Chick-peas............. & $774,35 I$ & $\ldots \ldots \ldots \ldots \ldots$ & 932,60860 \\
\hline Lima beans............. & $56 \mathrm{I}, \mathrm{I} 59$ & $\ldots \ldots \ldots \ldots \ldots$ & 624,53022 \\
\hline \multirow{2}{*}{\multicolumn{4}{|c|}{ Root plants : }} \\
\hline & & & \\
\hline Sweet potatoes. & $2,051,854$ & $\ldots \ldots \ldots$ & $859,46 \mathrm{I} 50$ \\
\hline Huacamote... & 235,939 & $\cdots \ldots \ldots \ldots \ldots$ & I 08,34882 \\
\hline Potatoes...... & $\ldots \ldots \ldots$ & $29,472,89445$ & 879,430 I5 \\
\hline \multicolumn{4}{|l|}{ Solanaceous : } \\
\hline Dried pepper..... & $\ldots \ldots \ldots$ & $9,724,44398$ & $1,731,85767$ \\
\hline Green pepper.... & $1,007,049$ & $\cdots \cdots \cdots \cdots \cdots$ & 758,19990 \\
\hline \multicolumn{4}{|l|}{ Cane products: } \\
\hline Sugar cane... & $\ldots \ldots \ldots$ & $5,924,612,232 \quad 56$ & $25,692,28 \mathrm{I} \quad 25$ \\
\hline Sugar....... & $\ldots \ldots \ldots \ldots \ldots$ & $316,531,23902$ & Io, $283,99+38$ \\
\hline Brown sugar.. & $\ldots \ldots \ldots \ldots \ldots$ & $152,300,90395$ & $7,942,78760$ \\
\hline Molasses..... & $\ldots \ldots \ldots \ldots \ldots$ & $12,748,07924$ & $3,304,78782$ \\
\hline
\end{tabular}




\begin{tabular}{|c|c|c|c|}
\hline ARTICLES. & BUSHELS. & $\begin{array}{c}\text { POUNDS AND } \\
\text { OTHER MEASURES. }\end{array}$ & VALUE. \\
\hline Oleaginous: & & & \\
\hline Sesame seed. & 214,469 & & $\$ \quad 144,773 \infty$ \\
\hline Peanuts.... & 357,569 & 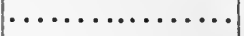 & 325,41300 \\
\hline Coquito de Aceite.... & 69,388 & .... & 130,95500 \\
\hline Cocoanuts................. & ........ & $\begin{array}{c}(310,953,000 \text { cocoa- } \\
\text { nuts })\end{array}$ & $3,522,789 \circ 0$ \\
\hline Linseed. & 303,425 & & 373,11500 \\
\hline Palma Chr & 59,460 & $\cdots$ & 83,434 oo \\
\hline Turnip see & 20,708 & & 34,80600 \\
\hline Lime-leaf & 9,968 & & 20,16800 \\
\hline Alcohol and Fermented Drinks: & & & \\
\hline Rum................... & & $12,768,716$ gals. & $5,056,47482$ \\
\hline Pulque whiskey............ & $\cdots$ & 270,876 gals. & 199,935 oo \\
\hline Mezcal.... & & $6,011,602$ gals. & $3,078,37200$ \\
\hline Pulque.... & & $54,624,835$ gals. & $3,562,435$ o5 \\
\hline Tlachique or unfermented & & & \\
\hline pulque.............. & & $24,013,901$ gals. & $I, 294,57500$ \\
\hline Textiles: & & & \\
\hline Her & & $93,427,740$ of & $4,104,096 \infty 0$ \\
\hline Ixtle & & $9,608,02679$ & 325,25095 \\
\hline Cotton.. & & $78,511,48626$ & $10,176,05050$ \\
\hline Grape Products : & & & \\
\hline Grape... & $, \ldots, \cdots$ & $3,114,51905$ & 161,37225 \\
\hline & ........ & I62,8 16 I6 gals. & 146,02870 \\
\hline $\mathrm{Br}$ & $\cdots$ & $9 \mathrm{I}, 65669$ gals. & 83,72480 \\
\hline Dyeing Plants: & & & \\
\hline Ind & & 299,76156 & 285,53000 \\
\hline $\mathrm{Br}$ & & 3585 & 64,79500 \\
\hline $\mathrm{Ca}$ & $\cdots$ & $171,604,0864 \mathrm{I}$ & $2,110,09850$ \\
\hline Mo & & $19,826,253 \quad 38$ & 195,30000 \\
\hline Tanning Plants: & & & \\
\hline Cascalot & & $4,798,99496$ & 242,07025 \\
\hline Tan & & $33,036,812$ of & 457,16726 \\
\hline Tropic & & & \\
\hline $\mathrm{Co}$ & & $5.346,718 \quad 17$ & $1,123,180 \infty 0$ \\
\hline $\operatorname{Cot}$ & & $42,019,01576$ & II $, 565,51928$ \\
\hline Tob & & I $24,852,59769$ & $6,464,73350$ \\
\hline Pepp & & II 9,27360 & 14,05500 \\
\hline Vanilla.. & & (10,714,000 vanilla & \\
\hline & & & $667, I 4550$ \\
\hline Gums & & & \\
\hline $\mathrm{Ch}$ & & $3.996,630 \quad 32$ & $549,865 \quad 50$ \\
\hline Indi & & $I, 354,851 \quad 48$ & 410,290 oO \\
\hline Me: & & 139,89697 & $7,292 \quad 75$ \\
\hline Copa & & $21,485 \quad 47$ & 10,31355 \\
\hline Medicinal Plan & & & \\
\hline & & 50,09900 & 6,945 oo \\
\hline Sarsaparilla.. & $\ldots$ & $1,514,33190$ & 100,73000 \\
\hline
\end{tabular}

\section{CONCLUSION.}

It has taken me a great deal of time and required a great deal of effort to obtain and prepare the data contained in this paper. I am sorry I have not been able to make it more complete than it is ; but I hope my article, by giving a general and superficial idea of Mexico, may promote the desire to read other papers and books treating on that subject in a fuller and more complete manner. 


\section{ADDENDA.}

Since this paper has been printed the Federal Treasury of Mexico finished the accounts of the fiscal year ended June 30,1897 , and I give below the general results, showing the total amount of the Federal revenues and expenses during that year. I also give a statement, taken from the Statistical Bureau of the Treasury Department of Mexico, published since this paper has gone to press, of the imports and exports in the same year, both by countries and custom houses, these two statements completing the data contained in this paper, and finally some data of the trade of both countries during the first nine months of the present calendar year.

FEDERAL REVENUE AND EXPENSES OF MEXICO IN THE FISCAL YEAR $1896-1897$.

RECEIPTS.

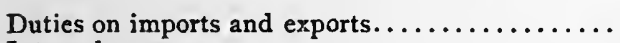

Internal revenue.......................

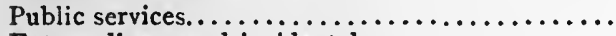

Extraordinary and incidental.

Extraordinary revenues proceeding from contracts

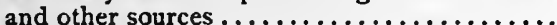

\section{EXPENSES.}

1. Legislative power.................

2. Executive power.................

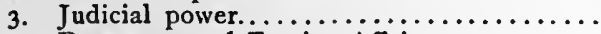

4. Department of Foreign Affairs...........

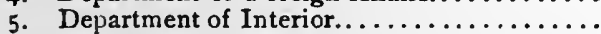

6. Department of Justice and Public Education.

7. Department of Fomento, Colonization, and

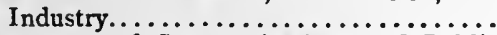

8. Department of Communications and Public

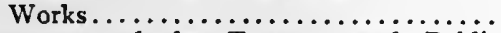

9. Department of the Treasury and Public

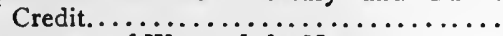

ro. Department of War and the Navy.........

Total..................
$\$ 23,639,580.91$

$24,323,798.46$

$2,057,409.92$

$2,084,496.30$

$\$ 52,105,285.59$

$\frac{2,819.17}{\$ 52,108,104.76}$

$\$ 989,75^{8} .38$

$62,100.26$

$428,687.46$

$470,122.37$

$3,354,888.95$

$2,184,556.52$

$6 \mathrm{II}, 863.83$

$5,494,593.34$

$24,218,207.75$

IO $, 550,955.18$

Surplus. .................. 
IMPORTS AND EXPORTS OF MEXICO BY COUNTRIES AND CUSTOM HOUSES IN THE FISCAL YEAR I896-97.

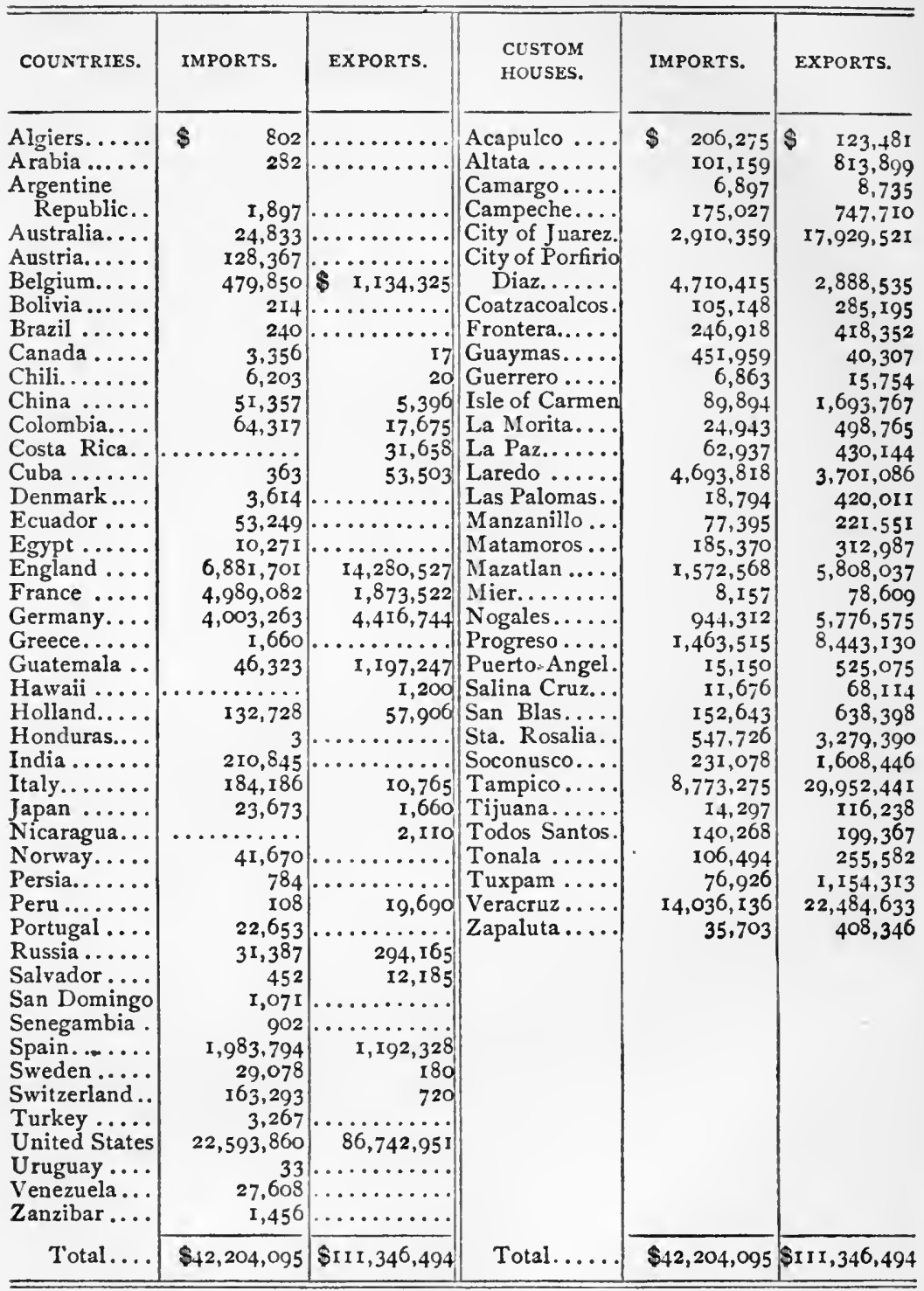

A comparison between the foreign trade in the fiscal year $1896-97$ with the year before, $1895^{-96}$, gives the following results: During the year $1896-97$ Mexico's exports increased $\$ 6,329,592$, but the value of the exports sent to the United States increased $\$ 7,09 \mathrm{r}, 25^{6}$. The 
total of Mexico's imports for the year $1896-97$ shows a falling-off of

- $\$ 49,843$, but, notwithstanding this fact, Mexico's imports from the United States increased $\$ 2,448,097$. During the year England's exports to Mexico decreased $\$ 1,023,315$, and her imports from Mexico show a loss of $\$ 2,186,622$, a combined loss of over 12 per cent. in her commercial relations with the Republic. Imports to Mexico from France fell off $\$ I, I I O, I O I$, a loss of one-sixth of all France's exports to Mexico. In $1895-96$ the United States imported 75.8 per cent. of the total exports from Mexico ; in 1896-97 American exporters furnished $53 \frac{1}{2}$ per cent. of all that Mexico bought abroad, and, more than this, the United States took 47.67 per cent. of all that was exported from Mexico. These figures sustain the prediction made, that any unsettlement or diminution of Mexico's importations either because of fluctuating silver or the increased production of home manufactories would affect American exporters less than those of any other country. The statistics given above show that these causes have affected them less than those of all the other countries combined; in fact, their loss has been the gain of the United States.

TRADE BETWEEN MEXICO AND THE UNITED STATES DURING THE FIRST NINE MONTHS OF THE CALENDAR YEAR I897.

The following data, taken from the publications of the Statistical Bureau of the United States Treasury Department, shows the results of the trade with Mexico in the nine months ended September 30 , 1897, as compared with the similar period ended September 30, 1896.

Mexican Exports to the United States.-In the following items the first group of figures represents the amounts and values exported in the first nine months of this year, and the second those of the similar period in 1896 :

Coffee, $30,016,967$ pounds, worth $\$ 4,574,252$ gold, against $\mathrm{I} 9,7 \mathrm{I} 5,264$ pounds, worth $\$ 3,333,385$. The much lower price of coffee this year accounts for the disproportionate valuation.

The people of the United States, besides being Mexico's chief customers for coffee, are buying more and more of our tobacco, which they now know and appreciate on its merits. The amount exported to the United States was 600,987 pounds, worth in gold $\$ 294,536$, against 191,303 , worth $\$ 78,769$.

Mexico exported, in the period under consideration, to the United States, hides and skins to the value of $\$ 1,534,306$ gold, against $\$ 1,055$,299. The quantities, respectively, were I I , 764,000 pounds, and 7, 102,465 pounds. No diminution of activity there.

It is worth noting that oranges were shipped out to the value of $\$ 22,444$ gold against $\$ 19,359$. 
Mexico's great argentiferous lead business did not fall behind, the nine months' exportation being $108,776,560$ pounds, worth in gold $\$ 1,226,525$, against $97,818,833$ pounds, worth $\$ 949,926$. The bulk of the American purchase of lead is from Mexico.

Yucatan is Mexico's henequen-growing region, and the exportation has been heavy, standing at 48,410 tons, worth in gold $\$ 2,889,003$, against 35,746 tons, worth $\$ 2,323,585$, a noteworthy increase. The henequen or sisal-grass trade in to the United States is overwhelmingly Mexican, "other countries" furnishing but 399 tons in the first nine months of this year!

Mexico both exports and imports coal, and shipped into the United States 85,890 tons, worth in gold $\$ 182,416$, against 52,674 tons, worth $\$ 115,015$.

Logwood exports were $\$ 44,028$, against $\$ 15,250$.

Mahogany fell off, being $\$ 290,044$ gold, against $\$ 306,7$ r 5 , but this trade is always variable.

Mexican Imports from the United States. - It is worthy of note that, in spite of the extraordinarily heavy gold premium, Mexico should be increasing her buying abroad of electrical apparatus, the purchase from the United States alone, in the first nine months of this year, amounting to $\$ 228,000$ gold, as against $\$ 200,000$ in the same period last year. Sewing machines went in to the value of $\$ 164,000$ gold in the ninemonth period, against \$5 $\$ 54,000$ last year. Builders' hardware fell off from $\$ 556,600$ gold value, in the first nine months of last year, to $\$ 424,000$ this year, but lumber for builders ran up to $\$ 1,079,000$ gold, against only $\$ 544,000$ last year, all coming from the United States. Furniture increased slightly, $\$ 141,000$ gold, against $\$ 126,000$.

Carriages, cars, and other vehicles, in the nine-months' period, came from the United States to the value of $\$ 664,000$ gold, as compared with $\$ 463,000$ last year. Bicycles amounted to $\$ 56,000$ gold, as against $\$ 37,700$.

Other importations were as follows :

Cotton :

9 MOS., 1897.

9 Mos., 1896.

Bales ..................... 9,936

Value.......................... * $\$ 4 \mathrm{II}, 973$

Crude petroleum imports :

Gallons.................. 6,260, 164

Value......................... $* \$ 277,300$

Refined petroleum :

Gallons................. 734,466

Value..................... \$1 $\$ 36,180$

Cotton seed oil :

Gallons................... I, ого, 580

Value........................... * $\$ 199,000$

* Gold.

23,127

$* \$ 1,020,000$

$5,486,667$

* $\$ 299,422$

588,242

$\$ 122,447$

प] 2,905

*\$195,000 


\section{APPENDIX.}

In the preceding paper I stated that I would give as an appendix some data concerning several subjects treated in the same, and I now append the documents mentioned; the first one being a paper published in the Bulletin of the American Geographical Society of New York for March 3I, I894, under the title of "Mexico a Central American State," the second, some itineraries of the principal roads in Mexico, which show the broken surface of that country, and the third and last, a paper on the "Drainage of the Valley of Mexico," published by the Engineering Magazine of New York, Vol. viii., No. 4, for January, I 895 .

\section{MEXICO A CENTRAL AMERICAN STATE.}

In the chapter of this paper entitled "Location, Boundaries, and Area," I referred, (page 9) to an article under the above heading, which I published in the Bulletin of the American Geographical Society of New York of March 31, 1894, and offered to give it in the appendix. That paper is the following:

\section{MEXICO A CENTRAL AMERICAN STATE. ${ }^{1}$}

There is in this city a social gathering of ladies and gentlemen called "The Travellers' Club," meeting weekly during the winter of each year, for the purpose of studying a foreign country, on the supposition that its members are then travelling in that particular country, and with that view papers are read referring to the same, and they are illustrated with an exhibition of views and objects manufactured in the country under study, and of everything else that may contribute to impart more or less complete information regarding the place supposed to be visited.

During the winter of $1887-88$ Mexico was chosen as the country under study by the club, and for that reason I received at the beginning of the year 1888 an invitation to attend some of its sessions, and to say something about the Republic. I accepted the invitation to attend some session, but stated to the invitation committee that, not having time to prepare a paper, I would only give some general notions on

1 This article was published in the Bulletin of the American Geographical Society of New York of March 31, 1894, and it is inserted here without any changes. Although the data contained in this article was published in the years 1887 and 1893, as it refers to the area which has not changed, I have not thought it necessary to revise the same. So far as the Mexican States are concerned, I have later and more accurate data; but the differences are insignificant, and it is not worth while to notice them. As regards the population, the increase has been proportionate; in respect to all the countries mentioned in this article there is no marked change in the general proportions. 
Mexico, in a conversational form, and would be glad to answer any question that might be put to me by those attending the meeting who felt the desire to have further information and more details.

Accordingly, the evening of the I6th of January, I888, I attended the meeting of the club and spoke for about an hour on the geographical position of Mexico, its physical conditions, its natural resources, and other matters connected with the situation of the country, but carefully avoiding to touch any political question, especially of an international character.

With a view to leave a record of what I intended to say, I had with me a stenographer to take down what I would say, and although his notes were not complete, by using them, and those taken by reporters, some extracts of my conversation were prepared and published the next morning.

Speaking of the geographical position of Mexico, I naturally stated, what is a fact, although not generally realized, that while the main portion of the territory of Mexico is located in North America it occupies a considerable portion of Central America, although politically it is considered as wholly situated in North America. On this subject I made the following remarks, taken from the newspapers, but which were correct:

"The isthmus of Panama divides the New World into two continents, one situated on the northern and the other on the southern hemisphere, but as the position of that isthmus does not correspond with the line of the equator, and lies considerably north of that line, a large portion of South America proper lies in the boreal hemisphere. North America proper is divided by the isthmus of Tehauntepec in two subdivisions-Central America from Panama to Tehauntepec, and North America from Tehauntepec to the North Pole.

"Central America in its present political organization includes the following States: Guatemala, Salvador, Honduras, Nicaragua, and Costa Rica, but from a geographical standpoint it has a much larger area, since it begins at the isthmus of Panama and ends at the isthmus of Tehuantepec. Taking this view, Mexico exercises sovereignty over a large portion of Central America, larger still than any single State of the five which are generally considered as the only components of the same, and representing a third of the total territorial area of Central America.

"The Mexican State of Chiapas and a part of Oaxaca, on the Pacific; of Yuca$\tan$, Campeche, and Tabasco, and a portion of the State of Vera Cruz on the Gulf of Mexico, are situated in geographical Central America.

"The following résume of the territorial area and population of the several sections of Central America, taken from the Statesman's Year Book, London, 1887, shows that Mexico is a Central American as well as a North American power:

FIVE STATES OF CENTRAL AMERICA.

\begin{tabular}{|c|c|c|}
\hline Guatemal & $\begin{array}{c}\text { ea in sq. miles. } \\
46,800\end{array}$ & $\begin{array}{l}\text { Population. } \\
1,224,602\end{array}$ \\
\hline Salvador. . & 7,225 & 634,120 \\
\hline Honduras..... & 46,400 & 458,000 \\
\hline Nicaragua..... & 49,500 & 275,815 \\
\hline Costa Rica. . . . $\ldots \ldots \ldots \ldots \ldots \ldots \ldots \ldots$ & 23,200 & 213,785 \\
\hline Tota & 173,125 & $2,806,322$ \\
\hline
\end{tabular}


MEXICo.

\begin{tabular}{|c|c|c|}
\hline $\begin{array}{c}\text { State. } \\
\text { Chiapas.................... }\end{array}$ & $\begin{array}{l}\text { Area in sq. miles. } \\
16,048\end{array}$ & $\begin{array}{r}\text { Population } \\
242,029\end{array}$ \\
\hline Oaxaca (one-fifth) $\ldots \ldots \ldots \ldots \ldots \ldots$ & 6,718 & 152,255 \\
\hline Yucatan $\ldots \ldots \ldots \ldots \ldots \ldots \ldots \ldots \ldots \ldots \ldots$ & 29,567 & 302,319 \\
\hline Campeche...$\ldots \ldots \ldots \ldots \ldots \ldots \ldots$ & 25,832 & 90,413 \\
\hline Tabasco.............................. & 11,815 & I40,747 \\
\hline Vera Cruz (one-fourth) .............. & $6,55^{8}$ & $\mathrm{I} 45,6 \mathrm{IO}$ \\
\hline Total. & 96,538 & $1,073,373$ \\
\hline
\end{tabular}
Mexico.

This shows that 36 per cent. of the total area of Central America belongs to

In the foregoing list $\mathrm{I}$ omitted to take into account that, besides the States referred to, there are in Central America proper the British Colony of Belize or British Honduras, and that part of the State of Panama, in Colombia, which lies north of the isthmus of Panama.

Taking the area and population of those places from the statistical and geographical data published by the Almanach de Gotha for 1893 , and from some official information in possession of Señor Doctor Don Manuel M. de Peralta, Costa Rican Minister to Washington, a gentleman very well versed in Central American affairs, the following results are obtained :

\begin{tabular}{|c|c|c|c|}
\hline & $\begin{array}{l}\text { Area in square } \\
\text { miles. }\end{array}$ & $\begin{array}{c}\text { Area in square } \\
\text { kilometers. }\end{array}$ & Population. \\
\hline Chiapas.. & I6,048 & 41,565 & 270,000 \\
\hline Oaxaca (one-fifth) ...... & 6,718 & 17,400 & 158,800 \\
\hline Yucatan .............. & 29,567 & 76,579 & 330,000 \\
\hline Campeche........... & 25,832 & 66,905 & 94,000 \\
\hline Tabasco............... & I I , 8 I 5 & 30,600 & 140,747 \\
\hline \multirow[t]{2}{*}{ Veracruz (one-fourth) ... } & $6,55^{8}$ & I6,986 & 181,000 \\
\hline & 96,538 & 250,035 & $\mathrm{I}, \mathrm{I} 74,547$ \\
\hline Guatemala........... & 48,300 & 125,100 & $\mathrm{I}, 520,000$ \\
\hline Honduras ............ & 46,262 & I I 9,820 & 400,000 \\
\hline 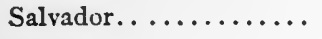 & 8,135 & 21,070 & 800,000 \\
\hline Nicaragua............ & 47,857 & I23,950 & 320,000 \\
\hline Costa Rica............ & 24,000 & 62,000 & 270,000 \\
\hline Panama (two-thirds)..... & I9,278 & 50,000 & 200,000 \\
\hline \multirow[t]{2}{*}{ British Honduras...... } & 8,300 & 21,475 & 31,500 \\
\hline & 202,132 & $523,4 \mathrm{I} 5$ & $3,54 \mathrm{I}, 500$ \\
\hline
\end{tabular}

GEOGRAPHICAL EXTENSION OF CENTRAL AMERICA.

Mexican Central America.......... 96,538 250,035

Five Republics of Central America..... I I4,554 45 I,940

British Honduras............... $8,300 \quad 21,475$

Panama (two-thirds) .......... $19,278 \quad 50,000$

$\overline{298,670} \quad \overline{773,450}$

The foregoing table shows that a little more than 32 per cent. of the whole of Central America, geographically speaking, belongs to Mexico. 
When those statements were translated into Spanish and published by Las Novedades, of New York, in its issue of the I 8th of January, r 888, they were read by Señor Don Manuel Montufar, Secretary of the Guatemalan Legation in Washington, who, in the absence of the Minister, Señor Don Francisco Lainfiesta, was acting as Chargé d'Affaires, and he considered my statements in this connection as a geographical heresy, and as an evidence of the design of Mexico against the several States of Central America. His alarm was so great that he called the attention of the other representatives of the Central American States in Washington to this incident, in order to point out to them the serious dangers which he foresaw for their respective countries on account of my views, which he considered as more than extraordinary.

Fortunately, one of them, the representative of Costa Rica, Señor Doctor Don Manuel M. de Peralta, had attended the meeting of the Travellers' Club at which I spoke, and, I think, Doctor Don Horacio Guzman, the Nicaraguan Minister, was also present, although I am not sure of this, and both failed to see anything in what I stated in this connection that was not a geographical fact, and that, consequently, it could not be disputed; and therefore this incident, that threatened to assume certain proportions, died in its very cradle.

Señor Montufar showed himself over-sensitive at my remarks when there was not the slightest ground for such feeling. If I had made a geographical mistake in averring that a portion of the territory of Mexico was in Central America, geographically speaking, I would be the only sufferer by my mistake, because I would have been the laughing-stock of everybody, including the school-boy studying geography; and, on the contrary, if I had stated a fact, nobody had reason to complain, and much less to be alarmed.

My object in now mentioning this incident is to show the extreme sensitiveness of some Guatemalan gentlemen in regard to Mexico, which goes so far that they cannot listen sometimes to indisputable facts without umbrage, and without ascribing it to purposes and designs against their country. Fortunately this incident happened when the long-pending boundary dispute between Mexico and Guatemala had already been settled for several years, as, had it taken place before, when that question was opened, the situation would have been still more embarrassing and unpleasant.

M. ROMERo.

Washington, December 29, 1893. 
MEXICAN PROFILES.

In the chapter on Orography of this paper (page $3 \mathrm{I}$ ) I stated that I would give some profiles of the Mexican surface, which would show in an exact manner the different altitudes from the sea-level to the high plateaus of the country. I have selected for that purpose the principal measurements by railroads built in Mexico, as they naturally followed the easiest ascent and descent, both from the coast to the interior and back to the coast. I will also supplement those measurements with others made for wagon roads to and from important places.

FROM VERACRUZ TO MEXICO BY ORIZABA, BY THE MEXICAN RAILWAY.

\begin{tabular}{|c|c|c|c|c|c|c|}
\hline \multirow{2}{*}{ STATIONS. } & \multicolumn{2}{|c|}{$\begin{array}{l}\text { Distance between } \\
\text { each station. }\end{array}$} & \multicolumn{2}{|c|}{ Distances. } & \multicolumn{2}{|c|}{ Altitudes. } \\
\hline & Kilom's. & Miles. & Kilom's. & Miles. & Metres. & Feet. \\
\hline eract & I5.500 & 9.63 & 0.000 & 0.00 & 1.89 & $0.2+3$ \\
\hline$m \cdot 0^{0}$ & 15.250 & 9.48 & $I_{5} .500$ & & 32.34 & 106. 10 \\
\hline Purg & II. 250 & 6.99 & 30.750 & Ig. II & 44.77 & 146.89 \\
\hline leda & 21.250 & $13.2 \mathrm{I}$ & 42.000 & 26.10 & 93,08 & 305.39 \\
\hline Camaron. & 12.750 & 7.92 & 63.250 & 39.31 & 340.76 & I I 16.47 \\
\hline Paso del Mach & 10.000 & 6.22 & 76.000 & 47.23 & 475.55 & I560.25 \\
\hline Atoyac ............ & 19.750 & 12.27 & 86.000 & 53.45 & 400.77 & I3I $4.9 \mathrm{I}$ \\
\hline & 26.250 & 16.52 & 105.750 & & 827.88 & $2713.6 \mathrm{I}$ \\
\hline & 20.250 & 12.58 & 132.000 & 82.04 & 1227.63 & 4027.80 \\
\hline & 20.250 & 12.59 & 152.250 & 94.62 & I601.79 & 5255.40 \\
\hline $1 \mathrm{Mor}$ & 6.500 & 4.04 & 172.500 & ro7.2I & 2415.36 & 7924.66 \\
\hline Espe & 24.250 & 15.07 & 179.000 & III.25 & 2451.79 & 8044.20 \\
\hline res & 20.500 & 12.74 & 203.250 & 126.32 & 2430.42 & 7974.08 \\
\hline Rinco & 18.000 & II. I9 & 223.750 & 139.06 & 2357.32 & 7734.24 \\
\hline San Marcos & 17.250 & 10.72 & 241.750 & & 2373.21 & 7786.37 \\
\hline Huan & 25.500 & 15.84 & 259.000 & 160.97 & 2488.06 & 8164.97 \\
\hline 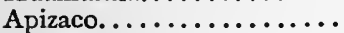 & 27.000 & 16.79 & 284.500 & $176.8 \mathrm{I}$ & 24 II. 5 I & 7912.03 \\
\hline Sol & I 9.500 & I2.I 2 & 311.500 & 193.60 & 2507.62 & 8227.37 \\
\hline & 15.500 & 9.63 & 331.000 & 205.72 & 2486.92 & 8159.45 \\
\hline & 22.000 & 13.67 & 346.500 & 215.35 & 2452.58 & 8046.78 \\
\hline Ots & II. 500 & 7.15 & 368.500 & 229.02 & 2349.41 & 7708.28 \\
\hline Tec & 11.250 & 6.99 & 380.000 & 236.17 & 2281.57 & $7485.7 \mathrm{I}$ \\
\hline $\mathrm{Te}$ & 32.500 & 20.20 & 380.000 & 236.17 & 2244.99 & 7365.69 \\
\hline Mexico & & & 423.750 & 263.36 & 2239.83 & 73.8 .76 \\
\hline
\end{tabular}

FROM APIZACO TO PUEBLA, A BRANCH OF

THE SAME ROAD.

\begin{tabular}{|c|c|c|c|c|c|c|}
\hline Mexico. & I 39.250 & 86.54 & 0.000 & 0.00 & 2239.83 & 7348.76 \\
\hline Apizaco.. & 16.750 & I0.4I & 139.250 & 86.54 & $24 \mathrm{II} .5 \mathrm{I}$ & 7912.03 \\
\hline Santa Ana. & 18.250 & II. 29 & 156.000 & 96.95 & 2288.31 & 7507.82 \\
\hline Panzacola..... & 12.000 & 7.52 & 174.250 & 108.24 & 2192.01 & 7 I91.86 \\
\hline Puebla ............... & $\ldots \ldots$. & $\ldots \ldots \ldots$ & 186.250 & I 55.76 & 2154.63 & 7069.22 \\
\hline
\end{tabular}


FROM VERACRUZ TO MEXICO BY JALAPA, BY THE INTEROCEANIC RAILWAY.

\begin{tabular}{|c|c|c|c|c|c|c|}
\hline \multirow[t]{2}{*}{ STATIONS. } & \multicolumn{2}{|c|}{$\begin{array}{c}\text { Distance between } \\
\text { each station. }\end{array}$} & \multicolumn{2}{|c|}{ Distances. } & \multicolumn{2}{|c|}{ Altitudes. } \\
\hline & Kilom's. & Miles. & Kilom's. & Miles. & Metres. & Feet. \\
\hline Ver & 20.234 & 12.58 & 0.000 & 0.00 & & 6.56 \\
\hline Santa Fé.. & I5.200 & 9.46 & 20.234 & $12.5^{8}$ & 28 & 93. \\
\hline La Antigua & 9.820 & 6.09 & 35.434 & 22.04 & $5 \cdot 50$ & 8.04 \\
\hline San Francisco & 21.644 & 13.45 & 45.254 & 28.13 & 24.44 & 8o. I8 \\
\hline Rinconada..... & 16.312 & I0.14 & 66.898 & 41.58 & 254.00 & 833.36 \\
\hline Colorado............... & $9 \cdot-8 I$ & 6.07 & 83.210 & 51.72 & 520.70 & 1708.39 \\
\hline El Palmar. & 15.603 & 9.70 & 92.991 & 57.79 & 690.08 & 2264.12 \\
\hline Chavarrillo. . & 14.675 & 9.12 & 108.594 & 67.49 & 941.24 & 3088.16 \\
\hline Pacho...... & $8.55^{8}$ & 5.32 & 123.269 & 76.61 & I 170.44 & 3840 . I 5 \\
\hline Jalapa. & 10.510 & 6.53 & 131.527 & 81.93 & 1336.18 & 4383.94 \\
\hline Banderilla .. & 14.227 & 8.84 & 142.337 & 88.46 & 1490.00 & 3.62 \\
\hline San Miguel. & 14.870 & 9.25 & I 56.564 & 97.30 & 1780.22 & .82 \\
\hline Cruz Verde & I6.569 & 10.29 & 171.434 & I 06.55 & 207309 & 6801.70 \\
\hline Las Vigas. . & 20.827 & 12.95 & 188.003 & I 16.84 & 2421.10 & 7943.50 \\
\hline Perote....... & 29.476 & 18.31 & 208.830 & 129.79 & 2390.30 & 7842.44 \\
\hline Tepeyahualco ............ & 17.041 & 10.59 & 233.297 & I.48. IO & 2321.50 & 7615.23 \\
\hline es $\ldots \ldots \ldots \ldots \ldots \ldots$ & 17.064 & $10.6 \mathrm{I}$ & 255.338 & 158.69 & 2346.40 & 7698.41 \\
\hline Ojo & II. 303 & 7.02 & 272.402 & 169.30 & 2348.33 & 7704.74 \\
\hline San Marcos & 14.014 & 8.71 & 283.705 & 176.32 & 2412.60 & 7915.61 \\
\hline La Venta. & 10.357 & 6.44 & 297.719 & 185.03 & 2559.05 & 8396.10 \\
\hline Acajete... & II. 344 & 7.05 & 308.076 & 191.47 & 2469.25 & 8101.48 \\
\hline Amo & 19.391 & 12.05 & 319.420 & I 98.52 & 2312.04 & $75^{85} .67$ \\
\hline Pue & 7.919 & 4.92 & $338.8 \mathrm{I} \mathrm{I}$ & 210.57 & 2155.60 & 7072.39 \\
\hline Arcos & $\mathrm{I} 5.586$ & 9.69 & 346.730 & 215.49 & 2130.96 & 6991.56 \\
\hline Analco ....... & 15.231 & 9.47 & 362.316 & 225.18 & 2197.50 & 7209.88 \\
\hline San Martin Tex & $12.72 \mathrm{I}$ & 7.91 & 377.547 & 234.65 & $2258.6 \mathrm{I}$ & 7410.38 \\
\hline Atotonilco & 24.259 & 15.05 & 390.268 & 242.56 & $2+72.10$ & 8110.83 \\
\hline Nana & 23.275 & 14.49 & 414.527 & 257.61 & 2740.16 & 0.31 \\
\hline Calpulalpar & 9.302 & 5.78 & 437.802 & 272.10 & 2576.10 & $8990.3 \mathrm{I}$ \\
\hline San Lorenz & 9.648 & 5.99 & 447.104 & 277.88 & 2484.22 & $8 \mathrm{r} 50.60$ \\
\hline Irolo . . . . . & 15.617 & 9.71 & 456.752 & 283.87 & 2447.25 & 8029.30 \\
\hline Soapayuca & 4.724 & 2.94 & 472.369 & $293.5^{8}$ & 2409.05 & 7903.96 \\
\hline Otumba.... & 31.209 & 19.39 & 477.093 & 296.52 & $236 \mathrm{I} .30$ & 7747.29 \\
\hline Texcoco... & I I. 452 & 7.92 & 508.302 & 315,91 & 2249.10 & 7379.13 \\
\hline San Vicente & $9 \cdot 353$ & 5. 19 & 519.754 & 323.03 & 2235.20 & 7333.52 \\
\hline I.os Reyes. & 17.495 & II 50 & 529.107 & 328.22 & 2240. I0 & $73+9.60$ \\
\hline Mexico... & $\ldots \ldots$ & 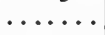 & 546.602 & $339 \cdot 7^{2}$ & 2240.00 & 7349.27 \\
\hline
\end{tabular}

FROM THE CITY OF MEXICO TO MORELOS, A BRANCH OF THE SAME ROAD.

\begin{tabular}{|c|c|c|c|c|c|c|}
\hline Mexico............... & 17.495 & II 50 & 0.000 & 0.00 & 2240.00 & 7349.27 \\
\hline Los Reyes . . . . . . . . . . . . & 7.005 & 3.73 & 17.495 & 11.50 & 2240.10 & 7349.60 \\
\hline 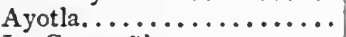 & $9 \cdot 300$ & 5.77 & 24.500 & 15.23 & 2243.30 & 60.09 \\
\hline La Compañia............ & I2.900 & 8.02 & 33.800 & 21.00 & $2244 \cdot 50$ & 7364.03 \\
\hline Tenango....... & 10.800 & $6.7 I$ & 46.700 & 29.02 & 2324.20 & 7625.53 \\
\hline Amecameca... & 12.200 & 7.59 & 57.500 & 35.73 & 2.466 .50 & 8092.42 \\
\hline Otumba....... & 22.900 & 14.23 & 69.700 & 43.32 & $232+\cdot 45$ & 7626.33 \\
\hline Nepantla............... & 26.800 & I6.66 & 92.600 & 57.55 & Ig68.65 & 6459.04 \\
\hline 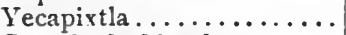 & 16.500 & 10.25 & I 19.400 & 74.21 & 1570.20 & 5151.75 \\
\hline Cuautla de Morelos.. & 8.200 & 5.10 & 135.900 & 84.46 & 1216.48 & 3991.20 \\
\hline Calderon...... & 14.000 & 8.70 & 144.100 & 89.56 & 1258. I 5 & 4127.92 \\
\hline Yautepec .... & I 8.000 & II.I9 & 158.100 & 98.26 & I I 54.72 & 3788.59 \\
\hline Ticuman..... & 8.200 & 5.09 & I76. 100 & 109.45 & 968.22 & 3176.69 \\
\hline Tlaltizapan ......... & 8.700 & $5.4 \mathrm{I}$ & I 84.300 & I 14.54 & 93 & 54.73 \\
\hline Tlalquitenango.......... & 2.300 & 1.43 & 193.000 & II 9.95 & 900.20 & $2953.5 I$ \\
\hline Jojutla........ & 12. 100 & 7.52 & 195.300 & 121.38 & 890.64 & 2922.15 \\
\hline San Jose........ & 7.600 & 4.73 & 207.400 & 128.90 & 992.35 & 3255.84 \\
\hline Puente de Ixtla........ & .. & $\cdots$ & 215.000 & 133.63 & Sg6.99 & 2942.99 \\
\hline
\end{tabular}


FROM PUEBLA TO IZÚCAR DE MATAMOROS, A BRANCH OF THE SAME ROAD.

\begin{tabular}{|c|c|c|c|c|c|c|}
\hline \multirow{2}{*}{ STATIONS. } & \multicolumn{2}{|c|}{$\begin{array}{l}\text { Distance between } \\
\text { each station. }\end{array}$} & \multicolumn{2}{|c|}{ Distances. } & \multicolumn{2}{|c|}{ Altitudes. } \\
\hline & Kilom's. & Miles. & Kilom's. & Miles. & Metres. & Feet. \\
\hline Puebla. & 7.919 & 4.92 & 0.000 & 0.00 & 2155.60 & 7072.36 \\
\hline Los Arcos. & 5.000 & $3.1 \mathrm{I}$ & 7.919 & 4.92 & 2530.96 & 6991.52 \\
\hline Cholula... & 8.900 & 5.53 & 12.919 & 8.03 & 2145.00 & 7037.58 \\
\hline Santa María.. & 18.100 & 11.25 & 21.819 & 13.56 & 2120.10 & 6955.89 \\
\hline San Augustin. & 5.850 & 3.64 & 39.919 & $24.8 I$ & 2030.20 & 6660.94 \\
\hline Atlixco...... & 19.150 & II.90 & 45.769 & 28.45 & 1196.60 & 3925.99 \\
\hline San José Teruel.. & 8.850 & 5.49 & 64.919 & 40.35 & 1685.18 & 5528.99 \\
\hline Tatetla.... & 10.543 & 6.56 & 73.769 & 45.84 & I 584.94 & 5200.10 \\
\hline Matamoros. & $\ldots \ldots$ & $\ldots \ldots$ & 84.412 & 52.40 & I 443.80 & 4737.03 \\
\hline
\end{tabular}

FROM MEXICO TO EL PASO DEL NORTE OR CIUDAD JUAREZ, BY THE CENTRAL MEXICAN RAILROAD.

\begin{tabular}{|c|c|c|c|c|c|c|}
\hline$\ldots \ldots \ldots \ldots \ldots$ & II.700 & 7.27 & 0.000 & 0.00 & 2240.00 & $7349 \cdot 32$ \\
\hline Tlalnepantla............ & 5.900 & 3.67 & 11.700 & 7.27 & 2250.10 & 2.46 \\
\hline 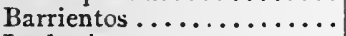 & 3.300 & 2.05 & 17.600 & I0.94 & 2298.50 & I. 26 \\
\hline$\ldots \ldots \ldots \ldots \ldots$ & 6.800 & 4.23 & 20.900 & I2.99 & 2253.20 & .63 \\
\hline 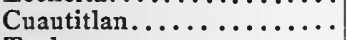 & 8.300 & 5.15 & 27.700 & 17.22 & 2252.50 & 7390.33 \\
\hline Teoloyucan............. & 10.500 & 6.52 & 36.000 & 22.37 & 2253.20 & 7392.63 \\
\hline Huehue & 6.000 & 3.74 & 46.500 & 28.89 & .80 & 7411.00 \\
\hline Nochisto & 9.900 & 6.15 & 52.500 & 32.63 & 2248.00 & 7375.57 \\
\hline El Salto & 17.600 & 10.96 & 62.400 & 38.78 & 2162.60 & .37 \\
\hline Tula. & 13.500 & 8.39 & 80.000 & $49 \cdot 7^{2}$ & 2030.00 & 6660.32 \\
\hline tonio..... & $24 \cdot 300$ & I5.10 & 93.500 & 58.II & 2157.00 & 7175.43 \\
\hline$\ldots \ldots \ldots$ & 3.800 & 2.37 & 117 & 73.21 & .80 & 9.84 \\
\hline (e & 8.300 & 5.15 & 121.600 & 75.58 & 2426.50 & 1.22 \\
\hline No & 8.000 & 5.04 & I 29.900 & 80.73 & 2341.40 & 2.00 \\
\hline $\mathrm{Dañ}$ & 14.000 & 8.63 & 137.900 & 85.77 & 2387.70 & 7833.92 \\
\hline Polc & 9.200 & 5.72 & 151.900 & 94.40 & 2292.30 & $.9 \pi$ \\
\hline $\mathrm{Caz}$ & 10.900 & 6.77 & 161.100 & I00. I 2 & 2249.50 & .49 \\
\hline$\ldots \ldots \ldots \ldots$ & I 8.600 & II. 57 & 172.000 & 106.89 & 2162.00 & 3.40 \\
\hline del Rio.... & 13.300 & 8.26 & I90.600 & I 18.46 & I905.50 & 1.84 \\
\hline ec...... & 12.200 & 7.59 & 203.900 & I 26.72 & I 894.90 & 6217.07 \\
\hline do... & 24.400 & 15.16 & 216.100 & 134.31 & 1907.70 & 6259.07 \\
\hline Hé & 5.000 & 3.11 & 240.500 & 149.47 & I 843.90 & 9.74 \\
\hline$\ldots \ldots \ldots \ldots \ldots \ldots$ & 18.500 & II.50 & 245.500 & 152.58 & 1813.20 & .02 \\
\hline$\ldots \ldots \ldots \ldots \ldots$ & 14.5 & 9.01 & 264. & 164.08 & 1788.20 & .00 \\
\hline e & I3.000 & 8.08 & 278.500 & 173.09 & 1767.40 & 5798.75 \\
\hline .. & I8.200 & II.3I & 291.500 & I 8I.I7 & 1757.40 & 5.94 \\
\hline$\ldots \ldots$ & 22.800 & 14.17 & 309.700 & I 92.48 & 1740.00 & .85 \\
\hline Salamanca ....... & I I. IOO & 6.90 & 332.500 & 206.65 & 1721.50 & 8.15 \\
\hline $\mathrm{Ch}$ & 9.200 & 5.72 & 343.600 & 213.55 & 1720.80 & 5.85 \\
\hline Ira & I6.600 & 10.31 & 352.800 & 219.27 & 1723.70 & .37 \\
\hline$\ldots$ & $\mathrm{I} 3.200$ & 8.20 & 369.400 & 229.58 & 1746.10 & 5728.87 \\
\hline Sil & 19.000 & I 1.82 & 382.600 & 237.78 & 1776.50 & 61 \\
\hline dad. & 14.200 & 8.82 & 401.600 & 249.60 & 1818.00 & 5964.77 \\
\hline Leo & 16.400 & 10.19 & 415.800 & 258.42 & 1785.80 & 5859.12 \\
\hline Francisco. & 15.400 & $9.5^{8}$ & 432.200 & 286.61 & 1765.00 & .88 \\
\hline Pedrito... & 13.700 & 8.51 & 447.600 & 278.19 & 1795.00 & $\cdot 30$ \\
\hline Lon & 13.600 & 8.55 & 461.300 & 286.70 & I 890.40 & 31 \\
\hline La & 10.600 & 6.59 & 474.900 & 295.15 & 1871.00 & 6138.66 \\
\hline
\end{tabular}


FROM MEXICO TO EL PASO DEL NORTE OR CUIDAD JUAREZ, BY THE CENTRAL MEXICAN RaIlroad.-Continued.

\begin{tabular}{|c|c|c|c|c|c|c|}
\hline \multirow{2}{*}{ STATIONS. } & \multicolumn{2}{|c|}{$\begin{array}{l}\text { Distance between } \\
\text { each station. }\end{array}$} & \multicolumn{2}{|c|}{ Distances. } & \multicolumn{2}{|c|}{ Altitudes. } \\
\hline & Kilom's. & Miles. & Kilom's. & Miles. & Metres. & Feet. \\
\hline (Ans & .300 & 6.77 & 485.500 & 01.74 & 2015.80 & $66 \mathrm{I} 3$. \\
\hline & & I 5.35 & & & 2035.00 & \\
\hline Sant & 0 & Io. & 520. & 323.49 & & 6051.71 \\
\hline Encarnacion. & 26.400 & $16.4 \mathrm{I}$ & 537.200 & 333.87 & $185 \mathrm{I} .00$ & 6073.04 \\
\hline Peñuelas. & 21.500 & 13.36 & & & 1878 & \\
\hline ient & 30.100 & I8.71 & 585.100 & 363.64 & 1884.00 & $6 \mathrm{I} 8 \mathrm{I} \cdot 3 \mathrm{I}$ \\
\hline & 8.500 & 5.28 & 615.200 & 382.35 & & 6261.69 \\
\hline de Rome & 20.500 & 12.74 & 623.700 & 387.63 & 1296.60 & 6321.08 \\
\hline & 5.800 & 32.20 & 644.200 & 400.37 & 1979.00 & 6493.00 \\
\hline$x_{0}$ & 9.900 & 6.15 & 696.000 & 432.57 & & \\
\hline$\omega_{0}$ & I 3.500 & 8. & 705.900 & & & \\
\hline Pim & 16. & 10.00 & 719.400 & $447.1 \mathrm{I}$ & & \\
\hline & 28.000 & 17.41 & 735.500 & 457.11 & 60 & \\
\hline & 15.500 & 0.63 & 763.500 & $474 \cdot 5^{2}$ & & \\
\hline & I 5 . & 9. & 779.000 & 484.15 & 210 & \\
\hline & & I3. & & +93.47 & & \\
\hline 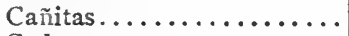 & 13. & & 816.100 & $507.2 I$ & 2006.60 & $6583.5 \mathrm{I}$ \\
\hline & 20.700 & I 2.86 & 829.600 & 515.60 & 1962.40 & 6438.53 \\
\hline $\mathrm{La}$ & 25.800 & 16.04 & 850.300 & 528.46 & $5057-7$ & 48 \\
\hline $\mathrm{P}$ & 19.000 & .01 & 870 & & & .72 \\
\hline & 19.700 & 12.24 & 895 & & 1810 & \\
\hline & 21.400 & 1 & & 55 & & \\
\hline & 21. & I & $\infty$ & 1.85 & I & .47 \\
\hline$\cdots$ & 23. & I & 958.100 & & & .44 \\
\hline & 24. & I & $9^{81} 1.300$ & & 1568 & 5147.48 \\
\hline & 0 & & & & I 55 & \\
\hline & & 14.85 & 26.300 & 637.85 & & 3.44 \\
\hline & I5. & 9.64 & $\infty$ & 70 & & .45 \\
\hline & I4. & & & 34 & & \\
\hline & & 8. & 80.100 & 29 & & \\
\hline & 25. & $I=67$ & 94.400 & 680.17 & & 87 \\
\hline $\mathrm{Ma}$ & 16.400 & 10.01 & 9.600 & 695.84 & $I_{1}$ & \\
\hline & 5.200 & & 5.000 & 705.85 & I I 4 & . 3 \\
\hline & 17. & 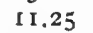 & $\infty$ & OI & & $5.5 \mathrm{I}$ \\
\hline & 20. & 12.43 & & 26 & & \\
\hline & & 14.6 & 78.900 & 732.69 & II 2 & 3693.36 \\
\hline & 22 & & & 61 & & \\
\hline & & & & 40 & & $1.6 \mathrm{I}$ \\
\hline & & & & & & .64 \\
\hline & I8. & & $\infty$ & & & $38004 \mathrm{I}$ \\
\hline $\mathrm{Za}$ & 14.600 & & $285.20 n$ & 798.76 & 1201.60 & $391^{2} .39$ \\
\hline & & & & 805.83 & & \\
\hline $\operatorname{Re}$ & 21. & & 317.800 & 819.02 & 1330.00 & 4363.66 \\
\hline & I9. 4 & I 2.06 & & & 1442.70 & \\
\hline & 14.7 & & oo & 8 & & 38 \\
\hline & & II. 87 & I 373.300 & & 1381.20 & .65 \\
\hline & I & & I 392.400 & & & \\
\hline & 19.200 & II.93 & 1411.200 & & I 298.90 & 4261.63 \\
\hline & & 9.76 & & & & \\
\hline & I6.000 & & 1446.100 & 898.76 & 1226 & 4022.45 \\
\hline & & 12.68 & 762.100 & 908.70 & 1216.60 & \\
\hline & 15.600 & 9.70 & 1482.500 & 921.38 & 1219.90 & 4002.43 \\
\hline & I6.100 & 10.00 & 1498.100 & & I 210.20 & \\
\hline & & & $15 I_{4} .200$ & $94^{1.08}$ & 1170.30 & 3839.69 \\
\hline & 24.300 & I 5.08 & $|1521.500|$ & 945.62 & II 57.10 & 3796.39 \\
\hline
\end{tabular}


FROM MEXICO TO EL PASO DEL NORTE OR CIUDAD JUAREZ, BY THE CENTRAL MEXICAN RAILROAD.-Continued.

\begin{tabular}{|c|c|c|c|c|c|c|}
\hline \multirow{2}{*}{ STATIONS. } & \multicolumn{2}{|c|}{$\begin{array}{c}\text { Distance between } \\
\text { each station. }\end{array}$} & \multicolumn{2}{|c|}{ Distances. } & \multicolumn{2}{|c|}{ Altitudes. } \\
\hline & Kilom's. & Miles. & Kilom's. & Miles. & Metres. & Feet. \\
\hline Bachimba . & 17.700 & 10.76 & $\mathrm{I} 545.800$ & 960.70 & 1264.10 & 4147.45 \\
\hline Horcasitas ............ & 22.400 & 13.91 & I 563.200 & 971.54 & 1366.50 & 4483.42 \\
\hline 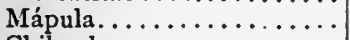 & 22.900 & 14.24 & I 585.600 & 985.45 & I 514.40 & 4968.66 \\
\hline Chihuahua..... & 23. I00 & 14.36 & 1608.500 & 999.69 & 1412.30 & 4633.68 \\
\hline Sacramento . & 15.100 & $9 \cdot 38$ & 1631.600 & IOI 4.05 & 1519.90 & 4986.71 \\
\hline Ferragas... & II.600 & 7.21 & 1646.700 & 1023.43 & 1591.50 & 5221.63 \\
\hline Sauz. : & I9.900 & 12.37 & 1658.300 & 1030.64 & 1564.40 & 5132.71 \\
\hline Encinillas .... & 13.900 & 8.64 & 1675.200 & 1043.01 & I 533.60 & 5031.66 \\
\hline Agua Nueva... & 13.400 & 8.33 & 1692.100 & 1051.65 & 1527.50 & 5011.65 \\
\hline Laguna.... & 20.400 & 12.67 & 1705.500 & 1059.98 & 1535.70 & 5038.55 \\
\hline Puerto... & 20.200 & I 2.56 & 1725.900 & 1072.65 & 1618.90 & 5311.53 \\
\hline Gallego. . & 29.000 & I8.02 & 1746.100 & 1085.21 & 1622.00 & $532 \mathrm{I} .7 \mathrm{I}$ \\
\hline Chivatito ... & 15.400 & 9.57 & 1775.100 & 1103.23 & 1450.50 & 4857.45 \\
\hline Moctezuma. & 13.100 & 8.14 & 1790.500 & III 2.80 & 1382.80 & 4536.89 \\
\hline Las Minas & I 3.500 & 8.33 & 1803.600 & I I 20.94 & 1318.10 & 4324.62 \\
\hline Ojo Calient & I I. 300 & 7.09 & 1817.100 & I 129.27 & 1233.30 & 4046.39 \\
\hline Cármen.. & 22.800 & 14.17 & 1828.400 & I I 36.36 & 1216.00 & 3989.64 \\
\hline San José. . & 24.100 & 14.97 & 1851.200 & I I 50.53 & II 94.60 & 3919.42 \\
\hline Ranchería. & 28.700 & 17.84 & I 875.300 & I 165.50 & 1281.80 & 4205.52 \\
\hline Los Médanc & 18.200 & 11.32 & 1904.000 & 1183.34 & I 298.30 & 4259.66 \\
\hline Samalayu & 16.100 & 10.00 & I 922.200 & 1194.66 & 1274.50 & 4181.57 \\
\hline Tierra Bla & I 4.400 & 8.95 & 1938.300 & I 204.66 & 1263.50 & $4^{1} 45.4^{8}$ \\
\hline Mesa. & 17.600 & 10.94 & 1952.700 & I $213.6 \mathrm{I}$ & 1207.10 & 3960.40 \\
\hline Ciudad & & & 1970.300 & 1224.55 & 1133.10 & 3717.64 \\
\hline
\end{tabular}

FROM AGUASCALIENTES TO TAMPICO, A BRANCH OF THE SAME ROAD.

\begin{tabular}{|c|c|c|c|c|c|c|}
\hline Aguascalientes. & $14 \cdot 300$ & 8.90 & 0.000 & 0.00 & I884.00 & 6181.3 \\
\hline Chicalote & 6.200 & 3.84 & 14.300 & 8.90 & 1891.00 & \\
\hline Cañada.. & 10.500 & 6.52 & 20.500 & I2.74 & 1921.50 & $6304 \cdot 34$ \\
\hline Gallardo. & 4.600 & 2.86 & 31.000 & 19.26 & I 955.75 & 6416.71 \\
\hline El Tule. . & I 5.200 & 9.45 & 35.600 & 22.12 & 1962.75 & 9.68 \\
\hline San Gil. & 8.200 & 5.10 & 50.800 & 31.57 & 2011.50 & 9.62 \\
\hline San Mar & I I. 000 & 6.84 & 00 & & & .42 \\
\hline $\mathrm{Ga}$ & 12.800 & 7 & bo & $43.7 \mathrm{I}$ & 7.40 & 7.07 \\
\hline $\mathrm{La}$ & II. 000 & & oo & 51.46 & 21 & 30 \\
\hline $\mathrm{Pe}$ & I6.200 & 10.07 & $\infty$ & 58.30 & .75 & 2.44 \\
\hline $\mathrm{Sa}$ & 13.600 & 8.44 & $\infty$ & 68.37 & & 0.91 \\
\hline Zo & I 3.500 & 8.39 & 123. & 76.81 & .50 & 7.24 \\
\hline Es & 25. & 15.79 & 137. & 85.20 & .25 & .39 \\
\hline So & 62. & .65 & I62. & I00.99 & .80 & 25 \\
\hline Sa & 17. & 10.96 & 224 & I 39.64 & 187 & 8.35 \\
\hline $\mathbf{L a}$ & 27.100 & 16.84 & 24 & 50.40 & I 827.00 & 4.30 \\
\hline Co & 15.100 & 9.37 & 269 & 167.24 & 17 & .62 \\
\hline & 7.500 & 4.69 & 284. & 176.61 & 17 & .86 \\
\hline Si & $6.45^{\circ}$ & 4.00 & $29 I$. & 181.30 & 15 & 0.95 \\
\hline n Jose. . & 15.650 & 9.72 & 298. & 185.30 & I 566.00 & 7.97 \\
\hline Sa & 13 & 8.33 & 313. & I95.02 & 12 & 4. 16 \\
\hline $\mathrm{Ce}$ & I I. & 6.97 & 32 & 203.35 & II 36.00 & 3727.16 \\
\hline la (El Gat & 17.300 & 10.76 & 338.400 & 210.32 & 1100.00 & 3609.04 \\
\hline Bart & 43.300 & 26.90 & 355.700 & 221.08 & 1030.00 & $3379 \cdot 38$ \\
\hline Tanqu & 14.200 & 8.82 & 399.000 & $247.9^{8}$ & I I 90.00 & 3904.33 \\
\hline Cárden & 14.700 & 9.14 & 413.200 & 256.80 & I 200.00 & 3937.14 \\
\hline La I & 8.200 & 5.10 & 427.900 & 265.94 & 1200.00 & 3937.14 \\
\hline
\end{tabular}


FROM AGUASCALIENTES TO TAMPICO, A BRANCH OF THE SAME ROAD.Continued.

\begin{tabular}{|c|c|c|c|c|c|c|}
\hline \multirow{2}{*}{ STATIONS. } & \multicolumn{2}{|c|}{$\begin{array}{l}\text { Distance between } \\
\text { each station. }\end{array}$} & \multicolumn{2}{|c|}{ Distances. } & \multicolumn{2}{|c|}{ Altitudes. } \\
\hline & Kilom's. & Miles. & Kilom's. & Miles. & Metres. & Feet. \\
\hline is & & & 436.100 & 271.04 & 990.00 & 3248.14 \\
\hline . & 18.8 & II. & 444.000 & 275.95 & 825.00 & 2706.78 \\
\hline Tamazopo (Ĺa Garita) & 16.800 & 10.44 & 462.800 & 287.63 & 350.00 & $\mathrm{II} 48.33$ \\
\hline Rascon... & 15.100 & $9 \cdot 3^{8}$ & 479.600 & 298.07 & 295.00 & 967.88 \\
\hline Las Cruc & 9,500 & $5.9 \mathrm{I}$ & 494.700 & 307.45 & 275.00 & 902.26 \\
\hline El Salto (Micos) & 10.700 & 6.6 & 504.200 & 313.36 & 218.00 & 715.25 \\
\hline San Mateo....... & 13.800 & $8.5^{8}$ & 514.900 & 320.01 & 175.00 & 574.16 \\
\hline Valle & I 1.900 & 7. & 528.700 & 328.59 & 75.00 & 246.07 \\
\hline San Felip & 2.300 & 1.43 & 540.600 & 335.98 & 160.00 & 524.95 \\
\hline El Ab & 4.000 & 2.49 & 542.900 & $337.4 \mathrm{I}$ & 165.00 & 541.35 \\
\hline Taninul. . & 8.000 & 4.98 & 546,900 & 339.90 & 125.00 & 410.11 \\
\hline Las 1 & 68,700 & 42.68 & 554. & 344.88 & 50.00 & 164.05 \\
\hline Chij & 13.700 & 8.52 & 623.600 & 38 & 65.00 & 213.25 \\
\hline Salinas (Chila) & 17.900 & II.13 & 637.300 & 396.08 & 5.00 & 16.40 \\
\hline Tamo & 13.100 & 8.14 & 655.200 & $407.2 \mathrm{I}$ & 20.00 & 6.56 \\
\hline Tampic & & & 668.300 & 415.35 & 0.00 & 0.00 \\
\hline
\end{tabular}

FROM IRAPUATO TO GUADALAJARA, A BRANCH OF THE SAME ROAD.

\begin{tabular}{|c|c|c|c|c|c|c|}
\hline & 5.100 & 3.17 & 0.000 & 0.00 & I 724.00 & 5656.36 \\
\hline$\ldots$ & II. 300 & 7.02 & .100 & 3.17 & 1721.00 & \\
\hline & .600 & 4.73 & 16.400 & 10.19 & .00 & 16.99 \\
\hline & 8.000 & & 24.000 & 14.92 & & 5577.62 \\
\hline at & 6.2 & & & & & .21 \\
\hline ......... & II. 600 & 7.22 & & 23.73 & & \\
\hline & 14.300 & 8.8 & & & & \\
\hline & & $4.4 \mathrm{I}$ & & 4 & & \\
\hline 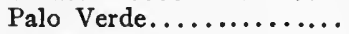 & 13.5 & 8. & & 44.25 & & .40 \\
\hline & 6.600 & 4.IO & & 52 & & \\
\hline & 20.100 & & & & & \\
\hline & 14. & & & 69 & & .78 \\
\hline & 21. & 13.05 & & 13 & & .56 \\
\hline & 6.4 & & bo & 91.18 & & .13 \\
\hline & 4. & 2. & & 95.15 & & \\
\hline & & & & 98 & & 66 \\
\hline & 13. & & 16 & 103.23 & & 5062.50 \\
\hline & & & & & & \\
\hline & & 13 & & 128 & & .60 \\
\hline & & & & & 15 & \\
\hline & & & & & & .63 \\
\hline & 24.800 & 15.40 & 234 & 145 & 1525.00 & .44 \\
\hline & & & & 161.03 & I 543.00 & 5062.50 \\
\hline
\end{tabular}

FROM MEXICO TO LAREDO TAMAULIPAS, BY THE MEXICAN NATIONAL RAILWAY.

\begin{tabular}{|c|c|c|c|c|c|c|}
\hline Mexicc & 4.600 & 2.86 & 0.000 & 0.00 & 2240.00 & 7349.32 \\
\hline Tacuba. & 4.800 & 2.98 & 4.600 & 2.86 & 2250.00 & 7382.13 \\
\hline Naucalpan. & 3.900 & 2.42 & 9.400 & 5.84 & 2280.00 & 7480.56 \\
\hline Rio Hondo........... & 8.700 & $5.4 \mathrm{I}$ & 13.300 & 8.26 & 2300.00 & 7546.17 \\
\hline San Bartolito. & 5.500 & 3.42 & 22.000 & 13.67 & 2460.00 & 8071.13 \\
\hline Dos Rios.......... & 5.500 & $3.4 \mathrm{I}$ & 27.500 & 17.09 & 2680.00 & 8792.94 \\
\hline Laurel........... & 5.900 & 3.68 & 33.000 & 20.50 & 2820.00 & 9252,27 \\
\hline Cumbre............. & 2.500 & I. 55 & 38.900 & 24.18 & 3050.00 & 10006.89 \\
\hline
\end{tabular}


FROM MEXICO TO LAREDO TAMAULIPAS. Continued.

\begin{tabular}{|c|c|c|c|c|c|c|}
\hline \multirow{2}{*}{ STATIONS. } & \multicolumn{2}{|c|}{$\begin{array}{l}\text { Distance between } \\
\text { each station. }\end{array}$} & \multicolumn{2}{|c|}{ Distances. } & \multicolumn{2}{|c|}{ Altitudes. } \\
\hline & Kilom's. & Miles. & Kilom's. & Miles. & Metres. & Feet. \\
\hline & 3.200 & I.99 & 41 & 25.73 & 3000.00 & $9^{8} 42.84$ \\
\hline . & 3.400 & & & 27.72 & & $95 I 4.74$ \\
\hline$\ldots \ldots$ & 2.500 & I. 56 & & & & \\
\hline & 5.600 & 3.48 & 50.500 & 31.39 & & 8924.18 \\
\hline & 3.000 & & & & 2600.00 & 8530.46 \\
\hline Lerma. . & 13.900 & 8.64 & 59.100 & 36.73 & 2540.00 & 3.60 \\
\hline Toluca... & 7.400 & 4.60 & 73.000 & $45 \cdot 37$ & 2640.00 & 1.70 \\
\hline Palmillas. & $\times 6.700$ & 10.38 & 80.400 & 49.97 & 2630.00 & \\
\hline Del Kio.. & 14.700 & 9.14 & & 60.35 & & 8464.84 \\
\hline Ixtlahuaca. & 12.300 & & I I I. 800 & 69.49 & 2540.00 & 8333.60 \\
\hline Tepetitlan. & 9.800 & 6.09 & I24.100 & & 2520.00 & 8267.98 \\
\hline Flor de $\mathrm{M}$ & 20.200 & I 2.56 & 133.900 & 8 & 2520.00 & 8267.98 \\
\hline Basoco.... & 4.000 & 2.48 & 154.100 & 95.78 & 2580.00 & 8464.84 \\
\hline Ven & 5.800 & 3.60 & 158.100 & & 2560.00 & 9.22 \\
\hline Tultenango & II.200 & 6.97 & I63.900 & & 2540.00 & 3.60 \\
\hline Solis...... & 10.900 & 6.77 & 175.100 & Io & 2430 & 2.70 \\
\hline Tepetongo & 7.100 & 4.41 & I86.000 & I I 5.60 & & .79 \\
\hline Agua Buena (Buena Vista). & 7.8 & 4.85 & 193.100 & .01 & 22 & \\
\hline$\ldots \ldots \ldots \ldots$ & 4.800 & 2.99 & 200.900 & 86 & 2160.00 & 7086.84 \\
\hline Pate & 3.400 & 2.10 & $225 \cdot 700$ & I27.85 & 2100.00 & 6889.98 \\
\hline Pom & 14.100 & 8.76 & 209.100 & 12 & $\infty$ & 3.13 \\
\hline Ma: & 12.000 & 7.47 & 223.200 & 138.71 & 2010 & 65 \\
\hline toni & 8.700 & 5.40 & 235.200 & 146.18 & 2080 & 4.37 \\
\hline uaro.......... & $\mathbf{1 2 . 0 0 0}$ & $7 \cdot 47$ & 243.900 & 151.58 & 2010.00 & 65 \\
\hline dacuao......... & 8.400 & 5.22 & 255.900 & & 1920.00 & 62 \\
\hline sé... & 8. & & & 27 & 1860.00 & .57 \\
\hline Pro & 12.900 & 8.02 & 272.800 & 169.55 & I 880 & . 19 \\
\hline Ac & 12.500 & 7.76 & 285.700 & 177.57 & I 860 & $6 \mathrm{I}$ \\
\hline istobal. & 17.500 & 10.88 & 298.200 & 18 & I 840 & 6.95 \\
\hline Salvatierra. & 15.500 & 9.63 & 315.700 & 196.21 & 1760.00 & 4.48 \\
\hline Cascalote. & 8.9 & 5.53 & 331.200 & 5.84 & 1760. & \\
\hline $\mathrm{Oj}$ & $\mathrm{I} 4.2$ & & 340.100 & 37 & 1770 & 58 \\
\hline $\mathrm{Ce}$ & 5.200 & 3.22 & 35 & $2 \mathrm{I}$ & I7 & 57 \\
\hline $\mathrm{Sa}$ & 7.400 & 4.60 & .500 & & 1760 & 57 \\
\hline Juan. & 3.800 & 2.37 & 366.900 & .03 & 1780. & 58 \\
\hline Sor & 7.200 & 4.47 & 370.700 & & 1785 . & 5.50 \\
\hline $\mathrm{Ch}$ & 8.900 & 5. & .900 & 87 & I 790 & .91 \\
\hline cillo. . & 13. & 8.08 & 386.800 & .40 & I 810 & 59 \\
\hline $\mathrm{Be}$ & 9. & 5 & 800 & 24 & & 7.73 \\
\hline e Alle & oo & 7.21 & OO & & 0 & 38 \\
\hline At & II. 300 & 7.03 & .500 & .34 & 1860 & .57 \\
\hline quia & 12.800 & 7.95 & 431.800 & 268.37 & I 870. & $6 r$ \\
\hline es Hidalgo.. & 7.200 & 4.48 & 444.600 & 276.32 & I 890.00 & .00 \\
\hline $\mathrm{Ri}$ & 11.3 & 7.02 & .800 & 280.80 & 1900.00 & 62 \\
\hline Peî & 9.I & 5.65 & 46 & & 19 & .23 \\
\hline $\mathrm{Tr}$ & 9.000 & 5.59 & 472.200 & 293.47 & 1950.00 & 6397.85 \\
\hline & I8. 700 & I 1.63 & 481.200 & 299.06 & I990.00 & 6529.09 \\
\hline Ciudad Gon & 14.400 & 8.95 & 499.900 & 310.69 & 2050. & 6725.94 \\
\hline Chirimoya. & 13.200 & 8.20 & 514.300 & 319.64 & I 860.00 & 6102.57 \\
\hline Jar & 16.700 & 10.38 & 527.500 & 327.84 & I 840.00 & 6036.95 \\
\hline de $\mathrm{Re}$ & 10.000 & 6.22 & $5+4.200$ & 338.22 & I 830.00 & 6004.14 \\
\hline Jesus Mari & 14.800 & 9.19 & 554.200 & 344.44 & I 810.00 & 5938.52 \\
\hline La Pila. & 15.000 & 9.33 & 569.000 & 353.63 & I 900.00 & .88 \\
\hline San & 13.400 & 8.33 & 584.000 & 362.96 & I 860.00 & 6102.57 \\
\hline Peñasco.. & 15.100 & $9 \cdot 37$ & 597.400 & & I 840.00 & 6036.95 \\
\hline Pinto.... & 12.500 & $7 \cdot 78$ & 612.500 & 380.66 & I 820.00 & 5971.33 \\
\hline Boc & 13.600 & 8.45 & 625.000 & 388.44 & 1700.00 & 5577.62 \\
\hline Enr & I 5.200 & 9.45 & 638.600 & 396.89 & 0.00 & 55 I 2.00 \\
\hline Moctezuma & 18.900 & I 1.75 & 653.800 & 406.34 & 1660.00 & 5446.38 \\
\hline
\end{tabular}


FROM MEXICO TO LAREDo TAMAUlipas.-Continuea.

\begin{tabular}{|c|c|c|c|c|c|c|}
\hline \multirow[t]{2}{*}{ STATIONS. } & \multicolumn{2}{|c|}{$\begin{array}{l}\text { Distance between } \\
\text { each station. }\end{array}$} & \multicolumn{2}{|c|}{ Distances. } & \multicolumn{2}{|c|}{ Altitudes. } \\
\hline & Kilom's. & Miles. & Kilom's. & Miles. & Metres. & Feet. \\
\hline & & 10.56 & $7,2.000$ & & $1 / 40.00$ & \\
\hline & & & & & & \\
\hline Laguna Neta a & 11.600 & 7.20 & 06.6 & & .00 & $6627.5 \mathrm{r}$ \\
\hline Berrendo... & & $9.5^{8}$ & & & & \\
\hline La Maroma... & 16.000 & 9.94 & 733.000 & & Do & S.19 \\
\hline$\ldots \ldots \ldots \ldots$ & & 5.35 & & & 1840.00 & \\
\hline Catorce............... & 6.800 & 4.23 & & 470.85 & I 820.00 & 5971.33 \\
\hline 'oblazon... & 15.200 & 9.44 & 764.400 & 475.08 & 178 & \\
\hline Vanegas. & 16.4 & & & 484.52 & 172 & \\
\hline deda (La sandua)... & 15.800 & & 0 & & & \\
\hline San Vicente.... ..... & & & & & & \\
\hline$\ldots \ldots \ldots \ldots \ldots$ & 15. & & & & & \\
\hline Lulu & Do & & & & & \\
\hline $\mathbf{L a}$ & 20.000 & & 863.400 & 536.60 & $\infty$ & 643.24 \\
\hline & 20.0 & & 0 & 549.03 & & \\
\hline s Farías............ & I3.200 & 8.20 & 04.300 & 562.03 & & \\
\hline ........... & 17. & 10.77 & & & & \\
\hline 果 & 0 & & & & 0 & .37 \\
\hline va. . & 13.2 & & & & & \\
\hline En & 6. & 3 . & & 59 & & \\
\hline ...... & 9.700 & 6. & & & & \\
\hline & & 7. & 97 & & & \\
\hline Lo & & & & & & \\
\hline & & 4. & 988. & & & \\
\hline & 9 . & 6. & 995.8 & $6 \mathrm{I}$ & & \\
\hline & & 4. & & 624.93 & & \\
\hline & & & 00 & 629.33 & & \\
\hline & 10.400 & 6.46 & .900 & 630 & & 1.66 \\
\hline & 7.700 & 4.78 & $1025 \cdot 300$ & 637 & 10 & \\
\hline & & & & & & \\
\hline & & & .500 & 64 & & 3.38 \\
\hline & & 13. I I & .700 & & & 2427.91 \\
\hline & $2.8 c$ & & 1069.800 & 664.88 & 640 & $2099.8 \mathrm{I}$ \\
\hline & & & 1072.600 & 666.62 & 600.00 & $1068=7$ \\
\hline & & & 300 & 66 & & .76 \\
\hline & & 6 & & & & \\
\hline & 7.6 & & & & D & 33 \\
\hline & 6.1 & & $\infty$ & 67 & & \\
\hline & 20.8 & & & & 48 & \\
\hline & & & oo & 69 & & J410.81 \\
\hline & 16.3 & Io & & & & 1509.24 \\
\hline Ste & & 5.40 & & & & 95 \\
\hline & & & & & & \\
\hline & I2 & 7.84 & 1163.600 & & & 1607.67 \\
\hline & 2.100 & .1 .31 & & & & \\
\hline & & & & & & \\
\hline & & 6.09 & 1181.700 & & 440.00 & 443.62 \\
\hline & & & & & 470.00 & \\
\hline & 12.000 & 7.46 & 1202.900 & &.$\infty$ & I345.19 \\
\hline & & & 1214.900 & & 380.00 & I 246.76 \\
\hline & 8.900 & 5.53 & I 227.000 & & 340.00 & I I I 5.52 \\
\hline & 20 & 14.48 & & & 300.09 & \\
\hline & 21.200 & 13.18 & & 782.59 & 40.00 & 787.43 \\
\hline & 12.400 & 7.71 & I 280.400 & & & \\
\hline & 11.5 & 7.15 & I 292.800 & & 200.00 & 656.19 \\
\hline & I6. 500 & 10.25 & I 304.300 & & 210.00 & \\
\hline & & 8.14 & I 320.800 & 820.88 & 200.00 & 656.19 \\
\hline & 16.100 & I0.0I & I 333.900 & 829.02 & 160.00 & 524.95 \\
\hline & & & - & 839.03 & 130.00 & 426. \\
\hline
\end{tabular}


FROM ACÁmbaro TO PÁTZCUARO, A BRANCH OF THE SAME ROAD.

\begin{tabular}{|c|c|c|c|c|c|c|}
\hline \multirow{2}{*}{ STATIONS. } & \multicolumn{2}{|c|}{$\begin{array}{l}\text { Distance between } \\
\text { each station. }\end{array}$} & \multicolumn{2}{|c|}{ Distances. } & \multicolumn{2}{|c|}{ Altitudes. } \\
\hline & Kilom's. & Miles. & Kilom's. & Miles. & Metres. & Feet. \\
\hline Acámbaro. . & I 3.250 & 8.23 & 0.000 & 0.00 & 1840.00 & 6036.95 \\
\hline La Cumbre...... & 17.610 & 10.96 & 13.250 & 8.23 & 1960.00 & 6430.66 \\
\hline Andocutin....... & 6.170 & 3.83 & 30.860 & I9. I9 & I 840.00 & 6036.95 \\
\hline Huingo.... & 12.360 & 7.68 & 37.030 & 23.02 & I 840.00 & 6036.95 \\
\hline Querendaro. & 4.000 & 2.49 & 49.390 & 30.70 & 1840.00 & 6036.95 \\
\hline Zinzimeo.... & 10.000 & 6.22 & 53.390 & 33.19 & 1840.00 & 6036.95 \\
\hline Quirio...... & 7.610 & 4.73 & 63.390 & $39.4 \mathrm{I}$ & 1860.00 & $6 \mathrm{IO} 2.57$ \\
\hline Charo ...... & 5.920 & 3.67 & 71.000 & 44.I4 & I870.00 & 6135.38 \\
\hline La Goleta. & 3.150 & I. 95 & 76.920 & $47.8 I$ & I870.00 & 6135.38 \\
\hline Atapaneo... & II. 200 & 6.96 & 80.070 & 49.76 & 1880.00 & 6168.19 \\
\hline Morelia.... & I9.900 & 12.37 & 91.270 & 56.72 & I 890.00 & 6201.00 \\
\hline Jacuaro..... & 9.610 & 5.98 & I II.I $7^{\circ}$ & 69.09 & 2000.00 & 6561.89 \\
\hline Coapa & 6.800 & 4.22 & I 20.780 & 75.07 & 2060.00 & 6758.75 \\
\hline Lagunillas & 10.380 & $6.4^{6}$ & 127.580 & 79.29 & 2100.00 & 6889.98 \\
\hline Ponce..... & 2.910 & 1.80 & 137.960 & 85.75 & 2120.00 & 6955.60 \\
\hline Chapultepec. & 12.530 & $7 \cdot 79$ & 140.870 & 87.55 & 2100.00 & 6889.98 \\
\hline Pátzcuaro... & (2) & & 153.400 & $95 \cdot 34$ & 2040.00 & 6693.13 \\
\hline
\end{tabular}

FROM PIEDRAS NEGRAS OR CIUDAD PORFIRIO DIAZ TO DURANGO, BY THE MEXICAN INTERNATIONAL RAILWAY.

\begin{tabular}{|c|c|c|c|c|c|c|}
\hline Ciudad Porfirio Diaz. & 6.540 & 4.06 & 0.000 & 0.00 & 220.00 & 721.81 \\
\hline$\ldots \ldots \ldots \ldots \ldots$ & 7.060 & $4 \cdot 39$ & 6.540 & 4.06 & 232.00 & 761.17 \\
\hline Rosa & 26.200 & 16.29 & 13.600 & 8.45 & 278.00 & 9I2. I I \\
\hline Nava... & 11.960 & 7.44 & 39.800 & 24.74 & 324.00 & 1063.02 \\
\hline Allende.............. & 14.940 & 9.28 & 51.760 & 32.18 & 375.00 & 1230.35 \\
\hline Leona . . . . . . . . . . . . . & I 5.640 & $9.7 \mathrm{I}$ & 66.700 & $4 \mathrm{r} \cdot 46$ & 455.00 & 1492.83 \\
\hline Peyotes. & 21.430 & $\mathrm{I} 3.32$ & 82.340 & 51.17 & 486.00 & I 594.55 \\
\hline Blanco... & I 2.850 & 7.99 & 103.770 & 64.49 & 387.00 & 1269.73 \\
\hline Sabinas. . & I 5.850 & 9.85 & I 16.620 & 72.48 & 340.00 & I I I 5.52 \\
\hline Soledad.. & $10.65^{\circ}$ & $6.6 \mathrm{I}$ & 132.470 & 82.33 & .00 & 125.23 \\
\hline Baroterán. & I4. 120 & 8.78 & 143.120 & 88.94 & 425.00 & I 394.40 \\
\hline 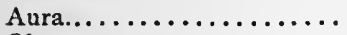 & I 5.090 & $9 \cdot 39$ & 157.240 & 97.72 & 453.00 & 1486.27 \\
\hline Obayos . & 15.330 & 9.52 & 172.330 & I07. I I & 396.00 & 1299.26 \\
\hline Baluarte.... & 10.690 & 6.65 & 187.660 & II6.63 & 373.00 & 1223.79 \\
\hline Hermanas .. & 21.230 & 13.18 & 198.350 & I 23.28 & 396.00 & I 299.26 \\
\hline tas. . & 13.570 & 8.44 & 219.580 & 136.46 & 465.00 & 1525.64 \\
\hline cia ...... & 4.770 & 2.97 & 233 & 144.90 & .00 & 1794.68 \\
\hline Mo & 18.560 & II. 54 & 237.920 & I 47.87 & 587.00 & 1925.92 \\
\hline$\ldots \ldots$ & 14.920 & 9.29 & 256.480 & I5 9.4 I & 748.00 & 2454.16 \\
\hline Glc & 19.590 & I2. 16 & 271.400 & 168.70 & 823.00 & 2700.22 \\
\hline Bajan. & I2.420 & 7.71 & 290.990 & I 80.86 & 843.00 & 2765.84 \\
\hline Joy & 20.410 & 12.68 & 303.410 & I 88.57 & 829.00 & 2719.91 \\
\hline Es & 12.080 & $7 \cdot 52$ & 323.820 & 201.25 & 817.00 & 2680.54 \\
\hline $\mathrm{Re}$ & 22.860 & 14.21 & 33 & 208.77 & .00 & 2952.85 \\
\hline$\ldots \ldots$ & 26.040 & I6. 16 & 358.760 & 222.98 & 890.00 & 2920.05 \\
\hline 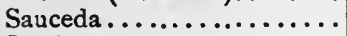 & 24.760 & 15.40 & 384.800 & 239.14 & .00 & 3271. I \\
\hline Jar & 23.020 & I4. 31 & 409.560 & 254.54 & I 144.00 & 3753.40 \\
\hline Pastora & 21.610 & 13.44 & 432.580 & 268.85 & I I 57.00 & 3796.06 \\
\hline Cármen & 23.970 & 14.89 & 454. I 90 & 282.29 & II 82.00 & 3878.08 \\
\hline $\mathrm{Pa}$ & 19.670 & 12.23 & 478.160 & 297.18 & I I 88.00 & 3897.77 \\
\hline $\mathrm{Mi}$ & I 6.540 & 10.28 & 497.830 & $309.4 \mathrm{I}$ & I I 32.00 & 3714.03 \\
\hline Rafael. & 12.970 & 8.05 & 514.370 & 319.69 & 1102.00 & 3615.60 \\
\hline Pozo .. & II. 290 & 7.02 & $527.34^{\circ}$ & 327.74 & I 105.00 & 3625.44 \\
\hline
\end{tabular}


FROM PIEDRAS NEGRAS OR CIUDAD PORFIRIO DIAZ TO DURANGO, BY THE MEXICAN INTERNATIONAL RAILWAY.-Continued.

\begin{tabular}{|c|c|c|c|c|c|c|}
\hline \multirow{2}{*}{ STATIONS. } & \multicolumn{2}{|c|}{$\begin{array}{l}\text { Distance between } \\
\text { each station. }\end{array}$} & \multicolumn{2}{|c|}{ Distances. } & \multicolumn{2}{|c|}{ Altitudes. } \\
\hline & Kilom's. & Miles. & Kilom's. & Miles. & Metres. & Feet. \\
\hline 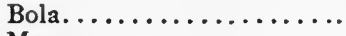 & I 3.480 & 8.38 & 538.630 & 334.76 & 1089.00 & 3572.96 \\
\hline 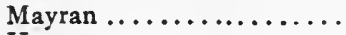 & 10.870 & 6.75 & 552.110 & 343.14 & 1094.00 & $35^{8} 9 \cdot 3^{6}$ \\
\hline Hornos. & 13.410 & 8.35 & 562.980 & 349.89 & 1096.00 & 3595.93 \\
\hline Colonia. & 17.620 & 10.95 & 576.390 & $35^{8} .24$ & 1105.00 & 5.44 \\
\hline Matamoros & 22.540 & 14.00 & 594.010 & 369.19 & I I 2.00 & $8.4 \mathrm{I}$ \\
\hline Torreon... & 8.050 & 5.00 & 616.550 & 383.19 & 1134.00 & .59 \\
\hline San Carlos.. & 15.740 & 9.18 & 624.600 & 388.19 & 1137.71 & 3732.77 \\
\hline Loma .... & 19.280 & II.98 & 640.340 & 397.97 & I $18 \mathrm{I} .52$ & $3876.5 I$ \\
\hline Choce & 20.870 & I 2.98 & 659.620 & 409.95 & 1377.25 & 4518.69 \\
\hline Huarichic. & I 5.200 & 9.45 & 680.490 & 422.93 & 1325.37 & 4348.45 \\
\hline Pedriceña... & 25.640 & 15.93 & 695.690 & 432.38 & 1318.85 & 4327.07 \\
\hline Pasaje....... & $24.54^{\circ}$ & 15.25 & 721.330 & 448.31 & 1605.28 & 5266.84 \\
\hline Yerbanís ........ & 21.580 & 13.41 & 745.870 & 463,56 & 1908.73 & 6262.53 \\
\hline Noria .. & 12.760 & 7.93 & 767.450 & 476.97 & 1895.00 & 6217.40 \\
\hline Catalina. & 12.150 & 7.56 & 780.210 & 484.90 & 1969.47 & 6461.73 \\
\hline Tapona. & 22.040 & 13.70 & 792.360 & 492.46 & 1982.72 & 6505.21 \\
\hline Gabriel. & 16.930 & 10.52 & 814.400 & 506.16 & 1955.20 & 9414.91 \\
\hline Cho & 26.420 & I6. 42 & 831.330 & 516.68 & I 868.10 & 6129.15 \\
\hline Labor... & II. 760 & $7 \cdot 30$ & 857.750 & 533.10 & I 864.38 & 6116.93 \\
\hline Durango & & & 869.510 & 540.40 & I 880.13 & 6168.62 \\
\hline
\end{tabular}

FROM SABINAS TO HONDO, A BRANCH OF THE SAME ROAD.

\begin{tabular}{|c|c|c|c|c|c|c|}
\hline Sabinas. & 17.530 & I0.83 & 0.000 & 0.00 & 340.00 & III 5.52 \\
\hline San Felipe..... & 2.380 & 1.48 & 17.430 & 10.83 & 313.00 & I026.93 \\
\hline 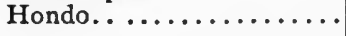 & $\ldots \ldots \ldots$ & $\ldots \ldots$ & 19.810 & $12.3 I$ & 319.00 & I046.62 \\
\hline
\end{tabular}

FROM THE CITY OF MEXICO TO CUERNAVACA AND ACAPULCO.

IINE FINISHED.

\begin{tabular}{|c|c|c|c|c|c|c|}
\hline Mexico ................ & 28.060 & I 7.44 & 0.000 & 0.00 & 2240.00 & 7349.27 \\
\hline Contreras $\ldots \ldots \ldots \ldots \ldots \ldots$ & 17.883 & II. II & 28.060 & I 7.44 & 2480.00 & 8091.75 \\
\hline Ajusco..... & 15.191 & $9 \cdot 44$ & $45 \cdot 943$ & 28.55 & 2840.00 & 9272.89 \\
\hline La Cima......... $\cdots \cdots \cdots$ & 12.966 & 8.07 & 61.134 & 37.99 & 3040.00 & 9974.08 \\
\hline Xacapexco (Tres Marías). & 18.400 & II.43 & 74.100 & 46.06 & 2800.00 & 9186.75 \\
\hline
\end{tabular}

LINE IN CONSTRUCTION.

\begin{tabular}{|c|c|c|c|c|c|c|}
\hline San Juanico ............ & 31.250 & 19.42 & 92.500 & 57.49 & 2290.00 & 7513.37 \\
\hline Cuernavaca. & 7.250 & $4.5 I$ & 123.750 & 76.91 & I 520.00 & 4987.04 \\
\hline Jiutepec..... & 6.750 & 4.20 & 131.000 & 82.42 & 1300.00 & 4265.23 \\
\hline San Vicente. & 21.000 & 13.05 & 137.750 & 85.62 & 1260.00 & 4134.00 \\
\hline Xoxocotla.. & 14.050 & 8.73 & 158.750 & 98.67 & 1030.00 & 3379.38 \\
\hline Puente de Ixtla........... & 8.950 & 5.56 & 172.800 & 107.40 & 900.00 & 2952.85 \\
\hline Rio Amacusac. . & 23.250 & 14.45 & 181.750 & I 12.96 & 890.00 & 2920.05 \\
\hline Buena Vista. & 21.000 & 13.05 & 205.000 & $127.4 I$ & I 200.00 & 3937.14 \\
\hline Iguala ....... & II. 1.00 & 6.84 & 226.000 & $\mathbf{1 4 0 . 4 6}$ & 720.00 & 2362.29 \\
\hline Tepecoacuilco. & 34.750 & 21.13 & 237.000 & 147.30 & 800.00 & 2624.76 \\
\hline Xalitla...... & 12.050 & 7.91 & 271.750 & 168.47 & 620.00 & 2034. I9 \\
\hline Mexcala .... & 28.700 & 17.84 & 283 & 176.38 & 480.00 & I 574.86 \\
\hline Venta del Zopilote. . & II. 500 & 7.15 & 312.500 & 194.22 & 760.00 & 2493.53 \\
\hline Zumpango ......... & 13.000 & 8.08 & 324.000 & 201.37 & 1000.00 & 3280.95 \\
\hline
\end{tabular}


FROM THE CITY OF MEXICO TO CUERNAVACA AND ACAPULCO.

LINE IN CONSTRUCTION. (Continued.)

\begin{tabular}{|c|c|c|c|c|c|c|}
\hline \multirow{2}{*}{ STATIONS. } & \multicolumn{2}{|c|}{$\begin{array}{l}\text { Distance between } \\
\text { each station. }\end{array}$} & \multicolumn{2}{|c|}{ Distances. } & \multicolumn{2}{|c|}{ Altitudes. } \\
\hline & Kilom's. & Miles. & Kilom's. & Miles. & Metre & Feet. \\
\hline Tierras Prietas........... & 4.800 & 2.98 & 337.000 & 209.45 & 1320.00 & 4330.85 \\
\hline Chilpancingo......... & 15.200 & 9.45 & 341.800 & 212.43 & 1200.00 & 3937.14 \\
\hline Cima de Valadez & 8.250 & 5.12 & 357.000 & 221.88 & 1300.00 & 4265.23 \\
\hline La Imagen..... & II.750 & $7 \cdot 31$ & 365.250 & 227.00 & 1060.00 & 3477.81 \\
\hline Los Cajones. . & 6.000 & 3.72 & 377.000 & 234.31 & 1000.00 & 3230.95 \\
\hline El Rincon...... & 12.000 & $7 \cdot 46$ & 383.000 & 238.03 & 670.00 & 2198.24 \\
\hline Dos Caminos... & 12.000 & 7.46 & 395.000 & 245.49 & 600.00 & 1968.57 \\
\hline Tierra Colorada. & 9.000 & 5.60 & 407.000 & 252.95 & 300.00 & 984.28 \\
\hline Rio Omitlan.... & 4.000 & 2.48 & 416.000 & 258.55 & 180.00 & 590.57 \\
\hline Peregrino..... & 32.000 & I 9.89 & 420.000 & 261.03 & 140.00 & 459.33 \\
\hline Cacahuatepec. & $24 \cdot 500$ & I 5.23 & 452.000 & 280.92 & 60.00 & 196.86 \\
\hline Marquez...... & 16.500 & 10.25 & 476.500 & 296.15 & 20.00 & 65.62 \\
\hline Acapulco. .... & $\ldots \ldots$ & $\ldots \ldots$ & +93.000 & 306.40 & 0.00 & 0.00 \\
\hline
\end{tabular}

FROM PUEBLA TO OAXACA, BY THE MEXICAN SOUTHERN RAILWAY.

\begin{tabular}{|c|c|c|c|c|c|c|}
\hline Puebla. . & 18.400 & II .43 & 0.000 & 0.00 & 2157.00 & 7077.00 \\
\hline Amozoc. & 7.600 & $4 \cdot 73$ & 18.400 & I I. 43 & 2312.00 & 7585.54 \\
\hline 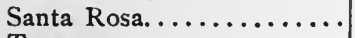 & II. 200 & 6.95 & 26.000 & I6. I6 & 2295.00 & 7529.77 \\
\hline Tepeaca ............... & 17.400 & I0.82 & 37.200 & 23. II & 2244.60 & $7364.4 I$ \\
\hline Rosendo Márquez. . & 10.500 & 6.53 & 54.600 & 33.93 & 2055.00 & 2.34 \\
\hline Tecamachalco ....... & 12.600 & 7. & 65.100 & 40.46 & 2014.10 & .15 \\
\hline Las Animas........ & $9 \cdot 400$ & 5.84 & 77.700 & 48.29 & 2000.00 & 6561.89 \\
\hline Tlacotepec...... & 31.300 & 19.46 & 87.100 & 54.13 & 8.25 & 6523.35 \\
\hline Carnero...... & 8.900 & 5.53 & I I 8.400 & 73.59 & 2.37 & .43 \\
\hline$\ldots \ldots \ldots \ldots \ldots$ & 14.700 & 9.13 & I $27 \cdot 300$ & 79.12 & 2.57 & $.8 \mathrm{I}$ \\
\hline La & 6.300 & 3.92 & 142.000 & 88.25 & 1453.29 & 18 \\
\hline Cruz. & 10.900 & 6.76 & 148.300 & 92.17 & 31 & $.9 I$ \\
\hline Pantzingo & 14.600 & 9.09 & 159.200 & 93 & 5.00 & 8.07 \\
\hline Nop & 6.400 & 3.97 & 173.800 & 108.02 & I060.56 & 3479.65 \\
\hline Salada............ & I 5.200 & $9 \cdot 4^{6}$ & 180.200 & I I I.99 & 972.07 & $9.3 \mathrm{I}$ \\
\hline Antonio............. & 8.700 & $5 \cdot 40$ & 195.400 & 121.45 & -87.92 & 2585.13 \\
\hline ... & 20.300 & I 2.62 & 204.100 & 126.85 & .00 & .26 \\
\hline 1avaca.......... & 10.900 & 6.78 & $224 \cdot 400$ & 139 & .71 & 1836.38 \\
\hline $\mathrm{Qu}$ & 17.000 & I0. 56 & $235 \cdot 300$ & 146.25 & 540.00 & 1771.71 \\
\hline Cui & 4.800 & 2.98 & 252.300 & I $56.8 \mathrm{I}$ & 592.00 & 1942.32 \\
\hline Tor & 19.200 & II. 93 & 257.100 & 159.79 & 672.00 & 2204.80 \\
\hline Alr & I6.500 & 10.26 & 276.300 & 171.72 & 1055.00 & $346 \mathrm{I} .40$ \\
\hline arina. & 16.200 & 10.06 & 292.800 & 181.98 & 1332.00 & 4370.22 \\
\hline El & 13.700 & 8.52 & 309.000 & 192.04 & $\mathrm{I} 495.00$ & 4905.02 \\
\hline $\mathrm{La}$ & 12.800 & 7.96 & 322.700 & 200.56 & I927.00 & 6322.39 \\
\hline San Pablo Huitzo. . & 13.100 & 8.13 & 335.500 & 208.52 & 1695.00 & 5561.21 \\
\hline Villa de Etla ...... & I 8.000 & II.I9 & 348.600 & 216.65 & 1642.00 & 5387.32 \\
\hline Oax & & & 366.600 & 227.84 & 1545.00 & 5069.06 \\
\hline
\end{tabular}

FROM COATZACOALCOS TO SALINA CRUZ, BY THE NATIONAL TEHUANTEPEC RAILWAY.

\begin{tabular}{|c|c|c|c|c|c|c|}
\hline Coatzacoalcos $\ldots \ldots \ldots$ & 21.749 & $13.5 \mathrm{I}$ & 0.000 & 0.00 & 2.00 & 6.56 \\
\hline Los Llmones ............ & 15.140 & 9.42 & 21.749 & $13.5 \mathrm{I}$ & 16.00 & 52.50 \\
\hline Chinameca ............ & 5.407 & 3.35 & 36.889 & 22.93 & 6.00 & 19.69 \\
\hline Jaltipan .......... & 20.547 & 12.77 & 42.296 & 26.28 & 40.00 & I 31.24 \\
\hline Oјара........ & I 2.568 & 7.83 & 62.843 & 39.05 & 32.00 & 104.99 \\
\hline Almagres.............. & II. 589 & 7.19 & 75.411 & 46.88 & 48.00 & I 57.49 \\
\hline
\end{tabular}




\begin{tabular}{|c|c|c|c|c|c|c|}
\hline \multirow{2}{*}{ STATIONS. } & \multicolumn{2}{|c|}{$\begin{array}{l}\text { Distance between } \\
\text { each station. }\end{array}$} & \multicolumn{2}{|c|}{ Distances. } & \multicolumn{2}{|c|}{ Altitudes. } \\
\hline & Kilom's. & Miles. & Kilom's. & Miles. & Metres. & Feet. \\
\hline Juile. & 9.284 & 5.77 & 87.000 & 54.07 & 40.00 & I $3 \mathrm{I} .24$ \\
\hline Medias Agu & 9.672 & 6.01 & 96.284 & 59.84 & 32.00 & 104.99 \\
\hline Tortugas.. & 21.044 & 13.08 & 105.956 & 65.85 & 44.00 & 144.36 \\
\hline Santa Lucrecia. & 7.000 & 4.36 & 127.000 & 78.93 & 30.00 & 98.43 \\
\hline Los Muertos.... & 10.000 & $6.2 \mathrm{r}$ & 134.000 & $s_{3.29}$ & 35.00 & II 4.83 \\
\hline Ubero......... & $14.80 \mathrm{r}$ & 9.20 & 144.000 & 89.50 & 25.00 & 82.02 \\
\hline Tolosa........ & 7.199 & 4.47 & 158.801 & 98.70 & 52.00 & I 70.61 \\
\hline Palomares....... & 20.570 & 12.78 & 166.000 & 103.17 & 88.00 & 288.73 \\
\hline Mogoñé.. & 15.176 & 9.43 & 186.570 & II 5.95 & 92.00 & 301.85 \\
\hline Rincon Antonio & 13.254 & 8.25 & 201.746 & 125.38 & 176.00 & 577.45 \\
\hline Lagunas.. & 17.764 & II.04 & 215.000 & 133.63 & 260.00 & 853.05 \\
\hline Chivela.. & 10.236 & 6.35 & 232.764 & $\mathrm{I} 44.67$ & 244.00 & 800.55 \\
\hline Rio Verde. & 17.186 & 10.68 & 243.000 & 151.02 & II 5.00 & 377.30 \\
\hline San Gerónimo. & 28.218 & I 7.54 & 260.186 & 161.70 & 56.00 & 183.74 \\
\hline Tehuantepec... & 3.596 & 2.24 & 288.404 & 179.24 & 36.00 & 108.12 \\
\hline Santa Cruz. & 17.617 & 10.94 & 292.000 & $18 \mathrm{r} .48$ & 36.00 & I08. I 2 \\
\hline Salina Cruz... & & & 309.617 & 192.42 & 2.00 & 6.56 \\
\hline
\end{tabular}

FROM THE CITY OF MEXICO TO PACHUCA, BY THE HIDAlgo AND NORTHEASTERN MEXICAN RAILWAY.

LINE FINISHED.

NORTHEASTERN RAILWAY FROM MEXICO TO TIZAYUCA.

\begin{tabular}{|c|c|c|c|c|c|c|}
\hline Mexico. & I9.000 & II. 80 & 0.000 & 0.00 & 2264.76 & 7430.56 \\
\hline Canal. & 11.400 & 7.10 & 19.000 & 11.80 & 2266. or & 7434.66 \\
\hline Ojo de Agua. & 5.200 & 3.23 & 30.460 & I 8.90 & $2272.9^{6}$ & 7457.46 \\
\hline Santa Ana & 14.800 & 9.20 & 35.600 & 22.13 & 2271.36 & 7452.21 \\
\hline Tizayuca. & $\cdots$ & 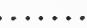 & 50.400 & 31.33 & 2294.65 & 7528.62 \\
\hline
\end{tabular}

HIDALGO RAILWAY TO TUXPAN.

\begin{tabular}{|c|c|c|c|c|c|c|}
\hline Tiz: & 16.100 & 10.00 & & & & \\
\hline Tezo & 10.800 & 6.52 & 66.500 & 41.33 & 2344.87 & 769 \\
\hline & 6.000 & 3.92 & $77 \cdot 300$ & & & \\
\hline & 8.4 & & & & & 790 \\
\hline & II. & 7. & & & & \\
\hline & ro. & 6. & & & & \\
\hline Las & & 4.34 & bo & & 250 & 821 \\
\hline Lo & II. & & I 21 & & & .64 \\
\hline & & & & & & \\
\hline $\mathrm{Tu}$ & 7.200 & 4.48 & 138.600 & 86.14 & 2187.29 & 7176.39 \\
\hline & & & 145.800 & 90.62 & 2171.46 & 7124.44 \\
\hline
\end{tabular}

FROM TEPA TO PACHUCA, A BRANCH OF THE HIDALGO RAILROAD.

\begin{tabular}{|c|c|c|c|c|c|c|}
\hline Tep & 8.7 & $5.4 \mathrm{I}$ & 0.000 & 0.00 & 2438.08 & 7999.21 \\
\hline Xoc & 17.300 & 10.75 & 8.700 & $5.4 I$ & 2380.06 & 7808.85 \\
\hline Pachuca & & 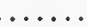 & 26.000 & 16.16 & 2420.99 & 7493.15 \\
\hline
\end{tabular}

FROM SAN AUGUSTIN TO IROLO, A BRANCH OF THE HIDALGO RAILWAY.

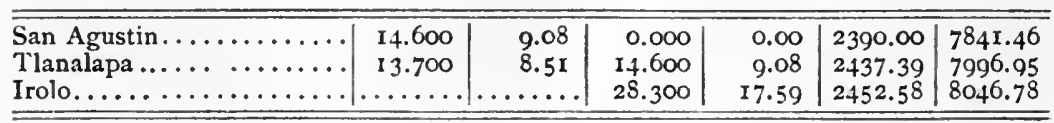


FROM DURANGO TO MAZATLAN BY BRIDLE-PATH.

\begin{tabular}{|c|c|c|c|c|c|}
\hline \multirow{2}{*}{ PLACES. } & \multicolumn{2}{|c|}{ Altitudes. } & \multirow{2}{*}{ PLACES. } & \multicolumn{2}{|c|}{ Altitudes. } \\
\hline & Metres. & Feet. & & Metres. & Feet. \\
\hline Durango. & 1880.13 & 6168.62 & La Ramona. & 1220.00 & 4002.76 \\
\hline Salitre. & I925.00 & 6315.82 & El Chapote. & 950.00 & 3116.90 \\
\hline El Salto. & I 900.00 & 6233.80 & Rio del Baluarte. & 630.00 & 2067.00 \\
\hline Arroyo Seco ......... & 1890.00 & 6201.00 & La Ventanita.... & 770.00 & 2526.34 \\
\hline Camino del Jaral..... & 1890.00 & 6201.00 & Sotolito........ & I 550.00 & 5085.47 \\
\hline El Escalon.......... & 1980.00 & 6496.28 & El Carrizo de Adentro. & 1825.00 & 5987.73 \\
\hline Las Indias. . & 2120.00 & 6955.60 & El Carrizo de Afuera. . & I 860.00 & 6102.57 \\
\hline Calzon Roto . & 2180.00 & 7152.46 & Las Loberas......... & 1970.00 & 6463.47 \\
\hline El Pino .... & 2260.00 & 7414.94 & El Venteadero......... & 1930.00 & 6332.23 \\
\hline Rio Chico..... & 2020.00 & 6627.51 & Puerta de los Pilares. . & I 250.00 & 4101.19 \\
\hline La Palmita... & 2220.00 & 7283.70 & o del Leon...... & I I 20.00 & 3674.66 \\
\hline Los Cerritos & 2260.00 & 7414.94 & Palotillo....... & IOro.00 & 3313.76 \\
\hline Los Mimbres. . & 2180.00 & $7 \times 52.46$ & Platanito.. & 940.00 & 3084.09 \\
\hline Buena Vista. & 2330.00 & 7644.60 & Santa Catarina. & 210.00 & 689.00 \\
\hline Los Charcos... & 2340.00 & 7674.41 & El Limon...... & 130.00 & 426.52 \\
\hline Los Navíos ... & 2350.00 & 7710.22 & El Tecc & Iro.00 & 360.90 \\
\hline Navajas.... & 2260.00 & 7414.94 & Tag & 85.00 & 278.88 \\
\hline Llano Gra & 2160.00 & 7086.84 & Rio del Presidio & 55.00 & 180.45 \\
\hline Cruz de Piedra. & 2230.00 & $7316.5 I$ & Porras.... & 65.00 & 213.26 \\
\hline Coyotes ... & 2270.00 & 7447.75 & Sigueros. . . . & 50.00 & 164.05 \\
\hline El Salto..... & 2280.00 & 7480.56 & La Cofradia.. . & 45.00 & 147.64 \\
\hline Piloncillos... & 2390.00 & 7841.46 & Confite...... & 62.00 & 203.42 \\
\hline La Florida. & 2440.00 & $8005.5 \mathrm{I}$ & 10 & 68.00 & 223 . II \\
\hline Junta de los Ca & 2390.00 & $784 \mathrm{r} .46$ & Las Higueras. . & 30.00 & 98.43 \\
\hline El Tecomate. & 2100.00 & 6889.98 & Las Conchas... & 22.30 & 73. 16 \\
\hline Chavarria.. & 1710.00 & $56 \mathrm{ro.43}$ & Carboneras .... & 15.50 & 50.85 \\
\hline La Cienega & 2160.00 & 7056.84 & Palos Prietos. & 1.54 & 5.05 \\
\hline Las Botijas . & 2050.00 & 6725.94 & Mazatlan ...... & 0.00 & 0.00 \\
\hline La Esscondida & $2035.00 \mid$ & 6676.72 & & & \\
\hline
\end{tabular}

FROM MANZANILLO TO GUADALAJARA BY WAGON ROAD.

\begin{tabular}{|c|c|c|c|c|c|}
\hline azanillo. & 0.00 & 0.00 & Ciudad Guzman (Zapot- & & \\
\hline Cerro del Vigia. & I 25.00 & 4IO. I I & lan). & $1+12.00$ & 4632.70 \\
\hline Cola de Iguana. & 50.00 & I64.05 & Santa C & $\mathrm{I} 4 \mathrm{I} 2.00$ & 32.70 \\
\hline El Ciruelo..... & 75.00 & 246.07 & La Cuesta ..... & 1450.00 & 4767.38 \\
\hline Canoa Verde & 75.00 & 346.07 & San Nicolás. & I 300.00 & 4265.23 \\
\hline Las Trojes. . & 100.00 & 328.09 & itlan .. & 1325.00 & 4347.25 \\
\hline Valer & 125.00 & 4 IO. II & Say & 1350.00 & 29.28 \\
\hline Tec & 17500 & 574.16 & . Mgua.. & 1360.00 & 2.09 \\
\hline La Noria & 312.00 & 1023.65 & ia...... & I 375.00 & 1.30 \\
\hline La I & 362.00 & 1187.70 & $\mathrm{Tec}$ & Do & 30 \\
\hline Col & 560.00 & 183 & $\mathrm{Cu}$ & $\infty$ & \\
\hline $\mathrm{La}$ & 650.00 & 213 & El & 13 & .25 \\
\hline San J & 65 & & $\mathrm{ElC}$ & 13 & .25 \\
\hline as & 850.00 & 278 & $\mathrm{Cel}$ & I3: & .28 \\
\hline Sar & 900.00 & 2952.85 & Lo & .00 & .25 \\
\hline Los & I 100.00 & 3609.04 & $\mathrm{Ch}$ & .00 & .25 \\
\hline La & II62.00 & 3812.46 & $\mathrm{Oc}$ & .00 & $.6 \overline{6}$ \\
\hline Tor & I 175.00 & $3854.6 I$ & Acatlan & .00 & .28 \\
\hline Cachepe & 975.00 & 3198 & $\mathrm{Pu}$ & OO & .42 \\
\hline & 985.00 & 323 & & .00 & .79 \\
\hline de Belt & 850.00 & $2788.8 \mathrm{I}$ & $\mathrm{S}$ & I 4 & 7.05 \\
\hline $\mathrm{Pla}$ & 1025.00 & 3362.97 & Ar & 1600.00 & $5+29.52$ \\
\hline nca Platar & 950.00 & 3116.90 & San & $\mathrm{OO}$ & 7.49 \\
\hline Lor & 1225.00 & 401 & La C & .00 & 7.49 \\
\hline de Atenquique & 1025.00 & 3362.97 & de Santa María. & .00 & 5.47 \\
\hline acho. & 1250.00 & 4101.19 & Guadalajara.......... & & 4921.42 \\
\hline Ped & 1375.00 & 4511.30 & & & \\
\hline
\end{tabular}


FROM TEHUACAN TO OAXACA AND PUERTO ANGEL BY WAGON ROAD.

\begin{tabular}{|c|c|c|c|c|c|}
\hline \multirow{2}{*}{ PLACES. } & \multicolumn{2}{|c|}{ Altitudes. } & \multirow{2}{*}{ PLACES. } & \multicolumn{2}{|c|}{ Altitudes. } \\
\hline & Metres. & Feet. & & Metres. & Feet. \\
\hline$c$ & 1660.00 & 5446.38 & Tierra Blar & 2000.00 & 6561.89 \\
\hline La Huerta & 1480.00 & .81 & Rio Atoyac. & 1660.00 & 5446.38 \\
\hline Arroyo de Buena & 1320.00 & 4330.85 & San Pablo Huitzo..... & 1700.00 & 5577.62 \\
\hline San Sebastian... & I 120.00 & 3674.66 & Santiago Huitzo...... & I 680.00 & .00 \\
\hline Camino de Calipán.... & 1060.00 & 3477.81 & Villa de Etla... & 1660.00 & 6.38 \\
\hline Calaveras. . & 960.00 & 3149.71 & Dolores.... & I640.00 & 0.76 \\
\hline San Antonic & 900.00 & $2952.8_{5}$ & Panzacola .... & I 540.00 & 2.66 \\
\hline Hacienda de Ayotla... & 860.00 & 2821.62 & Oaxaca... & I 540.00 & 2.66 \\
\hline Rio de Reyes ........ & 900.00 & 2952.85 & San Agustin Juntas... & 1530.00 & 5019.85 \\
\hline Teco & 620.00 & 2034.19 & Coyotepec........... & 1600.00 & 5249.52 \\
\hline lado.. & 600.00 & I 968.57 & ide .... & 1900.00 & 6233.70 \\
\hline Campanario. & 730.00 & 2395.10 & Santo Tomás Jalier & 1830.00 & $6004 \cdot 14$ \\
\hline Org & 700.00 & 2296.67 & Ocotlan. & 1720.00 & 5643.24 \\
\hline $\mathrm{Paj}$ & 680.00 & 2231.05 & Magdalena...... & 1700.00 & 7.62 \\
\hline Gai & 600.00 & 3.57 & 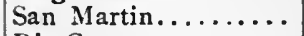 & 1700.00 & 62 \\
\hline Blan & 580.00 & 1902.95 & Coapa... & 1590.00 & 6.71 \\
\hline Rio Seco . & 560.00 & 1837.33 & tla. & 1540.00 & 2.66 \\
\hline Chonoslar. . & 700.00 & 2296.67 & rante & 1600.00 & 9.52 \\
\hline Rancho de Urrutia. & 620.00 & 2034.19 & ovo & 1840.00 & 6.95 \\
\hline o de Cuagulotal. & 620.00 & 2034.19 & & 181 & 52 \\
\hline lo de los Obbos... & 620.00 & 2034.19 & & I930.00 & 2.23 \\
\hline Hacienda de Güer & & & & 1840.00 & 0.95 \\
\hline lain. & 620.00 & 203 & huaje... & 1780.00 & 0.33 \\
\hline Rio Apo: & 540.00 & .71 & Miahuatlan. & 1800.00 & 5.71 \\
\hline Rio Tomellin & 540.00 & 17 & neco. & 2230.00 & 7316.51 \\
\hline lo... & 680.00 & 223 & ua del Sol... & 2400.00 & 4.27 \\
\hline $\mathrm{o}$ del $\mathrm{Ch}$ & 660.00 & 2165.43 & San José del Paci & 2600.00 & .46 \\
\hline 0. & 660.00 & 2165.43 & lel Enc & 2800.00 & 6.65 \\
\hline omingu & 750.00 & 2460.72 & Tres Cruces. . & 3160.00 & I0367.79 \\
\hline Dominguillo .. & 720.00 & 2362.29 & 10 de Canoa & 3000.00 & 9842.84 \\
\hline de Nopala.... & 710.00 & 2329.48 & San Miguel Xuchistepec & 2780.00 & .04 \\
\hline El & 1240.00 & 4068.38 & Rio de Sàn José. & 2340.00 & $.4 \mathrm{I}$ \\
\hline $\mathrm{Ca}$ & 1360.00 & 4452.09 & Santa $A$ & 2720.00 & .56 \\
\hline & 1500.00 & 4921.42 & de $\operatorname{Sin}$ Pedro... & 2500.00 & 8202.36 \\
\hline Puente de la Jo & 1400.00 & 3412.19 & El Porvenir. . & 800.00 & $2624 \cdot 76$ \\
\hline Vieja.. & 1600.00 & 9.52 & Garganta del $\mathrm{Ce}$ & & \\
\hline Pare & 1840.00 & .95 & la Plu & 900.00 & .85 \\
\hline Lla & 1900.00 & 6233.70 & La F & 830.00 & 2723.19 \\
\hline guilla . . & 2020.00 & 6627.51 & La: & 750.00 & 2460.72 \\
\hline Portezuelo. . & 2220.00 & 7283.70 & San José Totoltepec.. & 530.00 & 1738.90 \\
\hline La & 2080.00 & 6824.37 & Rio Chacalapa & 340.00 & I I I 5.52 \\
\hline Car & 2160.00 & 7086.84 & Pochutla & 160.00 & 524.95 \\
\hline & 2100,00 & 6889.98 & Puerto Angel. . & 0.00 & 0.00 \\
\hline
\end{tabular}

\section{THE VALLEY OF MEXICO'S DRAINAGE.'}

Mexico is finishing a great work, the drainage of the valley where the capital city is located, which has required for its completion nearly three hundred years and many millions of dollars, and has cost the lives of hundreds of thousands of men. The necessity, importance,

1 This article was published in the Engineering Magazine of New York for January, r895 (vol. viii., No 4), but has since been revised and considerably enlarged. 
and magnitude of this work, which will be classed among the grandest achievements of men, and the nearness of its completion, induce me to write this paper, which I hope will give some idea of its scope and purpose. I do not pretend to originality, as my work to some extent has been one of compilation from different monographs, which have appeared from time to time, and from some official publications of the Mexican Government.

Topographical Conditions of the Valley of Mexico.-The Valley of Mexico is an immense basin, of approximately circular shape with one extreme diameter of about sixty miles, completely bounded by high mountains, and having only two or three quite high passes out of it. No water drains out of the basin. The surface of this valley has a mean altitude above the sea of 7413 feet and an area of about 2220 square miles.

Mountain ranges rise on every side, making a great corral of rock containing dozens of villages and hamlets, with the ancient capital in the centre. In times past the fires of volcanoes licked up the earth, and such fires still live in the mammoth Popocatapetl, from whose great crater sulphur fumes and smoke with jets of flame have poured through the centuries.

The valley thus hemmed in with solid walls of rock had been an inland sea for many cycles, and during the early existence of man here the salt waters spread over a large extent of the depression. The waters have been gradually lessening by seepage and evaporation, and the Aztec pilgrims coming from the north in the fourteenth century, having received a sign that they were to build their queen-of-the-world city on a small island of the sea, set about building dikes and combating the overflow of the waters.

Evaporation is so excessive at certain periods of the year that malaria, consequent on drought, was far more dreaded by the inhabitants than the periodical floods, and thousands perished annually, so that proper drainage was an absolute necessity for the preservation of health.

Work done by the Indians. - Nearly fifty years before the discovery of America, which took place in 1492, Netzahualcoyotl, saw the necessity for a drainage canal, and commenced the work in $145^{\circ}$. He constructed an immense dike to divide the fresh from the saltwater lakes of the valley. The City of Mexico was at this time the centre of the Aztec nation, and was built on floating structures, like rafts, on the water in the numerous islets on the margins of the lakes, so that in the event of the water rising or the city being subjected to a state of siege, the whole city would float. Mexico City now occupies the site of the old Aztec capital.

The waters of these lakes were liable to disturbances of all kinds; 
thus it is recorded by Prescott in his History of the Conquest of Mexico : "In 1510 the great lake of Texcoco, without the occurrence of a tempest or earthquake, or any other visible cause, became violently agitated, overflowed its banks, and, pouring into the streets of Mexico, swept off many of the buildings by the fury of its water."

When Cortez arrived in Mexico from Spain in 1519 to take possession of the country in the name of the King of Spain, he found, to his great surprise, the defense of the city admirably arranged, and an almost enchanting view of flowering islets forming the floating capital. Little towns and villages lay half-concealed by the foliage, and from the distance these looked like companies of wild swans riding quietly on the waves.

A scene so new and wonderful filled the rude heart of the Spaniard with amazement. So astonished was he at the extent of the water of Lake Texcoco that he describes it as "a sea that embraces the whole valley," but upon hearing that it was a lake, with a mean depth of a few yards, he gave orders to cut a way through the dike and destroy the aqueduct of Chapultepec. The central dike dividing the fresh from the salt water lake was of such dimensions as to serve Cortez as a roadway for his army.

Prescott, in the work before alluded to, page 297, says: "Leaving the mainland, the Spaniards came on the great dike or causeway, which stretches some four or five miles in length, and divides Lake Chalco from Xochimilco on the west. It was a lance in breadth in the narrowest part, and in some places wide enough for eight horses to ride abreast. It was a solid structure of stone and lime, running directly through the lake, and struck the Spaniards as one of the most remarkable works they had seen in the country."

Having cut the dikes and drained the lake, the "floating city" was at once besieged, and where originally stood the great temple of the Aztecs a Christian temple was afterward raised. The Spaniards, finding themselves in complete possession, proceeded to erect the new City of Mexico, and building on the plan adopted by them at home, they cut down the points of the floating islands and by gradual extension soon placed the town below the mean average level of the lake. Hence arose the great difficulties of the drainage of the Valley of Mexico.

One of the immense dikes built by King Netzahualcoyotl was ten miles long. It divided Lake Texcoco into two parts. Of the two lakes thus formed one was allowed to remain salt, but the other was freshened by letting only fresh water enter by the streams flowing in, the water for the use of the city being taken from this latter. Little by little the waters have subsided since that period, and have been fought back, until now they are confined to six great lakes-Chalco, Xochi- 
milco, Texcoco, Xaltocan, San Cristobal, and Zumpango. Each of these lakes is fed by streams which have little volume during the dry season, but which in the rainy season swell to considerable size, and at times overflow the valleys. The lake of Zumpango was the most dangerous of these, for it received the waters of the Cuautitlan River, - a river draining a large area of country, and having during the rainy season a great volume of water. This river has been turned into the cut of Nochistongo, and has ceased to threaten Mexico and its environs with its overflow.

From these topographical conditions frequent floodings of the old Aztec city and of the Spanish capital, situated almost at the lowest point of the valley, were sure to come in times of unusually heavy rains. In early days, when the Aztecs lived in the middle of Lake Mexico, when their temples and wigwams were built on piles and the streets were often only canals, the periodical overflows from the upper lakes were a matter of small concern, though even then the Nahua engineers were called upon to protect the city by dikes. But when by evaporation, by filling in at the site of the city, by lessened waters, due to the fissures caused by earthquakes, Lake Mexico had disappeared, and the city had come to be built on the spongy soil, above all, when the short-sighted choice of Cortez had been confirmed and the capital of New Spain had come to stand on the ruins of the Aztec town, increasing rapidly in population and wealth, -it became a serious matter that on an average of once in twenty-five years the streets should be from two to six feet under water for an indefinite time.

Work done by the Spaniards. -From $\mathrm{I}_{5} \mathrm{r} 9$ to 1553 the Spaniards were busily engaged in building Mexico, and another grand dike, similar to that built by Netzahualcoyotl in 1450 , was formed around the city; this protection proved insufficient, for in 1580 another inundation took place. The Viceroy of the day, Señor Don Martin Enriquez de Almanza, assisted by engineers, engaged to find an outlet for the waters north of the valley. During the time they were thus engaged, important facts were gleaned respecting the River Cuautitlan, and its curious behavior at the foot of Nochistongo, whence it doubled its course at a certain altitude and ran toward Lake Texcoco, instead of into its own lake of Xaltocan. The scheme formed by Enriquez de Almanza to remedy this evil was kept in abeyance, as his services were required in Peru.

In the year 1604 a serious inundation attacked Mexico City. The Marquis de Montes Claros did all in his power to carry out the plan of Señor Don Martin Enriquez to relieve the rivers of the north and of the valley of the excess of water from the central and south lakes, which are of higher altitudes. The pros and cons of this plan were beset with many great difficulties, and respecting one of the methods 
tried, mention must be made of a dike of great strength, constructed to prevent any excess or overflow of water from destroying the town of Zumpango and washing away its crops. This dike, which was to check the strong current of the river Pachuca, would also direct the river Cuautitlan to Mexico, direct the rivers north into Zumpango, and would inundate that verdant district, and probably submerge the town; whereas, to divert them into Lake Texcoco would submerge Mexico. To prevent this evil it was decided to make a tunnel; but here, as in all countries and in all ages, engineers, when engaged in any work of magnitude, and of a different character from that commonly known, always find theorists to offer objections, and thus stop the way to actual progress. This was the case in Mexico City.

In 1607 another inundation, spreading over the whole valley, occurred, and, as all the dikes and other defences were swept away, caused a panic of terror among the inhabitants. The Marquis de Salinas was then Viceroy at Mexico City, and determined to carry out the plan of Señor Don Martin Enriquez, being assisted by an engineer of great repute named Enrico Martinez, and also solicited and obtained the co-operation of Father Sanchez, of the Society of Jesus. These three men, after many consultations, formulated the plan of embracing the whole of the lakes of the plain into one main channel of detention, and an outlet as required to keep the same under such control as to have at all times an abundance of water for use. The plan, broadly speaking, was to draw off the water from the south lakes which are at higher levels to those of the north, and to make them serve, by the scour the velocity of the water would cause, to deepen the passage for their exit, and, at the same time, assist the making of the grand canal

Great opposition to this plan was offered on the score of economy, and many insisted that the inundations were solely due to the waters of Cuautitlan and the freshets of Pachuca, and if these were directed north no more was needed, while the people of Zumpango tried to show that no more was needed to inundate their town and submerge the district. The Viceroy then requested Enrico Martinez to induce Father Sanchez to submit some modifications of his former scheme.

The plan was modified, and on November 28,1607 , Enrico Martinez started operations on the modified plan, and in about eleven months 6600 metres $\left(4 \frac{1}{10}\right.$ miles) of canal, with a transverse section of $3.5^{\circ}$ metres ( $\mathrm{I} I \frac{1}{2}$ feet) wide, and a depth of 4.20 metres ( $\mathrm{I} 3 \frac{3}{4}$ feet), was completed. At the same time other important drainage works were being made; the passage was opened from Boca de San Gregorio to Salto de Tula; this was 8600 metres $\left(5 \frac{1}{3}\right.$ miles) long, as well as two canals as aqueducts $6 \frac{1}{2}$ miles long, one for Lake Zumpango and the other for the river Cuautitlan from Teoloyucan to Huehuetoca. 
In December, 1608 , in the presence of the Viceroy Don Luis de Velasco and the Archbishop of Mexico, Enrico Martinez inaugurated the outlet of the waters, the whole of the work just described being executed in one year. Humboldt tells us that fifteen thousand native Indians were employed on these works.

In spite of the great good these works brought to the people, there was an outcry for economy, but it is certain that other motives prompted the disturbance and the attempt to harass and hamper the Viceroy. The object was to prevent a grant of money from being made to pay for the lining of the canal with cement. This was found to be necessary, as the greater part of the work was excavated in marl, and the liberated waters ran with such velocity that the symmetry of the tunnel was soon destroyed, and its passage and usefulness lessened by the debris that obstructed the fairway. This state of things was brought so forcibly home to the objectors that a small sum of money was reluctantly granted, sufficient to patch up the tunnel in places where the rush of waters had made the most havoc, hydraulic cement or mortar being used, but the sum granted proved to be totally inadequate, and for want of more money the tunnel was rendered perfectly useless by falling obstructions. This occurred in the year 1609 . Gossips and theorists then united to run down the scheme, although it was conceded that the work had averted a terrible inundation or submergence of Mexico City.

A few years elapsed before the question of continuing the works for the tunnel again caused excitement; but a general feeling grew up that the work of the tunnel should be continued. The opposition was strong enough to obtain the hearing of an appeal in Madrid, with the result that the Spanish Government in I6r4 procured the services of a Dutch engineer, named Adrian van Boot, to proceed to Mexico City to examine and report on the canal works, and to submit a plan to remedy the evils. As the result of his labors he condemned the plan of Father Sanchez, and recommended that the old means of defence used by the Indians should again be adopted, and that dams and dikes should be thrown up at once. This report had the effect of annoying almost everybody, and was the means of much fruitless discussion. In this dilemma the Spanish Government, when appealed to, confessed they were unable to advise the Viceroy of Mexico what to do, but sent the Marquis of Gelves to Mexico to see into matters, and he, having unbounded faith in the ability of the Dutch engineer, Adrian van Boot, and hoping to keep money in the treasury, ordered Enrico Martinez to close up the tunnel completely, and to return the rivers to their natural courses; but before these orders were half executed the enormous rush of waters grew so alarming that he had to accept again Enrico Martinez's plan over that of Adrian van Boot. The 
marquis was soon after deposed, his place being taken by the Marquis de Cerralvo, whose first act was to set Martinez free at the request of the city council who provided him with means of continuing his work on the canal and tunnel. The Viceroy revoked his predecessor's order and issued another to open up the tunnel, and that with all speed, on his personal responsibility. Although Cerralvo gave these orders, he forgot to give Martinez the money to carry them out, and, as a consequence, the works remained in a deplorable condition.

The tunnel was blocked up by this cause, and Martinez was cruelly scored for not having done his work aright by the very ones who had refused to give him the necessary material for it. He bravely essayed to repair the damage, but the water-soaked condition of the ground gave no resistance for the building of the needed walls, while death mowed down the enslaved workers. They were crushed to death by the frequent cavings in of the loose soil, or were sent to the grave by the deadly damps. Finally, the charge being made that the builder was blocking up the tunnel in revenge, he was thrown into prison, where he languished for many months. As there was no one else available who could carry on the great work, he was afterwards released and again put in charge. It was then decided that, the tunnel being completely useless, the next thing to be done would be to make a great cut down to the tunnel and thus open it out. This entailed the making of an excavation fourteen miles in length with an average depth of one hundred and eighty feet and width of four hundred feet.

On June 20, 1629, the ever troublesome river Cuautitlan over flowed and inundated the north of the plain, and swept with it other streams into Lake Texcoco. In the September following the increase of the water was greater than ever had been known. The city was so suddenly and completely submerged that thirty thousand persons perished, the bodies floating about the streets for some time after. The destruction of property and life, consequent on the inundation, was so great generally, and affected the tunnel to such an extent, that during a period of five years there was scarcely any reduction in the height of the water, and the water in the city remained during all this time as high as the second story of the houses; the slight difference in the heighth of the water being caused by evaporation.

The Spanish Government at Madrid gave orders to change the capital to a better and more secure site. To this suggestion the citizens demurred, saying, in effect, that to insure complete security an outlay of only $\$ 3,000,000$ was necessary, this being the estimated cost of completing the tunnel, whereas to build a new city would involve an outlay of $\$ 50,000,000$, with a loss of another $\$ 50,000,000$ in leaving the old one.

Several plans were now submitted in opposition to that of Enrico 
Martinez, and one by Simon Mendez was accepted, his plan being to direct all the waters of the valley by one canal into the neck of the Tula, the spot selected by Martinez for his outlet. It was soon discovered that the plan of Simon Mendez was far too costly, and as the money that could be spared was practically melting away without perceptible progress being made, Enrico Martinez was again requested to carry out the work as arranged with Father Sanchez.

The next Viceroy, the Marquis of Cadereita, was most desirous to see the work of the tunnel pushed on; but however enthusiastic he may have been, lack of funds prevented him from giving effect to his desires. The work continued very slowly, Martinez being unable to do any work at the tunnel, and he contented himself with improving the canal by lining it in bad places with cement. Martinez struggled on for thirty-seven years with this work, and died unnoticed and uncared for. All trace of his place of final rest was lost.

In 1637 an earthquake made sad havoc with the tunnel works, and for lack of funds no repairs could take place; but when funds were obtainable workmen could not be procured, the earthquakes and inundations having carried off many thousands of these poor fellows. The survivors lacked heart to return to such an unfortunate and, as they thought, accursed work.

In the year 1640 the work was being pressed on by men from the prisons, under the direction of the Franciscan monks, and carried on, with varying results, in this way for thirty-five years, until Señor Don Martin Solis was made head of the municipal council. He being an avowed enemy to the Franciscans, sent them away, and undertook the superintendence of the work himself; but his method of treating the prisoners was so harsh and cruel that they broke out into open revolt, and the works were threatened. Therefore, to save the works and his own life, he consented to the return of the Franciscans. It is estimated that up to this time some two hundred thousand men lost their lives on this work. The Franciscans steadily, but slowly, worked on, always with a very limited exchequer, until $I_{7} 67$, when there remained some I935 metres (It miles) still to be completed. A contract was entered into to finish this work in five years for $\$ 800,000$; but instead of five years it took twenty-two years, and, instead of 8 metres ( 25 feet wide), as contracted for, it was only 3 metres (9 feet ro inches) wide.

The Spaniards continued the work in other hands for one hundred and fifty years before the task of opening the cut was completed. Spasmodic work for a century and a half led at last to the accomplishment of this project in 1789 . The old tunnel of Martinez is now a gigantic trench from 30 to 160 feet in depth and some 300 feet broad in some places, and is known as the Tajo de Nochistongo. The immediate vicinity of the workings was depopulated of its native inhabit- 
ants by the insatiable demands of the killing labor, and recruits were then drawn from Puebla and other thickly populated Indian centres. Great prison barracks were built on the bare hills, and here all the criminals were sent to enter the work. The ones in charge were indifferent with regard to the lives entrusted to their care, and the slaughter, of which scant record remains in the parish burial books, and which resulted from a combination of defects in appliances for both the safety and the comfort of the workmen, was terrific. As the burial trenches were filled with new dead, the depths of the cut were tenanted by new laborers.

The victims of three years of bondage numbered fully two hundred thousand ere the work was done. Yet the results were but slight, only the excess of water from the highest lakes and streams being carried off. However, the danger from inundations of the city has been very materially decreased by the Nochistongo opening, and no more deluges have occurred since its completion.

Still the fact that the botton of the cut was thirty feet higher than the surface of Texcoco, the lowest lying of the lakes, left the city in danger of inundation, as Lake Texcoco is constantly filling up at the rate of one and one-half inches a year and is now but a few feet below the level of the main plaza of the city.

The drainage works had long been a heavy burden upon the Mexican treasury. Up to $6_{37}$ Bancroft estimates that $\$ 3,000,000$ had been expended. $U p$ to the year 1800 the outlay had reached $\$ 6,247,670$. $\mathrm{Up}$ to 1830 the total expenditure was $\$ 8,000,000$.

Work done by the Mexican Government.-The problem which the Mexican Government had to face was very different from that which confronted Martinez in 1607 . The question of preventing submergence is practically solved. The work of Martinez, unsatisfactory as it was, did a great deal to solve it. Since his day the area of the lakes has been gradually diminishing. The rapid evaporation in the rarefied air and under the direct sun of the valley partly accounts for this. Twice the water in Lake Texcoco has almost entirely disappeared, leaving only a sea of mud and a small pool. The great problem which the Mexican Government has now solved is not how to prevent an inflow of water, but how to provide an outlet for sewage. The danger to be averted was not that of drowning, but that of dying from the plague.

Lake Texcoco more than any other now menaces the security of the capital. The unwise cutting down of forests since the Spanish conquest permits the waters pouring down into the valley to bring with them annually great quantities of alluvial matter, which have so much raised the lake bottom and the water level that inundations have been of frequent occurrence. The general level of the City of Mexico is only 6.56 feet above the surface of the lake. The rainy season lasts 


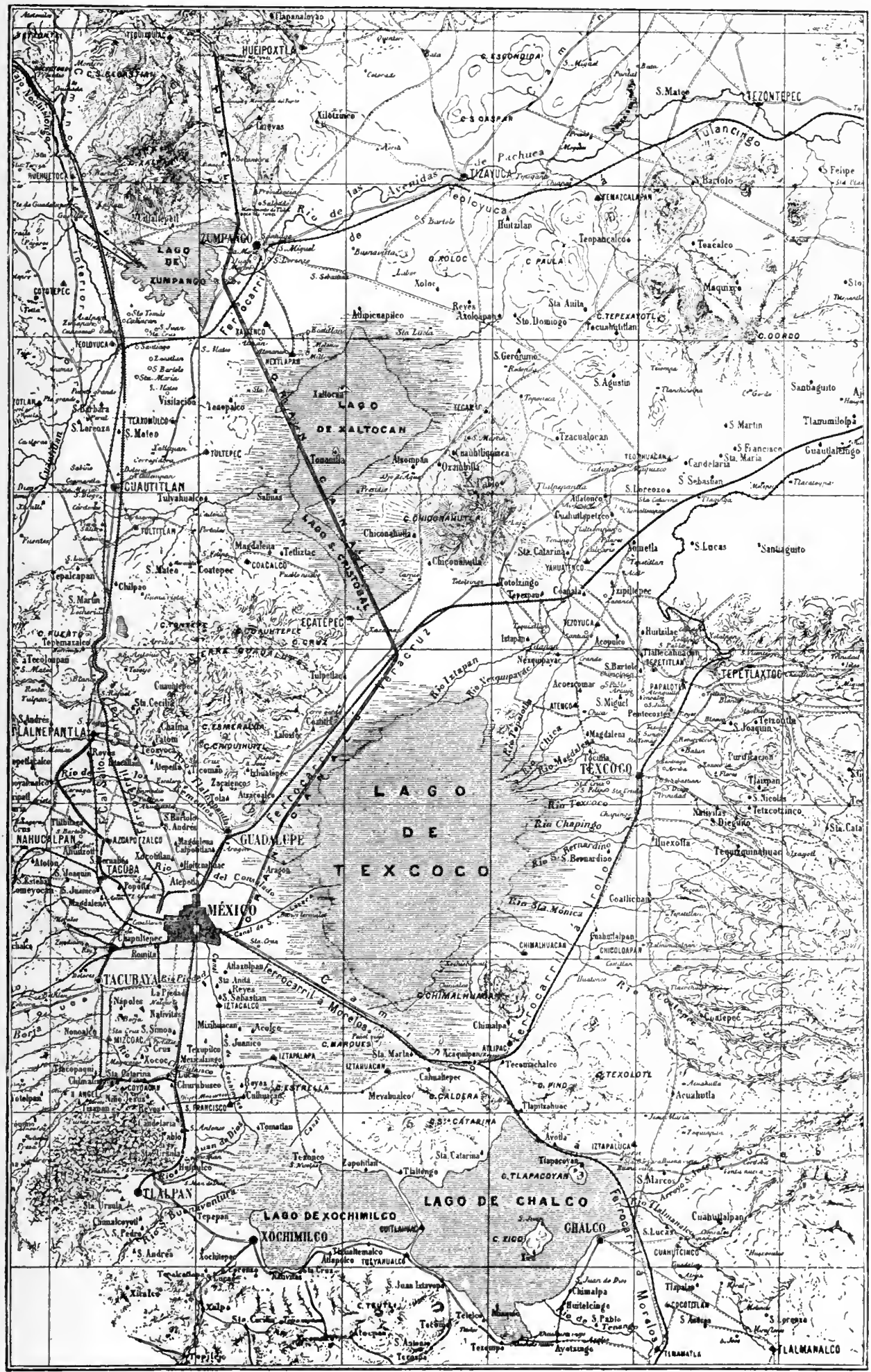

MAP OF THE VALLEY OF MEXICO, SHOWING THE CANAL AND TUNNEL. 

from June to October inclusive. During this season five times as much water falls as during the rest of the year, evaporation can no longer compensate for rainfall, and the valley is more or less flooded.

Originally built in the midst of a lake, the city has been left on dry ground by the receding waters. Lake Texcoco,--some three miles distant,-Chalco, and Xochimilco have altitudes nearly four feet greater than the pavement of the capital. Still more imperiously do the lakes to the north dominate the city. San Cristobal and Xaltocan are about five feet, while Zumpango is over thirteen feet, above it.

The project now almost completed is a modification of the scheme projected by Simon Mendez in the time of the Spanish Government, and which in 1849 was adopted by Captain Smith of the corps of American engineers which accompanied General Scott's army. The tunnel was ultimately located under the saddle and through the ravine of Acatlan, its mouth being near the village of Tequixquiac. The works have been begun several times, and then suspended without effecting anything of importance. In 1866 the works now nearing completion were commenced. A project proposed by Señor Don Francisco de Garay, a well-known engineer of the City of Mexico, was pronounced the most feasible. But the revolutionary struggle succeeded, and for many years the work was relegated to the background.

In 1879 engineer Don Luis Espinosa, the present director of the works, took charge of the undertaking. In the first period mentioned the cutting of Tequixquiac was excavated, and the greater part of the shafts were begun; but at that point the work was stopped by political agitations.

The present gigantic work cannot have been considered to have been seriously undertaken, with a view of completion at any cost, until the year 1885, when the City Council of Mexico submitted a project to the Government to which they offered to contribute largely in the event of its being adopted.

A special commission, with ample authority to deal with the funds set aside for the work, was appointed by President Porfirio Diaz. The City Council set aside the sum of $\$ 400,000$ per annum for the canal works, which sum was materially increased by the Federal Government.

In 1887 the City Council raised a loan in London of $\mathcal{E}^{2,400,000}$ to meet the cost of the work and guarantee its successful termination. The entire responsibility of the work was now assumed by the City Council, and the Government gave authority for the Council to make and collect new taxes. Still, there was not sufficient money forthcom-

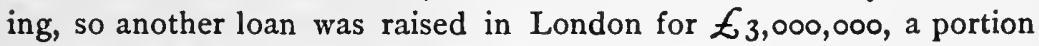
of which was held for the work. 
The drainage works, when carried out, will receive the surplus waters and sewage of the City of Mexico and carry them outside of the valley, and will also control the entire waters of the valley, affording an outlet, whenever found necessary, to those which might otherwise overflow fields and towns, rendering the soil stagnant and marshy. The work consists of three parts-rst, the tunnel; 2d, a canal starting from the gates of San Lázaro, and having a length of $67 \frac{1}{2}$ kilometres, or 43 miles, its line following on the eastern side of the Guadalupe range of hills and between that range and Lake Texcoco, changing its direction after arriving at the 2 oth kilometre to a northeasterly one, so as to diagonally cross Lake San Cristobal, a part of Lake Xaltocan, and a part of Lake Zumpango, and arriving finally at the mouth of the tunnel near the town of Zumpango; and $3 d$, the sewage of the City of Mexico.

The tunnel.-The contract for completing the tunnel was let to Messrs. Read \& Campbell, of Mexico, but for some reason they were unable to finish the work. It was therefore continued and satisfactorily completed by the City Council for a sum considerably less than the price contracted with Messrs. Read \& Campbell under their superintendence as hereafter stated.

The tunnel has a length of 10,021.79 metres, or 32,869 feet $(6 \mathrm{t}$ miles), with a curved section formed by four curves respectively of the following dimensions: The upper part has a span of 4.185 metres, or I 3 feet 9 inches, and a rise of 1.570 metres, or 5 feet $1 \frac{1}{2}$ inches; the two lateral arches have a chord each of 2.36 metres, or 7 feet 9 inches, a radius with a chord of 2.429 metres, or 8 feet, and a rise of 0.521 metre, or I foot $8 \frac{1}{2}$ inches; the elevation is 4.286 metres, or I4 feet, and the greatest width is the span of the upper arch. The accompanying drawings show this section. The tunnel is lined with brick, having a thickness in the upper part of 0.45 metre, or $\mathbf{I}$ foot 6 inches, and in the lower part over which the water runs, of 0.04 metre, or I foot 4 inches in the side arches, and of 0.30 metre, or I foot in the radius, this latter lining being of artificial stone made of sand and Portland cement. The elevation of the invert at the beginning of the tunnel is 9.20 metres, or 30 feet $\mathrm{I} \frac{1}{2}$ inches below datum; at the end of the tunnel, 17.53 metres, or 57 feet 6 inches below datum. The gradient is 0.00069 for the first 2170.74 metres, or I in 1449 for 7120 feet; 0.00072 for the following 5831 metres, or $I$ in 1389 for 19,125 feet 6 inches; 0.001 for 5100 metres, or 1 in 1389 for 16,728 feet; and $0.00135, \mathrm{I}$ in 740 , for the rest of the tunnel; these changes being in accordance with changes of details made from those of the original project, in some cases modifying the section and in other cases: the lining. Twenty-five shafts, each 2 by 3 metres, or 16 feet $6 \frac{3}{4}$ inches by 9 feet 10 inches, were opened at a distance of 400 metres, or $13 I_{2}$ 


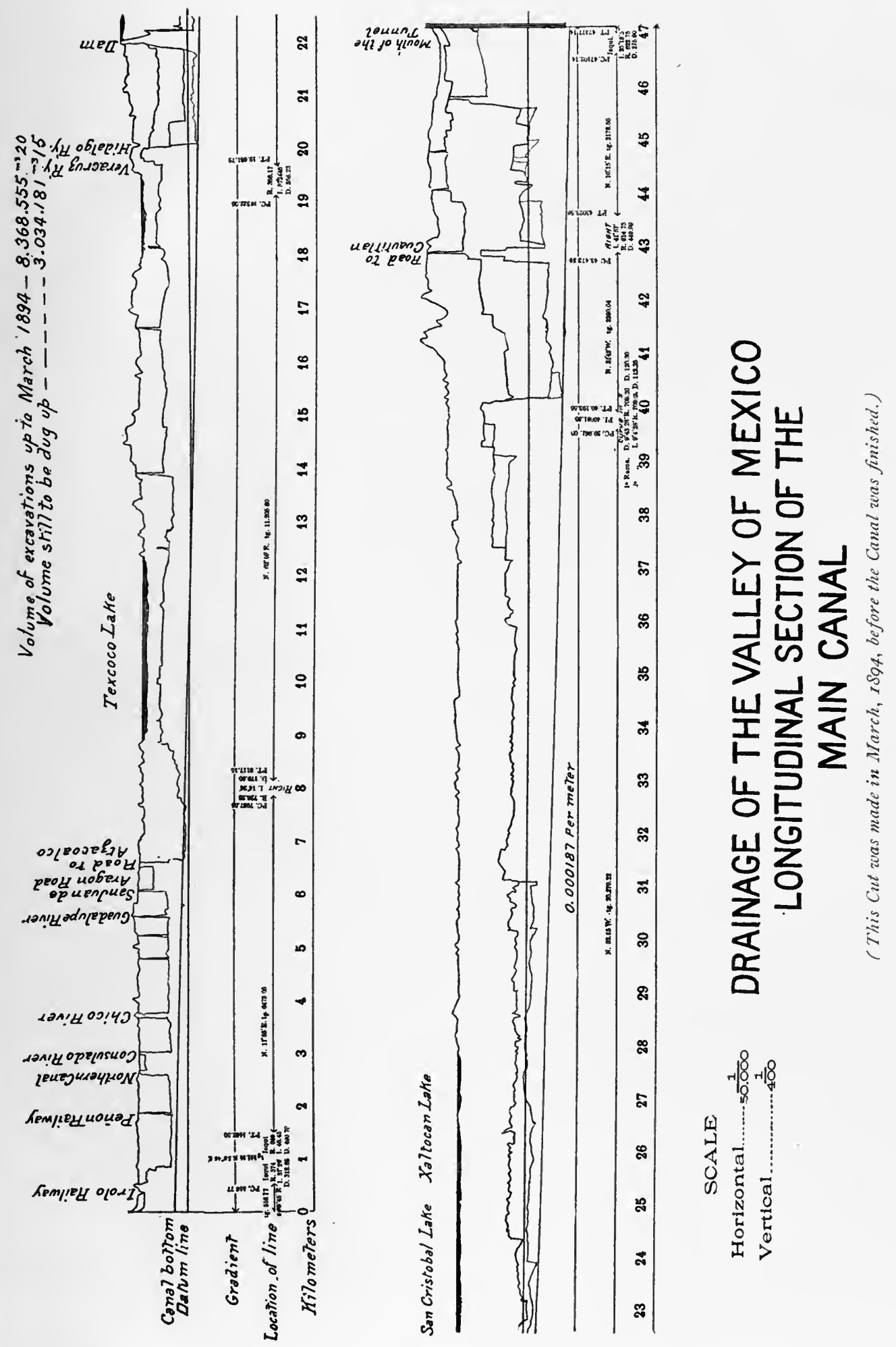



feet from eacin other. These served to ventilate the tunnel and to facilitate the work. The deepest of these shafts, situated on the saddle of Acatlan, has a depth of 92 metres, or 30 r feet 9 inches; the shallowest is $2 \mathrm{I}$ metres, or 68 feet ro inches.

To give an idea of the labor involved beyond the mere tunneling, it is as well to mention that the quantity of materials required per lineal yard of tunnel was I 800 bricks, 94 cement blocks, 3 cubic yards of mortar, and 70 cubic feet of volcanic stone.

Maximum discharge through the tunnel $=18$ cubic metres, $635 \frac{2}{3}$ cubic feet.

When the drainage board took charge of the work, it was executed by day labor both in the canal and in the tunnel, the latter having the larger amounts expended on it. But, shortly afterwards, the contract for the tunnel was let to Messrs. Read \& Campbell, of London, who, after having invested a considerable sum in the work, found themselves under the necessity of cancelling their contract at the beginning of the year $x 892$. These gentlemen continued to handle the work, but as managers, and under the direction of the board.

The canal.-In December, I889, the Department of Public Works contracted with the Bucyrus Company of the United States, of which Colonel Ellis was the president, for the construction of the canal.

This company started with two spoon dredgers capable of raising a maximum of rooo cubic metres, 1308 cubic yards, a day. They commenced operations at the twenty-second kilometre. In the opinion of the board of commissioners, the Bucyrus Company was not proceeding with the work at a suitable rate of speed, for at rooo cubic metres, 1308 cubic yards, per day, the work of dredging alone, as there were some $16,000,000$ of cubic metres, 20,928,000 cubic yards, of excavation to do, would take about forty-three years; their contract was therefore cancelled.

In May, r894, the Department of Public Works of Mexico contracted with Messrs. S. Pearson \& Son of London for the completion of the canal, modifying former contracts of December 25, 1889, March 30, I891, and April I8, I893, under the following bases: the unfinished excavation in the first nine kilometres, and that between kilometre 47 and the entrance of the tunnel of Tequixquiac, are to be continued by the Board of Drainage Directors, who must have the latter portion completed to ro metres below the surface of the soil by December 31,1894 , and to the required depth of the canal by May 31 , 1895 , in order that the water in the canal may settle to that level and permit the contractors to slope the walls as required by the contract. The contractors are to complete the canal between kilometres 9 and 47 for the sum of $\$ 3,506,000$. For making the monthly estimates the canal will be divided into two sections-kilometres 9 to 22 and kilometres 
22 to 47 . In the first section the provisional estimate will be 40 cents per cubic metre; in the second a sum equal to the quotient obtained by dividing the remainder of the money by the number of cubic metres to be removed. The contractors may suspend the work of the dredgers when they fall below 40 cubic metres per hour, and can proceed with the excavation in any way they wish. The excavation had to be completed by May r, 1896, except in the parts where the dredgers cannot work. Then for each day's delay the contractors must pay $\$ 500$ fine, and after five months the contract will be rescinded.

These contractors carried out the work of the canal in two different ways-by hand work with centrifugal pumps to draw off the water which filtered into the work, and by means of enormously powerful Couloir dredgers which have a capacity for 3000 cubic metres of excavation per day, and which throw the excavated earth to a distance of more than 200 metres from the centre of the canal. They had five of these dredgers at work, and by means of them excavated to a depth of 20 metres or 65 feet, raising the earth to an elevation of more than 16 metres, $52 \frac{1}{2}$ feet, so as to empty it into the shoots, along which it was carried by a stream of water that delivered it at a considerable distance from the dredger. The dredgers have now done their work, and they have been taken to pieces, packed and transferred to the harbor works at Veracruz. The portion of the canal contracted for was completed to the satisfaction of all concerned in six years.

The level of the bottom of the canal above the datum line adopted is 2.25 metres, or 7 feet 4 inches, and the mouth of the tunnel is 9.20 metres, or 30 feet $\frac{1}{2}$ inch below the same datum, supposed to pass ro metres, or 33.80 feet below the bottom of the Aztec calendar stone, since transferred to the National Museum. The level of the ground at the beginning of the canal is 8.94 metres, or 29 feet 4 inches, and at the end 15.86 metres, or 52 feet above datum. The uniform slope of the canal is at the rate of 0.187 per kilometre.

The canal has a depth, at its commencement, of 5.50 metres, or 18 feet, which in the last few kilometres is increased to 20.50 metres, or 67 feet 3 inches. The side slopes were projected with a batter of 45 degrees, and the width of the bottom is 5.50 metres, or 18 feet for the first 20 kilometres, or $12 \frac{1}{2}$ miles, and 6.50 metres or 21 feet 2 inches in the rest of the canal. The first 20 kilometres, or $12 \frac{1}{2}$ miles, may be considered as a prolongation of the net of sewers in the city, and will receive only the water that passes through them. The flow is calculated for an average of 5 cubic metres, or $176 \frac{1}{2}$ cubic feet, although, when heavy rains require $i t$, they can receive a greater volume; the rest of the canal communicates with Lake Texcoco, and will be utilized in controlling its waters, - the lowest in the valley, - which can be made to flow into the canal from all parts. Hence the canal has been built to 


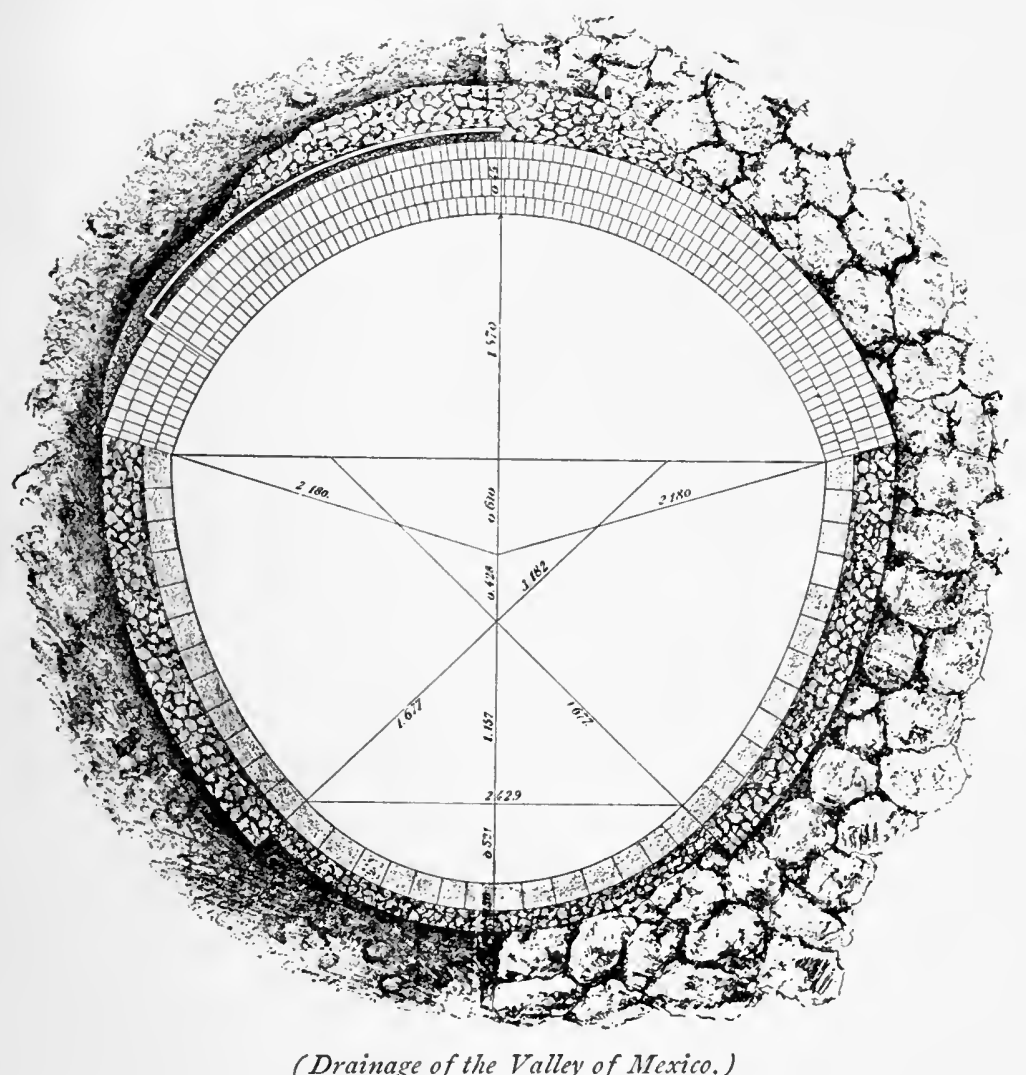

(Drainage of the Valley of Mexico.)

VERTICAL SECTION OF THE TUNNEL. 

carry the largest flow that can pass through the tunnel, or 18 cubic metres, $635 \frac{2}{3}$ cubic feet, per second. The cutting is through a strictly clay formation, comprising occasional thin strata of sand and sandstone.

For accommodation of railroads, wagon roads, and water-courses, it was necessary to construct five aqueducts - four of masonry and one of iron-to carry rivers, four iron bridges for the passage of railroads, and fourteen bridges for vehicular traffic.

The sewage.-The sewers of the City of Mexico form a network of covered channels, located sometimes in the middle and sometimes on the sides of the streets, these being almost aiways gorges, communicating with a system of secondary sewers that empty into a collecting sewer discharging into the canal of San Lázaro, which transports the sewage to Lake Texcoco. If the water is high in the lake, water backs up into the sewers and saturates the soil under the houses and streets. As this has been the condition for several centuries, the state of the subsoil under the city can be better imagined than described. The death-rate touches 40 per rooo-the highest in the civilized world. Mexico's elevation of over 7000 feet is all that saves it from a pestilence. Malarial and gastric fevers are almost continually epidemic.

For a century the problem has been settling into one of pure sanitation. The plans which the Government has been working since about I 883, though called plans for draining the valley, really seek to get a fall sufficient to dispose of the sewage. In fact, in the original plan, from considerations of economy, care was to be taken to keep out of the projected canal all water both from the surface of the valley and from the rivers. The Consulado and the Guadalupe rivers were to be carried over the new canal in iron aqueducts. The drainage system was thus to be simply a part of the sewage system of the city.

The excavated materials have been tipped on each side of the canal at their natural slopes, and a towpath near the canal level provided. Sluice gates will direct the city drainage either to the canal or to Lake Texcoco. A sluice gate at the junction of the smaller with the larger part of the canal will control the flow of Lake Texcoco, and another sluice gate will be placed at the entrance of the tunnel.

Completion of the work.-As this paper goes to press, the drainage works of the Valley of Mexico are practically finished, as the waters of the valley have been for several years passing through the canal and the tunnel to their outlet in the river which takes them to the Gulf of Mexico, and the company with whom the canal was contracted is now giving the finishing touches to the sides and bottom of the canal and will deliver it to the Government Board of the Drainage Directors in January, I898. It was agreed with the contractors that the portion of the canal between the City of Mexico and the 20 th kilometre, which is comparatively easy, because the canal is not deep there, and the ex- 
cavations do not exceed 200,000 cubic metres, will be made directly by the Board as soon as the other portion of the canal has been finished; this last section of the work is expected to be finished in June, 1898 , when the waters of the City of Mexico will leave the valley by the drainage works here mentioned.

The canal and six-mile tunnel through the mountain range have a total length approaching fifty miles. The present works will take rank with the great achievements of modern times, just as the immense " cut" of Nochistongo, their unsuccessful predecessor, was the leader among ancient earthworks in all the world. The completed system will have cost $\$ 20,000,000$.

I have dwelt on these works at some length, because their importance to the City of Mexico can hardly be overestimated. Instead of being one of the healthiest cities in the world, as it should be with its magnificent climate and situation, Mexico, unfortunately, has a terribly heavy death-rate, due principally to want of drainage and generally bad sanitary condition. When the existing danger of floods is removed, and the sanitary evils are remedied by a proper system of drainage, the increased security that will be enjoyed by life and property will certainly have its effect on the prosperity of the city. Property will rise in value, the population will grow with rapidity, not to mention the tide of tourists that will set in from the United States, and this will mean larger revenues for the municipality.

I could not well finish this paper without paying General Diaz, President of Mexico, a just tribute for the great interest he has taken in having this gigantic work brought to a close during his administration. To his exertions in this regard, and to his commanding position in Mexico, more than to anything else, this happy result, now in sight, is due. So after a weary search of centuries for relief, the beautiful Valley of Mexico will gain its deliverance not only from the engulfing floods, but from the sanitary evils which have long resulted from defective drainage. 


\section{INDEX.}

A.

Agave, where found, 48 ; use, 48,49

Agriculture, products, 243, 244

Alfalfa, how grown, and uses, 56

Alligator pear, use, 63

Americans in Mexico, cannot compete with Spaniards in frugality, 79 ; some Mexicans were afraid the country would become Americanized, 80

Area, of Mexico, 5, 9I ; of silver mines, 13; of City of Mexico, 98, 107

Army, strength of, 99, 100

\section{B}

Bananas, where grown, cost, yield, and size, 6I ; export of, variety, an article of food, 62

Bancroft, H. H., referred to, 108 ; his statistics on drainage of Mexico, 274

Banks, names of, 131, 225, 226; National Bank of Mexico, 131; Bank of London and Mexico, 132

Bees, 71, 72

Belize, occupied by, 6 ; boundary of, 7

Birds, 7r, 72

Bolson de Mapimi, I 2

Boundary of Mexico, with the United States, 5 ; with Guatemala, 6 ; with Belize, 6, 7

Brocklehurst, 109

Bucyrus Co., 277

Bustamante, Don Alejandro, I5

C

Cables in Mexico, where located, 123

Cactus, species, 5 I

Cadereita, Marquis of, Viceroy, 273

Canaigre, use, where found, 55

Canal, size of, 270, 2'78, 279; lining of, report on, $27 \mathrm{r}$; sum appropriated for building of, and loan, 275 ; contracted by, articles of contract, 277, 278; how work carried out, 278 ; flow, 278, 279 ; length of, 280
Castillo, Bernal Diaz del, I9

Catholics, wealth of, 93,94

Cattle, raising, export of, $56-8$; cost of fattening, lack of water, 57

Cerralvo, Marquis de, his plan in regard to canal and tunnel, 272

Cession of territory to the United States, by the treaty of Guadalupe Hidalgo, by the Gadsden treaty, by treaty signed at Washington with Mexico, 7, 8

Charcoal, 4

Chewing-gum, demand, production, 53; value, 54

City of Mexico, location and settlement of old city, 107, 108, 267-9; present city, 108, 109, 268 ; public buildings, rog, I IO ; factories, I ro ; mortality, II I, II4, II5, 279; threatened by an inundation in 1604, often flooded in the early days, 269; plan to change capital, 272

Climate, rainfall, 35,36 ; temperature, 36,37 ; climatic conditions, 37,38 ; meteorological observations taken in several cities of Mexico, 38, 40, 4I ; meteorological observations taken in several localities of Mexico, 39 ; Mexico as a sanitarium, 4r, 42; of City of Mexico, IIO, III ; meteorology in the Mexican Republic, $\mathrm{III}_{\mathrm{II}} \mathrm{Ir}_{\text {; climato- }}$ logical data of the City of Mexico, II 2 ; summary of meteorological observations of the City of Mexico, 113 ; good for work, I28; of City of Mexico, 274. 275

Clouds, 38

Coal, cost of, and mining, 22 ; coal-fields, 23-5

Cochineal, where cultivated, price, 53

Cocoa, where produced, 51,52 ; disadvantages of raising, 52

Cocoa-nuts, where grown, use, 62,63

Coffee, best location, production, 44, 45 ; advantages and disadvantages of raising, 127

Coinage of precious metals, gold and silver, 21 ; mints, 27, 109 
Colleges and universities established by the Spaniards, IOO-102

Copper, quality, amount produced, 22, 23 Cortez, Hernan, reference to, I9, 55, 123, 268,269

Cotton, best location, expense of production, 48 ; seed, 24

Courts, Supreme Federal, 26

\section{$\mathrm{D}$}

Debt of Mexico, bonds, loans, etc., 129, 130 ; accomplishing credit, I30; amount of debt, I30, I3I; National debt to June $30,1896,221,222$

Dering, Sir Henry, quotations from, 47 , $54,55,64$

Diaz, President, referred to, I I5-I8, 122-4, I30; tribute to, 280

Dikes, first dike in 1450,267 ; description of, by Prescott, 268 ; one built by Spaniards, 260

Domestic animals, $7 x, 72$

Drainage works of the Valley of Mexico, where article on, was first published, how long to complete work, 266 ; magnitude of work, 267; by the Mexican Government, 274-6 ; works consist of, 276 ; works completed, 279, 280 ; importance to the City of Mexico, 280

\section{E}

Egypt, compared with Mexico, ro, II

English in Mexico, immediately after the independence, nearly all disappeared, 79

Espinosa, Don Luis, present director of tunnel work, 275

Expenses, amount of, 137, 138 ; of Federal Government, I39-4I ; of customhouses, I47; of internal revenue, $\mathrm{I}_{4} 8$; of direct taxes, I49; of Mexican States, I5I ; of municipalities, I53 ; of Mexico in the year $1896-97,245$

Exports, from $1826-28$, 155 ; from $1877-$ 96 , I59; by countries and customhouses from I894-96, I60; value of metals and commodities exported in I895-96, I6I ; of commodities from I 886-96, I62; of agricultural products from IS77-96, I 64 ; destination and value of metals and commodities from I882-92, I68, I69; total exports, I69; value of Mexican exports during I87273. I72; from Mexico and to the United States, I73; of domestic merchandise to Mexico I $858-83$, I $78-80$; from the United States to Mexico I88997, 182,183 ; articles exported from the United States to Mexico, I84, I85; tropical products supplied by Mexico to the United States, I 85, 186 ; cattle exported to the United States, 186 ; of precious metals and minerals in the years $1879-30$, I889-90, and I894$95, \mathrm{I} 88$; of silver, of silver bullion, 189; of silver ore, Igo; of gold, I9o, I9I ; of gold from Mexico to the United States, 192; of Mexico by countries and custom-houses in the year 1896-97, 246; Mexican exports to the United States, 247

\section{F}

Financial condition, of Mexico, 126, 137, I38; of railroads, I19, I20, I95, I96; of banks, 132 ; of States and municipalities, I 54

Fish, 71, 72

Flora in Mexico, products raised, 42, 43 ; flowers grown, 63,64

Foreign immigration, encouragement to, I25; difference of, from the United States, 126, 127; cost of labor, 127; warning from consular reports, I27, 128 ; those who should immigrate, I2S

Foreign trade, small before railroads built, cost of transportation, I 54; amount of, with United States, 170; why difficult to have correct data with United States, I 70, I7I; commercial transactions between Mexico and the United States from I820-50, I 73 ; commerce in merchandise between the United States and Mexico from $\mathrm{I}_{5} \mathrm{I}$ 97, 174; total commerce between the United States and Mexico by years and decades from $185 \mathrm{I}-97$, I 75 ; increase of trade during $1896-97$, I 84 ; between Mexico and the United States during the first nine months of $r 897,247$

Forests, 37, 38 ; destruction of, 65,66 ; in Mississippi Valley, 66

Forey, Marshall, I08

Franciscan monks, work done by, 273

French in Mexico, own large dry-goods houses, 79

Fuel, 23-5 ; demand for, 24 ; consumption of, 64

G

Garay, Señor Don Francisco de, plan for tunnel, 275

Gelves, Marquis de, his orders about tunnel, 271

Geology, rock formations, 12 ; rich in ores, 12,13

Germans in Mexico, succeeded by English, and are doing well, 79

Gil, Mr. George, British Colonies, 6

Ginger, yield, 55

Gold, where found and how reduced, I4, 19,20 ; amount of production, extract from Mr. Cramer, 20 ; weight and standard value, I33; production of, in years $1879-80$, I889-90, and I 894-95, I 88 ; accredited to Mexico, 192 
Government of Mexico, 98, 99

Grasses, where grown, use, 56

Guatemala, boundary, latitude, length of southern boundary, 6 ; cochineal raised there, 53

Guggenheim, smelter, 23, 28, 29

$\mathrm{H}$

Henequen, where grown, average pounds per acre, 49

Humboldt, Baron von, reference to, I3, I5, 8I, I04, 27 I

Hydrography, coast, gulfs, harbors, bays, 32 ; islands, 33 ; rivers and torrents, 33,34

\section{I}

Imports, from I826-28, I 55 ; from I87275 , I 56 ; from $I 885-86$ and I888-90, I 57 ; from $1892-96$, I 58 ; by countries from I 888 -90 , by custom-houses from I894-96, I60; values of metals and commodities from I882-92, I65-7; résumé of total, 167 ; to Mexico and to the United States, I72; of merchandise from Mexico from $185^{8}-83,176,177$; into the United States, I8I, I 82 ; leading merchandise imports from Mexico to the United States, I84: of gold bullion, ore, and coin into the United States, I 91 ; of Mexico by countries and custom-houses in the year $1896-97,246$; from the United States, 248

Indians, Mexican, tribes, 72 ; classification of tribes, 73 ; similar to MalayAsiatic races, 73, 74; extract from San Francisco, Cal., Bulletin, 73 ; characteristics, 74,75 ; prominent men among them, marriages, 74; education, 76 , I05: strength, 78 ; religion, 97 ; Sir William Hingston on, 75 ; originated work on canal, $267-9$

India-rubber, places best adapted for it, 46,47 ; as an industry, amount of production, 46 ; profits and expense of, 47,48

Inhabitants, most thickly inhabited parts, 37 ; manner of living, 128 ; aborigines, per cent. of, 72

Inundations of the City of Mexico, used to be flooded once on an average of every twenty-five years, the one in I 580 , in 1604, 269; one in 1607,270 ; one which occurred in 1629,272 ; decrease in, since Nochistongo opening, caused by cutting of forests, 274

Iron, where found, 21, 22, 25 ; Cerro del Mercado mine, quality, 21 ; importation of, foundries, 22

Irrigation, but little at present in Mexico, 63 ; scarcity of water, 64,65 ; cause of decrease in rainfall, good investment, 66 ; reason for short grain supply, 70 ; Nazas irrigation, $67-70$
L

Lakes, number of, description of, 268 , 269 ; disappearance of Lake Mexico, 269 ; Lake Texcoco filling up, lake almost disappeared, 274 ; altitudes of, 275 ; canal crosses Lake Texcoco, 276

Lamoreaux, map showing cession of territory, 7

Languages in Mexico, varieties, 85,86 ; Indian, similar to Oriental, 74 ; synopsis of Indian, 86-8

Latitude, of Mexico, 5 ; of Guatemala, 6 ; of silver mines, 13 ; of City of Mexico, 107

Laws, mining, 25-7 ; lands, 124 ; colonization, I25, I26; banking, I3I

Lead, ores. I 7, I8; yield, 28, 29

Lemons, where grown, 60

Lemprière, Notes on Mexico, 9

Libraries in Mexico, 106; names, number of volumes and students, 233-5

Li Hung Chang and the Mexican silver mines, I8, I9

Limes and shaddocks, where planted, variety, $6 \mathrm{I}$

Longitude, of Mexico, 5 ; of silver mines, 13 ; of City of Mexico, $\mathrm{IO}_{7}$

\section{M}

Mamey, use of, 63

Mangoes, cultivated taste, transportation of, 63

Manufacturing, factories in 1893,236 ; additional establishments, 237

Martinez, Eurico, his plan for canal, 270; plan inaugurated, 271 ; plan accepted in $1614,271,272$; scored for not doing his work right, 272 ; referred to, $272-4$; again requested to carry out work, 273

Matthews, Mr. James F., I8

Maximilian, IOS ; downfall, 95

Mendez, Simon, his plan for canal, 273 ; reference to, 275

Mercado, Gines Vazquez del, Cerro del, 2 I

Mexico as a Central American State, where article was published, 249; how article originated, 249, 250 ; geographical situation of Mexico, 250 ; five States of Central America, 250; States of Mexico, 25 I ; geographical extension of Central America, 25I; how remarks were received by a Guatemalan representative, 252

Miller, Mr. Chas., I 8

Mining, richness of mines, $\mathrm{I}_{3}$; miners, 25 ; Mexico offers great advantages in, I2S, 129

Money, weights and measures, I33, I34

Montes Claros, Marquis de, reference to, 269

Museum, National, ro3 
Navigation, number of vessels, 237 ; vessels arrived at Mexican ports in 1895 , 238; vessels departed from Mexican ports in 1895, 239; foreign passengers arrived at Mexican ports in I 895,240 ; foreign passengers departed from Mexican ports in 1895, 24I; résumé of vessels and passengers arrived and departed by rail and ports in I895, 242 ; vessels arrived and departed from Mexican ports in $1894-96,243$

Navy, strength of, Ioo

Netzahualcoyotl, saw the necessity for a drainage canal, 267 ; one of the dikes built by, 268

Newspapers, 106

Noyes, Theodore W., Mexico and Egypt, IO, II

\section{0}

Ophidians, $7 \mathrm{r}$

Oranges, where and how raised, irrigation, distillation, 59; flavor, yield compared with coffee, Frederico Atristain referred to, the cyclone in Florida, 60

Orography, mountains and plateaus, 2932 ; elevation of mountain ranges, $3 \mathrm{I}$

\section{$\mathrm{P}$}

Papaya, use, 63

Patents, number of, $\mathrm{I}_{32}$

Pearson, S., \& Son, contractors for canal, 277

Peat, 23, 24

Peppermint, where grown, 55

Pineapples, uses, where grown, 62

Political organizations of Mexico, of Federal Government, 98, 99

Political parties, Church, its wealth, 93, 94; Liberal, 94

Population of Mexico, increase of, 76,77 ; decrease of Mexican Indians, 77,78 ; from 1795 to 1895,89 ; parts most thickly settled, 90 ; of United Mexican States, 9I

Position of Mexico, 9

Postal service, number of offices and agencies, 123, 124; mail carried, receipts, I33; post-offices in Mexico in I 895, 223; earnings and expenditures of post-offices from 1869-96, 224; number of postal pieces transported from $1878-95,225$

Prescott, History of Conquest of Mexico, 268

Profiles, Mexican, from Veracruz to Mexico by the Mexican Railway, from Apizaco to Puebla, a branch of the Mexican Railway, 253; from Veracruz to Mexico by the Interoceanic Railway, from the City of Mexico to Morelos by a branch of the Interoceanic, 254; from Puebla to Izúcar de Matamoros, a branch of the Interoceanic, 255 ; from the City of Mexico to El Paso del Norte by the Central Mexican, 255-7 ; from Aguascalientes to Tampico by the Mexican Central, 257, 258; from Irapuato to Guadalajara, a branch of the Mexican Central, 258; from the City of Mexico to Laredo Tamaulipas by the Mexican National, 258-60; from Acámbaroto Pátzcuaro, a branch of the Mexican National, 26I ; from Piedras Negras to Durango by the Mexican International, 26r, 262 ; from Sabinas to Hondo, a branch of the Mexican International, 262; from the City of Mexico to Cuernavaca and Acapulco, 262, 263; from Puebla to Oaxaca by the Mexican Southern, 263 ; from Coatzacoalcos to Salina Cruz by the National Tehuantepec, 263, 26.4; from the City of Mexico to Pachuca by the Hidalgo and Northeastern Railway, from San Augustin to Irolo, a branch of the Hidalgo Railway, 264; from Durango to Mazatlan by bridle path, from Manzanillo to Guadalajara by wagon road, 265 ; from Tehuacan to Oaxaca and Puerto Angel by wagon road, 266

Publications about Mexico, non-official, r34; newspapers, 228

Public lands, granted to Indians and Spaniards, survey of, I2 4 ; division of, I 24, I25; price of, 125; titles of, 227, 228

Pulque, where and how cultivated, 48, 49 ; fermentation of, expense and profit, 50 ; thorn and root useful, $5 \mathrm{I}$

Purpose of this paper, 244

Q

Quicksilver, production of, 23

$\mathrm{R}$

Railway itineraries (see Profiles)

Railways in Mexico, history of, II5, I16 ; extent, I 16, I I9; President Diaz's policy on, I I7, II8; President Diaz's statistics on, IIg ; financial condition of, IIg$2 I$; length of, passengers and tons carried, I33; mileage in operation October $3 \mathrm{I}, 1896,193-5$; résumé of, 195; Mexican Central, I96, I97; Mexican National, I 66-8; Mexican International, I99, 200 ; Mexican Southern, 200,201; Mexican Railroad, 20I; Interoceanic Railway, Sonora Railway, Hidalgo and Northeastern Railivay, 202 ; Mérida and Progreso Railway, Tehuacan and Esperanza Railway, 
Railways in Mexico-Continued.

Mérida and Peto Railway, 203; Sinaloa and Durango Railway, Mérida and Campeche Railway, Mérida and Valladolid Railway, 207; Tlalmanalco Railway, San Juan Bautista and Carrizal Passenger Railway, San Andres and Chalchicomula Railway, 205; Orizaba and Ingenio Railway, Santa $A n a$ and Tlaxcala Railway, Cárdenas and Rio Grijalva Railway, 206; Toluca and San Juan de las Huertas Railway, Vanegas, Cedral, Matehuala, and Rio Verde Railway, Mérida and Izamal Railway, San Marcos and Nautla Railway, 207; Monterey and Gulf Railway, Cordova and Tuxtepec Railway, Maravatio and Cuernavaca Railway, Salamanca and Santiago Valley Railway, 208; Monte Alto Railway, Valley of Mexico Railway, Puebla Industrial Railway, Mexican Northern Railway, Mexico, Cuernavaca, and Pacific Railway, 209 ; Federal District Tramways, Veracruz and Alvarado Railway, 2 Io ; traffic and receipts of Mexican railroads, 2II ; subsidies paid by Mexican Government to June $30,1896,212-20$

Read \& Campbell, Messrs., contractors of tunnel, 276, 277

Real del Monte, 15-17

Religion in Mexico, Catholic clergy and convents, 92, 93; in politics, 94 ; Catholics of to-day, 94, 95; Protestant missionaries, 95-7; Protestant churches established by Mr. Henry C. Riley, 96 ; statistics on Protestants, 97,98

Revenue, increase, 137 ; difficult to get data, I38 ; statistics of, from $1808-67$, 139 ; statistics on, from $1867-88$, 140; statistics on, from 1888-96, I4I ; Federal appropriations from I 868-95, I42 ; sources of, import duties, 143 ; additional import duties, export duties, I44; custom receipts, I45, 146; internal revenue, 146, 147; direct taxes, 148, I 49 ; of Mexican States, I50 ; of municipalities, 152 ; of Mexico in the year 1896-97, 245

Rice, how cultivated, 53

Ruins in Mexico, Uxmal, 8o, 8I ; $\mathrm{Pa}$ lenque, Cholula, $8 \mathrm{I}$; Teotihuacan, $8 \mathrm{I}$ 83 ; Mitla, 83 ; extract from Sir Vivien Cory on, $83-5$

\section{S}

Sanchez, Father, plan for tunnel, 270 ; plan condemned, $27 \mathrm{I}$

Sandy Plains of Mexico, 12

Sanitarium, Mexico as a, 4I, 42

School of Engineering, 103

School of Medicine, 102, 103

Schools, statistics of, 105, 106; public, 229, 230 ; private, 231, 232
Sewage of the City of Mexico, danger of, 274 ; description of, and how to be effected, 279

Sheep, mistakes made in raising, 58

Shipping, mercantile marine, vessels in foreign and coasting trade, tons carried, 133

Silk culture, where grown, varieties, 52 ; how sold, 53

Silver, yield, and where found, I3, I4 ; system of reduction, I4; history of some mines, I5, I6; duties on, 28 ; weight and standard value, I33; total coinage of, 186; total production of, coined by Mexican mints from 1535 to 1895,187 ; production of in the years I879-80, I889-90, and 1894-95, 188 ; coined and exported from 187496,189

Smelting plants, Mexican Metallurgical Co., 28 ; National Mexican Smelter at Monterey, 28, 29; Central Mexican Smelter, Velardeña Mining Co., The Chihuahua Mining Co., The Mazapil Copper Co., Limited, Sabinal Mining and Smelting Co., Chihuahua, La Preciosa, The Boleo Smelter, 29

Smith, Captain, referred to, 275

Spaniards in Mexico, characteristics, 78 , 79; climate check on growth, little education, 79 ; built dike for canal, 269 Starr, Professor, his theory, 76

States of Mexico, classification and division, etc., 90, 9I

Sugar-cane, size, places best adapted for raising, cost of raising, 45

Switzerland, compared with Mexico, to

\section{$\mathrm{T}$}

Technical schools, at the present time, 103, 104 ; reorganization of, 104, 105

Tejada, Señor Lerdo de, II 5

Telegraphs, number of different companies, I2I-3; length of, 133 ; earnings and expenditures from $1869-96$, 224

Telephones, length of, I33

Terreros, Don Pedro José Romero de, I5, 109

Texas, annexation of, 7

Tobacco, quality of, 45,46

Topia, new mines, 17

Trade-marks, number of, 132,133

Transportation, of money, I3I ; cost of, railroads have revolutionized, 154,155 ; of mangoes, 63 ; of postal pieces, 225

Treaties, Guadalupe-Hidalgo, Gadsden, one signed at Washington between the United States and Texas, 7, 8

Tunnel, originated, 270,271 ; blocked up, 272; work carried on in 1614 , closed, $27 \mathrm{I}$; opened out, 272 ; earthquake destroyed it in 1637 ; condition of old tunnel now, 273 ; dangers 


\section{Inoex.}

Tunnel-Continued.

in building, 273, 274; location of, 275 ; contract for, size, 276,277 ; discharged. managed by, 277 ; length of, 280

\section{$\mathrm{V}$}

Valley of Mexico, its development, I06, I07; topographical conditions, 267

Van Boot, Adrian, sent to make a report, his plan, 27 I

Vanilla, where grown, production, varieties, etc., 52 ; how sold, 53

Vegetation, 36

Velasco, Viceroy Don Luis de, 27 I

W

Wages, advantages of foreign labor, 48 ; prevents immigration to Mexico of poor people, I26-9
Warner, Charles Dudley, Mexico compared with other countries, to ; climate of Mexico, 42, 43; on church edifices, 92,93

Water, Mr. J. A., Pinos Altos Gold Mine, I4

Winds, 38

Woods, cabinet and dye, where grown, some of the species, $43,44,55$

\section{$\mathrm{Y}$}

Yuca, when and where grown, 54 ; yield 55

Yucatan, configuration, civilization, 9

\section{Z}

Zapote, use, 63

Zones, products of cold, temperate, and hot, $5^{8}$ 


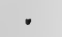

. 


8098

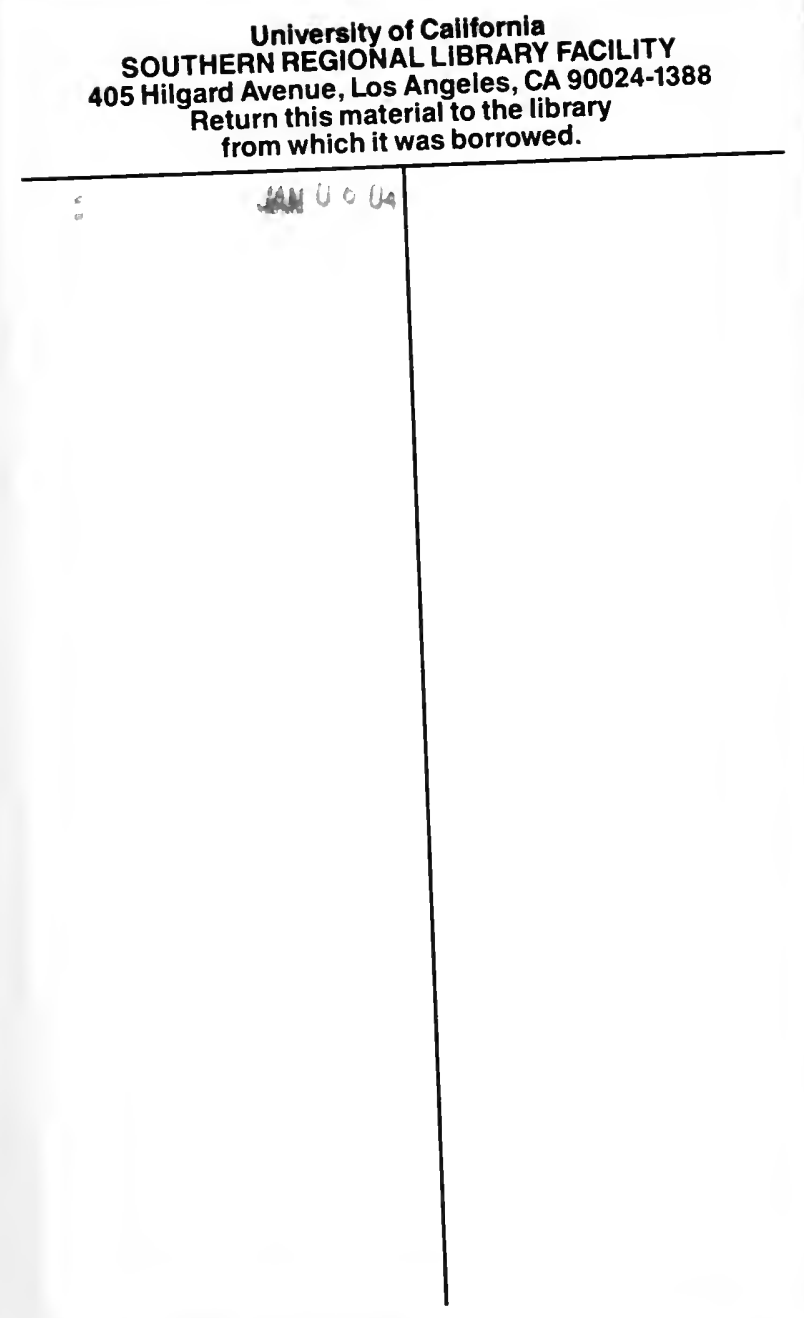


